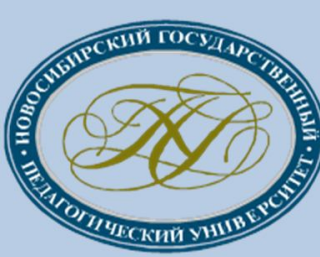

ISSN 2226-3365

www.vestnik.nspu.ru

\title{
$\mathscr{B E} C \mathscr{T} \mathcal{H} \mathcal{H} \mathcal{K}$
}

Новосибирского государственного педагогичесқого университета

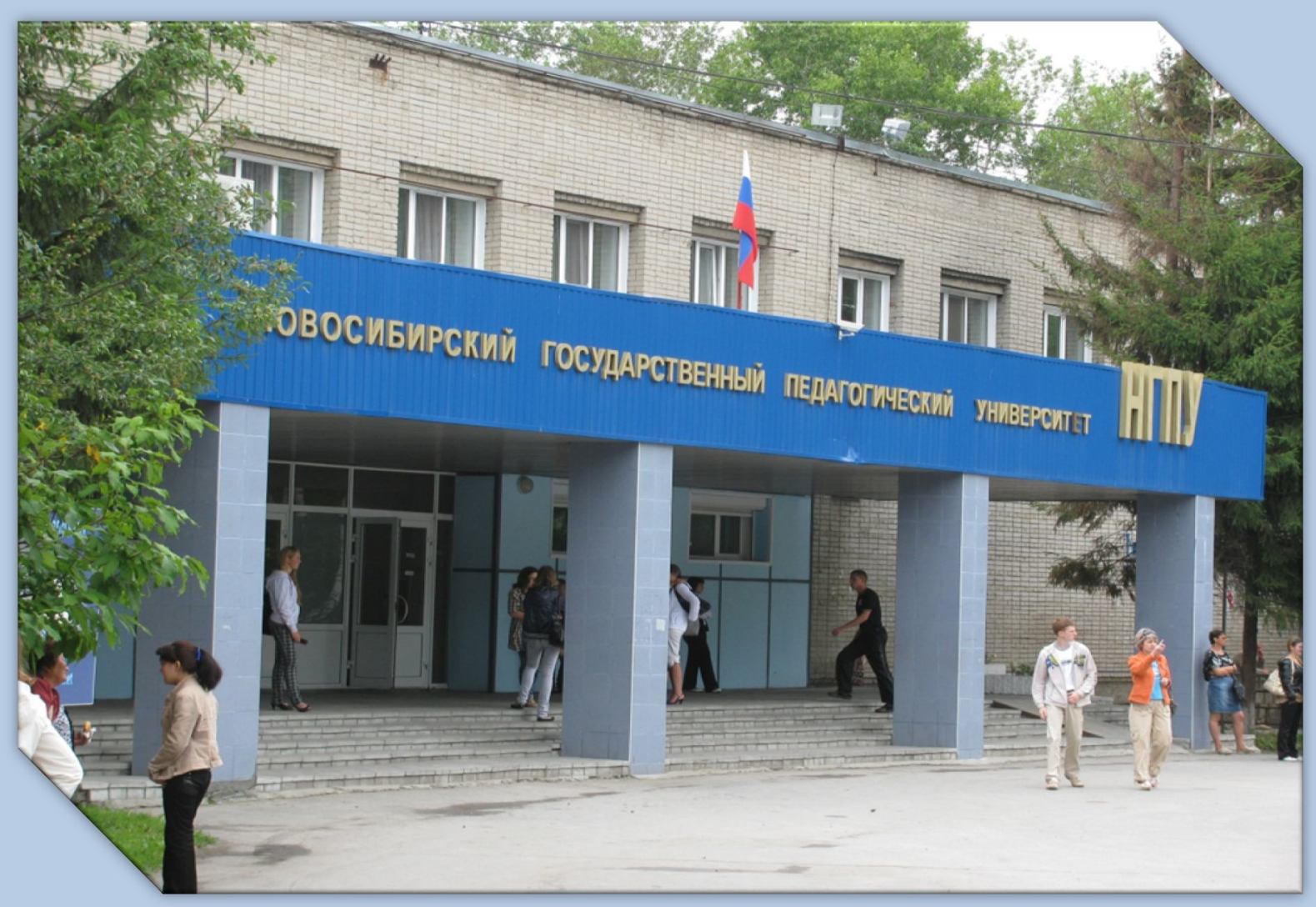

\author{
Novosibirsk State \\ Pedagogical University \\ BULLETIN \\ 1(17) 2014
}


Учредитель журнала:

ФГБОУ ВПО «Новосибирский государственный педагогический

университет»
Электронный журнал «Вестник Новосибирского государственного педагогического университета» зарегистрирован Федеральной службой по надзору в сфере связи, информационных технологий и массовых коммуникаций (Роскомнадзор).

ЭЛ № ФС77-50014

\section{РЕДАКЦИОННАЯ КОЛЛЕГИЯ И РЕДАКЦИОННЫЙ СОВЕТ НАУЧНОГО ЭЛЕКТРОННОГО ЖУРНАЛА «ВЕСТНИК НОВОСИБИРСКОГО ГОСУДАРСТВЕННОГО ПЕДАГОГИЧЕСКОГО УНИВЕРСИТЕТА»}

\section{Редакционная коллегия}

главный редактор

Пушкарёва Е. А., д-р филос. наук, проф. заместитель главного редактора

Майер Б. О., д-р филос. наук, проф.

педагогические и психологические науки

Синенко В.Я., Д-р пед. наук, профессор

Богомаз С. А., д-р психол. наук, проф. (Томск)

философские и гуманитарные науки

Майер Б. О., д-р. филос. наук, проф.

Зверев В. А., Д-р ист. наук, проф.

науки о земле; физико-математические и

технические науки

Трофимов В. М., д-р физ.-мат. наук, проф.

социально-экономические науки

Ряписов Н. А., д-р экон. наук, проф.,

биологические, химические, медиичнские науки

Айзман Р. И., д-р биол. наук, проф., член-корр.

МАНВШ, заслуж. деят. науки РФ

Просенко А. Е., Д-р хим. наук, проф.

культурология и искусствоведение

Чапля Т. В., д-р культурологии, проф.

филологические науки

Трипольская Т. А., д-р. филолог. наук, проф.

\section{Международный редакционный совет}

Айзман О., д-р филос., д-р мед., Каролинский институт (Стокгольм, Швеция)

Ангелика Ригер, д-р, проф. (Ахен, Германия)

Анна Паола Бонола, проф. славистики,

Миланский университет (Милан, Италия)

Балгимбеков Ш.А., д-р мед. наук, проф,

(Алматы, Казахстан)

Бухтова Б., д-р наук, Университет им.

Масарика (Брно, Чехия)

Валькенхорст Ф., д-р наук, проф., университет

Кельна (Кельн, Германия)

Винго Чарльз С., д-р мед. наук, проф., универ. Флориды (Гейнсвилль, Флорида, США)

Джанни Челси, д-р филос., проф., (Уппсала,

Швеция)

Логунов Д., н.с., ун-т Манчестера

(Великобритания)

Мукатаева Ж.М., д-р биол. наук (Павлодар,

Казахстан)

Чагин А., д-р филос., н. с., Каролинский

институт (Стокгольм, Швеция)

Шмайс Й., д-р наук, Университет им. Масарика

(Брно, Чехия)

Юй Вень Ли, д-р полит. образов., Пекинский

университет (Пекин, Китай)

\section{Редакционный совет}

председатель редакиионного совета

Герасёв А. Д., д-р биол. наук, проф. (Новосибирск)

Афтанас Л.И., д-р мед. наук, проф., акад. РАМН, вицепрезидент РАМН, Президент СО РАМН (Новосибирск)

Баликоев В.3., д-р экон. наук, проф. (Новосибирск)

Безруких М.М., Д-р биол. наук, проф., почетный профессор НГПУ, академик РАО (Москва)

Бережнова Е.В., д-р пед. наук, проф. (Москва)

Винокуров Ю.И., д-р геогр. наук, проф. (Барнаул)

Галажинский Э.В., д-р психол. наук, проф.,

академик РАО (Томск)

Жафяров А.Ж., д-р физ.-мат. наук, проф.,

член.-корр. РАО (Новосибирск)

Жукоцкая 3.Р., д-р культурол., проф. (Нижневартовск)

Иванова Л.Н., д-р мед. наук, проф., акад. РАН

(Новосибирск)

Казин Э.М., д-р биол. наук, проф., заслуж. деят. науки РФ, академик МАНВШ (Кемерово)

Клочко В.Е., Д-р психол. наук, проф. (Томск)

Князев Н.А., Д-р филос. наук, проф. (Красноярск)

Кондаков И.В., д-р филос. наук, проф., акад. РАЕН, почетный работник общего образования (Москва) Краснорядцева О.М., д-р психол. наук, проф. (Томск) Кривощеков С.Г., д-р мед. наук, проф. (Новосибирск) Кудашов В.И., д-р филос. наук, проф. (Красноярск)

Медведев М.А., д-р мед. наук, проф., академик РАМН, заслуж. деят. науки РФ (Томск)

Мокрецова Л.А., Д-р пед. наук, проф. (Бийск)

Овчинников Ю.Э., д-р физ.-мат. наук, проф.

(Новосибирск)

Печерская Т.И., д-р филолог. наук, проф.

(Новосибирск)

Пузырев В.П., д-р мед. наук, проф., академик РАМН

(Томск)

Серый А.В., д-р психол. наук, проф. (Кемерово)

Федоров В.И., д-р биол. наук, проф. (Новосибирск)

Чупахин Н.П., д-р филос. наук, проф. (Томск)

Шошенко К.А., д-р мед. наук, проф. (Новосибирск)

Основан в 2011 году, выходит 6 раз в год

Редакционно-издательский отдел:

630126, г. Новосибирск, ул. Вилюйская, д. 28, к. 22

тел. 8 (383) 244-34-50

E-mail:vestnik@nspu.ru

Номер подписан к выпуску 14.02.14 


\section{The founder The registration certificate}

The electronic journal «Novosibirsk State Pedagogical University Bulletin»

Novosibirsk State

Pedagogical University

is registered in Federal service on legislation observance in sphere of communication, information technologies and mass communications The registration certificate ЭЛ № ФС77-50014

\section{EDITORIAL BOARD AND EDITORIAL COUNCIL OF SCIENTIFIC ELECTRONIC JOURNAL «NOVOSIBIRSK STATE PEDAGOGICAL UNIVERSITY BULLETIN»}

\section{Editorial Board}

Editor-in-chief

Pushkareva E.A., Dr. of philosophical Sc., Prof. of the NSPU

Deputy editor-in-chief

Mayer B.O., Dr. of philosophical Sc., Prof. of the NSPU Pedagogical Sciences and Psychology

Sinenko V.Ya, Dr. of Pedagogical Sciences, Professor Bogomaz S.A., Dr. of Psychological Sc., Prof. (Tomsk) Philosophy and Humanities Sciences

Mayer B.O., Dr. of philosophical Sciences, Professor Zverev V.A., Dr. of Historical Sciences, Professor Earth Sciences. Physics, Mathematics, Engineering Sciences

Trofimov V.M., Dr. of Physical and Mathematical Sciences, Professor

Social and Economics Sciences

Ryapisov N.A., Dr. of Economic Sciences, Professor Biological, Chemical Sciences and Medicine

Aizmam R.I., Dr. of Biological Sciences, Prof. of the NSPU, Corr-Member of IASHS

Prosenko A.E., Dr. of chemical Sciences, Professor Cultural and Art Sciences

Chaplya T. V., Dr. of Cultural Sciences, Professor Philology Sciences

Tripolskay T. A., Dr. of Philological Sciences, Prof.

\section{International Editorial Council}

Aizman O., Ph.D., M.D., Karolinska Institute, (Stockholm, Sweden);

Angelica Rieger, Dr., Professor (Aachen, Germany)

Anna Paola Bonola, Professor Università Cattolica del Sacro Cuore (Milan, Italy)

Balgimbekov Sh.A., Dr. of Medical Sciences, Professor (Almaty, Kazakhstan)

Buhtova B., Ph.D., Masaryk University (Brno, Czech Republic)

Chagin A., Ph.D., Karolinska Institute (Stockholm, Sweden)

Charles S. Wingo, M. D., Professor, University of Florida (Gainesville, Florida, USA)

Gianni Celsi, Ph.D., Professor, Uppsala University, (Uppsala, Sweden)

Logunov D., Ph.D., University of Manchester

(Manchester, United Kingdom)

Mukataeva Zh.M., Dr. of Biological Sciences

(Pavlodar, Kazakhstan)

Walkenhorst Philipp, Dr., Professor, University of Cologne (Cologne, Germany)

Šmajs Jozef, Dr. of Philosophy, Professor, Masaryk University (Brno, Czech Republic)

Yu Wen Li, Ph.D., Professor Peking University

(Peking, People's Republic of China)

\section{Editorial Council}

Chairman of Editorial Council

Gerasev A.D., Dr. of Biological Sc., Prof. (Novosibirsk)

Aftanas L.I., Dr. of Medical Sc., Prof., Acad. of RAMS (Novosibirsk)

Balikoev V.Z., Dr. of Economical Sc., Prof. (Novosibirsk) Bezrukih M.M., Dr. of Biological Sc., Prof. (Moscow) Berezhnova E.V., Dr. of Pedagogical Sc., Prof. (Moscow) Chupahin N.P.,Dr. of Philosophical Sc., Prof. (Tomsk) Fedorov V. I., Dr. of Biological Sc., Prof. (Novosibirsk) Galazhinsky E. V., Dr. of Psychological Sc., Professor, the academician of RAE (Tomsk)

Ivanova L.N., Dr. of Medical Sc, Prof., Academ. of RAS, Institute of Citology and Genetics (Novosibirsk)

Kazin E.M., Dr. of Biological Sc., the academician of IASHS, Professor (Kemerovo)

Klochko V.E., Dr. of Psychological Sc., Prof. (Tomsk) Knyazev N.A., Dr. of Philosophical Sc., Prof. (Kasnoyarsk) Kondakov I. V., Dr. of Philosophical Sc., Prof., Academ. of Russian Academy of Sciences (Moskow)

Krasnoryadstceva O.M., Dr. of Psychological Sciences, Professor (Tomsk)

Krivoshekov S.G., Dr. of Medical Sc., Prof. (Novosibirsk) Kudashov V.I., Dr. of Philosophical Sciences, Professor (Kasnoyarsk)

Medvedev M.A., Dr. of Medical Sc., Prof., the Academic. of RAMS, Institute of Medical Genetics (Tomsk, Russia)

Mokretsova L.A., Dr. of Pedagogical Sciences, Professor (Biysk, Russia)

Ovchinnikov Yu.E., Dr. of Physical and Mathematical

Sciences, Professor (Novosibirsk, Russia)

Pecherskaya T. I., Dr. of philological Sciences,

Professor (Novosibirsk, Russia)

Puzirev V.P., Dr. of Medical Sc., Prof., the Academician of RAMS, Institute of Medical Genetics (Tomsk, Russia)

Seryi A.V., Dr. of Psychological Sc., Prof. (Kemerovo)

Shoshenko K.A., Dr. of Medical Sc., Prof. (Novosibirsk)

Vinokurov Yu.I., Dr. of Geography Sc., Prof. (Barnaul)

Zhukotskaya Z.R., Dr. of Cultural Sciences, Professor

(Nizhnevartovsk)

Zhafyarov A.Zh., Dr. of Physical and Mathematical Sc., Prof., Corr.- Member of the RAE (Novosibirsk)

The journal leaves 6 times a year

The academic journal is established in 2011

Editorial publishing department: 630126, Novosibirsk, Vilyuiskaya, 28, r. 22 tel. 8 (383) 244-34-50 E-mail: vestnik@nspu.ru 
Вестник Новосибирского государственного педагогического университета Novosibirsk State Pedagogical University Bulletin

1(17) $2014 \quad$ www.vestnik.nspu.ru

ISSN 2226-3365

\section{СОДЕРЖАНИЕ}

\section{БИОЛОГИЧЕСКИЕ, ХИМИЧЕСКИЕ, МЕДИЦИНСКИЕ НАУКИ}

Айзман Р.И. (Новосибирск, Россия), Казин Э.М., Федоров А.И., Шинкаренко А.С. (Кемерово, Россия). Проблемы и задачи здоровьесберегающей деятельности в системе образования на современном этапе

\section{Мониторинг здоровья учащихся и здоровьесберегающей деятельности образовательного учреждения}

Быков Е.В., Маченко С.В., Кашицина К.А., Чипьшев А.В., Пугачева М.Е., Рязанщев А.В.

(Челябинск, Россия). Мониторинг психофизиологического и физического развития учащихся-участников интеллектуально-игрового всеобуча

Васина Е. В., Кошко Н. Н. (Кемерово, Россия). Адаптация подростков в процессе обучения по разным профильным программам

Михайлова Л.А., Кимяева С.И. (Красноярск, Россия). Влияние двигательного режима на гемодинамические показатели у старшеклассников, имеющих повышенные учебные нагрузки

Мукатаева Ж.М., Кабиева С.Ж. (Павлодар, Казахстан). Мониторинг физического развития и здоровья учащихся Павлодарской области

Панкова Н.Б. (Москва, Россия). Методология саногенетического мониторинга функционального состояния организма учащихся и спортсменов ....

Шилов С.Н., Солдатова О.Г., Наливайко Н.Д. (Красноярск, Россия). Темпераментальные черты личности ребенка, как фактор, определяющий резерв здоровья

Судоргина Л.В. (Новосибирск, Россия). Комплексная оценка здоровьесберегающей деятельности современного общеобразовательного учреждения

Физическое и психическое здоровье студентов и педагогов

Кабачкова А.В., Капилевич Л.В. (Томск, Россия). Мониторинг здоровья студентов вуза: организационные и методические проблемы

Барбараш Н. А., Кувиинов Д. Ю. (Кемерово, Россия). Двадцатилетний опыт поведенческой коррекции здоровья у студентов-медиков

Лебедев А. В., Рубанович В. Б., Айзман Н. И., Айзман Р. И. (Новосибирск, Россия).

Морфо-функциональные особенности студентов первого курса педагогического вуза .........

Будук-оол Л.К., Сарыл С.К., Ховальгг А.М. (Кызыл, Россия). Психофизиологические характеристики студентов-тувинцев с разными социотипами

Жомин К.М., Рубанович В.Б. (Новосибирск, Россия). Морфофункциональные особенности девушек в зависимости от уровня двигательной активности в процессе обучения в вузе ......

Попова М.А., Говорухина А.А., Дронь А.Ю., Новоселов А.А. (Сургут, Россия). Мониторинг функционального состояния педагогов, проживающих на Севере 
Вестник Новосибирского государственного педагогического университета Novosibirsk State Pedagogical University Bulletin

Ханна Либерска (Быдгощ, Польша), Марзана Фарниска (Зелена Гора, Польша).

Влияние различных факторов на здоровье человека

Кудря О.Н. (Омск, Россия). Оценка функционального состояния и физической подготовленности спортсменов по показателям вариабельности сердечного ритма

Мельникова М.М. (Новосибирск, Россия). Несбалансированное питание как фактор риска развития алиментарно-зависимых заболеваний

Иглина Н.Г., Мазур С.В. (Новосибирск, Россия). Факторы риска в развитии гестоза у пациенток дневного стационара МАУЗ «Городская поликлиника № 1» г.Новосибирска .......

Хайбуллина 3.Р., Собиржанова Ч.К. (Ташкент, Узбекистан). Некоторые аспекты действия сверхмалых доз антиоксидантов при экспериментальной гипоксии плода …..................

Мамадалиева Н.И., Саатов Т.С., Хайбуллина 3.Р., Умеров О.И. (Таикент, Узбекистан). Влияние фармакокоррекции на активность ферментов защиты от активных форм кислорода в сердце при адаптации к гипоксии различной интенсивности и длительности ....

\section{Экспертный совет}

Айзман Р.И. (Новосибирск, Россия) - доктор биологических наук, профессор, заслуженный деятель науки РФ, зав. кафедрой анатомии, физиологии и безопасности жизнедеятельности, Новосибирский государственный педагогический университет.

Рубанович В.Б. (Новосибирск, Россия) - доктор медицинских наук, профессор, кафедра физического воспитания, Новосибирский государственный педагогический университет.

Карганов М.Ю. (Москва, Россия) - доктор биологических наук, профессор, зав. лабораторией полисистемных исследований НИИ общей патологии и патофизиологии РАМН;

Елисеев Е.В. (Челябинск, Россия) - доктор биологических наук, профессор, зав. кафедрой физического воспитания и спорта Челябинского государственного университета;

Казин Э. М. (Кемерово, Россия) - доктор биологических наук, профессор, заслуженный деятель науки РФ, зав. кафедрой физиологии человека и валеологии, Кемеровский государственный университет. 
Вестник Новосибирского государственного педагогического университета Novosibirsk State Pedagogical University Bulletin

1(17) $2014 \quad$ www.vestnik.nspu.ru ISSN 2226-3365

\section{CONTENTS}

\section{BIOLOGICAL, CHEMICAL SCIENCES AND MEDICINE}

Aizman R. I. (Novosibirsk,_Russia), Kazin E. M., Fedorov A. I., Shinkarenko A. S. (Kemerovo, Russia). Problems and aims of health care activity in the education system at the present stage

\section{Monitoring the health of students and health-activity educational institution}

Bykov E. V., Matsenko S. V., Kashitsina K. A., Chipyshev A. V., Pugacheva M. E., Ryazantsev A.V. (Chelyabinsk, Russia). Monitoring of psychophysiological and physical development of participating students of the intellectual game-universal education

Vasina T. V., Koshko N. N. (Kemerovo, Russia). Adaptation of teenagers in the course of training according to different profile programs

Mikhaylova L. A., Kimyaeva S. I. (Krasnoyarsk, Russia). Influence of the motive mode on haemo dynamic indicators of the seniors having raised academic loads

Mukataeva Zh. M., Kabieva S. Zh. (Pavlodar, Kazakhstan). Monitoring of physical development and health of pupils of the Pavlodar region

Pankova N. B. (Moscow, Russia). Methodology for sanogenetic monitoring of functional state of students's and athletes's health

Shilov S. N., Soldatov O. G., Nalivayko N. D. (Krasnoyarsk, Russia). Temperamental personality traits of the child as a factor determining reserve health

Sudorgina L. V. (Novosibirsk). Complex estimation health protection activity of modern educational establishment

Physical and mental health of students and teachers

Kabachkova A. V., Kapilevich L. V. (Tomsk, Russia).Monitoring of students' health: organizational and methodical problems

Barbarash N. A., Kuvshinov D. Yu. (Kemerovo, Russia). Twenty years' experience of behavioral correction of health of medical students

Lebedev A. V., Rubanovich V. B., Aizman N. I., Aizman R. I. (Novosibirsk, Russia).

Morphofunctional features of first-year students of pedagogical university

Buduk-ool L. K., Saryg S. K. Khovalyg A. M. (Kyzyl, Russia). Psychophysiological characteristics of Tuvinian students with different social types

Zhomin K. M., Rubanovich V. B. (Novosibirsk, Russia). Morphofunctional features of girls depending on the level of physical activity during university education

Popova M. A., Govoruchina A. A., Dron A. Y. (Surgut, Russia). Monitoring of the functional condition of the teachers living in the north

Hanna Liberska (Bydgoszcz, Poland), Marzanna Farnicka (Zielona Gora, Poland).

The sense of well-being of women involved in lifelong education 
The influence of various factors on human health

Kudrya O. N. (Omsk, Russia). Evaluation of functional state and physical preparedness of athletes on indicators of the heart rate variability

Mel'niкоva M. M. (Novosibirsk, Russia). Unbalanced nutrition as risk factor of alimentary-dependent diseases

Iglina N. G., Masur S. V. (Novosibirsk, Russia). Risk factors of gestational toxicosis developing of patients of city hospital number 1of Novosibirsk

Khaybullina Z. R., Sobirjanova Ch. K. (Tashkent, Uzbekistan). Ultra low concentrations of antioxidants at experimental hypoxia of fetus - some aspects of action mechanism .........

Mamadalyeva N. I., Saatov T. S., Khaybullina Z. R., Umerov O. I. (Tashkent, Uzbekistan).

Activity of the reactive oxygen species scavenger enzymes in the heart tissues after pharmacological correction of hypoxia of various intensity and duration

\section{Expert Board}

Aizman Roman Idelevich, Sc.D., the professor, the head of the department of anatomy, physiology and life safety, Novosibirsk State Pedagogical University.

Rubanovich Viktor Borisovich, MD, the professor of the department of anatomy, physiology and life safety, Novosibirsk State Pedagogical University.

Kazin Eduard Mihailovich, the doctor of biological sciences, the professor, the head of department of physiology and valeology, Kemerovo State University.

Karganov M. Yu., the doctor of biological sciences, the professor, the head of department of polysystem research and valeology, Institute of General Pathology and Pathophysiology RAMS.

Eliseev E. V., the doctor of biological sciences, the professor, the head of department of physical education and sport, Chelyabinsk State University. 


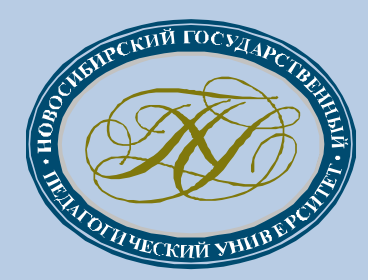

www.vestnik.nspu.ru

\section{БИОЛОГИЧЕСКИЕ, ХИМИЧЕСКИЕ, МЕДИЦИНСКИЕ НАУКИ}


Вестник Новосибирского государственного педагогического университета Novosibirsk State Pedagogical University Bulletin

1(17) $2014 \quad$ www.vestnik.nspu.ru ISSN 2226-3365

(C) Р. И. Айзман, Э. М. Казин, А. И. Федоров, А. С. Шинкаренко

УДК $373.3+614$

\title{
ПРОБЛЕМЫ И ЗАДАЧИ ЗДОРОВЬЕСБЕРЕГАЮЩЕЙ ДЕЯТЕЛЬНОСТИ В СИСТЕМЕ ОБРАЗОВАНИЯ НА СОВРЕМЕННОМ ЭТАПЕ*
}

\author{
Р. И. Айзман (Новосибирск, Россия), Э. М. Казин, А. И. Федоров, \\ А. С. Шинкаренко (Кемерово, Россия)
}

В статье рассматриваются основные проблемы здоровьесберегающей деятельности в системе образования: низкий уровень профессиональной компетентности педагогических работников, научно-методической, материально-технической, информационной базы; неудовлетворительное использование здоровьесберегающего потенциала ряда образовательных программ; отсутствие механизма ведомственного и межведомственного сотрудничества, неразвитость нормативно-правовой базы. Ставятся неотложные задачи по решению этих проблем и определяются основные направления деятельности созданного координационного совета по вопросам здоровья обучающихся и педагогов в рамках Экспертного Совета по вопросам здоровья и физического воспитания обучаюшихся при Комитете по образованию Госдумы РФ. В статье излагаются итоги межрегионального координационного совещания в г. Кемерово (14-15 октября 2013 г.), посвященные этим вопросам.

Ключевые слова: здоровьесберегающая деятельность, система образования, межрегиональный координационный совет.

* Статья подготовлена по результатам работы Всероссийской научной школы с Международным участием «Опыт использования мониторинга здоровья и физической подготовленности учащейся молодежи» (12-14 ноября 2013 г.).

Айзман Роман Иделевич - доктор биологических наук, профессор, заслуженный деятель науки РФ, заведующий кафедрой анатомии, физиологии и безопасности жизнедеятельности, Новосибирский государственный педагогический университет.

E-mail: roman.aizman@mail.ru

Казин Эдуард Михайлович - доктор биологических наук, профессор, заслуженный деятель науки РФ, заведующий кафедрой физиологии человека и валеологии, Кемеровский государственный университет.

E-mail: valeol@kemsu.ru

Федоров Андрей Иванович - доктор биологических наук, профессор, директор, Кемеровский областной психолого-валеологический центр.

E-mail: opvc@mail.ru

Шинкаренко Андрей Семенович - аспирант кафедры педагогики, Кемеровский государственный университет.

E-mail: valeol@kemsu.ru 

Novosibirsk State Pedagogical University Bulletin

Состояние физического, психического и духовно-нравственного здоровья участников образовательного процесса остается в числе актуальных проблем отечественного образования $[1 ; 6 ; 10]$. На здоровье обучающихся, помимо организационных, социальноэкономических и климато-географических факторов, негативное влияние оказывает и целый ряд других компонентов, связанных с процессом обучения: высокая интенсивность образовательного прочесса, низкая физическая активность обучающихся, несоблюдение требований СанПиН, несбалансированное питание, неэффективная организаџия учебной деятельности, отсутствие медикопсихолого-педагогического сопровождения образовательного процесса и др. [7].

Система образования испытывает следующие трудности в организации деятельности по сохранению и укреплению здоровья обучающихся в образовательных организациях:

- низкий уровень профессиональной компетентности педагогических работников, научно-методической, материально-технической, информационной обеспеченности деятельности по сохранению и укреплению здоровья обучающихся;

- неудовлетворительное использование здоровьесберегающего потенциала содержания ряда образовательных программ (биология, химия, физика, русский язык и литература, физическая культура, основы безопасности жизнедеятельности, музыка и др.);

- отсутствие механизма ведомственного и межведомственного сотрудничества в сохранении и укреплении здоровья обучающихся;
- недостаточное включение в систему образовательных организаций организационно-управленческих структур и механизмов, обеспечивающих результативность деятельности по сохранению и укреплению здоровья обучающихся;

- несовершенство нормативно-правовой базы, регулирующей осуществление здоровьесберегающей деятельности в образовательных организациях [8-9].

Не случайно анализ состояния здоровья обучающихся в условиях различных образовательных организаций свидетельствует о тенденции снижения уровня здоровья детей и подростков. Президент Российской Федерации В. В. Путин 13 марта 2013 г. в своем выступлении отметил: «Мы сталкиваемся с крайне тревожными тенденциями: в 14 лет две трети детей России уже имеют хронические заболевания, у половины - нарушения в сердечно-сосудистой и дыхательной системах; до 40 \% призывников не в состоянии выполнить минимальные нормативы физической подготовки военнослужащих». Не лучше ситуация со здоровьем студентов - до $80 \%$ имеют низкие резервы физического и психического потенциала.

В соответствии с Концепцией долгосрочного социально-экономического развития Российской Федерации на период до 2020 г.; Национальной образовательной инициативой «Наша новая школа», Указами Президента Российской Федерации № 598 от 7 мая 2012 г. «О совершенствовании государственной политики в сфере здравоохранения», № 606 от 7 мая 2012 г. «О мерах по реализации демографической политики Российской Федерации», № 761 от 1 июня 2012 г. «О Национальной стратегии действий в интересах детей на 2012-2017 годы», государственной про- 
Вестник Новосибирского государственного педагогического университета Novosibirsk State Pedagogical University Bulletin

граммой Российской Федерации «Развитие образования» на 2013-2020 годы; приказом Минобрнауки РФ от 28 декабря 2010 г. № 2106 «Об утверждении федеральных требований к образовательным учреждениям в части охраны здоровья обучающихся, воспитанников», Федеральным законом «Об образовании в РФ» от 26 декабря 2012 г., Федеральными государственными образовательными стандартами дошкольного, общего и профессионального образования актуальными задачами являются: формирование экологической культуры, здорового и безопасного образа жизни у обучающихся; возрождение и сохранение духовно-нравственных, гражданских традиций и семейных ценностей; совершенствование и повышение результативности реализуемых программ профилактики аддикций, развитие физической культуры и спорта [1].

Решение данной задачи предполагает:

- создание адаптивно-развивающей и безопасной среды в образовательных организачиях;

- подготовку, переподготовку и регулярное повышение квалификации педагогических и управленческих кадров;

- укрепление межведомственного взаимодействия в развитии научноисследовательской деятельности и практическом выполнении мониторинговых исследований, а также содействие в разработке их нормативного $и$ аппаратно-программного обеспечения, методическом сопровождении деятельности образовательных организаций в области здоровьесбережения;

- включение организационно-управленческих, структур и механизмов, обеспечивающих результативность деятельности образовательных организаций по сохранению и укреплению здоровья обучающихся.

В этой связи предъявляются новые требования к профессиональным компетенциям педагогов и специалистов системы образования, перед которыми встали задачи разработки образовательных программ, формирования универсальных учебных действий, осуществления психолого-педагогического сопровождения обучающихся и воспитанников, эффективного управления всей деятельностью по сохранению и укреплению здоровья субъектов образовательного процесса [2-3; 5].

Целью здоровьесбережения участников образовательного прочесса является содействие образовательным организачиям в обеспечении достижения личностных, метапредметных, предметных результатов образовательной деятельности в соответствии с требованияли ФГОС, создании условий для сохранения и укрепления здоровья детей, полноценного личностного развития обучающихся и воспитанников с учетом их индивидуальных возможностей и особенностей.

Задачи здоровьесберегающей деятельности в системе образования:

- создать условия для сохранения и укрепления здоровья, личностного, интеллектуального, социального развития обучающихся, воспитанников и других участников образовательного процесса;

- проводить диагностику и мониторинговые исследования уровня физического и психического развития, сформированности культуры здоровья и безопасного образа жизни, состояния образовательной среды;

- осуществлять комплексную психолого-педагогическую и медико-социальную помощь и поддержку обучающимся, воспитанникам, их родителям, педагогическому коллективу, администрации образовательной 
Вестник Новосибирского государственного педагогического университета Novosibirsk State Pedagogical University Bulletin

1(17) $2014 \quad$ www.vestnik.nspu.ru $\quad$ ISSN 2226-3365

организации по выявлению, профилактике и преодолению отклонений в развитии, обучении и социализации ребенка в процессе реализации ФГОС;

- осуществлять просветительскую деятельность по развитию культуры здорового и безопасного образа жизни;

- способствовать распространению и внедрению в практику образовательных организаций новейших достижений в области отечественной и зарубежной психологии, педагогики, физиологии с целью повышения эффективности реализации ФГОС.

Таким образом, здоровье выпускников школы становится одним из важных показателей качества школьного образования [1; 4].

Теоретический и организационнопрактический опыт, накопленный в ряде регионов РФ, позволяет говорить о необходимости формирования адаптивно-развивающей и безопасной образовательной среды, которую можно определить как совокупность организачионно-педагогических условий и психолого-физиологических факторов, способствующих реализащии приспособительных возможностей индивидуума, сохранению $и$ укреплению духовно-нравственного, психического и физического здоровья обучаюшихся $и$ предупреждению аддиктивного поведения.

С позиций системно-деятельностного, онтогенетического и компетентностного подходов цели образования, направленные на сохранение и укрепление здоровья, увеличение приспособительных возможностей организма и развитие здоровой личности можно охарактеризовать достаточно четко: развитие природных возможностей и психофизиологических способностей личности в различные периоды онтогенеза; обеспечение физического и личностного становления, сочииального созревания; содействие нравственному, фи- зическому самосовершенствованию и профессиональному самоопределению учащчихся стариих классов, формирование и развитие социально-профессиональных компетенций студентов и педагогов $[1 ; 9]$.

Одной из важнейших составляющих в структуре профессиональной культуры педагога является здоровьесберегающая компетентность, требующая постоянного углубления медико-биологических и психологопедагогических знаний, навыков рациональной организации образовательного процесса, формирования установок на здоровый и безопасный образ жизни.

Отношение к здоровью как к целостному многомерному феномену позволяет выделить пять основных критериев результативности здоровьесберегающей деятельности: мотивационно-ценностный, когнитивный, эмоционально-волевой, инструментальнодеятельностный и адаптивно-ресурсный.

На основе вышеуказанных критериев могут быть разработаны и апробированы следующие основные направления оценки эффективности здоровьесберегающей деятельности образовательных учреждений:

- динамика состояния физического и психического здоровья, физической подготовленности, функционального состояния и резервов организма;

- уровень готовности индивида к ведению здорового и безопасного образа жизни, выбору профиля обучения с учетом индивидуально-типологических особенностей субъектов образовательного прочесса, устойчивость к различным видам аддикиุйі;

- уровень готовности педагогов к здоровьесберегающей деятельности и сформированность адаптивно-развивающей образовательной среды. 
Вестник Новосибирского государственного педагогического университета Novosibirsk State Pedagogical University Bulletin

1(17) $2014 \quad$ www.vestnik.nspu.ru $\quad$ ISSN 2226-3365

В связи с этим необходима интеграция дошкольного, общего, профессионального, послевузовского и дополнительного образования, которая позволяет реализовать непрерывное здоровьесберегающее сопровождение образовательного процесса.

В настоящее время в ряде регионов РФ (Кемеровская, Новосибирская, Ростовская, Челябинская, Омская, Московская, Белгородская области и др.) разработаны и внедрены различные подходы, направленные на реализацию здоровьесберегающей деятельности в образовании и оценку ее эффективности, в частности система психолого-валеологических центров, методика комплексного мониторинга показателей индивидуального здоровья и адаптации субъектов образовательного процесса, электронный паспорт здоровья, саногенетический мониторинг и др.

Однако здоровьесберегающая деятельность в системе образования имеет разрозненный характер, отсутствует координация деятельности по здоровьесбережению как на федеральном, так и на межрегиональном уровнях, слабая преемственность подходов, используемых на разных образовательных уровнях, неразработан единый научнометодический подход к критериям оценки эффективности здоровьесберегающей деятельности в сфере образования.

Таким образом, актуализируется необходимость создания в стране механизма межрегиональной координации деятельности образовательных организаций, позволяющего реализовать систему непрерывного здоровьесберегающего и безопасного сопровождения образовательного процесса на всех этапах обучения.

В этой связи проведение регулярных встреч представителей вузовской и академической науки с целью выработки общих взглядов и решений, подготовка новых кадров в области здоровьесбережения является важным шагом в решении поставленных задач. Проведенное в октябре 2013 г. межрегиональное координационное совещание в г. Кемерово привело к созданию межрегионального координационного совета по вопросам здоровья обучающихся и педагогов в рамках Экспертного Совета по вопросам здоровья и физического воспитания обучающихся при Комитете по образованию Госдумы РФ; Общероссийской общественной организации содействия укреплению здоровья в системе образования.

В рамках его деятельности планируется:

- провести анализ и обобщение существующих методических подходов и технологий, направленных на обеспечение здоровьесберегающей деятельности образовательных организаций;

- создать банк инновационных программ и технологий, распространить передовой опыт в области здоровьесберегающей деятельности образовательных организаций;

- осуществить отбор критериев эффективности здоровьесберегающей деятельности образовательных организаций;

- рекомендовать к внедрению программы дополнительного профессионального образования и профессиональной переподготовки по различным аспектам здоровьесберегающей деятельности;

- $\quad$ подготовить пакет предложений для Экспертного Совета по вопросам здоровья и физического воспитания, обучающихся при Комитете по образованию Госдумы РФ, Госдумы, Правительства, Минобрнауки, Минздрава, Минспорта РФ, руководителей органов исполнительной власти субъектов РФ и руководителей организаций образования по вопросам содействия здоровьесберегающей деятельности образовательных организаций; 
Вестник Новосибирского государственного педагогического университета Novosibirsk State Pedagogical University Bulletin

1(17) $2014 \quad$ www.vestnik.nspu.ru $\quad$ ISSN 2226-3365

- стимулировать разработку на конкурсной основе инновационных проектов, направленных на различные аспекты здоровьесберегающей деятельности;

- привлечь внимание общественности и средств массовой информации к проблеме сохранения и укрепления здоровья подрастающего поколения;

- в рамках Экспертного Совета по вопросам здоровья и физического воспитания, обучающихся при Комитете по образованию Госдумы РФ создать информационноресурсный портал «Здоровьесберегающее образование»;

- c целью анализа и интеграции накопленного опыта под патронажем межрегионального координационного совета «Куль- тура здоровья и безопасного образа жизни» организовать ежегодное проведение различных форм научно-практических мероприятий (школы, конференции, совещания, форумы и т. д.) по проблемам здоровья.

Международная научная школа-семинар «Опыт использования мониторинга здоровья учащейся молодежи», которая проводится 12-16 ноября 2013 г. на базе НГПУ, продолжит решение вопросов, поднятых в настоящей статье. Публикуемые в этом номере журнала статьи позволят подвести некоторые итоги мониторинговой деятельности образовательных учреждений разного уровня в области здоровьесбережения и расширить географию участников данного межрегионального проекта.

\section{СПИСОК ЛИТЕРАТУРЫ}

1. Айзман Р.И. Здоровье педагогов и обучающихся - ключевая задача современной школы // Вестник Новосибирского государственного педагогического университета. - 2012. № 3(7). - С. 24-35.

2. Айзман Р.И., Айзман Н.И., Лебедев А.В., Плетнёва Е.Ю., Рубанович В.Б. Мониторинг здоровья учащихся и педагогов с применением компьютера и программных средств // Народное образование. - 2010. - № 6. - С.147-155.

3. Айзман Р.И., Айзман Н.И., Лебедев А.В., Рубанович В.Б. Компьютерная программа скрининг контроля состояния здоровья участников образовательного процесса // Сибирский учитель. - 2011. - № 2(75). - С. 36-39.

4. Айзман Р.И. Мельникова М., Косованова Л. Скрининг-диагностика здоровья школьников и студентов. Организация оздоровительной работы в образовательных учреждениях. - LAP LAMBERT Academic Publishing GmbH \& Co. KG, 2011. - 239 c.

5. Айзман Р.И., Плетнёва Е.Ю. Роль учителя в формировании и мониторинге здоровья обучающихся // Здоровьесберегающее образование. - 2010. - № 5(9). - С. 93-99.

6. Айзман Р.И., Рубанович В.Б., Суботялов М.А. Основы медицинских знаний и здорового образа жизни: учебное пособие. - Новосибирск, 2010. - 286 с.

7. Безруких М.М. Школьные факторы риска и здоровье детей // Магистр. - 1999. - № 3. C. $30-38$.

8. Казин Э. М., Касаткина Н. Э., Руднева Е. Л. и др. Здоровьесберегающая деятельность в системе образования: теория и практика: учебное пособие / 3-е изд., перераб. - М.: Издательство «Омега-Л», 2013. - 443 с.

9. Казин Э.М., Працун Э.В., Краношлыкова О.Г., Федоров А.И. Формирование здоровьесберегающей компетентности педагогов в инфраструктуре образовательных учреждений 
Вестник Новосибирского государственного педагогического университета Novosibirsk State Pedagogical University Bulletin

1(17) 2014 www.vestnik.nspu.ru

ISSN 2226-3365

(методологические и организационно-педагогические аспекты) // Валеология. - 2013. № 3. - С. 38-44.

10.Рубанович В.Б., Айзман Р.И. Основы здорового образа жизни: учебное пособие. - Новосибирск: АРТА, 2011. - 256 с. 
Вестник Новосибирского государственного педагогического университета Novosibirsk State Pedagogical University Bulletin

1(17) $2014 \quad$ www.vestnik.nspu.ru ISSN 2226-3365

(C) R. I Aizman, E. M. Kazin, A. I. Fedorov, A. S. Shinkarenko

UDC $373.3+614$

\title{
PROBLEMS AND AIMS OF HEALTH CARE ACTIVITY IN THE EDUCATION SYSTEM AT THE PRESENT STAGE
}

\author{
R. I Aizman (Novosibirsk,_Russia), E. M. Kazin, A. I. Fedorov, \\ A. S. Shinkarenko (Kemerovo, Russia)
}

In article the main problems of health care activity in an education system, such as: low level of professional competence of pedagogical workers and scientifically-methodical, material, information base; unsatisfactory use of health care activity - potential of some educational programs; absence of the mechanism of departmental and interdepartmental - cooperation, backwardness of standardlegal base are considered.

Urgent problems for the decision of these problems are put and the basic directions of activity of the created coordination council on health of pupils and teachers within the frame of Advisory council on health and physical training of the State Duma of the Russian Federation at Committee of Education are defined. In article results of inter-regional coordination meeting in Kemerovo (on October, 14-15th, 2013), devoted to solution of these problems are stated.

Keywords: health care activity, an education system, inter-regional coordination council.

\section{REFERENCES}

1. Aizman R.I. Zdorov'e pedagogov i obuchayushchikhsya - klyuchevaya zadacha sovremennoi shkoly [Health of teachers and pupils - a key problem of modern school]. The Bulletin of Novosibirsk State Pedagogical University, 2012, vol. 7, no. 3, pp. 24-35.

2. Aizman R.I., Aizman N.I., Lebedev A.V., Pletneva E.Yu., Rubanovich V.B. Monitoring zdorov'ya uchashchikhsya i pedagogov s primeneniem komp'yutera i programmnykh sredstv [Monitoring of health of pupils and teachers with application of a computer and software]. National education, 2010, no. 6, pp. 147-155.

3. Aizman R.I., Aizman N.I., Lebedev A.V., Rubanovich V. B. Komp'yuternaya programma skrining kontrolya sostoyaniya zdorov'ya uchastnikov obrazovatel'nogo protsessa [The computer program of the screening control of a state of health of participants of educational process]. Siberian teacher, 2011, vol. 75, no. 2, pp. 36-39.

4. Aizman R. I., Mel'nikova M., Kosovanova L. Skrining-diagnostika zdorov'ya shkol'nikov i studentov. Organizatsiya ozdorovitel'noi raboty v obrazovatel'nykh uchrezhdeniyakh [Screeningdiagnostics of health of schoolboys and students. The organisation of improving work in educational organizations]. LAP LAMBERT Academic Publishing GmbH and Co. KG, 2011, $239 \mathrm{p}$.

5. Aizman R. I., Pletneva E. Yu. Rol' uchitelya $v$ formirovanii i monitoringe zdorov'ya obuchayushchikhsya [Role of the teacher in formation and monitoring of health of the students]. Healthcare Education, 2010, vol. 9, no. 5, pp. 93-99. 
6. Aizman R.I., Rubanovich V.B., Subotyalov M. A. Osnovy meditsinskikh znanii i zdorovogo obraza zhizni: uchebnoe posobie [Bases of medical knowledge and healthy way of life]. Novosibirsk, 2010, $286 \mathrm{p}$.

7. Bezrukih M. M. Shkol'nye faktory riska i zdorov'e detei [Shool risk factors and health of children]. The Magister, 1999, no. 3, pp. 30-38.

8. Kazin Э. M., Kasatkina D. C., Rudneva E. L., etc. Zdorov'esberegayushchaya deyatel'nost' v sisteme obrazovaniya: teoriya i praktika: uchebnoe posobie [Healthcare activity in an education system: the theory and practice: the manual]. Moscow, Publishing house "Omega-l", 2013, 443 p.

9. Kazin E. M., Pratsun E. V., Kranoshlykova O. G., Fedorov A. I. Formirovanie zdorov'esberegayushchei kompetentnosti pedagogov $\mathrm{V}$ infra-strukture obrazovatel'nykh uchrezhdenii (metodologicheskie i organizatsi-onno-pedagogicheskie aspekty) [Formation of healthcare competence of teachers in an infrastructure of educational institutions (methodological and organizational-pedagogical aspects)]. Valeology, 2013, no. 3, pp. 38-44.

10. Rubanovich V.B., Aizman R.I. Osnovy zdorovogo obraza zhizni: uchebnoe posobie [Bases of a healthy way of life]. Novosibirsk, 2011, 256 p.

Aizman Roman Idelevich, the doctor of biological sciences, the professor, the head of department of anatomy, physiology and safety of life, Novosibirsk State Pedagogical University.

E-mail: roman.aizman@mail.ru

Kazin Eduard Mihailovich, the doctor of biological sciences, the professor, the head of department of physiology and valeology, Kemerovo State University.

E-mail: valeol@kemsu.ru

Fedorov Andrey Ivanovich, the doctor of biological sciences, the professor, the head, Kemerovo State Phycology Center.

E-mail: opvc@mail.ru

Shinkarenko Andrey Semenovich, the post-graduate student of department of pedagogical sciences,

Kemerovo State University.

E-mail:valeol@kemsu.ru 


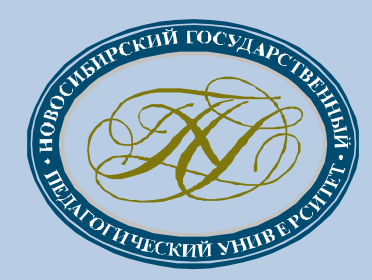

www.vestnik.nspu.ru

\section{БИОЛОГИЧЕСКИЕ, ХИМИЧЕСКИЕ, МЕДИЦИНСКИЕ НАУКИ}

Мониторинг здоровья учащихся и здоровьесберегающей деятельности образовательного учреждения 
Вестник Новосибирского государственного педагогического университета Novosibirsk State Pedagogical University Bulletin

(C) Е. В. Быков, С. В. Маценко, К. А. Кашищина, А. В. Чипышев, М. Е. Пугачева, А. В. Рязанцев

УДК $612.66+612.063+371.7$

\title{
МОНИТОРИНГ ПСИХОФИЗИОЛОГИЧЕСКОГО И ФИЗИЧЕСКОГО РАЗВИТИЯ УЧАЩИХСЯ-УЧАСТНИКОВ ИНТЕЛЛЕКТУАЛЬНО-ИГРОВОГО ВСЕОБУЧА*
}

\author{
E. В. Быков, С. В. Маценко, К. А. Кашищина, А. В. Чипьшев, \\ М. Е. Пугачева, А. В. Рязанцев (Челябинск, Россия)
}

Обучение шахматам учащихся младших классов проводится во многих странах мира, но комплексной физиологической оценки «иены» адаптации к повыменным умственным нагрузкам не проводилось. Нами было проведено изучение особенностей физического и психофизиологического развития, состояния здоровья учащихся младших и средних классов школ 2. Челябинска, участвующих в программе шахматного всеобуча. Выявлено, что во всех возрастных группах преобладают ученики со средним уровнем физического развития; от пер-

* Статья подготовлена по результатам работы Всероссийской научной школы с Международным участием «Опыт использования мониторинга здоровья и физической подготовленности учащейся молодежи» (12-14 ноября 2013 г.).

Быков Евгений Витальевич - доктор медицинских наук, профессор, заведующий кафедрой спортивной медицины и физической реабилитации, Уральский государственный университет физической культуры.

E-mail: bev58@yandex.ru

Маценко Сергей Вадимович - аспирант кафедры адаптивной физической культуры и медикобиологической подготовки, Южно-Уральский государственный университет.

E-mail: noobie90@yandex.ru

Кашицина Ксения Анатольевна - аспирант кафедры адаптивной физической культуры и медико-биологической подготовки, Южно-Уральский государственный университет.

E-mail: marafon4219@yandex.ru

Чипышев Антон Викторович - кандидат биологических наук, доцент кафедры адаптивной физической культуры и медико-биологической подготовки, Южно-Уральский государственный университет.

E-mail: jk_m@bk.ru

Пугачева Мария Евгеньевна - аспирант кафедры адаптивной физической культуры и медико-биологической подготовки, Южно-Уральский государственный университет.

E-mail: puga4eva.me@yandex.ru

Рязанцев Александр Владимирович - кандидат биологических наук, тренер сборной России по шахматам.

E-mail: gm_riazantsev@rambler.ru 
Вестник Новосибирского государственного педагогического университета Novosibirsk State Pedagogical University Bulletin

1(17) $2014 \quad$ www.vestnik.nspu.ru ISSN 2226-3365

вого к четвертому классу увеличивается на $5 \%$ количество мальчиков с «высоким уровнем» длины тела и уровнем массы тела ниже среднего, на 7 \% - девочек с уровнем массы тела ниже среднего, а количество девочек с уровнем массы тела выше среднего - на 5 \%. В динамике обучения в младших классах произошло уменьшение с 23,3-23,9 \% до 13,7-14,1\% мальчиков и девочек, отнесенных к первой группе здоровья.

Учашчеся обоего пола, занимающиеся по программе шахматного всеобуча свыше 3 лет, более адаптированы к обучению в школе: имели повышение гуморально-метаболических факторов регуляции при умственной нагрузке (в группе контроля выявлена симпатикотоническая реакция), у них более высокие показатели в тестах “Оценка внимания» и «Помехоустойчивость», успеваемости по предметам «математика» и «информатика», однако, выше показатели заболеваемости, больше число лиц с признаками вегетативных изменений (45 \%), что требует разработки требует и проведения коррекционных мероприятий.

Ключевые слова: учашчиеся, адаптаџия, умственные нагрузки, вариабельность ритма сердиа, психофизиологическое и физическое развитие.

\section{Актуальность проблемы.}

Обучение в школе - один из наиболее стрессогенных периодов жизнедеятельности человека, когда на формирующиеся механизмы мозгового обеспечения познавательной деятельности детей и подростков существенное влияние оказывает повышенный уровень информационной составляющей, связанный с внедрением инновационных педагогических технологий, интенсификацией умственных нагрузок (дополнительные занятия, секции, кружки), компьютеризацией образовательного процесса в условиях перехода на новые стандарты обучения в общеобразовательной школе $[1 ; 2$, с. $74 ; 3 ; 4$, с. $214 ; 5$, с. $144 ; 6-7 ; 8$, с. $75 ; 9$, с. 8 и др.].

Влияние внедряемых инновационных программ далеко не всегда физиологически обосновано, не изучается «цена» адаптации к повышенным умственным нагрузкам, как в краткосрочном, так и долговременном аспекте. Так, во многих странах мира и в отдельных регионах России внедряется программа шахматного всеобуча, предполагается ее введение во всех общеобразовательных школах [10-12]. Тем не менее, проведенные к настоящему времени исследования посвящены в основном изучению психологических или пе- дагогических аспектов влияния повышенных интеллектуальных нагрузок при занятиях по программе шахматного всеобуча $[13$, с. 21; 14 , с. $155 ; 15$, с. 171$]$.

В то же время, данные о состоянии здоровья, физическом и психофизиологическом развитии детей, обучающихся по инновационным программам, разноречивы. Выявлено как ухудшение показателей $[9$, с. 8 ; 16, с. 76; 17 , с. $17 ; 18$, с. 248-249], так и отсутствие негативных изменений показателей [19, с. 58; 20, с. 183], либо преобладание средних значений показателей физического развития среди обследованной популяции учащихся [21, с. 64; 22, с. 121]. Так, по данным Е.В. Поповой $[17$, с. 17$]$ с $44 \%$ до $8 \%$ снизилось число детей предшкольного возраста с высоким уровнем интеллекта, для школьников 7-10 лет характерно недостаточное умение обобщать, а в 11-14 лет ею определен низкий уровень решения арифметических задач, свидетельствующий о недостаточной способности к формированию новых навыков. Достижение максимального эффекта как с точки достижения результатов педагогического процесса, так и с позиций сохранения и укрепления здоровья обучающихся различных возрастных групп возможно при органи- 
Вестник Новосибирского государственного педагогического университета Novosibirsk State Pedagogical University Bulletin

зации мониторинга, предполагающего интегративную диагностику текущего состояния, программирование и осуществление корректирующих мероприятий непосредственно в учреждениях образования [9, с. $8 ; 18$, с. 251 ; 23 , с. $15 ; 24$, с. $267 ; 26]$.

\section{Цель работы:}

изучить особенности физического и психофизиологического развития, состояния здоровья учащихся младших и средних классов, участвующих в программе интеллектуально-игрового (шахматного) всеобуча, связанных с влиянием на них повышенных умственных нагрузок.

\section{Организация и методы исследования.}

Нами на протяжении 8 лет осуществляется комплексное лонгитюдное исследование (мониторинг) показателей физического и психофизиологического развития учащихся младших и средних классов - участников программы интеллектуально-игрового (шахматного) всеобуча в г. Челябинске и юных шахматистов, включающее оценку морфометрических и функциональных показателей сердечно-сосудистой, центральной и вегетативной нервной системы детей и подростков в условиях покоя и при различных пробах: пробы активного ортостаза и Штанге; умственная нагрузка (УН) - устный счет - у учащихся 2-4-х классов - сложение, у 11летних учащихся и старше - умножение; степени выраженности вегетативных изменений; успеваемости (по классным журналам) и уровня заболеваемости на основе анализа медицинских карт. Основную группу составили со стажем занятий по программе шахматного всеобуча от 1 года до 5 лет; в группу контроля входят их сверстники.

Исследования проводятся на базе МОУ СОШ №67, 98 и № 100 г. Челябинска, детскоюношеской спортивной школы олимпийского резерва № 9 г. Челябинска и научных лабораториях кафедр адаптивной физической культуры и спорта Южно-Уральского государственного университета и спортивной медицины и физической реабилитации Уральского государственного университета физической культуры (г. Челябинск).

Оценка нейровегетативной регуляции системы кровообращения проведена при помощи сертифицированной компьютерной технологии «Кентавр» фирмы «Микролюкс» (г. Челябинск) (метод импедансной реографии). Оценка психологического состояния учащихся проведена с помощью методики диагностики уровня школьной тревожности Филипса, личностной шкалы проявления тревоги (Дж. Тейлор, адаптация Т.А. Немчинова), методики диагностики самочувствия, активности и настроения (опросник теста САН). Оценка нейродинамических характеристик проведена с помощью сертифицированного аппаратно-программного комплекса «HCПсихоТест» фирмы «Нейрософт» (г. Иваново).

\section{Результаты исследования.}

Уровень физического развития определяли совокупностью показателей, основанных на измерениях основных морфологических признаков: длины, массы тела, окружности грудной клетки (таблица 1). 
Вестник Новосибирского государственного педагогического университета Novosibirsk State Pedagogical University Bulletin
1(17) 2014
www.vestnik.nspu.ru
ISSN 2226-3365

Таблица 1

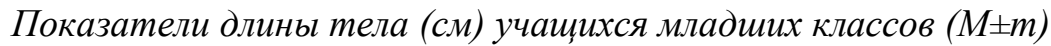

\begin{tabular}{|c|c|c|c|c|}
\hline $\begin{array}{c}\text { Возраст, } \\
\text { лет }\end{array}$ & Группа & Мальчики & Девочки & $\mathrm{p}$ \\
\hline \multirow{3}{*}{7} & осн. & $124,77 \pm 1,27$ & $125,02 \pm 1,24$ & $>0,05$ \\
\hline & контр. & $124,93 \pm 1,26$ & $125,07 \pm 1,25$ & $>0,05$ \\
\hline & $\mathrm{p}$ & $>0,05$ & $>0,05$ & \\
\hline \multirow{3}{*}{8} & осH. & $129,52 \pm 1,22$ & $128,61 \pm 1,13$ & $>0,05$ \\
\hline & контр. & $129,46 \pm 1,34$ & $128,85 \pm 1,18$ & $>0,05$ \\
\hline & $\mathrm{p}$ & $>0,05$ & $>0,05$ & \\
\hline \multirow{3}{*}{9} & осн. & $137,09 \pm 1,32$ & $132,63 \pm 1,48$ & $<0,05$ \\
\hline & контр. & $136,81 \pm 1,29$ & $133,90 \pm 1,35$ & $>0,05$ \\
\hline & $\mathrm{p}$ & $>0,05$ & $>0,05$ & \\
\hline \multirow{3}{*}{10} & осH. & $140,76 \pm 1,34$ & $136,06 \pm 1,30$ & $>0,05$ \\
\hline & контр. & $140,55 \pm 1,32$ & $139,64 \pm 1,33$ & $>0,05$ \\
\hline & $\mathrm{p}$ & $>0,05$ & $>0,05$ & \\
\hline \multirow{3}{*}{11} & осH. & $145,78 \pm 1,46$ & $146,59 \pm 1,40$ & $>0,05$ \\
\hline & контр. & $145,47 \pm 1,48$ & $147,12 \pm 1,51$ & $>0,05$ \\
\hline & $\mathrm{p}$ & $>0,05$ & $>0,05$ & \\
\hline
\end{tabular}

Среднегрупповые значения длины тела учащихся младших классов 7-11 лет обоего пола в целом соответствовали возрастнополовым стандартам, при этом не было выявлено достоверно значимых различий между показателями учащихся основной и контрольной группы - как у мальчиков, так и у девочек во всех возрастных группах, также отсутствовали половые различия. Мальчики имели более высокие показатели длины тела в возрасте 8-10 лет, в 11 лет девочки были незначительно выше своих сверстников (все различия на уровне тенденции), что было обусловлено различными темпами прироста длины тела. В сравнительном аспекте длина тела мальчиков г. Челябинска в возрасте 7 лет не имела существенных различий с детьми соседних регионов - Тюменской области, Северного Казахстана, Поволжья, а также с данными других челябинских исследователей.

Показатели длины тела 11-летних детей не имели различий с данными по Северному Казахстану, Тюменской области и Южному Уралу, но были несколько меньше (на 2-3 см) по сравнению с их ровесниками СевероЗападного и Центрального региона. Представленные данные могут отражать особенности темпов физического развития в различных регионах Росси, что требует создания региональных нормативов и их систематического пересмотра [16, с. 77]. Полученные нами значения показателя массы тела 7-летних мальчиков и девочек не имели различий, они незначительно меньше (1-1,5 кг) чем у детей Тюменской области, но также незначительно (около 1,5 кг) превышают данные по Центральному региону. 
Вестник Новосибирского государственного педагогического университета Novosibirsk State Pedagogical University Bulletin

11-летние девочки имели массу тела на 1,5-2,5 кг больше, чем их сверстники. Выявлено, что во всех возрастных группах преобладают ученики со средним уровнем анализируемых показателей - 55-65 \%; от первого к четвертому классу количество мальчиков с «высоким уровнем» длины тела и уровнем массы тела ниже среднего увеличивается на $5 \%$, девочек с уровнем массы тела ниже среднего - на 7 \%, а количество девочек с уровнем массы тела выше среднего - на $5 \%$, независимо от принадлежности к основной или контрольной группе.

Среднегрупповая величина показателя окружности во всех изученных группах соответствовала возрастной норме, а наиболее существенный прирост ОГК наблюдался на возрастных отрезках 9-10 (мальчики и девочки - на 4,8-5,5 \%) и 10-11 лет (девочки, на 4,5-5,5\%). На данном возрастном отрезке в наибольшей степени зафиксированы изменения показателя массы тела - ее увеличение составило от $52-53,5 \%$ у мальчиков до 58-63\% у девочек, в меньшей степени увеличились длина тела (16,6-17,8 \%) и окружность грудной клетки (12,9-14 \% у мальчиков и $17-18,2$ \% у девочек).

Обследование 7-летних детей в начале первого года обучения показало, что число гармонично развитых мальчиков по сравнению со сверстницами было на 4,5\% больше, среди девочек также больше лиц с резко дисгармоничным развитием (по признаку дефицита массы тела). К 11-летнему возрасту установлена тенденция к увеличению доли учащихся с дисгармонией в развитии (дисгармоничное и резко дисгармоничное развитие), в большей степени также среди девочек (около $28 \%$ у мальчиков и около $32 \%$ у девочек). Распределение 7-летних учащихся по группам здоровья показало, что преобладают дети со II группой здоровья - от 58,3 \% среди девочек основной группы до 61,2 \% среди мальчиков основной группы, а количество учащихся младших классов, относящихся к III группе здоровья, в первом классе составляло от 23,3 до 23,9 \%. В динамике произошло уменьшение учащихся обоего пола, отнесенных к первой группе здоровья до $13,7-14,1$ \%, аналогичная тенденция наблюдалась с количеством детей второй группы здоровья. За годы обучения в начальной школе увеличивалось количество детей, отнесенных к 3-й и 4-й группе здоровья. Распределение учащихся по нозологиям показало, что в первом классе наибольшее число учащихся имеют нарушения опорно-двигательного аппарата (более 54 \%), далее - патология желудочно-кишечного тракта, заболевания органов дыхания, кожные заболевания (в основном дерматиты) и заболевания нервной системы. К четвертому классу возрастает число детей с нарушениями функции органов зрения четвертое место в рейтинге, на пятом месте - патология сердечнососудистой системы.

Далее представлены результаты спектрального анализа медленно волновой вариабельности ритма сердца в состоянии покоя и после проведения пробы с УН: как известно, спектральный анализ ритма сердца интегрально отражает адаптацию организма к воздействию средовых факторов [26, с. 251]. Известно, что для детей младшего школьного возраста характерной считается симпатикотония, хотя в ряде работ представлены данные о положительной роли снижения уровня симпатикотонии при адаптации учащихся к умственным нагрузкам [27, с. 78$]$.

Нами в группах сравнения 8-9-летних учащихся исходная величина ЧСС, а также общей мощности спектра не имели достоверных различий. Не было выявлено также ген- 
Вестник Новосибирского государственного педагогического университета Novosibirsk State Pedagogical University Bulletin

дерных различий указанных показателей в основной и контрольной группах. Наиболее высокий уровень активности метаболических (по данным некоторых авторов - внутрисердечных) факторов регуляции, маркером которых являются ультранизкочастотные колебания (УНЧ) зафиксирован у мальчиков основной группы, их мощность была на 40 \% выше, чем у сверстников, но без наличия достоверной степени различий. У мальчиков основной группы также наиболее высока мощность очень низкочастотных колебаний (ОНЧ), отражающих активность надсегментарного уровня вегетативной регуляции ритма сердца, наиболее низкая зарегистрирована у девочек контрольной группы. Нами установлено, что у мальчиков основной группы и девочек контрольной мощность в ОНЧдиапазоне спектра выше по сравнению с мощностью колебаний в других диапазонах; у мальчиков контрольной группы значения влияние сегментарного и надсегментарного уровня равнозначны (ОНЧ=НЧ), у девочек основной группы - активность сегментарного уровня регуляции (наиболее высока мощность НЧ-колебаний).

У 6-классников обоего пола превалировала НЧ-составляющая ОМС, но у девочек значимость НЧ-компоненты была достоверно выше, чем относительная мощность ВЧ- и ОНЧ-колебаний. У мальчиков хронотропная функция являлась результирующей влияния надсегментарных структур (ОНЧ\%), симпатического (НЧ\%) и парасимпатического отделов (ВЧ\%) вегетативной (автономной) нервной системы (ВНС); помимо этого, относительная доля НЧ-колебаний у девочек превышала ее величину у мальчиков на $18 \%$. Можно полагать, что этот факт является отражением более раннего начала полового созревания у девочек и активизации симпато- адреналовой системы. Индивидуальный анализ активности уровней регуляции показал, что ОНЧ-компонента являлась доминирующей у $23 \%$ девочек и у $33 \%$ мальчиков; НЧ\% - у 54 \% девочек и 43\% мальчиков и ВЧ\% - у 23 и $24 \%$ соответственно. Таким образом, в данном возрасте симпатикотонический исходный тонус является наиболее характерным для лиц обоего пола; почти четверть обследованных учащихся могут быть отнесены к «ваготоникам». По сравнению с показателями учащихся 4-х классов у девочек снизилась доля УНЧ-колебаний (с 17 \%) и ОНЧ\% (36,5 \%) за счет возрастания активности симпатического отдела ВНС (был $25 \%$ ). У мальчиков 6-х классов мы отметили большую стабильность распределения ОМС по диапазонам спектра в сравнении с учащимися 4-х классов. Соотношение активности различных уровней регуляции оценивали с помощью индексов централизации (ИЦ=(НЧ+ВЧ)/ОНЧ) и вагосимпатического (НЧ/ВЧ). Вагосимпатический индекс не имел различий у мальчиков и девочек, а ИЦ был выше у девочек (на $26 \%$ ).

Ортопроба привела к росту значимости симпатического отдела ВНС - доля НЧколебаний превышала $40 \%$ и была несколько выше, чем у мальчиков. Также отмечалось существенное повышение роли гуморальнометаболических факторов регуляции РС, судя по динамике УНЧ\% и ОНЧ\% у лиц обоего пола за счет резкого падения значимости ВЧсоставляющей ОМС. Соответственно, сама величина ОМС также снижалась в пределах 15-20\%. Резко возрастал вагосимпатический индекс при снижении ИЦ.

Под влиянием УН отмечена тенденция к возрастанию ОМС. Наблюдалась различная динамика ОНЧ\%: у мальчиков отмечена тенденция к снижению, а у девочек рост соста- 
Вестник Новосибирского государственного педагогического университета Novosibirsk State Pedagogical University Bulletin

1(17) $2014 \quad$ www.vestnik.nspu.ru

ISSN 2226-3365

вил $28 \%$, у них же отмечена и выраженная активность симпатического отдела ВНС (НЧ\% составила около $45 \%$, у мальчиков около 39 \%). У девочек, таким образом, ответ на УН был более оптимальным: повышалась мощность колебаний ОНЧ-диапазона, отражая вовлечение центральных структур ЦНС в обеспечение результативности проводимого теста. В возрастном аспекте реакция на УН стала также благоприятнее, судя по динамике роста ОНЧ- и НЧ-составляющей РС: в группе 10-летних детей симпатикотония составляла 43,6 \% у девочек и 46,1 \% у мальчиков - это свидетельствовало об избыточной активации симпато-адреналовой системы как ответной адаптационной реакции на воздействие стресс-фактора. Умственная нагрузка, таким образом, вела к перераспределению значимости факторов регуляции, что подтверждалось и при анализе ИЦ и вагосимпатического индекса.

Нами установлено, что независимо от программы обучения большинство учащихся (более 50 \% детей обеих групп) имеют уровень тревожности повышенный и высокий (выявлен у 70-80 \% обследованных лиц различных поло-возрастных групп). Учащиеся 4-х классов обоего пола, занимающиеся по программе шахматного всеобуча более 3 лет, имеют достоверно более высокие показатели успеваемости по предметам «математика» и «информатика». Однако, «цена» адаптации к повышенным умственным нагрузкам у них выше: анализ заболеваемости свидетельствует об ухудшении здоровья с возрастом - около $40 \%$ всех обследованных детей имеют признаки «вегетативных изменений», что отражает наличие у них напряжения адаптационных процессов, при этом более чем у $45 \%$ участников интеллектуально-игрового всеобуча. Несомненно, для них требуется разра- ботка и реализация коррекционно-профилактических мероприятий.

\section{Заключение.}

Результаты 8-летнего мониторинга показали, что физическое развитие учащихся 7-12 лет обоего пола, имеющих дополнительные к общеобразовательной программе интеллектуальные нагрузки по программе шахматного всеобуча, соответствует возрастно-половым нормативам; антропометрические показатели (длина и масса тела, окружность грудной клетки), их возрастная динамика, распределение по группам здоровья и для занятий физической культурой не имеют достоверных различий со сверстниками, обучающихся по стандартной общеобразовательной программе. Учащиеся обоего пола, занимающиеся по программе шахматного всеобуча более 3 лет, имеют достоверно более высокие показатели успеваемости по предметам «математика» и «информатика», однако у них выше показатели заболеваемости, больше число лиц с признаками вегетативных изменений (45 \%), что требует проведения коррекционных мероприятий.

В онтогенезе у детей обоего пола от 8 лет к 11 годам наблюдается увеличение активности надсегментарного и сегментарного уровня регуляции ритма сердца и инотропной функции и тонуса крупных сосудов. У 11-летних девочек по сравнению с мальчиками выше активность надсегментарного уровня регуляции хроно- и инотропной функции сердца в состоянии покоя; возрастание значимости парасимпатикотонических влияний на хроно- и инотропную функцию при умственных нагрузках у девочек выявлено в более раннем возрасте (в 8-9 лет) по сравнению с мальчиками (11 лет). 
Вестник Новосибирского государственного педагогического университета Novosibirsk State Pedagogical University Bulletin

1(17) $2014 \quad$ www.vestnik.nspu.ru $\quad$ ISSN 2226-3365

Адаптация к дополнительным интеллектуальным нагрузкам (занятия по программе шахматного всеобуча) приводит к различиям реакции на умственную нагрузку: у детей основной группы определены однонаправленные изменения показателей медленно волновой вариабельности ритма сердца и ударного объема - повышение значимости гуморально-метаболических факторов регуляции (увеличение относительной мощности очень низкочастотных колебаний ритма до 25-37\%) и активности симпатического отдела (увеличение абсолютной мощности НЧколебаний до $30 \%, \mathrm{p}<0,05)$; в группе контроля ответная реакция сопровождалась выраженной симпатикотонической реакцией со значительным увеличением абсолютной мощности низкочастотных колебаний ритма сердца (более чем в 2 раза, $\mathrm{p}<0,01$ ). Две трети детей 8-9 лет имеют силу нервной системы на среднем и ниже среднего уровня. Вероятно, это отражает как общую картину состояния здоровья учащихся (менее $10 \%$ здоровых лиц), так и незрелость их нервной системы. Все показатели умственной работоспособности в этом возрасте повышаются, но учащиеся могут справиться только с 39-53 \% объема заданий, выполняемых старшеклассниками. Результаты тестов «Оценка внимания» и «Помехоустойчивость» позволили выявить совершенствование свойств внимания и помехоустойчивости - способности сопротивляться воздействию фоновых помех при восприятии какого-либо объекта - как одного из важнейших факторов адаптации к интеллектуально-игровым нагрузкам шахмат (сочетание умственных нагрузок и соревновательной деятельности). Данный возраст является сенситивным для развития качества помехоустойчивости. Выявленные нами особенности психофизиологического состояния позволяют рекомендовать педагогам особое внимание уделять элементам профилактики утомления, более широко использовать игровой компонент при проведении занятий.

\section{СПИСОК ЛИТЕРАТУРЫ}

1. Айзман Р.И. Здоровье педагогов и обучающихся - ключевая задача современной школы // Вестник Новосибирского государственного педагогического университета. - 2012. № 3(7). - C. 24-35.

2. Безруких М.М., Сонькин В.Д. Педагогическая физиология // Альманах «Новые исследования». - М., 2004. - № 1-2. - С. 74-75.

3. Быструшкин С.К., Айзман Р.И., Афтанас Л.И. Особенности организации внимания и эмоционального восприятия у детей в норме и при нарушениях интеллектуального развития // Бюллетень Сибирского отделения Российской академии наук. - 2007. - № 3. C. $159-162$.

4. Копосова Т.С., Кондратьева М.Ю. Особенности эмоционального статуса младших школьников, обучающихся по разным образовательным программам // Новые исследования. - №1-2. - 2004. - С. 213-214.

5. Криволапчук И.А. Психофизиологическая цена напряженной информационной нагрузки у детей и подростков в 5-14 лет // Физиология человека. - 2008. - Т. 34, № 4. - С. 28-35.

6. Русинова С.И. Предпосылки дезадаптации и дизадаптации к условиям школьной деятельности // Научные труды І съезда физиологов СНГ. - М.: Медицина-Здоровье, 2005. - Т. 1. C. $144-145$. 
Вестник Новосибирского государственного педагогического университета Novosibirsk State Pedagogical University Bulletin

1(17) $2014 \quad$ www.vestnik.nspu.ru ISSN 2226-3365

7. Сабирьянов А.Р., Сабирьянова Е.С., Возницкая О.Э. Современные особенности морфофункционального состояния сельских и городских детей младшего школьного возраста // Педиатрия. Журнал им. Г.Н. Сперанского. - 2006. - № 5. - С. 105-107.

8. Шибкова Д.З., Макунина О.А., Якубовская И.А. Особенности психофизиологических функций школьников // Вестник Уральской медицинской академической науки. - 2006. № 3-2. - С. 75 .

9. Быков Е.В., Рязанцев А.А., Чипышев А.В., Мекешкин Е.А. Мониторинг состояния здоровья учащихся младших классов и подходы к реализации здоровьесберегающих технологий // Вестник Южно-Уральского государственного университета. Серия: Образование, здравоохранение, физическая культура. - 2012. - № 8(267). - С. 6-8.

10. Комплексный план мероприятий по развитию дополнительного образования детей в области шахмат в системе образования Российской Федерации на 2008-2010 годы: Министерство образования и науки РФ, 18 июня 2008 г. -№АФ-19/06 вн. - [Электронный реcypc]. - URL :http:// www.russiachess.org/ content/view/2359/343/

11. Бареев Е.И. Проект российской шахматной федерации «Школьные шахматы» // Психолого-педагогические и медико-биологические проблемы физической культуры, спорта, туризма и олимпизма: инновации и перспективы развития: в 3 ч. / матер. Междунар. науч.практ. конф. - Челябинск: Изд. центр ЮУрГУ, 2011. - Ч. 3. - 137-138.

12. Левитов И.В. Шахматы как важный ресурс интеллектуального развития детей // Психолого-педагогические и медико-биологические проблемы физической культуры, спорта, туризма и олимпизма: инновации и перспективы развития: матер. Междунар. науч.-практ. конф. в 3 ч. - Челябинск: Изд. центр ЮУрГУ, 2011. - Ч. 3. - 157-159.

13. Вершинин М.А. Педагогическая система формирования логического мышления обучаемых на основе шахматного материала: автореф. дис. канд. пед. наук. - Волгоград: ВГАФК, 2002. $-22 \mathrm{c}$.

14. Зарецкий В.К., Гордон М.М., Глухова О.В. Шахматы для общего развития // Психологопедагогические и медико-биологические проблемы физической культуры, спорта, туризма и олимпизма: инновации и перспективы развития: в 3 ч.: матер. Междунар. науч.-практ. конф. - Челябинск: Изд. центр ЮУрГУ, 2011. - Ч. 3. - 152-155.

15. Сухин И.Г. Национальные и нетрадиционные аспекты шахматного образования // Психолого-педагогические и медико-биологические проблемы физической культуры, спорта, туризма и олимпизма: инновации и перспективы развития: в 3 ч.: матер. Междунар. науч.практ. конф. - Челябинск: Изд. центр ЮУрГУ, 2011. - Ч. 3. - С. 170-173.

16. Ямпольская Ю.А. Региональное разнообразие и стандартизированная оценка физического развития детей и подростков // Педиатрия. - 2005. - № 6. - С. 73-77.

17. Попова Е.В. Психофизиологический анализ интеллекта и стратегий принятия решения у детей предшкольного и школьного возраста: автореф. дис. ...канд. биол. наук. - Архангельск, 2009. - 20 с.

18. Быков Е.В. Влияние уровня двигательной активности на функциональное состояние здоровых учащихся и физиологическое обоснование рекреационных и коррекционных программ: дис. ...докт. мед. наук. - Челябинск, 2002. - 316 с.

19. Сонькин В.Д., Корниенко И.А., Тамбовцева Р.В., Зайцева В.В., Изаак С.И. Основные закономерности и типологические особенности роста и физического развития // Физиология развития ребенка / Под ред. М.М. Безруких, Д.А. Фарбер. - М., 2000. - С. 31-60.

20. Волокитина Т.В., Тихонова О.Н., Попова Е.В. Особенности психомоторной организации 
Вестник Новосибирского государственного педагогического университета Novosibirsk State Pedagogical University Bulletin

двигательной сферы младших школьников // XX съезд Физиологического общества имени И.П. Павлова. - М., 2007. - С. 183.

21. Изаак С.И., Панасюк Т.В. Характеристика физического развития школьников различных регионов России // Материалы пленума научного совета по экологии человека и гигиена окружающей среды РАМН и МЗ РФ. - М., 2003. - С. 61-64.

22. Макунина О.А. Динамика морфофункциональных показателей учащихся 7-10 лет в зависимости от профиля обучения: дисс. ... канд. биол. наук. - Челябинск, 2005. - 145 с.

23. Айзман Р.И. Мониторинг здоровья учащихся и преподавателей: теоретические и прикладные аспекты // Мониторинг здоровья и физической подготовленности молодежи: матер. Республ. науч.-практ конф. с междунар. участием. - Новосибирск, 2009. - С. 10-17.

24. Рубанович В.Б. Мониторинг здоровья школьников для оптимизации физкультурнооздоровительной и спортивной деятельности // Мониторинг здоровья и физической подготовленности молодежи: матер. Республ. науч.-практ конф. с междунар. участием. - Новосибирск, 2009. - С. 266-267.

25. Айзман Р.И., Айзман Н.И., Лебедев А.В., Рубанович В. Б. Компьютерная программа скрининг контроля состояния здоровья участников образовательного процесса // Сибирский учитель. - 2011. - № 2(75). - С. 36-39.

26. Баевский Р.М., Иванов Г.Г., Чирейкин Л.В. Анализ вариабельности сердечного ритма при использовании различных электрокардиографических систем (методические рекомендации): протокол №4 от 11.04.2000 Комиссии по клинико-диагностическим приборам и аппаратам Комитета по новой медицинской технике МЗ РФ // Вариабельность сердечного ритма: теоретические аспекты и практическое применение: тез. докл. междунар. симп. Ижевск: Изд-во Удм. гос. ун-та, 2003. - С. 200-255.

27. Псеунок А.А. Адаптивные возможности сердечно-сосудистой системы детей, обучающихся по инновационным программам // Педиатрия. - 2005. - № 6. - С. 77-79. 
Вестник Новосибирского государственного педагогического университета Novosibirsk State Pedagogical University Bulletin

(C) E. V. Bykov, S. V. Matsenko, K. A. Kashitsina, A. V. Chipyshev, M. E. Pugacheva, A. V. Ryazantsev

UDC $612.66+612,063+371.7$

\title{
MONITORING OF PSYCHOPHYSIOLOGICAL AND PHYSICAL DEVELOPMENT OF PARTICI- PATING STUDENTS OF THE INTELLECTUAL GAME-UNIVERSAL EDUCATION
}

\author{
E. V. Bykov, S. V. Matsenko, K. A. Kashitsina, A. V. Chipyshev, \\ M. E. Pugacheva, A. V. Ryazantsev (Chelyabinsk, Russia)
}

Training chess of pupils of elementary grades is provided in many countries around the world, but a comprehensive evaluation of the physiological «cost» of adaptation to increased mental stress wasn't carried out. We carried out studying of features of physical and psychophysiological development, health of junior and secondary schools in Chelyabinsk classes participating in the chess education. Found that in all age groups predominate students with an average level of physical development, from the 1-st to the 4-th grade is increased by $5 \%$ the number of boys with "high level» of the body length and the level of body weight below the average of $7 \%$ - girls with lower levels of body mass medium, and the amount girls level above average weight - $5 \%$. In the dynamics of learning in the lower grades have decreased from 23,3-23,9\% and 13,7-14,1\% of the boys and girls belonging to the first group of health. Students of both sexes engaged in chess education program for more than 3 years, more adapted for school: they have increase humoral factors of metabolic regulation during mental stress (in the control group revealed sympathicotonic reaction), they have higher scores in tests «Assessment of attention» and "Immunity» achievement in the subjects of «math» and "science», however, higher morbidity, more than the number of persons with symptoms of autonomic changes (45\%), which requires the development and implementation requires corrective measures.

Keywords: students, adaptation, mental stress, heart rate variability, psycho-physiological and physical development.

\section{REFERENCES}

1. Aizman R.I. Zdorov'e pedagogov i obuchayushchikhsya - klyuchevaya zadacha sovremennoi shkoly [Health of teachers and schoolchildren is a key problem of modern school]. Novosibirsk State Pedagogical University Bulletin, 2012, no. 3(7), pp. 24-35.

2. Bezrukhih M.M., Son'kin V.D. Pedagogicheskaya fiziologiya [Educational Physiology]. Almanac «New research», Moscow, 2004, no. 1-2, pp. 74-75.

3. Bystrushkin S.K., Aizman R.I., Aftanas L.I. Osobennosti organizatsii vnimaniya i emotsional'nogo vospriyatiya $\mathrm{u}$ detei $\mathrm{v}$ norme i pri narusheniyakh intellektual'nogo razvitiya [Features of the organization of attention and emotional perception at children in norm and at infringements of intellectual development]. Bulletin of the Siberian branch of the Russian academy of sciences, 2007, no. 3, pp. 159-162.

4. Koposova T.S., Kondratieva M.U. Osobennosti emotsional'nogo statusa mladshikh shkol'nikov, obuchayushchikhsya po raznym obrazovatel'nym programmam [Features of the emotional status 
of junior students enrolled in different educational programs]. New investigations, no. 1-2, 2004, pp. 213-214.

5. Rusinova S.I. Predposylki dezadaptatsii i dizadaptatsii k usloviyam shkol'noi deyatel'nosti [Prerequisites maladjustment and disadaptative to the conditions of school activity]. Proceedings of I Congress of Physiologists of the CIS, Moscow, Medical-Health, 2005, vol. 1, pp. 144-145.

6. Krivolapchuk I.A. Psikhofiziologicheskaya tsena napryazhennoi informatsionnoi nagruzki u detei i podrostkov v 5-14 let [Psychophysiological price of hard information overload in children and adolescents 5-14 years old]. Human Physiology, 2008, vol. 34, no. 4, pp. 28-35.

7. Sabiryanov A.R., Sabirianova E.S., Woznitskaya O.E. Sovremennye osobennosti morfofunktsional'nogo sostoyaniya sel'skikh i gorodskikh detei mladshego shkol'nogo vozrasta [Modern features of morphology and function of the state of the rural and urban primary school children]. Pediatrics Journal nam. G.N.Speranskii, 2006, no. 5, pp. 105-107.

8. Shibkova D.Z., Makunina O.A., Yakubovskaya I.A. Osobennosti psikhofiziologicheskikh funktsii shkol'nikov [Features of psycho-physiological functions of schoolchildren]. Bulletin of the Ural Medical Academic Science, 2006, no. 3-2, pp. 75.

9. Bykov E.V., Ryazantsev A.A., Chipyshev A.V., Mekeshkin E.A. Monitoring sostoyaniya zdorov'ya uchashchikhsya mladshikh klassov i podkhody k realizatsii zdorov'esberegayushchikh tekhnologii [Monitoring of the health of those in lower grades and approaches to the implementation of health-technology]. Bulletin of the South Ural State University. Series: Education, health, physical education, 2012, vol. 267, no. 8, pp. 6-8.

10. Kompleksnyi plan meropriyatii po razvitiyu dopolnitel'nogo obrazovaniya detei v oblasti shakhmat $v$ sisteme obrazovaniya Rossiiskoi Federatsii na 2008-2010 gody [Comprehensive plan for the development of additional education in the field of chess in the education system of the Russian Federation in 2008-2010]. Ministry of Education and Science of the Russian Federation, June 18, 2008, no. AF-19/06 ext. Available at: http:// www.russiachess .org/content/view/2359/343.

11. Bareyev E.I. Proekt rossiiskoi shakhmatnoi federatsii «Shkol'nye shakhmaty» [The project of the Russian Chess Federation, «School Chess»]. Psycho-pedagogical and medico-biological problems of physical culture, sport, tourism and olimpizm: Innovation and Development Prospects in 3 p. (Sourcebook of Intern. scientific and practical. Conf.), Chelyabinsk, SUSU, 2011, Part 3, pp. 137-138.

12. Levitov I.V. Shakhmaty kak vazhnyi resurs intellektual'nogo razvitiya detei [Chess as an important resource of intellectual development of children]. Psycho-pedagogical and medico-biological problems of physical culture, sport, tourism and Olympism: Innovation and Development Prospects. (Sourcebook of Intern. scientific and practical. Conf.), Chelyabinsk, SUSU, 2011, Part 3, pp. $157-159$.

13. Vershinin M.A. Pedagogicheskaya sistema formirovaniya logicheskogo myshleniya obuchaemykh na osnove shakhmatnogo materiala. Avtoref. diss. kand. ped. nauk. [Pedagogical system of formation of logical thinking of students on the basis of chess material. Author. Candidate pedagog. Science diss.]. Volgograd, VGAFK, 2002, 22 p.

14. Zaretsky V.K, Gordon M.M., Glukhova O.V. Shakhmaty dlya obshchego razvitiya [Chess for the overall development]. Psycho-pedagogical and medico-biological problems of physical culture, sport, tourism and Olympism: Innovation and Development Prospects. (Sourcebook of Intern. scientific and practical. Conf.), Chelyabinsk, SUSU, 2011, Part 3, pp. 152-155.

15. Sukhin I.G. Национальные и нетрадиционные аспекты шахматного образования [National and non-traditional aspects of chess education]. Psycho-pedagogical and medico-biological prob- 
lems of physical culture, sport, tourism and Olympism: Innovation and Development Prospects. (Sourcebook of Intern. scientific and practical. Conf.), Chelyabinsk, SUSU, 2011, Part 3, pp. $170-173$.

16. Yampol'skaya Y.A. Regional'noe raznoobrazie i standartizirovannaya otsenka fizicheskogo razvitiya detei i podrostkov [Regional diversity and standardized assessment of the physical development of children and adolescents]. Pediatrics, 2005, no. 6, pp. 73-77 .

17. Popova E.V. Psikhofiziologicheskii analiz intellekta $i$ strategii prinyatiya resheniya $u$ detei predshkol'nogo i shkol'nogo vozrasta. Avtoref. diss. kand. biol. nauk. [Psychophysiological analysis of intelligence and decision-making strategies in children of preschool and school age. Author. candidate biol. science diss.]. Archangelsk, 2009, 20 p.

18. Bykov E.V. Vliyanie urovnya dvigatel'noi aktivnosti na funktsional'noe sostoyanie zdorovykh uchashchikhsya i fiziologicheskoe obosnovanie rekreatsionnykh i korrektsionnykh programm. Diss. dokt. med. nauk. [The influence of the level of physical activity on functional status of disabled students and physiological basis of recreational and remedial programs. Doctor medical science diss.]. Chelyabinsk, 2002, pp. 316.

19. Son'kin V.D., Kornienko I.A., Tambovtseva R.V., Zaitsev V.V. Osnovnye zakonomernosti i tipologicheskie osobennosti rosta i fizicheskogo razvitiya [Basic laws and typological features of growth and physical development]. Physiology of the child, Moscow, 2000, pp. 31-60.

20. Volokitina T.V., Tikhonov O.N., Popova E.V. Osobennosti psikhomotornoi organizatsii dvigatel'noi sfery mladshikh shkolnikov [Features psychomotor motor areas of the organization of junior]. XX Congress of Physiological Society named I.P. Pavlov, Moscow, 2007, p. 183.

21. Izaak S.I., Panasiuc T.V. Kharakteristika fizicheskogo razvitiya shkol'nikov razlichnykh regionov Rossii [Characterization of the physical development of pupils of different regions of Russia]. Proceedings of the plenum of the Scientific Council for Human Ecology and Environmental Health Medical Sciences and Health Ministry, Moscow, 2003, pp. 61-64.

22. Makunina O.A. Dinamika morfofunktsional'nykh pokazatelei uchashchikhsya 7-10 let v zavisimosti ot profilya obucheniya. Diss. kand. biol. nauk [The dynamics of morphological and functional performance of students $7-10$ years depending on the profile of training. Candidate biol. science diss.]. Chelyabinsk, 2005, 145 p.

23. Aizman R.I. Monitoring zdorov'ya uchashchikhsya i prepodavatelei: teoreticheskie i prikladnye aspekty [Monitoring the health of students and teachers: theoretical and applied aspects]. Monitoring of health and physical fitness of young people. Mater. Repub. Scientific-practical conference with Intern. Participation, Novosibirsk, 2009, pp. 10-17.

24. Rubanovich V.B. Monitoring zdorov'ya shkol'nikov dlya optimizatsii fizkul'turno-ozdorovitel'noi i sportivnoi deyatel'nosti [Monitoring of the health of school children in order to optimize health and fitness and sports activities]. Monitoring of health and physical fitness of young people: Mater. Repub. Scientific-practical conference with Intern. Participation, Novosibirsk, 2009, pp. 266267.

25. Aizman R.I., Aizman N.I., Lebedev A.V., Rubanovich V.B. Komp'yuternaya programma skrining kontrolya sostoyaniya zdorov'ya uchastnikov obrazovatel'nogo protsessa [The computer program of the screening control of a state of health of participants of educational process]. Siberian teacher, 2011, vol. 75, no. 2, - pp. 36-39.

26. Bayevsky R.M., Ivanov G.G., Chireykin L.V. Analiz variabel'nosti serdechnogo ritma pri ispol'zovanii razlichnykh elektrokardiograficheskikh sistem (metodicheskie rekomendatsii): protokol №4 ot 11.04.2000 Komissii po kliniko-diagnosticheskim priboram i apparatam Komiteta 
po novoi meditsinskoi tekhnike MZ RF [Analysis of heart rate variability using different electrocardiographic systems (guidelines): protocol number 4 of the Commission on 11.04 .2000 clinical diagnostic instruments and apparatus of the Committee on New Medical Technology Health Ministry]. Heart rate variability: theoretical aspects and practical application. Theses of Reports. Intern. Symp, Izhevsk, Publishing House of the UdmSU, 2003, pp. 200-255.

27. Pseunok A.A. Adaptivnye vozmozhnosti serdechno-sosudistoi sistemy detei, obuchayushchikhsya po innovatsionnym programmam [The adaptive capacity of the cardiovascular system of children enrolled in the innovative programs]. Pediatrics, 2005, no. 6, pp. 77-79.

Bykov Evgenii Vitalevich, MD, professor, the head of department sports medicine and physical rehabilitation, Ural State University of Physical Culture.

E-mail: bev58@yandex.ru

Matsenko Sergei Vadimovich, the post-graduate student of department of adaptive physical education and biomedical training, South Ural State University.

E-mail: noobie90@yandex.ru

Kashitsina Ksenia Anatolevna, the post-graduate student of department of adaptive physical education and biomedical training, South Ural State University.

E-mail: marafon4219@yandex.ru

Chipyshev Anton Viktorovich, Ph.D., the associate professor of department of adaptive physical education and biomedical training, South Ural State University.

E-mail: jk_m@bk.ru

Pugacheva Maria Evgenevna, the post-graduate student of department of adaptive physical education and biomedical training, South Ural State University.

E-mail: puga4eva.me@yandex.ru

Ryazancev Alexander Vladimirovich, Ph.D., the coach of the Russian Chess Federation.

E-mail: gm_riazantsev@rambler.ru 
Вестник Новосибирского государственного педагогического университета Novosibirsk State Pedagogical University Bulletin

1(17) $2014 \quad$ www.vestnik.nspu.ru ISSN 2226-3365

(C) E. В. Васина, Н. Н. Кошко

\title{
УДК 614+371.7
}

\section{АДАПТАЦИЯ ПОДРОСТКОВ В ПРОЦЕССЕ ОБУЧЕНИЯ ПО РАЗНЫМ ПРОФИЛЬНЫМ ПРОГРАММАМ*}

\author{
Е. В. Васина, Н. Н. Кошко (Кемерово, Россия)
}

В статье приводятся результаты исследования адаптивных изменений возникаюших у учашихся в прочессе обучения по разным профильным программам с 8 по 11 класс. Цель статьи - обосновать, что адаптаџия старшеклассников к обучению зависит от сложности и содержания учебной деятельности. Отмечается, что на предпрофильном и профильном этапах обучения проявления адаптивных реакций у подростков различается. При увеличении учебной нагрузки с переходом на профильный этап обучения напряжение систем вегетативной регуляциии сердечного ритма у школьников всех профилей усиливается. В ходе обучения по программам разных профилей у подростков наблюдается различия в изменении параметров сердечного ритма. Наибольшее напряжение установлено у учащчихся лингвистического и физикоматематического профилей обучения.

Ключевые слова: адаптация, учащчеся, профиль обучения, вариабельность сердечного ритма, напряжение механизмов вегетативной регуляции.

Реакция системы кровообращения, особенно характер изменений сердечного ритма у детей и подростков при информационных и эмоциональных нагрузках, позволяет оценить функциональные резервы, мобилизацию и расходование оперативных и стратегических ресурсов организма на этапах срочной и долговременной адаптации [1-2; 4]. В настоящее время особую актуальность приобретают вопросы изучения адаптации подростков к обучению, в целом [3; 8-9], профильному обучению, - в частности [4]. Профильное обучение характеризуется значительной силой и интенсивностью воздействия из-за сложности изучаемых предметов и большого объема учебной нагрузки [11].

\footnotetext{
* Статья подготовлена по результатам работы Всероссийской научной школы с Международным участием «Опыт использования мониторинга здоровья и физической подготовленности учащейся молодежи» (12-14 ноября 2013 г.).
}

Васина Евгения Владимировна - кандидат биологических наук, заведующий лабораторией развития здоровьесберегающей деятельности в системе профессионального образования, Кузбасский региональный институт развития профессионального образования.

E-mail: ev-va08@mail.ru

Кошко Наталья Николаевна - кандидат биологических наук, преподаватель кафедры физиологии человека и животных и валеологии, Кемеровский государственный университет.

E-mail: koshko80@mail.ru 
Вестник Новосибирского государственного педагогического университета Novosibirsk State Pedagogical University Bulletin

Продолжительное действие этих факторов обусловливает функциональные, адаптационные изменения в организме учащихся. В связи с этим, в условиях возросших требований к адаптационным возможностям подростков, обучающихся в профильных классах, особый интерес представляет изучение вариабельности сердечного ритма у учащихся разных профильных классов на протяжении предпрофильного и профильного обучения.

С этой целью у одних и тех же подростков в динамике 4 лет ежегодно оценивалось состояние регуляторных систем организма по показателям вариабельности сердечного ритма (ВСР) в покое и при выполнении ортопробы по методике Р.М. Баевского (2002) при помощи автоматизированного комплекса «ORTO Expert» [6]. При анализе сердечного ритма оценивались показатели: частота сердечных сокращений (ЧСС), мода (Мо), амплитуда моды (АМо), вариационный размах $(\Delta \mathrm{X})$, индекс напряжения регуляторных си-

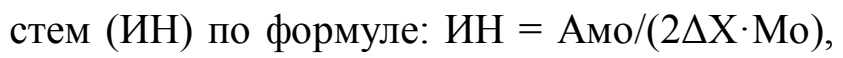
показатели спектрального анализа сердечного ритма (TF, HF, LF, VLF). В исследовании участвовали 372 гимназиста в возрасте от 13 до 17 лет, обучающиеся в с 8 по 11 класс по естественно-математическому направлению (физико-математический и химикобиологический профили) и по гуманитарному профилю (лингвистический и историкофилологический профили). Контрольной группой являлись учащиеся общеобразовательных классов того же возраста в количестве 672 человек.

В результате проведенного исследования выявлено, что обучение в течение 4 лет на повышенном образовательном уровне сопровождалось разнонаправленными изменениями показателей ВСР у учащихся разных профилей обучения. Анализ показателей ВСР у восьмиклассников разных профилей обучения показал, что значение индекса напряжения в покое (ИН) - интегрального показателя, отражающего уровень напряжения механизмов регуляции сердечного ритма не различается у гимназистов разных профилей обучения и общеобразовательных классов и отражает неоптимальный уровень функционирования сердечно-сосудистой системы, за счет напряжения регуляторных механизмов характерный для подросткового возраста [7; 10]. В связи с этим от 27 до $35 \%$ восьмиклассников характеризуются увеличением влияния симпатического отдела ВНС в регуляции сердечного ритма (Табл. 1; Рис. 1).

Дальнейшее Формирования адаптивного ответа организма подростков на длительное влияние факторов образовательной среды в процессе обучения различалось в зависимости от профиля обучения. Так у учащихся ФМ, ХБ и ИФ профилей в 9 классе происходит увеличение парасимпатических влияний на сердечный ритм, о чем свидетельствует снижение ЧСС и увеличение $\Delta \mathrm{X}$ у гимназистов ФМ профиля и снижению показателей ИН в ортостазе у учащихся ХБ профиля (Табл. 1). У гимназистов ГМ профиля наблюдается более выраженная реакция: значительное снижение ИН, АМО, увеличение $\Delta \mathrm{X}$ и увеличение числа лиц с повышенным влиянием парасимпатического отдела ВНС на СР почти в 2 раза, свидетельствующее о снижении уровня функционирования ССС (Табл. 1; Рис. 1). У девятиклассников ИФ профилей наблюдается увеличение спектральной мощности волновой структуры сердечного ритма (TF,VLF, LF, HF), связано, по мнению Р.М. Баевскиого и соавт. с активацией высших вегетативных центров. У гимна- 
Вестник Новосибирского государственного педагогического университета Novosibirsk State Pedagogical University Bulletin

зистов ЛГ профиля от 8 к 9 классу происходит значительное повышение ИН в ортостазе и АМо в покое (Табл. 1). Количество лиц с увеличенным влиянием симпатического отдела ВНС в регуляции СР возрастает более чем в 2 раза (Рис. 1).

Таблица 1

Динамика показателей вариабельности сердечного ритма у учащихся разных профилей обучения с 8 по 11 класс

\begin{tabular}{|c|c|c|c|c|c|c|c|}
\hline \multirow{3}{*}{$\begin{array}{c}\text { Пока- } \\
\text { зате- } \\
\text { ли }\end{array}$} & \multirow{3}{*}{$\begin{array}{l}\mathrm{K} \\
Л \\
\mathrm{~A} \\
\mathrm{C} \\
\mathrm{C}\end{array}$} & \multicolumn{2}{|c|}{$\begin{array}{c}\text { Естественно-математическое } \\
\text { направление }\end{array}$} & \multicolumn{2}{|c|}{ Гуманитарное направление } & \multirow[b]{2}{*}{$\begin{array}{c}\text { Общеобразо- } \\
\text { вательные } \\
\text { классы } \\
\text { n }=245\end{array}$} & \multirow{3}{*}{$\begin{array}{c}\text { Достовер- } \\
\text { ность } \\
\text { различий } \\
\text { p }<0,05\end{array}$} \\
\hline & & $\begin{array}{c}\text { Физико- } \\
\text { математический } \\
\text { профиль } \\
\text { n = } 115\end{array}$ & $\begin{array}{c}\text { Химико- } \\
\text { биологи- } \\
\text { ческий профиль } \\
\mathrm{n}=86\end{array}$ & $\begin{array}{c}\text { Лингвисти- } \\
\text { ческий } \\
\text { профиль } \\
\mathrm{n}=81 \\
\end{array}$ & $\begin{array}{c}\text { Историко- } \\
\text { филологи- } \\
\text { ческий } \\
\text { профиль } \\
\text { n=90 }\end{array}$ & & \\
\hline & & 1 & 2 & 3 & 4 & 5 & \\
\hline \multirow{4}{*}{$\begin{array}{l}\text { ЧСС } \\
\text { по- } \\
\text { кой, } \\
\text { уд / } \\
\text { мин }\end{array}$} & 8 & $85,9 \pm 1,3$ & $82,9 \pm 1,9$ & $86,6 \pm 1,7$ & $85,7 \pm 1,4$ & $85,6 \pm 0,75$ & нет \\
\hline & 9 & $79,3 \pm 1,7^{*}$ & $84,3 \pm 1,8$ & $87,1 \pm 1,7$ & $73,7 \pm 1,6^{*}$ & $85,8 \pm 1,3$ & $\begin{array}{l}1-2,3,4,5 ; 4 \\
-2,3,5\end{array}$ \\
\hline & 10 & $87,2 \pm 2,0^{*}$ & $81,2 \pm 2,0$ & $83,9 \pm 1,6^{*}$ & $78,9 \pm 1,8^{*}$ & $82,3 \pm 0,9$ & $\begin{array}{l}4-1,3,5 \\
1-5\end{array}$ \\
\hline & 11 & $82,3 \pm 2,0^{*}$ & $80,2 \pm 1,7$ & $82,6 \pm 2,7$ & $83,0 \pm 2,6^{*}$ & $82,5 \pm 1,1$ & нет \\
\hline \multirow{4}{*}{$\begin{array}{l}\text { ИН } \\
\text { по- } \\
\text { кой, } \\
\text { усл. } \\
\text { ед. }\end{array}$} & 8 & $167,2+15,7$ & $195,9 \pm 15,3$ & $196,5 \pm 13,7$ & $163,3 \pm 19,7$ & $172,4 \pm 13,3$ & нет \\
\hline & 9 & $143,7 \pm 19,9$ & $211,7 \pm 20,7$ & $212,3 \pm 24,7$ & $110,9 \pm 20,9^{*}$ & $186,7 \pm 18,2$ & $1,4-2,3,5$ \\
\hline & 10 & $259,9 \pm 24,6^{*}$ & $164,2+21,8^{*}$ & $227,0 \pm 17,6$ & $184,2 \pm 17,2^{*}$ & $184,3 \pm 17,9$ & $1-2,4,5 ; 2-3$ \\
\hline & 11 & $220,6 \pm 19,1$ & $141,7 \pm 24,4$ & $256,4 \pm 14,8$ & $174,3 \pm 20,6$ & $154,5 \pm 15,7$ & $1,3-2,4,5$ \\
\hline \multirow{4}{*}{$\begin{array}{l}\text { ИН } \\
\text { нагруз } \\
\text { ка, } \\
\text { усл. } \\
\text { ед. }\end{array}$} & 8 & $395,7 \pm 29,9$ & $412,6 \pm 22,9$ & $426,1 \pm 29,1$ & $438,2 \pm 31,1$ & $294,8 \pm 24,8$ & $5-1,2,3,4$ \\
\hline & 9 & $325,1 \pm 28,9$ & $349,2 \pm 22,1^{*}$ & $508,9 \pm 39,7^{*}$ & $221,9 \pm 24,9^{*}$ & $356,2 \pm 31,2$ & $\begin{array}{l}3-1,2,4,5 \\
4-1,2,5\end{array}$ \\
\hline & 10 & $484,7 \pm 24,0^{*}$ & $417,5 \pm 29,6^{*}$ & $495,9 \pm 24,1$ & $395,1 \pm 29,3^{*}$ & $281,4 \pm 27,9$ & $\begin{array}{l}5-1,2,3,4 \\
1-4 ; 3-2,4\end{array}$ \\
\hline & 11 & $472,2 \pm 27,4$ & $403,2 \pm 31,8$ & $542,1 \pm 36,2$ & $438,7 \pm 38,2$ & $382,6 \pm 30,9$ & $\begin{array}{l}3-1,2,3,5 \\
1-2,5\end{array}$ \\
\hline \multirow{4}{*}{$\begin{array}{l}\text { AMO } \\
\text { по- } \\
\text { кой, } \\
\%\end{array}$} & 8 & $41,1 \pm 1,8$ & $40,2 \pm 2,9$ & $42,8 \pm 2,2$ & $41,1 \pm 2,1$ & $41,8 \pm 1,2$ & нет \\
\hline & 9 & $40,1 \pm 2,5$ & $46,1 \pm 3,5$ & $48,1 \pm 2,2^{*}$ & $34,2 \pm 3,2^{*}$ & $43,6 \pm 1,4$ & $\begin{array}{l}3-1,5 \\
4-2,3,5 \\
\end{array}$ \\
\hline & 10 & $45,9 \pm 3,1$ & $40,3 \pm 2,8$ & $47,1 \pm 2,2$ & $43,2 \pm 2,4^{*}$ & $42,1 \pm 1,3$ & $3-2,5$ \\
\hline & 11 & $44,0 \pm 3,0$ & $40,7 \pm 2,9$ & $51,6 \pm 3,0$ & $44,8 \pm 2,9$ & $40,8 \pm 1,6$ & $3-1,2,5$ \\
\hline \multirow{4}{*}{$\begin{array}{l}\Delta \mathrm{X} \\
\text { по- } \\
\text { кой, } \\
\text { Сек }\end{array}$} & 8 & $0,24 \pm 0,01$ & $0,27 \pm 0,02$ & $0,25 \pm 0,02$ & $0,28 \pm 0,01$ & $0,26 \pm 0,01$ & $1-4$ \\
\hline & 9 & $0,31 \pm 0,02^{*}$ & $0,27 \pm 0,03$ & $0,24 \pm 0,02$ & $0,38 \pm 0,03^{*}$ & $0,25 \pm 0,02$ & $\begin{array}{l}4-1,2,3,5 \\
1-3,5\end{array}$ \\
\hline & 10 & $0,28 \pm 0,02$ & $0,29 \pm 0,02$ & $0,24 \pm 0,02$ & $0,29 \pm 0,03^{*}$ & $0,30 \pm 0,02$ & $3-5$ \\
\hline & 11 & $0,28+0,02$ & $0,34 \pm 0,03^{*}$ & $0,24 \pm 0,02$ & $0,30 \pm 0,03$ & $0,34 \pm 0,02$ & $2,5-1,3$ \\
\hline
\end{tabular}


Вестник Новосибирского государственного педагогического университета Novosibirsk State Pedagogical University Bulletin

1(17) $2014 \quad$ www.vestnik.nspu.ru ISSN 2226-3365

Рисунок 1

Изменение состояния систем вегетативной регуляиии сердечного ритма у гимназистов разных профилей обучения от $8 \kappa 11$ классу

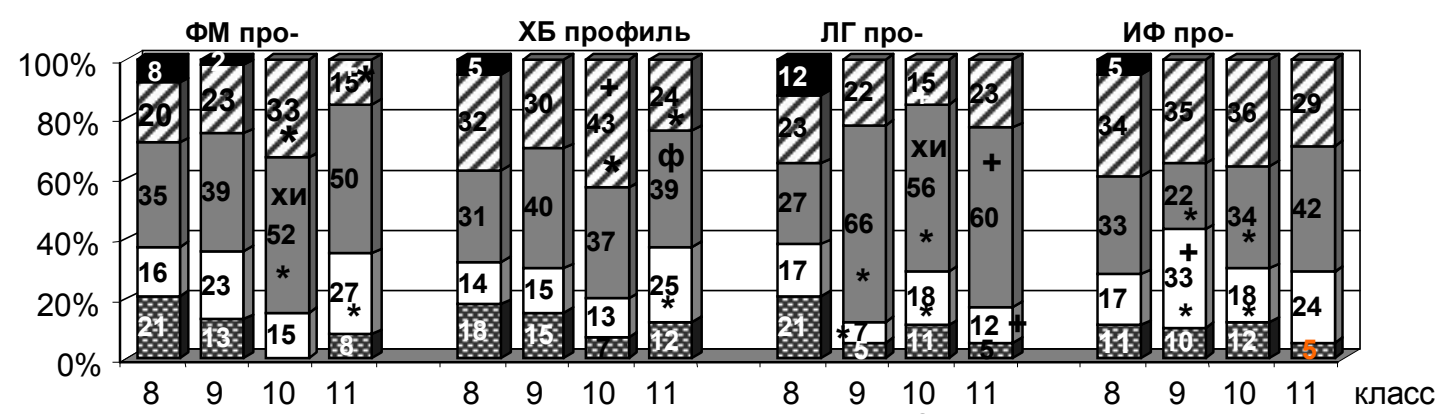

снижение тонуса симпатического и парасимпатического отделов ВНС

\рассогласование симпатического и парасимпатического отделов ВНС 圈 нормальное

$\square$ увеличенное влияние симпатического отдела ВН $\square$ увеличенное влияние парасимпатического отдела ВНС

Примечание - достоверность различий по сравнению с предыдущим годом в профиле:

* - $<<0,05$; от других профилей одного года обучения: $+-\mathrm{p}<0,05$, от ФМ профиля: $\boldsymbol{\phi}-\mathrm{p}<0,05$, от ХБ профиля: $\mathbf{x}-\mathrm{p}<0,05$, от ИФ профиля: $\mathbf{и}-\mathrm{p}<0,05$.

Изменение вегетативного баланса в виде активации симпатического отдела ВНС рассматривается как неспецифический компонент адаптационной реакции в ответ на различные стрессорные воздействия среды [3; 5 и др.].

У десятиклассников ХБ профиля ИН в покое снижается, а в ортостазе - увеличивается ( $<<0,05)$, что свидетельствует о повышении реактивности организма и включении компенсаторных реакций при нагрузочной пробе. В подтверждение этого, количество лиц с рассогласованием влияний симпатического и парасимпатического отделов ВНС и со значительным напряжением механизмов регуляции сердечного ритма увеличивается в 10 классе до $43 \%$ (Рис. 1, 2).

Увеличение обшей мощности спектральных характеристик сердечного ритма (TR, VLF, LF, HF) свидетельствует о возрастании центральных влияний на сердечный ритм [12]. Совокупность неблагоприятных реакций, вероятно, вызвана увеличением учебной нагрузки с переходом на профильную ступень обучения. В 11 классе у гимназистов ХБ профиля наблюдаются более благоприятные адаптационные изменения в регуляции сердечной деятельности: снижается количество лиц со значительным напряжением механизмов регуляции, возрастает парасимпатическая активность в управлении сердечным ритмом, на что указывает увеличение $\Delta \mathrm{X}$ и увеличение количества лиц с повышенным влиянием парасимпатического отдела ВНС в регуляции сердечным ритмом (Рис. 1, 2). Снижение мощности диапазона VLF свидетельствует об уменьшении влияний центрального контура управления на сердечный ритм. Значения индекса напряжения в покое соответствует возрастной норме и ниже, чем у одиннадцатиклассников ФМ и ЛГ профилей $(\mathrm{p}<0,05)$, что указывает на отсутствие напряжения механизмов вегетативной регуляции. 
Вестник Новосибирского государственного педагогического университета Novosibirsk State Pedagogical University Bulletin

1(17) $2014 \quad$ www.vestnik.nspu.ru ISSN 2226-3365

Рисунок 2

Изменение функционального состояния организма учащихся разных профилей в динамике четьрехлетнего обучения с 8 по 11 класс

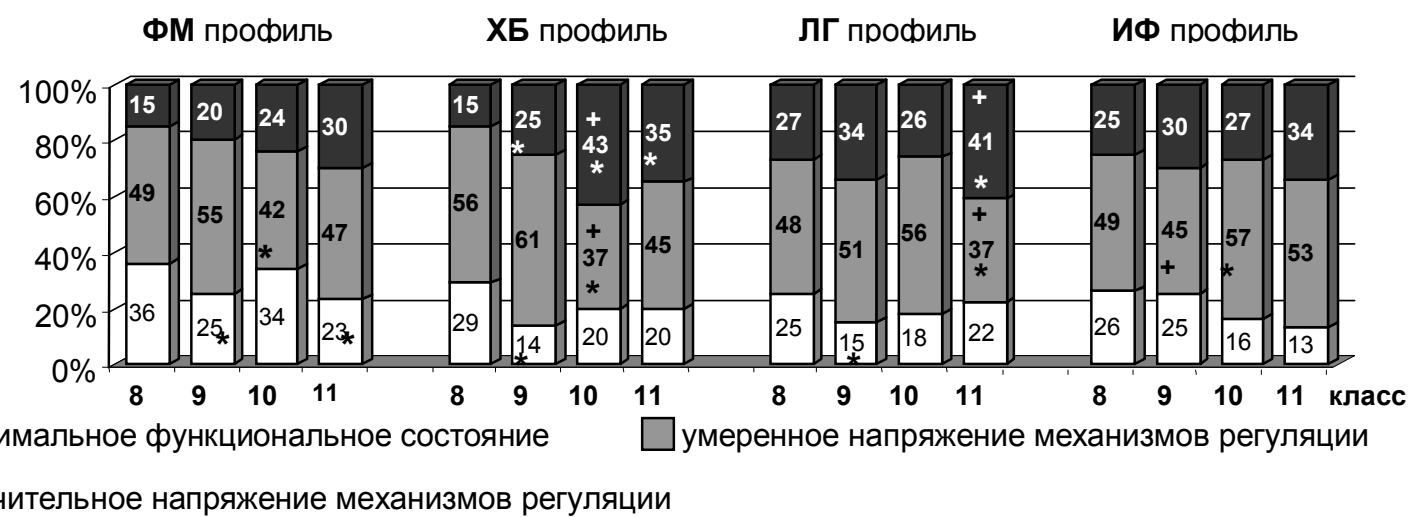

Примечание - достоверность различий по сравнению с предыдущим годом в одном профиле: * $-\mathrm{p}<0,05$; между разными профилями одного года обучения: $+-\mathrm{p}<0,05$.

У учащихся ЛГ профиля высокие показатели ИН сохраняются до 11 класса и имеют тенденцию к увеличению (Табл. 1). В результате этого одиннадцатиклассники ЛГ профиля отличаются от гимназистов ИФ и ХБ профилей и школьников общеобразовательных классов высоким значением ИН в покое и высоким значением ИН в ортостазе от учащихся всех групп $(p<0,05)$. Снижение показателя $\mathrm{HF}$ - маркера активности парасимпатической нервной системы в 11 классе свидетельствует об увеличении симпатических влияний на сердечный ритм, не свойственном данному возрасту [6]. Группа учащихся с неудовлетворительной адаптацией увеличивается до $41 \%$, а с увеличенным влиянием симпатического отдела ВНС в регуляции сердечного ритма составляет $60 \%$, что достоверно превышает аналогичные группы учащихся других профилей (Рис. 1, 2). Полученные данные свидетельствуют о неблагоприятном функциональном состоянии организма у гимназистов ЛГ профиля на протяжении всего периода профильного обучения. У старшеклассников ГМ профиля в 10 классе наблюдается увеличение симпатической активности: повышение ИН, АМо, снижение $\Delta \mathrm{X}$ в покое и ортостазе и увеличивается количество лиц с увеличенным влиянием симпатического отдела ВНС в регуляции сердечного ритма. В 11 классе наблюдается тенденция к увеличению АМО, ИН в ортостазе, но статистически значимо увеличивается только ЧСС в покое. Значения ИН у гимназистов этого профиля ниже, чем у учащихся ФМ и ЛГ профилей $(\mathrm{p}<0,05)$, что свидетельствуют о более успешной адаптации представителей ИФ профиля к обучению.

Таким образом, степень напряжения механизмов регуляции сердечного ритма у подростков в процессе долговременной адаптации к обучению по разным профильным программам различается:

- увеличение напряжения механизмов вегетативной регуляции у учащихся физико- 
Вестник Новосибирского государственного педагогического университета Novosibirsk State Pedagogical University Bulletin

математического профиля отмечается в 10 классе и сохраняется до конца обучения;

- в химико-биологическом профиле напряжение механизмов вегетативной регуляции увеличивается у учащихся в 10 классе и снижается в 11 классе;

- у учащихся лингвистического профиля значительное напряжение механизмов вегетативной регуляции наблюдается с 9 по 11 класс;
- в историко-филологическом профиле у учащихся напряжение механизмов вегетативной регуляции наблюдается в 9 классе и снижается к 10 классу.

Представленные в настоящей работе результаты свидетельствуют о выраженном влиянии специфики учебной нагрузки на организм подростков на разных этапах профильного обучения.

\section{СПИСОК ЛИТЕРАТУРЫ}

1. Айзман Р.И., Рубанович В.Б., Суботялов М.А. Основы медицинских знаний и здорового образа жизни: учебное пособие. - Новосибирск, 2010. - 286 с.

2. Баевский Р.М., Берсенев Е.Ю., Берсенева И.А. Медленные волны сердечного ритма, как индикатор возрастного развития детей и подростков / Медленные колебательные процессы в организме человека. Теоретические и прикладные аспекты нелинейной динамики в физиологии. Сб. материалов III Симпозиума и Школы. - Новокузнецк, 2001. - С. 105-109.

3. Баевский Р.М. и др. Анализ вариабельности сердечного ритма при использовании различных электрокардиографических систем: метод. рекомендации // Вестник аритмологии. 2001. - T. 24. - C. 69.

4. Быструшкин С.К., Айзман Р.И., Афтанас Л.И. Особенности организации внимания и эмоционального восприятия у детей в норме и при нарушениях интеллектуального развития // Бюллетень Сибирского отделения Российской академии наук. - 2007. - № 3. C. $159-162$.

5. Гиренко Л.А., Головин М.С., Колмогоров А.Б., Айзман Р.И. Функциональные резервы юношей, занимающихся лыжным спортом // Вестник Новосибирского государственного педагогического университета. - 2012. - № 6. - С. 45-50.

6. Игишева Л.Н., Галлеев А.Р. Комплекс ORTO EXPERT, как компонент здоровьесберегающих технологий в образовательных учреждениях: Методическое руководство. - Кемерово, 2003. $-36 \mathrm{c}$.

7. Казин Э.М., Блинова Н.Г., Душенина Т.В., Галеев А.Р. Комплексное лонгитудинальное исследование особенностей физического и психофизиологического развития учащихся на этапах детского, подросткового и юношеского периодов онтогенеза // Физиология человека. - 2003.- Т. 29, № 21. - С.70-76.

8. Мукатаева Ж.М. Морфофункциональная характеристика сельских детей и подростков разного пола северного Казахстана // Вестник Новосибирского государственного педагогического университета. - 2013. - № 2(12).- С. 70-79.

9. Пушкарёва Е.А., Судоргина Л.В. Культура самоопределения: адаптационные механизмы личности // Вестник Новосибирского государственного педагогического университета. 2012. - № 4. - С. 80-87.

10. Сафронова А.И., Вахмистрова А.В., Никулин В.Н., Каримова Л.Н. Функциональное состояние вегетативной нервной системы школьников и гимназистов в условиях комплекс- 
Вестник Новосибирского государственного педагогического университета Novosibirsk State Pedagogical University Bulletin

ного воздействия факторов школьной и окружающей среды // Гигиена и санитария. -2009. - № 4. - С 55-58.

11. Степанова М.И., Александрова И.Э., Седова А.С. Новая шкала трудности учебных предметов в общеобразовательной школе // Вестник образования России. - 2004. - № 5. C. $43-48$.

12. Stauss H.M. Physiologic mechanisms of heart rate variability. Rev Bras Hipertens 14. - 2007. pp. 8-15. 


\title{
UDC 614+371.7
}

\section{ADAPTATION OF TEENAGERS IN THE COURSE OF TRAINING ACCORDING TO DIFFERENT PROFILE PROGRAMS}

\author{
T. V. Vasina, N. N. Koshko (Kemerovo, Russia)
}

The article presents the results of research of students adaptive changes occurring in the training process according to different profile programs from 8 to 11 . Purpose of the article is to justify that adaptation of high school students to the process of training depends on the complexity and content of the training activities. It is shown that at preprofile and profile training stages of manifestation of adaptive responses in adolescents are different. With an increase in the teaching load the transition of systems of vegetative regulation of a cardiac rhythm of the pupils of all profiles increases. The highest voltage is found at students of linguistic and physical-mathematical profiles.

Key words: adaptation, the students, the profile of training, heart rate variability, stress mechanisms of autonomic regulation.

\section{REFERENCES}

1. Aizman R.I., Rubanovich V.B., Subotyalov M. A. Osnovy meditsinskikh znanii i zdorovogo obraza zhizni: uchebnoe posobie [Bases of medical knowledge and healthy way of life]. Novosibirsk, 2010, $286 \mathrm{p}$

2. Bayevsky R.M., Bersenev E.J., Berseneva I.A. Medlennye volny serdechnogo ritma, kak indikator vozrastnogo razvitiya detei i podrostkov [Slow waves of heart rate as an indicator of the age of children and adolescents]. Slow oscillatory processes in the human body. Teoreticheskie and applied aspects of nonlinear dynamics in physiology. Sat Materials III Symposium and School, Novokuznetsk, 2001, pp. 105-109.

3. Bayevsky R.M. etc. Analiz variabel'nosti serdechnogo ritma pri ispol'zovanii razlichnykh elektrokardiograficheskikh sistem: metod. rekomendatsii [Analysis of heart rate variability using different electrocardiographic systems: the method. recommendations]. Herald arrhythmology, 2001, vol. 24, p. 69.

4. Bystrushkin S.K., Aizman R.I., Aftanas L.I. Osobennosti organizatsii vnimaniya i emotsional'nogo vospriyatiya $\mathrm{u}$ detei $\mathrm{v}$ norme i pri narusheniyakh intellektual'nogo razvitiya [Features of the organization of attention and emotional perception at children in norm and at infringements of intellectual development]. Bulletin of the Siberian branch of the Russian academy of sciences, 2007, no. 3, pp. 159-162.

5. Girenko L.A., Golovin M.S., Kolmogorov A.B., AjzmanR.I. Funktsional'nye rezervy yunoshei, zanimayushchikhsya lyzhnym sportom [Functional reserves of the young men engaged skiing]. Novosibirsk State Pedagogical University Bulletin. 2012, no. 6, pp. 45-50.

6. Igisheva L.N., Galleev A.R. Kompleks ORTO EXPERT, kak komponent zdorov'esberegayushchikh tekhnologii v obrazovatel'nykh uchrezhdeniyakh. Metodicheskoe rukovodstvo [The complex 
ORTO EXPERT, as a component of health-saving technologies in educational institutions. A guide]. Kemerovo, 2003, 36 p.

7. Kazin E.M., Blinov N., Dushenina T.V., Galeev A.R. Kompleksnoe longitudinal'noe issledovanie osobennostei fizicheskogo i psikhofiziologicheskogo razvitiya uchashchikhsya na etapakh detskogo, podrostkovogo i yunosheskogo periodov ontogeneza [The complex features a longitudinal study of physical and psycho-physiological development of pupils at the stages of child, adolescent and youth periods of ontogenesis]. Human Physiology, 2003, vol. 29, no. 21, pp. 70-76.

8. Mukataeva Zh.M. Morfofunktsional'naya kharakteristika sel'skikh detei i podrostkov raznogo pola severnogo Kazakhstana [Morphological and functional characteristic of rural children and teenagers of the different sex of northern Kazakhstan]. Novosibirsk State Pedagogical University Bulletin, 2013, no. 2(12), pp. 70-79.

9. Pushkareva E.A., Sudorgina L.V. Kul'tura samoopredeleniya: adaptatsionnye mekhanizmy lichnosti [Culture of self-determination: adaptable mechanisms of the person]. Novosibirsk State Pedagogical University Bulletin. 2012, no. 4, pp. 80-87.

10. Safronov A.I., Vahmistrova A.V., Nikulin V., Karimov L.N. Funktsional'noe sostoyanie vegetativnoi nervnoi sistemy shkol'nikov i gimnazistov $\mathrm{v}$ usloviyakh kompleksnogo vozdeistviya faktorov shkol'noi i okruzhayushchei sredy [The functional state of the autonomic nervous system and high-school students in a complex influence factors of school and environment]. Hygiene and sanitation, 2009, no. 4, pp. 55-58.

11. Stepanova M.I., Alexandrov I.E., Sedov A. Novaya shkala trudnosti uchebnykh predmetov v obshcheobrazovatel'noi shkole [The new scale of difficulty of subjects in secondary school]. Journal of Education of Russia, 2004, no. 5, pp. 43-48.

12. Stauss H.M. Physiologic mechanisms of heart rate variability. Rev Bras Hipertens 14, 2007, pp. 8 15.

Vasina Eugeniya Vladimirovna, Ph.D., the heard of the laboratory of development of health-related activities within the vocational education, Kuzbass Regional development institution of vocational education.

E-mail: ev-va08@mail.ru

Koshko Nataliya Nikolayevna, Ph.D., the lecturer in human and animal physiology and valeology, Kemerovo State University.

E-mail: koshko80@mail.ru 
Вестник Новосибирского государственного педагогического университета Novosibirsk State Pedagogical University Bulletin

1(17) $2014 \quad$ www.vestnik.nspu.ru ISSN 2226-3365

(С) Л. А. Михайлова, С. И. Кимяева

УДК $612.13+612.143+796.3$

\title{
ВЛИЯНИЕ ДВИГАТЕЛЬНОГО РЕЖИМА НА ГЕМОДИНАМИЧЕСКИЕ ПОКАЗАТЕЛИ У СТАРШЕКЛАССНИКОВ, ИМЕЮЩИХ ПОВЫШЕННЫЕ УЧЕБНЫЕ НАГРУЗКИ*
}

\author{
Л. А. Михайлова, С. И. Кимяева (Красноярск, Россия)
}

С целью выяснения влияния учебных нагрузок и двигательной активности на состояние сердечно-сосудистой системы были обследованы старшеклассники 15-17 лет, обучающиеся по специальной учебной программе. I группа находилась на обычном двигательном режиме, II группа дополнительно занималась цииклическими игровыми видами спорта. Показано, что у юношей по сравнению с девушками независимо от уровня двигательной активности отмечается более высокий уровень показателей артериального давления и минутного объема кровообращения, но низкие значения частоты сердечных сокращений. Систематические занятия ииклическими и игровыми видами спортивной деятельности повышают производительность сердия в покое (снижение частоты сердечных сокращений и двойного произведения при относительно стабильном уровне систолического выброса и минутного объема кровообращения).

Ключевые слова: подростки, центральная гемодинамика, двигательная активность, учебные нагрузки.

Процесс обучения в старших классах сопровождается увеличением объема воспринимаемой информации, получаемой при использовании компьютерных средств и телекоммуникационных сетей глобального масштаба. Это приводит к сокращению времени активного отдыха, повышению доли статической нагрузки, а также может сопровождаться снижением резервных возможностей ве- дущих функциональных систем организма, в т.ч. и сердечно-сосудистой [1-6]. В последнее время все чаще обсуждается вопрос включения в новые образовательные технологии оздоровительную физическую тренировку различного вида и интенсивности, что позволяет оптимизировать двигательный режим и повысить качество жизни школьника [7-16].

* Статья подготовлена по результатам работы Всероссийской научной школы с Международным участием «Опыт использования мониторинга здоровья и физической подготовленности учащейся молодежи» (12-14 ноября 2013 г.).

Михайлова Людмила Аркадьевна - доктор биологических наук, профессор, кафедра физиологии, Красноярский государственный медицинский университет им. проф. В. Ф. ВойноЯсенецкого»Минздрава РФ.

E-mail: krasphysiol@mail.ru;

Кимяева Светлана Игоревна - аспирант, кафедра физиологии, Красноярский государственный медицинский университет им. проф. В. Ф. Войно-Ясенецкого Минздрава РФ.

E-mail: krasphysiol@mail.ru 
Вестник Новосибирского государственного педагогического университета Novosibirsk State Pedagogical University Bulletin

Цель проведенного исследования - исследовать основные показатели гемодинамики и дать оценку влияния двигательной активности на состояние сердечно-сосудистой системы у школьников старших классов с повышенной учебной нагрузкой, находящихся на различном двигательном режиме.

\section{Объект и методы исследования}

Проведено динамическое обследование 131 школьника 15-17 лет, из них лиц мужского пола 69 (52,7 \%) и лиц женского пола 62 (47,3 \%), обучающихся по специальной учебной программе, разработанной для ОУ «Школа космонавтики» (г. Железногорск).

I группа школьников (экспериментальная) имела повышенную двигательную активность (ДА): дополнительные занятия циклическими и игровыми видами спорта до трех раз в неделю с мощностью работы по ЧСС 130-150 уд/мин.

II группа (контрольная) находилась на обычном двигательном режиме с двумя уроками физкультуры в неделю. Обследование проводилось дважды в начале (сентябрь) и конце учебного года (май).

Состояние сердечно-сосудистой системы исследовали на аппаратно-программном комплексе «Valenta+». Полученные материалы обработаны с помощью пакета прикладных программ для Windows-2000. Анализ распределения исследуемых величин показал отклонения от нормального, что послужило основанием использовать непараметрические критерии Уилкоксона (анализ динамики показателей) и Манна-Уитни (межгрупповые различия) для расчета коэффициентов достоверности между группами. Обследования проведены в соответствии с юридическими и этическими принципами медико-биологических исследований у человека (заключение локального этического комитета КрасГМУ № 40 от 04.05.2012).

\section{Результаты исследований и обсуждение}

Как известно, артериальное давление (АД) является ведущей физиологической константой, обеспечивающей стабильный кровоток и отражающей насосную функцию сердца. Выявлены половые отличия и определенная динамика этого показателя в течение года обучения. Данные представлены в табл.1.

Показатели цеентральной гемодинамики у юношей старшеклассников с различной ДА (медиана и квартили [25 - 75])

\begin{tabular}{|c|c|c|c|c|c|}
\hline \multirow{3}{*}{ Показатели } & \multicolumn{2}{|c|}{$\begin{array}{c}\text { I группа } \\
\text { (повышенная } \text { ДА),n=38 }\end{array}$} & \multicolumn{2}{|c|}{$\begin{array}{c}\text { II группа } \\
\text { (обычная ДА), } \mathrm{n}=31\end{array}$} & \multirow[t]{3}{*}{$\begin{array}{l}\text { Достоверность } \\
\text { различий }\end{array}$} \\
\hline & Начало года & Конец года & Начало года & Конец года & \\
\hline & 1 & 2 & 3 & 4 & \\
\hline $\begin{array}{l}\text { САД, мм рт. } \\
\text { ст. }\end{array}$ & $\begin{array}{c}125,00 \\
{[120,00-130,00]}\end{array}$ & $\begin{array}{c}125,00 \\
{[120,00-130,00]}\end{array}$ & $\begin{array}{c}120,00 \\
{[115,00-130,00]}\end{array}$ & $\begin{array}{c}120,00 \\
{[110,00-130,00]}\end{array}$ & p $2-4<0,05$ \\
\hline $\begin{array}{l}\text { ДАД, мм рт. } \\
\text { ст. }\end{array}$ & $\begin{array}{c}80,00 \\
{[75,00-85,00]}\end{array}$ & $\begin{array}{c}80,00 \\
{[75,00-85,00]}\end{array}$ & $\begin{array}{c}80,00 \\
{[75,00-85,00]}\end{array}$ & $\begin{array}{c}80,00 \\
{[72,00-85,00]}\end{array}$ & \\
\hline $\begin{array}{l}\text { ПАД, мм } \\
\text { рт. ст. }\end{array}$ & $\begin{array}{c}45,00 \\
{[37,00-45,00]}\end{array}$ & $\begin{array}{c}45,00 \\
{[40,00-45,00]}\end{array}$ & $\begin{array}{c}40,00 \\
{[35,00-50,00]}\end{array}$ & $\begin{array}{c}40,00 \\
{[35,00-45,00]}\end{array}$ & \\
\hline
\end{tabular}


Вестник Новосибирского государственного педагогического университета Novosibirsk State Pedagogical University Bulletin

1(17) 2014

www.vestnik.nspu.ru

ISSN 2226-3365

\begin{tabular}{|c|c|c|c|c|c|}
\hline $\begin{array}{l}\text { СДД, } \\
\text { мм.рт.ст. }\end{array}$ & $\begin{array}{c}98,90 \\
{[93,90-104,00]}\end{array}$ & $\begin{array}{c}98,90 \\
{[94,70-103,90]}\end{array}$ & $\begin{array}{c}98,90 \\
{[91,80-102,60]}\end{array}$ & $\begin{array}{c}96,80 \\
{[89,70-101,80]}\end{array}$ & p $2-4<0,01$ \\
\hline СО, мл & $\begin{array}{c}62,80 \\
{[57,77-67,85]}\end{array}$ & $\begin{array}{c}63,09 \\
{[59,87-67,05]}\end{array}$ & $\begin{array}{c}63,98 \\
{[60,56-68,69]}\end{array}$ & $\begin{array}{c}64,14 \\
{[60,50-68,98]}\end{array}$ & $\begin{array}{c}\text { p } 1-3<0,05 \\
\text { p 2-4 }=0,053\end{array}$ \\
\hline $\begin{array}{l}\text { ЧСС, } \\
\text { уд/мин. }\end{array}$ & $\begin{array}{c}72,00 \\
{[66,00-80,00]}\end{array}$ & $\begin{array}{c}72,00 \\
{[66,00-78,00]}\end{array}$ & $\begin{array}{c}78,00 \\
{[72,00-84,00]}\end{array}$ & $\begin{array}{c}78,00 \\
{[72,00-84,00]}\end{array}$ & $\begin{array}{c}\text { p } 1-3<0,05 \\
\text { p } 2-4<0,001\end{array}$ \\
\hline МОК, л & $\begin{array}{c}4,64 \\
{[4,04-5,20]}\end{array}$ & $\begin{array}{c}4,54 \\
{[3,98-5,03]}\end{array}$ & $\begin{array}{c}4,94 \\
{[4,40-5,66]}\end{array}$ & $\begin{array}{c}4,94 \\
{[4,42-5,49]} \\
\end{array}$ & $\begin{array}{c}\text { p } 1-3<0,01 \\
\text { p } 2-4<0,001\end{array}$ \\
\hline $\begin{array}{l}\text { Индекс кро- } \\
\text { вообраще- } \\
\text { ния, мл/кг }\end{array}$ & $\begin{array}{c}57,37 \\
{[47,36-69,20]}\end{array}$ & $\begin{array}{c}49,44 \\
{[40,94-63,11]}\end{array}$ & $\begin{array}{c}64,60 \\
{[56,14-83,16]}\end{array}$ & $\begin{array}{c}57,87 \\
{[49,58-66,65]}\end{array}$ & $\begin{array}{c}\text { p } 1-2<0,001 \\
\text { p } 3-4<0,001 \\
\text { p } 1-3<0,05 \\
\text { p } 2-4<0,05\end{array}$ \\
\hline $\begin{array}{l}\text { Сердечный } \\
\text { индекс, } \\
\text { л/ мин./мI }\end{array}$ & $\begin{array}{c}2,09 \\
{[1,85-2,42]}\end{array}$ & $\begin{array}{c}1,86 \\
{[1,55-2,16]}\end{array}$ & $\begin{array}{c}2,30 \\
{[2,02-2,81]}\end{array}$ & $\begin{array}{c}2,08 \\
{[1,80-2,33]}\end{array}$ & $\begin{array}{l}\text { p } 1-2<0,001 \\
\text { p } 3-4<0,001 \\
\text { p } 1-3<0,05 \\
\text { p } 2-4<0,05\end{array}$ \\
\hline $\begin{array}{l}\text { Ударный } \\
\text { индекс, } \\
\text { мл/мI }\end{array}$ & $\begin{array}{c}32,95 \\
{[30,34-35,94]}\end{array}$ & $\begin{array}{c}31,96 \\
{[29,18-34,14]}\end{array}$ & $\begin{array}{c}33,55 \\
{[31,09-37,24]}\end{array}$ & $\begin{array}{c}32,81 \\
{[29,84-35,75]}\end{array}$ & $\begin{array}{l}\text { p } 1-2<0,05 \\
\text { p } 3-4<0,05\end{array}$ \\
\hline $\begin{array}{l}\text { Двойное } \\
\text { произведе- } \\
\text { ние, у.е. }\end{array}$ & $\begin{array}{c}75,62 \\
{[69,00-80,01]}\end{array}$ & $\begin{array}{c}68,40 \\
{[62,40-76,25]}\end{array}$ & $\begin{array}{c}85,20 \\
{[70,00-97,50]}\end{array}$ & $\begin{array}{c}71,40 \\
{[63,80-76,80]}\end{array}$ & $\begin{array}{l}\text { p } 1-2<0,05 \\
\text { p } 3-4<0,001 \\
\text { p } 1-3<0,05\end{array}$ \\
\hline
\end{tabular}

Согласно полученным данным, у юношей I группы (повышенная ДА) показатель САД в течение обследуемого периода не изменяется, медиана составляла 120,0 мм рт.ст. У школьников контрольной группы САД в конце учебного года по сравнению с сентяб- рем снижается на $6,54 \pm 1,21 \%$, что ниже, чем у I группы. Показатель ДАД является относительно стабильным в обеих исследуемых группах. Отмечается его снижение к концу учебного года у девушек независимо от уровня их ДА (табл. 2).

Таблица 2.

Показатели цеентральной гемодинамики у девушек старшеклассниц с различной ДА (медиана и квартили [25 - 75])

\begin{tabular}{|c|c|c|c|c|c|}
\hline \multirow{3}{*}{ Показатели } & \multicolumn{2}{|c|}{$\begin{array}{c}\text { I группа } \\
\text { ( повышенная ДА), } \mathrm{n}=25\end{array}$} & \multicolumn{2}{|c|}{$\begin{array}{c}\text { II группа } \\
\text { (обычная } \text { ДА), } \mathrm{n}=\mathbf{3 7}\end{array}$} & \multirow[t]{3}{*}{$\begin{array}{l}\text { Достоверность } \\
\text { различий }\end{array}$} \\
\hline & Начало года & $\begin{array}{c}\text { Конец } \\
\text { года }\end{array}$ & Начало года & Конец года & \\
\hline & 1 & 2 & 3 & 4 & \\
\hline $\begin{array}{l}\text { САД, мм рт. } \\
\text { ст. }\end{array}$ & $\begin{array}{c}120,00 \\
{[110,00-125,00]}\end{array}$ & $\begin{array}{c}115,00 \\
{[110,00-120,00]}\end{array}$ & $\begin{array}{c}115,00 \\
{[110,00-120,00]}\end{array}$ & $\begin{array}{c}115,00 \\
{[105,00-120,00]}\end{array}$ & $\begin{array}{l}\text { p } 1-2<0,05 \\
\text { p } 1-3<0,05\end{array}$ \\
\hline $\begin{array}{l}\text { ДАД, мм рт. } \\
\text { ст. }\end{array}$ & $\begin{array}{c}80,00 \\
{[75,00-85,00]}\end{array}$ & $\begin{array}{c}75,00 \\
{[70,00-80,00]}\end{array}$ & $\begin{array}{c}80,00 \\
{[70,00-85,00]}\end{array}$ & $\begin{array}{c}77,00 \\
{[70,00-85,00]}\end{array}$ & $\begin{array}{l}\text { p } 1-2<0,01 \\
\text { p } 3-4<0,05\end{array}$ \\
\hline
\end{tabular}


Вестник Новосибирского государственного педагогического университета Novosibirsk State Pedagogical University Bulletin

1(17) $2014 \quad$ www.vestnik.nspu.ru ISSN 2226-3365

\begin{tabular}{|c|c|c|c|c|c|}
\hline $\begin{array}{l}\text { ПАД, мм рт. } \\
\text { ст. }\end{array}$ & $\begin{array}{c}40,00 \\
{[35,00-40,00]}\end{array}$ & $\begin{array}{c}40,00 \\
{[35,00-40,00]}\end{array}$ & $\begin{array}{c}35,00 \\
{[35,00-40,00]}\end{array}$ & $\begin{array}{c}38,00 \\
{[35,00-40,00]}\end{array}$ & $\begin{array}{l}\text { p 1-3 }=0,054 \\
\text { p 2-4 }=0,064\end{array}$ \\
\hline $\begin{array}{l}\text { СДД, } \\
\text { мм.рт.ст. }\end{array}$ & $\begin{array}{c}96,80 \\
{[91,00-101,80]}\end{array}$ & $\begin{array}{c}93,90 \\
{[87,60-98,90]}\end{array}$ & $\begin{array}{c}93,90 \\
{[89,45-99,70]}\end{array}$ & $\begin{array}{c}92,60 \\
{[86,80-97,60]}\end{array}$ & $\begin{array}{l}\text { p } 1-2<0,01 \\
\text { p } 3-4<0,01 \\
\text { p } 1-3<0,05\end{array}$ \\
\hline СО, мл & $\begin{array}{c}63,11 \\
{[59,69-66,25]}\end{array}$ & $\begin{array}{c}63,75 \\
{[60,37-67,80]}\end{array}$ & $\begin{array}{c}63,25 \\
{[58,09-67,68]}\end{array}$ & $\begin{array}{c}63,78 \\
{[59,19-67,88]}\end{array}$ & p $1-2=0,059$ \\
\hline ЧСС, уд/мин. & $\begin{array}{c}78,00 \\
{[72,00-84,00]}\end{array}$ & $\begin{array}{c}76,00 \\
{[72,00-78,00]}\end{array}$ & $\begin{array}{c}78,00 \\
{[72,00-84,00]}\end{array}$ & $\begin{array}{c}75,50 \\
{[70,50-80,00]}\end{array}$ & $\begin{array}{l}\text { p } 1-2<0,05 \text { p } 3-4< \\
0,05\end{array}$ \\
\hline МОК, л & $\begin{array}{r}4,88 \\
4,36-5,52]\end{array}$ & $\begin{array}{c}4,86 \\
{[4,29-5,29]}\end{array}$ & $\begin{array}{c}4,90 \\
{[4,47-5,43]}\end{array}$ & $\begin{array}{c}4,73 \\
{[4,37-5,36]}\end{array}$ & \\
\hline $\begin{array}{l}\text { Индекс кро- } \\
\text { вообраще- } \\
\text { ния, мл/кг }\end{array}$ & $\begin{array}{c}79,58 \\
{[63,27-90,36]}\end{array}$ & $\begin{array}{c}68,60 \\
{[58,64-76,08]}\end{array}$ & $\begin{array}{c}74,14 \\
{[67,26-82,17]}\end{array}$ & $\begin{array}{c}73,61 \\
{[59,24-80,48]}\end{array}$ & $\begin{array}{l}\text { p } 1-2<0,01 \\
\text { p } 3-4<0,05\end{array}$ \\
\hline $\begin{array}{l}\text { Ударный } \\
\text { индекс, } \\
\text { мл/мI }\end{array}$ & $\begin{array}{c}38,36 \\
{[35,11-40,96]}\end{array}$ & $\begin{array}{c}36,66 \\
{[34,15-38,67]}\end{array}$ & $\begin{array}{c}36,56 \\
{[34,14-39,51]}\end{array}$ & $\begin{array}{c}36,12 \\
{[33,12-38,42]}\end{array}$ & \\
\hline $\begin{array}{l}\text { Сердечный } \\
\text { индекс, } \\
\text { л/ мин./мI }\end{array}$ & $\begin{array}{c}2,73 \\
{[2,34-3,11]}\end{array}$ & $\begin{array}{c}2,41 \\
{[2,13-2,63]}\end{array}$ & $\begin{array}{c}2,64 \\
{[2,39-2,80]}\end{array}$ & $\begin{array}{c}2,53 \\
{[2,14-2,70]}\end{array}$ & $\begin{array}{l}\text { p } 1-2<0,01 \\
\text { p } 3-4<0,05\end{array}$ \\
\hline $\begin{array}{l}\text { Двойное } \\
\text { про- } \\
\text { изведение, } \\
\text { у.е. }\end{array}$ & $\begin{array}{l}78,20 \\
{[68,25-88,55]}\end{array}$ & $\begin{array}{l}67,85 \\
{[59,85-78,10]}\end{array}$ & $\begin{array}{l}77,70 \\
{[69,30-85,80]}\end{array}$ & $\begin{array}{l}73,00 \\
{[67,00-80,50]}\end{array}$ & $\begin{array}{l}\text { p } 1-2<0,001 \\
\text { p 3-4 }<0,05\end{array}$ \\
\hline
\end{tabular}

Расчет среднего динамического давления (СДД) выявил половые отличия: СДД у юношей по сравнению с девушками выше на $7,69 \pm 1,54 \%(\mathrm{p}<0,01)$ и в течение года не изменяется. Двигательный режим оказывает влияние на этот показатель. Установлено, что у школьников с повышенной ДА в конце учебного года отмечается статистически значимое увеличение СДД на 5,13\% $\pm 0,92$ по сравнению с исходным уровнем и на 7,5 \pm $1,2 \%$ по сравнению с контрольной группой. Для юношей, находящихся на обычном двигательном режиме, СДД к концу года снижается. Эту разнонаправленную динамику можно объяснить различной степенью тренированности организма и необходимостью поддержания высокого уровня кровотока у лиц, занимающихся в спортивных секциях. У де- вушек, находящихся на различном двигательном режиме, статистически значимых отличий между группами и динамики в течение года не выявлено.

Ведущим гемодинамическим показателей является минутный объем кровообращения (МОК), напрямую зависящий от уровня потребности организма в кислороде. Средний уровень МОК в исследуемых группах в начале учебного года не имеет значимых половых отличий, а в конце учебного года у девушек МОК выше, чем у юношей на 10,3 $\pm 1,01 \%$ $(p<0,001)$. У юношей с повышенной ДА этот показатель ниже, чем в контрольной группе, у девушек статистически значимых отличий между исследуемыми группами не выявлено (табл. 1 и 2). 
Вестник Новосибирского государственного педагогического университета Novosibirsk State Pedagogical University Bulletin

1(17) $2014 \quad$ www.vestnik.nspu.ru $\quad$ ISSN 2226-3365

Для выяснения этих отличий был проведен анализ таких показателей, как систолический объем (СО) и число сердечных сокращений в минуту (ЧСС).

К концу учебного года СО снижается у юношей на 5,62 $\pm 0,38 \%(\mathrm{p}<0,001)$, а у девушек на 4,94 $\pm 0,69 \%(\mathrm{p}<0,05)$. Причем, для юношей с повышенной ДА это снижение составило 7,01 $\pm 1,95 \%$, а при обычном двигательном режиме $\mathrm{CO}$ практически не изменяется, отличий от показателей контрольной группы нет.

ЧСС имеет аналогичную динамику: наиболее частый сердечный ритм отмечен в начале учебного года, а к концу учебного года он снижается у юношей на $6,15 \pm 0,51 \%$ $(\mathrm{p}<0,001)$, у девушек на $4,93 \pm 0,71 \%$ $(\mathrm{p}<0,05)$. Для юношей, систематически занимающихся игровыми видами спорта, к концу года ЧСС снижается на $6,30 \pm 0,78 \%$, а при обычной ДА на 11,27 $\pm 1,28$ \%. Причем, если в начале учебного года различия составляли $11,81 \pm 1,53 \%$, то в мае $-5,88 \pm 0,86 \%$.

Можно предположить, что в начале учебного года у юношей МОК поддерживается относительно высокими показателями $\mathrm{CO}$ и ЧСС, а к концу года возрастает доля ЧСС в обеспечении тканей кислородом, причем, для лиц, находящихся на обычном двигательном режиме, - в большей степени. Значение двойного произведения (ДП = САД $\mathrm{x}$ ЧСС), косвенно характеризующего, аэробную производительность сердечной мышцы и насосную функцию сердца, имеет тенденцию к снижению в конце учебного года по сравнению с первым измерением. Для юношей с повышенной ДА по сравнению с контрольной группой это снижение составило 9,55 $\pm 1,32 \%$ и $16,2 \pm 1,58 \%$ а для девушек $13,23 \pm 1,53 \%$ и $6,04 \pm 0,54 \%$ соответственно (табл. 1 и табл. 2 ). Это снижение происходит, в основном, за счет уменьшения нагрузки на сердце (снижение ЧСС), что также свидетельствует ог носительном повышении экономичности работы миокарда, поскольку при этом значение СО не увеличивается, что обычно наблюдается у взрослых спортсменов. Выяснение механизмов регуляции этого процесса у подростков с указанным уровнем ДА будет являться предметом дальнейших исследований.

Расчет относительных показателей, таких как сердечный индекс СИ (МОК/поверхность тела) и ударный индекс УИ (УО/поверхность тела) свидетельствует о более интенсивной сердечной деятельности у девушек по сравнению с юношами и независимо от пола к концу учебного года эти показатели имеют тенденцию к снижению. Систематические занятия циклическими и игровыми видами спорта сопровождаются повышением интенсивности метаболических процессов $[1,5]$. Об этом свидетельствуют более высокие, чем в контрольной группе, значения СИ, хотя УИ остается практически неизменным (табл.1 и табл.2). Кроме этого, полученные данные также свидетельствуют о том, что в становлении регуляции процесса кровообращения наибольшая роль отводится экстракардиальным влияниям, а не интракардиальным рефлексам.

\section{Заключение}

Для старшеклассников, имеющих повышенную учебную нагрузку, дополнительные систематические занятия игровыми циклическими видами спорта способствуют улучшению функционального состояния сердечно-сосудистой системы. Наиболее отчетливо это проявляется для юношей: показатели артериального давления в этой группе выше, чем в группе с обычным двигательным 
Вестник Новосибирского государственного педагогического университета Novosibirsk State Pedagogical University Bulletin

1(17) $2014 \quad$ www.vestnik.nspu.ru $\quad$ ISSN 2226-3365

режимом. Двигательный режим у девушек не отражается на их артериальном давлении.

Регулярные тренировки позволяют повысить производительность сердца в покое. Обеспечение организма кислородом за счет поддержания минутного объема кровообращения на оптимальном для организма уровне у лиц, занимающихся в спортивных секциях, по сравнению с контрольной группой, осуществляется за счет повышения относительной эффективности работы сердца (снижение частоты сердечных сокращений и двойного произведения при относительно низких или неизменных значениях систолического объема).

\section{СПИСОК ЛИТЕРАТУРЫ}

1. Будук-оол Л.К., Красильникова В.А., Айзман Р.И. Динамика процессов адаптации к обучению студентов, проживающих в дискомфортном климато-географическом регионе // Физиология человека. - 2009. - Т. 35. - № 4. - С. 103-110.

2. Демидов В.А., Мальцев Д.Н., Мавлиев Ф.А. Влияние повышенной двигательной активности на кардиогемодинамическую устойчивость подростков в условиях напряженной информационной нагрузки// Физиология человека. - 2008. - № 4. - С. 133-140.

3. Киршина Е.Д. Взаимосвязь учебной и двигательной деятельности старшеклассников во время обучения // Вестник Томского государственного университета. - 2009. - №319. C. $169-172$.

4. Красильникова В.А., Будук-Оол Л.К., Айзман Р.И. Морфофункциональное развитие школьников тувинской и русской национальностей // Физиология человека, 2008. - Т. 34 № $1 .-$ C. $74-82$.

5. Михайлова Л.А., Кимяева С.И. Динамика физической подготовленности и показателей внешнего дыхания у юношей-подростков, обучающихся по специальной учебной программе // Вестник ЮУрГУ. Серия «Образование, здравоохранение, физическая культура». 2012. - вып. 31. - С. 41-45.

6. Шуленина Н.С., Корощенко Г.А., Терехова Э.А., Лысова Н.Ф. Анализ состояния здоровья школьников МКОУ Доволенской СОШ № 1 Новосибирской области // Вестник Новосибирского государственного педагогического университета. - 2012. - № 5. - С. 58-66.

7. Айзман Р.И., Рубанович В.Б., Суботялов М.А. Основы медицинских знаний и здорового образа жизни: учебное пособие. - Новосибирск, 2010. - 286 с.

8. Алферова О.П., Осин А.Я. Особенности вегетативной регуляции и интегрированных показателей адаптированности сердечно-сосудистой системы у подростков// Современные проблемы науки и образования. - 2012. - № 2. - С. 113-116.

9. Борцова О. А. Медико-социальные аспекты обучения школьников правильному образу жизни // Философия образования. - 2006. - № 1. - С. 211-214.

10. Быструшкин С.К., Айзман Р.И., Афтанас Л.И. Особенности организации внимания и эмоционального восприятия у детей в норме и при нарушениях интеллектуального развития // Бюллетень Сибирского отделения Российской академии наук. - 2007. - № 3. - С. 159-162.

11. Лучицкая Е.С., Русанов В.Б. Функциональные особенности гемодинамики подростков в условиях различной двигательной активности // Физиология человека. - 2009. - № 4. C. $43-50$. 
Вестник Новосибирского государственного педагогического университета Novosibirsk State Pedagogical University Bulletin

1(17) 2014

www.vestnik.nspu.ru

ISSN 2226-3365

12. Молоканова Ю.П. Факторы, определяющие ритм сердечных сокращений у лиц юношеского возраста// Вестник Московского государственного областного университета. Серия: естественные науки. - 2013. - № 2. - С. 63-66.

13. Рубанович В.Б., Айзман Р.И. Основы здорового образа жизни: учебное пособие. - Новосибирск : АРТА, 2011.-256 с.

14. Спивак Е.М. Особенности вегетативной регуляции и функциональное состояние сердечнососудистой системы у юных спортсменов // Вопросы практической педиатрии. - 2008. Т. 3. - № 3. - С. 20-23.

15. Томенко А.А. Уровень двигательной активности школьников и пути его повышения в условиях общеобразовательной школы // Педагогика, психология и медико-биологические проблемы физического воспитания и спорта. - 2008. - № 2. - С. 141-146.

16. Aizman R.I., Krasilnikova V.A., Buduk-ool L.K. Morphological, functional, and Psychological development of children living permanently in the Tuva Republic. Alaska medicine, 2007, vol. 49, no. 2, pp. 133-138. 
UDC $612.13+612.143+796.3$

\title{
INFLUENCE OF THE MOTIVE MODE ON HAEMO DYNAMIC INDICATORS OF THE SENIORS HAVING RAISED ACADEMIC LOADS
}

\author{
L. A. Mikhaylova, S. I. Kimyaeva (Krasnoyarsk, Russia)
}

For the purpose of clarification of influence of academic loads and physical activity on a condition of cardiovascular system of the seniors of 15-17 years who are training on the special training program were surveyed. The I group was on the usual motive mode, the II group in addition was engaged in cyclic game sports. It is shown that young men in comparison with girls irrespective of level of physical activity higher level of indicators of arterial pressure and minute volume of blood circulation, but low values of frequency of warm reductions. Systematic occupations by cyclic and game types of sports activity increase heart productivity in rest (decrease in frequency of warm reductions and double work at rather stable level of systolic emission and minute volume of blood circulation).

Keywords: teenagers, central haemo dynamics, physical activity, academic loads.

\section{REFERENCES}

1. Buduk-ool L.K., Krasil'nikova V.A., Aizman R.I. Dinamika protsessov adaptatsii k obucheniyu studentov, prozhivayushchikh $\mathrm{v}$ diskomfortnom klimato-geograficheskom regione [Dynamics of processes of adaptation to training the students living in discomfortable climate-geographical region]. Human physiology, 2009, vol. 35, no.4, pp. 103-110.

2. Demidov V.A., Mal'cev D.N., Mavliev F.A. Vlijanie povyshennoj dvigatel'noj aktivnosti na kardiogemodinamicheskuju ustojchivost' podrostkov v uslovijah naprjazhennoj informacionnoj nagruzki [Influence of the raised impellent activity on kardiogemodynamic stability of teenagers in conditions of the intense information loading]. Human physiology. 2008, no. 4, pp. 133-140.

3. Kirshina E.D. Vzaimosvjaz' uchebnoj i dvigatel'noj dejatel'nosti starsheklassnikov vo vremja obuchenija [Interrelation of educational and impellent activity of senior pupils during training]. Tomsk state university Bulletin. 2009, no. 3, pp. 169-172.

4. Krasil'nikova V.A., Buduk-Ool L.K., Aizman R.I. Morfofunktsional'noe razvitie shkol'nikov tuvinskoi i russkoi natsional'nostei [Morphological and functional development of children of Tuva and Russian nationalities]. Human physiology, 2008, vol. 34, no 1, pp. 74-82.

5. Mihajlova L.A., Kimjaeva S.I. Dinamika fizicheskoj podgotovlennosti i pokazatelej vneshnego dyhanija u junoshej-podrostkov, obuchajushhihsja po special'noj uchebnoj programme [Dynamics of physical readiness and parameters of external breath at the young men-teenagers trained under the special curriculum]. South-Ural state university Bulletin. A series "Formation, public health services, physical training». 2012, no. 31, pp. 41-45.

6. Shulenina N.S., Koroshchenko G.A., Terehova I.A., Lysova N.F. Analiz sostoyaniya zdorov'ya shkol'nikov MKOU Dovolenskoi SOSh № 1 Novosibirskoi oblasti [The analysis of the state of health of schoolchildren of Dovolenskaya school №1 of Novosibirsk region]. Novosibirsk State Pedagogical University Bulletin. 2012, no. 5, pp. 58-66. 
7. Aizman R.I., Rubanovich V.B., Subotyalov M.A. Osnovy meditsinskikh znanii i zdorovogo obraza zhizni: uchebnoe posobie [Bases of medical knowledge and healthy way of life]. Novosibirsk, 2010, $286 \mathrm{p}$.

8. Alferova O.P., Osin A. Ja. Osobennosti vegetativnoj reguljacii i integrirovannyh pokazatelej adaptirovannosti serdechno-sosudistoj sistemy u podrostkov [Features of vegetative regulation and the integrated parameters of adaptedness of cardiovascular system at teenagers]. Modern problems of a science and education. 2012, no. 2, pp. 113-116.

9. Bortsova O. A. Mediko-sotsial'nye aspekty obucheniya shkol'nikov pravil'nomu obrazu zhizni [Medicine and social aspects of training of pupils to a correct way of life]. Philosophy of education. 2006, no. 1, pp. 211-214.

10. Bystrushkin S. K., Aizman R. I., Aftanas L. I. Osobennosti organizatsii vnimaniya i emotsional'nogo vospriyatiya $u$ detei v norme i pri narusheniyakh intellektual'nogo razvitiya [Features of the organization of attention and emotional perception at children in norm and at infringements of intellectual development]. Bulletin of the Siberian branch of the Russian academy of sciences. 2007, no. 3, pp. 159-162.

11. Luchickaja E.S., Rusanov V.B. Funkcional'nye osobennosti gemodinamiki podrostkov v uslovijah razlichnoj dvigatel'noj aktivnosti [Functional features гемо dynamics of teenagers in conditions of various impellent activity]. Human physiology. 2009, no. 4, pp. 43-50.

12. Molokanova Ju.P. Faktory, opredeljajushhie ritm serdechnyh sokrashhenij u lic junosheskogo vozrasta [The factors defining a rhythm of intimate reductions at persons of youthful age]. Bulletin of the Moscow state regional university. A series: natural sciences. 2013, no. 2, pp. 63-66.

13. Rubanovich V.B., Aizman R.I. Osnovy zdorovogo obraza zhizni: uchebnoe posobie [Bases of a healthy way of life]. Novosibirsk, 2011, $256 \mathrm{p}$.

14. Spivak E.M. Osobennosti vegetativnoj reguljacii i funkcional'noe sostojanie serdechno-sosudistoj sistemy u junyh sportsmenov [Features of vegetative regulation and a functional condition of cardiovascular system at young sportsmen]. Questions of practical pediatrics. 2008, vol. 3, no. 3, pp. 20-23.

15. Tomenko A.A. Uroven' dvigatel'noj aktivnosti shkol'nikov i puti ego povyshenija v uslovijah obshheobrazovatel'noj shkoly [Level of impellent activity of schoolboys and ways of its increase to conditions of a comprehensive school]. Pedagogic, psychology and medical and biologic problems of physical training and sports. 2008, no. 2, pp. 141-146.

16. Aizman R.I., Krasilnikova V.A., Buduk-ool L.K. Morphological, functional, and Psychological development of children living permanently in the Tuva Republic. Alaska medicine, 2007, vol. 49, no. 2, pp. 133-138.

Mikhaylova Lyudmila Arkadyevna, the doctor of biological science, the professor of the department of physiology, Krasnoyarsk State Medical University at prof. V.F. Voyno-Yasenetsky.

E-mail: krasphysiol@mail.ru

Kimyaeva Svetlana Igorevna, the post-graduate student of the department of physiology, Krasnoyarsk State Medical University at prof. V.F. Voyno-Yasenetsky.

E-mail: krasphysiol@mail.ru 
Вестник Новосибирского государственного педагогического университета Novosibirsk State Pedagogical University Bulletin

1(17) $2014 \quad$ www.vestnik.nspu.ru ISSN 2226-3365

(C) Ж. М. Мукатаева, С. Ж. Кабиева

УДК 612. 821

\title{
МОНИТОРИНГ ФИЗИЧЕСКОГО РАЗВИТИЯ И ЗДОРОВЬЯ УЧАЩИХСЯ ПАВЛОДАРСКОЙ ОБЛАСТИ*
}

\author{
Ж. М. Мукатаева, С. Ж. Кабиева (Павлодар, Казахстан)
}

В статье анализируются результаты комплексного исследования морфологических показателей городских и сельских детей 7-15 лет на территории Павлодарской области. Цель статьи - провести мониторинг физического развития и здоровья учащихся 7-15 лет Павлодарской области. В ходе исследования установлень сравнительно большие тотальнье размеры тела у городских детей в сравнении с сельскими сверстниками. Определены жировой и мышечный компоненты состава тела у детей и подростков. У городских детей выявлены более высокие показатели резервного жира, активной массы тела и мышечной силь по сравнению с сельскими школьниками. На основе пробы $P W_{170}$ установлены физическая работоспособность и аэробная производительность детей и подростков 7-15 лет. У сельских школьников установлень более высокие показатели физической работоспособности и аэробной производительности. В заключении делаются выводы о результатах мониторинга развития и здоровья учащихся Павлодарской области.

Ключевые слова: морфункииональные показатели, городские и сельские дети, жировой и мылиечный компонент, физическая работоспособность, аэробная производительность.

Развитие современной науки приносит все новые доказательства, что здоровье является одним из наиболее интегральных, сложных, комплексных процессов. В последние годы резко обострилась проблема здоровья детей школьного возраста, отмечается ухудшение морфофункционального и психофизиологического статуса детей, что, как правило, связывают с возросшим экосоциальным неблагополучием и увеличением учебной нагрузки [1].

Павлодарская область является крупным промышленным центром Казахстана с высоко развитой индустрией, что приводит к высокому загрязнению атмосферного воздуха, почвы. Известно, что наиболее чувствитель-

* Статья подготовлена по результатам работы Всероссийской научной школы с Международным участием «Опыт использования мониторинга здоровья и физической подготовленности учащейся молодежи» (12-14 ноября 2013 г.)

Мукатаева Жанат Макановна - доктор биологических наук, профессор, проректор по научнометодической работе и новым технологиям, Павлодарский государственный педагогический uнституm.

E-mail: MukataevaZh@mail.ru

Кабиева Салтанат Жумабаевна - кандидат биологических наук, дочент, заведующий кафедрой анатомии, физиологии и дефектологии, Павлодарский государственньий педагогический институт.

E-mail: Dairbaevasg@mail.ru 
ным контингентом к действию неблагоприятных факторов окружающей среды являются дети [2-3].

Отрицательные последствия переживаемого страной социально-экономического кризиса в наибольшей мере проявились в сельских районах, где население изначально находилось в худших условиях развития инфраструктуры производственной и бытовой сферы [4].

Доказаны неблагоприятные воздействия негативных факторов природной и социальной среды на физическое развитие организма, что проявляется понижением показателей, отражающих физическое развитие (рост, вес, окружность грудной клетки, изменение соотношений между жировой, мускульной и костной тканями). Социальные факторы являются одним из основных условий, определяющих уровень и сдвиги в состоянии здоровья населения и его отдельных возрастно-половых, социальных, этнонациональных групп [2].

Физическое развитие позволяет дать характеристику уровня здоровья, общей заболеваемости, прогнозировать дальнейшее развитие детей и подростков, проводить рациональное планирование учебнотренировочных нагрузок при занятиях физической культурой [3].

Большинство исследований в области возрастной физиологии связано с изучением состояния здоровья и развития детей, проживающих в условиях города [5-7]. При этом практически без внимания остаются дети, проживающие в сельской местности.

Очевидно, что условия развития сельских и городских детей, в первую очередь внешнесредовые факторы, значительно отличаются. Это касается особенностей условий проживания, уровня информацион- ных нагрузок и др. На городских детей больше воздействуют антропогенные, а на сельских - природные факторы среды [8-12].

Цель работы провести мониторинг физического развития и здоровья учащихся 7-15 лет Павлодарской области.

\section{Задачи исследования:}

1. Исследовать морфофункциональные особенности развития городских и сельских детей и подростков в онтогенезе.

2. Провести сравнительный анализ морфологических показателей и функциональных возможностей организма детей и подростков в зависимости от пола, возраста и места проживания (город, село).

Методы исследования: нами было обследовано 700 городских (из них 349 мальчиков, 351 девочек) и 367 сельских (из них 187 мальчиков и 180 девочек) школьников в возрасте 7-15 лет. Все учащиеся относились к основной медицинской группе и не занимались в спортивных секциях. Обследуемые были распределены на группы по возрасту, месту проживания.

Объектом наших исследований были практически здоровые школьники городской и сельской школ Павлодарской области. Исследования проводили в первую половину дня с исключением физической нагрузки в предыдущий день.

Проведено комплексное исследование морфофункциональных особенностей детей и подростков.

Общепринятыми методами ${ }^{1}$ определяли основные антропометрические показатели физического развития: длину тела (ДТ), массу тела (МТ), окружность грудной клетки (ОГК),

\footnotetext{
${ }^{1}$ Бунак В.В. Антропометрия. - М.: Учпедгиз, 1941. $182 \mathrm{c}$.
} 
Вестник Новосибирского государственного педагогического университета Novosibirsk State Pedagogical University Bulletin

1(17) $2014 \quad$ www.vestnik.nspu.ru

ISSN 2226-3365

кистевую и становую мышечную силу (КС и СтС). Для оценки гармоничности физического развития рассчитывались индексы Кетле (ИК=МТ, кг/ДТ, м²), стении (ИС=ДТ, см /(2*МТ, кг + ОГК, см), силовые индексы - кистевой (КИ) и становой (СтИ).

Содержание резервного жира определяли непрямым методом калиперометрии [13].

Степень полового созревания оценивали по методике Ставицкой с соавт. [14] и Д.В. Колесова, Н.Б. Сельверовой [15] с учетом выраженности вторичных половых признаков.

Функцию внешнего дыхания оценивали по показателю жизненной емкости легких (ЖЕЛ) с помощью суховоздушного спирометра, а также рассчитывали жизненный индекс (ЖИ=ЖЕЛ/МТ).

Состояние сердечно-сосудистой системы оценивали по частоте сердечных сокращений (ЧСС) в условиях относительного покоя и при стандартной физической нагрузке. Частоту сердечных сокращений определяли с помощью электрокардиографа «Аксион ЭК 1Т-07», артериальное давление (АД) измеряли аускультативным методом Короткова.

Систолический объем крови (СОК) рассчитывали по формуле Старра [16] в модификации Н.С. Пугиной и Я.Ф. Бомаш [17] для детей 7-15 лет $(\mathrm{COK}=40+0,5$ ПД0,6ДД+3,2А), где ПД- пульсовое давление, ДД- диастолическое давление, А-возраст. Минутный объем крови определяли по формуле: $\mathrm{MOK}=\mathrm{COK} *$ ЧСС.

$\mathrm{C}$ целью изучения адаптации к физическим нагрузкам и оценки функциональных резервов организма проводилось степэргометрическое тестирование [18]. Определяли абсолютные и относительные показатели физической работоспособности (ФР) и аэробной производительности (МПК):

$$
\Phi \mathrm{P}_{170}=\mathrm{N}_{1}+\left(\mathrm{N}_{2}-\mathrm{N}_{1}\right) *\left(170-\mathrm{f}_{1}\right) /\left(\mathrm{f}_{2}-\mathrm{f}_{1}\right) \text {, }
$$

где $\mathrm{N}_{1},-$ мощность первой нагрузки, $\mathrm{N}_{2}-$ мощность второй нагрузки, $\mathrm{f}_{1}-$ частота сердечных сокращений в конце первой нагрузки, $\mathrm{f}_{2}$ - частота сердечных сокращений в конце второй нагрузки;

$$
\mathrm{M \Pi K}=\mathrm{A}+\sqrt{ } \mathrm{N} /(\mathrm{f}-\mathrm{h}){ }^{*} \mathrm{\kappa},
$$

где А-поправочный коэффициент с учетом возраста и пола, $\mathrm{N}$-мощность нагрузки, f-пульс в конце нагрузки, h-возрастнополовая поправка к пульсу, к-возрастной коэффициент.

Экономичность деятельности сердечнососудистой системы при выполнении стандартной нагрузки оценивали по величине минутного объема крови организма на единицу физической работоспособности (МОК, л/ФР $170 /$ кг) [19], двойному произведению (ДП = ЧСС*АД систолическое/100) [20].

Весь полученный материал обработан с использованием методов статистического анализа. Достоверность различий оценивалась по t-критерию Стьюдента и по ANOVA для непараметрических независимых выборок. Различия считались достоверными при $\mathrm{p}<0,05$ [21].

\section{Результаты исследований и их обсуждение}

Анализ полученных данных по физическому развитию выявил, что мальчики 7-15 лет, проживающие в городской и сельской местности, имели неодинаковые показатели морфофункционального развития (таблица 1). В онтогенезе как у городских, так и у сельских школьников все абсолютные значения показателей физического развития увеличивались: длина и масса тела, окружность грудной клетки, активная масса тела, резервный жир, мышечная сила (кистевая и становая) (таблица 1). С возрастом наблюдалось увели- 
Вестник Новосибирского государственного педагогического университета Novosibirsk State Pedagogical University Bulletin

\section{1(17) $2014 \quad$ www.vestnik.nspu.ru $\quad$ ISSN 2226-3365}

чение индекса Кетле, характеризующего плотность телосложения, и уменьшение индекса стении. У городских и сельских мальчиков абсолютное содержание резервного жира с возрастом увеличивалось к 15-летнему возрасту на 4,2 и 5,6 кг $(97,6$ \% и 133,3 \% соответственно) по сравнению с исходными значениями. Показатели длины тела во всех возрастных группах у школьников, проживающих в городских условиях, выше по сравне- нию со сверстниками из сельской местности, достоверность отмечалась в 11 и 13-15 лет. Наиболее выраженная прибавка в росте наблюдалась у городских и у сельских детей в 13-15 лет, что, по-видимому, связано с пубертатным периодом. У городских школьников рост увеличивался на 4,9\%, у сельских на 4,0 \% по сравнению с предыдущим возрастным периодом. У городских школьников рост увеличивался на 4,9\%, у сельских на 4,0 \%

Таблица 1

Показатели физического развития мальчиков 7-15 лет, проживающих в городских и сельских условиях

\begin{tabular}{|c|c|c|c|c|c|c|}
\hline \multirow[t]{2}{*}{ Показатели } & & \multicolumn{5}{|c|}{ Возраст, лет } \\
\hline & & 7 & 8 & 9 & 10 & 11 \\
\hline \multirow[t]{2}{*}{ N (кол-во) } & $\Gamma$ & $\mathrm{n}=38$ & $\mathrm{n}=38$ & $\mathrm{n}=42$ & $\mathrm{n}=38$ & $\mathrm{n}=39$ \\
\hline & $\mathrm{c}$ & $\mathrm{n}=18$ & $\mathrm{n}=20$ & $\mathrm{n}=20$ & $\mathrm{n}=23$ & $\mathrm{n}=21$ \\
\hline \multirow[t]{2}{*}{ ДТ, см } & $\Gamma$ & $124,3 \pm 0,7$ & $126,7 \pm 0,9^{*}$ & $132,6 \pm 0,8^{*}$ & $138,0 \pm 0,9^{*}$ & $146,4 \pm 1,1^{*}$ \\
\hline & $\mathrm{c}$ & $123,4 \pm 0,9$ & $126,4 \pm 1,0^{*}$ & $131,2 \pm 1,1^{*}$ & $137,2 \pm 0,9^{*}$ & $142,2 \pm 1,6^{*} \epsilon$ \\
\hline \multirow[t]{2}{*}{ МТ, кг } & $\Gamma$ & $23,9 \pm 0,7$ & $25,2 \pm 0,6$ & $28,1 \pm 1,2^{*}$ & $31,4 \pm 1,5$ & $36,1 \pm 1,2^{*}$ \\
\hline & $\mathrm{c}$ & $23,0 \pm 1,1$ & $24,5 \pm 0,8$ & $27,5 \pm 0,8^{*}$ & $31,4 \pm 0,4^{*}$ & $35,1 \pm 1,3^{*}$ \\
\hline \multirow{2}{*}{ ОГК, см } & $\Gamma$ & $57,4 \pm 0,6$ & $59,5 \pm 0,6^{*}$ & $60,8 \pm 0,5$ & $63,5 \pm 1,3^{*}$ & $67,1 \pm 0,9^{*}$ \\
\hline & $\mathrm{c}$ & $57,1 \pm 0,9$ & $59,0 \pm 0,7$ & $60,0 \pm 0,8$ & $63,3 \pm 0,7^{*}$ & $65,4 \pm 0,9$ \\
\hline \multirow{2}{*}{$\begin{array}{l}\text { Индекс Кетле, } \\
\text { у.е. }\end{array}$} & $\Gamma$ & $15,4 \pm 0,3$ & $15,7 \pm 0,2$ & $15,8 \pm 0,4$ & $16,3 \pm 0,5$ & $16,7 \pm 0,3$ \\
\hline & $\mathrm{c}$ & $14,9 \pm 0,5$ & $15,9 \pm 0,3$ & $16,7 \pm 0,6$ & $16,7 \pm 0,2$ & $17,2 \pm 0,5$ \\
\hline \multirow{2}{*}{$\begin{array}{l}\text { Индекс стении, } \\
\text { у.е. }\end{array}$} & $\Gamma$ & $1,19 \pm 0,02$ & $1,16 \pm 0,01$ & $1,15 \pm 0,02$ & $1,12 \pm 0,02$ & $1,07 \pm 0,02$ \\
\hline & $\mathrm{c}$ & $1,20 \pm 0,02$ & $1,15 \pm 0,01^{*}$ & $1,09 \pm 0,02 * \epsilon$ & $1,09 \pm 0,01$ & $1,06 \pm 0,02$ \\
\hline \multirow[t]{2}{*}{ \% Рез.жира } & $\Gamma$ & $17,4 \pm 0,6$ & $17,5 \pm 0,3$ & $18,5 \pm 0,6$ & $19,4 \pm 0,6$ & $20,2 \pm 0,6$ \\
\hline & c & $17,8 \pm 0,7$ & $18,6 \pm 0,7$ & $19,0 \pm 0,5$ & $18,3 \pm 0,3$ & $19,3 \pm 0,5$ \\
\hline \multirow[t]{2}{*}{ Рез.жир, кг } & $\Gamma$ & $4,3 \pm 0,3$ & $4,5 \pm 0,2$ & $5,4 \pm 0,4^{*}$ & $6,4 \pm 0,5$ & $7,6 \pm 0,4^{*}$ \\
\hline & $\mathrm{c}$ & $4,2 \pm 0,4$ & $4,8 \pm 0,3$ & $5,6 \pm 0,2^{*}$ & $5,8 \pm 0,1$ & $6,9 \pm 0,4^{*}$ \\
\hline \multirow[t]{2}{*}{ AMT, кг } & $\Gamma$ & $19,6 \pm 0,3$ & $20,7 \pm 0,4^{*}$ & $22,7 \pm 0,6^{*}$ & $25,1 \pm 1,0^{*}$ & $28,5 \pm 0,9^{*}$ \\
\hline & $\mathrm{c}$ & $18,8 \pm 0,7$ & $20,7 \pm 0,5^{*}$ & $23,9 \pm 0,6^{*}$ & $25,7 \pm 0,3^{*}$ & $28,2 \pm 0,9 *$ \\
\hline \multirow{2}{*}{$\begin{array}{l}\text { Кистевая сила } \\
(\text { (пр+л), кг }\end{array}$} & $\Gamma$ & $16,9 \pm 0,4$ & $18,3 \pm 0,5^{*}$ & $20,5 \pm 0,6^{*}$ & $24,3 \pm 0,9^{*}$ & $28,8 \pm 0,7^{*}$ \\
\hline & $\mathrm{c}$ & $15,7 \pm 0,7$ & $18,1 \pm 0,7^{*}$ & $20,0 \pm 0,7^{*}$ & $24,2 \pm 0,6^{*}$ & $27,4 \pm 1,2^{*}$ \\
\hline \multirow[t]{2}{*}{ КИ, кг/кг } & $\Gamma$ & $0,71 \pm 0,02$ & $0,73 \pm 0,02$ & $0,74 \pm 0,02$ & $0,80 \pm 0,02$ & $0,82 \pm 0,02$ \\
\hline & $\mathrm{c}$ & $0,69 \pm 0,03$ & $0,72 \pm 0,03$ & $0,76 \pm 0,02$ & $0,77 \pm 0,02$ & $0,79 \pm 0,03$ \\
\hline \multirow{2}{*}{$\begin{array}{l}\text { Становая сила, } \\
\text { кг }\end{array}$} & $\Gamma$ & $25,0 \pm 1,1$ & $28,5 \pm 0,7^{*}$ & $33,3 \pm 1,4^{*}$ & $38,3 \pm 1,5^{*}$ & $44,7 \pm 1,5^{*}$ \\
\hline & $\mathrm{c}$ & $15,0 \pm 1,6 \epsilon$ & $19,5 \pm 1,5^{*} \epsilon$ & $27,3 \pm 1,3^{*} \epsilon$ & $28,1 \pm 1,6 \epsilon$ & $43,1 \pm 2,9^{*}$ \\
\hline \multirow[t]{2}{*}{ СтИ, кг/кг } & $\Gamma$ & $1,05 \pm 0,05$ & $1,13 \pm 0,04$ & $1,19 \pm 0,05$ & $1,25 \pm 0,04$ & $1,26 \pm 0,03$ \\
\hline & $\mathrm{c}$ & $0,64 \pm 0,04 \epsilon$ & $0,76 \pm 0,06 \epsilon$ & $0,93 \pm 0,04 * \epsilon$ & $0,89 \pm 0,04 \epsilon$ & $1,24 \pm 0,05^{*}$ \\
\hline
\end{tabular}


Вестник Новосибирского государственного педагогического университета Novosibirsk State Pedagogical University Bulletin

1(17) 2014

www.vestnik.nspu.ru

ISSN 2226-3365

Продолжение. Таблица 1

\begin{tabular}{|c|c|c|c|c|c|}
\hline \multirow[t]{2}{*}{ Показатели } & & \multicolumn{4}{|c|}{ Возраст, лет } \\
\hline & & 12 & 13 & 14 & 15 \\
\hline \multirow{2}{*}{ N (кол-во) } & $\Gamma$ & $n=39$ & $n=33$ & $\mathrm{n}=40$ & $\mathrm{n}=42$ \\
\hline & $\mathrm{c}$ & $\mathrm{n}=20$ & $\mathrm{n}=20$ & $\mathrm{n}=25$ & $\mathrm{n}=20$ \\
\hline \multirow[t]{2}{*}{ ДТ, см } & $\Gamma$ & $149,1 \pm 1,2$ & $158,2 \pm 1,4^{*}$ & $164,5 \pm 1,2 *$ & $172,4 \pm 1,3^{*}$ \\
\hline & $\mathrm{c}$ & $146,3 \pm 1,0^{*}$ & $148,2 \pm 2,2 \epsilon$ & $159,9 \pm 1,7^{*} \epsilon$ & $164,7 \pm 2,3 \epsilon$ \\
\hline \multirow[t]{2}{*}{ МТ, кг } & $\Gamma$ & $39,1 \pm 1,3$ & $46,0 \pm 2,1^{*}$ & $50,7 \pm 1,4^{*}$ & $56,8 \pm 1,6^{*}$ \\
\hline & $\mathrm{c}$ & $38,5 \pm 1,6$ & $40,9 \pm 2,5$ & $47,5 \pm 1,8^{*}$ & $54,7 \pm 3,5$ \\
\hline \multirow{2}{*}{ ОГК, см } & $\Gamma$ & $70,1 \pm 1,0^{*}$ & $73,8 \pm 1,3^{*}$ & $76,1 \pm 1,3$ & $80,4 \pm 1,4^{*}$ \\
\hline & $\mathrm{c}$ & $67,4 \pm 1,6$ & $69,2 \pm 1,2 \epsilon$ & $72,8 \pm 1,4^{*}$ & $78,9 \pm 2,2 *$ \\
\hline \multirow{2}{*}{$\begin{array}{c}\text { Индекс Кетле, } \\
\text { у.е. }\end{array}$} & $\Gamma$ & $17,5 \pm 0,4$ & $18,2 \pm 0,5$ & $18,6 \pm 0,5$ & $19,1 \pm 0,5$ \\
\hline & $\mathrm{c}$ & $17,9 \pm 0,6$ & $18,4 \pm 1,0$ & $18,4 \pm 0,6$ & $19,8 \pm 0,9$ \\
\hline \multirow{2}{*}{$\begin{array}{c}\text { Индекс стении, } \\
\text { у.е. }\end{array}$} & $\Gamma$ & $1,02 \pm 0,02 *$ & $0,98 \pm 0,02$ & $0,94 \pm 0,02$ & $0,90 \pm 0,02$ \\
\hline & $\mathrm{c}$ & $1,03 \pm 0,02$ & $1,00 \pm 0,02$ & $0,97 \pm 0,02$ & $0,90 \pm 0,03 *$ \\
\hline \multirow[t]{2}{*}{ \% Рез.жира } & $\Gamma$ & $18,9 \pm 0,6$ & $17,3 \pm 0,7$ & $13,8 \pm 0,9 *$ & $14,1 \pm 0,8$ \\
\hline & $\mathrm{c}$ & $19,2 \pm 0,8$ & $15,6 \pm 0,5^{*} \epsilon$ & $16,3 \pm 0,8 \epsilon$ & $17,1 \pm 0,9 \epsilon$ \\
\hline \multirow[t]{2}{*}{ Рез.жир, кг } & $\bar{\Gamma}$ & $7,7 \pm 0,5$ & $8,3 \pm 0,7$ & $7,3 \pm 0,7$ & $8,5 \pm 0,7$ \\
\hline & $\mathrm{c}$ & $7,7 \pm 0,7$ & $6,6 \pm 0,8$ & $8,0 \pm 0,6$ & $9,8 \pm 1,1$ \\
\hline \multirow[t]{2}{*}{ AMT, кг } & $\Gamma$ & $31,4 \pm 0,8^{*}$ & $37,6 \pm 1,3^{*}$ & $43,4 \pm 0,9 *$ & $48,4 \pm 0,9 *$ \\
\hline & $\mathrm{c}$ & $30,9 \pm 0,9 *$ & $34,3 \pm 1,9$ & $39,5 \pm 1,3 * \epsilon$ & $44,9 \pm 2,4^{*}$ \\
\hline \multirow{2}{*}{$\begin{array}{c}\text { Кистевая сила } \\
(\text { (пр+л), кг }\end{array}$} & $\Gamma$ & $33,1 \pm 0,8^{*}$ & $40,7 \pm 1,6^{*}$ & $48,2 \pm 1,1 *$ & $55,9 \pm 0,8^{*}$ \\
\hline & $\mathrm{c}$ & $30,9 \pm 1,1 *$ & $34,1 \pm 1,6 \epsilon$ & $46,8 \pm 2,1 *$ & $54,9 \pm 3,0 *$ \\
\hline \multirow[t]{2}{*}{ КИ, кг/кГ } & $\bar{\Gamma}$ & $0,86 \pm 0,02$ & $0,90 \pm 0,03$ & $0,96 \pm 0,02$ & $1,00 \pm 0,02$ \\
\hline & $\mathrm{c}$ & $0,81 \pm 0,03$ & $0,86 \pm 0,04$ & $0,98 \pm 0,02^{*}$ & $1,00 \pm 0,03$ \\
\hline \multirow{2}{*}{$\begin{array}{c}\text { Становая сила, } \\
\text { кг }\end{array}$} & $\Gamma$ & $50,6 \pm 1,4^{*}$ & $64,5 \pm 2,1^{*}$ & $75,8 \pm 2,3^{*}$ & $84,0 \pm 2,4^{*}$ \\
\hline & $\mathrm{c}$ & $46,4 \pm 2,0$ & $51,4 \pm 3,2 \epsilon$ & $62,2 \pm 3,6^{*} \epsilon$ & $85,3 \pm 5,9 *$ \\
\hline \multirow[t]{2}{*}{ СтИ, кг/кг } & $\Gamma$ & $1,32 \pm 0,03$ & $1,45 \pm 0,06$ & $1,49 \pm 0,04$ & $1,50 \pm 0,03$ \\
\hline & $\mathrm{c}$ & $1,24 \pm 0,05$ & $1,31 \pm 0,09$ & $1,31 \pm 0,04 \epsilon$ & $1,60 \pm 0,10^{*}$ \\
\hline \multicolumn{6}{|c|}{$\begin{array}{c}\text { Примечание - Достоверные различия средних величин по ANOVA для непараметрических } \\
\text { независимых выборок: } \\
\text { * - по отношению к предыдущей возрастной группе }(\mathrm{P}<0,05) ; \epsilon \text { - при сравнении городских и } \\
\text { сельских школьников }(\mathrm{P}<0,05)\end{array}$} \\
\hline
\end{tabular}

по сравнению с предыдущим возрастным периодом. Масса тела у городских учащихся, также как и длина тела, превышала массу тела сельских учащихся, увеличение массы тела в 13-15 лет составило в среднем у городских ребят $13,3 \%$; в то время как у сельских $12,4 \%$. В целом масса тела от 7 до 15 лет у городских школьников увеличилась на 137,6 \%, а у сельских - на $137,8 \%$, что в абсолютных значениях составило в среднем 32,9 кг и 
Вестник Новосибирского государственного педагогического университета Novosibirsk State Pedagogical University Bulletin

31,7 кг соответственно. Снижение прироста резервного жира у городских мальчиков наблюдалось в14 лет, у сельских сверстников

Сопоставление мышечной силы в онтогенезе у городских и сельских школьников выявило (таблица 1), что кистевая сила у городских школьников выше, чем у сельских во всех возрастных группах. Характер возрастных изменений кистевой и становой силы у городских школьников почти одинаковый, однако в 13 лет прирост, в особенности становой силы, - более высокий. В этом же возрасте отмечалось повышение прироста АМТ, при этом наблюдалось снижение процента резервного жира. У сельских мальчиков прирост мышечной силы носил характер параллельных изменений, но наблюдалось отставание в развитии мышц руки по сравнению с мышцами спины. Изучение данных показателей у обследованных мальчиков выявило, что у городских мальчиков мышечная сила в 13 лет, в то время как увеличение AMT у горожан происходило в 9, 11, 13 лет, а у сельских ребят в 9 и 14 лет (таблица 1).

выше, нежели у сельских ребят. Достоверность отмечалась с 7-10 лет и в14 лет.

Таким образом, проведенный сравнительный анализ физического развития мальчиков 7-15 лет, проживающих в сельской и городской местности, показал, что городские школьники по всем изучаемым показателям и практически во всех возрастных группах имеют более высокие показатели.

Как видно из полученных данных (таблице 2) І стадия полового развития характерна для всех 11-летних городских и сельских школьников. Доля 12-летних городских подростков со II стадией превышает на 16,2 \% сельских сверстников, в 13 лет - на 20,3 \% больше городских ребят с III стадией. Опережение по темпам полового созревания городскими подростками выявлено с 12 лет, и сохраняется до 15 лет.

Таблица 2

Распределение обследованных городских и сельских мальчиков по стадиям полового созревания в онтогенезе (в \%)

\begin{tabular}{|c|c|c|c|c|c|c|c|c|c|}
\hline \multirow{3}{*}{$\begin{array}{c}\text { Возраст, } \\
\text { лет }\end{array}$} & \multirow{3}{*}{$\begin{array}{c}\text { город-г } \\
\text { село -c n }\end{array}$} & \multicolumn{8}{|c|}{ Стадии полового созревания } \\
\hline & & \multicolumn{2}{|c|}{ I } & \multicolumn{2}{|c|}{ II } & \multicolumn{2}{|c|}{ III } & \multicolumn{2}{|c|}{ IV } \\
\hline & & $\Gamma$ & $\mathrm{c}$ & $\Gamma$ & c & $\Gamma$ & $\mathrm{c}$ & $\Gamma$ & c \\
\hline \multirow[t]{2}{*}{11} & $\Gamma-39$ & 100,0 & & - & & - & & - & \\
\hline & c-21 & & 100,0 & & - & & - & & - \\
\hline \multirow[t]{2}{*}{12} & $\Gamma-39$ & 53,8 & & 46,2 & & - & & - & \\
\hline & c-20 & & 70,0 & & 30,0 & & - & & - \\
\hline \multirow[t]{2}{*}{13} & $\Gamma-33$ & 36,4 & & 33,3 & & 30,3 & & - & \\
\hline & c-20 & & 55,0 & & 35,0 & & 10,0 & & - \\
\hline \multirow[t]{2}{*}{14} & $\Gamma-40$ & 12,5 & & 40,0 & & 30,0 & & 17,5 & \\
\hline & $\mathrm{c}-25$ & & 24,0 & & 40,0 & & 36,0 & & - \\
\hline \multirow[t]{2}{*}{15} & $\Gamma-42$ & - & & 28,6 & & 47,6 & & 23,8 & \\
\hline & c-20 & & - & & 40,0 & & 40,0 & & 20,0 \\
\hline
\end{tabular}


Вестник Новосибирского государственного педагогического университета Novosibirsk State Pedagogical University Bulletin

1(17) $2014 \quad$ www.vestnik.nspu.ru ISSN 2226-3365

Таким образом, сопоставление подростков по уровню стадий полового развития в пределах одного и того же возраста показало, что у детей, проживающих в сельской местности, в сравнении с городскими имелось замедление полового созревания.

Из представленных данных в таблице 3 видно, что в онтогенезе наблюдалось достоверное увеличение жизненной емкости легких (ЖЕЛ) у городских школьников с
$1,53 \pm 0,04$ до $3,39 \pm 0,07$ л, а у сельских с $1,38 \pm 0,04$ до $3,16 \pm 0,13$ л. Сравнение ЖЕЛ в зависимости от проживания выявило направленность к превышению этого показателя у городских мальчиков, однако достоверные превышения были обнаружены только у 7, 11 и 13-летних городских школьников. ЖИ достоверно не различался, что обусловлено меньшими показателями физического развития сельских детей.

Таблица 3

Показатели кардио-респираторной системы мальчиков 7-15 лет, проживающих в городских и сельских местностях в условиях покоя

\begin{tabular}{|c|c|c|c|c|c|c|c|c|c|c|}
\hline \multirow{2}{*}{$\begin{array}{c}\text { Показа } \\
\text { тели }\end{array}$} & & \multicolumn{9}{|c|}{ Возраст (лет) } \\
\hline & & 7 & 8 & 9 & 10 & 11 & 12 & 13 & 14 & 15 \\
\hline \multirow{2}{*}{$\begin{array}{c}\mathrm{N} \text { (кол- } \\
\text { во) }\end{array}$} & $\Gamma$ & $\mathrm{n}=38$ & $\mathrm{n}=38$ & $\mathrm{n}=42$ & $\mathrm{n}=38$ & $\mathrm{n}=39$ & $\mathrm{n}=39$ & $\mathrm{n}=33$ & $\mathrm{n}=40$ & $\mathrm{n}=42$ \\
\hline & $\mathrm{C}$ & $\mathrm{n}=18$ & $\mathrm{n}=20$ & $\mathrm{n}=20$ & $\mathrm{n}=23$ & $\mathrm{n}=21$ & $\mathrm{n}=20$ & $\mathrm{n}=20$ & $\mathrm{n}=25$ & $\mathrm{n}=20$ \\
\hline \multicolumn{11}{|c|}{ Показатели системы внешнего дыхания } \\
\hline \multirow[t]{2}{*}{ ЖЕЛ, л } & $\Gamma$ & $\begin{array}{c}1,53 \pm \\
0,04\end{array}$ & $\begin{array}{c}1,55 \pm \\
0,02\end{array}$ & $\begin{array}{c}1,81 \pm 0,0 \\
5^{*}\end{array}$ & $1,99 \pm 0,03^{*}$ & $\begin{array}{c}2,30 \pm 0,0 \\
4 *\end{array}$ & $2,35 \pm 0,03$ & $\begin{array}{c}2,78 \pm 0,0 \\
7 *\end{array}$ & $3,01 \pm 0,1$ & $\begin{array}{c}3,39 \pm 0 \\
07^{*}\end{array}$ \\
\hline & $\mathrm{c}$ & $\begin{array}{c}1,38 \pm 0,0 \\
4 €\end{array}$ & $\begin{array}{c}1,54 \pm 0,0 \\
4^{*}\end{array}$ & $\begin{array}{c}1,80 \pm 0,0 \\
3 *\end{array}$ & $1,97 \pm 0,04^{*}$ & $\begin{array}{c}2,07 \pm 0,0 \\
6 \epsilon\end{array}$ & $2,32 \pm 0,05^{*}$ & $\begin{array}{c}2,35 \pm 0,07 \\
\epsilon\end{array}$ & $\begin{array}{c}2,92 \pm 0,0 \\
9 *\end{array}$ & \begin{tabular}{|c|}
$3,16 \pm 0$ \\
13
\end{tabular} \\
\hline \multirow[t]{2}{*}{$\begin{array}{l}\text { ЖИ, } \\
\text { мл/кг }\end{array}$} & $\Gamma$ & $64,5 \pm 1,4$ & $62,0 \pm 1,4$ & $66,2 \pm 2,1$ & $66,6 \pm 2,1$ & $65,8 \pm 1,7$ & $62,2 \pm 1,8$ & $62,6 \pm 2,1$ & $60,3 \pm 1,9$ & $\begin{array}{c}60,6 \pm 1 \\
8\end{array}$ \\
\hline & $\mathrm{c}$ & $60,8 \pm 2,6$ & $61,2 \pm 2,3$ & $63,7 \pm 2,2$ & $62,7 \pm 0,9$ & $60,4 \pm 2,0$ & $61,6 \pm 2,1$ & $59,8 \pm 2,5$ & $62,6 \pm 1,8$ & $\begin{array}{c}59,6 \pm 1 \\
8\end{array}$ \\
\hline \multicolumn{11}{|c|}{ Показатели сердечно-сосудистой системы в условиях покоя } \\
\hline \multirow{2}{*}{$\begin{array}{l}\text { ЧСС, } \\
\text { уд/мин }\end{array}$} & $\Gamma$ & $92,2 \pm 1,6$ & $89,0 \pm 1,7$ & $86,2 \pm 1,1$ & $87,9 \pm 2,0$ & $87,3 \pm 1,7$ & $87,3 \pm 0,9$ & $87,4 \pm 1,7$ & $85,1 \pm 1,3$ & $81,0 \pm 1,3^{*}$ \\
\hline & $\mathrm{c}$ & $93,0 \pm 1,9$ & $92,2 \pm 1,7$ & $90,1 \pm 2,4$ & $84,9 \pm 1,5$ & $86,1 \pm 2,2$ & $81,9 \pm 1,7 \epsilon$ & $81,5 \pm 2,0 \epsilon$ & $80,6 \pm 2,6$ & $81,6 \pm 1,7$ \\
\hline \multirow{2}{*}{$\begin{array}{l}\text { САД, } \\
\text { мм. рт. } \\
\text { ст. }\end{array}$} & $\Gamma$ & $93,2 \pm 1,1$ & $93,7 \pm 1,1$ & $\begin{array}{c}98,4 \pm 1,4 \\
*\end{array}$ & $97,9 \pm 0,7$ & $\begin{array}{c}101,2 \pm 1 \\
1 *\end{array}$ & $101,2 \pm 1,1$ & $\begin{array}{c}104,4 \pm 1 \\
2^{*}\end{array}$ & $\begin{array}{c}107,4 \pm 1 \\
8\end{array}$ & \begin{tabular}{|c|}
$111,0 \pm 0$ \\
, 7
\end{tabular} \\
\hline & $\mathrm{c}$ & $91,1 \pm 0,9$ & $\begin{array}{c}97,7 \pm 1,1 \\
* \epsilon\end{array}$ & $\begin{array}{c}101,8 \pm 1 \\
7 *\end{array}$ & $101,8 \pm 1,6 \epsilon$ & $104,8 \pm 1,7$ & $106,8 \pm 2,3 \epsilon$ & $107,3 \pm 1,7$ & $\begin{array}{c}110,2 \pm 1 \\
5\end{array}$ & $\begin{array}{c}111,8 \pm 1 \\
, 4\end{array}$ \\
\hline \multirow{2}{*}{$\begin{array}{l}\text { ДАД, } \\
\text { мм. рт. } \\
\text { ст. }\end{array}$} & $\Gamma$ & $57,5 \pm 1,5$ & $57,4 \pm 0,7$ & $\begin{array}{c}60,2 \pm 1,0 \\
*\end{array}$ & $59,7 \pm 0,3$ & $60,4 \pm 1,1$ & $59,0 \pm 0,7$ & $61,5 \pm 1,2$ & $60,3 \pm 0,7$ & $\begin{array}{c}61,4 \pm 0 \\
7\end{array}$ \\
\hline & $\mathrm{c}$ & $57,2 \pm 0,6$ & $57,5 \pm 0,5$ & $\begin{array}{c}59,0 \pm 0,5 \\
*\end{array}$ & $56,9 \pm 0,5 * \epsilon$ & $59,5 \pm 1,7$ & $60,0 \pm 1,1$ & $\begin{array}{c}57,2 \pm 0,8^{*} \\
\epsilon\end{array}$ & $\begin{array}{c}55,0 \pm 1,5 \\
\epsilon\end{array}$ & $\begin{array}{c}60,5 \pm 2 \\
0^{*}\end{array}$ \\
\hline \multirow{2}{*}{$\begin{array}{l}\text { ПД, } \\
\text { мм. рт. } \\
\text { ст. }\end{array}$} & $\Gamma$ & $35,7 \pm 1,1$ & $36,3 \pm 1,1$ & $38,1 \pm 1,4$ & $38,2 \pm 0,7$ & $\begin{array}{c}40,7 \pm 1,1 \\
*\end{array}$ & $42,2 \pm 1,1$ & $42,8 \pm 1,6$ & $47,1 \pm 2,0$ & $\begin{array}{c}49,5 \pm 1 \\
0\end{array}$ \\
\hline & $\mathrm{c}$ & $33,8 \pm 1,2$ & $\begin{array}{c}40,2 \pm 1,7 \\
* \epsilon\end{array}$ & $\begin{array}{c}42,7 \pm 1,7 \\
\epsilon\end{array}$ & $44,7 \pm 1,6 \epsilon$ & $\begin{array}{c}45,2 \pm 1,7 \\
\epsilon\end{array}$ & $46,7 \pm 2,3$ & $\begin{array}{c}50,0 \pm 1,7 \\
\epsilon\end{array}$ & $\begin{array}{c}55,2 \pm 2,0^{*} \\
\epsilon\end{array}$ & $\begin{array}{c}51,2 \pm 1 \\
4\end{array}$ \\
\hline \multirow[t]{2}{*}{$\begin{array}{l}\text { ДП, } \\
\text { у.е. }\end{array}$} & $\Gamma$ & $85,9 \pm 1,4$ & $83,6 \pm 2,1$ & $85,0 \pm 1,9$ & $86,1 \pm 2,0$ & $88,4 \pm 2,2$ & $88,4 \pm 1,4$ & $91,4 \pm 2,6$ & $91,3 \pm 1,8$ & $\begin{array}{c}90,0 \pm 1 \\
9\end{array}$ \\
\hline & $\mathrm{c}$ & $84,7 \pm 1,7$ & $\begin{array}{c}90,3 \pm 2,7 \\
\epsilon \\
\end{array}$ & $\begin{array}{c}91,9 \pm 3,0 \\
\epsilon \\
\end{array}$ & $86,3 \pm 2,0$ & $90,6 \pm 3,0$ & $87,2 \pm 2,2$ & $87,5 \pm 2,8$ & $89,3 \pm 3,6$ & $\begin{array}{c}91,4 \pm 2 \\
6\end{array}$ \\
\hline \multirow[t]{2}{*}{$\begin{array}{l}\text { СОК, } \\
\text { мл. }\end{array}$} & $\Gamma$ & $45,8 \pm 1,4$ & $\begin{array}{c}49,3 \pm 1,0 \\
*\end{array}$ & $51,7 \pm 1,3$ & $55,2 \pm 0,4^{*}$ & $\begin{array}{c}59,4 \pm 1,0 \\
*\end{array}$ & $64,1 \pm 1,0^{*}$ & $66,1 \pm 1,3$ & $\begin{array}{c}72,2 \pm 1,2 \\
*\end{array}$ & $\begin{array}{c}75,9 \pm 0 \\
9 *\end{array}$ \\
\hline & $\mathrm{c}$ & $45,0 \pm 1,0$ & $\begin{array}{c}51,2 \pm 1,2 \\
*\end{array}$ & $\begin{array}{c}54,7 \pm 1,2 \\
*\end{array}$ & $60,2 \pm 0,8^{*} \epsilon$ & $62,1 \pm 1,6$ & $65,7 \pm 1,5$ & $\begin{array}{c}72,2 \pm 1,2^{*} \\
\epsilon \\
\end{array}$ & $\begin{array}{c}79,4 \pm 1,6^{*} \\
\epsilon \\
\end{array}$ & \begin{tabular}{|c|}
$77,3 \pm 2$ \\
0
\end{tabular} \\
\hline
\end{tabular}


Вестник Новосибирского государственного педагогического университета Novosibirsk State Pedagogical University Bulletin

\begin{tabular}{|c|c|c|c|c|c|c|c|c|c|c|}
\hline \multirow{2}{*}{$\begin{array}{l}\text { МOK, } \\
\text { л. }\end{array}$} & $\Gamma$ & $4,2 \pm 0,1$ & $4,3 \pm 0,1$ & $4,4 \pm 0,1$ & $4,8 \pm 0,1 *$ & $5,2 \pm 0,1^{*}$ & $5,6 \pm 0,1^{*}$ & $5,7 \pm 0,1$ & $6,1 \pm 0,1$ & $6,2 \pm 0,1$ \\
\hline & $\mathrm{c}$ & $4,1 \pm 0,1$ & $\begin{array}{c}4,7 \pm 0,1^{*} \\
\epsilon\end{array}$ & $4,9 \pm 0,1 \epsilon$ & $5,1 \pm 0,1 \epsilon$ & $5,3 \pm 0,1$ & $5,4 \pm 0,1$ & $5,8 \pm 0,1 *$ & $6,4 \pm 0,3 *$ & $6,3 \pm 0,1$ \\
\hline \multicolumn{11}{|c|}{$\begin{array}{l}\text { Примечание - Достоверные различия средних величин по ANOVA для непараметрических независимых } \\
\text { выборок: }\end{array}$} \\
\hline \multicolumn{11}{|c|}{ * - по отношению к предыдущей возрастной группе $(\mathrm{P}<0,05)$} \\
\hline
\end{tabular}

В состоянии относительного покоя у городских мальчиков наблюдалось уменьшение ЧСС с 92,2 $\pm 1,6$ до 81,0 $0 \pm 1,3$ ударов/мин, а у сельских с 93,0 11,9 до $81,6 \pm 1,7$ ударов/мин (таблица 3). С 10 по 14 лет у сельских школьников ЧСС была ниже, в сравнении с город- скими сверстниками. У городских и сельских детей в онтогенезе наблюдалась тенденция к росту величин систолического (САД), пульсового (ПД) давления, однако с 8 до 14 лет можно отметить более низкие значения величин САД и ПД у городских школьников.

Таблица 4

Показатели сердечно-сосудистой системь мальчиков 7-15 лет, проживаюших в городских и сельских местностях в условиях нагрузки

\begin{tabular}{|c|c|c|c|c|c|c|c|c|c|c|}
\hline \multirow{2}{*}{$\begin{array}{l}\text { Показа } \\
\text { тели }\end{array}$} & & \multicolumn{9}{|c|}{ Возраст (лет) } \\
\hline & & 7 & 8 & 9 & 10 & 11 & 12 & 13 & 14 & 15 \\
\hline \multirow{2}{*}{$\begin{array}{c}\mathrm{N} \text { (кол- } \\
\text { во) }\end{array}$} & $\Gamma$ & $\mathrm{n}=38$ & $\mathrm{n}=38$ & $n=42$ & $\mathrm{n}=38$ & $n=39$ & $n=39$ & $n=33$ & $\mathrm{n}=40$ & $\mathrm{n}=42$ \\
\hline & $\mathrm{c}$ & $\mathrm{n}=18$ & $n=20$ & $\mathrm{n}=20$ & $n=23$ & $n=21$ & $\mathrm{n}=20$ & $n=20$ & $\mathrm{n}=25$ & $\mathrm{n}=20$ \\
\hline \multirow{2}{*}{$\begin{array}{l}\text { ЧСС, } \\
\text { уд/мин }\end{array}$} & $\Gamma$ & $\begin{array}{c}162,1 \pm 2 \\
4\end{array}$ & $\begin{array}{c}156,7 \pm 1 \\
7\end{array}$ & $\begin{array}{c}157,2 \pm 2 \\
7\end{array}$ & $159,1 \pm 1,9$ & $\begin{array}{c}162,4 \pm 2 \\
0\end{array}$ & $160,7 \pm 2$ & $\begin{array}{c}163,2 \pm 2 \\
1\end{array}$ & $\begin{array}{c}162,7 \pm 1 \\
7\end{array}$ & $\begin{array}{c}162,6 \pm \\
2,5\end{array}$ \\
\hline & $\mathrm{c}$ & $\begin{array}{c}144,6 \pm 2 \\
5 €\end{array}$ & $\begin{array}{c}145,3 \pm 2 \\
3 \epsilon\end{array}$ & $\begin{array}{c}150,2 \pm 3 \\
5\end{array}$ & $\begin{array}{c}149,2 \pm 3,3 \\
\epsilon\end{array}$ & $\begin{array}{c}146,7 \pm 3 \\
0 €\end{array}$ & $\begin{array}{c}146,2 \pm 2,0 \\
\epsilon\end{array}$ & $\begin{array}{c}140,1 \pm 3 \\
4 \epsilon\end{array}$ & $\begin{array}{c}140,2 \pm 2 \\
5 \mathrm{\epsilon}\end{array}$ & $\begin{array}{c}144,7 \pm \\
2,2 \epsilon\end{array}$ \\
\hline \multirow{2}{*}{$\begin{array}{l}\text { САД, } \\
\text { мм. рт. } \\
\text { ст. }\end{array}$} & $\Gamma$ & $\begin{array}{c}115,3 \pm 1 \\
5\end{array}$ & $\begin{array}{c}119,3 \pm 1 \\
5\end{array}$ & $\begin{array}{c}127,8 \pm 1 \\
7 *\end{array}$ & $127,2 \pm 1,9$ & $\begin{array}{c}130,9 \pm 1 \\
8\end{array}$ & $132,8 \pm 2,2$ & $\begin{array}{c}144,2 \pm 2 \\
9 *\end{array}$ & $\begin{array}{c}145,5 \pm 2 \\
1\end{array}$ & $\begin{array}{c}148,1 \pm \\
2,4\end{array}$ \\
\hline & $\mathrm{c}$ & $\begin{array}{c}111,7 \pm 2 \\
5\end{array}$ & $\begin{array}{c}122,3 \pm 1 \\
7 *\end{array}$ & $\begin{array}{c}128,5 \pm 2 \\
9\end{array}$ & $129,1 \pm 1,6$ & $\begin{array}{c}131,2 \pm 1 \\
7\end{array}$ & $132,0 \pm 1,7$ & $\begin{array}{c}138,0 \pm 2 \\
3 *\end{array}$ & $\begin{array}{c}138,4 \pm 2 \\
0 €\end{array}$ & $\begin{array}{c}139,5 \pm \\
2,3 \epsilon\end{array}$ \\
\hline \multirow{2}{*}{$\begin{array}{l}\text { ДАД, } \\
\text { мм. рт. } \\
\text { ст. }\end{array}$} & $\Gamma$ & $59,5 \pm 0,7$ & $57,9 \pm 0,7$ & $\begin{array}{c}61,2 \pm 0,7 \\
*\end{array}$ & $59,7 \pm 0,7$ & $60,0 \pm 1,4$ & $61,5 \pm 1,1$ & $\begin{array}{c}57,6 \pm 1,2 \\
*\end{array}$ & $59,5 \pm 0,7$ & $\begin{array}{c}59,8 \pm 1 \\
0\end{array}$ \\
\hline & $\mathrm{c}$ & $58,3 \pm 0,6$ & $\begin{array}{c}56,7 \pm 0,5 \\
*\end{array}$ & $\begin{array}{c}58,5 \pm 0,5 \\
* \epsilon\end{array}$ & $57,3 \pm 1,6$ & $57,3 \pm 0,8$ & $60,0 \pm 1,7$ & $57,5 \pm 0,5$ & $\begin{array}{c}54,4 \pm 0,5 \\
* \epsilon\end{array}$ & $\begin{array}{c}55,0 \pm 1 \\
1 \epsilon\end{array}$ \\
\hline \multirow{2}{*}{$\begin{array}{l}\text { ПД, } \\
\text { мм. рт. } \\
\text { ст. }\end{array}$} & $\Gamma$ & $55,8 \pm 1,9$ & $\begin{array}{c}61,4 \pm 1,5 \\
*\end{array}$ & $\begin{array}{c}66,7 \pm 1,7 \\
*\end{array}$ & $67,5 \pm 1,9$ & $70,8 \pm 1,8$ & $71,2 \pm 2,2$ & $\begin{array}{c}86,7 \pm 2,4 \\
*\end{array}$ & $86,0 \pm 2,1$ & $\begin{array}{c}88,3 \pm 2 \\
8\end{array}$ \\
\hline & $\mathrm{c}$ & $53,3 \pm 2,5$ & $\begin{array}{c}65,5 \pm 1,7 \\
*\end{array}$ & $70,0 \pm 2,9$ & $71,7 \pm 2,1$ & $73,8 \pm 1,7$ & $72,0 \pm 2,3$ & $\begin{array}{c}80,5 \pm 2,3 \\
*\end{array}$ & $84,0 \pm 2,0$ & $\begin{array}{c}84,5 \pm 2 \\
3\end{array}$ \\
\hline \multirow[t]{2}{*}{$\begin{array}{l}\text { ДП, } \\
\text { у.е. }\end{array}$} & $\Gamma$ & $\begin{array}{c}187,0 \pm 4 \\
1\end{array}$ & $\begin{array}{c}187,1 \pm 3 \\
7\end{array}$ & $\begin{array}{c}202,3 \pm 6 \\
1 *\end{array}$ & $202,9 \pm 3,7$ & $\begin{array}{c}212,6 \pm 3 \\
3 *\end{array}$ & $214,7 \pm 6,2$ & $\begin{array}{c}235,7 \pm 6 \\
8^{*}\end{array}$ & $\begin{array}{c}236,5 \pm 4 \\
2\end{array}$ & $\begin{array}{c}241,7 \pm \\
6,2\end{array}$ \\
\hline & $\mathrm{c}$ & $\begin{array}{c}161,7 \pm 5 \\
3 \epsilon\end{array}$ & $\begin{array}{c}177,7 \pm 4 \\
5^{*}\end{array}$ & $\begin{array}{c}192,9 \pm 6 \\
4 *\end{array}$ & $192,9 \pm 6,0$ & $\begin{array}{c}192,9 \pm 5 \\
1 \epsilon\end{array}$ & $\begin{array}{c}193,2 \pm 4,2 \\
\epsilon\end{array}$ & $\begin{array}{c}193,7 \pm 5 \\
8 \epsilon\end{array}$ & $\begin{array}{c}194,9 \pm 5 \\
5 €\end{array}$ & $\begin{array}{c}202,3 \pm \\
5,7 \epsilon\end{array}$ \\
\hline \multirow[t]{2}{*}{$\begin{array}{l}\text { СОК, } \\
\text { мл. }\end{array}$} & $\Gamma$ & $54,6 \pm 1,2$ & $\begin{array}{c}61,6 \pm 1,0 \\
*\end{array}$ & $\begin{array}{c}65,4 \pm 1,3 \\
*\end{array}$ & $69,9 \pm 1,1^{*}$ & $\begin{array}{c}74,6 \pm 1,6 \\
*\end{array}$ & $77,1 \pm 1,6$ & $\begin{array}{c}90,4 \pm 1,3 \\
*\end{array}$ & $92,1 \pm 1,3$ & $\begin{array}{c}96,3 \pm 1 \\
7 *\end{array}$ \\
\hline & c & $54,0 \pm 1,2$ & $\begin{array}{c}64,3 \pm 1,2 \\
*\end{array}$ & $\begin{array}{c}68,7 \pm 1,8 \\
*\end{array}$ & $73,4 \pm 2,0$ & $77,6 \pm 1,2$ & $78,4 \pm 2,2$ & $\begin{array}{c}87,3 \pm 1,1 \\
*\end{array}$ & $\begin{array}{c}94,1 \pm 1,3 \\
*\end{array}$ & $\begin{array}{c}97,2 \pm 1 \\
5\end{array}$ \\
\hline \multirow[t]{2}{*}{$\begin{array}{l}\text { МOK, } \\
\text { л. }\end{array}$} & $\Gamma$ & $8,8 \pm 0,2$ & $9,6 \pm 0,2^{*}$ & $10,3 \pm 0,3$ & $11,1 \pm 0,1^{*}$ & $\begin{array}{c}12,2 \pm 0,2 \\
*\end{array}$ & $12,4 \pm 0,3$ & $\begin{array}{c}14,7 \pm 0,3 \\
*\end{array}$ & $14,9 \pm 0,2$ & $\begin{array}{c}15,7 \pm 0 \\
3\end{array}$ \\
\hline & $\mathrm{c}$ & $7,8 \pm 0,2$ & $9,3 \pm 0,2^{*}$ & $\begin{array}{c}10,3 \pm 0,3 \\
*\end{array}$ & $10,9 \pm 0,3$ & $\begin{array}{c}11,3 \pm 0,3 \\
\epsilon\end{array}$ & $11,4 \pm 0,4$ & $\begin{array}{c}12,3 \pm 0,4 \\
\epsilon\end{array}$ & $\begin{array}{c}13,2 \pm 0,3 \\
\epsilon\end{array}$ & $\begin{array}{c}14,1 \pm 0, \\
3^{*} \epsilon\end{array}$ \\
\hline
\end{tabular}


Вестник Новосибирского государственного педагогического университета Novosibirsk State Pedagogical University Bulletin

1(17) $2014 \quad$ www.vestnik.nspu.ru $\quad$ ISSN 2226-3365

\begin{tabular}{|c|c|c|c|c|c|c|c|c|c|c|}
\hline \multirow{2}{*}{$\begin{array}{l}\text { МОК/ } \\
\text { ФР170/ } \\
\text { кг, л. }\end{array}$} & $\Gamma$ & $\begin{array}{c}0,67 \pm 0,0 \\
4\end{array}$ & $\begin{array}{c}0,71 \pm 0,0 \\
2\end{array}$ & $\begin{array}{c}0,79 \pm 0,0 \\
8\end{array}$ & $0,84 \pm 0,02$ & $\begin{array}{c}0,94 \pm 0,0 \\
3^{*}\end{array}$ & $0,96 \pm 0,05$ & $\begin{array}{c}1,17 \pm 0,0 \\
5^{*}\end{array}$ & $\begin{array}{c}1,18 \pm 0,0 \\
4\end{array}$ & $\begin{array}{c}1,25 \pm 0 \\
05\end{array}$ \\
\hline & $\mathrm{c}$ & $\begin{array}{c}0,47 \pm 0,0 \\
2 \epsilon\end{array}$ & $\begin{array}{c}0,57 \pm 0,0 \\
3^{*} \epsilon\end{array}$ & $\begin{array}{c}0,70 \pm 0,0 \\
5^{*}\end{array}$ & $\begin{array}{c}0,76 \pm 0,04 \\
\epsilon\end{array}$ & $\begin{array}{c}0,75 \pm 0,0 \\
4 €\end{array}$ & $\begin{array}{c}0,76 \pm 0,04 \\
\epsilon\end{array}$ & $\begin{array}{c}0,77 \pm 0,0 \\
5 \epsilon\end{array}$ & $\begin{array}{c}0,83 \pm 0,0 \\
4 €\end{array}$ & $\begin{array}{c}0,92 \pm 0 \\
04 \epsilon\end{array}$ \\
\hline \multicolumn{11}{|c|}{$\begin{array}{l}\text { Примечание- Достоверные различия средних величин по ANOVA для непара } \\
\text { выборок: } \\
\text { * - по отношению к предыдущей возрастной группе }(\mathrm{P}<0,05) \\
\epsilon \text { - при сравнении городских и сельских школьников }(\mathrm{P}<0,05)\end{array}$} \\
\hline
\end{tabular}

Систолический объем (СОК), минутный объем (МОК) крови в онтогенезе имеют тенденцию к возрастанию, причем значения МОК и СОК у сельских школьников выше, особенно в 8-10 лет. Увеличение в онтогенезе МОК имело следующие особенности: у городских мальчиков с 7 до 11 лет оно составило 5,5\%, у сельских 6,6\%. С 11 до 15 лет наблюдалось снижение темпов прироста в среднем у городских и сельских мальчиков до 4,5\%.

Сравнительный анализ изменений ЧСС, СОК и МОК в онтогенезе позволяет сделать заключение, что повышение МОК с 7 до 15 лет вызвано увеличением ударного объема крови, поскольку ЧСС в данном возрастном периоде уменьшалась. Эта закономерность общеизвестна из литературных данных.

О состоянии системы кровообращения и еe резервных возможностях судят по ее реакции в ответ на дозированную физическую нагрузку. Из представленных в таблице 4 результатов видно, что выполнение стандартной степ-эргометрической нагрузки мощностью 12 кгм/мин·кг сопровождалось увеличением частоты сердечных сокращений и двойного произведения по сравнению с покоем. Анализ реакции частоты пульса на стандартную нагрузку показал, что у сельских школьников достоверно ниже значения ЧСС в сравнении с городскими детьми, что указывает на экономизацию реакции системы кровообращения. Более низкие значения ДП после нагрузки у сельских школьников по сравнению с городскими сверстниками свидетельствуют о возрастании суммарной «цены» адаптации к физическим нагрузкам у городских мальчиков.

Адаптивная реакция сердечнососудистой системы к дозированной нагрузке сопровождалась увеличением МОК. Установлено, что у 7-летних городских и сельских мальчиков прирост на нагрузку в сравнении с покоем составлял 109,5 \% и 90,2 \% соответственно, у 12 летних 121,4\% и $111,1 \%$, а в 13-15 лет - в среднем $151,7 \%$ и $114,8 \%$ соответственно. Из приведенных выше данных видно, что прирост МОК на нагрузку по сравнению с покоем у городских школьников в онтогенезе выше, нежели у сельских сверстников.

Увеличение МОК у городских школьников обеспечивалось более высокой ЧСС на физическую нагрузку. Такой механизм повышения МОК менее рациональный, поскольку связан с повышенным расходованием хронотропного резерва сердца [22-23].

Величина кровоснабжения организма на единицу физической работоспособности $\left(\right.$ МОКнагр/ФР $\left.{ }_{170}\right)$ у обследованных школьников, проживающих в городской и сельской местностях, в онтогенезе увеличивалась.

Также следует отметить, что сельские школьники по величине МОКнагр/ФР 170 достоверно опережали городских сверстников (таблица 4).

В онтогенезе показатели абсолютной 
Вестник Новосибирского государственного педагогического университета Novosibirsk State Pedagogical University Bulletin

физической работоспособности увеличивались с 10-летнего возраста как у городских, так и сельских школьников (рисунок 1А). Сельские школьники опережали городских сверстников по абсолютной физической работоспособности, достоверность отмечалась в 7, 8, 10, 14 лет. Сравнение относительной физической работоспособности школьников (рисунок 1Б) показало достоверно более высокие показатели у сельских мальчиков, чем у городских сверстников. Сельские школьники опережали городских сверстников по показателям максимальной аэробной производительности (рисунок 2).

Рисунок 1

Показатели абсолютной (А) и относительной физической работоспособности (Б) городских и сельских мальчиков 7-15 лет
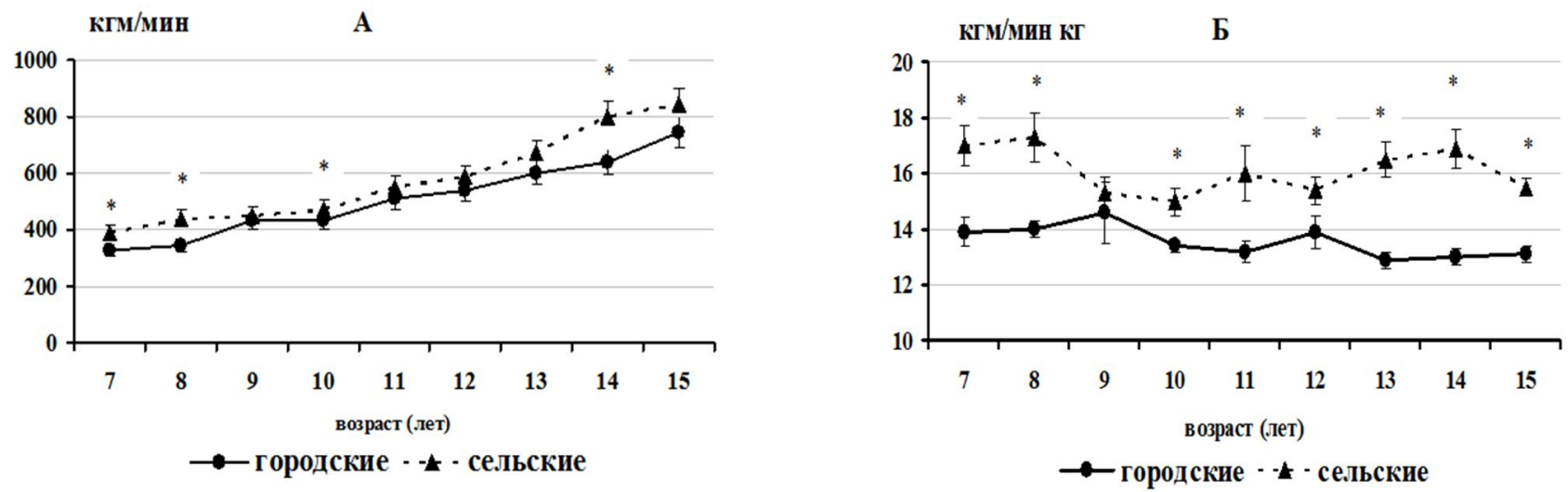

* - Достоверные отличия городских мальчиков по отношению к сельским

Рисунок 2

Показатели абсолютной (А) и относительной (Б) максимальной аэробной производительности городских и сельских мальчиков 7-15 лет
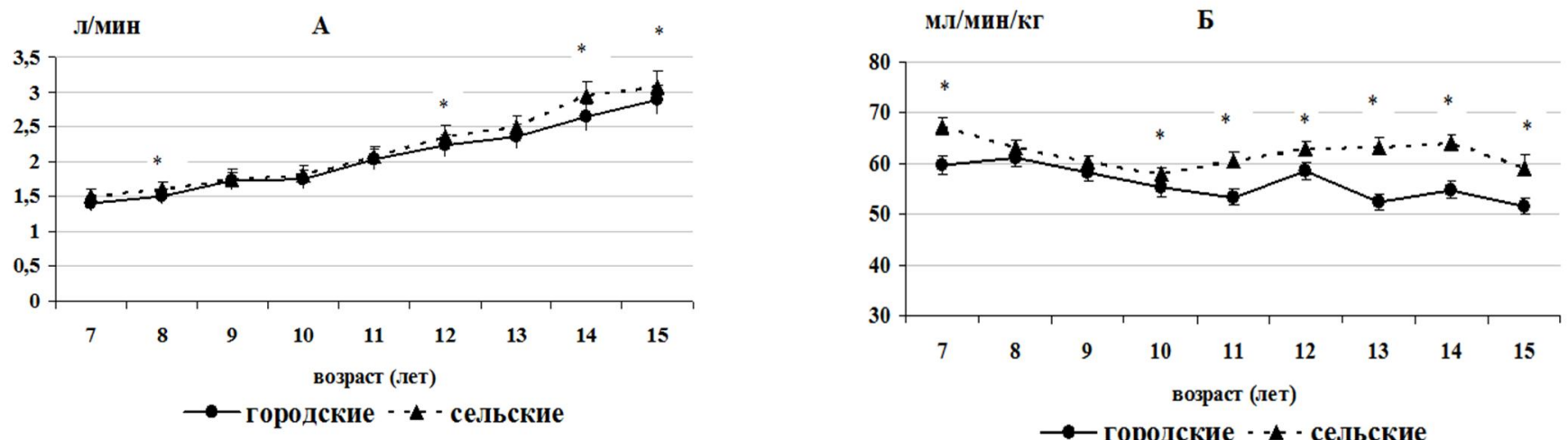

* - Достоверные отличия городских мальчиков по отношению к сельским 
Вестник Новосибирского государственного педагогического университета Novosibirsk State Pedagogical University Bulletin

1(17) $2014 \quad$ www.vestnik.nspu.ru $\quad$ ISSN 2226-3365

Сравнение показателей абсолютной максимальной производительности показало достоверно более высокие показатели у сельских мальчиков в 8, 12, 14 лет. Более выраженное отличие наблюдалось при сравнении относительных показателей максимальной аэробной производительности. Сельские школьники в большинстве возрастных групп достоверно опережали городских мальчиков.
Интегральная характеристика морфофункционального развития городских и сельских школьников была получена методом морфокинетического анализа [24]. Из рисунка 2 видно, что морфофункциональное развитие городских и сельских мальчиков протекало приблизительно одинаково, с некоторым замедлением темпов развития у сельских мальчиков в 12-14 лет.

Рисунок 3

Интегральная характеристика морфофункиионального развития городских и сельских мальчиков 7-15 лет

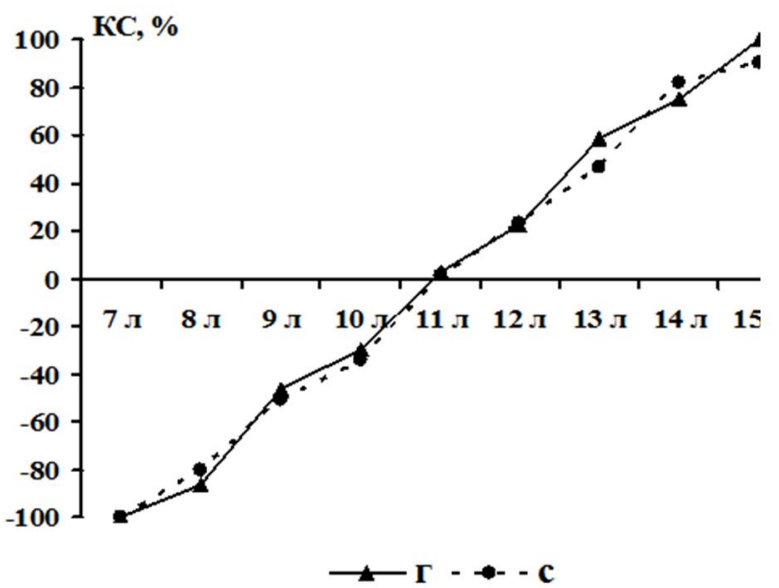

Однако темпы развития обследуемых детей и подростков неравномерны. $\mathrm{У}$ городских мальчиков наибольшие темпы отмечались с 8 до 9 лет и с 12 до 13 лет, а у сельских сверстников развитие до 13 лет происходило более равномерно, а с 13 до 14 лет отмечался скачок развития. Эти данные свидетельствуют, во-первых, о том, что формирование функциональных систем и их интеграция с морфологическим созреванием у сельских школьников происходит более гармонично, чем у городских; и, во-вторых, у сельских школьников дефинитивный уровень развития достигается примерно на 1 год позже, чем у городских. Эти заключения совпадают с литературными данными о том, что оптимальная физическая нагрузка в
(КС - коэффициент связи между исследуемыми показателями в \%) процессе онтогенеза оказывает гармонизирующее влияние на морфофункциональное развитие детей [25].

Проведенное антропометрическое обследование городских и сельских девочек 7-15 лет позволило выявить ряд особенностей физического развития. Как видно из таблицы 5, с возрастом как у городских, так и у сельских девочек наблюдалось увеличение показателей физического развития: длины, массы тела, окружности грудной клетки, индекса Кетле, активной массы тела, мышечной силы (кистевой и становой). По длине, массе тела, окружности грудной клетки городские школьницы опережали сельских сверстниц, достоверность наблюдалась в большинстве возрастных периодов по длине и массе тела. 
Вестник Новосибирского государственного педагогического университета Novosibirsk State Pedagogical University Bulletin

1(17) $2014 \quad$ www.vestnik.nspu.ru ISSN 2226-3365

В целом с 7 до 15 лет прирост длины тела составил у городских школьниц - 33,8 \%, у сельских - 38,1\%, что в абсолютных значениях соответствовало 41,7 и 44,3 см, и к 15 годам рост тела в длину равнялся в среднем 164,9 и 160,4 см.

Масса тела у городских школьниц, также как и длина тела, превышала сельских сверстниц во всех возрастных группах с наиболее выраженными различиями в 11,13 и 15 лет. В целом масса у городских девочек с 7 до 15 лет увеличивалась на $137 \%$, а у сельских - на $145 \%$, что в абсолютных значениях составило в среднем 32,2 и 28,5 кг соответственно.

Отношение массы тела к длине тела (индекс Кетле) у городских и сельских школьниц имело тенденцию к повышению, только в 7 и 15 лет оно было достоверно выше у городских школьниц по сравнению с сельскими. Индекс стении с возрастом в обеих сравниваемых возрастных группах имел

Таблица 5

Показатели физического развития девочек 7-15 лет, проживающих в городских и сельских условиях

\begin{tabular}{|c|c|c|c|c|c|c|c|c|c|c|}
\hline \multirow{2}{*}{$\begin{array}{c}\text { Показате } \\
\text { ли }\end{array}$} & & \multicolumn{9}{|c|}{ Возраст, лет } \\
\hline & & 7 & 8 & 9 & 10 & 11 & 12 & 13 & 14 & 15 \\
\hline \multirow{2}{*}{$\begin{array}{c}\text { N (кол- } \\
\text { во) }\end{array}$} & $\begin{array}{cl}\Gamma \\
\end{array}$ & $\mathrm{n}=37$ & $n=39$ & $\mathrm{n}=40$ & $n=43$ & $n=41$ & $n=45$ & $\mathrm{n}=35$ & $n=34$ & $n=37$ \\
\hline & $\mathrm{c}$ & $\mathrm{n}=19$ & $\mathrm{n}=20$ & $\mathrm{n}=20$ & $\mathrm{n}=21$ & $\mathrm{n}=20$ & $\mathrm{n}=20$ & $\mathrm{n}=20$ & $\mathrm{n}=18$ & $\mathrm{n}=22$ \\
\hline \multirow[t]{2}{*}{ ДТ см } & $\Gamma$ & $\begin{array}{l}123,2 \pm 0 \\
8\end{array}$ & $\begin{array}{l}128,1 \pm 0, \\
6^{*}\end{array}$ & $\begin{array}{l}136,9 \pm 1, \\
1 *\end{array}$ & $\begin{array}{l}138,1 \pm 0, \\
7\end{array}$ & $\begin{array}{l}147,5 \pm 0 \\
8^{*}\end{array}$ & $\begin{array}{l}150,6 \pm 1, \\
0^{*}\end{array}$ & $\begin{array}{l}157,8 \pm 1, \\
03 *\end{array}$ & $\begin{array}{l}159,1 \pm 0, \\
9\end{array}$ & $\begin{array}{l}164,9 \pm 0, \\
8^{*}\end{array}$ \\
\hline & $\mathrm{c}$ & $\begin{array}{l}116,1 \pm 1, \\
4 €\end{array}$ & $\begin{array}{l}125,9 \pm 1 \\
3 *\end{array}$ & $\begin{array}{l}131,4 \pm 1 \\
0 * \epsilon\end{array}$ & $\begin{array}{l}135,6 \pm 1, \\
3 *\end{array}$ & $\begin{array}{l}140,9 \pm 1, \\
6^{*} \epsilon\end{array}$ & $\begin{array}{l}148,9 \pm 1 \\
1 *\end{array}$ & $\begin{array}{l}154,7 \pm 0 \\
9 * \epsilon\end{array}$ & $\begin{array}{l}156,5 \pm 1, \\
2\end{array}$ & $\begin{array}{l}160,4 \pm 1 \\
3 * \epsilon\end{array}$ \\
\hline \multirow[t]{2}{*}{ МТ, кг } & $\Gamma$ & $23,5 \pm 0,6$ & $25,4 \pm 0,7^{*}$ & $29,2 \pm 1,0 *$ & $30,0 \pm 0,7$ & $36,7 \pm 0,9 *$ & $39,3 \pm 0,9 *$ & $46,2 \pm 1,2 *$ & $46,7 \pm 1,5$ & $55,7 \pm 1,2^{*}$ \\
\hline & $\mathrm{c}$ & $\begin{array}{l}19,6 \pm 0,3 \\
\epsilon\end{array}$ & & $27,4 \pm 0,5$ & 8 & $\begin{array}{l}32,7 \pm 1,3 \\
*_{\epsilon}\end{array}$ & $\begin{array}{l}38,7 \pm 0,9 \\
*\end{array}$ & $\begin{array}{l}43,2 \pm 1,8 \\
*\end{array}$ & ,6 & $\begin{array}{l}48,1 \pm 1,5 \\
\epsilon\end{array}$ \\
\hline \multirow[t]{2}{*}{ ОГК, см } & $\begin{array}{llll} \\
\end{array}$ & $56,8 \pm 0,4$ & $\begin{array}{l}58,8 \pm 0,7 \\
*\end{array}$ & $\begin{array}{l}63,8 \pm 1,0 \\
*\end{array}$ & $63,9 \pm 0,6$ & $\begin{array}{l}67,2 \pm 0,7 \\
*\end{array}$ & $68,4 \pm 0,6$ & $\begin{array}{l}74,8 \pm 1,0 \\
*\end{array}$ & $75,1 \pm 1,0$ & $\begin{array}{l}79,5 \pm 0,7 \\
*\end{array}$ \\
\hline & $\mathrm{c}$ & $\begin{array}{l}55,3 \pm 0,4 \\
\epsilon\end{array}$ & $\begin{array}{l}58,7 \pm 0,5 \\
*\end{array}$ & $\begin{array}{l}62,5 \pm 0,7 \\
*\end{array}$ &, 9 & $\begin{array}{l}63,3 \pm 1,4 \\
\epsilon\end{array}$ & $\begin{array}{l}70,2 \pm 0,8 \\
*\end{array}$ & $72,5 \pm 1,2$ & 0 & $\begin{array}{l}75,6 \pm 1,0 \\
\epsilon\end{array}$ \\
\hline \multirow{2}{*}{$\begin{array}{l}\text { Индекс } \\
\text { Кетле, } \\
\text { у.е. }\end{array}$} & $\Gamma$ & $15,4 \pm 0,3$ & $15,4 \pm 0,4$ & $15,4 \pm 0,3$ & $15,6 \pm 0,3$ & $16,7 \pm 0,2^{*}$ & $17,3 \pm 0,4$ & $18,4 \pm 0,3^{*}$ & $18,4 \pm 0,5$ & $20,4 \pm 0,5^{*}$ \\
\hline & $\mathrm{c}$ & $14,5 \pm 02 \epsilon$ & $15,9 \pm 0,6^{*}$ & $15,9 \pm 0,3$ & $\overline{5,6}$ & $16,3 \pm 0,5$ & 17,4 & $17,9 \pm 0,5$ & 18, & $18,6 \pm 0,4 \epsilon$ \\
\hline \multirow{2}{*}{$\begin{array}{l}\text { Индекс } \\
\text { стении, } \\
\text { у.е. }\end{array}$} & $\Gamma$ & $\begin{array}{l}1,19 \pm 0,0 \\
1\end{array}$ & $\begin{array}{l}1,18 \pm 0,0 \\
2\end{array}$ & $\begin{array}{l}1,13 \pm 0,0 \\
2^{*}\end{array}$ & $\begin{array}{l}1,12 \pm 0,0 \\
1\end{array}$ & $\begin{array}{l}1,06 \pm 0,0 \\
2^{*}\end{array}$ & & $\begin{array}{l}0,96 \pm 0,0 \\
2^{*}\end{array}$ & $\begin{array}{l}0,96 \pm 0,0 \\
2\end{array}$ & $\begin{array}{l}0,87 \pm 0,0 \\
1^{*}\end{array}$ \\
\hline & $\mathrm{c}$ & $\begin{array}{l}1,22 \pm 0,0 \\
1 \epsilon\end{array}$ & $\begin{array}{l}1,16 \pm 0,0 \\
2^{*}\end{array}$ & $\begin{array}{l}1,12 \pm 0,0 \\
1 *\end{array}$ & $\begin{array}{l}1,13 \pm 0,0 \\
2\end{array}$ & $\begin{array}{l}1,08 \pm 0,0 \\
2^{*}\end{array}$ & $\begin{array}{l}1,01 \pm 0,0 \\
1 * \epsilon\end{array}$ & $\begin{array}{l}0,98 \pm 0,0 \\
2\end{array}$ & $\begin{array}{l}0,94 \pm 0,0 \\
2\end{array}$ & $\begin{array}{l}0,94 \pm 0,0 \\
1 \epsilon\end{array}$ \\
\hline \multirow{2}{*}{$\begin{array}{l}\text { \% } \\
\text { резервно } \\
\text { го жира }\end{array}$} & $\Gamma$ & $21,6 \pm 0,5$ & $21,4 \pm 0,5$ & $22,5 \pm 0,5$ & $21,7 \pm 0,4$ & $22,3 \pm 0,6$ & $22,8 \pm 0,4$ & $19,4 \pm 0,8^{*}$ & $19,3 \pm 0,8$ & $20,5 \pm 0,7$ \\
\hline & $\mathrm{c}$ & $19,8 \pm 0,3 \epsilon$ & $20,9 \pm 0,5^{*}$ & $21,5 \pm 0,5$ & $22,0 \pm 0,5$ & $22,3 \pm 0,5$ & $22,6 \pm 0,5$ & $18,7 \pm 1,0^{*}$ & $18,9 \pm 1,0$ & $18,7 \pm 0,6$ \\
\hline \multirow{2}{*}{$\begin{array}{l}\text { Резервн } \\
\text { ый жир, } \\
\text { кг }\end{array}$} & $\Gamma$ & $5,2 \pm 0,2$ & $5,6 \pm 0,3$ & $6,7 \pm 0,4^{*}$ & $6,6 \pm 0,2$ & $8,3 \pm 0,4^{*}$ & $9,1 \pm 0,4$ & $9,3 \pm 0,6$ & $9,4 \pm 0,7$ & $11,7 \pm 0,6^{*}$ \\
\hline & $\mathrm{c}$ & $3,8 \pm 0,1 \epsilon$ & $5,4 \pm 0,4^{*}$ & $5,9 \pm 0,2$ & $6,4 \pm 0,3$ & $7,4 \pm 0,5^{*}$ & $8,7 \pm 0,3^{*}$ & $8,4 \pm 0,8$ & $8,9 \pm 0,8$ & $9,1 \pm 0,5 \epsilon$ \\
\hline \multirow[t]{2}{*}{ AMT, кг } & $\Gamma$ & $18,3 \pm 0,4$ & $\begin{array}{l}19,9 \pm 0,4 \\
*\end{array}$ & $\begin{array}{l}22,4 \pm 0,6 \\
*\end{array}$ & 0,5 & $\begin{array}{l}28,3 \pm 0,5 \\
*\end{array}$ & $\begin{array}{l}30,2 \pm 0,5 \\
*\end{array}$ & $\begin{array}{l}36, \\
*\end{array}$ & $37,3 \pm 1,0$ & $\begin{array}{l}44,0 \pm 0,8 \\
*\end{array}$ \\
\hline & $\mathrm{C}$ & $\begin{array}{l}15,6 \pm 0,2 \\
\epsilon\end{array}$ & $\begin{array}{l}20,0 \pm 0,9 \\
*\end{array}$ & $21,4 \pm 0,3$ & 22,4 & $\begin{array}{l}25,2 \pm 0,8 \\
* \epsilon\end{array}$ & $\begin{array}{l}29,8 \pm 0,6 \\
*\end{array}$ & $\begin{array}{l}34,7 \pm 0,9 \\
* \epsilon\end{array}$ & $\begin{array}{l}37,1 \pm 0,8 \\
*\end{array}$ & $\begin{array}{l}38,9 \pm 0,9 \\
\epsilon\end{array}$ \\
\hline
\end{tabular}


Вестник Новосибирского государственного педагогического университета Novosibirsk State Pedagogical University Bulletin

\begin{tabular}{|c|c|c|c|c|c|c|c|c|c|c|}
\hline \multirow{2}{*}{$\begin{array}{l}\text { Кистева } \\
\text { я сила } \\
\text { (пр+л), } \\
\text { кг }\end{array}$} & $\Gamma$ & $12,5 \pm 0,3$ & $\begin{array}{l}14,7 \pm 0,6 \\
*\end{array}$ & $\begin{array}{l}17,6 \pm 0,5 \\
*\end{array}$ & $\begin{array}{l}21,0 \pm 0,8 \\
*\end{array}$ & $\begin{array}{l}26,7 \pm 0,9 \\
*\end{array}$ & $\begin{array}{l}29,0 \pm 0,8 \\
*\end{array}$ & $\begin{array}{l}37,0 \pm 1,2 \\
*\end{array}$ & $39,1 \pm 1,4$ & $\begin{array}{l}45,7 \pm 1,5 \\
*\end{array}$ \\
\hline & $\mathrm{c}$ & $12,3 \pm 0,3$ & $\begin{array}{l}15,7 \pm 0,6 \\
*\end{array}$ & $16,1 \pm 0,8$ & $\begin{array}{l}21,0 \pm 0,9 \\
*\end{array}$ & $\begin{array}{l}22,6 \pm 1,7 \\
\epsilon\end{array}$ & $\begin{array}{l}31,8 \pm 1,6 \\
*\end{array}$ & $\begin{array}{l}36,2 \pm 1,1 \\
*\end{array}$ & $37,3 \pm 1,3$ & $\begin{array}{l}37,1 \pm 0,9 \\
\epsilon\end{array}$ \\
\hline \multirow{2}{*}{$\begin{array}{l}\text { КИ, } \\
\text { кг/кг }\end{array}$} & $\Gamma$ & $\begin{array}{l}0,54 \pm 0,0 \\
2\end{array}$ & $\begin{array}{l}0,58 \pm 0,0 \\
2\end{array}$ & $\begin{array}{l}0,61 \pm 0,0 \\
2\end{array}$ & $\begin{array}{l}0,71 \pm 0,0 \\
3 *\end{array}$ & $\begin{array}{l}0,73 \pm 0,0 \\
2\end{array}$ & $\begin{array}{l}0,75 \pm 0,0 \\
2\end{array}$ & $\begin{array}{l}0,81 \pm 0,0 \\
3 *\end{array}$ & $\begin{array}{l}0,86 \pm 0,0 \\
4\end{array}$ & $\begin{array}{l}0,88 \pm 0,0 \\
3\end{array}$ \\
\hline & $\mathrm{c}$ & $\begin{array}{l}0,50 \pm 0,0 \\
1 \epsilon\end{array}$ & $\begin{array}{l}0,57 \pm 0,0 \\
3^{*}\end{array}$ & $\begin{array}{l}0,64 \pm 0,0 \\
3\end{array}$ & $\begin{array}{l}0,84 \pm 0,0 \\
4 * \epsilon\end{array}$ & $\begin{array}{l}0,79 \pm 0,0 \\
6\end{array}$ & $\begin{array}{l}0,82 \pm 0,0 \\
3 €\end{array}$ & $\begin{array}{l}0,80 \pm 0,0 \\
4\end{array}$ & $\begin{array}{l}0,76 \pm 0,0 \\
5\end{array}$ & $\begin{array}{l}0,81 \pm 0,0 \\
2 €\end{array}$ \\
\hline \multirow{2}{*}{$\begin{array}{l}\text { Станова } \\
\text { я сила, } \\
\text { кг }\end{array}$} & $\Gamma$ & $15,1 \pm 0,9$ & $16,0 \pm 0,7$ & $\begin{array}{l}24,8 \pm 1,2 \\
*\end{array}$ & $27,3 \pm 1,0$ & $\begin{array}{l}33,8 \pm 1,2 \\
*\end{array}$ & $\begin{array}{l}37,4 \pm 1,1 \\
*\end{array}$ & $\begin{array}{l}44,4 \pm 1,8 \\
*\end{array}$ & $45,3 \pm 2,0$ & $\begin{array}{l}52,4 \pm 1,5 \\
*\end{array}$ \\
\hline & $\mathrm{c}$ & $9,8 \pm 0,1 \epsilon$ & $14,2 \pm 0,6^{*} \epsilon$ & $17,8 \pm 1,4^{*} \epsilon$ & $24,6 \pm 1,4^{*}$ & $25,8 \pm 2,8 \epsilon$ & $32,0 \pm 1,7^{*} \epsilon$ & $34,3 \pm 1,8 \epsilon$ & $34,6 \pm 1,9 \epsilon$ & $39,0 \pm 1,6 \epsilon$ \\
\hline \multirow{2}{*}{$\begin{array}{l}\text { СтИ, } \\
\text { кг/кг }\end{array}$} & $\bar{\Gamma}$ & $\begin{array}{l}0,64 \pm 0,0 \\
4\end{array}$ & $\begin{array}{l}0,64 \pm 0,0 \\
3\end{array}$ & $\begin{array}{l}0,86 \pm 0,0 \\
5 *\end{array}$ & $\begin{array}{l}0,92 \pm 0,0 \\
5\end{array}$ & $\begin{array}{l}0,91 \pm 0,0 \\
4\end{array}$ & $\begin{array}{l}0,96 \pm 0,0 \\
3\end{array}$ & $\begin{array}{l}0,97 \pm 0,0 \\
3\end{array}$ & $\begin{array}{l}0,98 \pm 0,0 \\
4\end{array}$ & $\begin{array}{l}0,94 \pm 0,0 \\
2\end{array}$ \\
\hline & $\mathrm{c}$ & $\begin{array}{l}0,50 \pm 0,0 \\
1 \epsilon\end{array}$ & $\begin{array}{l}0,57 \pm 0,0 \\
3\end{array}$ & $\begin{array}{l}0,64 \pm 0,0 \\
3 \epsilon\end{array}$ & $\begin{array}{l}0,84 \pm 0,0 \\
4^{*}\end{array}$ & $\begin{array}{l}0,79, \pm 0,0 \\
6\end{array}$ & $\begin{array}{l}0,82 \pm 0,0 \\
3 \epsilon\end{array}$ & $\begin{array}{l}0,80 \pm 0,0 \\
4 \epsilon\end{array}$ & $\begin{array}{l}0,76 \pm 0,0 \\
5 €\end{array}$ & $\begin{array}{l}0,81 \pm 0,0 \\
2 €\end{array}$ \\
\hline
\end{tabular}

тенденцию к снижению, а в 7 и 15 лет он был ниже у городских девочек. Увеличение содержания абсолютного жира к 15-летнему возрасту составило у городских и сельских школьниц 6,5 кг и 5,3 кг (125\% и 139,4 \%) по сравнению с 7-летними.

Городские школьницы опережали по показателям резервного жира, активной массы тела сельских сверстниц, отличия имели достоверный характер в некоторых возрастных группах: 7,11,13 и 15 лет. В 13-14 лет у городских и сельских школьниц отмечалась отрицательная динамика содержания резервного жира, в то же время наблюдали увеличение активной массы тела (таблица 5).

Снижение прироста процентного содержания жира отмечалось у городских школьниц в 10 лет, а также более резкое снижение в 14 лет как у городских, так и у сельских девочек. Более высокий прирост активной массы тела выявлен у сельских школьниц в возрасте 8 лет.

Городские школьницы имели более высокие показатели мышечной силы, нежели девочки, проживающие в сельской местности (таблица 5).

Обследованные девочки в одних и тех же возрастных периодах находились на различных стадиях полового созревания. I стадия полового созревания у городских девочек обнаружена в 9 лет, тогда как у сельских - в 10 лет (таблица 6).

Таблица 6

Распределение обследованных городских и сельских девочек по стадиям полового созревания в онтогенезе (в \%)

\begin{tabular}{|c|c|c|c|c|c|c|c|c|c|}
\hline \multirow{3}{*}{$\begin{array}{c}\text { Возраст, } \\
\text { лет }\end{array}$} & \multirow{3}{*}{$\begin{array}{c}\text { город - Г } \\
\text { село - с } \\
\text { (n ) }\end{array}$} & \multicolumn{8}{|c|}{ Стадии полового созревания } \\
\hline & & \multicolumn{2}{|c|}{ I } & \multicolumn{2}{|c|}{ II } & \multicolumn{2}{|c|}{ III } & \multicolumn{2}{|c|}{ IV } \\
\hline & & $\Gamma$ & $\mathrm{c}$ & $\Gamma$ & $\mathrm{c}$ & $\Gamma$ & c & $\Gamma$ & c \\
\hline \multirow[t]{2}{*}{9} & $\Gamma-40$ & 100,0 & & - & & - & & - & \\
\hline & $c-20$ & & - & & - & & - & & - \\
\hline
\end{tabular}


Вестник Новосибирского государственного педагогического университета Novosibirsk State Pedagogical University Bulletin

1(17) 2014

www.vestnik.nspu.ru

ISSN 2226-3365

\begin{tabular}{|c|c|c|c|c|c|c|c|c|c|}
\hline 10 & $\Gamma-43$ & 97,7 & & 2,3 & & - & & - & \\
\cline { 2 - 10 } & $\mathrm{c}-21$ & & 100,0 & & - & & - & & - \\
\hline \multirow{2}{*}{11} & $\Gamma-41$ & 92,7 & & 7,3 & & - & & - & \\
\cline { 2 - 11 } & $\mathrm{c}-20$ & & 95,5 & & 5,0 & & - & & - \\
\hline \multirow{2}{*}{12} & $\Gamma-45$ & 20,0 & & 73,3 & & 6,6 & & - & \\
\cline { 2 - 11 } & $\mathrm{c}-20$ & & 45,0 & & 50,0 & & 5,0 & & - \\
\hline \multirow{2}{*}{13} & $\Gamma-35$ & 20,0 & & 60,0 & & 20,0 & & - & \\
\cline { 2 - 11 } & $\mathrm{c}-20$ & & 30,0 & & 55,0 & & 15,0 & & - \\
\cline { 2 - 11 } & $\mathrm{r}-34$ & 17,6 & & 38,2 & & 20,6 & & 23,6 & \\
\hline \multirow{2}{*}{15} & $\mathrm{c}-18$ & & 16,6 & & 44,5 & & 22,3 & & 16,6 \\
\cline { 2 - 10 } & $\mathrm{r}-37$ & - & & 16,2 & & 43,3 & & 40,5 & \\
\hline
\end{tabular}

Таблица 7

Показатели кардио-респираторной системы девочек 7-15 лет, проживающих в городских и сельских местностях в условиях покоя

\begin{tabular}{|c|c|c|c|c|c|c|c|c|c|c|}
\hline \multicolumn{2}{|c|}{ Показатели } & \multicolumn{9}{|c|}{ Возраст, лет } \\
\hline \multirow{3}{*}{$\begin{array}{l}\mathrm{N} \\
\text { (кол-во) }\end{array}$} & & 7 & 8 & 9 & 10 & 11 & 12 & 13 & 14 & 15 \\
\hline & $\Gamma$ & $\mathrm{n}=37$ & $\mathrm{n}=39$ & $\mathrm{n}=40$ & $\mathrm{n}=43$ & $\mathrm{n}=41$ & $\mathrm{n}=45$ & $\mathrm{n}=35$ & $\mathrm{n}=34$ & $\mathrm{n}=37$ \\
\hline & $\mathrm{c}$ & $\mathrm{n}=19$ & $\mathrm{n}=20$ & $\mathrm{n}=20$ & $\mathrm{n}=21$ & $\mathrm{n}=20$ & $\mathrm{n}=20$ & $\mathrm{n}=20$ & $\mathrm{n}=18$ & $n=22$ \\
\hline \multicolumn{11}{|c|}{ Показатели системы внешнего дыхания } \\
\hline \multirow[t]{2}{*}{ ЖЕЛ, Л } & $\Gamma$ & $\begin{array}{c}1,42 \pm 0,0 \\
3\end{array}$ & $\begin{array}{c}1,53 \pm 0,05 \\
*\end{array}$ & $\begin{array}{c}1,77 \pm 0,0 \\
3 *\end{array}$ & $\begin{array}{c}1,79 \pm 0,0 \\
4\end{array}$ & $\begin{array}{c}1,95 \pm 0,04 \\
*\end{array}$ & $\begin{array}{c}2,03 \pm 0,0 \\
4\end{array}$ & $\begin{array}{c}2,45 \pm 0 \\
, 04 *\end{array}$ & $\begin{array}{c}2,48 \pm 0,0 \\
5\end{array}$ & $\begin{array}{c}2,82 \pm 0 \\
, 06^{*}\end{array}$ \\
\hline & $\mathrm{c}$ & $\begin{array}{c}1,21 \pm 0,0 \\
1 €\end{array}$ & $\begin{array}{c}1,41 \pm 0,02 \\
* \epsilon\end{array}$ & $\begin{array}{c}1,64 \pm 0,0 \\
4 * \epsilon\end{array}$ & $\begin{array}{c}1,68 \pm 0,0 \\
5\end{array}$ & $\begin{array}{c}1,87 \pm 0,09 \\
*\end{array}$ & $\begin{array}{c}2,17 \pm 0,0 \\
5^{*} \epsilon\end{array}$ & $\begin{array}{l}2,35 \pm 0 \\
, 04 * \epsilon\end{array}$ & $2,52 \pm 0,1$ & $\begin{array}{c}2,59 \pm 0 \\
, 07 \epsilon\end{array}$ \\
\hline \multirow[t]{2}{*}{$\begin{array}{l}\text { ЖИ, } \\
\text { мл/кг }\end{array}$} & $\Gamma$ & $61,3 \pm 1,5$ & $61,0 \pm 1,9$ & $62,1 \pm 1,7$ & $\begin{array}{c}61,0 \pm 0,0 \\
4\end{array}$ & $54,0 \pm 1,3^{*}$ & $52,8 \pm 1,2$ & $\begin{array}{c}54,7 \pm 1 \\
, 8 \\
\end{array}$ & $54,9 \pm 2,1$ & $\begin{array}{c}51,4 \pm 1 \\
, 4\end{array}$ \\
\hline & $\mathrm{c}$ & $62,2 \pm 0,8$ & $57,7 \pm 1,9^{*}$ & $60,3 \pm 1,8$ & $59,0 \pm 1,6$ & $58,4 \pm 3,2$ & $56,3 \pm 1,5$ & $\begin{array}{c}55,5 \pm 1 \\
, 6 \\
\end{array}$ & $54,9 \pm 1,5$ & $\begin{array}{c}54,7 \pm 1 \\
, 9 \\
\end{array}$ \\
\hline \multicolumn{11}{|c|}{ Показатели сердечно-сосудистой системы в условиях покоя } \\
\hline \multirow[t]{2}{*}{$\begin{array}{l}\text { ЧСС, } \\
\text { уд/мин }\end{array}$} & $\Gamma$ & $97,9 \pm 2,0$ & $96,4 \pm 1,4$ & $95,2 \pm 2,2$ & $93,5 \pm 1,3$ & $93,4 \pm 1,7$ & $92,5 \pm 1,5$ & $\begin{array}{c}92,8 \pm 2 \\
, 6 \\
\end{array}$ & $88,6 \pm 2,0$ & $\begin{array}{c}87,5 \pm 2 \\
, 0 \\
\end{array}$ \\
\hline & $\mathrm{c}$ & $97,6 \pm 1,2$ & $95,2 \pm 2,6$ & $\begin{array}{c}88,0 \pm 2,5 \\
* \epsilon\end{array}$ & $\begin{array}{c}87,9 \pm 0,7 \\
\epsilon \\
\end{array}$ & $87,5 \pm 0,5 \epsilon$ & $\begin{array}{c}85,8 \pm 2,5 \\
\epsilon \\
\end{array}$ & $\begin{array}{c}85,0 \pm 1 \\
, 0 € \\
\end{array}$ & $\begin{array}{c}83,9 \pm 1,2 \\
\epsilon \\
\end{array}$ & $\begin{array}{c}83,0 \pm 1 \\
, 8 \\
\end{array}$ \\
\hline \multirow{2}{*}{$\begin{array}{l}\text { САД, } \\
\text { мм. рт. } \\
\text { ст. }\end{array}$} & $\begin{array}{ll}\Gamma \\
\end{array}$ & $90,9 \pm 1,1$ & $91,8 \pm 1,4$ & $93,9 \pm 1,4$ & $\begin{array}{c}91,6 \pm 1,2 \\
*\end{array}$ & $\begin{array}{c}102,2 \pm 1,4 \\
*\end{array}$ & $\begin{array}{c}101,6 \pm 1, \\
0\end{array}$ & $\begin{array}{c}102,3 \pm \\
1,2 \\
\end{array}$ & $\begin{array}{c}105,3 \pm 1 \\
4\end{array}$ & $\begin{array}{c}111,8 \pm \\
1,9^{*} \\
\end{array}$ \\
\hline & $\mathrm{c}$ & $\begin{array}{c}87,6 \pm 1,2 \\
\epsilon\end{array}$ & $\begin{array}{c}98,8 \pm 2,6^{*} \\
\epsilon\end{array}$ & $\begin{array}{c}107,0 \pm 1 \\
4^{*} \epsilon\end{array}$ & $\begin{array}{c}107,0 \pm 2 \\
0 €\end{array}$ & $\begin{array}{c}109,0 \pm 1,1 \\
\epsilon\end{array}$ & $\begin{array}{c}111,0 \pm 1, \\
1 €\end{array}$ & $\begin{array}{c}112,0 \pm \\
1,1 \epsilon\end{array}$ & $\begin{array}{c}113,0 \pm 1, \\
2 \epsilon\end{array}$ & $\begin{array}{c}115,0 \pm \\
1,1 \epsilon\end{array}$ \\
\hline \multirow{2}{*}{$\begin{array}{l}\text { ДАД, } \\
\text { мм. рт. } \\
\text { ст. }\end{array}$} & $\Gamma$ & $56,5 \pm 1,5$ & $57,6 \pm 1,1$ & $\begin{array}{c}60,9 \pm 1,1 \\
*\end{array}$ & $59,7 \pm 1,3$ & $60,4 \pm 1,0$ & $59,2 \pm 0,8$ & $\begin{array}{c}60,0 \pm 1 \\
, 2 \\
\end{array}$ & $60,4 \pm 1,2$ & $\begin{array}{c}63,1 \pm 1 \\
, 3 \\
\end{array}$ \\
\hline & $\mathrm{c}$ & $53,7 \pm 0,6$ & $56,0 \pm 1,1^{*}$ & $\begin{array}{c}56,8 \pm 0,5 \\
\epsilon \\
\end{array}$ & $60,2 \pm 2,0$ & $57,8 \pm 0,5 \epsilon$ & $58,8 \pm 1,4$ & $\begin{array}{c}57,0 \pm 0 \\
, 5 € \\
\end{array}$ & $56,9 \pm 1,6$ & $\begin{array}{c}57,7 \pm 1 \\
, 1 \\
\end{array}$ \\
\hline \multirow{2}{*}{$\begin{array}{l}\text { ПД, мм. } \\
\text { рт. ст. }\end{array}$} & $\Gamma$ & $34,4 \pm 1,1$ & $34,2 \pm 1,1$ & $33,0 \pm 1,1$ & $37,9 \pm 1,0$ & $41,8 \pm 1,8$ & $42,3 \pm 1,0$ & $42,2 \pm 1,2$ & $44,8 \pm 1,6$ & $48,6 \pm 1,5$ \\
\hline & $\mathrm{c}$ & $33,9 \pm 1,5$ & $42,8 \pm 1,7^{*} \epsilon$ & $50,0 \pm 1,1 * \epsilon$ & $47,1 \pm 2,0 \epsilon$ & $50,8 \pm 1,1 \epsilon$ & $52,3 \pm 1,7 \mathrm{e}$ & $54,8 \pm 1,7 \mathrm{\epsilon}$ & $56,4 \pm 2,5 \epsilon$ & $57,0 \pm 2,2 \mathrm{e}$ \\
\hline
\end{tabular}


Вестник Новосибирского государственного педагогического университета Novosibirsk State Pedagogical University Bulletin

\begin{tabular}{|c|c|c|c|c|c|c|c|c|c|c|}
\hline \multirow[t]{2}{*}{ ДП, у.е. } & $\Gamma$ & $89,0 \pm 2,0$ & $88,2 \pm 1,4$ & $89,5 \pm 2,8$ & $91,5 \pm 2,0$ & $95,6 \pm 2,1$ & $93,8 \pm 1,9$ & $95,0 \pm 3,4$ & $93,6 \pm 2,9$ & $97,5 \pm 2,3$ \\
\hline & $\mathrm{c}$ & $85,5 \pm 2,1$ & $93,6 \pm 3,1^{*}$ & $93,7 \pm 2,1$ & $94,2 \pm 1,7$ & $94,9 \pm 1,4$ & $95,2 \pm 3,4$ & $94,9 \pm 1,6$ & $95,2 \pm 2,1$ & $95,1 \pm 2,2$ \\
\hline \multirow[t]{2}{*}{$\begin{array}{l}\text { COK, } \\
\text { мл. }\end{array}$} & $\Gamma$ & $45,7 \pm 1,5$ & $48,2 \pm 0,9$ & $48,8 \pm 1,0$ & $\begin{array}{c}55,2 \pm 1,1 \\
*\end{array}$ & $59,9 \pm 1,1^{*}$ & $\begin{array}{c}64,0 \pm 0,9 \\
*\end{array}$ & $\begin{array}{c}66,7 \pm 1 \\
, 1 *\end{array}$ & $\begin{array}{c}71,0 \pm 1,3 \\
*\end{array}$ & $\begin{array}{c}74,5 \pm 1 \\
, 4\end{array}$ \\
\hline & $\mathrm{c}$ & $47,1 \pm 0,9$ & $\begin{array}{c}53,3 \pm 1,2^{*} \\
\epsilon\end{array}$ & $\begin{array}{c}59,7 \pm 0,9 \\
* \epsilon\end{array}$ & $\begin{array}{c}59,4 \pm 1,9 \\
\epsilon\end{array}$ & $\begin{array}{c}65,9 \pm 0,9^{*} \\
\epsilon\end{array}$ & $\begin{array}{c}69,2 \pm 1,6 \\
\epsilon\end{array}$ & $\begin{array}{c}74,7 \pm 1 \\
, 2 * \epsilon\end{array}$ & $\begin{array}{c}78,8 \pm 2,0 \\
\epsilon\end{array}$ & $\begin{array}{c}81,8 \pm 1 \\
, 7 €\end{array}$ \\
\hline \multirow[t]{2}{*}{ МОК, л. } & $\Gamma$ & $4,5 \pm 0,1$ & $4,6 \pm 0,1$ & $4,7 \pm 0,2$ & $5,2 \pm 0,1 *$ & $5,5 \pm 0,1^{*}$ & $5,9 \pm 0,1$ & $\begin{array}{c}6,2 \pm 0 \\
2\end{array}$ & $6,3 \pm 0,1$ & $\begin{array}{c}6,5 \pm 0 \\
2 \\
\end{array}$ \\
\hline & $\mathrm{c}$ & $4,5 \pm 0,1$ & $5,0 \pm 0,1 * \epsilon$ & $\begin{array}{c}5,2 \pm 0,1 \\
\epsilon \\
\end{array}$ & $5,2 \pm 0,1$ & $5,7 \pm 0,1 *$ & $5,9 \pm 0,2$ & $\begin{array}{c}6,3 \pm 0 \\
1 \\
\end{array}$ & $6,6 \pm 0,2$ & $\begin{array}{c}6,7 \pm 0 \\
2\end{array}$ \\
\hline
\end{tabular}

В 12 лет среди городских девочек выявлено 6,6 \% с III стадией, однако среди сельских школьниц - 5 \%. К 15 летнему возрасту 40,5 \% городских школьниц завершали половое развитие, тогда как среди сельских подростков - только $27,3 \%$.

Полученные результаты по физическому развитию школьниц, проживающих в городской и сельской местностях, показали, что городские девочки опережали сельских сверстниц по абсолютным показателям физического развития и срокам полового созревания, однако отличия не всегда носили достоверный характер.

Жизненная емкость легких городских школьниц (таблица 7) превышала в большинстве случаев достоверно ЖЕЛ девочек, проживающих в сельских условиях, чего нельзя сказать о жизненном индексе (ЖИ), который достоверно не различался.

В нашем исследовании девочки в онтогенезе показали постоянное и неуклонное достоверное урежение ЧСС в покое, особенно сельские в сравнении с городскими сверстницами. У девочек в покое ЧСС в онтогенезе снижалась: у городских с $97,9 \pm 2,0$ до $87,5 \pm 2,0$ уд/мин, у сельских со $97,6 \pm 1,2$ до $83,0 \pm 1,8$ уд/мин (таблица 7). Такие гемодинамические показатели в покое как САД, ПД, СОК, МОК у сельских школьниц были достоверно выше, чем у городских девочек в большинстве возрастных группах. Эти данные могут свидетельствовать о лучшем функциональном состоянии сердечно-сосудистой системы сельских школьниц.

При выполнении стандартной степэргометрической нагрузки мощностью 12 кгм/мин·кг у сельских школьниц выявлены достоверно более низкие значения ЧСС по сравнению с девочками, проживающими в городской местности (таблица 8). По величине САД нагрузки превышение наблюдалось у сельских девочек только в 8-9 летнем возрасте, тогда как в 7, 12-15 лет, наоборот, САД у городских школьниц было выше. ДАД нагрузки городских школьниц в большинстве случаев достоверно превышало показатели сельских детей, кроме 8-летних школьниц. Превышение значений ПД у сельских школьниц 8-15 лет не всегда имело достоверное отличие.

Показатель абсолютной физической работоспособности (рисунок 4 А) в онтогенезе увеличивался у сельских школьниц с 11 до 15 лет, а у городских с 12 до 15 лет, значения величины абсолютной физической работоспособности у сельских школьниц выше, причем достоверно в большинстве возрастных групп. Относи- 
Вестник Новосибирского государственного педагогического университета Novosibirsk State Pedagogical University Bulletin

тельная физическая работоспособность сельских школьниц (рисунок 4Б) достоверно выше, чем у городских девочек. Снижение уровня относительной работоспособности наблюдалось у сельских девочек с 9 лет, а городские школьницы в онтогенезе имели приблизительно одинаковый уровень.

Таблица 8

Показатели сердечно-сосудистой системы девочек 7-15 лет, проживающих в городских и сельских местностях в условиях нагрузки

\begin{tabular}{|c|c|c|c|c|c|c|c|c|c|c|}
\hline $\begin{array}{l}\text { Показ } \\
\text { атели }\end{array}$ & \multicolumn{10}{|c|}{ Возраст, лет } \\
\hline \multirow{3}{*}{$\begin{array}{l}\text { N } \\
\text { (кол- } \\
\text { во) }\end{array}$} & & 7 & 8 & 9 & 10 & 11 & 12 & 13 & 14 & 15 \\
\hline & $\Gamma$ & $\mathrm{n}=37$ & $n=39$ & $\mathrm{n}=40$ & $n=43$ & $\mathrm{n}=41$ & $\mathrm{n}=45$ & $\mathrm{n}=35$ & $\mathrm{n}=34$ & $\mathrm{n}=37$ \\
\hline & $\mathrm{c}$ & $\mathrm{n}=19$ & $\mathrm{n}=20$ & $\mathrm{n}=20$ & $\mathrm{n}=21$ & $\mathrm{n}=20$ & $\mathrm{n}=20$ & $\mathrm{n}=20$ & $\mathrm{n}=18$ & $\mathrm{n}=22$ \\
\hline \multirow{2}{*}{$\begin{array}{l}\text { ЧСС, } \\
\text { уд/ми } \\
\text { н }\end{array}$} & $\Gamma$ & $\begin{array}{c}169,7 \pm 3 \\
1\end{array}$ & $\begin{array}{c}168,5 \pm 2 \\
0\end{array}$ & $\begin{array}{c}168,4 \pm 1 \\
3\end{array}$ & $\begin{array}{c}168,2 \pm \\
1,6\end{array}$ & $168,0 \pm 1,5$ & $\begin{array}{c}168,0 \pm 2 \\
0\end{array}$ & $\begin{array}{c}167,7 \pm \\
1,7\end{array}$ & $167,0 \pm 2,2$ & $167,0 \pm 1,0$ \\
\hline & $\mathrm{c}$ & $\begin{array}{c}152,0 \pm 3 \\
9 \epsilon\end{array}$ & $\begin{array}{c}152,0 \pm 1 \\
9 \epsilon\end{array}$ & $\begin{array}{c}151,0 \pm 1 \\
9 \epsilon\end{array}$ & $\begin{array}{c}151,0 \pm \\
0,5 \epsilon\end{array}$ & $\begin{array}{c}149,0 \pm 1,0 \\
\epsilon\end{array}$ & $\begin{array}{c}148,0 \pm 1 \\
6 \epsilon\end{array}$ & $\begin{array}{c}147,0 \pm \\
0,5 €\end{array}$ & $\begin{array}{c}146,0 \pm 0,7 \\
\epsilon\end{array}$ & $\begin{array}{c}145,0 \pm 1,2 \\
\epsilon\end{array}$ \\
\hline \multirow{2}{*}{$\begin{array}{l}\text { САД, } \\
\text { мм. } \\
\text { рт. ст. }\end{array}$} & $\Gamma$ & $\begin{array}{c}112,4 \pm 1 \\
1\end{array}$ & $\begin{array}{c}115,6 \pm 2 \\
2\end{array}$ & $\begin{array}{c}121,8 \pm 1 \\
8^{*}\end{array}$ & $\begin{array}{c}129,7 \pm \\
1,3^{*}\end{array}$ & $132,9 \pm 2,1$ & $\begin{array}{c}136,6 \pm 1 \\
6\end{array}$ & $\begin{array}{c}136,9 \pm \\
2,4\end{array}$ & $144,3 \pm 2,0^{*}$ & $147,6 \pm 1,5$ \\
\hline & $\mathrm{c}$ & $\begin{array}{c}105,7 \pm 1 \\
8 \epsilon\end{array}$ & $\begin{array}{c}126,0 \pm 4 \\
7 * \epsilon\end{array}$ & $\begin{array}{c}127,5 \pm 1 \\
7 \epsilon\end{array}$ & $\begin{array}{c}131,4 \pm \\
1,1^{*}\end{array}$ & $134,0 \pm 2,9$ & $\begin{array}{c}135,5 \pm 3 \\
5\end{array}$ & $\begin{array}{c}136,5 \pm \\
2,0\end{array}$ & $\begin{array}{c}138,3 \pm 1,2 \\
\epsilon\end{array}$ & $\begin{array}{c}140,4 \pm 1,6 \\
\epsilon\end{array}$ \\
\hline \multirow{2}{*}{$\begin{array}{l}\text { ДАД, } \\
\text { мм. } \\
\text { рт. ст. }\end{array}$} & $\Gamma$ & $57,3 \pm 0,7$ & $56,9 \pm 0,7$ & $\begin{array}{c}59,8 \pm 0,7 \\
*\end{array}$ & $\begin{array}{c}59,8 \pm 1 \\
3\end{array}$ & $58,5 \pm 0,7$ & $59,0 \pm 0,8$ & $\begin{array}{c}58,4 \pm 0 \\
4\end{array}$ & $59,6 \pm 1,0$ & $61,6 \pm 1,3$ \\
\hline & $\mathrm{c}$ & $\begin{array}{c}55,0 \pm 0,6 \\
\epsilon\end{array}$ & $\begin{array}{c}57,2 \pm 0,5 \\
*\end{array}$ & $\begin{array}{c}57,5 \pm 0,5 \\
\epsilon\end{array}$ & $\begin{array}{c}59,0 \pm 1 \\
7\end{array}$ & $56,7 \pm 0,8$ & $\begin{array}{c}54,0 \pm 1,7 \\
\epsilon\end{array}$ & $\begin{array}{c}53,2 \pm 1 \\
1 \epsilon\end{array}$ & $52,5 \pm 1,2 \epsilon$ & $52,9 \pm 0,5 \epsilon$ \\
\hline \multirow{2}{*}{$\begin{array}{l}\text { ПД, } \\
\text { мм. } \\
\text { рт. ст. }\end{array}$} & $\Gamma$ & $55,1 \pm 1,5$ & $58,7 \pm 1,6$ & $62,0 \pm 2,2$ & $\begin{array}{c}69,8 \pm 1 \\
7\end{array}$ & $74,3 \pm 2,1$ & $77,5 \pm 1,6$ & $\begin{array}{c}78,4 \pm 2 \\
4\end{array}$ & $84,7 \pm 1,6$ & $85,9 \pm 1,9$ \\
\hline & $\mathrm{c}$ & $50,8 \pm 2,4$ & $\begin{array}{c}68,8 \pm 4,7 \\
* \epsilon\end{array}$ & $\begin{array}{c}70,0 \pm 2,3 \\
\epsilon \\
\end{array}$ & $\begin{array}{c}72,4 \pm 1 \\
7\end{array}$ & $77,3 \pm 2,9$ & $81,5 \pm 4,1$ & $\begin{array}{c}83,3 \pm 2 \\
0\end{array}$ & $85,8 \pm 1,9$ & $87,5 \pm 2,2$ \\
\hline \multirow[t]{2}{*}{$\begin{array}{l}\text { ДП, } \\
\text { у.е. }\end{array}$} & $\Gamma$ & $\begin{array}{c}190,8 \pm 3 \\
7\end{array}$ & $\begin{array}{c}194,9 \pm 5 \\
2\end{array}$ & $\begin{array}{c}204,8 \pm 3 \\
3\end{array}$ & $\begin{array}{c}218,0 \pm \\
3,2^{*}\end{array}$ & $223,4 \pm 3,7$ & $\begin{array}{c}229,4 \pm 5 \\
0\end{array}$ & $\begin{array}{c}229,7 \pm \\
4,3\end{array}$ & $242,3 \pm 5,4^{*}$ & $246,2 \pm 2,8$ \\
\hline & $\mathrm{c}$ & $\begin{array}{c}161,3 \pm 6 \\
2 \epsilon\end{array}$ & $\begin{array}{c}192,3 \pm 8 \\
0\end{array}$ & $\begin{array}{c}193,0 \pm 3 \\
9 \epsilon\end{array}$ & $\begin{array}{c}198,5 \pm \\
2,3 \epsilon \\
\end{array}$ & $\begin{array}{c}199,7 \pm 5,3 \\
\epsilon \\
\end{array}$ & $\begin{array}{c}200,2 \pm 6 \\
6 \epsilon \\
\end{array}$ & $\begin{array}{c}200,4 \pm \\
2,9 \epsilon\end{array}$ & $\begin{array}{c}201,5 \pm 2,7 \\
\epsilon \\
\end{array}$ & $\begin{array}{c}203,1 \pm 2,7 \\
\epsilon \\
\end{array}$ \\
\hline \multirow[t]{2}{*}{$\begin{array}{l}\text { СОК, } \\
\text { мл. }\end{array}$} & $\Gamma$ & $55,6 \pm 1,2$ & $\begin{array}{c}60,8 \pm 1,0 \\
*\end{array}$ & $\begin{array}{c}64,0 \pm 1,3 \\
*\end{array}$ & $\begin{array}{c}71,1 \pm 1 \\
5 *\end{array}$ & $77,3 \pm 1,3^{*}$ & $\begin{array}{c}81,8 \pm 0,8 \\
*\end{array}$ & $\begin{array}{c}85,8 \pm 1 \\
2 *\end{array}$ & $91,4 \pm 0,9^{*}$ & $94,0 \pm 1,6$ \\
\hline & $\mathrm{c}$ & $54,7 \pm 1,6$ & $\begin{array}{c}65,6 \pm 2,3 \\
* \epsilon\end{array}$ & $\begin{array}{c}69,3 \pm 1,5 \\
\epsilon\end{array}$ & $\begin{array}{c}72,7 \pm 1 \\
9\end{array}$ & $79,7 \pm 1,8^{*}$ & $\begin{array}{c}86,7 \pm 2,8 \\
*\end{array}$ & $\begin{array}{c}91,2 \pm 2 \\
6 €\end{array}$ & $96,2 \pm 1,7 \epsilon$ & $99,9 \pm 1,4 \epsilon$ \\
\hline \multirow[t]{2}{*}{$\begin{array}{l}\text { MOK, } \\
\text { л. }\end{array}$} & $\Gamma$ & $9,4 \pm 0,3$ & $\begin{array}{c}10,2 \pm 0,1 \\
*\end{array}$ & $10,7 \pm 0,2$ & $\begin{array}{c}11,9 \pm 0 \\
2 *\end{array}$ & $12,9 \pm 0,2 *$ & $\begin{array}{c}13,7 \pm 0,2 \\
*\end{array}$ & $\begin{array}{c}14,3 \pm 0 \\
2 *\end{array}$ & $15,3 \pm 0,2 *$ & $15,6 \pm 0,2$ \\
\hline & $\mathrm{c}$ & $8,3 \pm 0,3 \epsilon$ & $9,9 \pm 0,3^{*}$ & $10,4 \pm 0,3$ & $\begin{array}{c}10,9 \pm 0 \\
2 \epsilon\end{array}$ & $\begin{array}{c}11,8 \pm 0,3^{*} \\
\epsilon \\
\end{array}$ & $\begin{array}{c}12,8 \pm 0,4 \\
* \epsilon\end{array}$ & $\begin{array}{c}13,3 \pm 0 \\
2 \epsilon\end{array}$ & $\begin{array}{c}14,0 \pm 0,3^{*} \\
\epsilon \\
\end{array}$ & $14,4 \pm 0,2 \epsilon$ \\
\hline \multirow{2}{*}{$\begin{array}{l}\text { МОК/ } \\
\text { ФР17 } \\
\text { 0/кг, л }\end{array}$} & $\Gamma$ & $\begin{array}{c}0,81 \pm 0,0 \\
4 \\
\end{array}$ & $\begin{array}{c}0,86 \pm 0,0 \\
3 \\
\end{array}$ & $\begin{array}{c}0,89 \pm 0,0 \\
5 \\
\end{array}$ & $\begin{array}{c}1,03 \pm 0 \\
04 *\end{array}$ & $1,07 \pm 0,02$ & $\begin{array}{c}1,14 \pm 0,0 \\
3 \\
\end{array}$ & $\begin{array}{c}1,18 \pm 0 \\
03\end{array}$ & $1,27 \pm 0,04$ & $1,28 \pm 0,02$ \\
\hline & $\mathrm{c}$ & $\begin{array}{c}0,57 \pm 0,0 \\
5 \epsilon \\
\end{array}$ & $\begin{array}{c}0,66 \pm 0,0 \\
3 \epsilon \\
\end{array}$ & $\begin{array}{c}0,71 \pm 0,0 \\
3 € \\
\end{array}$ & $\begin{array}{c}0,74 \pm 0 \\
02 \epsilon\end{array}$ & $\begin{array}{c}0,81 \pm 0,02^{*} \\
\epsilon \\
\end{array}$ & $\begin{array}{c}0,87 \pm 0,0 \\
4 \epsilon \\
\end{array}$ & $\begin{array}{c}0,91 \pm 0 \\
01 \epsilon\end{array}$ & $\begin{array}{c}0,96 \pm 0,02 * \\
\epsilon \\
\end{array}$ & $\begin{array}{c}0,99 \pm 0,01 \\
\epsilon \\
\end{array}$ \\
\hline \multicolumn{11}{|c|}{$\begin{array}{r}\text { Примечание - Достоверные различия средних величин по ANOVA для непараметрических независимых выборок: } \\
* \text { - по отношению к предыдущей возрастной группе }(\mathrm{P}<0,05) \\
\epsilon \text { - при сравнении городских и сельских школьниц }(\mathrm{P}<0,05)\end{array}$} \\
\hline
\end{tabular}


Аналогичные результаты получены при изучении показателей аэробной производительности городских и сельских детей (рисунок 5 А, Б). В онтогенезе наблюдалось увеличение абсолютного значения МПК в обеих сравниваемых группах девочек. Сельские школьницы опережали городских сверстниц по абсолютному показателю МПК (рисунок 5 А).

Относительный показатель МПК/кг в онтогенезе снижался как у городских, так и у сельских девочек, однако значения относительного показателя МПК/кг у сельских девочек были достоверно выше в сравнении с городскими школьницами (рисунок 5 Б).

Величина кровоснабжения организма на единицу физической работоспо-собности (МОКнагр./ФР 170$)$ у сельских школьниц была достоверно ниже во всех обследуемых возрастных периодах, нежели у городских сверстниц.

Рисунок 4

Показатели абсолютной (А) и относительной (Б) физической работоспособности городских и сельских девочек 7-15 лет
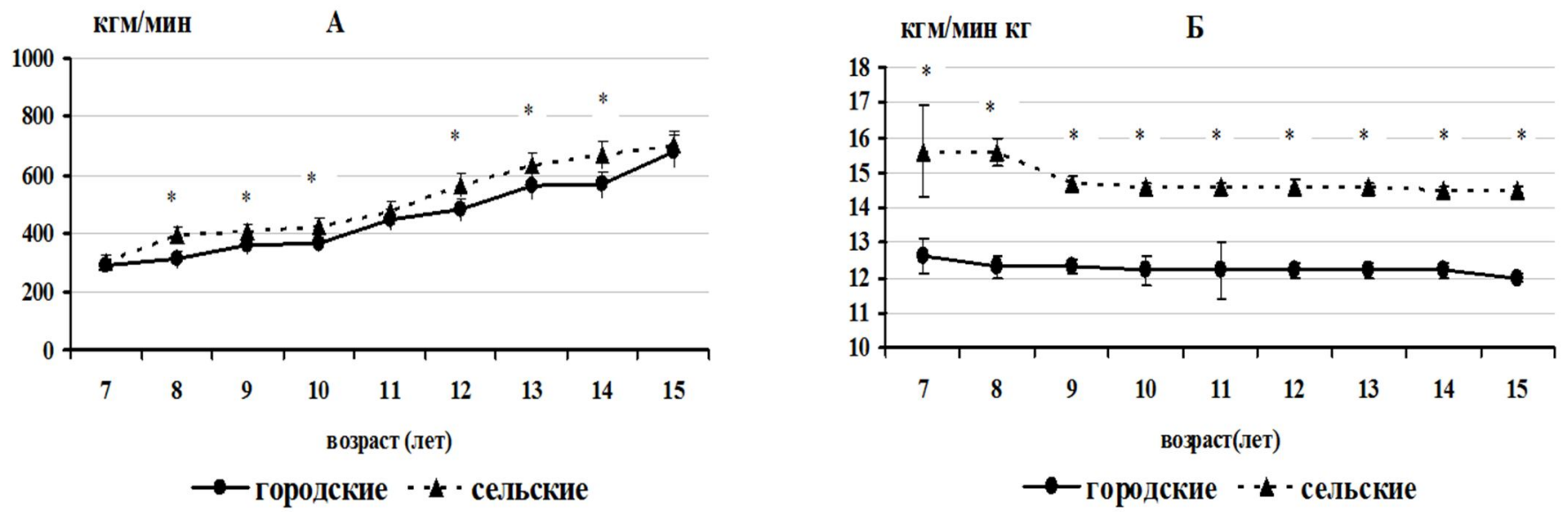

(* - достоверные отличия городских девочек по отношению к сельским)

Из полученных результатов видно, что девочки, проживающие в сельской местности, обладали большими резервными возможностями сердечно-сосудистой системы, нежели городские сверстницы. Как и при исследовании мальчиков, нами для получения интегральной характеристики применен метод морфокинетического синтеза [24].
Как видно из рисунка 6, у городских школьниц повышение темпов развития наблюдалось в 8-9, 10-11 лет и 12-15 лет, а у девочек, проживающих в сельской местности, в 7-8 лет и 11-14 лет. Сельские школьницы по темпам морфофункционального развития превышали городских сверстниц в 7-8 лет и с 12 до 14 лет. 
Вестник Новосибирского государственного педагогического университета Novosibirsk State Pedagogical University Bulletin

1(17) $2014 \quad$ www.vestnik.nspu.ru ISSN 2226-3365

Рисунок 5

Показатели абсолютной (А) и относительной (Б) максимальной аэробной производительности городских и сельских девочек 7-15 лет
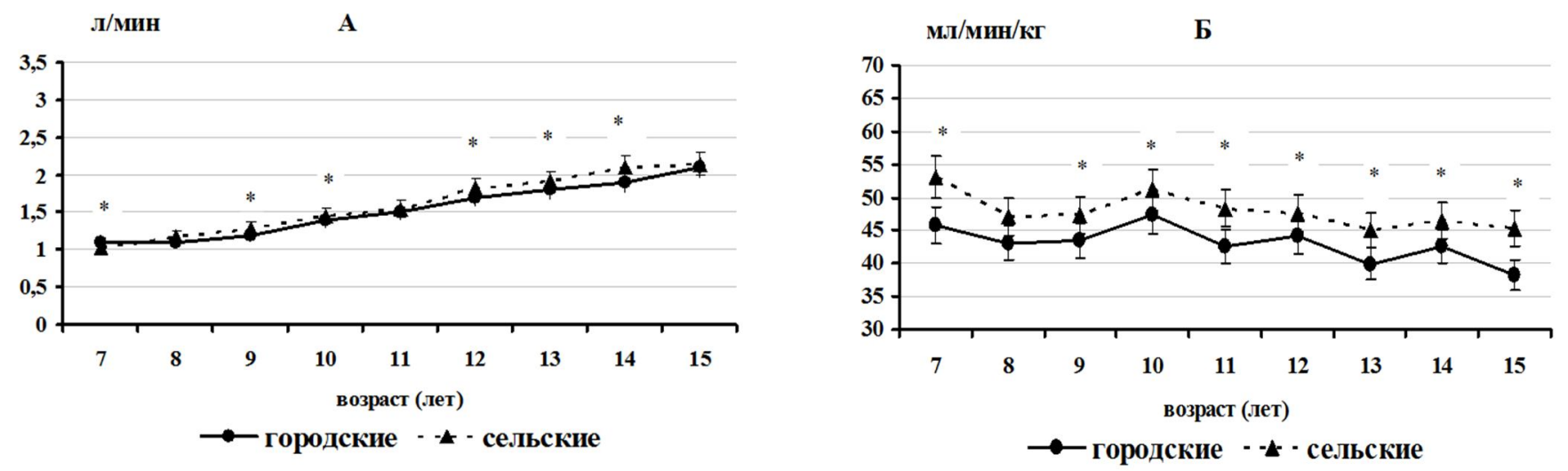

(* - достоверные отличия городских девочек по отношению к сельским).

Рисунок 6

Интегральная характеристика морфофункиионального развития городских и сельских девочек 7-15 лет

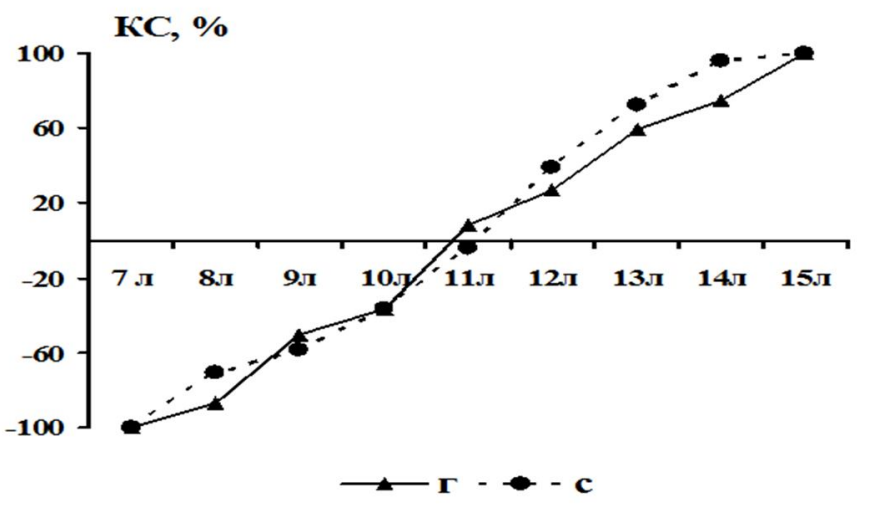

(КС - коэффициент связи между исследуемыми показателями в \%)

\section{Выводы}

1. Городские дети и подростки опережают сельских сверстников по показателям физического развития (длина, масса тела, резервный жир, мышечная сила). Сельские дети и подростки характеризуются более высокими функциональными возможностями сердечно-сосудистой системы по сравнению со сверстниками, проживающими в городской местности.
2. Сравнительная оценка морфофункциональных показателей городских и сельских детей и подростков выявляет различия по полу. Мальчики, независимо от места проживания, имеют более высокие тотальные размеры и адаптивные возможности сердечно-сосудистой системы по сравнению со сверстницами. Девочки, независимо от места проживания, отличаются большими показате- 
Вестник Новосибирского государственного педагогического университета Novosibirsk State Pedagogical University Bulletin

1(17) $2014 \quad$ www.vestnik.nspu.ru $\quad$ ISSN 2226-3365

лями резервного жира и более ранним половым созреванием.

3. Характер изменений показателей гемодинамики городских детей и подростков разного пола и возраста в ответ на дозированную физическую нагрузку свидетельствует о более низких адаптационных возможностях по сравнению с сельскими школьниками, и связано это, по-видимому, с недостаточной двигательной активностью, отрицательным влиянием факторов урбанизации.

\section{СПИСОК ЛИТЕРАТУРЫ}

1. Айзман Р.И. Здоровье населения России: медико-социальные и психолого-педагогические аспекты его формирования. - Новосибирск: СО РАМН, 1996. - 27 с.

2. Гребнева Н.Н. Эколого-физиологический портрет современных детей и подростков в условиях Тюменской области. - Тюмень: Изд-во ТГУ, 2006. - 240 с.

3. Учакина Р.В. Эколого-физиологическое обоснование гормонального статуса, физического и полового развития детей Дальневосточного региона: автореф. ... докт. биол. наук, 03.00.13. - Хабаровск, 2006. - 43 с.

4. Кабанов Ю.Н. Морфофункциональное состояние детей с разным уровнем двигательной активности, проживающих в экологических условиях города и села: автореф....канд. биол. наук: 03.00.16, 03.00.13. - Новосибирск, 2005. - 21 с.

5. Айзман Р.И. Здоровье педагогов и обучающихся - ключевая задача современной школы // Вестник Новосибирского государственного педагогического университета. - 2012. № 3(7). - C. 24-35.

6. Борцова О.А. Медико-социальные аспекты обучения школьников правильному образу жизни // Философия образования. - 2006. - № 1. - С. 211-214.

7. Быструшкин С.К., Айзман Р.И., Афтанас Л.И. Особенности организации внимания и эмоционального восприятия у детей в норме и при нарушениях интеллектуального развития // Бюллетень Сибирского отделения Российской академии наук. - 2007. - № 3. C. $159-162$.

8. Мукатаева Ж.М., Муханова А.А., Даирбаева С.Ж., Рубанович В.Б. Айзман Р.И. Морфофункциональное развитие школьниц разных соматотипов, проживающих в городской и сельской местности // Наука и новые технологии. - 2008. - № 5-6. - С. 88-94.

9. Мукатаева Ж.М. Морфофункциональная характеристика сельских детей и подростков разного пола северного Казахстана // Вестник Новосибирского государственного педагогического университета. -2013. - № 2.- С. 70-79.

10. Козлов А.И., Вершубская Г.Г. Медицинская антропология коренного населения России. М., Изд-во МН ЭПУ, 1999. - 288 с.

11. Анохина Ж.А., Колесниченко С.М., Корденко А.Н. и др. Сравнительная характеристика физического развития подростков города и села Воронежской области // Международная конференция, посвященная 55-летию Института возрастной физиологии РАО «Физиология развития человека». - М., 2000. - С. 66.

12. Федоров А.И., Казны Э.М., Селятицкая В.Г., Овчинникова О.В. Использование модели физиологического мониторинга для комплексной оценки адаптационных возможностей учащихся в процессе образовательной деятельности. Особенности гормонального психо- 
Вестник Новосибирского государственного педагогического университета Novosibirsk State Pedagogical University Bulletin

вегетативного статуса у подростков, проживающих в разных социально-экологических условиях // Физиология человека. - 2002. - Т. 28, № 6.-С. 64-68.

13. Табунов А.И. Основные методы определения количества жировой ткани в организме ребенка и их значение // Педиатрия. - 1977 - № 10. - С. 90.

14. Ставицкая А.Б, Арон Д.И. Методика исследования физического развития детей и подростков. - М.: 1959. - 185 с.

15. Колесова Д.В., Сельверова Н.Б. Физиолого-педагогические аспекты полового созревания. - М.: Педагогика, 1978. - 145 с.

16. Starr J. Clinical tests of simple method of estimating cardiac stroke volume from blood pressure and age. Circulation, 1954, no. 9, pp. 664.

17. Пугина Н.С., Бомаш Я.Ф. Об использовании метода Старра у детей // Сборник научных работ аспирантов Ленинградского института усовершенствования врачей. - 1963. - Л.: Вып. 40. - С. 64.

18. Карпман В.Л., Белоцерковский 3.Б., Гудков И.А. Тестирование в спортивной медицине. М.: Физкультура и спорт, 1988. - 207 с.

19. Рубанович В.Б. Морфофункциональное развитие детей и подростков разных конституциональных типов в зависимости от двигательной активности: дисс. ... докт. мед. наук. - Новосибирск, 2004. - 406 с.

20. Чурин В.Д. О хроноинотропном резерве миокарда // Физиология человека. - 1978. - Т. 4, № 3. - С. 394.

21. Лакин Г.Ф. Биометрия: учеб. пособие для билогич. спец. вузов. - 3-е изд; перераб. и доп. М.: Высш. школа, 1980. - 293 с.

22. Рубанович В.Б. Морфофункциональное развитие детей и подростков разных типов в зависимости от двигательной активности: автореф. ... докт. мед. наук, 03.00.13. - Томск, 2004. $50 \mathrm{c}$.

23. Рубанович В.Б., Айзман Р.И. Основы здорового образа жизни: учебное пособие Новосибирск : АРТА, 2011. - 256 с.

24.. Стефанов С.Б. Измерение морфофункционального единства (Метод и некоторые результаты). - Пущино : Научный центр биологических исследований, 1974. -14 с.

25. Никитюк Б.А. Факторы роста и морфофункционального созревания организма (анализ наследственных и средовых влияний на постнатальный онтогенез). - М.: Наука, 1978. $143 \mathrm{c.}$ 


\section{MONITORING OF PHYSICAL DEVELOPMENT AND HEALTH OF PUPILS OF THE PAVLODAR REGION}

\section{Zh. M. Mukataeva, S. Zh. Kabieva (Pavlodar, Kazakhstan)}

The article analyzes the results of a comprehensive study of the morphological indicators of urban and rural children aged 7-15 years in Pavlodar region. Purpose of the article is to monitor the physical development and health of pupils 7-15 years in Pavlodar oblast. The study found relatively large body size in all-out urban children compared to rural counterparts. It was identified the adipose and muscle components of body composition in children and adolescents. Urban children have higher rates of back-fat, active body mass and muscle strength compared to rural pupils. Based on a sample RWC 170 physical performance and aerobic capacity of children and adolescents aged 7-15 years were set. Rural pupils have a set of higher rates of physical capacity and aerobic performance. Finally, author gives the results of monitoring the pupils'development and health in Pavlodar region.

Keywords: morphfunctional indicators, urban and rural children, fat and muscle components, physical performance, and aerobic performance.

\section{REFERENCES}

1. Ayzman R.I. Zdorov'e naseleniya Rossii: mediko-sotsial'nye i psikhologo-pedagogicheskie aspekty ego formirovaniya [The health of the Russian population: medical-social and psycho-pedagogical aspects of his formation]. Novosibirsk: Siberian Branch of RAMS, 1996, 27 p.

2. Grebneva N.N. Ekologo-fiziologicheskii portret sovremennykh detei i podrostkov $v$ usloviyakh Tyumenskoi oblasti [Ecological and physiological portrait of contemporary children and adolescents in the Tyumen region]. Tyumen Publishing House of the Tbilisi State University, 2006, $240 \mathrm{p}$.

3. Uchakina R.V. Ekologo-fiziologicheskoe obosnovanie gormonal'nogo statusa, fizicheskogo i polovogo razvitiya detei Dal'nevostochnogo regiona: avtoref. dokt. biol. nauk [Ecological and physiological basis of the hormonal status, physical and sexual development of children's Far East region. Authoref. Doctor. Biol. Sciences diss.]. Khabarovsk, 2006, 43 p.

4. Kabanov Y.N. Morfofunktsional'noe sostoyanie detei s raznym urovnem dvigatel'noi aktivnosti, prozhivayushchikh v ekologicheskikh usloviyakh goroda i sela. Avtoref. kand. biol. nauk diss. [Morphological and functional state of children with different levels of physical activity, environmental conditions, living in cities and villages. Author. Candidate. Biol. Sciences diss.]. Novosibirsk, 2005, 21 p.

5. Aizman R.I. Zdorov'e pedagogov i obuchayushchikhsya - klyuchevaya zadacha sovremennoi shkoly [Zdorov'e pedagogov i obuchayushchikhsya - klyuchevaya zadacha sovremennoi shkoly [Health of teachers and schoolchildren is a key problem of modern school]. Novosibirsk State Pedagogical University Bulletin, 2012, no. 3, pp. 24-35. 
6. Bortsova O.A. Mediko-sotsial'nye aspekty obucheniya shkol'nikov pravil'nomu obrazu zhizni [Medicine and social aspects of training of pupils to a correct way of life]. Philosophy of education. 2006, no. 1, pp. 211-214.

7. Bystrushkin S. K., Aizman R. I., Aftanas L. I. Osobennosti organizatsii vnimaniya i emotsional'nogo vospriyatiya $\mathrm{u}$ detei $\mathrm{v}$ norme i pri narusheniyakh intellektual'nogo razvitiya [Features of the organization of attention and emotional perception at children in norm and at infringements of intellectual development]. Bulletin of the Siberian branch of the Russian academy of sciences. 2007, no. 3, pp. 159-162.

8. Mukataeva Zh.M., Mukhanova A.A., Dairbaeva S.Zh., Rubanovich V.B. Aizman R.I. Morfofunktsional'noe razvitie shkol'nits raznykh somatotipov, prozhivayushchikh $\mathrm{v}$ gorodskoi i sel'skoi mestnosti [Morfofunctional development of schoolgirls different somatotypes, living in city and a countryside]. Science and new technologies, 2008, no. 5-6, pp. 88-94.

9. Mukataeva Zh.M. Morfofunktsional'naya kharakteristika sel'skikh detei i podrostkov raznogo pola severnogo Kazakhstana [The morfofunctional characteristic of rural children and teenagers of the different sex of northern Kazakhstan]. Novosibirsk State Pedagogical University Bulletin. 2013, no. 2, pp. 70-79.

10. Kozlov A.I., Vershubskya G.G. Meditsinskaya antropologiya korennogo naseleniya Rossii [Medical Anthropology Indigenous Russia]. Moscow, Univ. of MN EPA, 1999, 288 p.

11. Anokhin Zh.K., Kolesnychenko S.M., Kordenko A.N. etc. Sravnitel'naya kharakteristika fizicheskogo razvitiya podrostkov goroda i sela Voronezhskoi oblasti [Comparative characteristics of the physical development of teenagers in the town and village of the Voronezh region]. International conference devoted to the 55th anniversary of the Institute of Physiology of RAO "Physiology of human development", Moscow, 2000., P. 66.

12. Fedorov A.E., Treasury E.M., Selyatitskaya V.G., Ovchinnikov O.V. Ispol'zovanie modeli fiziologicheskogo monitoringa dlya kompleksnoi otsenki adaptatsionnykh vozmozhnostei uchashchikhsya v protsesse obrazovatel'noi deyatel'nosti. Osobennosti gormonal'nogo psikhovegetativnogo statusa u podrostkov, prozhivayushchikh $\mathrm{v}$ raznykh sotsial'no-ekologicheskikh usloviyakh [The use of models of physiological monitoring for comprehensive evaluation of the adaptive capabilities of the students in the process of educational activity. Features hormonal psycho-vegetative status in adolescents living in different socio-ecological conditions]. Human Physiology, 2002, vol. 28, no. 6, pp. 64-68.

13. Tabunov A.I. Osnovnye metody opredeleniya kolichestva zhirovoi tkani v organizme rebenka i ikh znachenie [Basic methods for determining the amount of adipose tissue in the body of the child and the value of]. Pediatrics, 1977 , no. 10, 90 p.

14. Stavitskaya A.B., Aaron D.E. Metodika issledovaniya fizicheskogo razvitiya detei i podrostkov [Methodology study of the physical development of children and adolescents]. Moscow, 1959, $185 \mathrm{p}$.

15. Kolesova D.V., Selverova N.B. Fiziologo-pedagogicheskie aspekty polovogo sozrevaniya [Physiological and pedagogical aspects of puberty]. Moscow, Pedagogy, 1978, 145 p.

16. Starr J. Clinical tests of simple method of estimating cardiac stroke volume from blood pressure and age. Circulation, 1954, no. 9, pp. 664.

17. Pugina N.S., Bomash Ya.S. Ob ispol'zovanii metoda Starra u detei [On the use of the method of Starr in children]. Collection of scientific works of the post of the Leningrad Institute of Postgraduate Medical. Leningrad, 1963, vol. 40, p. 64. 
18. Karpman V.L., Belotserkovsky Z.B., Gudkov A.E. Testirovanie v sportivnoi meditsine [Testing in sport medicine]. Moscow, Physical Culture and Sports, 1988, 207 p.

19. Rubanovich V.B. Morfofunktsional'noe razvitie detei i podrostkov raznykh konstitutsional'nykh tipov v zavisimosti ot dvigatel'noi aktivnosti. Dokt. med. nauk diss. [Morphological and functional development of the children and adolescents of different constitutional types, depending on the motor activity. Doctor. Med. Science Diss.]. Novosibirsk, 2004, 406 p.

20. Churin V.D. O khronoinotropnom rezerve miokarda [About hronoinotropny reserve infarction]. Human Physiology, 1978, vol. 4, no. 3, 394 p.

21. Lakin G.F. Biometriya: ucheb. posobie dlya bilogich. spets. vuzov [Biometrics: Proc. Allowance for bilogich. specials. Universities]. Moscow, Vyshshaya school, 1980, 293 p.

22. Rubanovich V.B. Morfofunktsional'noe razvitie detei i podrostkov raznykh tipov v zavisimosti ot dvigatel'noi aktivnosti. Avtoref. dokt. med. nauk [Morfofunchional development of children and teenagers of different types depending on impellent activity. Authoref. Doctor. Med. Science diss.]. Tomsk, 2004, $50 \mathrm{p}$.

23. Rubanovich V.B., Aizman R.I. Osnovy zdorovogo obraza zhizni: uchebnoe posobie [Bases of a healthy way of life]. Novosibirsk, Arta, 2011, 256 p.

24. Stefanov S.B. Izmerenie morfofunktsional'nogo edinstva (Metod i nekotorye rezul'taty) [Measurement morfofunchional unities]. Pushino, 1974, $14 \mathrm{p}$.

25. Nikitjuk B.A. Faktory rosta i morfofunktsional'nogo sozrevaniya organizma (analiz nasledstvennykh $i$ sredovykh vliyanii na postnatal'nyi ontogenez). [Factors of growth and morfofunchional maturing of an organism]. - Moscow, Nauka, 1978, 143 p.

Mukataeva Zhanat Makanovna, the doctor of biological sciences, the professor, the vice-rector for scientific and methodical work and new technologies, Pavlodar State Pedagogical Institute.

E-mail: MukataevaZh@mail.ru

Kabieva Saltanat Zhumabaevna, the candidate of biological sciences, the associate professor, the head of the department of anatomy, physiology and defectology, Pavlodar State Pedagogical Institute.

E-mail: Dairbaevasg@mail.ru 
Вестник Новосибирского государственного педагогического университета Novosibirsk State Pedagogical University Bulletin

1(17) $2014 \quad$ www.vestnik.nspu.ru ISSN 2226-3365

(C) Н. Б. Панкова

УДК 612.084

\title{
МЕТОДОЛОГИЯ САНОГЕНЕТИЧЕСКОГО МОНИТОРИНГА ФУНКЦИОНАЛЬНОГО СО- СТОЯНИЯ ОРГАНИЗМА УЧАЩИХСЯ И СПОРТСМЕНОВ*
}

\author{
Н. Б. Панкова (Москва, Россия)
}

\begin{abstract}
В статье изложены теоретические основы конщепџии саногенеза, а также методологические подходы к организачии и проведению полисистемного саногенетического мониторинга функционального состояния организма учащихся и спортсменов. Рассмотрены базовые принципы саногенетического мониторинга: комплексный характер оценки состояния здоровья испытуемых, использование нагрузочных тестов (функииональных проб) для оиенки функииональных резервов организма, оченка динамики изменения показателей состояния здоровья (мониторинговый подход), установление связей между влиянием средовых факторов и изменением показателей здоровья обучающихся. Приведены результаты собственных мониторинговых исследований динамики функиионального состояния организма школьников (в контексте донозологической диагностики влияния на здоровье обучающихся факторов образовательной среды) и спортсменов разного возраста. Рассмотрены различные варианты статистической обработки и графической формы представления результатов мониторинговых работ.
\end{abstract}

Ключевые слова: школьники, спортсмены, здоровье, функциональное состояние, донозологическая диагностика, мониторинг.

С точки зрения научной методологии, корректная оценка состояния здоровья населения, требует применения комплекса биохимических, физиологических и других методов, позволяющих выявить не только грубую патологию, но и диагностировать состояния организма в зависимости от степени изменения адаптационных механизмов [1]. Это означает, что для оценки влияния факторов образовательной среды на здоровье учащихся, или спортивной тренировки на здоровье спортсменов, недостаточно отслеживать только показатели заболеваемости и одномоментные показатели соматического и психического здоровья. Необходим динамический контроль состояния здоровьем здоровых людей оценка изменения в процессе обучения или спортивного цикла уровня функциональных

* Статья подготовлена по результатам работы Всероссийской научной школы с Международным участием «Опыт использования мониторинга здоровья и физической подготовленности учащейся молодежи» (12-14 ноября 2013 г.).

Панкова Наталия Борисовна - доктор биологических наук, профессор кафедры здоровьесберегающего содержания образовательных технологий, ГАОУ ВПО Московский институт открытого образования.

E-mail: nbpankova@gmail.com 
Вестник Новосибирского государственного педагогического университета Novosibirsk State Pedagogical University Bulletin

1(17) $2014 \quad$ www.vestnik.nspu.ru ISSN 2226-3365

резервов организма, его адаптивных возможностей как меры здоровья человека. Только в этом случае выявляется общее направление влияния средовых факторов, на здоровье обследуемых - способствование укреплению здоровью (саногенез) или, наоборот, наличие патогенетической компоненты. В гигиене применение таких методов оценки здоровья детей, основанных на достижениях современной физиологии, дает несколько иные результаты, по сравнению с санитарногигиенической оценкой: обнаружено, что, несмотря на перманентное ухудшение здоровья школьников, о котором сейчас не говорит только ленивый [2], большинство школьников успешно справляются с учебной нагрузкой и адаптируются к условиям образовательной среды [3-5].

Целью данной работы является рассмотрение теоретических основ и методологических подходов к организации, проведению и анализу результатов полисистемного саногенетического мониторинга функционального состояния организма учащихся и спортсменов.

O патогенетических механизмах индукции и развития разного рода заболеваний к настоящему времени известно довольно много. Меньше известно о механизмах саногенетических. Согласно теории академика C.M. Павленко, сформулированной в 1960-е гг. прошлого столетия [6], болезнь начинается с разрушения или недостаточной активности саногенетических механизмов, а стимуляция саногенеза является физиологическим механизмом восстановительных процессов. По определению С.М. Павленко, патогенез - это динамический комплекс нарушений саморегуляции организма, развивающийся на почве функционального или структурного повреждения чрезвычайным раздра- жителем соответствующих рефлекторных аппаратов. Саногенез - это динамический комплекс защитно-приспособительных механизмов (физиологического или патофизиологического характера), возникающий при воздействии чрезвычайного раздражителя и развивающийся на протяжении всего болезненного периода (от состояния предболезни до выздоровления) и направленный на восстановление нарушенной саморегуляции организма [6]. Как видно из определений, при некоторой терминологической коррекции основные идеи данного подхода актуальны и сегодня. По более позднему определению академика Г.Н. Крыжановского, саногенез осуществляется на всех уровнях сложного организма, начиная с молекулярных и клеточных процессов и кончая высшими системными и межсистемными отношениями. В своей совокупности и в своем взаимодействии все эти механизмы составляют общую саногенетическую систему организма, результатом деятельности которой является здоровье [7].

С точки зрения современной патофизиологии функционирование систем саногенеза индуцируется и реализуется при активации адаптивных реакций организма, которые, в свою очередь, базируются на мобилизации функциональных резервов его органов и систем [8]. Оценить функциональные резервы и адаптивные возможности организма можно по его реактивности на различные воздействия, т.е. при выполнении функциональных проб.

Концепция саногенеза разрабатывалась в 1960-1970-е годы, хотя сам академик С.М.Павленко [9] справедливо замечал, что истоки представлений о саногенезе зародились еще в XIX в., когда клиницисты и физиологи говорили о защитно-приспособительных свойствах и силах организма. Наиболее 
Вестник Новосибирского государственного педагогического университета Novosibirsk State Pedagogical University Bulletin

1(17) $2014 \quad$ www.vestnik.nspu.ru $\quad$ ISSN 2226-3365

полно эти представления описаны в трудах И.П.Павлова («Павловские среды»), где говорится о том, что при воздействии патогенного фактора первыми активируются как раз защитно-приспособительные силы организма, т.е. системы саногенеза. Возврат интереса к концепции саногенеза произошел в последние годы, с развитием технических возможностей оценки адаптивных процессов в организме, особенно с использованием неинвазивной техники. Особый интерес эта концепция представляет с точки зрения развития функциональных резервов организма в онтогенезе, при оценке состояния здоровья детей и подростков. В практике взаимодействия образовательной среды и разных областей медицины и экспериментальной биологии в последнее время также утвердился термин «саногенетический мониторинг», обозначающий оценку разных показателей организма здоровых детей. Концепция саногенетического мониторинга использована также для разработки автоматизированного рабочего места спортивного врача [10]. Этот термин отражает противопоставление физиологического (и патофизиологического) подхода к оценке здоровья детей методам врачебной диспансеризации, которые основаны на данных медицинской статистики и принципах нозологического мониторинга, проводимого на базе и методами клинического контроля.

Оценка уровня здоровья здоровых людей требует количественных методов измерения функционального состояния. Все многообразие функциональных состояний организма от «здоров как лошадь» до «почти умер» можно условно поделить на несколько диапазонов - физиологическая норма, напряжение функциональных резервов, преморбидные состояния и собственно болезнь, или патологическое состояние [11]. Если целью медицинской диспансеризации является выявление больных людей и определение частоты перехода между состояниями «болезнь» и «здоровье», то для саногенетического мониторинга объектом изучения являются процессы внутри состояния «здоровье» (рис. 1).

По современным представлениям, диапазон «здоровье» не так однороден, как диапазон «болезнь». Есть несколько переходных состояний от физиологической нормы до срыва адаптации, или болезни, в виде стадии мобилизации функциональных резервов, стадии напряжение адаптации, или предболезни, которые относятся еще к диапазону «здоровье», но сигнализируют о неблагополучии. Оценку функционального состояния организма внутри диапазона «здоровье» проводят с применением методов измерения функциональных резервов организма $[8,11]$. Впервые необходимость выделения в диапазоне «здоровье» разных градаций возникла при профессиональном отборе в группы риска, особенно в космонавтике. Была разработана система функциональных проб, или тестов, позволяющих понять, может ли организм остаться в зоне «здоровья», если ему предъявить нагрузку, например физическую работу, многократно превышающую обыденные объемы этой же работы. Таким способом определяют так называемые функциональные резервы организма. Метод функциональных проб в настоящее время является обязательным при обследовании сердечно-сосудистой системы, при обследовании головного мозга, при исследованиях большинства внутренних органов, а также при оценке состоянии здоровья спортсменов, военнослужащих, космонавтов. В последнее время его стали применять при оценке состояния здоровья простых смертных, не имеющих отношение к профессиональному риску, в том числе и в школах. 
Вестник Новосибирского государственного педагогического университета Novosibirsk State Pedagogical University Bulletin

Рисунок 1

Схема различий в задачах медицинской диспансеризаџии и саногенетического мониторинга.

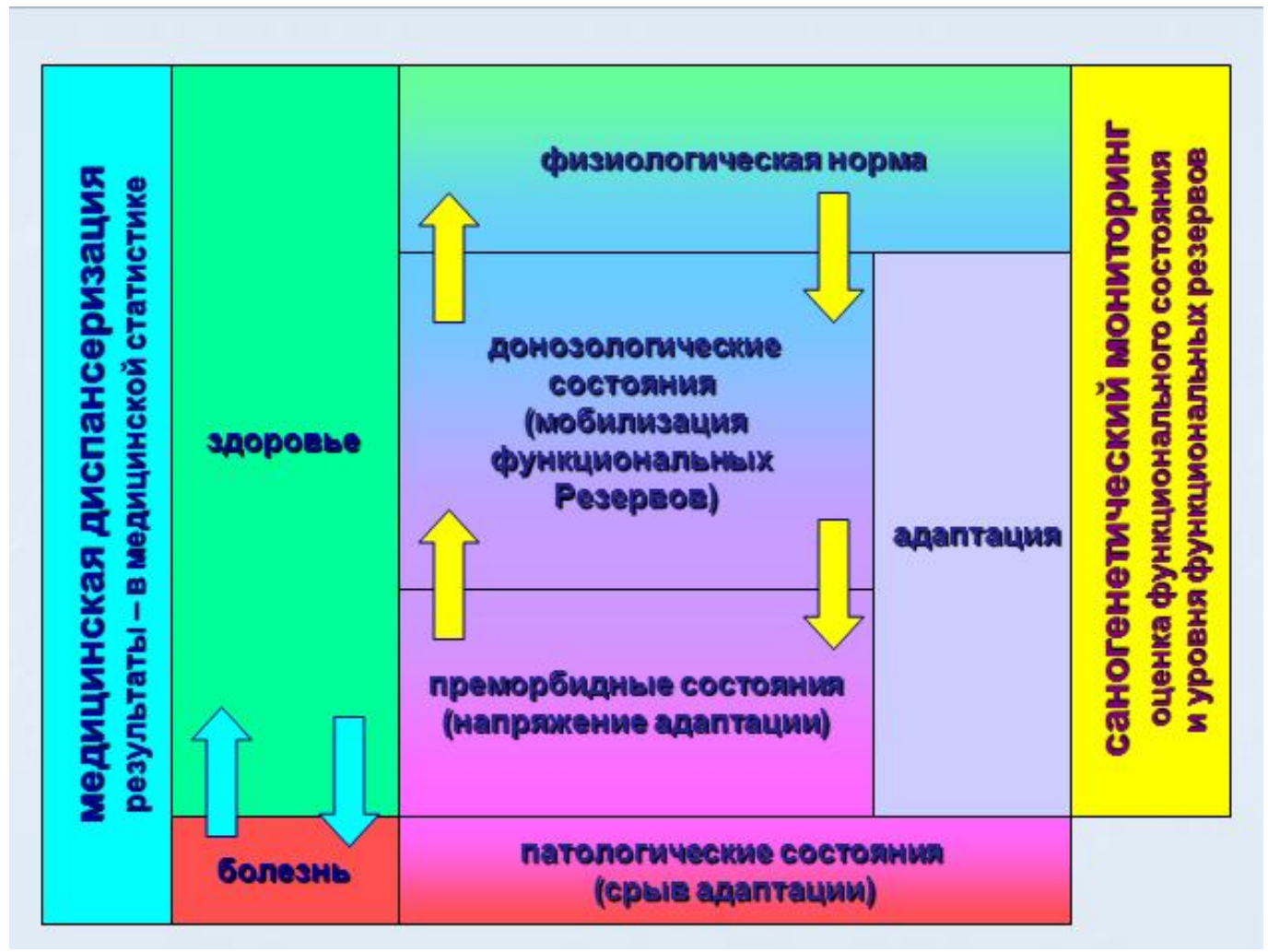

Задачами саногенетического мониторинга являются: оценка функциональных резервов организма как показателя и меры здоровья, как способность организма приспосабливаться к условиям окружающей среды, и выявление признаков функционального напряжения систем организма (в первую очередь - регуляторных) на доклиническом уровне (донозологическая диагностика). В этом контексте основными методологическими принципами саногенетического мониторинга можно считать:

- Комплексный характер оценки состояния здоровья испытуемых,

- Использование тестов (функциональных проб) для оценки функциональных резервов организма,
- Оценку динамики изменения показателей состояния здоровья (мониторинговый подход);

- Установление связей между влиянием средовых факторов и изменением показателей здоровья испытуемых.

Комплексный характер обследования означает использование максимально возможного количества оцениваемых параметров. В частности, в оценке состояния сердечно-сосудистой системы в саногенетическом мониторинге ГАОУ ВПО Московский института открытого образования и лаборатории полисистемных исследований ФГБУ НИИ общей патологии и патофизиологии РАМН используются следующие показатели:

- Стандартные показатели усредненного за время регистрации сердечного ком- 
Вестник Новосибирского государственного педагогического университета Novosibirsk State Pedagogical University Bulletin

плекса (по ЭКГ в 1-м стандартном отведении),

- Частота сердечных сокращений (ЧСС среднее, минимальное и максимальное значения),

- Пальцевое артериальное давление (АД систолическое и диастолическое, среднее, минимальное и максимальное значения),

- Показатели сердечной производительности (ударный объем сердца и минутный объем кровообращения),

- Спектральные показатели вариабельности сердечного ритма и пальцевого АД,

- Величина чувствительности артериального барорефлекса.

Две последние группы показателей в эксперименте и клинике используются для оценки состояния систем автономной регуляции. Одновременная регистрация показателей сердечно-сосудистой системы и показателей дыхания позволяет проводить функциональные нагрузочные пробы с изменением частоты и глубины дыхания (например, стандартная проба с частотой дыхания 6 циклов в минуту - для оценки величины чувствительности артериального барорефлекса).

Сравнительный анализ результатов саногенетического мониторинга здоровья подростков, проживающих в разных регионах Российской Федерации (Москва, Московская и Новгородская области, республика Адыгея) позволил выявить нарушения состояния сердечной мышцы, сосудистого тонуса, а также систем вегетативной регуляции сердечного ритма и периферического АД у школьников г. Москвы [12]. Показано, что жизнь в мегаполисе изменяет также возрастную динамику формирования основных систем организма подростков и модифицирует механизмы этого процесса. При оценке реактивности сер- дечно-сосудистой системы в функциональных пробах обнаружено, что условиях недостаточной двигательной активности, характерных для жизни в большом городе и приводящих к снижению активности периферических регуляторных механизмов, ведущим фактором развития становится не функциональное созревание симпатического отдела вегетативной регуляции, а активность высших отделов регуляторных систем, включая эмоциональные и психогенные [13]. 3-летний мониторинг функционального состояния организма у юных фигуристов в возрасте от 8 до 14 лет, с уровнем спортивной квалификации «кандидат в мастера спорта» или «мастер спорта», показал информативность анализа реактивности (степени изменения) показателей при выполнении дозированной специальной субмаксимальной физической нагрузки [14].

Как и в большинстве длительных наблюдений, в саногенетическом мониторинге остро стоит проблема контрольных групп. Так, мониторинг функционального состояния организма спортсменов часто проводится в тренировочный период, захватывающий 2-3 сезона. Использование различных образовательных технологий происходит, как правило, в течение учебного года, на протяжении трех сезонов. Для корректной интерпретации результатов таких исследований следует знать, что в 1970-80 гг., в Тартуском университете был проведен многолетний мониторинг показателей сердечно-сосудистой системы у крыс, мышей, кроликов [15-17]. Животных содержали в условиях вивария, на постоянном световом режиме (12 на 12 часов смены дня и ночи), на постоянном рационе. И даже в этих условиях было выявлено, что все анализируемые показатели имеют четкую привязанность к временам года, когда весной регистрируются минимальные величины ЧСС 
Вестник Новосибирского государственного педагогического университета Novosibirsk State Pedagogical University Bulletin

и АД, при максимальном уровне вегетативной и гормональной активности. И в школе, при двукратном обследовании в течение учебного года, также наблюдаются сезонные колебания показателей сердечно-сосудистой системы и психомоторики, что показано в наших работах [18].

Мониторинг состояния здоровья спортсменок высшей спортивной квалификации (национальная сборная по регби) в соревновательный период (апрель-ноябрь) выявил позитивные сдвиги в состоянии систем антиоксидантной защиты, а также изменения характера метаболизма [19]. При этом изме- нения биохимических показателей сопровождались значимым и корреляционносвязанным повышением функциональных резервов сердечно-сосудистой системы (за счет повышения уровня функциональной активности симпатического звена вегетативной регуляции) и улучшением показателей психомоторной сферы. Тестирование основных показателей сердечно-сосудистой системы показало, что за соревновательный период происходит снижение диастолического АД, снижение чувствительности артериального барорефлекса и возрастание ударного объема сердца (рис. 2).

Динамика показателей диастолического пальиевого АД

Рисунок 2

(в мм рт.ст.), и ударного объема сердияа (в мл) у регбисток и в контроле. Отличия от показателей весеннего тестирования (по непараметрическому парному критерию Вилкоксона): \# - p $<0.05$.
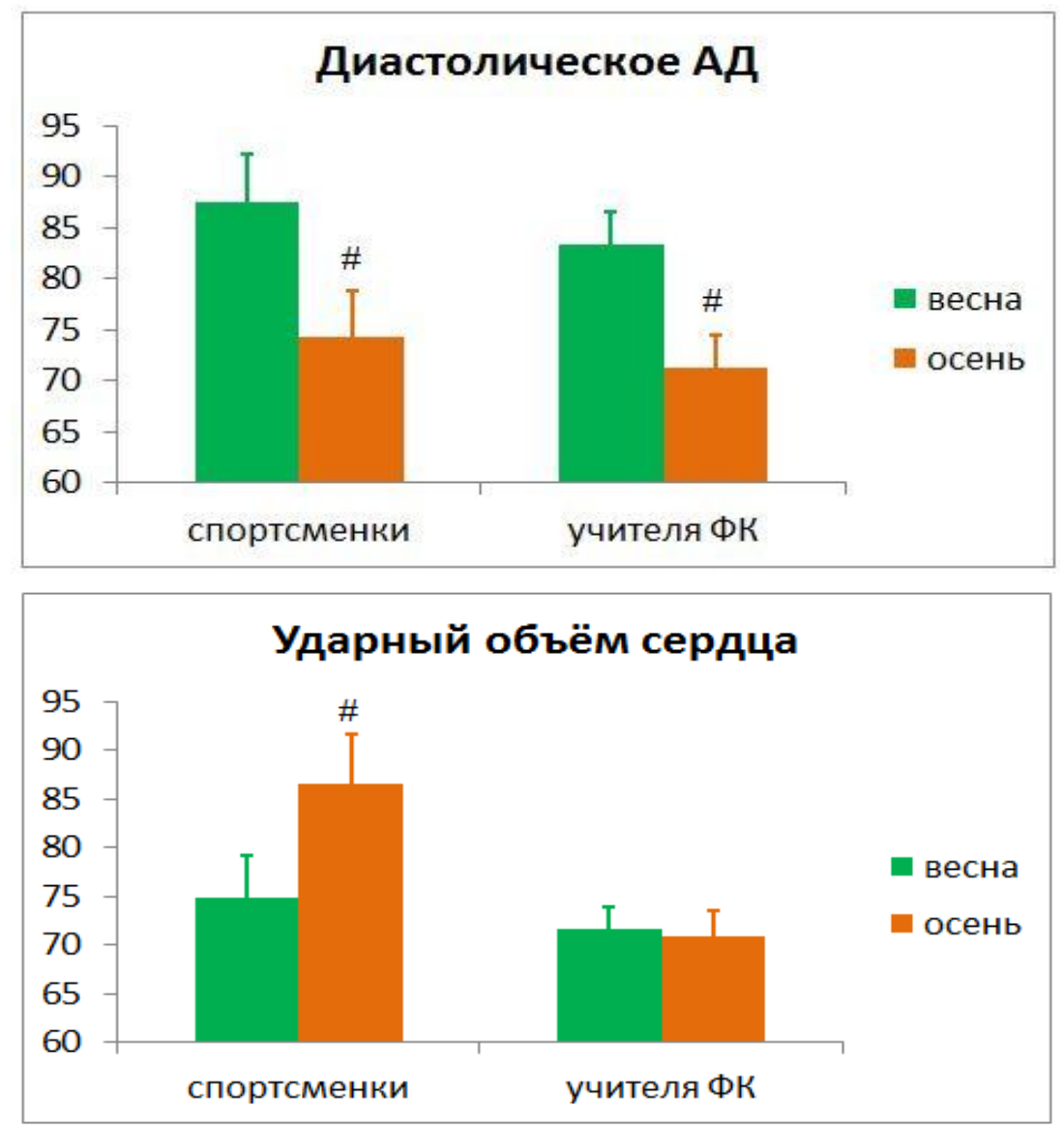
Вестник Новосибирского государственного педагогического университета Novosibirsk State Pedagogical University Bulletin

Однако оказалось, что снижение к зиме диастолического АД является нормальным физиологическим феноменом, отражающим сезонные колебания вегетативной активности в организме испытуемых, чей образ жизни связан с физическими нагрузками (учителя физкультуры в школе). Изменения двух других параметров являются специфическими для соревновательного периода у спортсменов, причем повышенная вариабельность ударного объема сердца уже описана у женщин-регбисток, и показано, что степень вариабельности находится в положительной корреляционной связи с уровнем спортивной квалификации.
Для саногенетического мониторинга, как и для мониторинговых исследований в целом, важной проблемой является выбор алгоритма статистического анализа получаемых данных и способ представления результатов исследований. Приведём следующий пример.

Проведен мониторинг функционального состояния организма учащихся 3-х и 4-х классов во время беговой разминки в условиях спортивного зала. Величина ЧСС до выполнения упражнения (прыжок через скамейку) и сразу после него приведены в таблице 1. Внизу приведены результаты стандартной статистической обработки.

Результатьл измерения ЧСС (уд./мин) до (фон) и после (тест)

Таблица 1 выполнения физического упражнения

\begin{tabular}{|c|c|c|c|c|c|c|c|c|c|}
\hline имя & пол & фон & тест & дельта & имя & пол & фон & тест & дельта \\
\hline Аня & ж & 93 & 97 & 4 & Eгор & $M$ & 96 & 98 & 2 \\
\hline Аня & ж & 96 & 101 & 5 & Erop & $\mathrm{M}$ & 110 & 112 & 2 \\
\hline Аня & ж & 90 & 93 & 3 & Егор & $\mathrm{M}$ & 108 & 111 & 3 \\
\hline Аня & ж & 96 & 100 & 4 & Erop & $\mathrm{M}$ & 108 & 110 & 2 \\
\hline Аня & ж & 93 & 97 & 4 & Eгор & $\mathrm{M}$ & 76 & 78 & 2 \\
\hline Аня & ж & 75 & 79 & 4 & Erop & $\mathrm{M}$ & 86 & 91 & 5 \\
\hline Аня & ж & 80 & 85 & 5 & Егор & $\mathrm{M}$ & 89 & 91 & 2 \\
\hline Аня & ж & 96 & 100 & 4 & Егор & $\mathrm{M}$ & 107 & 109 & 2 \\
\hline Аня & ж & 101 & 105 & 4 & Erop & $\mathrm{M}$ & 91 & 95 & 4 \\
\hline Аня & ж & 97 & 101 & 4 & Erop & $\mathrm{M}$ & 75 & 77 & 2 \\
\hline Аня & ж & 98 & 102 & 4 & Erop & M & 95 & 95 & 0 \\
\hline Аня & ж & 84 & 87 & 3 & Егор & $\mathrm{M}$ & 82 & 83 & 1 \\
\hline Аня & ж & 95 & 99 & 4 & Eгор & $\mathrm{M}$ & 93 & 94 & 1 \\
\hline Аня & ж & 96 & 104 & 8 & Erop & $\mathrm{M}$ & 89 & 91 & 2 \\
\hline Аня & ж & 102 & 106 & 4 & Eгор & $\mathrm{M}$ & 94 & 98 & 4 \\
\hline \multirow[t]{5}{*}{ Аня } & & 105 & 124 & 19 & Егор & $\mathrm{M}$ & 71 & 74 & 3 \\
\hline & $n$ & 16 & 16 & 16 & & $n$ & 16 & 16 & 16 \\
\hline & $\mathrm{M}$ & 93,56 & 98,75 & 5,19 & & $\mathrm{M}$ & 91,88 & 94,19 & 2,31 \\
\hline & SD & 7,95 & 10,12 & 3,85 & & SD & 12,20 & 12,17 & 1,25 \\
\hline & $\mathrm{SE}$ & 1,99 & 2,53 & 0,96 & & $\mathrm{SE}$ & 3,05 & 3,04 & 0,31 \\
\hline
\end{tabular}


Вестник Новосибирского государственного педагогического университета Novosibirsk State Pedagogical University Bulletin

Графическое представление результатов статистической обработки в форме $\mathrm{M} \pm \mathrm{SE}$ (рис. 3) показывает очевидное отсутствие различий между девочками и мальчиками и наличие неочевидной динамики показателя ЧСС.

Рисунок 3

\section{Динамика ЧСС при выполнении физического упражнения}

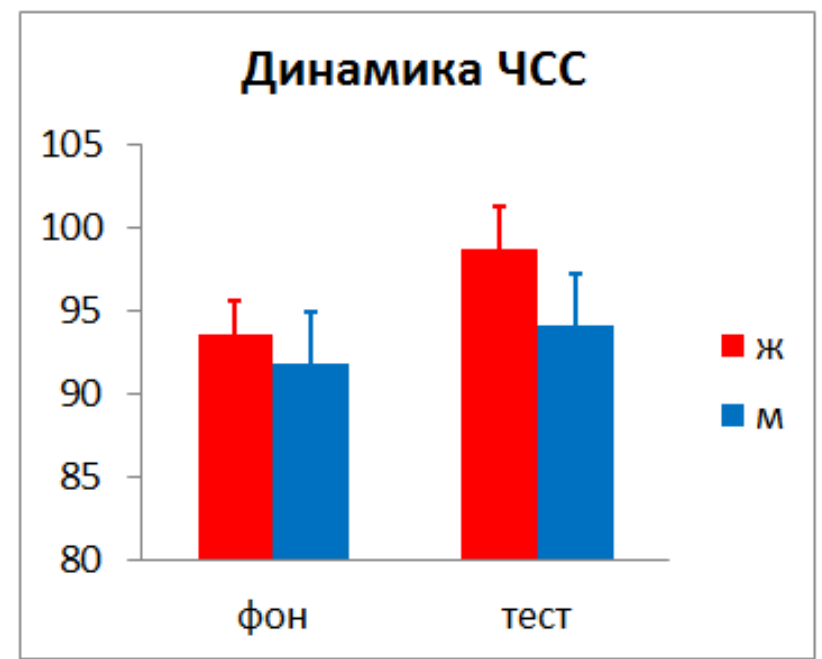

Статистический анализ полученных результатов по алгоритму оценки независимых выборок (One way ANOVA) показывает отсутствие статистически значимых различий между мальчиками и девочками, как в фоно- вом, так и в тестовом обследовании (рис. 4), при значимом возрастании показателя в выборке в целом (Wilks lambda $=0.78796, \mathrm{~F}(2$, 29) $=3.9020, p=0.03157)$.

Рисунок 4

Результаты статистического анализа динамики ЧСС при выполнении физического упражснения по алгоритму One way ANOVA

Динамика ЧСС: медиана, 25\% - 75\%

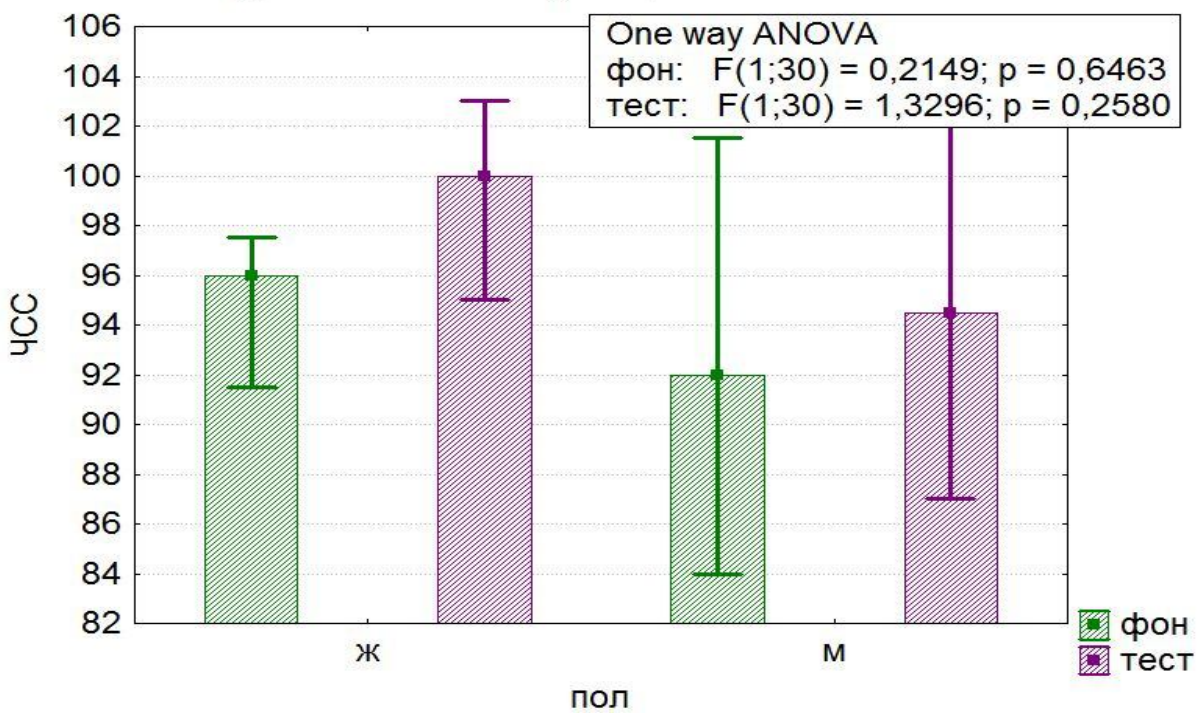


Вестник Новосибирского государственного педагогического университета Novosibirsk State Pedagogical University Bulletin

Однако, использование для анализа алгоритма двухфакторного дисперсионного анализа (разминка Ч пол) по алгоритму Repeated measures ANOVA показало не только статистические значимые изменения ЧСС после выполнения физического упражнения в выборке в целом, но и значимые различия в динамике ЧСС у мальчиков и девочек (табл. 2).

Таблица 2

Результаты статистического анализа динамики ЧСС при выполнении физического упражнения по алгоритму Repeated measures ANOVA

\begin{tabular}{|c|c|c|c|c|c|}
\hline \multirow[b]{2}{*}{ Effect } & \multicolumn{5}{|c|}{$\begin{array}{l}\text { Repeated Measures Analysis of Variance (пример_для } \\
\text { Sigma-restricted parameterization } \\
\text { Effective hypothesis decomposition }\end{array}$} \\
\hline & SS & $\begin{array}{l}\text { Degr. of } \\
\text { Freedom }\end{array}$ & MS & $\mathrm{F}$ & $p$ \\
\hline Intercept & 572670,6 & 1 & 572670,6 & 2521,227 & 0,000000 \\
\hline пол & 156,3 & 1 & 156,3 & 0,688 & 0,413430 \\
\hline Error & 6814,2 & 30 & 227,1 & & \\
\hline РАЗМИНКА & 225,0 & 1 & 225,0 & $\overline{54,906}$ & 0,000000 \\
\hline РАЗМИНКА* & 33,1 & 1 & 33,1 & 8,068 & 0,008017 \\
\hline Error & 122,9 & 30 & 4,1 & & \\
\hline
\end{tabular}

Вместе с тем, графическое представление этих результатов в форме, предлагаемой пакетом Statistica 7.0 для алгоритма Repeated measures ANOVA (рис. 5, слева) мало отличается от привычной формы (рис. 3), где разли- чия в динамике ЧСС у мальчиков и девочек неочевидны. В этой ситуации более наглядным способом представления результатов служит «дельта» - средняя величина прироста показателя ЧСС (рис. 5, справа).

Рисунок 5

Динамика ЧСС при выполнении физического упражнения
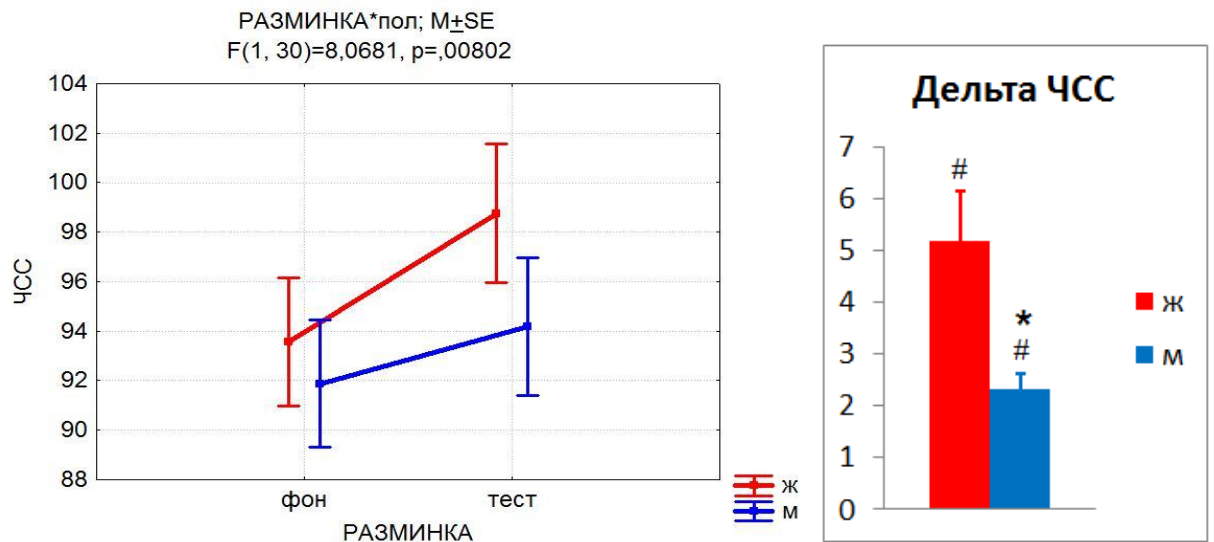

Слева - результаты анализа данных по алгоритму Repeated measures ANOVA.

Справа - средняя величина прироста ЧСС.

Статистическая значимость отличий от фонового тестирования: \#-p $<0.05$; статистическая значимость межполовых различий: * - p $<0.05$. 
Вестник Новосибирского государственного педагогического университета Novosibirsk State Pedagogical University Bulletin

1(17) $2014 \quad$ www.vestnik.nspu.ru $\quad$ ISSN 2226-3365

Важно, что по методологии саногенетического мониторинга состояние кардиореспираторной системы должно оцениваться одновременно с показателями психомоторной координации и другими психофизиологическими и психологическими показателями. Так, ранее нами было показано, что во время летнего отдыха за период лагерной смены у детей значимо улучшаются показатели выполнения функциональных проб с задержкой дыхания - Штанге и Генчи [20]. Одновременное с мониторингом сердечно-сосудистой системы тестирование психологических показателей выявило снижение за этот период у детей уровня тревожности, и наличие значимой корреляционной связи между степенью изменения показателей сердечно-сосудистой системы и уровня тревожности («дельты» с «дельтой»). В рассмотренном выше примере высока вероятность того, что большая степень реактивности ЧСС на выполнение физического упражнения у девочек обусловлена не особенностями нейровегетативной регуляции в их организме, а эмоциональным отношением к предложенному упражнению (прыжок через скамейку). Однако данное предположение нуждается в проверке, которая в данном случае не была проведена.

В целом, в практической работе по оценке влияния образовательной среды и ее факторов на уровень здоровья учащихся, а также спортивной тренировки на здоровье спортсменов, особенно юных, с целью корректной интерпретации полученных результатов необходимо учитывать следующие обстоятельства.

1. Уровень физиологического развития организма школьников в процессе обучения в школе и в процессе многолетней спортивной тренировки постоянно изменяется происходят как количественные, так и каче- ственные изменения, связанные с ростом, функциональным развитием и функциональным созреванием разных органов и систем их организма, причем эти процессы часто не совпадают по времени.

2. При оценке влияния конкретной образовательной технологии необходимо исключать влияние («обнулять») любых других факторов, оказывающих воздействие на состояние здоровья детей: экологических, климатических, экономических, социальных, культурных и др., выбирая в качестве группы сравнения аналогичную выборку, отличающуюся от тестируемой только набором педагогических приёмов. В спортивной практике, особенно в лонгитюдных исследованиях, обязательно наличие контрольных групп для дифференциации эффектов тренировки и естественных хронобиологических процессов.

3. При оценке уровня здоровья совершенно недостаточно оценивать т.н. «показатели покоя» - те показатели, которые отражают стационарное состояние организма школьников, например, однократное измерение ЧСС, АД, запись кардиограммы. Данный тип показателей используется при медицинской диспансеризации и достаточно эффективен в поиске признаков органической патологии. В саногенетическом же мониторинге участвуют в основном здоровые дети, все изменения, которые происходят в их организме под влиянием факторов образовательной среды, или занятий спортом, не выходят за рамки их половозрастной нормы, и связаны с изменением уровня активности и эффективности работы регуляторных систем организма. Такого рода показатели можно протестировать лишь в функциональных пробах, или тестах, где дается ответ на вопрос об уровне функциональных резервов организма - его 
Вестник Новосибирского государственного педагогического университета Novosibirsk State Pedagogical University Bulletin

1(17) $2014 \quad$ www.vestnik.nspu.ru ISSN 2226-3365

способности переживать физические, психоэмоциональные или иные нагрузки, многократно превосходящие обыденные, без вреда для здоровья, т.е. способность организма эффективно адаптироваться к изменяющимся условиям внешнего мира.

4. Однократное тестирование функциональных резервов организма детей и подростков достаточно информативно при оценке различий между выборками, отличными друг от друга по экологическим, климатическим или иным природным факторам, уровню физической нагрузки или спортивной специализации. В этом случае оценивается эффект долговременной адаптации организма детей к условиям жизнедеятельности. Для оценки влияния психолого-педагогических факторов образовательной среды или факторов специальной спортивной тренировки не- обходим другой подход - оценка изменения уровня функциональных резервов организма, его адаптивных возможностей, в процессе занятий, т.е. необходимо динамическое наблюдение за здоровьем детей. Только в этом случае выявляется влияние средовых факторов среды на здоровье детей - способствование укреплению здоровью или, наоборот, наличие патогенетической компоненты.

Принципы и методы полисистемного саногенетического мониторинга (одновременная комплексная оценка состояния нескольких систем организма, оценка как одномоментных, так и динамических показателей, использование тестов для оценки функциональных резервов организма, установление связей между влиянием средовых факторов и изменением показателей здоровья) данным условиям соответствуют.

\section{СПИСОК ЛИТЕРАТУРЫ}

1. Рахманин Ю.А., Новиков С.М., Иванов С.И. Современные научные проблемы совершенствования методологии оценки риска здоровью населения // Гигиена и санитария. -2005 . № 2. - C. 7-10.

2. Баранов А.А., Кучма В.Р., Сухарева Л.М. Состояние здоровья современных детей и подростков и роль медико-социальных факторов в его формировании // Вестник Российской академии медицинских наук. - 2009. - № 5. - С. 6-10.

3. Крыжановский Г.Н., Курнешова Л.Е., Пивоваров В.В., Носкин Л.А., Карганов М.Ю. Здоровье и его полифункциональная оценка // Інтегративна Антропологія. - 2003. - № 2. C. $46-51$.

4. Панков Д.Д., Панкова Т.Б. Состояние здоровья выпускных классов (данные профилактических осмотров) // Российский педиатрический журнал. - 2006. - № 6. - С. 10-12.

5. Панков Д.Д., Панкова Т.Б., Берова Г.И., Натальина О.И. Новый методический подход к анализу результатов профилактического осмотра школьников // Российский педиатрический журнал. - 2006. - № 2. - С. 25-29.

6. Павленко С.М. Изучение саногенеза - естественный путь дальнейшего развития медицины // Саногенез: Материалы конф. Московского городского научного общества патофизиологов. - Москва, 1968. - С. 7-13.

7. Крыжановский Г.Н. Некоторые общепатологические и биологические категории: здоровье, болезнь, гомеостаз, саногенез, адаптация, иммунитет. Новые подходы и представления // Патогенез. - 2003. - Т. 1, № 1. - С. 11-14. 
Вестник Новосибирского государственного педагогического университета Novosibirsk State Pedagogical University Bulletin

1(17) $2014 \quad$ www.vestnik.nspu.ru ISSN 2226-3365

8. Агаджанян Н.А., Баевский Р.М., Берсенева А.П. Проблемы адаптации и учение о здоровье. - М.: Изд-во РУДН, 2006. -284 с.

9. Павленко С.М. Учение о саногенезе - важнейшая проблема медицины // Патол. физиология и эксперим. терапия. - 1967. - Т. 11, № 3. - С. 91-95.

10.Эйгель М.Я., Кузнецов П.П., Панкова Н.Б., Фесенко А.Г., Карганов М.Ю. Инновационные подходы к созданию автоматизированного рабочего места (АРМ) спортивного врача // Врач и информационные технологии. - 2013. - № 1. - С. 27-31.

11.Баевский Р.М. Концепция физиологической нормы и критерии здоровья // Рос. физиол. журн. им. И.М. Сеченова. - 2003. - Т. 89, № 4. - С. 473-487.

12.Панкова Н.Б., Чамокова А.Я., Мамгетов К.Ю., Пустовет 3.Т., Черепов А.Б., Карганов М.Ю. Сравнительный анализ особенностей функционирования сердечно-сосудистой и психомоторной систем организма школьников в зависимости от региона проживания и учебной нагрузки // Экология человека. - 2006. - Прил. 4/2. - С. 212-214.

13.Панкова Н.Б., Алчинова И.Б., Черепов А.Б., Карганов М.Ю. Региональные особенности функциональных показателей сердечно-сосудистой системы у подростков // Российский педиатрический журнал. - 2008. - № 1. - С. 37-42.

14.Панкова Н.Б., Карганов М.Ю., Эйгель М.Я., Кузнецов П.П. Использование дискриминантного анализа для оценки результатов мониторинга функционального состояния организма юных фигуристов // Валеология. - 2012. - № 4. - С. 24-28.

15.Оттер М.Я. Сезонные и суточные изменения содержания и скорости метаболизма серотонина в мозге белых мышей // Бюллетень экспериментальной биологии и медицины. - 1982. T. 94, № 7. - С. 84-86.

16.Оттер М.Я., Нурманд Л.Б. Сезонные колебания катехоламинов в мозге белых крыс// Бюллетень экспериментальной биологии и медицины. - 1980. - Т. 89, № 2. - С. 215-217.

17.Оттер М.Я., Шоттер А.В. Сезонные изменения сердечно-сосудистых показателей и содержания моноаминов в мозге кроликов. // Бюллетень экспериментальной биологии и медицины. - 1991. - Т. 111, № 5. - С. 540-542.

18.Панкова Н.Б., Карганов М.Ю. Обратимые изменения в сердечно-сосудистой системе организма учащихся, индуцируемые образовательной средой // Валеология. - 2009. - № 2. C. $54-59$.

19.Фесенко А.Г., Скальный А.В., Панкова Н.Б., Архипова Е.Н., Алчинова И.Б., Карганов М.Ю. Элементный статус и динамика функционального состояния организма девушекрегбисток в соревновательный период // Микроэлементы в медицине. - 2011. - Т. 12, № 1-2. - С. 27-38.

20.Панкова Н.Б., Мустафина И.З., Афанасьева Е.В., Карганов М.Ю., Кучма В.Р. Функциональная перестройка кардио-респираторной системы, психомоторной координации и психоэмоционального состояния у подростков во время летнего отдыха // Российский педиатрический журнал. - 2006. - № 2. - С. 8-16. 
Вестник Новосибирского государственного педагогического университета Novosibirsk State Pedagogical University Bulletin

\title{
UDC 612.084
}

\section{METHODOLOGY FOR SANOGENETIC MONITORING OF FUNCTIONAL STATE OF STUDENTS'S AND ATHLETES'S HEALTH}

\author{
N. B. Pankova (Moscow, Russia)
}

The paper presents the theoretical foundations of the concept of sanogenesis and methodological approaches to the organization and implementation of polysistemic sanogenetic monitoring of functional status in pupils and athletes. The basic principles of sanogenetic monitoring are describes: comprehensive assessment of the health of the person, the use of load tests (functional tests) to assess the functional reserves, estimation of the dynamics of change in health status indicators (monitoring approach), linking the effect of environmental factors and changes in health outcomes of students. Submitted the results of monitoring studies concerned the dynamics of functional state of pupil's organism (in the context of prenosological diagnosis in the studying of educational environment factors effects on health), and athletes of varied ages. Different versions of statistical analysis and graphical presentation of the results of monitoring activities are considered.

Keywords: students, athletes, health, functional state, prenosological diagnosis, monitoring.

\section{REFERENCES}

1. Rakhmanin Yu. A., Novikov S. M., Ivanov S. I. Sovremennye nauchnye problemy sovershenstvovaniya metodologii otsenki riska zdorov'yu naseleniya [Modern scientific problems of improving the methodology for assessing the health risk]. Hygiene and sanitation, 2005, no. 2, pp. 7-10.

2. Baranov A. A., Kuchma V. R., Sukhareva L. M. Sostoyanie zdorov'ya sovremennykh detei i podrostkov i rol' mediko-sotsial'nykh faktorov $\mathrm{v}$ ego formirovanii [The state of health of today's children and adolescents and the role of medical and social factors in shaping it]. Annals of the Russian Academy of Medical Sciences, 2009, no. 5, pp. 6-10.

3. Kryzhanovskii G. N., Kurneshova L. E., Pivovarov V. V., Noskin L. A., Karganov M. Yu. Zdorov'e i ego polifunktsional'naya otsenka [Health and it's multifunctional evaluation]. Integrative anthropology, 2003, no. 2, pp. 46-51. (In Ukraine).

4. Pankova D. D., Pankova T. B. Sostoyanie zdorov'ya vypusknykh klassov (dannye profilakticheskikh osmotrov) [The health status of graduate classes (data of preventive inspection)]. Russian Journal of Pediatrics, 2006, no. 6, pp. 10-12.

5. Pankova D. D., Pankova T. B., Berova G. I., Natal'ina O. I. Novyi metodicheskii podkhod k analizu rezul'tatov profilakticheskogo osmotra shkol'nikov [A new methodological approach to the analysis of the results of a check-school children]. Russian Journal of Pediatrics, 2006, no. 2, pp. 25-29.

6. Pavlenko S. M. Izuchenie sanogeneza - estestvennyi put' dal'neishego razvitiya meditsiny [Study sanogenesis - a natural way of further development of medicine]. Sanogenesis. Proceedings of the conference. Moscow City Society of pathophysiology, Moscow, 1968, pp. 7-13. 
7. Kryzhanovskii G. N. Nekotorye obshchepatologicheskie i biologicheskie kategorii: zdorov'e, bolezn', gomeostaz, sanogenez, adaptatsiya, immunitet. Novye podkhody i predstavleniya [Some general pathological and biological categories: health, disease, homeostasis, sanogenesis, adaptation, immunity. New approaches and views]. Pathogenes, 2003, vol. 1, no. 1, pp. 11-14.

8. Aghajanyan N. A., Baevskii R. M., Berseneva A. P. Problemy adaptatsii i uchenie o zdorov'e [Problems of adaptation and teaching about health]. Moscow, publishing RUDN, 2006, $284 \mathrm{p}$.

9. Pavlenko S. M. Uchenie o sanogeneze - vazhneishaya problema meditsiny [The doctrine of sanogenesis - the most important issue of Medicine]. Pathological Physiology and Experimental Therapy, 1967, vol. 11, no. 3, pp. 91-95.

10. Eigel M. Ya., Kuznetsov P. P., Pankova N. B., Fesenko A. G., Karganov M. Yu. Innovatsionnye podkhody k sozdaniyu avtomatizirovannogo rabochego mesta (ARM) sportivnogo vracha [Innovative Approaches to the Creation of the Sports Doctor Workstation]. Physician and Information Technology, 2013, no. 1, pp. 27-31.

11. Baevskii R. M. Kontseptsiya fiziologicheskoi normy i kriterii zdorov'ya [The concept of physiological norms and criteria for health]. I. M. Sechenov Physiological Journal, 2003, vol. 89, no. 4, pp. 473-487.

12. Pankova N. B., Chamokova A. Ya., Mamgetov K. Yu., Pustovet Z. T., Cherepov A. B., Karganov M. Yu. Sravnitel'nyi analiz osobennostei funktsionirovaniya serdechno-sosudistoi i psikhomotornoi sistem organizma shkol'nikov $\mathrm{v}$ zavisimosti ot regiona prozhivaniya i uchebnoi nagruzki [Comparative analysis of the functioning of the cardiovascular and psycho-motor systems of the body schoolchildren depending on the region of residence and study load]. Human Ecology, 2006, suppl. 4/2, pp. 212-214.

13. Pankova N. B., Alchinova I. B., Cherepov A. B., Karganov M. Yu. Regional'nye osobennosti funktsional'nykh pokazatelei serdechno-sosudistoi sistemy u podrostkov [Regional characteristics of the functional parameters of the cardiovascular system in adolescents]. Russian Journal of Pediatrics. 2008, no. 1, pp. 37-42.

14. Pankova N. B., Karganov M. Yu., Eigel M. Ya., Kuznetsov P. P. Ispol'zovanie diskriminantnogo analiza dlya otsenki rezul'tatov monitoringa funktsional'nogo sostoyaniya organizma yunykh figuristov [Using Discrimination Analysis to evaluate the Results of the Functional State of the Organism in Young Skaters]. Valueology, 2012, no. 4, pp. 24-28.

15. Otter M. Ia. Sezonnye i sutochnye izmeneniya soderzhaniya i skorosti metabolizma serotonina $\mathrm{v}$ mozge belykh myshei [Seasonal and circadian changes in the serotonin content and metabolic rate in the brain of white mice]. Bulletin of Experimental Biology and Medicine, 1982, vol. 94, no. 4, pp. 84-86.

16. Otter M. Ia., Nurmand L. B. Sezonnye kolebaniya katekholaminov v mozge belykh krys [Seasonal fluctuations in the catecholamine content in the brain of white rats]. Bulletin of Experimental Biology and Medicine, 1980, vol. 89, no. 2, pp. 215-217.

17. Otter M. Ia., Shotter A. V. Sezonnye izmeneniya serdechno-sosudistykh pokazatelei i soderzhaniya monoaminov $\mathrm{v}$ mozge krolikov [Seasonal changes in cardiovascular indices and monoamine content in the brain of rabbits]. Bulletin of Experimental Biology and Medicine. 1991, vol. 111, no. 5, pp. 540-542.

18. Pankova N. B., Karganov M. Yu. Obratimye izmeneniya v serdechno-sosudistoi sisteme organizma uchashchikhsya, indutsiruemye obrazovatel'noi sredoi [Returnable alterations in cardiovascular system of pupil's organism induced by educational environment]. Valueology, 2009, no. 2, pp. 54-59. 
19. Fesenko A. G., Skalny A. V., Pankova N. B., Arkhipova E. N., Alchinova I. B., Karganov M. Yu. Elementnyi status i dinamika funktsional'nogo sostoyaniya organizma devushek-regbistok $\mathrm{v}$ sorevnovatel'nyi period [Effect of a trace elements correction on the dynamics of the women rugby players organism functional status in the competitive period (results of polysystemic monitoring)]. Trace elements in medicine, 2011, vol. 12, no. 1-2, pp. 27-38.

20. Pankova N. B., Mustafina I. Z., Afanaseva E. V., Karganov M. Yu., Kuchma V. R. Funktsional'naya perestroika kardio-respiratornoi sistemy, psi-khomotornoi koordinatsii i psikhoemotsional'nogo sostoyaniya u podrostkov vo vremya letnego otdykha [Functional reorganization of cardio-respiratory system, psychomotor coordination, and psycho-emotional state of adolescents during the summer holidays]. Russian Journal of Pediatrics, 2006, no. 2, pp. 8-16.

Pankova Nataliya Borisovna, the doctor of biological sciences, the professor of the department of health saving content of educational technology, Moscow Institute of Open Education.

E-mail: nbpankova@gmail.com 
Вестник Новосибирского государственного педагогического университета Novosibirsk State Pedagogical University Bulletin

1(17) $2014 \quad$ www.vestnik.nspu.ru ISSN 2226-3365

(C) С. Н. Шилов, О. Г. Солдатова, Н. Д. Наливайко

УДК 612+159.91

\title{
ТЕМПЕРАМЕНТАЛЬНЫЕ ЧЕРТЫ ЛИЧНОСТИ РЕБЕНКА, КАК ФАКТОР, ОПРЕДЕЛЯЮЩИЙ РЕЗЕРВ ЗДОРОВЬЯ*
}

\begin{abstract}
С. Н. Шилов, О. Г. Солдатова, Н. Д. Наливайко (Красноярск, Россия)
В статье анализируется влияние темпераментальных особенностей ребенка, в частности, ребенка младшего школьного возраста, на резерв его здоровья. Цель статьи - исследовать взаимосвязь степени выраженности темпераментальных черт личности ребенка младшего школьного возраста и его показателя сантивности. Установлено, что темпераментальные свойства личности детей 7-10 лет влияют на функииональные возможности их организма и резерв их здоровья. Дети спокойные имеют большие функииональные резервы организма и более высокий показатель сантивности, то есть резерв здоровья, чем дети интенсивные, характеризуюшиеся высокой поведенческой активностью. Сопоставление данных физического развития и индекса сантивности выявило, что показатели физического развития детей не всегда указывают на достаточный уровень здоровья и адаптивные возможности организма. $B$ заключении, делаются выводы о влиянии темпераментальных свойств личности детей на функииональные возможности их организма и резерв их здоровья.
\end{abstract}

Ключевые слова: темперамент, индивидуальное здоровье, младшие школьники, адаптация, резистентность, сантивность.

В последнее время все чаще в работах отечественных и зарубежных психологов и физиологов проявляется интерес к исследованию поведения на уровне физиологических систем и человека в целом. Почему в одной и той же семье дети ведут себя по- разному? Чем объяснить трудности воспитания ребенка? Объяснение проявлений поведенческих реакций только с социальных позиций в настоящее время большинством специалистов признается не лучшим методом. Конечно, социальный фактор в воспита-

* Статья подготовлена по результатам работы Всероссийской научной школы с Международным участием «Опыт использования мониторинга здоровья и физической подготовленности учащейся молодежи» (12-14 ноября 2013 г.).

Шилов Сергей Николаевич - доктор медицинских наук, профессор кафедры специальной психологии, Красноярский государственный педагогический университет им. В.П. Астафьева. E-mail: shiloff.serg@yandex.ru

Солдатова Ольга Глебовна - доктор медицинских наук, профессор кафедры физиологии, Красноярский государственный медицинский университет им. проф. В.Ф.Войно-Ясенецкого.

Наливайко Наталья Дмитриевна - ассистент кафедры специальной психологии, Красноярский государственный педагогический университет им. В.П. Астафьева.

E-mail: nalimmyshka@mail.ru 
Вестник Новосибирского государственного педагогического университета Novosibirsk State Pedagogical University Bulletin

1(17) $2014 \quad$ www.vestnik.nspu.ru $\quad$ ISSN 2226-3365

нии человека имеет большое значение, но, чтобы его правильно использовать, надо учитывать индивидуально типологические особенности поведения или темперамент. Темперамент обусловлен врожденными свойствами нервной системы и проявляется в поведении устойчивым сочетанием временных и энергетических характеристик.

В основе современных представлений о темпераменте лежит фундаментальная концепция функционально - системной организации работы мозга, предложенная П.К. Анохиным [2].

Свойства нервной системы при этом трактуются как базовые характеристики функциональных систем, обеспечивающих интегративную деятельность нервной системы. Индивидуальные свойства психики, в том числе и свойства темперамента, обусловленные индивидуальными свойствами нервной системы, играют важную роль в приспособлении организма к окружающей среде. Темперамент позволяет индивиду более экономично расходовать свои генетически заданные энергетические возможности. Индивид, предъявляя себя среде и социуму, демонстрирует свои энергетические и динамические возможности, адекватные требованиям среды, что является залогом успешной адаптации его к этой среде. Общеизвестно, что одна и та же ситуация некоторыми индивидами может расцениваться как опасная и быть стрессогенной, а другими как привлекательная и не обладающая стрессовыми свойствами в зависимости от темперамента, конституциональных особенностей систем торможения и активности поведения. Деятельность системы торможения поведения проявляется в снижении текущей активности, повышением уровня внимания. Активация систем достижения приводит к импульсивному пове- дению и снижению сосредоточенности. Обе системы вызывают вегетативную мобилизацию [20], что во многом и обуславливает приспособительную адаптивную роль темперамента [22]. Темперамент является основой индивидуального стиля приспособления, развивающегося в конкретных условиях жизни, социальные условия и стиль приспособления, в свою очередь оказывают влияние на темперамент, ослабляя одни проявления и усиливая другие [15].

По данным официальной статистики, состояние здоровья детей и подростков в Российской федерации ухудшается с каждым годом [3; 6]. Современная жизнь связана с большим количеством факторов, ведущих к стрессорным реакциям, с развитием физиологических, а зачастую патологических изменений $[8 ; 13]$. При этом именно детское население является наиболее чувствительным контингентом, быстро реагирующим на любые изменения окружающей среды в силу незавершенности процессов роста и развития [3]. Значительную роль в изменении уровня здоровья детей стало играть обучение в школе. При этом главным фактором, вызывающим нарушение механизмов саморегуляции отдельных функциональных систем у школьников, с последующим развитием хронических заболеваний, нередко является психоэмоциональный стресс [1]. Сложилась такая ситуация, что в настоящее время в России обучение в школе является одним из основных факторов риска снижения уровня здоровья детей, особенно остро данный вопрос встал в связи с инновациями в процессе обучения [1; $9 ; 16]$.

Есть данные об особенностях темпераментальных характеристик у младших школьников с ЗПР [17]. Поэтому тем более интересно выяснить влияние темперамен- 
Вестник Новосибирского государственного педагогического университета Novosibirsk State Pedagogical University Bulletin

1(17) $2014 \quad$ www.vestnik.nspu.ru $\quad$ ISSN 2226-3365

тальных особенностей личности ребенка, в частности, ребенка младшего школьного возраста, на уровень и резерв его здоровья.

Согласно трехмерной модели здоровья, наряду с континуумом количественных проявлений здоровья (продолжительность жизни, энергетический потенциал, адаптивные возможности, резистентность, физическое развитие) и качественных проявлений здоровья (психологическая стрессоустойчивость, тревожность, удовлетворенность жизнью и пр.), существует глубинная ось, отражающая поведенческую адаптацию - число степеней свободы поведения, или свобода жизни [5]. Если в медицине превалирует взгляд на здоровье как состояние, характеризующееся отсутствие болезни, то с позиции трехмерной модели здоровья наличие болезни еще не значит отсутствие здоровья. Здоровье и болезнь - противоположные проявления одного явления под названием жизнь. Поломка защитных систем организма, дезадаптация приводят к болезни, что сопровождается снижением трудоспособности, приспособляемости, сопротивляемости неблагоприятным факторам, настроения, то есть состояния резервов здоровья. Выздоровление как бы отвоевывает у болезни тот объем, который занимало здоровье до болезни в континууме жизни. Потенциал здоровья, существующий в организме и противостоящий его повреждению, определяющий количество и качество здоровья, обозначен термином сантивность. В противоположность ему - пативность - это вероятность болезни, ограничения жизни и сама смерть. Понятие о сантивности и пативности предоставило возможность совершенствовать методику диагностики здоровья. Проверка показателя сантивности на выборке здоровых и больных показала, что он обладает достаточной чувствительностью (80 \%) - доля больных, у которых с помощью данного метода был выявлен срыв адаптации, специфичностью (85 \%) - доля здоровых лиц, у которых срыв адаптации (низкий уровень здоровья) данным методом не определялся, и диагностической эффективностью (81%) [4-5].

Данный методологический подход, реализованный в виде автоматизированного программного комплекса «Хелми-тест 7-10 лет» [5], мы использовали для оценки уровня здоровья у младших школьников города Красноярска с различной выраженностью темпераментальных черт.

У практически здоровых детей 8-10 лет мы определяли черты темперамента с помощью родительского опросника DOTS R [23], адаптированного для России (Колпаков с соавт., 1987). В методике заложена возможность точной количественной оценки 9 черт темперамента детей: 1 - АКТИВНОСТЬ, 2 - РИТМИЧНОСТЬ, 3 - АДАПТИВНОСТЬ, 4 - ПРИБЛИЖЕНИЕ, 5 - ИНТЕНСИВНОСТЬ, 6 - ПОРОГ ЧУВСТВИТЕЛЬНОСТИ (УЯЗВИМОСТЬ), 7 - НАСТРОЕНИЕ, 8 - НАСТОЙЧИВОСТЬ, 9 - ОТВЛЕКАЕМОСТЬ. Оценка вариантов родительских ответов проводилась по 7-ми бальной шкале (Е.Ю. Петросян и соавт., 2003). Всего обследовано 513 практически здоровых детей младшего школьного возраста, 273 девочки и 240 мальчиков.

Установлено, что мальчики активнее девочек, имеют более высокую интенсивность реакций, но в тоже время труднее переходят от одного вида деятельности к другому, то есть больше отвлекаются на внешние раздражители, что согласуется с литературными данными и считается генетически детерминированным [7; 21]. Девочки достоверно лучше адаптируются к новым условиям, бо- 
Вестник Новосибирского государственного педагогического университета Novosibirsk State Pedagogical University Bulletin

1(17) $2014 \quad$ www.vestnik.nspu.ru ISSN 2226-3365

лее настойчивы, имеют показатели приблиствительность по сравнению с мальчиками жения выше, и обнаруживают меньшую чув(Табл. 1).

Таблица 1

Средние значения 9 черт темперамента детей младшего школьного возраста города Красноярска.

\begin{tabular}{|l|c|c|c|}
\hline \multicolumn{1}{c|}{$\begin{array}{c}\text { черта } \\
\text { темперамента }\end{array}$} & мальчики & девочки & $\begin{array}{c}\text { доверительный } \\
\text { интервал }\end{array}$ \\
\hline АКТИВНОСТЬ & $3,95 \pm 0,04$ & $3,55 \pm 0,03$ & $\mathrm{p}<0,01$ \\
\hline РИТМИЧНОСТЬ & $4,12 \pm 0,03$ & $4,48 \pm 0,03$ & $\mathrm{p}<0,01$ \\
\hline ПРИБЛИЖЕНИЕ & $4,70 \pm 0,05$ & $5,13 \square 0,04$ & $\mathrm{p}<0,01$ \\
\hline АДАПТАБЕЛЬНОСТЬ & $4,31 \pm 0,04$ & $4,73 \pm 0,02$ & $\mathrm{p}<0,01$ \\
\hline ИНТЕНСИВНОСТЬ & $3,90 \pm 0,05$ & $3,51 \pm 0,04$ & $\mathrm{p}<0,01$ \\
\hline НАСТРОЕНИЕ & $4,32 \pm 0,05$ & $4,65 \pm 0,03$ & $\mathrm{p}<0,01$ \\
\hline НАСТОЙЧИВОСТЬ & $4,55 \pm 0,04$ & $4,96 \pm 0,04$ & $\mathrm{p}<0,01$ \\
\hline ОТВЛЕКАЕМОСТЬ & $4,88 \pm 0,04$ & $4,22 \pm 0,04$ & $\mathrm{p}<0,01$ \\
\hline ПОРОГ & $4,02 \pm 0,04$ & $4,42 \pm 0,03$ & $\mathrm{p}<0,01$ \\
\hline
\end{tabular}

Полученные данные свидетельствуют об успешности адаптации и зрелости психофизиологических механизмов темперамента, ответственных за приспособление к условиям и требованиям среды у популяции младших школьников Красноярска в целом [11].

Bce обследованные дети были разделены нами на группы по индексу выраженности поведенческих проявлений (ИВПП), который представляет собой сумму таких темпераментальных черт, как общая активность, настроение, чувствительность, интенсивность [14]. Дети интенсивные (ИН) имеют высокий ИВПП, адекватные (АД) - со средний ИВПП, и спокойные (СП) - с низким ИВПП.

Оказалось, что 53,3 \% практически здоровых мальчиков характеризуются средними значениями выраженности поведенческих реакций. Практически в равной степени встречаются мальчики интенсивные и спокойные. Популяция девочек младшего школьного возраста демонстрировала похожую картину распределения черт темперамента (табл.2).

Таблица 2

Распределение исследуемых школьников по индексу выраженности поведенческих проявлений

\begin{tabular}{|c|c|c|}
\hline \multicolumn{3}{|c|}{ Встречаемость } \\
\hline Спокойные & Адекватные & Интенсивные \\
\hline Мальчики $-22,9 \%$ & Мальчики $-53,3 \%$ & Мальчики $-23,7 \%$ \\
\hline Девочки $-24,2 \%$ & Девочки $-51,3 \%$ & Девочки $-24,5 \%$ \\
\hline
\end{tabular}

Объективное обследование детей проводилось в соответствии с требованиями про- граммы («Хелми-тест 7-10 лет»), в итоге выдавалось заключение по показателю сантив- 
Вестник Новосибирского государственного педагогического университета Novosibirsk State Pedagogical University Bulletin

ности (ПС, потенциал здоровья, определяющий его вероятностное количество и качество) и пативности (вероятность болезни, ограничение жизнестойкости). В заключении также содержались данные о состоянии физического развития, вегетативной реактивности, физической работоспособности, стрессоустойчивости. В дополнение мы определяли у детей критерии резерва функции внешнего дыхания - показатель ЖЕЛ, отнесенный к массе тела, данные резерва мышечной системы - динамометрия более сильной кисти, отнесенная к массе тела, выраженная в процентах. У всех обследуемых детей была определена зависимость между общей выносливостью, объемом физиологических резервов и проявлением экономизации функций кардиореспираторной системы. В качестве критерия резерва и экономизации функций рассматривалось время восстановления частоты сердечных сокращений до исходного уровня по- сле дозированной физической нагрузки и двойное произведение в покое (ДП), величина которого определялась по формуле: ДП=ЧСС ${ }^{*}$ САД $/ 100$. Отдельно оценивалась также толерантность к гипоксии при помощи пробы Штанге.

Данные физического развития обследованных детей находились в пределах возрастных региональных норм. Но, при достаточном резерве функции внешнего дыхания, во всех группах снижены показатели резерва функций сердечно-сосудистой и мышечной систем. Кроме того, обращают на себя внимание низкие показатели пробы Штанге, что также свидетельствует о сниженном объеме физиологических резервов и отсутствии экономизации функций кардио-респираторной системы у исследованных нами детей (табл. 4-5).

Таблица 3.

Функциональные показатели девочек

\begin{tabular}{|l|c|c|c|c|c|}
\hline & $\begin{array}{l}\text { ЧСС } \\
\text { 00,у. е. }\end{array}$ & Д/МТ, \% & ЖЕЛ/МТ\% & $\begin{array}{l}\text { ИНДЕКС } \\
\text { РУФЬЕ, у. е. }\end{array}$ & $\begin{array}{l}\text { ПРОБА } \\
\text { ШТАНГЕ }\end{array}$ \\
\hline Норма -7 лет & $90-81$ & $46-50$ & $48-55$ & $6-10$ & 30 \\
В группе & $84 \pm 0,43$ & $47 \pm 0,23$ & $53 \pm 0,35$ & $11 \pm 0,02$ & $22 \pm 0,17$ \\
\hline Норма - 8 лет & $90-81$ & $46-50$ & $48-55$ & $6-10$ & 36 \\
В группе & $90 \pm 0,53$ & $43 \pm 0,15$ & $60 \pm 0,44$ & $13 \pm 0,01$ & $27 \pm 0,19$ \\
\hline 9 лет норма & $90-81$ & $46-50$ & $48-55$ & $6-10$ & 40 \\
В группе & $93 \pm 0,54$ & $44 \pm 0,23$ & $57 \pm 0,43$ & $13 \pm 0,02$ & $26 \pm 0,18$ \\
\hline Норма - 10 лет & $90-81$ & $46-50$ & $48-55$ & $6-10$ & 50 \\
В группе & $85 \pm 0,53$ & $44 \pm 0,22$ & $55 \pm 0,36$ & $11 \pm 0,01$ & $27 \pm 0,16$ \\
\hline
\end{tabular}


Вестник Новосибирского государственного педагогического университета Novosibirsk State Pedagogical University Bulletin

Таблица 4

Функичиоальные показатели мальчиков

\begin{tabular}{|l|c|c|c|c|c|}
\hline & $\begin{array}{c}\text { ЧСС САД/100, } \\
\text { у. е. }\end{array}$ & Д/МТ, \% & ЖЕЛ/МТ\% & $\begin{array}{c}\text { ИНДЕКС } \\
\text { РУФЬЕ, у. е. }\end{array}$ & $\begin{array}{c}\text { ПРОБА } \\
\text { ШТАНГЕ }\end{array}$ \\
\hline Норма-7лет & $90-81$ & $51-60$ & $51-60$ & $6-10$ & 36 \\
В группе & $88 \pm 0,54$ & $50 \pm 0,45$ & $64 \pm 0,42$ & $13 \pm 0,03$ & $31 \pm 0,19$ \\
\hline Норма -8лет & $90-81$ & $51-60$ & $51-60$ & $6-10$ & 40 \\
В группе & $93 \pm 0,55$ & $48 \pm 0,46$ & $58 \pm 0,41$ & $12 \pm 0,02$ & $27 \pm 0,18$ \\
\hline 9лет норма & $90-81$ & $51-60$ & $51-60$ & $6-10$ & 44 \\
В группе & $95 \pm 0,49$ & $49 \pm 0,43$ & $60 \pm 0,45$ & $12 \pm 0,02$ & $30 \pm 0,19$ \\
\hline Норма - 10лет & $90-81$ & $51-60$ & $51-60$ & $6-10$ & 50 \\
В группе & $93 \pm 0,52$ & $49 \pm 0,44$ & $58 \pm 0,43$ & $12 \pm 0,02$ & $35 \pm 0,18$ \\
\hline
\end{tabular}

При этом, у спокойных детей ниже индекс Руфье и больше время задержки дыхания, что свидетельствует о больших резервах и экономизации функций кардиореспираторной и мышечной систем у этих детей по сравнению с детьми интенсивными (табл. 5). Таким образом, спокойные дети имеют большие функциональные возможности организма по сравнению с детьми, чей темперамент характеризуется выраженным компонентом поведенческих проявлений.

Таблица 5

Функииональные показатели детей с разной поведенческой активностью

\begin{tabular}{|c|c|c|c|c|c|c|}
\hline & & ЧСС*САД/100,y. е. & ЖЕЛ/МТ\% & Д/МТ, \% & ИНДЕКСРУФЬЕ, у. е. & ПРОБАШТАНГЕ \\
\hline \multirow[b]{2}{*}{ СП } & мал & $90,88 \pm 0,35$ & $63,82 \pm 0,25$ & $59,6 \pm 0$ & $11,37 \pm 0,2$ & $29,95 \pm 0,3$ \\
\hline & дев & $90,95 \pm 0,26$ & $62,07 \pm 0,34$ & $58,93 \pm$ & $12,12 \pm 0,1$ & $28,58 \pm 0,4$ \\
\hline \multirow[b]{2}{*}{ АД } & мал & $93,41 \pm 0,34$ & $61,12 \pm 0,35$ & $59,20 \pm$ & $12,01 \pm 0,3$ & $27,18 \pm 0,4$ \\
\hline & дев & $92,44 \pm 0,44$ & $56,63 \pm 0,41$ & $56,66 \pm$ & $12,67 \pm 0,2$ & $27,15 \pm 0,3$ \\
\hline \multirow[b]{2}{*}{ ИН } & мал & $94,48 \pm 0,36$ & $63,92 \pm 0,33$ & $59,61 \pm$ & $12,88 \pm 0,3$ & $26,02 \pm 0,3$ \\
\hline & дев & $93,95 \pm 0,56$ & $59,59 \pm 0,29$ & $59,07 \pm$ & $12,98 \pm 0,2$ & $26,25 \pm 0,3$ \\
\hline
\end{tabular}

На основе характера распределения показателя сантивности и его средних значений в группах здоровых и больных выделяется пять градаций (степеней) вероятности утраты здоровья, определяемой по величине показателя [5]:

1. минимальная вероятность (ПС $-90-100 \%)$;

2. низкая вероятность (ПС - 70-90\%);
3. умеренная вероятность (ПС $-30-70 \%)$;

4. высокая вероятность (ПС $-10-30 \%)$;

5. максимальная вероятность (ПС $-0-10 \%)$.

Нами установлено, что все обследованные школьники имели в среднем показатель сантивности не превышающий $60 \%$, что свидетельствует об умеренном резерве их здоровья и достаточно высокой вероятности 
Вестник Новосибирского государственного педагогического университета Novosibirsk State Pedagogical University Bulletin

развития заболеваний. При этом спокойные дети имеют более высокий показатель сантивности, характеризующий резерв их здоровья (рис.1, табл.6), чем дети интенсивные.

Таблица 6

Показатели сантивности и пативности у детей разного ВП - типа темперамента

\begin{tabular}{|c|c|c|c|c|c|c|c|}
\hline & \multicolumn{2}{|c|}{ спокойные } & \multicolumn{2}{c|}{ адекватные } & \multicolumn{2}{c|}{ интенсивные } & Достоверность \\
\hline & мальчики & девочки & мальчики & девочки & мальчики & девочки & \\
\hline 1 & 2 & 3 & 4 & 5 & 6 & 7 & 8 \\
\hline ПАТ. & $41 \% \pm 0,3$ & $41 \% \pm 0,4$ & $44 \% \pm 0,3$ & $43 \% \pm 0,2$ & $47 \% \pm 0,2$ & $45 \% \pm 0,2$ & $2-6,3-7 \mathrm{p}<0,05$ \\
\hline САН. & $59 \% \pm 0,3$ & $59 \% \pm 0,4$ & $56 \% \pm 0,3$ & $57 \% \pm 0,2$ & $53 \% \pm 0,2$ & $55 \% \pm 0,2$ & $2-6,3-7 \mathrm{p}<0,05$ \\
\hline
\end{tabular}

Рисунок 1

Показатель сантивности у младших школьников с разной выраженностью поведенческих проявлений

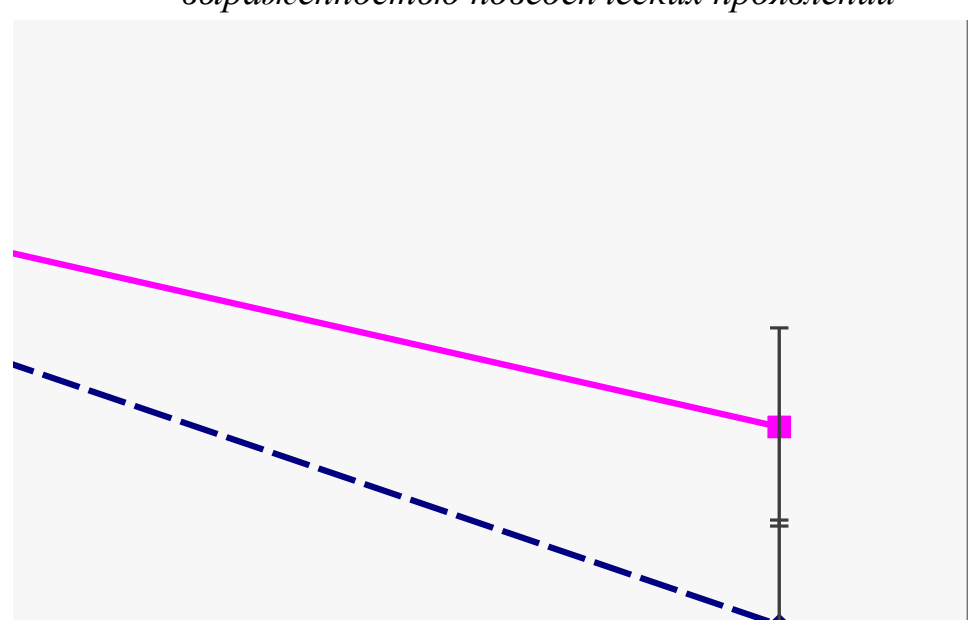

Сопоставление данных физического развития и индекса сантивности выявило, что показатели физического развития детей не всегда указывают на достаточный уровень здоровья и адаптивные возможности организма.

Таким образом, полученные нами результаты свидетельствуют о влиянии темпераментальных свойств личности детей на функциональные возможности их организма и резерв их здоровья [11]. Дети спокойные имеют большие функциональные резервы организма и более высокий показатель сантивности, то есть резерв здоровья, чем дети интенсивные, характеризующиеся высокой поведенческой активностью.

На проявление темпераментальных черт у младших школьников оказывает влияние окружение, особенно близкое (родственников, друзей, учителей), смена отношений (к ребёнку начинают относиться как ко взрослому, выдвигая новые требования и обязанности, чаще при этом оставляя прежние детские права), и изменение социальных условий [18]. Использование 
Вестник Новосибирского государственного педагогического университета Novosibirsk State Pedagogical University Bulletin

1(17) $2014 \quad$ www.vestnik.nspu.ru ISSN 2226-3365

закономерностей изменения черт темперамента и особенностей поведения детей позволит формировать не оторванные от человека абстрактные программы воспитания, а индивидуализировать эту работу с учетом влияния темпераментальных черт личности ребенка на функциональные возможности и уровень его здоровья.

Стратегия поведения родителей, уклад жизни в семье, которые следуют за характеристиками темперамента своих детей, акцентируют характеристики темперамента ребенка. С другой стороны, жесткое, неадекватное требованиям темперамента отношение окружающих может привести к потере ранее имеющихся адаптивных способностей ребенка, к нарушениям поведения, снижению уровня здоровья, или даже к психосоматическим расстройствам.

\section{СПИСОК ЛИТЕРАТУРЫ}

1. Авилов О.В. Особенности функционального состояния школьников различных классов при психоэмоциональном стрессе // Физиология развития человека: матер. междунар. конф., посвящ. 55-летию ин-та возрастной физиологии РАО. - М., 2000. - С. 60-61.

2. Анохин П. К. Биология и нейрофизиология условного рефлекса. - М.: Медицина, 1968. $287 \mathrm{c}$.

3. Баранов А.А., Щеплягина Л.А. Фундаментальные и прикладные исследования по проблемам роста и развития детей и подростков // Рос. педиатр. журн. - 2000. - № 5. C. $5-12$.

4. Безматерных Л.Э., Куликов В.П. Диагностическая эффективность методов количественной оценки индивидуального здоровья // Физиология человека. - 1998. - № 3. - С. 79-85.

5. Куликов В.П. Трехмерная модель здоровья. Сантивность и пативность // Валеология. 2000. - № 1. - C. 15-21.

6. Кушнир С.М. О механизме нарушений вегетативной регуляции у детей, больных нейроциркуляторной дистонией // Педиатрия. - 2001. - № 1. - С. 28-31.

7. Макарова Г.А. Особенности темперамента детей и подростков здоровых и с резидуальноорганическими психическими нарушениями: дис.... канд. мед. наук. - СПб., 1998. - 206 с.

8. Медведев В.И. Взаимодействие физиологических и психологических механизмов в процессе адаптации //Физиология человека. - 1998. - № 4. - С. 7-13.

9. Особености физического и полового развития девушек - учащихся образовательных учреждений различного вида / Э.Я. Мингазова, А.Х. Яруллин, Л.М. Фатхутдинова и др. // Физиология развития человека: Матер. междунар. Конф., посвященной 55-летию ин-та возрастной физиологии РАО. - М., 2000. - С. 313.

10. Патент. Российская Федерация МПК 7А 61 В 5/16. Способ АЦП-типирования черт темперамента / Петросян Е.Ю., Савченков Ю.И., Домрачева М.Я., Домрачеев А.А.; заявитель и патентообладатель ГОУ ВПО Красноярская гос. мед. Академия Росздрава. № 2266047, заявл. 01.12.2003., опубл. 20.12.2005. Бюлл.№35.

11. Петросян Е.Ю., Солдатова О.Г. Темперамент и здоровье. - Новосибирск : Наука. 2006. $-158 \mathrm{c}$.

12. Петросян Е.Ю. Диапазон пластичности темпераментальных свойств при воздействии на человека различных факторов: автореф. дис... докт. мед. наук. - Томск, 2007. - 35с. 
Вестник Новосибирского государственного педагогического университета Novosibirsk State Pedagogical University Bulletin

1(17) 2014

www.vestnik.nspu.ru

ISSN 2226-3365

13. Пшенникова М.Г. Феномен стресса. Эмоциональный стресс и его роль в патологии // Патол. физиология и эксперим. терапия. -2000. - № 3. - С. 20-26.

14. Савченков Ю.И., Петросян Е.Ю. АЦП-типы черт темперамента и их представительство в молодежной популяции одного из городов Восточной Сибири // Вестн. Юж.-Урал. гос. ун-та. - 2004. - № 6(б). - С. 74-83.

15. Слободская Е.Р. Развитие ребенка: индивидуальность и приспособление. - Новосибирск: CO РАMН. - 415c.

16. Струч С.В. Состояние здоровья и метаболические параметры иммунокомпетентных клеток у первоклассников при разном уровне информационных нагрузок: автореф. дис.... канд. мед. наук. - Красноярск, 2005. - 24 с.

17. Хабарова И.В., Шилов С.Н. Особенности активационных процессов лобной коры головного мозга и темпераментальных характеристик у младших школьников с задержкой психического развития // Дефектология. - № 3. - 2012. - С. 52-60.

18. Щедрина А.Г. Онтогенез и теория здоровья: методолог. аспекты. - Новосибирск, CO PAMH, 2003. - 164c.

19. Chess S., Thomas A. Temperament theory and practice, N. Y. Brunner/Mazel, Inc, 1996, 684 p.

20. Gray J. A. Fundamental systems of emotion in the mammalian brain, Coping with Uncertainty: Biological, Behavioral and Developmental Perspectives, Hillsdale, 1989, pp. 173-195.

21. Hegvik R. L., McDevitt S. C., Carey W. B. The middle childhood temperament questionnaire. J. Dev. Behav. Rediatr. 1982, vol. 3, no. 4, pp. 197-200.

22. Strelau J. Temperament. Personality. Activity, London; N. Y. Acad. Press, 1983, 375 p.

23. Thomas A., Chess S., Birch H. G. Temperament and Behavior Disorder in Children, N. Y., London, 1968, $145 \mathrm{p}$ 
Вестник Новосибирского государственного педагогического университета Novosibirsk State Pedagogical University Bulletin

1(17) $2014 \quad$ www.vestnik.nspu.ru ISSN 2226-3365

(C) S. N. Shilov, O. G. Soldatov, N. D. Nalivayko

UDC 612+ 159.91

\title{
TEMPERAMENTAL PERSONALITY TRAITS OF THE CHILD AS A FACTOR DETERMINING RESERVE HEALTH
}

\author{
S. N. Shilov, O. G. Soldatov, N. D. Nalivayko (Krasnoyarsk, Russia)
}

The paper analyzes the impact of temperamental characteristics of the child, in particular, children of primary school age in the provision of health. Purpose of the article - to investigate the relationship of expression of personality traits temperamental child of primary school age, and his record santivnosti. Found that the properties of the individual temperamental children 7-10 years affect the functionality of their bodies and their health provision. Children are quiet large, functional reserves of the body as well as higher santivnosti, then there is a reserve of health than children intensive, characterized by high behavioral activity. Comparison of data and physical development index santivnosti revealed that the performance of the physical development of the children do not always indicate an adequate level of health and adaptive capacity of the organism. Finally, conclusions about the influence of personality traits temperamental children on the functionality of their body and their health provision.

Keywords: temperament, personal health, younger students, adaptation, resistance, santivnost.

\section{REFERENCES}

1. Avilov O. V. Osobennosti funktsional'nogo sostoyaniya shkol'nikov razlichnykh klassov pri psikhoemotsional'nom stresse [Features of the functional state of the various classes in the school psycho-emotional stress]. Physiology of human development: Mater. Intern. Conf., dedicated. 55th anniversary of the Institute of Physiology of radioactive waste. Moscow, 2000, pp. 60-61. (In Russia).

2. Anokhin P. K. Biologiya i neirofiziologiya uslovnogo refleksa [Biology and neurophysiology of conditioned reflex]. Moscow, Medicine, 1968.

3. Baranov A. A., Scheplyagina L. A. Fundamental'nye i prikladnye issledovaniya po problemam rosta i razvitiya detei i podrostkov [Fundamental and applied research on the growth and development of children and adolescents]. Rus. pediatrician. Journal, 2000, no. 5. - pp. 5-12.

4. Bezmaternykh L. E., Kulikov V. P. Diagnosticheskaya effektivnost' metodov kolichestvennoi otsenki individual'nogo zdorov'ya [The diagnostic efficiency of methods for quantitative evaluation of individual health]. Human Physiology, 1998, no. 3, pp. 79-85.

5. Kulikov V. P. Trekhmernaya model' zdorov'ya. Santivnost' i pativnost' [Three-dimensional model of health. Santivnost and dissipative]. Valueology, 2000, no. 1, - pp. 15-21.

6. Kushnir S. M. O mekhanizme narushenii vegetativnoi regulyatsii u detei, bol'nykh neirotsirkulyatornoi distoniei [On the mechanism of regulation of autonomic disorders in children with neuro dystonia]. Pediatrics. 2000, no. 1. - pp. 28-31.

7. Makarova G. A. Osobennosti temperamenta detei i podrostkov zdorovykh i s rezidual'noorganicheskimi psikhicheskimi narusheniyami. Diss. kand. med. nauk [Features temperament of 
children and adolescents healthy and residual - organic mental disorders. Cand. med. science diss.]. St. Petersburg, 1998, 206 p.

8. Medvedev V. I. Vzaimodeistvie fiziologicheskikh i psikhologicheskikh mekhanizmov v protsesse adaptatsii [The interaction of physiological and psychological mechanisms in the adaptation]. Human Physiology, 1998, no. 4. pp. 7-13.

9. Mingazova E. Y., Yarullin A. H., Fatkhutdinova L. M. and oth. Osobenosti fizicheskogo i polovogo razvitiya devushek - uchashchikhsya obrazovatel'nykh uchrezhdenii razlichnogo vida [Special features of the physical and sexual development of girls - students of educational institutions of various types]. Physiology of human development: Mater. Intern. Conf., dedicated. 55th anniversary of the Institute of Physiology of radioactive waste. Moscow, 2000, P. 313.

10. Petrosyan E. J., Savchenko Y., Domrachava M. Y., Domracheev A. A. Sposob ATsP-tipirovaniya chert temperamenta [The method ADC-typing features of temperament]. Patent RF IPC 7A 61 5/16. Applicant and patentee HPE Krasnoyarsk State. Med. The Academy of Medical University, no. 2266047, filed. 01.12.2003., Publ. 20.12.2005. Bull. no. 35. (In Russia).

11. Petrosyan E. J., Soldatova O. G. Temperament i zdorov'e [Temperament and health]. Novosibirsk, Nauka, 2006.

12. Petrosyan E. J. Diapazon plastichnosti temperamental'nykh svoistv pri vozdeistvii na cheloveka razlichnykh faktorov, avtoref. Diss. dokt. med. nauk [The range of plasticity temperamental properties when subjected to various human factors. Author. Doctor. Med. Science Diss.]. Tomsk, 2007.

13. Pshennikova M. G. Fenomen stressa. Emotsional'nyi stress i ego rol' v patologii [The phenomenon of stress. Emotional stress and its role in the pathology]. Patol. fiziologiya and experimental. Therapy, 2000, no. 3. pp. 20-26.

14. Savchenko J. I., Petrosyan E. J. ATsP-tipy chert temperamenta i ikh predstavitel'stvo v molodezhnoi populyatsii odnogo iz gorodov Vostochnoi Sibiri [ADC types of temperament traits and their representation in the youth population of a town in Eastern Siberia]. Bulletin. Yuzh.Urals. State. Univ., 2004, no. 6(b). pp. 74-83.

15. Suburban E. R. Razvitie rebenka: individual'nost' i prisposoblenie [Child development: an individual and device]. Novosibirsk: Siberian Branch of RAMS, $415 \mathrm{p}$.

16. Struchev S. V. Sostoyanie zdorov'ya i metabolicheskie parametry immunokompetentnykh kletok u pervoklassnikov pri raznom urovne informatsionnykh nagruzok, avtoref. Diss. kand. med. nauk [Health and metabolic parameters of immune cells in the first grade at a different level of information load. Author. Diss. cand. med. Science]. Krasnoyarsk, 2005.

17. Habarova I. V., Shilov S. N. Osobennosti aktivatsionnykh protsessov lobnoi kory golovnogo mozga i temperamental'nykh kharakteristik u mladshikh shkol'nikov s zaderzhkoi psikhicheskogo razvitiya [Features of activation processes of the frontal cortex of the brain and temperamentalnyh performance in primary school children with mental retardation]. Defectology, no. 3, 2012, pp. $52-60$.

18. Shchedrin A. G. Ontogenez i teoriya zdorov'ya: metodolog, aspekty [Ontogeny and the theory of health: methodology]. Aspects, Novosibirsk: Siberian Branch of RAMS, 2003, 164 p.

19. Chess S., Thomas A. Temperament theory and practice, N. Y. Brunner/Mazel, Inc, 1996, 684 p.

20. Gray J. A. Fundamental systems of emotion in the mammalian brain, Coping with Uncertainty: Biological, Behavioral and Developmental Perspectives, Hillsdale, 1989, pp. 173-195.

21. Hegvik R. L., McDevitt S. C., Carey W. B. The middle childhood temperament questionnaire. J. Dev. Behav. Rediatr. 1982, vol. 3, no. 4, pp. 197-200. 
Вестник Новосибирского государственного педагогического университета Novosibirsk State Pedagogical University Bulletin

22. Strelau J. Temperament. Personality. Activity, London; N. Y. Acad. Press, 1983, 375 p.

23. Thomas A., Chess S., Birch H. G. Temperament and Behavior Disorder in Children, N. Y., London, 1968, $145 \mathrm{p}$

Shilov Sergey Nikolaevich, MD, the professor of department of special psychology, Krasnoyarsk State Pedagogical University.

E-mail: shiloff.serg@yandex.ru

Soldatova Olga Glebovna, MD, the professor of department of special psychology, Krasnoyarsk State Medical University at prof. V.F.Voyno-Yasenetsky.

Nalivayko Natalia Dmitrievna, the assistant of department of special psychology, Krasnoyarsk State Pedagogical University.

E-mail: nalimmyshka@mail.ru 
Вестник Новосибирского государственного педагогического университета Novosibirsk State Pedagogical University Bulletin

1(17) $2014 \quad$ www.vestnik.nspu.ru ISSN 2226-3365

(C) Л. В. Судоргина

УДК $373.3+612$

\title{
КОМПЛЕКСНАЯ ОЦЕНКА ЗДОРОВЬЕСБЕРЕГАЮЩЕЙ ДЕЯТЕЛЬНОСТИ СОВРЕМЕННОГО ОБЩЕОБРАЗОВАТЕЛЬНОГО УЧРЕЖДЕНИЯ
}

\author{
Л. В. Судоргина (Новосибирск, Россия)
}

Высокий уровень патологии здоровья школьников указывает на приоритетность решения проблемы здоровья подрастающего поколения для современной школь. Настало время для объединения усилий всех заинтересованных структур для совместной деятельности по охране здоровья подрастающего поколения. При помощи мониторинга проводится выявление и оценивание проведенных педагогических действий. Программа мониторинга гуманитарной образовательной среды предполагает реализачию личностно-ориентированного подхода, так как в центре внимания находится человек как личность, человек в самых сущностных, самых человечных своих проявлениях.

Задачи мониторинга:

- экспертиза различных направлений деятельности образовательного учреждения;

- экспертное оченивание качества образования, соответствие образовательному стандарту;

- исследование педагогического и управленческого профессионального мастерства;

- психологическая, педагогическая и медицинская диагностика участников образовательного прочесса.

Начинать мониторинг необходимо с самоанализа форм и методов здоровьесберегающей деятельности и здоровьесберегающего потенщиала образовательного учреждения.

Ключевые слова: здоровье школьников, мониторинг, образовательная среда, оченка деятельности образовательного учреждения.

Крайне высокий уровень патологии здоровья школьников указывает на приоритетность решения проблемы здоровья подрастающего поколения для современной школы. Практика показывает, что решить данную проблему одной медицине не под силу. Поэтому в соответствии с государственной политикой часть этой работы обязаны взять на себя образовательные учреждения в соответ- ствии с Законом об образовании и Концепцией модернизации российского образования, которая предусматривает «создать в образовательных учреждениях условия для сохранения и укрепления здоровья обучающихся».

Настало время для объединения усилий всех заинтересованных структур для совместной деятельности по охране здоровья подрастающего поколения. Значительную

Судоргина Любовь Вилениновна - учитель географии высшей квалификационной категории, заслуженный учитель России, директор, МБОУ Гимназия № 14 «Университетская».

E-mail: lubov_sudorgina@mail.ru 
Вестник Новосибирского государственного педагогического университета Novosibirsk State Pedagogical University Bulletin

роль в этой деятельности должна сыграть школа, которой предстоит сформировать у детей новую философию жизни, цель которой здоровый образ жизни, жизнь без вредных привычек. Каждый ребенок должен понимать, что здоровье в его руках и от этого зависит вся будущая жизнь, ведь «в здоровом теле - здоровый дух». Разве мы можем противоречить этой истине? Давно известно: «посеешь поступок - пожнешь привычку, посеешь привычку - пожнешь характер, посеешь характер - пожнешь судьбу». В целом мы можем говорить о создании нового направления в педагогике - здоровьесберегающей педагогики. Понимая под здоровьесберегающей педагогикой - образовательную систему, провозглашающую приоритет культуры здоровья, которую необходимо воспитывать у всех участников образовательного проиесса (учащчихся, учителей, родителей); обеспечивающую ее реализачию при организачии обучения и воспитания, в содержании учебных программ и в создании инфраструктуры школьного пространства.

Ведущей задачей современности становится качество образовательного процесса и в связи с этим инновационные процессы, охватившие образовательное пространство нашей страны диктуют и новые подходы к организации педагогического мониторинга, прежде всего, мониторинга здоровьесберегающей деятельности образовательного учреждения. Своевременное выявление позитивных и негативных явлений в педагогической системе позволяет быстро реагировать на них, изменяя тактику при сохранении общих направлений образовательной стратегии. При помощи мониторинга проводится выявление и оценивание проведенных педагогических действий. При этом обеспечивается обратная связь, показывающая соответствие фактиче- ских результатов деятельности педагогической системы ее целям.

Образовательным учреждениям дано право выбора образовательной программы, использования различных педагогических технологий, учебно-методических комплексов, но вместе с тем проблема сохранения духовного и физического здоровья каждого ученика остается актуальной. Модернизация образования, принявшая форму широкомасштабного общенационального эксперимента, сделала как никогда актуальным вопрос и об оценке эффективности проводимых инноваций с точки зрения здоровьесберегающей педагогики. Конечная цель оценки эффективности и качества работы школы заключается в том, чтобы помочь педагогическому коллективу выявить не только истоки затруднений, но и сильные стороны, возможности роста, ресурсы развития здоровьесберегающего пространства.

Значимость внедрения мониторинга здоровья обучающихся в образовательных учреждениях подтверждается Приказом Министерства образования и науки РФ от 12.01.07, в котором ставится задача организации и проведения ежегодного мониторинга здоровья обучающихся, воспитанников образовательных учреждений. Организация мониторинга здоровьесберегающей деятельности нашего образовательного учреждения опирается на современные научные теории и нормативно-правовую базу:

- здоровьесберегающие технологии в общеобразовательной школе, качественная система оценки деятельности образовательных учреждений по охране и укреплению здоровья (М.М. Безруких [1-2]);

- формирование культуры здоровья в развивающейся образовательной среде, опыт 
Вестник Новосибирского государственного педагогического университета Novosibirsk State Pedagogical University Bulletin

реализации проекта в различных регионах России [3-8];

- санитарно-эпидемилогические правила (2.4.2.1178-02), Междисциплинарная программа «Здоровье» для средних общеобразовательных учреждений, Практические рекомендации по организации системной комплексной работы по сохранению и укреплению здоровья подростков в образовательной среде, оздоровительная программа г. Новосибирска «Здоровый город» и др.

«Все, что мы несем детям и что может повлиять на их судьбу, подлежит проверке судом совести, согласно императиву: "Не вреди!». И здесь он должен быть строже, чем во врачевании...» Г.С. Батищуев

\section{Модель службы мониторинга}

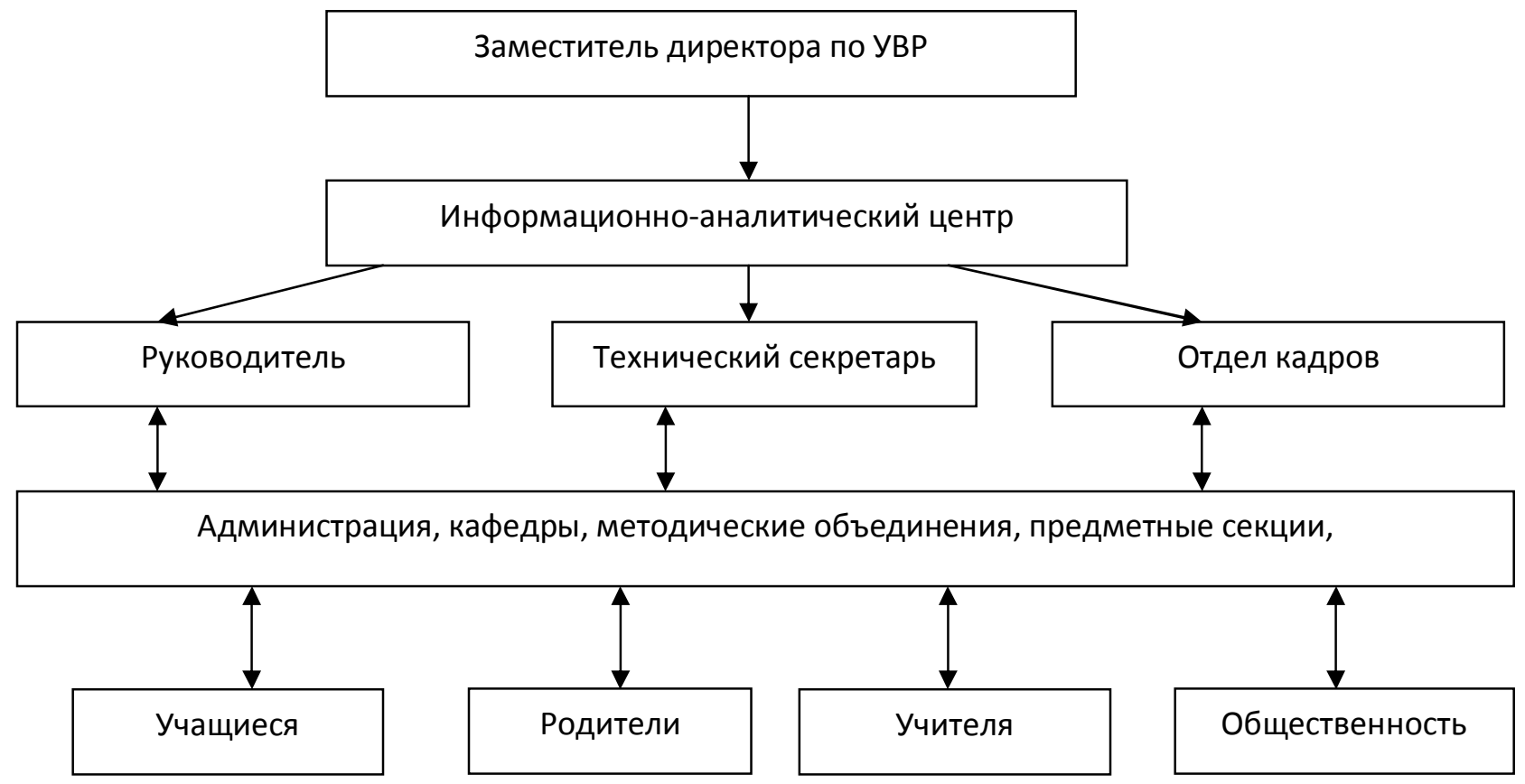

В гимназии № 14 «Университетская» разработана и внедрена концепция и программа мониторинга гуманитарной образовательной среды, осуществление которой предполагает реализацию личностно-ориентированного подхода, т.к. в центре внимания находится человек как личность, человек в самых сущностных, самых человечных своих проявлениях [9-10]. Полноценное изучение образовательной среды должно осуществляться, прежде всего, по базовым гуманитарным, общечеловеческим критериям, которые 
Вестник Новосибирского государственного педагогического университета Novosibirsk State Pedagogical University Bulletin

в каждом конкретном случае должны дополняться соответствующими частными показателями: уровнем знаний и умений, уровнем развития отдельных психических функций и т.П. Современное образование, провозглашающее демократические ценности заинтересовано в изучении сферы образования на предмет ее «гуманитарной полноценности». Мониторинг гуманитарной образовательной среды социально-ориентирован на тот социум, который окружает данное образовательное учреждение. Таким образом, центральной определяющей «сферой интересов» педагогического мониторинга гуманитарной образовательной среды является ребенок, его жизнь, здоровье и развитие.

Цель мониторинга - получение объективной информации, анализ и прогнозирование состояния гуманитарной образовательной среды в соответствии с концепцией развития гимназии до 2020 г.

\section{Задачи:}

- экспертиза различных направлений деятельности образовательного учреждения;

- экспертное оценивание качества образования, соответствие образовательному стандарту;

- исследование педагогического и управленческого профессионального мастерства;

- психологическая, педагогическая и медицинская диагностика участников образовательного процесса;

- оценка инновационной деятельности образовательного учреждения.

\section{Уровни мониторинга}

(под уровнями мониторинга понимается система организационных форм и методов изучения особенностей образовательного процесса, индивидуальных особенностей учашихся)

1 уровень - учителя, классные руководители, руководители доп. образования;

2 уровень - предметные секции, методические объединения, кафедры;

3 уровень - общегимназический: администрация, функциональные службы гимназии

А начинать необходимо с самоанализа форм и методов здоровьесберегающей деятельности и здоровьесберегающего потенциала образовательного учреждения. Методические рекомендации под ред. М.М. Безруких, В.Д. Сонькина [2].

Такой анализ позволяет создать школьную программу здоровья, отвечающую современным требованиям конкретного образовательного учреждения, учитывающую специфику данного образовательного учреждения и способствующую естественному развитию учеников.

Для анализа здровьесберегающего потенциала образовательного учреждения, также используем рекомендации института возрастной физиологии РАО. Алгоритм здоровьесберегающего потенциала образовательного учреждения сравнивается с предложенными в анкете критериями, соответствующими каждому баллу. Далее баллы по всем пунктам суммируются, и определяется суммарный балл. 


1(17) $2014 \quad$ www.vestnik.nspu.ru ISSN 2226-3365

\section{Схема}

экспертного анализа форм и методов здоровьесберегающей деятельности образовательного учреждения

\section{Предварительный мониторинг}

\section{•анализ инфраструктуры и внутришкольной среды \\ -анализ организации учебного процесса \\ -анализ организации двигательного режима и физкультурно- оздоровительной работы}

•анализ организации работы по формированию ценности здоровья

и здорового образа жизни

•анализ состояния медицинской помощи, состояния здоровья школьников

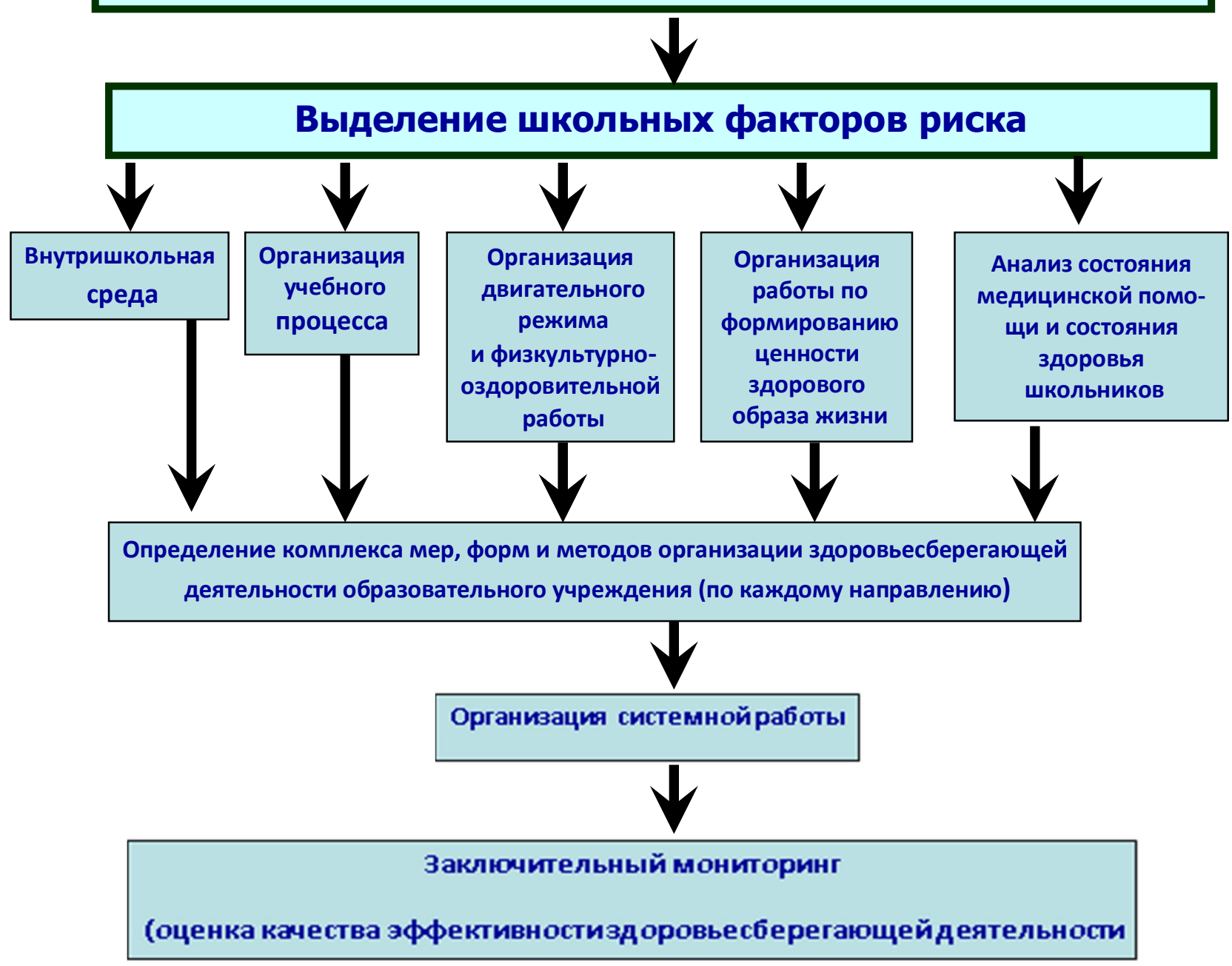




1(17) $2014 \quad$ www.vestnik.nspu.ru ISSN 2226-3365

Анализ здоровьесберегающей инфраструктуры образовательного учреждения свидетельствует о том, что гимназия обладает достаточными ресурсами для развития здоровьесберегающего процесса.

Для углубленного анализа здоровьесберегающей деятельности образовательного учреждения, оценки проводимых здоровьесберегающих мероприятий мы осуществляем качественную систему оценки деятельности гимназии по охране и укреплению здоровья участников образовательного процесса, которая представлена в следующей таблице:

\section{Мониторинг здоровьесберегающего процесса}

Цель: анализ состояния и условий здоровьесберегающего пространства гимназии

\begin{tabular}{|c|c|c|c|c|}
\hline Направления & Показатели & $\begin{array}{c}\text { Диагностические } \\
\text { средства }\end{array}$ & $\begin{array}{l}\text { Испытуемые/ } \\
\text { экспертыл }\end{array}$ & $\begin{array}{c}\text { Использование } \\
\text { результатов }\end{array}$ \\
\hline $\begin{array}{l}\text { Эффективность } \\
\text { здоровьесбере- } \\
\text { гающей дея- } \\
\text { тельности гим- } \\
\text { назии }\end{array}$ & $\begin{array}{c}\text { Рациональная организа- } \\
\text { ция учебного процесса } \\
\text { Рациональная организа- } \\
\text { ция режима дня } \\
\text { Состояние здоровья, из- } \\
\text { менения функционально- } \\
\text { го состояния, напряжен- } \\
\text { ности и текущей заболе- } \\
\text { ваемости } \\
\text { Характеристика физиче- } \\
\text { ского развития и физиче- } \\
\text { ской подготовленности } \\
\text { Изменение отношения } \\
\text { детей к своему здоровью, } \\
\text { здоровому образу жизни }\end{array}$ & $\begin{array}{c}\text { Качественная система } \\
\text { оценки деятельности } \\
\text { образовательных } \\
\text { учреждений по } \\
\text { охране и укреплению } \\
\text { здоровья (М.М. Без- } \\
\text { руких, М., 2005) }\end{array}$ & $\begin{array}{c}\text { Учителя, родителя, } \\
\text { учащиеся 1-11 клас- } \\
\text { сов / заместитель } \\
\text { директора по учеб- } \\
\text { но-воспитательной } \\
\text { работе и функичо- } \\
\text { нальные службы } \\
\text { гимназии }\end{array}$ & $\begin{array}{l}\text { Педагогический совет, } \\
\text { семинары различных } \\
\text { уровней, методические } \\
\text { объединения и предмет- } \\
\text { ные секции учителей- } \\
\text { предметников, совет при } \\
\text { директоре, индивидуаль- } \\
\text { ные собеседования, ана- } \\
\text { литический отчет, роди- } \\
\text { тельское собрание, ро- } \\
\text { дительская конференция. }\end{array}$ \\
\hline
\end{tabular}

Такой анализ позволяет создать школьную программу здоровья, отвечающую совре- менным требованиям конкретного образовательного учреждения 


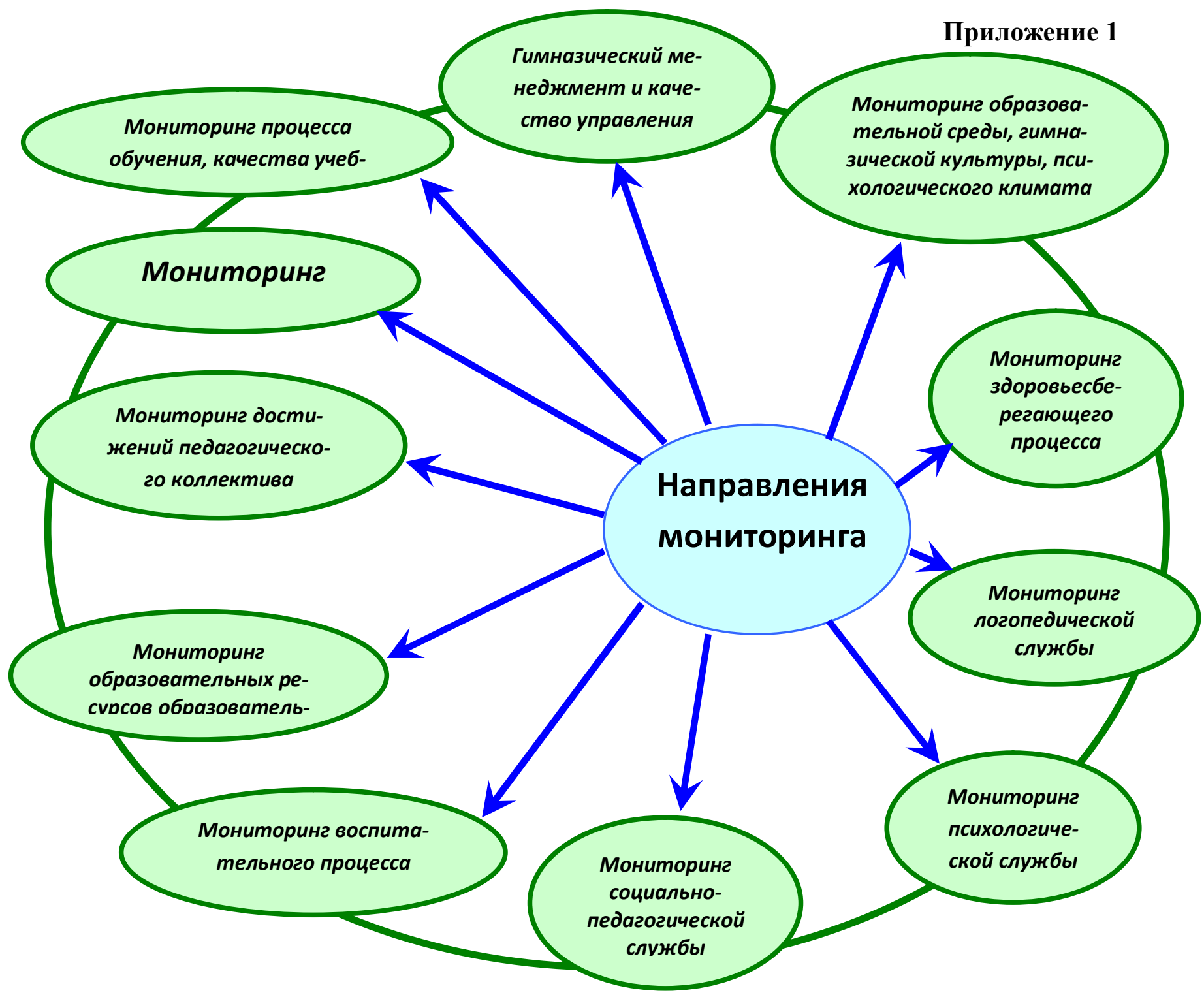


Вестник Новосибирского государственного педагогического университета Novosibirsk State Pedagogical University Bulletin

\section{СПИСОК ЛИТЕРАТУРЫ}

1. Безруких М.М. Школьные факторы риска и здоровье детей // Магистр. - 1999. - № 3. C. 30-38.

2. Безруких М.М., Сонькин В.Д., Фарбер Д.А. Возрастная физиология: учеб. пособ. - М.: Изд-во ACADEMA, 2002. - 415 с.

3. Айзман Р.И. Здоровье педагогов и обучающихся - ключевая задача современной школы // Вестник Новосибирского государственного педагогического университета. - 2012. № 3(7). - С. 24-35.

4. Айзман Р. И., Айзман Н.И., Лебедев А.В., Плетнёва Е.Ю., Рубанович В.Б. Мониторинг здоровья учащихся и педагогов с применением компьютера и программных средств // Народное образование. - 2010. - № 6. - С.147-155.

5. Борцова О. А. Медико-социальные аспекты обучения школьников правильному образу жизни // Философия образования. - 2006. - № 1. - С. 211-214.

6. Епоян Т.Г., Плахутина Ю.Б. Фактологический обоснованный подход к профилактическому образованию // Вестник Новосибирского государственного педагогического университета. - 2012. - № 5. - С. 5-13.

7. Казин Э. М., Касаткина Н. Э., Руднева Е. Л. и др. Здоровьесберегающая деятельность в системе образования: теория и практика: учебное пособие / 3-е изд., перераб. - М.: Издательство «Омега-Л», 2013. - 443 с.

8. Шуленина Н.С., Корощенко Г.А., Терехова Э.А., Лысова Н.Ф. Анализ состояния здоровья школьников МКОУ Доволенской СОШ №1 Новосибирской области // Вестник Новосибирского государственного педагогического университета. - 2012. - № 5. - С. 58-66.

9. Пушкарёва Е.А., Судоргина Л.В. Культура самоопределения: адаптационные механизмы личности // Вестник Новосибирского государственного педагогического университета. 2012. - № 4. - С. 80-87.

10. Судоргина Л.В. Здоровьесберегающие аспекты раздельно-параллельного образования // Вестник Новосибирского государственного педагогического университета - 2012. - № 3. C. 36-42. 


\section{COMPLEX ESTIMATION HEALTH PROTECTION ACTIVITY OF MODERN EDUCATIONAL ESTABLISHMENT}

\section{V. Sudorgina (Novosibirsk, Russia)}

The high level of a pathology of health of schoolboys specifies on Priority of decisions of a problem of health of rising generation for modern school. Time for association of efforts of all interested structures for joint activity on health protection of rising generation has come. By means of monitoring revealing and Estimation of the lead pedagogical actions is spent. The program of monitoring of the humanitarian educational environment assumes realization of the person-focused approach as in the center of attention there is a person as the person, the person in the most intrinsic, most human displays.

Problems of monitoring:

- Examination of various directions of activity of educational establishment;

- Expert Estimation of qualities of education, conformity to the educational standard;

- Research of pedagogical and administrative professional skill;

- Psychological, pedagogical and medical diagnostics of participants of educational process.

To begin monitoring it is necessary from introspection of forms and methods of Health protection for activity and Health protection of potential of educational establishment.

Keywords: health of schoolboys, monitoring, the educational environment, an estimation of activity of educational establishment.

\section{REFERENCES}

1. Bezrukih M.M. Shkol'nye faktory riska i zdorov'e detei [Shool risk factors and health of children]. The Magister, 1999, no. 3, pp. 30-38.

2. Bezrukih M.M., Sonkin V.D., Farber D.A. Vozrastnaya fiziologiya [Age physiology]. Moscow, Publishing House of the ACADEMA, 2002, 415 p.

3. Aizman R.I. Zdorov'e pedagogov i obuchayushchikhsya - klyuchevaya zadacha sovremennoi shkoly [Health of teachers and pupils - a key problem of modern school]. Novosibirsk State Pedagogical University Bulletin, 2012, no. 3, pp. 24-35.

4. Aizman R.I., Aizman N.I., Lebedev A.V., Pletneva E.Yu., Rubanovich V.B. Monitoring zdorov'ya uchashchikhsya i pedagogov s primeneniem komp'yutera i programmnykh sredstv [Monitoring of health of pupils and teachers with application of a computer and software]. National education, 2010, no. 6, pp. 147-155.

5. Bortsova O.A. Mediko-sotsial'nye aspekty obucheniya shkol'nikov pravil'nomu obrazu zhizni [Medicine and social aspects of training of pupils to a correct way of life]. Philosophy of education, 2006, no. 1, pp. 211-214. 
6. Epoyan T.G., Plakhutina Yu.B. Faktologicheskii obosnovannyi podkhod k profilakticheskomu obrazovaniyu [The factological proved approach to preventive education and use of informationcommunication technologies in informal education]. Novosibirsk State Pedagogical University Bulletin, 2012, no. 5, pp. 5-13.

7. Kazin Э.M., Kasatkina D.C., Rudneva E.L., etc. Zdorov'esberegayushchaya deyatel'nost' v sisteme obrazovaniya: teoriya i praktika [Healthcare activity in an education system: the theory and practice]. Moscow, Publishing house "Omega-1", 2013, 443 p.

8. Shulenina N.S., Koroshchenko G.A., Terehova I.A., LysovaN.F. Analiz sostoyaniya zdorov'ya shkol'nikov MKOU Dovolenskoi SOSh №1 Novosibirskoi oblasti [The analysis of the state of health of schoolchildren of Dovolenskaya school №1 of Novosibirsk region]. Novosibirsk State Pedagogical University Bulletin, 2012, no. 5, pp. 58-66.

9. Pushkareva E.A., Sudorgina L.V. Kul'tura samoopredeleniya: adaptatsionnye mekhanizmy lichnosti [Culture of self-determination: adaptable mechanisms of the person]. Novosibirsk State Pedagogical University Bulletin, 2012, no. 4, pp. 80-87.

10. Sudorgina L.V. Zdorov'esberegayushchie aspekty razdel'no-parallel'nogo obrazovaniya [Health protection aspects of separate and parallel education]. Novosibirsk State Pedagogical University Bulletin, 2012, no. 3, pp. 36-42.

Sudorgina Lubov Vileninovna, the teacher of the maximum qualifying category, the deserved teacher of Russia, the Grammar School 14 «University».

E-mail: Lubov_sudorgina@mail.ru 


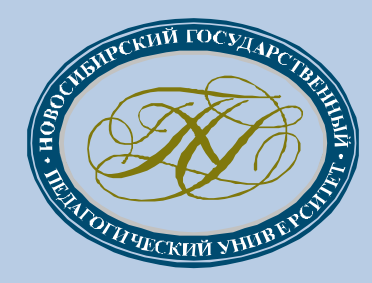

www.vestnik.nspu.ru

\section{БИОЛОГИЧЕСКИЕ, ХИМИЧЕСКИЕ, МЕДИЦИНСКИЕ НАУКИ}

Физическое и психическое здоровье студентов и педагогов 
Вестник Новосибирского государственного педагогического университета Novosibirsk State Pedagogical University Bulletin

1(17) $2014 \quad$ www.vestnik.nspu.ru ISSN 2226-3365

(C) А. В. Кабачкова, Л. В. Капилевич

УДК 314.144+ 614

\title{
МОНИТОРИНГ ЗДОРОВЬЯ СТУДЕНТОВ ВУЗА: ОРГАНИЗАЦИОННЫЕ И МЕТОДИЧЕСКИЕ ПРОБЛЕМЫ*
}

\author{
А. В. Кабачкова, Л. В. Капилевич (Томск, Россия)
}

\begin{abstract}
В статье рассматривается явление мониторинга в различных сферах деятельности человека, возможности использования мониторинга как способа исследования. Особое место отводится мониторингу в области физического воспитания и здоровья обучающихся. Здесь понятие «мониторинг» определено и принимается большинством научного сообщества, его статус закреплен на законодательном уровне. Примером служит общероссийский мониторинг состояния физического здоровья населения, физического развития детей, подростков и молодежи. Цель статьи - обобщить опыт современных исследований и выявить основные проблемы, возникаютие при организации мониторинга здоровья студентов.
\end{abstract}

Ключевые слова: организачия мониторинга, информативные показатели, стандарт, частота тестирования.

В настоящее время мониторинг как специфический вид научного исследования охватил самые различные сферы деятельности людей: экологию, социологию, психологию, политику, экономику, образование. Границы использования мониторинга за последнее десятилетие чрезвычайно расширились. Есть основания говорить, что осталось достаточно мало областей деятельности, где в той или иной мере не использовался бы мониторинг. Само понятие «мониторинг» представляет интерес с точки зрения его теоретического анализа, так как не имеет точного однозначного толкования, ибо изучается и используется в рамках различных сфер научно-практической деятельности [1-4]. Мониторинг можно рассматривать как способ исследования реальности, который используется в различных науках, и как способ обеспечения сферы управления различными

* Статья подготовлена по результатам работы Всероссийской научной школы с Международным участием «Опыт использования мониторинга здоровья и физической подготовленности учащейся молодежи» (12-14 ноября 2013 г.).

Кабачкова Анастасия Владимировна - кандидат биологических наук, доцент кафедры спортивно-оздоровительного туризма, спортивной физиологии и медицины, Томский государственный университет.

E-mail: avkabachkova@gmail.com

Капилевич Леонид Владимирович - доктор медицинских наук, профессор, заведующий кафедрой спортивно-оздоровительного туризма, спортивной физиологии и медицины, Томский государственный университет.

E-mail: kapil@yandex.ru 
Вестник Новосибирского государственного педагогического университета Novosibirsk State Pedagogical University Bulletin

1(17) $2014 \quad$ www.vestnik.nspu.ru ISSN 2226-3365

видами деятельности посредством представления своевременной и качественной информации. Если диагностика ситуации осуществляется систематически с определенной заданной периодичностью и с использованием одной и той же (во всяком случае, базовой) системы индикаторов, мы имеем дело с мониторингом. Различия же в толковании сущности мониторинга, в целеполагании и средствах его осуществления отражают специфику и уровень разработанности проблем мониторинга в каждой из областей его применения [1].

Различные системы мониторинга, обладая общими чертами, существуют и развиваются достаточно изолировано в рамках той или иной науки или области управления. Можно отметить, что степень изученности и интенсивность использования его в различных сферах деятельности неравнозначны. На сегодняшний день можно говорить и об определенном уровне зрелости в решении проблем мониторинга, как на прикладном, так и на теоретическом уровнях в сфере физического воспитания [5-7]. Здесь понятие «мониторинг» определено и принимается большинством научного сообщества [8-11]. Статус мониторинга закреплен на законодательном уровне. Примером служит общероссийский мониторинг состояния физического здоровья населения, физического развития детей, подростков и молодежи, который представляет собой систему мероприятий по наблюдению, анализу, оценке и прогнозу состояния физического здоровья населения, физического развития детей, подростков и молодежи ${ }^{1}$.

\footnotetext{
${ }^{1}$ Об общероссийской системе мониторинга состояния физического здоровья населения, физического развития детей, подростков, молодежи: Постановление Правительства Российской Федерации от 29 декабря 2001 г. № 916.
}

Современные системы мониторинга представляют собой постоянные динамические наблюдения интересующих групп населения, с целью получения дополнительной информации. Результаты, получаемые в ходе таких наблюдений, помогают в решении поставленных задач. Поэтому организация мониторинга в сфере физического воспитания обеспечивает анализ причинно-следственных связей между: физическим состоянием детей, подростков и молодежи; факторами среды обитания человека и социальноэкономическими условиями жизни населения; прогнозирование динамики наблюдаемых явлений на уровне субъектов Российской Федерации. В настоящее время можно отметить лишь спонтанную деятельность в области осуществления мониторинга. Существует многочисленный опыт работы в этом направлении в различных городах Российской Федерации (Москва, Санкт-Петербург, Нальчик, Новосибирск, Иркутск, Екатеринбург, Казань, Волгоград, Сургут, Ульяновск, Тула, Челябинск, Томск, Кемерово, Мурманск и др.), но недостаточно проработан методологический аппарат осуществления мониторинга.

\section{Проблемы организации мониторинга} носят не только общий характер, но и имеют свою специфику, учитывая особенности функций мониторинга в образовательных учреждениях. Одна из таких общих и наиболее значимых проблем - определение содержания мониторинга, которое, по-видимому, должно быть единым для всех уровней. Совершенно очевидно, что одно из самых необходимых требований в данном случае - выбор таких характеристик (и соответственно методик для оценивания), которые бы в достаточно полной и объективной мере отражали состояние именно физического здоровья 
Вестник Новосибирского государственного педагогического университета Novosibirsk State Pedagogical University Bulletin

1(17) $2014 \quad$ www.vestnik.nspu.ru ISSN 2226-3365

обследуемых. Многочисленные исследования так и не дали окончательно ответа на вопрос: «Как и с каким набором тестов и измерений целесообразно проводить обследования испытуемых?». Трудность решения этого вопроса связана с целым рядом проблем - отсутствием концепции по содержанию и экономическому обоснованию системы мониторинга; попыткой решать задачу с позиций одной специальности - педагогики, медицины, биологии, физиологии и т.д.; появлением новых работ, расширяющих возможности обследования. Желание одних авторов максимально расширить набор тестов и измерений делает систему громоздкой, дорогостоящей и малопригодной для массовых обследований. Другая крайность - использование 2-3 тестов не позволяет объективно оценить уровень физического состояния [12-17].

Мониторинг и осуществляемая на его основе оценка будут настолько эффективны, насколько корректно заданы стандарты и нормы. Норма - одно из самых необходимых условий и оснований мониторинга, так как только при наличии нормы становится возможным сравнение получаемых результатов. Следует заметить, что мониторинг - не только процесс выявления отклонений от стандартов и норм, но и основа для их пересмотра.

Чрезвычайно важно, чтобы в образовательном учреждении была возможность снять требуемые показатели. А это предполагает наличие определенного инструментария (если используются инструментальные методики) и подготовленного персонала.

И следующее, что так же, как и предыдущее требование, носит специфический характер, - это возможность в условиях образовательного учреждения использовать получаемую в результате проведения мониторинга информацию с целью коррекционного воз- действия на отклонения, выявляемые в состоянии физического здоровья. Большое значение в данном случае имеет привязка результатов мониторинга к преподаваемым в образовательном учреждении учебным предметам.

Обобщение опыта и проведенные исследования показывают, что при большом разнообразии в подходах и способах разных авторов оценка физического состояния сводится к анализу показателей антропометрии, физической подготовленности, функционального состояния и адаптационных резервов сердечно-сосудистой и дыхательной систем, биохимических показателей, образа жизни. Однако большинство предложенных диагностических систем дают неодинаковые оценки. Несмотря на это организация регулярного контроля динамики развития физических качеств и оптимизация содержания этой деятельности является важной задачей.

На сегодняшний день разработаны различные информационно-аналитические системы мониторинга, нацеленные главным образом на оценку индивидуальных и среднегрупповых показателей уровня развития основных физических качеств или функционального состояния организма студентов специальной медицинской группы. Например, научно-методические принципы мониторинга функционального состояния организма базируются на оценке состояний, на грани нормы и патологии и направлены не на поиск болезни, а на установление степени адаптивного состояния индивида.

Организация мониторинга в образовательном учреждении, как отмечалось выше, - процедура достаточно сложная. Во-первых, необходимо определить основные задачи, решение которых будет осуществляться с помощью результатов его результатов. Веро- 
Вестник Новосибирского государственного педагогического университета Novosibirsk State Pedagogical University Bulletin

1(17) $2014 \quad$ www.vestnik.nspu.ru ISSN 2226-3365

ятной целью будет являться получение нового взгляда и расширение понимания здоровья обучающихся, благополучия и поведения, влияющего на здоровье в социальном контексте. Теоретико-методологическую основу мониторинга должны составлять труды отечественных и зарубежных ученых в области физиологических, нейрофизиологических аспектов формирования психической, двигательной деятельности и индивидуальности человека; методологии внедрения здоровьесберегающих технологий; индивидуальных оздоровительных программ по коррекции состояний; методологии интегральных компьютерных систем, включающих аппаратно-программный комплекс и математическое моделирование.

Во-вторых, определить частоту тестирования и количество тестов, простых в использовании и имеющих высокую корреляцию с основными показателями здоровья. С учетом непосредственной связи мониторинга с учебным процессом, тестирование наиболее целесообразно проводить дважды - в начале и в конце учебного года. Наиболее приемлемые сроки проведения осеннего мониторинга - середина октября. К этому времени завершаются процессы острой адаптации организма студентов у учебной деятельности и их работоспособность входит в стабильный режим, что позволяет получать более надежные результаты. Для проведения весеннего этапа мониторинга оптимальной является середина апреля, когда сезонная перестройка организ- ма, связанная с переходом от зимнего к весенне-летнему сезону, уже завершается, а накопившееся за учебный год утомление еще не препятствует решению большинства задач мониторинга. При невозможности осуществлять мониторинг два раза в год, можно ограничиться однократным его проведением весной, по итогам учебного года. Доступные и информативные показатели должны характеризовать не только уровень физической подготовленности, но и функциональное состояния и физическое развитие. Целесообразно включить в систему мониторинга следующие блоки: теоретические вопросы, двигательные умения и навыки, тесты на определение уровня физической подготовленности, гармоничность физического развития, показатели здоровья и функционального состояния, критерии уровня физической активности и здорового образа жизни.

В-третьих, мониторинг и осуществляемая на его основе оценка будут настолько эффективны, насколько корректно заданы стандарты и нормы. Как отмечено выше, мониторинг может служить основой для пересмотра имеющихся стандартов.

Получение комплексной информации по итогам мониторинга показателей здоровья и физической культуры студенческой молодежи позволит оптимизировать оценку эффективности и коррекции содержания применяемых в образовательных учреждениях программ физического воспитания.

\section{СПИСОК ЛИТЕРАТУРЫ}

1. Мониторинг как практическая система. - М., 2002.

2. Бакаев В. А. Современное состояние мониторинга малых озер Новосибирской области по данным геохимического и трофического мониторинга // Вестник Новосибирского государственного педагогического университета. - 2013. - № 2(12). - С. 49-58. 
Вестник Новосибирского государственного педагогического университета Novosibirsk State Pedagogical University Bulletin

1(17) $2014 \quad$ www.vestnik.nspu.ru ISSN 2226-3365

3. Латуха О. А., Пушкарёв Ю. В. Роль высших учебных заведений в создании инноваций // Вестник Новосибирского государственного педагогического университета. - 2013. № 3(13). - C. 66-72.

4. Чанчаева Е. А., Айзман Р. И., Герасёв А. Д. Современное представление об антиоксидантной системе организма человека // Экология человека. - 2013. - № 7. - С. 50-58.

5. Айзман Р. И. Здоровье педагогов и обучающихся - ключевая задача современной школы // Вестник Новосибирского государственного педагогического университета. - 2012. № 3(7). - C. 24-35.

6. Борцова О. А. Медико-социальные аспекты обучения школьников правильному образу жизни // Философия образования. - 2006. - № 1. - С. 211-214.

7. Рубанович В. Б., Айзман Р. И. Основы здорового образа жизни: учебное пособие. - Новосибирск: АРТА, 2011.-256 с.

8. Айзман Р. И., Айзман Н. И., Рубанович В. Б., Лебедев А. В. Методика комплексной оценки здоровья учащихся общеобразовательных школ: методическое пособие. - Новосибирск: Изд. ООО Рекламно-издательская фирма «Новосибирск», 2008. -124 с.

9. Айзман Р. И., Айзман Н. И., Лебедев А. В., Рубанович В. Б. Методика комплексной оценки физического и психического здоровья, физической подготовленности студентов высших и средних профессиональных учебных заведений: метод. пособ. - Новосибирск: Изд. «РИФ Новосибирск». 2009 - 100 с.

10. Ондар А. О., Айзман Р. И., Будук-оол Л. К., Шыырапай У. И. Скрининговая оценка уровня здоровья студентов-первокурсников Тувинского государственного университета // Вестник Костромского государственного университета им. Н. А. Некрасова, 2013. T. 19. - № 1. - C. 101-105.

11. Тихонова И. Л., Латуха О. А. Инновации медицинского вуза в обучении студентов // Медицина и образование в Сибири. - 2009. - № 1. - С. 2.

12. Айзман Р. И., Айзман Н. И., Лебедев А. В., Рубанович В. Б. Компьютерная программа скрининг контроля состояния здоровья участников образовательного процесса // Сибирский учитель. - 2011. - №2(75). - С. 36-39.

13. Айзман Р. И., Айзман Н. И., Лебедев А.В., Плетнёва Е. Ю., Рубанович В. Б. Мониторинг здоровья учащихся и педагогов с применением компьютера и программных средств // Народное образование. - 2010. - № 6. - С.147-155.

14. Айзман Р. И., Айзман Н. И., Рубанович В. Б., Лебедев А. В. Принципы и алгоритмы мониторинга здоровья учащихся и студентов // Сибирское медицинское обозрение. - 2009. № 3(57) - С. 101-103.

15. Айзман Р. И., Плетнёва Е. Ю. Роль учителя в формировании и мониторинге здоровья обучающихся // Здоровьесберегающее образование. - 2010. - № 5(9). - С. 93-99.

16. Рубанович В. Б., Айзман Р. И. Мониторинг физического здоровья школьников в процессе физкультурно-оздоровительной и спортивной деятельности // Здоровьесберегающее образование. - 2010. - № 1(5). - С. 97-100.

17. Гаврилов Д. Н., Комков А. В., Малинин А. В. и др. Особенности мониторинга физического состояния населения // Теория и практика физической культуры. - 2006. - № 3. C. $60-62$. 
Вестник Новосибирского государственного педагогического университета Novosibirsk State Pedagogical University Bulletin

1(17) $2014 \quad$ www.vestnik.nspu.ru ISSN 2226-3365

(C) A. V. Kabachkova, L. V. Kapilevich

\title{
UDC 314.144+614
}

\section{MONITORING OF STUDENTS' HEALTH: ORGANIZATIONAL AND METHODICAL PROBLEMS}

\author{
A. V. Kabachkova, L. V. Kapilevich (Tomsk, Russia)
}

The article deals with the phenomenon of monitoring in various fields of human activity, the possibility of using monitoring as a way to study. Special attention is paid to the monitoring of physical education and health of students. Here the concept of "monitoring" is defined and accepted by the majority of the scientific community, its status is enshrined in law. An example is the all-Russian monitoring of physical health, physical development of children, adolescents and young adults. The purpose of article is to summarize the experience of current research and identify key issues for the organization of monitoring the health of students.

Keywords: organization of monitoring, informative indicators, the standard, frequency of testing.

\section{REFERENCES}

1. Monitoring kak prakticheskaya sistema [Monitoring as a practical system]. Moscow, 2002.

2. Bakaev V.A. Sovremennoe sostoyanie monitoringa malykh ozer Novosibirskoi oblasti po dannym geokhimicheskogo i troficheskogo monitoringa [Current condition of small lakes of Novosibirsk region according to geochemical and trophic monitoring]. Novosibirsk State Pedagogical University Bulletin, 2013, no. 2, pp. 49-58.

3. Latukha O.A., Pushkarev Yu.V. Rol' vysshikh uchebnykh zavedenii v sozdanii innovatsii [Role of higher educational institutions in creation of innovations]. Novosibirsk State Pedagogical University Bulletin, 2013, no. 3, pp. 66-72.

4. Chanchaeva E.A., Aizman R.I., Gerasev A.D. Sovremennoe predstavlenie ob antioksidantnoi sisteme organizma cheloveka [Modern representation about antyoxygen to system of an organism of the person]. Ecology of the person, 2013, no. 7, pp. 50-58.

5. Aizman R.I. Zdorov'e pedagogov i obuchayushchikhsya - klyuchevaya zadacha sovremennoi shkoly [Health of teachers and schoolchildren is a key problem of modern school]. Novosibirsk State Pedagogical University Bulletin, 2012, no. 3, pp. 24-35.

6. Bortsova O.A. Mediko-sotsial'nye aspekty obucheniya shkol'nikov pravil'nomu obrazu zhizni [Medicine and social aspects of training of pupils to a correct way of life]. Philosophy of education, 2006, no. 1, pp. 211-214.

7. Rubanovich V.B., Aizman R.I. Osnovy zdorovogo obraza zhizni: uchebnoe posobie [Bases of a healthy way of life]. Novosibirsk, 2011, 256 p.

8. Aizman R. I., Aizman N.I., Rubanovich V.B., Lebedev A. Metodika kompleksnoi otsenki zdorov'ya uchashchikhsya obshcheobrazovatel'nykh shkol [Technique of a complex estimation of health of pupils of comprehensive schools], Novosibirsk, 2008, $124 \mathrm{p}$.

9. Aizman R.I., Aizman N.I., Lebedev A.V., Rubanovich V.B. Metodika kompleksnoi otsenki fizicheskogo i psikhicheskogo zdorov'ya, fizicheskoi podgotovlennosti studentov vysshikh i srednikh 
professional'nykh uchebnykh zavedenii [Methodology comprehensive assessment of physical and mental health, physical fitness of students of higher and secondary vocational schools: the method. Benefits]. Novosibirsk, 2009, 100 p.

10. Ondar A.O., Aizman R.I., Buduk-ool L.K., Shyyrapai Skriningovaya otsenka urovnya zdorov'ya studentov-pervokursnikov Tuvinskogo gosudarstvennogo universiteta [Screening estimation of a level of health of students-first-year students of the Tuva State University]. Bulletin of Kostroma State University it. N.A.Nekrasov, 2013, vol. 19, no. 1, pp. 101-105.

11. Tikhonova I. L., Latukha O. A. Innovatsii meditsinskogo vuza v obuchenii studentov [Innovations of medical high school in training students]. Medicine and education in Siberia, 2009, no. 1, p. 2.

12. Aizman R.I., Aizman N.I., Lebedev A.V., Pletneva E.Yu., Rubanovich V.B. Monitoring zdorov'ya uchashchikhsya i pedagogov s primeneniem komp'yutera i programmnykh sredstv [Monitoring of health of pupils and teachers with application of a computer and software]. National Education, 2010, no. 6, pp. 147-155.

13. Aizman R.I., Aizman N.I., Lebedev A.V., Rubanovich V. B. Komp'yuternaya programma skrining kontrolya sostoyaniya zdorov'ya uchastnikov obrazovatel'nogo protsessa [The computer program of the screening control of a state of health of participants of educational process]. Siberian teacher, 2011, vol. 75, no. 2, - pp. 36-39.

14. Aizman R.I., Aizman N.I., Rubanovich V.B., Lebedev A.V. Printsipy i algoritmy monitoringa zdorov'ya uchashchikhsya i studentov [Principle and algorithms of monitoring of health of pupils and students]. Siberian Medical Review, 2009, no. 3, pp. 101-103.

15. Aizman R. I., Pletneva E. Yu. Rol' uchitelya $v$ formirovanii i monitoringe zdorov'ya obuchayushchikhsya [Role of the teacher in formation and monitoring of health of the students]. Healthcare Education, 2010. no. 5, pp. 93-99.

16. Rubanovich V.B. Aizman R.I. Monitoring fizicheskogo zdorov'ya shkol'nikov v protsesse fizkul'turno-ozdorovitel'noi i sportivnoi deyatel'nosti [Monitoring of physical health of schoolboys during physical-improving and sports activity]. Healthcare Education, 2010. no. 1, pp. 97100 .

17. Gavrilov D.N., Komkov A.V., Malinin A.V. etc. Osobennosti monitoringa fizicheskogo sostoyaniya naseleniya [Features monitor the health status of the population]. Theory and Practice of Physical Culture, 2006, no. 3, pp. 60-62.

Kabachkova Anastasiya Vladimirovna, Ph.D., the associate professor of department of sports tourism, sports physiology and medicine, Tomsk State University.

E-mail: avkabachkova@gmail.com

Kapilevich Leonid Vladimirovich, Ph.D., MD, the professor, the head of department of sports tourism, sports physiology and medicine, Tomsk State University.

E-mail: kapil@yandex.ru 
Вестник Новосибирского государственного педагогического университета Novosibirsk State Pedagogical University Bulletin

1(17) $2014 \quad$ www.vestnik.nspu.ru ISSN 2226-3365

(C) Н. А. Барбараш, Д. Ю. Кувшинов

УДК 613.94 + 616-057.875

\title{
ДВАДЦАТИЛЕТНИЙ ОПЫТ ПОВЕДЕНЧЕСКОЙ КОРРЕКЦИИ ЗДОРОВЬЯ У СТУДЕНТОВ-МЕДИКОВ*
}

\begin{abstract}
Н. А. Барбараш, Д. Ю. Кувшинов (Кемерово, Россия)
В статье представлены данные о системе работы кафедры нормальной физиологии медицинской академии по формированию мотивачии студентов-медиков на здоровый образ жизни (ЗОЖ) и отказ от вредных привычек. Эта система была названа мотивационноинформирующей, поскольку она включала как тестирование привычек и образа жизни, так и разъяснительную работу по повышению знаний о роли ЗОЖ в здоровье человека. В результате длительной работы по этой системе у большинства студентов произошла модификация их образа жизни, здоровье сохранялось на более высоком уровне, чем в контрольной группе, происходило снижение количества лии типа А коронарного поведения, отмечалось ограничение курения, стрессов и роста артериального давления.
\end{abstract}

Ключевые слова: студенты-медики, коррекция образа жизни.

В 2009 г. в России появился новый проект профилактики и формирования здорового образа жизни (ЗОЖ) - всероссийская акция «Здоровые сердца» [8], целью которой явилось широкое привлечение внимания руководящих структур, общественности, медицинских и образовательных учреждений к здоровью населения. В странах Европы половина смертности населения связана с патологией сердечно-сосудистой системы; в этом направлении Россия занимает одно из печально лидирующих мест в Европе.

Сегодня только 25 \% здоровья связаны с факторами внешней среды [21]. Более половины - 50-55 \% здоровья определяется образом жизни человека [8]. Формирование ЗОЖ ограничивает факторы риска и повышает здоровье в целом.

* Статья подготовлена по результатам работы Всероссийской научной школы с Международным участием «Опыт использования мониторинга здоровья и физической подготовленности учащейся молодежи» (12-14 ноября 2013 г.).

Барбараш Нина Алексеевна - доктор медицинских наук, профессор кафедры нормальной физиологии, Кемеровская государственная медицинская академия Минздрава России.

E-mail: olb61@mail.ru

Кувшинов Дмитрий Юрьевич - доктор медицинских наук, заведующий кафедрой нормальной физиологии, Кемеровская государственная медицинская академия Минздрава России.

E-mail: phisiolog@mail.ru 
В недавно появившейся статье «Здоровье врачей в России» [7] представлены данные обследования 700 врачей 12 медучреждений. Отмечено, что у 70 \% врачей нарушен обмен холестерина (ХC), у 56 \% имеется артериальная гипертония (АГ), у 35 \% - абдоминальное ожирение, курят $14 \%$ врачей (в Москве - $35 \%$ мужчин и $15 \%$ женщинврачей); 17 \% курящих не планируют прекращение курения. Половина обследованных не знает уровень своего ХC, $32 \%$ - уровень глюкозы. Только 62 \% мужчин и 80 \% женщин-врачей с АГ лечатся медикаментозно.

Эта печальная картина - серьезная основа для внимания к здоровью будущих врачей-студентов. Наша кафедра посвятила этой проблеме более 20 лет своей научной деятельности. Российский академик-кардиолог Р.Г. Оганов [8] среди задач по оздоровлению образа жизни населения страны выдвигает необходимость дальнейшего расширения и ресурсного обеспечения научных исследований по формированию ЗОЖ.

В 1991-1994 гг. мы провели подобного рода исследование, куда был включен 301 практически здоровый студент (87 юношей и 214 девушек) 17-23 лет. С интервалом 8-10 месяцев у них провели две серии исследований по количественной оценке стрессреактивности, физической работоспособности и здоровья. После первого обследования студентов разделили на контрольную (126 человек) и группу воздействий (175 человек). Студентам этой группы раздали буклеты (по 1,5-2 страницы), отражающие различные приемы коррекции образа жизни (ОЖ): самооценку здоровья, поддержание оптимальной массы тела (МТ), двигательной активности, адекватное использование биоритмов, ограничение избыточных стрессов, профилактику АГ, отказ от курения и др. [4].
С небольшими группами студентов - по 5-15 человек - преподаватели-валеологи проводили беседы о коррекции стрессов, МТ, двигательной активности, ограничении курения. На плановых учебных занятиях все студенты в начале и конце учебного года оценивали количество своего здоровья и биологический возраст.

Выяснилось далее, что у испытуемых контрольной группы за 8-10 месяцев резервы здоровья не повысились, некоторые параметры, и общий уровень здоровья стали ниже исходных значений. Это могло быть связано с трудностями адаптации студентов к вузовскому обучению и, возможно, с неблагоприятными влияниями экологии г. Кемерово, крупного центра химической промышленности. Аналогичные данные получены при обследовании студентов Тувы [9].

В группе воздействий, не отличавшейся от контрольной по возрасту, профилю обучения и исходным данным, количество здоровья не снизилось. При этом у лиц с повышенной МТ произошло ее достоверное снижение, у «тревожных» - ограничение склонности к психо-эмоциональным стрессам. Среди девушек вдвое снизилось число курящих.

Эту систему мы назвали мотивационноинформирующей, т.к. она направлена на формирование мотивации ЗОЖ и соответствующих знаний. Среди россиян с высшим образованием с возрастом меньше повышаются МТ и объем талии, реже развивается АГ [13]. Подобные данные получены и при анализе параметров больных людей США [14] и Израиля [20]. Очень важно, что примененная нами система ограничила у студентов неадекватный рост МТ, представляющий «эпидемию» современного мира $[2 ; 5 ; 19 ; 20,25]$.

На втором этапе работы (1997-2004 гг.) проведено исследование по ограничению у студентов развития поведения «коронарного» 
Вестник Новосибирского государственного педагогического университета Novosibirsk State Pedagogical University Bulletin

1(17) $2014 \quad$ www.vestnik.nspu.ru

ISSN 2226-3365

типа А, впервые описанного в США [18]. Лиц этого типа отличают большая склонность к стрессам, гневу, враждебности, соревновательности, меньшее внимание к своему здоровью, более частое развитие ишемической болезни сердца. У лиц юношеского возраста эти исследования в те годы не проводились.

При обследовании 425 студентовмедиков выяснилось, что у представителей типа А больше, чем у лиц типов АБ и Б, возбудимость центральной нервной системы и стрессреактивность, ниже качество сна и вариабельность ритма сердца, больше артери- альное давление (АД) в покое и при стрессах, больше частота проатерогенных изменений крови, при стрессе - больше снижение в альвеолярном воздухе концентрации метаболитов оксида азота, мощного стресслимитирующего и вазодилататорного фактора.

С половиной этих студентов провели беседы и выдали буклеты с информацией об особенностях типа А и способах ограничения стрессов.

Через 8-10 месяцев в группе воздействия выраженность типа А и стрессреактивность снизились (Таблица 1).

Таблица 1

Коронарный риск поведения типа А и его изменения в динамике у лиц юношеского возраста

\begin{tabular}{|c|c|c|c|}
\hline Показатели & & $\begin{array}{c}\text { Лица типа А контрольной } \\
\text { группы }\end{array}$ & $\begin{array}{c}\text { Лица типа А группы } \\
\text { воздействия }\end{array}$ \\
\hline \multirow{2}{*}{$\begin{array}{c}\text { Коронарный риск } \\
\text { поведения (баллы) }\end{array}$} & 1 & $27,6 \pm 0,1$ & $28,0 \pm 0,3$ \\
\hline & 2 & $30,7 \pm 1,8$ & $31,9 \pm 1,5$ \\
\hline $\mathrm{p}$ & & $>0,05$ & $<0,05$ \\
\hline \multirow{2}{*}{$\begin{array}{l}\text { Суммарный уро- } \\
\text { вень СР (баллы) }\end{array}$} & 1 & $13,6 \pm 0,2$ & $13,1 \pm 0,5$ \\
\hline & 2 & $12,9 \pm 0,9$ & $11,9 \pm 0,3$ \\
\hline $\mathrm{p}$ & & $>0,05$ & $<0,05$ \\
\hline
\end{tabular}

Примечание:

1 - данные первого обследования,

2 - данные обследования, проведенного через 8-10 месяцев.

На третьем этапе работы (2002-2008 гг.) было проведено исследование по ограничению курения у юношей. Этому предшествовали наши исследования по изучению физиологических основ индивидуального годичного цикла (ИГЦ) [3], состоящего из четырех (IIV) триместров (в каждом - по 3 месяца), начиная от дня рождения. Самым неблагоприятным для здоровья и отличающимся высокими стрессреакциями является IV триместр, за ним следует I; у лиц мужского пола самым благоприятным является II триместр ИГЦ.

Ограничение курения, особенно среди молодежи, сегодня является одной из наиболее актуальных проблем здоровья как в России [6], так и в других странах [16, 22-24], отсюда весьма важным может быть выявление факторов, оптимизирующих отказ от курения среди молодежи.

В исследование было включено 632 студента, из которых с 313 провели информационно-мотивирующие воздействия, вклю- 
Вестник Новосибирского государственного педагогического университета Novosibirsk State Pedagogical University Bulletin

чавшие ограничение стрессов, их связь с курением, влияние курения на организм и способы его устранения.

Через 6-8 месяцев в группе контроля отказались от курения 3,65 \% юношей, а в группе воздействия - 26,3 \%; число начавших в этот период курить составило соответ- ственно 9,8 и 2,8\%. Самым неэффективным в этом отношении оказался IV триместр ИГЦ (8,5 \% студентов), а самым «продуктивным» - II триместр (58,3 \%) (Рис. 1). Видимо, эти данные следует использовать в работе по стимуляции отказов от курения.

Рисунок 1

Количество (\%) отказавшихся от курения юношей в разные триместры индивидуального года

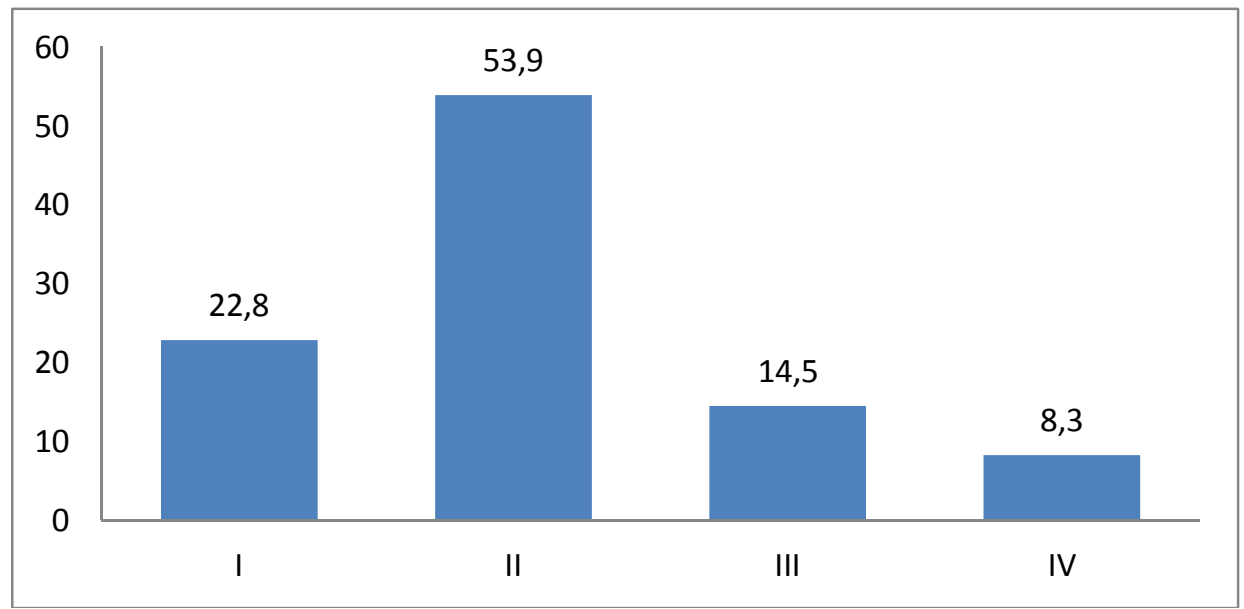

На четвертом этапе (2006-2008 гг.) была проведена работа по профилактике повышения АД у студентов.

Россия относится к странам с наиболее высокой частотой развития АГ. В настоящее время привлекает все большее внимание предгипертония [15], т.е. АД, при котором его систолический уровень достигает 120-139 мм рт. ст. Это состояние «около болезни», которое сочетается с развитием атеросклероза, может начинаться в детстве и прогрессировать всю жизнь. Ограничение его развития может снизить число больных АГ в последующем. За 3 года из 238 студентов было выявлено 15 юношей и 40 девушек 17-21 года с высоким уровнем тревожности. В течение 1,5 месяцев с ними провели шесть 40-минутных занятий по поведенческой коррекции риска повышения АД (неадекватных питания, стрессов, двигательной активности), студентам выдали буклеты, в том числе на тему: «Скажите «нет» гипертонии!».

Через 0,5 года у этих студентов снизилась ситуационная тревожность. Обычно возрастной ежегодный рост систолического АД в юношеском возрасте составляет 1,5-1,9 мм рт. ст. У испытуемых же АД снизилось, но эффект зависел от триместра ИГ, с которым совпадали воздействия (таблица 2). Он был больше у юношей, с которыми проводили беседы в I половине ИГЦ, а у девушек - во II его половине. 
Вестник Новосибирского государственного педагогического университета Novosibirsk State Pedagogical University Bulletin

1(17) $2014 \quad$ www.vestnik.nspu.ru $\quad$ ISSN 2226-3365

Таблица 2

Изменения систолического артериального давления (мм рт. ст.) после мотивационно-обучающего воздействия

\begin{tabular}{|c|c|c|c|}
\hline & & Группа 1 & Группа 2 \\
\hline \multirow{2}{*}{ Юноши } & 1 & $132,3 \pm 2,9$ & $135,2 \pm 3,2$ \\
\cline { 2 - 4 } & 2 & $123,8 \pm 2,6$ & $131,3 \pm 3,2$ \\
\hline $\mathrm{p}$ & & $<0,05$ & $<0,05$ \\
\hline \multirow{2}{*}{ Девушки } & 1 & $115,9 \pm 1,4$ & $116,4 \pm 2,2$ \\
\cline { 2 - 4 } & 2 & $115,1 \pm 1,9$ & $110,7 \pm 2,4$ \\
\hline $\mathrm{p}$ & & $>0,05$ & $<0,05$ \\
\hline
\end{tabular}

Примечание:

1 - данные первого обследования,

2 - данные обследования, проведенного через 6 месяцев;

группа I - первая половина ИГ, II - вторая половина.

Разработанная нами система может быть использована для оптимизации образа жизни не только молодежи, но и других категорий населения. Следует формировать и поддерживать отношение к здоровью как одной из самых значимых ценностей человека. Педагоги образовательных учреждений могут играть в этом решающую роль [1; 10-12].

\section{СПИСОК ЛИТЕРАТУРЫ}

1. Айзман Р.И. Здоровье педагогов и обучающихся - ключевая задача современной школы // Вестник Новосибирского государственного педагогического университета. - 2012. - № 3. C. 24-35.

2. Акимова Е.В., Гакова Е.И., Каюмов Р.Х. и др. Избыточная масса тела в городской сибирской популяции - двенадцатилетние тренды // Кардиоваск. тер. и профил. - 2012. № 3. - C. 58-62.

3. Барбараш Н.А., Кувшинов Д.Ю., Калентьева С.В. и др. Индивидуальный год человека: монография. Кемерово : ИНТ. - 2011. - 220 с.

4. Барбараш Н.А., Кувшинов Д.Ю. Негенитальные особенности физиологии и здоровья женщин // Вестник Новосибирского государственного педагогического университета. 2013. - № 1.- С. 75-83.

5. Еганян Р.А. Избыточная масса тела и ожирение в первичном звене здравоохранения // Профил. мед. - 2010. - № 4. - С. 12-21.

6. Кавешников В.С., Трубачева И.А., Серебрякова В.Н. Современные подходы к проблеме ограничения курения // Профил. мед. - 2011. - № 3. - С. 35-40.

7. Кобалава Ж.Д., Котовская Ю.В., Шальнова С.А. Сердечно-сосудистый риск у врачей разных специальностей. Результаты российской многоцнтровой научно-образовательной программы «Здоровье врачей России» // Кардиоваск. тер. и профил. - 2010. - № 4. - С. 12 14. 
Вестник Новосибирского государственного педагогического университета Novosibirsk State Pedagogical University Bulletin

1(17) $2014 \quad$ www.vestnik.nspu.ru ISSN 2226-3365

8. Оганов Р.Г. Всероссийская образовательная акция «Здоровье сердца - масштабный профилактический проект» // Профил. мед. - 2010. - № 3. - С. 3-5.

9. Ондар А.О., Ондар С.О., Айзман Р.И. Сравнительная характеристика уровней физического здоровья и физической подготовленности студентов-первокурсников ТувГУ // Вестник Новосибирского государственного педагогического университета. - 2013. - № 4914). C. $68-79$.

10. Рубанович В.Б., Айзман Р.И. Основы здорового образа жизни: учебное пособие. - Новосибирск: АРТА, 2011.-256 с

11. Тихонова И.Л., Латуха О.А. Инновации медицинского вуза в обучении студентов // Медицина и образование в Сибири. - 2009. - № 1. - С. 2.

12. Чанчаева Е.А., Айзман Р.И., Герасёв А.Д. Современное представление об антиоксидантной системе организма человека // Экология человека. - 2013. - № 7. - С. 50-58.

13. Шальнова С.А., Деев А.Д., Карманова Н.С. Гендерные особенности связи образовательного статуса и характеристик массы тела по данным обследования российской национальной представительной выборки // Кардиоваск. тер. и профил. - 2009. - № 7. - С. 17-24.

14. Mehta R.H., O'Shea J.C., Stebbins A.L. and e.a. Association of mortality with years of education in patients with ST-segment elevation myocardial infarction treated with fibrinolysis // J.A.C.C. -2011 . - vol. 57. - pp. 138-146.

15. Carrington M. Prehypertension causes a mounting problem of harmful cardiovascular disease risk in young adults // Hypertension. - 2009. - no. 2. - pp. 214-215.

16. Cao Y., Kemfield S., Song Y. and e.a. Cigarette smoking cessation and total and cause - specific mortality. A 22-year follow up study among US male physicians // Arch. Intern. Med. - 2011. - vol. 171. - no. 21. - pp. 1956-1958.

17. Frey P.F. Endothelial dysfunction evident after 30 minutes of exposure to low levels of secondhand smoke // J.A. C.C. - 2012. - vol. 59. - pp. 190-213.

18. Fridman M. S., Hell T. A., Harris M. T. Type A behavior, nonverbal expressive style and health // Pers. Psychol. - 1985. - vol. 48. - pp. 1299-1315.

19. Romeo-Corral A., Mohtor V.M., Somers V.K. and e.a. Modest visceral fat gain causes endothelial dysfunction in healthy humans // J.A. C.C. -2010 . - vol. 56. - no. 8. - pp. 662-666.

20. Steinvil A., Shirom A., Melamed S. and e.a. Relation of educational level to inflammation sensitive biomarker level // Am. J. Cardiol. - 2008. - vol. 102. - pp. 1034-1039.

21. Bern A.E., Pollay Y., Holtz T.H. Textbook of international health global health and dynamic world. Oxford United Kindrom, Oxford University Press, 2009. - 735 p.

22. Arrazova A.A., Dube S.R., Kaufmann R.B. and e.a. Tobacco use among middle and high school students - United States 2000-2009 // JAMA. - 2010. - vol. 304. - no. 22. - pp. 25862587.

23. Kaufmann R.B., Barr S., Malloran O. and e.a. Vital signs: Current cigarette smoking among adults aged $\geq 18$ years - United States, 2009 // JAMA. - 2010. - vol. 304. - no. 17. - pp. 11351140.

24. King B., Dube S., Kaufmann R. and e.a. Vital sings: current cigarette smoking among adults aged $\geq 18$ years - United States, 2005-2010 // JAMA. - 2011. - vol. 306. - no. 17. - pp. 18571860 .

25. Jacobs E.J., Newton C.C., Wang Y. and e.a. Waist circumference and all - cause mortality in large US cogort // Arch. Intern. Med. - 2010. - vol. 170. - no. 15. - pp. 1291-1301. 
Вестник Новосибирского государственного педагогического университета Novosibirsk State Pedagogical University Bulletin

1(17) $2014 \quad$ www.vestnik.nspu.ru ISSN 2226-3365

(C) N. A. Barbarash, D. Yu. Kuvshinov

UDC 613.94 + 616-057.875

\title{
TWENTY YEARS' EXPERIENCE OF BEHAVIORAL CORRECTION OF HEALTH OF MEDICAL STUDENTS
}

\author{
N. A. Barbarash, D. Yu. Kuvshinov (Kemerovo, Russia)
}

In article data about system of work of Department of normal physiology of medical academy on formation of motivation of medical students on a healthy life style (HLS) and refusal of bad habits are presented. This system has been named by motivation-informing as it included both testing of habits and a life style, and explanatory work on increasing of knowledge of HLS role in health of the person. As a result of long work on this system the majority of students had an updating of their style of life, health remained at higher level, than in control group, there was a decrease in quantity of persons of type A coronary behavior, restriction of smoking, stresses and growth of arterial pressure was marked.

Keywords: medical students, mode of life correction.

\section{REFERENCES}

1. Aizman R.I. Zdorov'e pedagogov i obuchayushchikhsya - klyuchevaya zadacha sovremennoi shkoly [Health of teachers and schoolchildren is a key problem of modern school]. Novosibirsk State Pedagogical University Bulletin, 2012, no. 3, pp. 24-35.

2. Akimov E.V., Gakova E.I., Kaumov B.C. and ets. Izbytochnaya massa tela v gorodskoi sibirskoi populyatsii - dvenadtsatiletnie trendy [Excess body weight in the Siberian city population twelve-year trends]. Kardiovask, ter. and profile, 2012, no. 3, pp. 58-62.

3. Barbarash N.A., Kuvshinov D.Yu., Kalentyeva S.V. and etc. Individual'nyi god cheloveka [Individual year man]. Kemerovo, INT, 2011, 220 p.

4. Barbarash N.A., Kuvshynov D.Yu. Negenital'nye osobennosti fiziologii i zdorov'ya zhenshchin [Nongenital peculiarities of female physiology and health]. Novosibirsk State Pedagogical University Bulletin, 2013, no. 1, pp. 75-83.

5. Eganyan R.A. Izbytochnaya massa tela $\mathrm{i}$ ozhirenie $\mathrm{v}$ pervichnom zvene zdravookhraneniya [Overweight and obesity in primary care]. Pro. Honey, 2010, no. 4, pp. 12-21.

6. Kaveshnikov V.S., Trubacheva I.A., Serebriakova V.N. Sovremennye podkhody k probleme ogranicheniya kureniya [Current approaches to the problem of smoking restrictions]. Pro. Honey, 2011, no. 3, pp. 35-40.

7. Kobalava J.D., Kotovskaya Y., Shalnova S.A. Serdechno-sosudistyi risk u vrachei raznykh spetsial'nostei. Rezul'taty rossiiskoi mnogotsntrovoi nauchno-obrazovatel'noi programmy «Zdorov'e vrachei Rossii» [Railway Cardiovascular risk among physicians of different specialties. Results mnogotsntrovoy Russian scientific and educational program "Health Physicians Russia"]. Kardiovask . ter. and profile, 2010, no. 4, pp. 12-14. 
8. Oganov R.G. Vserossiiskaya obrazovatel'naya aktsiya «Zdorov'e serdtsa - masshtabnyi profilakticheskii proekt» [National educational campaign "Heart Health - a large-scale preventive project"]. Pro. Honey, 2010, no. 3, pp. 3-5.

9. Ondar A.O.,Ondar S.O., Aizman R.I. Sravnitel'naya kharakteristika urovnei fizicheskogo zdorov'ya i fizicheskoi podgotovlennosti studentov-pervokursnikov TuvGU [Comparative characteristics of the level of physical health and physical preparedness of students in their freshman year TuvSU]. Novosibirsk State Pedagogical University Bulletin, 2013, no. 4, pp. 68-79.

10. Rubanovich V.B., Aizman R.I. Osnovy zdorovogo obraza zhizni: uchebnoe posobie [Bases of a healthy way of life]. Novosibirsk, 2011, 256 p.

11. Tikhonova I.L., Latukha O.A. Innovatsii meditsinskogo vuza v obuchenii studentov [Innovations of medical high school in training students]. Medicine and education in Siberia, 2009, no. 1, p. 2.

12. Chanchaeva E.A., Aizman R.I., Gerasev A.D. Sovremennoe predstavlenie ob antioksidantnoi sisteme organizma cheloveka [Modern representation about antyoxygen to system of an organism of the person]. Ecology of the person, 2013, no. 7, pp. 50-58.

13. Shalnova S.A., Deev A.D., Karmanova N.S. Gendernye osobennosti svyazi obrazovatel'nogo statusa i kharakteristik massy tela po dannym obsledovaniya rossiiskoi natsional'noi predstavitel'noi vyborki [Gender characteristics of communication and educational status and characteristics of body weight according to a survey of the Russian national representative sample]. Kardiovask . ter. and profile, 2009, no. 7, pp. 17-24.

14. Mehta R.H., O'Shea J.C., Stebbins A.L. and e.a. Association of mortality with years of education in patients with ST-segment elevation myocardial infarction treated with fibrinolysis. J.A.C.C., 2011, vol. 57, pp. 138-146.

15. Carrington M. Prehypertension causes a mounting problem of harmful cardiovascular disease risk in young adults. Hypertension, 2009, no. 2, pp. 214-215.

16. Cao Y., Kemfield S., Song Y. and e.a. Cigarette smoking cessation and total and cause - specific mortality. A 22-year follow up study among US male physicians. Arch. Intern. Med., 2011, vol. 171, no. 21, pp. 1956-1958.

17. Frey P.F. Endothelial dysfunction evident after 30 minutes of exposure to low levels of secondhand smoke. J.A. C.C., 2012, vol. 59, pp. 190-213.

18. Fridman M. S., Hell T. A., Harris M. T. Type A behavior, nonverbal expressive style and health. Pers. Psychol., 1985, vol. 48, pp. 1299-1315.

19. Romeo-Corral A., Mohtor V.M., Somers V.K. and e.a. Modest visceral fat gain causes endothelial dysfunction in healthy humans. J.A. C.C., 2010, vol. 56, no. 8, pp. 662-666.

20. Steinvil A., Shirom A., Melamed S. and e.a. Relation of educational level to inflammation - sensitive biomarker level. Am. J. Cardiol., 2008, vol. 102, pp. 1034-1039.

21. Bern A.E., Pollay Y., Holtz T.H. Textbook of international health global health and dynamic world. Oxford United Kindrom, Oxford University Press, 2009 - 735 p.

22. Arrazova A.A., Dube S.R., Kaufmann R.B. and e.a. Tobacco use among middle and high school students - United States 2000-2009. JAMA, 2010, vol. 304, no. 22, pp. 2586-2587.

23. Kaufmann R.B., Barr S., Malloran O. and e.a. Vital signs: Current cigarette smoking among adults aged $\geq 18$ years - United States, 2009. JAMA, 2010, vol. 304, no. 17, pp. 1135-1140.

24. King B., Dube S., Kaufmann R. and e.a. Vital sings: current cigarette smoking among adults aged $\geq 18$ years - United States, 2005-2010. JAMA, 2011, vol. 306, no. 17, pp. 1857-1860. 
Вестник Новосибирского государственного педагогического университета Novosibirsk State Pedagogical University Bulletin

25. Jacobs E.J., Newton C.C., Wang Y. and e.a. Waist circumference and all - cause mortality in large US cogort. Arch. Intern. Med., 2010, vol. 170, no. 15, pp. 1291-1301.

Barbarash Nina Alekseevna, the doctor of medical sciences, the professor of normal physiology department, Kemerovo State Medical Academy.

E-mail: olb61@mail.ru

Kuvshinov Dmitry Yur'evich, the doctor of medical sciences, the head of normal physiology department, Kemerovo State Medical Academy.

E-mail: phisiolog@mail.ru 
Вестник Новосибирского государственного педагогического университета Novosibirsk State Pedagogical University Bulletin

1(17) $2014 \quad$ www.vestnik.nspu.ru ISSN 2226-3365

(C) А. В. Лебедев, В. Б. Рубанович, Н. И. Айзман, Р. И. Айзман

УДК $612.6+378$

\section{МОРФОФУНКЦИОНАЛЬНЫЕ ОСОБЕННОСТИ СТУДЕНТОВ ПЕРВОГО КУРСА ПЕДАГОГИЧЕСКОГО ВУЗА*}

А. В. Лебедев, В. Б. Рубанович, Н. И. Айзман, Р. И. Айзман (Новосибирск, Россия)

В статье представлены данные о морфофункииональных особенностях студентов 18-20 лет педагогического университета. Обследовано 1000 человек (833 девушек и 167 юношей) - студентов обоего пола разных факультетов вуза. Показано, что если антропометрические параметры студентов первого курса были в пределах возрастно-половой нормы, то по многим функииональным показателям обследуемые имели уровень, ниже среднего и низкий. На основе показателей физического развития и реакиии на нагрузку был рассчитан интегральный показатель, характеризующий уровень физического здоровья и составлен «паспорт здоровья». В заключении делаются выводы о необходимости медико-педагогической коррекции учебного процесса на занятиях физической культурой и спортом, а также участия вузовского профилактория в оздоровлении студентов.

Ключевые слова: «паспорт здоровья», мониторинг здоровья, морфологические особенности, функиииональные особенности, адаптация.

* Статья подготовлена по результатам работы Всероссийской научной школы с Международным участием «Опыт использования мониторинга здоровья и физической подготовленности учащейся молодежи» (12-14 ноября 2013 г.).

Лебедев Алексей Владимирович - кандидат биологических наук, доцент кафедры анатомии, физиологии и безопасности жизнедеятельности, Новосибирского государственного педагогического университета.

E-mail: lebedev_05@mail.ru

Рубанович Виктор Борисович - доктор медицинских наук, профессор кафедры анатомии, физиологии и безопасности жизнедеятельности, Новосибирского государственного педагогического университета.

E-mail: rubanovich08@mail.ru

Айзман Нина Игоревна - кандидат психологических наук, директор центра практической психологии, Новосибирского государственного педагогического университета.

E-mail: nina.aizman@mail.ru

Айзман Роман Иделевич - доктор биологических наук, профессор кафедры анатомии, физиологии и безопасности жизнедеятельности, Новосибирского государственного педагогического университета.

E-mail: roman.aizman@mail.ru 
Вестник Новосибирского государственного педагогического университета Novosibirsk State Pedagogical University Bulletin

1(17) $2014 \quad$ www.vestnik.nspu.ru $\quad$ ISSN 2226-3365

Профессионально-личностное здоровье учителя играет важную роль в механизме модернизации российского образования, является одним из факторов успешности образовательной системы, предопределяет эффективность процесса обучения и воспитания обучающихся $[1-2 ; 11 ; 20-21 ; 25 ; 29]$. Поэтому формирование профессиональных и личностных качеств педагогов, укрепление их физического и психического здоровья должно начинаться уже на студенческой скамье, в процессе подготовки к будущей педагогической деятельности. Только здоровый (в целостном понимании этого слова) учитель может воспитать здоровую личность [2]. В связи с этим вопросы здоровья будущего учителя приобретают особую актуальность. Однако, по данным разных авторов, в последнее десятилетие наблюдается снижение показателей здоровья студентов [18-19; 23-24].

Можно выделить ключевые факторы, определяющие низкий уровень здоровья студенческой молодежи:

- отсутствие осознанной потребности в здоровье и здоровом образе жизни;

- отсутствие необходимых знаний по охране здоровья;

- недостаточный уровень оздоровительных программ и первичной профилактической помощи.

Кроме того, низкий уровень превентологической грамотности учителей и родителей усугубляет это влияние [1].

Следствием является искажение образа жизни, распространение факторов риска заболеваний, формирование форм поведения, приводящих к снижению уровня здоровья. Это:

• низкий уровень двигательной активности;

• несбалансированное питание;
- информационные перегрузки, связанные с интенсификацией обучения и нерациональным режимом труда, высокий уровень стресса;

• лояльное отношение к употреблению алкогольных напитков;

- широкое распространение табакокурения.

Наряду с факторами образа жизни, отдельно следует выделить проблемы организационного и нормативного плана:

- отсутствие программных документов по охране здоровья субъектов образовательного процесса,

- отсутствие доступных, информативных и дешевых скрининговых методов комплексной оценки состояния здоровья человека,

• недостаточность профилактической работы в образовательных учреждениях,

- отсутствие интегративного подхода к проблеме здоровья.

Отсутствие установок на сохранение здоровья создает риск для будущего сегодняшних студентов, связанного с созданием семьи, профессиональным и личностным ростом.

Это диктует необходимость разработки подходов, направленных на оценку и сохранение уровня здоровья этого контингента населения как трудового потенциала страны.

В этом аспекте приобретает особое значение правильная и своевременная оперативная диагностика состояния здоровья будущих педагогов и обучение их методам скрининг самоконтроля и коррекции. В настоящее время в литературе представлено множество вариантов скринингового исследования состояния здоровья учащейся молодежи [15-17]. Однако результатов комплексной оценки морфо-функционального состояния студен- 
Вестник Новосибирского государственного педагогического университета Novosibirsk State Pedagogical University Bulletin

1(17) $2014 \quad$ www.vestnik.nspu.ru $\quad$ ISSN 2226-3365

тов педагогического вуза в динамике обучения еще крайне мало [14; 18].

В настоящей работе была поставлена цель - описать морфо-функциональные показатели студентов первого курса педагогического вуза.

\section{Задачи исследования:}

1. Дать характеристику физического развития студентов первого курса на основе их морфо-функциональных показателей.

2. Оценить уровень физического здоровья студентов первого курса.

3. Выявить половые различия между студентами по уровню морфо-функционального статуса.

\section{Контингент и методы исследования}

Обследованы 1000 человек первого курса (833 девушек и 167 юношей) 18-20 лет студентов Новосибирского государственного педагогического университета разных факультетов (гуманитарные, технические и естественно - научные профили).

Все обследования проводили в первой половине дня (с 9 до 12 часов).

Морфо-функииональные показатели определяли с использованием стандартных методик:

Антропометрические параметры: длина (ДТ), масса (МТ) тела, обхват грудной клетки (ОГК) [30]. Рассчитывали индекс индекс Кетле (ИК), равный МТ (кг)/ДТ (мI)

Функииональные параметры: сила кистей рук (КС) (динамометром) и кистевой индекс (КИ) по формуле: КИ= КС (кг) / МТ (кг); жизненная емкость легких (ЖЕЛ) (воздушным спирометром) и жизненный индекс (ЖИ) по формуле: ЖЕЛ (мЛ) / МТ (кг); вариабельность ритма сердца (в условиях физиологического покоя и после нагрузки) [8-9]. Адаптацию к физическим нагрузкам и определение функциональных резервов организма оцени- вали с помощью степ-эргометрической нагрузки [27]. Физическую работоспособность при ЧСС 170 уд/мин определяли по пробе PWC170 [27]. Экономичность деятельности сердечно-сосудистой системы в условиях относительного покоя оценивали по двойному произведению (ДП): ДП $=($ САД $\mathrm{x}$ ЧСС) / 100, где: САД - систолическое артериальное давление, мм рт.ст., ЧСС - частота сердечных сокращений, уд./мин.; качество реакции сердечно-сосудистой системы на физическую нагрузку - по показателю эффективности кровообращения (ПЭК): ПЭК = (САД: ЧСС) х 100 [6].

На основе полученных данных физического развития и функционального состояния дыхательной и сердечно-сосудистой систем автоматически рассчитывалась интегральная оценка физического здоровья по разработанной компьютерной программе «Комплексная оценка здоровья и развития студентов высших и средних учебных заведений» [3-5].

Полученный материал обработан методами вариационной и разностной статистики с применением непараметрических критериев Стьюдента и Фишера для независимых выборок при уровне значимости $\mathrm{p} \leq 0,05$ [22].

\section{Результаты исследования и их обсуждение \\ Учитывая половые морфофунк-} циональные различия в юношеском возрасте [6; 10], на первом этапе мы провели анализ соответствующих показателей у студентов 18-20 лет в зависимости от пола без учета профиля обучения.

Анализ физического развития обследуемых выявил различия по многим морфофункциональным показателям.

Длина тела является достаточно жестким, генетически детерминированным показателем по сравнению с другими антропомет- 
Вестник Новосибирского государственного педагогического университета Novosibirsk State Pedagogical University Bulletin

рическими параметрами [12], он характеризует состояние пластических процессов в организме. Достоверно более высокие показатели обнаружены у юношей по сравнению с девушками (табл. 1).

По мнению многих авторов, масса тела в большей степени подвержена воздействию факторов окружающей среды и преимущественно определяется физическим воспитанием, количественным и качественным составом пищи и режимом питания [32-33]. Кроме того, данный показатель, характеризующий конституциональные особенности организма, является более лабильным параметром [12; 27]. Как видно из табл. 1, у юношей достоверно более высокие значения массы тела по сравнению с девушками.
Проведенная оценка массо-ростового соотношения (по индексу Кетле) у студентов первого курса показала, что больший процент студентов обоего пола (70,3 \% девушек и 79,8 \% юношей) находился в пределах возрастно-половой и региональной нормы [4-5], однако были студенты с дефицитом (16,8 \% и $10,5 \%)$ и избытком массы тела (12,9 \% и 9,6 \%, соответственно) (табл. 2). Как видно, среди девушек по сравнению с юношами преобладали лица, как с дефицитом, так и с избытком массы тела, что свидетельствует о большей лабильности этого показателя у представителей женского пола, вероятно, в связи с особенностями питания и «моды на сохранение фигуры». Достоверных различий между девушками и юношами по индексу Кетле не установлено.

Таблица 1

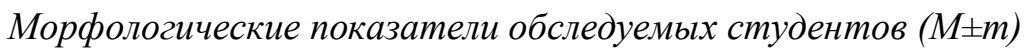

\begin{tabular}{|c|c|c|c|}
\hline Показатели & девушки & юноши & $\begin{array}{c}\text { Достоверность } \\
\text { различий }\end{array}$ \\
\hline Длина тела, см & $164,1 \pm 0,2$ & $177,5 \pm 0,5$ & $* * *$ \\
\hline Масса тела, кг & $59,5 \pm 0,4$ & $69,7 \pm 0,9$ & $* * *$ \\
\hline Индекс Кетле & $22,0 \pm 0,1$ & $22,1 \pm 0,2$ & н/д \\
\hline
\end{tabular}

Примечание:

этой и последующих таблицах звездочками указаны достоверные отличия между студентами разного пола: $* \leq 0,05 ; * * \leq 0,001 ; * * * \leq 0,001$, н/д - недостоверные.

Таблица 2

Распределение студентов по массе тела (\%)

\begin{tabular}{|c|c|c|c|c|c|}
\hline \multicolumn{2}{|c|}{ дефицит массы тела } & \multicolumn{2}{|c|}{ норма } & \multicolumn{2}{c|}{ избыток массы тела } \\
\hline девушки & юноши & девушки & юноши & девушки & юноши \\
\hline 16,8 & $10,5^{*}$ & 70,3 & 79,8 & 12,9 & 9,6 \\
\hline
\end{tabular}


Вестник Новосибирского государственного педагогического университета Novosibirsk State Pedagogical University Bulletin

1(17) $2014 \quad$ www.vestnik.nspu.ru ISSN 2226-3365

Поскольку масса тела студентов различалась, функциональные показатели рассчитывались на единицу массы тела, что позволяло более объективно оценить функциональное состояние организма. При оценке показателей мышечной силы кистей рук и жизненной емкости легких (по их индексам) обнаружено, что юноши по всем силовым и функциональным показателям кардиореспираторной системы имели достоверно более высокие показатели, чем девушки, что отражает их половую дифференциацию и полностью соответствует литературным данным [6] (табл.3). При анализе распределения студентов по величине этих показателей ока- залось, что большая часть исследуемого контингента находилась в группах с низким и ниже среднего уровнем развития кистевой силы, а по жизненному индексу - высоким и выше среднего, что, с одной стороны, свидетельствует о слабом развитии мускулатуры и низких силовых показателях, с другой, - о достаточных резервных возможностях респираторной системы (табл. 4). Следует отметить, что среди юношей, к сожалению, было достоверно больше студентов с низким уровнем развития этих показателей по сравнению с девушками. По остальным группам половые различия были несущественные.

Таблица 3

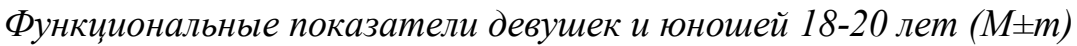

\begin{tabular}{|c|c|c|c|}
\hline Показатели & девушки & оноши & $\begin{array}{c}\text { достоверность } \\
\text { различий }\end{array}$ \\
\hline Кистевой индекс, кг/кг & $43,6 \pm 0,3$ & $59,7 \pm 0,9$ & $* * *$ \\
\hline Жизненный индекс, мл/кг & $59,3 \pm 0,6$ & $71,3 \pm 1,4$ & $* * *$ \\
\hline Двойное произведение, у.е. & $92,8 \pm 0,6$ & $98,6 \pm 1,4$ & $* *$ \\
\hline РWС170, кгм/мин·кг & $11,8 \pm 0,1$ & $14,5 \pm 0,2$ & $* * *$ \\
\hline ПЭК, у.е. & $68,6 \pm 0,3$ & $77,7 \pm 0,7$ & $* * *$ \\
\hline Уровень физического здоровья, балл & $10,4 \pm 0,3$ & $10,5 \pm 0,3$ & н/д \\
\hline
\end{tabular}

Показатель двойного произведения (ДП) отражает экономичность расходования миокардом кислорода [9; 13]. Установлено, что у студенток это показатель был достоверно ниже, чем у юношей, что свидетельствует о более высоких функциональных резервах сердца у девушек. Это подтверждается и распределением студентов по уровню развития функций миокарда: среди студенток было больше лиц с уровнем выше среднего, а среди юношей - ниже среднего. При выполнении физической нагрузки в пробе «степ-тест» юноши показали большую работоспособность (PWC170/кг), чем девушки, что отражает развитие их выносливости. Однако общий уровень физической работоспособности 
Вестник Новосибирского государственного педагогического университета Novosibirsk State Pedagogical University Bulletin

был в пределах возрастно-половой нормы в обеих половых группах (норма: для девушек 11-14 кгм/мин·кг, для юношей - 13-16 кгм/мин·кг) [6]. Количество девушек и юношей, имевших средний $(41,4$ и $37,7 \%$ ) и ниже среднего (37,9 и 28,9 \%, соответственно) уровни физической работоспособности, было преобладающим. Обращает на себя внимание тот факт, что в группе юношей было больше студентов с низким уровнем физической работоспособности и больше лиц с высоким уровнем $Ф \mathrm{P}_{170}$, чем среди девушек.
Качество реакции сердечнососудистой системы на физическую нагрузку оценивают также по показателю эффективности кровообращения (ПЭК) [4-5; 31]. У юношей отмечена более высокая эффективность кровообращения при нагрузке, однако процент лиц с низким и высоким показателем ПЭК был почти в 2 раза выше, чем среди девушек. Однако в группе ниже среднего уровня преобладали девушки (соответственно, 45,4 \% девушек и 35,1\% юношей), тогда как в остальных группах половых различий по ПЭК не было (табл. 4).

Таблица 4

Распределение студентов по уровню физического здоровья (\%)

\begin{tabular}{|c|c|c|c|c|c|c|c|c|c|c|}
\hline \multirow[b]{2}{*}{ Показатели } & \multicolumn{2}{|c|}{ Низкий } & \multicolumn{2}{|c|}{ Ниже среднего } & \multicolumn{2}{|c|}{ Средний } & \multicolumn{2}{|c|}{ Выше среднего } & \multicolumn{2}{|c|}{ Высокий } \\
\hline & $\begin{array}{c}\text { девуш- } \\
\text { ки }\end{array}$ & юноши & $\begin{array}{c}\text { девуш } \\
\text { вуш- } \\
\text { ки }\end{array}$ & юноши & $\begin{array}{c}\text { девуш } \\
\text { вуш- } \\
\text { ки }\end{array}$ & юноши & $\begin{array}{c}\text { девуш } \\
\text { вуш- } \\
\text { ки }\end{array}$ & юноши & $\begin{array}{c}\text { девуш- } \\
\text { ки }\end{array}$ & $\begin{array}{c}\text { юно- } \\
\text { Ши }\end{array}$ \\
\hline $\begin{array}{c}\text { Кистевой ин- } \\
\text { декс }\end{array}$ & 36,0 & $46,5^{*}$ & 45,3 & $19,3 * * *$ & 11,4 & 15,8 & 3,8 & $16,6^{* *}$ & 3,5 & $1,8^{*}$ \\
\hline $\begin{array}{c}\text { Жизненный } \\
\text { индекс }\end{array}$ & 5,9 & $10,5 * *$ & 10,1 & $6,1 *$ & 19,6 & $10,5^{*}$ & 21,9 & 18,4 & 42,5 & $54,5^{*}$ \\
\hline $\begin{array}{c}\text { Двойное } \\
\text { произведение }\end{array}$ & 15,4 & $24,6^{* *}$ & 23,6 & $31,6^{*}$ & 23,1 & 19,3 & 31,1 & $19,2 *$ & 6,8 & 5,3 \\
\hline$\Phi P_{170 / \text { кт }}$ & 3,2 & $7,0 * *$ & 37,9 & $28,9 *$ & 41,4 & 37,7 & 14,0 & 18,5 & 3,5 & $7,9 *$ \\
\hline ПЭК & 14,7 & $24,6^{* *}$ & 45,4 & $35,1^{*}$ & 29,0 & 27,2 & 8,7 & 10,5 & 2,2 & 2,6 \\
\hline $\begin{array}{c}\text { Уровень фи- } \\
\text { зического } \\
\text { здоровья }\end{array}$ & 13,8 & 12,3 & 31,1 & 36,0 & 42,0 & 37,7 & 11,2 & 10,5 & 1,9 & $3,5^{*}$ \\
\hline
\end{tabular}

На основе показателей физического развития и реакции на нагрузку был рассчитан уровень физического здоровья и функциоинтегральный показатель, характеризующий нальных резервов организма [3-5] (рис.1). 
Вестник Новосибирского государственного педагогического университета Novosibirsk State Pedagogical University Bulletin

1(17) $2014 \quad$ www.vestnik.nspu.ru ISSN 2226-3365

Рисунок 2

Скриншоты паспорта здоровья студентов

\begin{tabular}{|c|}
\hline М Мониторинг здоровья \\
\hline $\begin{array}{l}\text { Новосибирский государственный педагогический } \\
\text { университет }\end{array}$ \\
\hline $\begin{array}{c}\text { Касредра анатомии, фризиологии и безопасности } \\
\text { жизнедеятельности }\end{array}$ \\
\hline $\begin{array}{c}\text { Программа комплексной } \\
\text { оценки здоровья и развития } \\
\text { студентов высших и средних } \\
\text { учебных заведений }\end{array}$ \\
\hline г. Новосибирск \\
\hline
\end{tabular}

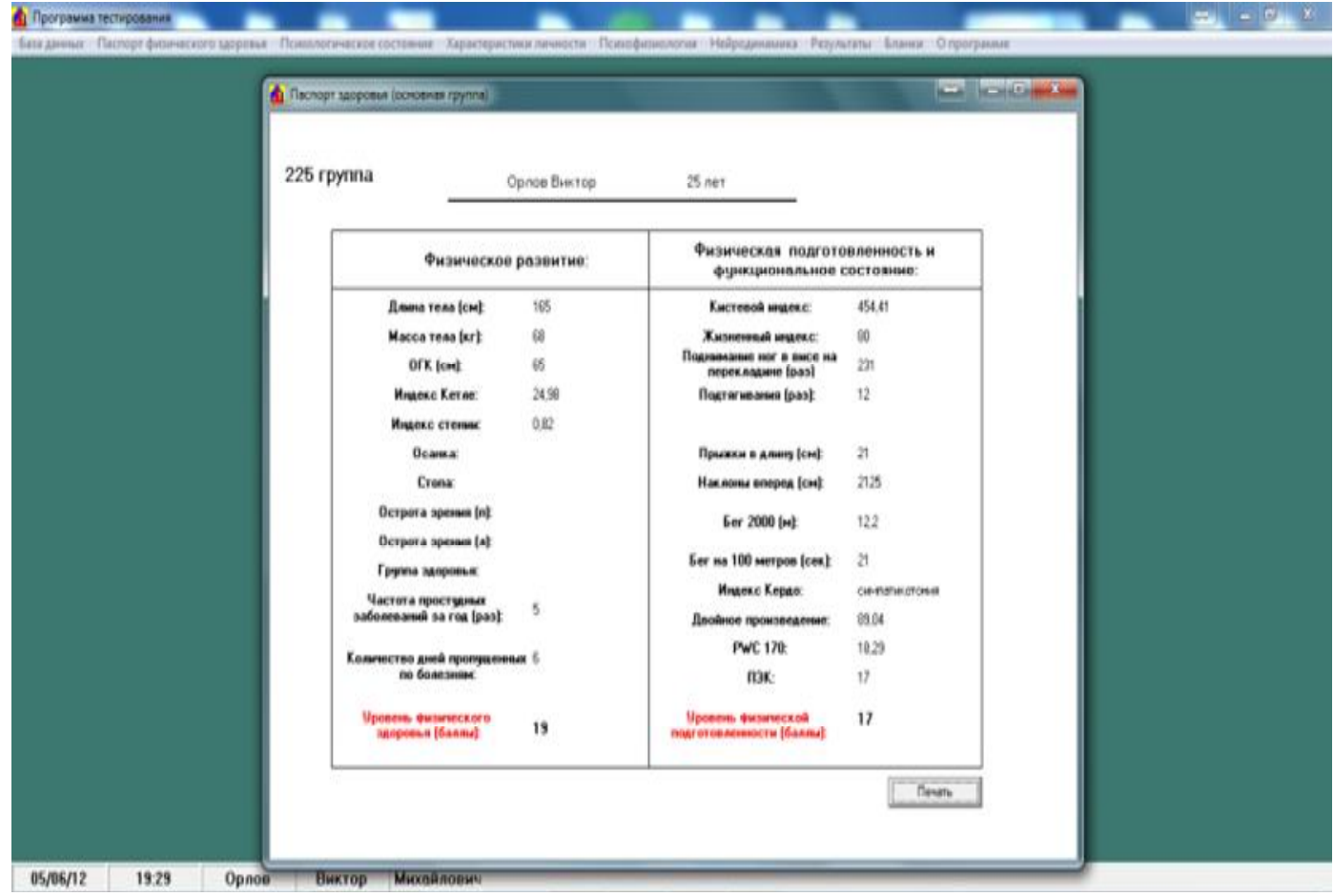

По среднему баллу интегральный показатель здоровья не отличался между студентами обоего пола, был ниже среднего уровня (норма 11-14) [6], и, к сожалению, большинство студентов 1-го курса имели средний $(42,0$ и $37,7 \%)$ и ниже среднего $(31,1$ и
$36,0 \%$ ) уровни физического здоровья (табл. 4). Вызывает особую тревогу, что уже в начале обучения примерно $13 \%$ студентов обоего пола имели низкий уровень здоровья и $31-36 \%$ - ниже среднего. 
Вестник Новосибирского государственного педагогического университета Novosibirsk State Pedagogical University Bulletin

1(17) $2014 \quad$ www.vestnik.nspu.ru ISSN 2226-3365

Таким образом, анализ морфофункциональных показателей свидетельствует о том, что если антропометрические параметры студентов первого курса находятся в пределах нормы, то ряд функциональных показателей имели уровень ниже среднего и низкий. Полу- ченные данные диктуют необходимость медико-педагогической коррекции учебного процесса на занятиях физической культурой и спортом, а также участия вузовского профилактория в оздоровлении студентов.

\section{СПИСОК ЛИТЕРАТУРЫ}

1. Айзман Р.И. Здоровье и безопасность - ключевые задачи образования в современных условиях // Здоровьесберегающее образование. - 2011. - № 6(18). - С.48-52.

2. Айзман Р.И. Здоровье педагогов и обучающихся - ключевая задача современной школы // Вестник Новосибирского государственного педагогического университета. - 2012. - № 3. C. 24-35.

3. Айзман Р.И., Айзман Н.И., Лебедев А.В. Методика оценки социально-психологической адаптации и личностного потенциала студентов: метод. пособ. - Новосибирск. 2013 - 40 с.

4. Айзман Р.И., Айзман Н.И., Лебедев А.В., Плетнёва Е.Ю., Рубанович В.Б. Мониторинг здоровья учащихся и педагогов с применением компьютера и программных средств // Народное образование. - 2010. - № 6. - С. 147-155.

5. Айзман Р.И., Айзман Н.И., Лебедев А.В., Рубанович В.Б. Методика комплексной оценки физического и психического здоровья, физической подготовленности студентов высших и средних профессиональных учебных заведений: метод. пособ. - Новосибирск: Изд. «РИФ Новосибирск». $2009-100$ с.

6. Айзман Р.И., Лысова Н.Ф. Возрастная физиология: учеб. пособ. -Новосибирск: Изд. НГПУ, 2010. - $202 \mathrm{c}$.

7. Айзман Р.И., Рубанович В.Б., Суботялов М.А. Основы медицинских знаний и здорового образа жизни: учеб. пособ. - Новосибирск, 2010. - 286 с.

8. Баевский Р.М., Иванов Г.Г. Вариабельность сердечного ритма: теоретические аспекты и возможности клинического применения.- М.: Медицина, 2000. - 295 с.

9. Баевский P.М. Проблема оценки и прогнозирования функционального организма и ее развитие в космической медицине // Успехи физиологических наук. - 2006. - Т. 37. - № 3. C. $42-57$.

10.Безруких М.М., Сонькин В.Д., Фарбер Д.А. Возрастная физиология: учеб. пособ. - М.: Изд-во ACADEMA, 2002. -415 с.

11.Борцова О. А. Медико-социальные аспекты обучения школьников правильному образу жизни // Философия образования. - 2006. - № 1. - С. 211-214.

12.Година Е.3. Биосоциальные влияния на процессы роста и развития // Человек, экология, симметрия. - Минск, 1991. - С. 21-22.

13. Ендропов О.В. Валеологические аспекты двигательной активности человека. - Новосибирск, 1996. -230 с.

14. Жомин К.М. Морфофункциональные и психофизиологические особенности студенток в зависимости от вида и режима физкультурно-спортивной деятельности: автореф. дисс. ...канд. биол. наук. - Челябинск, 2013. - 22 с. 
Вестник Новосибирского государственного педагогического университета Novosibirsk State Pedagogical University Bulletin

1(17) $2014 \quad$ www.vestnik.nspu.ru ISSN 2226-3365

15. Иванов В.И., Литвинова Н.А., Березина М.Г. Автоматизированные методы психодиагностики: методические рекомендации (инструкция пользователя к комплексу «Status PF»). Keмеровский государственный университет. - Кемерово: Изд-во Кузбассвузиздат, 2002. - 28 с.

16. Казин Э.М., Лурье С.Б. Состояние здоровья школьников и факторы его формирующие. // Валеологические аспекты образования. - Кемерово. - 1995. - С. 96-115.

17. Кирсанов В.М., Шибкова Д.З. Психофизиологическая характеристика личности студентов в период адаптации к обучению в вузе // Сиб. педагог. журнал. - Новосибирск. - 2012. - № 9. - C. $127-132$.

18. Кужугет А.А. Особенности физического развития, функции кардиореспираторной системы и соматического здоровья студентов в зависимости от организованной двигательной активности: автореф. дисс. ...канд. биол. наук. - Челябинск, 2012. - 23 с.

19. Кузнецова Л.М., Кузнецов В.Д., Тимошенко К.Т. Показатели психического здоровья современных старшеклассников и студентов вуза // Гигиена и санитария. - 2008. - № 3. C. 59-63.

20. Латуха О.А., Пушкарёв Ю.В. Экономическое развитие современного общества и проблема подготовки инновационных кадров // Вестник Новосибирского государственного педагогического университета. - 2012. - № 5(9). - С. 50-56.

21. Майер Б.О., Евзрезов Д.В. Изменения в системе современного общества и реформы высшего образования // Вестник Новосибирского государственного педагогического университета. - 2012. - № 6(10). - С. 37-44.

22. Наследов А.Д. Математические методы психологического исследования. Анализ и интерпретация данных: учеб. пособ. - СПб.: Изд-во Речь, 2004. - 392 с.

23.Негашева М.А., Мишкова Т.А. Антропометрические параметры и адаптационные возможности студенческой молодежи к началу XXI века // Российский педагогический журнал. 2005. - № 5. - С. 12-16.

24.Особенности адаптации системы внешнего дыхания, кровообращения, морфофункциональных показателей и уровня здоровья студентов / под ред. С.А. Кабанова, Т.В. Потапова, А.П.Исаева // Теория и практика физ. Культуры. - 2005. -№ 8. - С. 45-48.

25.Пушкарева Е.А. Взаимодействие науки и образования в условиях формирования инновационной культуры образовательного учреждения // Вестник Новосибирского государственного педагогического университета. - 2013. - № 4(14). - С. 29-37.

26.Пушкарёва Е.А., Судоргина Л.В. Культура самоопределения: адаптационные механизмы личности // Вестник Новосибирского государственного педагогического университета. 2012. - № 4(8). - С. 80-87.

27.Рубанович В.Б. Морфофункциональное развитие детей и подростков разных конституциональных типов в зависимости от двигательной активности: дис.... докт. мед. наук. - Новосибирск. 2004. - $406 \mathrm{c}$.

28.Рубанович В.Б., Айзман Р.И. Основы здорового образа жизни: учеб. пособ. - Новосибирск: APTA, 2011. $-256 \mathrm{c}$.

29.Тихонова И.Л., Латуха О.А. Инновации медицинского вуза в обучении студентов // Медицина и образование в Сибири. - 2009. - № 1. - С. 2

30.Ставицкая А.Б., Арон Д.И. Методика исследования физического развития детей и подростков. - М.: Медгиз, 1959. - 250 с.

31.Фомин Н.А., Вавилов Ю.Н. Физиологические основы двигательной активности // Физкультура и спорт. - М., 1991. - 224 с. 
Вестник Новосибирского государственного педагогического университета Novosibirsk State Pedagogical University Bulletin

1(17) 2014 www.vestnik.nspu.ru

ISSN 2226-3365

32.Fulton J.E., McGuire M.T., Caspersen C.J., \& Dietz W.H. (2001).Interventions for weight loss and weight gain prevention among youth: Current issues. Sports Medicine, 31, P. 153-165.

33.Xie B., Chou C.P., Spruijt-Metz D, et a1/Weight Perceptions and Weight-related Socio-cultural and Behavioral Factors in Chinese Adolescents. Prev Med. 2006; 42(3): 229-34. 
Вестник Новосибирского государственного педагогического университета Novosibirsk State Pedagogical University Bulletin

1(17) $2014 \quad$ www.vestnik.nspu.ru ISSN 2226-3365

(C) A. V. Lebedev, V. B. Rubanovich, N. I. Aizman, R. I. Aizman

UDC $612.6+378$

\title{
MORPHOFUNCTIONAL FEATURES OF FIRST-YEAR STUDENTS OF PEDAGOGICAL UNIVERSITY
}

\author{
A. V. Lebedev, V. B. Rubanovich, N. I. Aizman, R. I. Aizman (Novosibirsk, Russia)
}

The paper presents data on the morphofunctional features of 18-20-years-old students of pedagogical university. A total of 1,000 people (833 women and 167 men) - male and female students of different faculties of the university were studied. It was noted that if the anthropometric parameters of the first-year students were in the normal range, the students by some functional indicators were below average and low level. On the basis of physical development and response to stress the integral parameter of the physical health was calculated and "health passport" was performed. Finally, conclusions about the necessity of medical and teaching correction on physical education and sports lessons, as well as the participation of university dispensary in improving students physical state were done.

Keywords: "health passport", health monitoring, morphological, functional features, adaptation.

\section{REFERENCES}

1. Aizman R. I. Zdorov'e i bezopasnost' - klyuchevye zadachi obrazovaniya v sovremennykh usloviyakh [Health and Safety - the key task of education in today's conditions]. School health education. - 2011. - № 6 (18). - P. 48-52.

2. Aizman R. I. Zdorov'e pedagogov i obuchayushchikhsya - klyuchevaya zadacha sovremennoi shkoly [Health educators and students - a key task of the modern school]. Bulletin of the Novosibirsk State Pedagogical University, 2012, no. 3, pp. 24-35.

3. Aizman R. I., Aizman N. I., Lebedev A. V. Metodika otsenki sotsial'no-psikhologicheskoi adaptatsii $i$ lichnostnogo potentsiala studentov: metod. posob. [Methods of assessing the sociopsychological adaptation and personal potential students], Novosibirsk, 2013, 40 p.

4. Aizman R. I., Aizman N. I., Lebedev A. V., Pletneva E. Yu., Rubanovich V. B. Monitoring zdorov'ya uchashchikhsya i pedagogov s primeneniem komp'yutera i programmnykh sredstv [Monitoring of health of pupils and teachers with application of a computer and software]. National education, 2010, no. 6, pp. 147-155.

5. Aizman R. I., Aizman N. I., Lebedev A. V., Rubanovich V. B. Metodika kompleksnoi otsenki fizicheskogo i psikhicheskogo zdorov'ya, fizicheskoi podgotovlennosti studentov vysshikh i srednikh professional'nykh uchebnykh zavedenii: metod. Posob. [Methodology comprehensive assessment of physical and mental health, physical fitness of students of higher and secondary vocational schools: the method. Benefits]. Novosibirsk, "RIF Novosibirsk", 2009, 100 p. 
6. Aizman R. I., Lisova N. F. Vozrastnaya fiziologiya: ucheb. posob. [Age physiology: studies. Benefits]. Novosibirsk, NGPU, 2010, 202 p.

7. Aizman R. I., Rubanovich V. B., Subotyalov M. A. Osnovy meditsinskikh znanii i zdorovogo obraza zhizni [Bases of medical knowledge and healthy way of life]. Novosibirsk, 2010, $286 \mathrm{p}$.

8. Bayevsky R. M., Ivanov G. G. Variabel'nost' serdechnogo ritma: teoreticheskie aspekty $i$ vozmozhnosti klinicheskogo primeneniya [Heart rate variability: theoretical aspects and clinical applications]. Moscow, Medicine, 2000, 295 p.

9. Baevskii R. M. Problema otsenki i prognozirovaniya funktsional'nogo organizma i ee razvitie v kosmicheskoi meditsine [Problem with assessing and predicting the function of the organism and its development in space medicine]. Successes of physiological sciences, 2006, vol. 37, no. 3. pp. $42-57$.

10. Bezrukih M. M., Sonkin V. D., Farber D. A. Vozrastnaya fiziologiya [Age physiology: studies]. Moscow, Publishing House of the ACADEMA, 2002, 415 p.

11. Bortsova O. A. Mediko-sotsial'nye aspekty obucheniya shkol'nikov pravil'nomu obrazu zhizni [Medicine and social aspects of training of pupils to a correct way of life]. Philosophy of education, 2006, no. 1, pp. 211-214.

12. Godina E. Z. Biosotsial'nye vliyaniya na protsessy rosta i razvitiya [Biotsocial impact on the growth and development]. Human Ecology, symmetry. Minsk, 1991, pp. 21-22.

13. Endropov O. V. Valeologicheskie aspekty dvigatel'noi aktivnosti cheloveka [Valeological aspects of human physical activity]. Novosibirsk, 1996, $230 \mathrm{p}$.

14. Jomini K. M. Morfofunktsional'nye i psikhofiziologicheskie osobennosti studentok v zavisimosti ot vida i rezhima fizkul'turno-sportivnoi deyatel'nosti. Avtoref. diss. kand. biol. nauk [Morphological and physiological characteristics of students, depending on the type and mode of sports activity. Author. candidate. biol. science. diss.]. Chelyabinsk, 2013, 22 p.

15. Ivanov V. I., Litvinov N. A., Berezina M. G. Avtomatizirovannye metody psikhodiagnostiki: metodicheskie rekomendatsii (instruktsiya pol'zovatelya k kompleksu "Status PF») [Automated methods of psycho-diagnostics: guidelines (user to the complex «Status PF»)]. Kemerovo State University, Kemerovo Kuzbassvuzizdat Publishing House, 2002, 28 p.

16. Kazin E. M. Lurie, S. B. Sostoyanie zdorov'ya shkol'nikov i faktory ego formiruyushchie [The health status of school children and the factors shaping it]. Valeological aspects of education. Kemerovo, 1995, pp. 96-115.

17. Kirsanov V. M., Shibkova D. Z. Psikhofiziologicheskaya kharakteristika lichnosti studentov v period adaptatsii $\mathrm{k}$ obucheniyu $\mathrm{v}$ vuze [Psycho-physiological characteristics of the individual students in the period of adaptation to training in high school]. Siberian pedagogical magazine, Novosibirsk, 2012, no. 9, pp. 127-132.

18. Kuzhuget A. A. Osobennosti fizicheskogo razvitiya, funktsii kardiorespiratornoi sistemy i somaticheskogo zdorov'ya studentov $v$ zavisimosti ot organizovannoi dvigatel'noi aktivnosti. Avtoref. diss. kand. biol. nauk. [Features physical disabilities, cardiorespiratory function and physical health of students, depending on the organized physical activity. Author. candidate. biol. science diss.]. Chelyabinsk, 2012, pp. 23. 
19. Kuznetsova L. M., Kuznetsov V. D., Timoshenko K. T. Pokazateli psikhicheskogo zdorov'ya sovremennykh starsheklassnikov i studentov vuza [Indicators of mental health of modern high school and university students]. Hygiene and sanitation, 2008, no. 3, pp. 59-63.

20. Latuha O. A., Pushkarev Yu. V. Ekonomicheskoe razvitie sovremennogo obshchestva i problema podgotovki innovatsionnykh kadrov [Economic development of modern society and the problem of innovation staff training]. Bulletin of the Novosibirsk State Pedagogical University, 2012, no. 5, pp. 50-56.

21. Mayer B. O., Evzrezov D. V. Izmeneniya $v$ sisteme sovremennogo obshchestva i reformy vysshego obrazovaniya [Changes in the system of modern society and the reform of higher education]. Bulletin of the Novosibirsk State Pedagogical University, 2012, no. 6. pp. 37-44.

22. Nasledov A. D. Matematicheskie metody psikhologicheskogo issledovaniya. Analiz i interpretatsiya dannykh [Mathematical methods of psychological research. Analysis and interpretation of data]. St. Petersburg, Publishing House of Speech, 2004, 392 p.

23. Negasheva M. A., Mishkova T. A. Antropometricheskie parametry i adaptatsionnye vozmozhnosti studencheskoi molodezhi k nachalu XXI veka [Anthropometric parameters and adaptive capabilities of students to the beginning of the XXI century]. Russian Journal of Teachers, 2005, no 5, pp. $12-16$.

24. Osobennosti adaptatsii sistemy vneshnego dykhaniya, krovoobrashcheniya, morfofunktsional'nykh pokazatelei i urovnya zdorov'ya studentov [Features of the system's adaptation of respiratory, circulatory, morphological and functional indicators and the level of students' health]. ed. S. A. Kabanov, T. V. Potapov, A. P. Isaeva, Theory and Practice of Physics. Culture. 2005, no. 8, pp. 45-48.

25. Pushkareva E. A. Vzaimodeistvie nauki i obrazovaniya v usloviyakh formirovaniya innovatsionnoi kul'tury obrazovatel'nogo uchrezhdeniya [The interaction of science and education in the emerging culture of innovation educational institution]. Bulletin of the Novosibirsk State Pedagogical University, 2013, no. 4. pp. 29-37.

26. Pushkareva E. A., Sudorgina L. V. Kul'tura samoopredeleniya: adaptatsionnye mekhanizmy lichnosti [Culture of self-determination: adaptable mechanisms of the person]. Novosibirsk State Pedagogical University Bulletin, 2012, no. 4, pp. 80-87.

27. Rubanovich V. B. Morfofunktsional'noe razvitie detei i podrostkov raznykh konstitutsional'nykh tipov v zavisimosti ot dvigatel'noi aktivnosti. Diss. dokt. med. nauk. [Morphological and functional development of the children and adolescents of different constitutional types, depending on the motor activity. Doctor. honey. science. diss.]. Novosibirsk, 2004, 406 p.

28. Rubanovich V. B., Aizman R. I. Osnovy zdorovogo obraza zhizni [Bases of a healthy way of life]. Novosibirsk, 2011, $256 \mathrm{p}$.

29. Tikhonova I. L., Latukha O. A. Innovatsii meditsinskogo vuza v obuchenii studentov [Innovations of medical high school in training students]. Medicine and education in Siberia, 2009, no. 1, p. 2

30. Stavitskaya A. B., Aaron D. I. Metodika issledovaniya fizicheskogo razvitiya detei i podrostkov [Technique to study the physical development of children and adolescents]. Moscow, Medgiz, $1959,250$. 
31. Fomin N. A., Vavilov Yu. N. Fiziologicheskie osnovy dvigatel'noi aktivnosti [Physiological basis of motor activity]. Physical Education and Sports, Moscow, 1991, 224 p.

32. Fulton J. E., McGuire M. T., Caspersen C. J., \& Dietz W. H. (2001). Interventions for weight loss and weight gain prevention among youth. Current issues. Sports Medicine, no. 31, pp. 153-165.

33. Xie B., Chou C. P., Spruijt-Metz D., et al. Weight Perceptions and Weight-related Socio-cultural and Behavioral Factors in Chinese Adolescents. Prev Med., 2006, no. 42(3), pp. 229-234.

Lebedev Alexey Vladimirovich, Ph.D., the associate professor of the department of anatomy, physiology and life safety, Novosibirsk State Pedagogical University.

E-mail: lebedev_05@mail.ru

Rubanovich Viktor Borisovich, MD, the professor of the department of anatomy, physiology and life safety, Novosibirsk State Pedagogical University.

E-mail: rubanovich08@mail.ru

Aizman Nina Igorevna, Ph.D., the head of the Center of Applied Psychology, Novosibirsk State Pedagogical University.

E-mail: nina.aizman@mail.ru

Aizman Roman Idelevich, Sc.D., the professor, the head of the department of anatomy, physiology and life safety, Novosibirsk State Pedagogical University.

E-mail: roman.aizman@mail.ru 
Вестник Новосибирского государственного педагогического университета Novosibirsk State Pedagogical University Bulletin

1(17) $2014 \quad$ www.vestnik.nspu.ru ISSN 2226-3365

\author{
(С) Л. К. Будук-оол, С. К. Сарыг, А. М. Ховальгг
}

УДК $612.821+159.9+378+316.6$

\title{
ПСИХОФИЗИОЛОГИЧЕСКИЕ ХАРАКТЕРИСТИКИ СТУДЕНТОВ-ТУВИНЦЕВ С РАЗНЫМИ СОЦИОТИПАМИ*
}

\author{
Л. К. Будук-оол, С. К. Сарыг, А. М. Ховальцг (Кызыл, Россия)
}

\begin{abstract}
В статье анализируются особенности психофизиологических характеристик студентов тувинского государственного университета в зависимости от социотипа. Цель статьи - выявить психофизиологические особенности личности студента с разным социотипом. У студентов Тувинского государственного университета доминируют социалы и гуманитарии, что указывает на преобладание в университете сочиально-гуманитарного направления подготовки специалистов. Показано, что среди студентов-юномей преобладают сочиалы, затем следуют управленць, среди девушек - гуманитарии и затем также сочиалы. Среди девушек оказалось меньше всего управленцев, а среди юношей - сайентистов. Определены следуюшие психофизиологические особенности студентов тувинского университета разных соииотипов: социаль и управленць характеризовались достоверно более высоким уровнем невротизации, они используются разнообразные стратегии поведения в конфликтных ситуациях, управленцы отличались достоверно более низким уровнем психопатизачии. Гуманитарии и сайентисты оказались более высоко тревожными. Для гуманитариев характерны компромиссы и избегание в разрешении конфликтных ситуаций, у сайентистов преобладают стратегии избегания, компромисса и приспособления. Все соииотипы характеризовались оптимальным уровнем стрессоустойчивости.
\end{abstract}

Ключевые слова: студенты, сочиотипь, личностная тревожность, стратегии поведения, психопатизация, невропатизация.

* Статья подготовлена по результатам работы Всероссийской научной школы с Международным участием «Опыт использования мониторинга здоровья и физической подготовленности учащейся молодежи» (12-14 ноября 2013 г.).

Будук-оол Лариса Кара-Саловна - доктор биологических наук, доцент, профессор кафедры анатомии, физиологии и безопасности жизнедеятельности, Тувинский государственный университет.

E-mail: buduk-ool@mail.ru

Сарыг Сайлык Кызыл-ооловна - кандидат биологических наук, старший преподаватель кафедры анатомии, физиологии и безопасности жизнедеятельности, Тувинский государственный университет.

Ховалыг Айана Могушовна - аспирант кафедры анатомии, физиологии и безопасности жизнедеятельности, Тувинский государственный университет. 
Вестник Новосибирского государственного педагогического университета Novosibirsk State Pedagogical University Bulletin

1(17) $2014 \quad$ www.vestnik.nspu.ru $\quad$ ISSN 2226-3365

В современной психофизиологии большое внимание уделяется исследованиям характеристик индивидуально-типологических особенностей личности, поскольку это является основой индивидуализации обучения, профессиональной и спортивной ориентации, и т.д. Одной из популярных классификаций индивидуально-типологических свойств личности является классификация социотипов, определяющая направленность человека на тот или иной вид деятельности и выбора профессии.

Социотипические характеристики еще очень мало обоснованы с точки зрения психофизиологических особенностей человека. Имеющиеся работы[7; 10-11] содержат разрозненные данные о распределении социотипов среди различных контингентов обследуемых и их особенностях, основанные, главным образом, на психологических и социологических исследованиях. Психофизиологические особенности лиц с разными социотипами студентов национальных групп, изучены крайне мало, что определило тему нашего исследования.

Классификация, разработанная А. Аугустинавичюте [3] и названная ею «соционикой», характеризует социотипы, или направленность на определенный вид деятельности.

Социотип - устойчивая структура личности человека, основанная на пропорциях между основными компонентами его психики - сенсорикой, интуицией, мышлением и чувствованием. Спектр данных возможностей детерминирован сильными функциями в структуре психики личности. К. Г. Пиликян [9] рассматривает каждую их этих функций следующим образом, отметив, что эти функции представляют дихотомические пары: сенсорика и интуиция - функции восприятия информации, а логика и этика - функции оценки и принятия решения.

Сенсорика - это функция конкретного восприятия окружающего мира через органы чувств; ориентация на конкретику и точность воспринимаемой информации в пространстве. С помощью сенсорики мир воспринимается как чувственная реальность в ее конкретных формах, цвете, запахе.

Интуиция - это функция отвлеченного восприятия мира в целостных образах и картинах фантазии; это вторичное ассоциативное восприятие, воображение, эвристическое мышление, связанное с извлечением сенсорных образов из памяти. Логика - это функция психики человека, обрабатывающая информацию, способ мышления или рассуждения, устанавливающий необходимую связь явлений, закономерностей объективного мира. Этика - психическая функция субъективного суждения или оценки, основанная на вовлечённости во внутренний, душевный мир окружающих людей.

У каждого человека сильными являются одна воспринимающая (сенсорика или интуиция) и одна оценивающая (логика или этика) функция. Таким образом, выделяют 4 социотипа (или установки на вид деятельности) гуманитарии, исследователи, социалы и управленцыс учётом признаков: сенсорика интуиция, логика - этика.

По данным В. Н. Васильева и др. [8], у студентов г. Томска (160 женщин и 90 мужчин) меньше всего было выявлено интуитивно-логических экстравертов (по психологической классификации), соответствующих социотипу исследователя.

По данным А. В. Букалова и соавторов [7], у работников разных профессиональных групп, работающих на Крайнем севере России, отмечалось преобладание социалов, то- 
Вестник Новосибирского государственного педагогического университета Novosibirsk State Pedagogical University Bulletin

1(17) $2014 \quad$ www.vestnik.nspu.ru $\quad$ ISSN 2226-3365

гда как среди студентов педагогического университета преобладали гуманитарии. Авторы объясняют, с одной стороны, направленностью вуза, с другой - спецификой выборки, половыми особенностями обследуемого контингента, регионом проживания, профессиональной направленностью обследованных. Однако по количеству исследователей и управленцев принципиальных различий не выявилось. По-видимому, в процессе эволюции в человеческой популяции формируется разное соотношение социотипов, в котором количество исследователей и управленцев представлено меньше по сравнению с другими социотипами, независимо от сферы деятельности.

В исследованиях А. В. Лебедева, М. А. Суботялова, Р. И. Айзмана $[1 ; 11]$ показано, что при оценке распределения социотипов среди девушек-студенток разных факультетов педагогического университета г. Новосибирска наиболее часто, среди данной популяции, встречались гуманитарный и социальный социотипы, реже всего - управленческий и исследовательский.

Объектом нашего исследования служили студенты Тувинского государственного университета сельскохозяйственного, экономического, инженерно-технического и физико-математического факультетов. Обследовано 110 студентов, в том числе юношей -41 , девушек -69 .

Исследование социотипа и психофизиологических показателей проводили с помощью компьютерной программы «Комплексная оценка здоровья и развития студентов высших и средних учебных заведений» [2]. Программа включает следующие методики: социотип определяли на основании теста D. Keirsey (1984), уровень реактив- ной и личностной тревожности - опроснику Ч. Д. Спилбергера и Ю. Л. Ханина, уровень агрессивности и враждебности - опросника Басса-Дарки, уровень мотивации - по шкале оценки потребности в достижении успеха T. Элерса, стратегии поведения личности в конфликтном взаимодействии - по методике К. Томаса.

Наибольшая доля лиц среди студентов университета относится к социотипу - гуманитарии, всего на 1,9\% меньше оказалось социалов. Наименьшее количество студентов относится к группе сайентистов (рис. 1). Наши данные согласуются с данными А. В. Лебедева с соавторами [10], которые также отметили среди студенток преобладающее большинство гуманитариев и социалов.

При оценке распределения студентов юношей и девушек по социотипам в зависимости от факультета оказалось, что наиболее часто среди данной выборки встречались гуманитарный $(30,6$ \%) и социальный $(28,4 \%)$ социотипы, реже всего - управленческий и исследовательский (по 20,5 \%). Это доказывает то, что существует соответствие индивидуально-типологических особенностей студентов выбранному профилю, однако особенности когнитивной сферы зависимости от социотипа изучены недостаточно.

Анализ распределения студентов в зависимости от пола показал, что среди юношей наибольшая доля лиц приходится на социалов - 33,3 \%, доля управленцев составляет $28,6 \%$, гуманитариев - 23,8 \%, остальные $14,3 \%$ - сайентисты.

Среди девушек преобладают гуманитарии $(41,2 \%)$, затем следуют социалы $27,9 \%$, сайентисты - $19,9 \%$ и управленцы $11 \%$. 
Вестник Новосибирского государственного педагогического университета Novosibirsk State Pedagogical University Bulletin

1(17) $2014 \quad$ www.vestnik.nspu.ru ISSN 2226-3365

Рисунок 1

Распределение студентов по социотипам без учета половой принадлежности

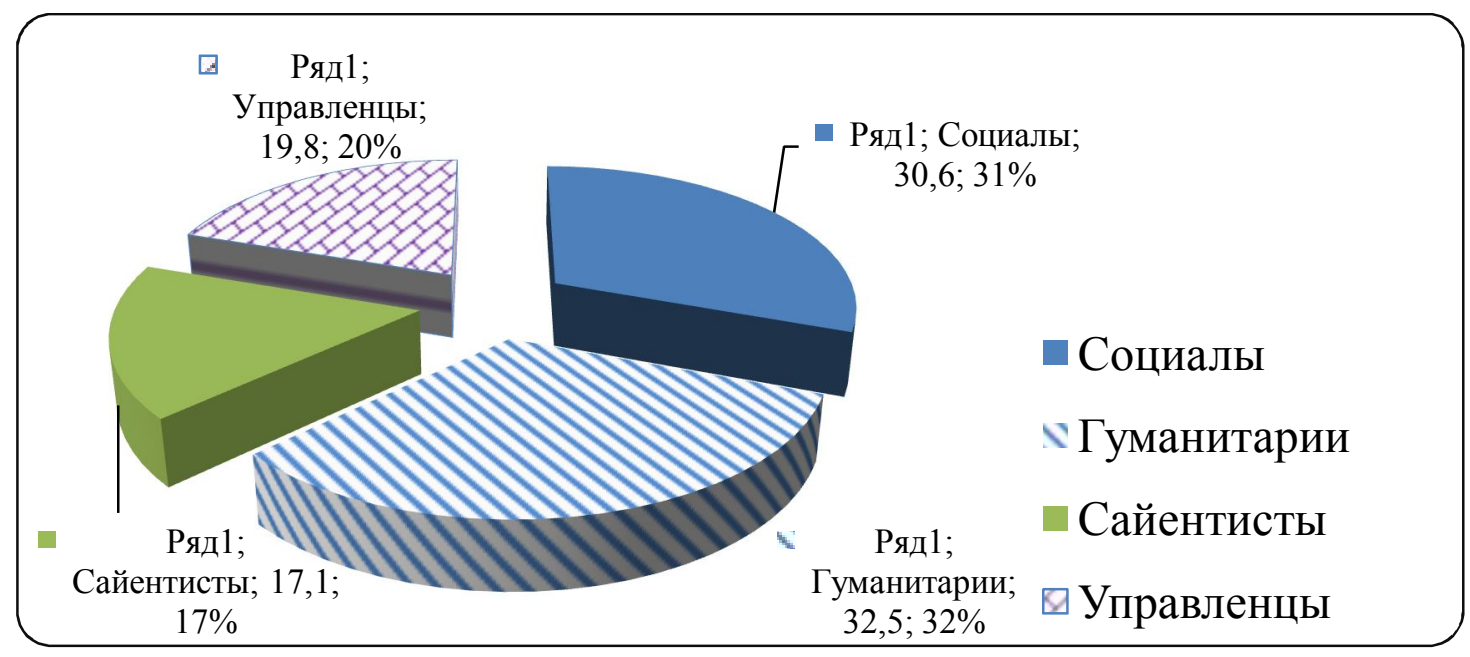

Таким образом, у девушек, по сравнению с юношами, на 17,6 \% больше управленцев, на $17,4 \%$ - гуманитариев, а у юношей больше социалов (на 5,4 \%). Наличие половых различий в преобладании разных социотипов указывает на гендерные особенности формирования психологических и социальных типов, определяющих различные стратегии поведения и социализации юношей и девушек. Наши данные также согласуются с исследованиями, проведенными на девушках Новосибирского государственного педагогического университета под руководством Р. И. Айзмана (2009-2011), которые показали преобладание девушек-гуманитариев. Однако по количеству лиц на третьем месте у девушек Новосибирского педагогического университета оказались управленцы, а затем сайентисты (исследователи), в то время как среди тувинок - управленцы занимают последнее место в рейтинговом ряду. Вероятно, это может быть связано с этно-психофизиологическими особенностями индивидуальнотипологической конституции тувинских девушек. Такие предположения подтверждаются нашими исследованиями [4-6; 12-16], в которых показано наличие этнических психофизиологических особенностей тувинских студентов в сравнении с русскими, в частности, у тувинских девушек преобладающим типом темперамента является меланхолический, не соответствующий управленческому социотипу.

Оченка уровня сочиально-психологической адаптации у разных сочиотипов.

Оценка уровня социальнопсихологической адаптации по А. К. Осницкому показала, что по интегральным показателям достоверных различий между юношами разных социотипов не оказалось.

В группе девушек социалы достоверно лучше адаптированы, имеют более высокие показатели самопринятия, интернальности, эмоциональной комфортности, стремления к доминированию по сравнению с гуманитариями и сайентистами (табл. 1).

Таким образом, девушек-социалов отличает настрой на общение, неформальные связи, эмоциональный комфорт все то, что характеризует их как социальноадаптированных личностей. Они по своей природе настроены на групповое взаимодей- 
Вестник Новосибирского государственного педагогического университета Novosibirsk State Pedagogical University Bulletin

ствие, удовлетворение текущих физических потребностей человека - в еде, отдыхе, общении, семье и т.п., т.е. более заботятся о повседневных житейских проблемах. Их стремление к доминированию проявляется в основном среди друзей, знакомых и родственников. Высокие значения шкалы интернальности говорят о том, что девушки полагают, что происходящие с ним события являются результатом их деятельности, они в большей мере принимают ответственность за события, происходящие в их жизни, на себя, объясняя их своим поведением, характером, способно- стями, это говорит о наличии у них внутреннего (интернального) контроля. Девушки более склонны приписывать причины происходящего внешним факторам (окружающей среде, судьбе или случаю), т.е. у них выше внешний (экстернальный) контроль.

Минимальными показателями адаптации обладают студенты-сайентисты, что указывает на их низкую личностную зрелость, сниженное чувство собственного достоинства, неумение уважать других, непонимание своих проблем и в связи с этим, неумение справиться с ними.

Таблица 1

Интегральные показатели социально-психологической адаптации студентов с разным социотипом

\begin{tabular}{|c|c|c|c|c|c|c|}
\hline $\begin{array}{c}\text { Интегральные } \\
\text { показатели }\end{array}$ & пол & $\begin{array}{c}\text { Социалы } \\
(\mathrm{Co})\end{array}$ & $\begin{array}{c}\text { Гумани- } \\
\text { тарии (Г) }\end{array}$ & $\begin{array}{c}\text { Сайенти- } \\
\text { сты (Са) }\end{array}$ & $\begin{array}{c}\text { Управлен- } \\
\text { цы (У) }\end{array}$ & $\mathrm{P}<0.05$ \\
\hline \multirow{2}{*}{ Адаптация } & юноши & $63,1 \pm 2,6$ & $61,8 \pm 2,2$ & $60,0 \pm 1,8$ & $64,0 \pm 2,4$ & \\
\cline { 2 - 7 } & девушки & $62,3 \pm 1,5$ & $58,3 \pm 1,2$ & $56,6 \pm 1,8$ & $60,9 \pm 2,1$ & Со-Г, Со-Са \\
\hline \multirow{2}{*}{ Самопринятие } & юноши & $73,7 \pm 2,7$ & $72,9 \pm 3,7$ & $69,5 \pm 2,7$ & $73,3 \pm 2,7$ & \\
\cline { 2 - 7 } & девушки & $75,4 \pm 1,5$ & $71,6 \pm 1,4$ & $67,6 \pm 1,7$ & $74,07 \pm 4,0$ & Со-Са \\
\hline $\begin{array}{c}\text { Принятие дру- } \\
\text { гих }\end{array}$ & юноши & $66,7 \pm 2,9$ & $66,6 \pm 2,2 *$ & $63,1 \pm 1,9$ & $64,4 \pm 2,7$ & \\
\cline { 2 - 7 } & девушки & $62,3 \pm 1,7$ & $61,2 \pm 1,3$ & $61,7 \pm 2,2$ & $62,3 \pm 2,0$ & \\
\hline $\begin{array}{c}\text { Эмоциональная } \\
\text { комфортность }\end{array}$ & юноши & $63,1 \pm 2,9$ & $59,2 \pm 3,1$ & $58,1 \pm 2,2$ & $63,6 \pm 3,1$ & \\
\hline \multirow{2}{*}{$\begin{array}{c}\text { Интерналь- } \\
\text { ность }\end{array}$} & юноши & $65,3 \pm 2,4$ & $55,3 \pm 1,9$ & $52,2 \pm 2,2$ & $57,2 \pm 3,8$ & Со-Г, Со-Са \\
\cline { 2 - 7 } & девушки & $68,5 \pm 2,5$ & $63,8 \pm 2,3$ & $69,0 \pm 3,6$ & $70,5 \pm 2,5$ & \\
\hline $\begin{array}{c}\text { Стремление к } \\
\text { доминирова- } \\
\text { нию }\end{array}$ & юноши & $47,7 \pm 4,5 *$ & $52,7 \pm 1,5$ & $60,7 \pm 2,0$ & $62,7 \pm \pm 3,7$ & Со-Г \\
\cline { 2 - 7 } & девушки & $60,6 \pm 2,6$ & $55,6 \pm 2,4$ & $50,4 \pm 2,4$ & $57,8 \pm 4,2$ & Со-Са \\
\hline
\end{tabular}

Примечание: * - достоверные различия по полу,

буквами - различия между сочиотипами в одной половой группе.

Анализ социально-психологической адаптации у студентов с разными социотипами показал достоверные половые различия в группе социалов по шкале стремления к доминированию: у девушек степень стремления к доминированию в межличностных отношениях выше, чем у юношей. Высокие показа- тели данной школы говорят о склонности подавлять другого человека, чувствовать превосходство над другими.

В группе гуманитариев, у юношей по сравнению с девушками, достоверно выше шкала принятия других, что отражает уровень их дружественности к окружающим лю- 
Вестник Новосибирского государственного педагогического университета Novosibirsk State Pedagogical University Bulletin

дям, к миру, принятие людей, одобрение их жизни и отношения к себе в целом, ожидание позитивного отношения к себе окружающих. Девушки-гуманитарии более критичны по отношению к людям, проявляют раздражение, презрение по отношению к ним и ожидают от них негативного отношения к себе.

Характеристика уровня тревожности у студентов разных соичиотипов.

Личностная тревожность - готовность (установка) человека к переживанию страха и волнений по поводу широкого круга субъективно значимых явлений. Личностная тревожность - это устойчивое состояние. Она характеризует склонность человека воспринимать большой круг ситуаций как угрожающие, реагировать на такие ситуации состоянием тревоги. Сама по себе тревожность не является изначально негативной чертой личности. Определенный уровень тревожности естественная и обязательная для каждого человека уровень «полезной тревоги».

Анализ состояния тревожности у студентов с разными социотипами свидетельствует о том, что по уровню реактивной тревожности достоверных различий не обнаружено, это указывает на доминирование ситуации, в которой проводится тестирование, над соционическими особенностями личности.

Реактивная тревожность во всех исследуемых группах оказалась ниже 30 баллов, что соответствует низкому уровню.

Анализ уровня личностной тревожности, независящей от конкретной ситуации, показал статистически достоверно более высокую тревожность у сайентистов и гуманитариев, а самую низкую - у управленцев.

У девушек личностная тревожность была выше, чем у юношей у гуманитариев и сайентистов (таблице 2).

В группе юношей достоверных различий между социотипами по личностной тревожности не обнаружено, при этом уровень тревожности находился в диапазоне умеренной тревожности. У девушек уровень тревожности был умеренным только у управленцев и социалов, а у гуманитариев и сайентистов он соответствовал высокому уровню.

Таблица 2

Показатели тревожности у юношей и девущек разных соџиотипов

\begin{tabular}{|l|c|c|c|c|}
\hline \multirow{2}{*}{\multicolumn{1}{|c|}{ Социотип }} & \multicolumn{2}{|c|}{ Реактивная тревожность } & \multicolumn{2}{c|}{ Личностная тревожность } \\
\cline { 2 - 5 } & юноши & девушки & юноши & девушки \\
\hline Социалы & $23,0 \pm 1,5$ & $24,8 \pm 1,3$ & $39,0 \pm 1,4$ & $42,7 \pm 1,3(\Gamma)$ \\
\hline Гуманитарии & $27,2 \pm 1,7$ & $27,9 \pm 1,4$ & $38,9 \pm 1,7 *$ & $46,1 \pm 1,5(\mathrm{У}, \mathrm{Ca})$ \\
\hline Управленцы & $26,3 \pm 1,8$ & $27,0 \pm 1,5$ & $39,5 \pm 1,7$ & $41,8 \pm 1,8(\mathrm{Ca})$ \\
\hline Сайентисты & $23,9 \pm 1,8$ & $26,1 \pm 2,7$ & $37,7 \pm 1,9 *$ & $45,6 \pm 1,5$ \\
\hline
\end{tabular}

Примечание: * - достоверные различия по полу; буквами -различия между социотипами в одной половой группе. 
Вестник Новосибирского государственного педагогического университета Novosibirsk State Pedagogical University Bulletin

1(17) $2014 \quad$ www.vestnik.nspu.ru $\quad$ ISSN 2226-3365

В группе девушек наибольшей личностной тревожностью обладают гуманитарии по сравнению со всеми остальными социотипами (таблица 2). Полученные данные совпадают с результатами новосибирских авторов $[1 ; 11]$.

Характеристика психических состояний по уровню невротизации и психопатизаизии (УНП) студентов разных социотипов.

Утверждения, входящие в шкалу невротизации, содержат такие характерные проявления невротических состояний, как быстрая утомляемость, нарушения сна, ипохондрическая фиксация на неприятных соматических ощущениях, снижение настроения, повышенная раздражительность, возбудимость, наличие страхов, тревоги, неуверенности в себе.

Утверждения шкалы психопатизации охватывают лишь некоторые из черт, характерных для психопатических личностей: равнодушие к принципам долга и морали, безразличие к мнению окружающих, повышенный нонконформизм, стремление выделиться среди окружающих, лицемерие, вспыльчивость, подозрительность, повышенное самолюбие и самоуверенность.

Невротизация формируется под влиянием трех классов психических явлений. Прежде всего, ее уровень опосредован эмоционально. И, наконец, фактором, определяющим уровень невротизации, является собственное состояние человека, его самочувствие, основной тон его переживания. Поскольку уровень невротизации отражает как динамически изменяющиеся особенности человека (состояния), так и относительно более статичные (свойства личности), то невротизацию можно представить как вариативную личностную переменную. Типичный для конкретного человека уровень невротизации, в основном обусловленный его личностными особенностями, и определяет вероятный диапазон изменений ее уровня, вызываемых различными психо-, сомато- и социогенными факторами.

При высоком уровне невротизации (высокая по абсолютной величине отрицательная оценка) может наблюдаться выраженная эмоциональная возбудимость, продуцирующая различные негативные переживания (тревожность, напряженность, беспокойство, растерянность, раздражительность), это, в свою очередь, формирует чувство собственной неполноценности, затрудненность в общении, социальную робость и зависимость.

При низком уровне невротизации (высокая по абсолютной величине положительная оценка) отмечается эмоциональная устойчивость и положительный фон основных переживаний (спокойствие, оптимизм). Оптимизм и инициативность, простота в реализации своих желаний формируют чувство собственного достоинства, социальную смелость, независимость, легкость в общении.

Высокий уровень психопатизации свидетельствует о беспечности и легкомыслии, холодном отношении к людям, напористости, упрямстве в межличностных взаимодействиях. Этим лицам присуща тенденция к выходу за рамки общепринятых норм и морали, что может приводить к непредсказуемости их поступков и созданию конфликтных ситуаций.

Низкий уровень психопатизации может говорить об осмотрительности, уступчивости, ориентированности на мнение окружающих, о приверженности к строгому соблюдению общепринятых правил и норм поведения.

По данным нашего исследования, социалы и управленцы характеризовались достоверно более высоким уровнем невротизации по сравнению с сайентистами, при этом их 
Вестник Новосибирского государственного педагогического университета Novosibirsk State Pedagogical University Bulletin

уровень невротизации был ниже среднего от нормативных значений.

При низком уровне невротизации (высокая по абсолютной величине положительная оценка) отмечается эмоциональная устойчивость и положительный фон основных переживаний (спокойствие, оптимизм). Оптимизм и инициативность, простота в реализации своих желаний формируют чувство собственного достоинства, социальную смелость, независимость, легкость в общении.

Все студенты характеризовались средним уровнем психопатизации, но при этом управленцы отличались достоверно более низким уровнем по сравнению с другими социотипами. Низкий уровень психопатизации свидетельствует об осмотрительности, уступчивости, ориентированности на мнение окружающих, о приверженности к строгому соблюдению общепринятых правил и норм поведения.

Все исследуемые студенты, независимо от социотипов, характеризуются средним уровнем психопатизации, однако у девушек он статистически достоверно выше по сравнению с юношами (таблица 3).

Анализ половых различий показал, что невротизация девушек, независимо от социотипа, соответствует среднему уровню (до 30 баллов), юношей - ниже среднего (от 31 до 79 баллов).

Таблица 3

Показатели УНП у юношей и девушек с разными соџиотипами

\begin{tabular}{|c|c|c|c|c|c|c|}
\hline $\begin{array}{c}\text { Интегральные } \\
\text { показатели }\end{array}$ & пол & $\begin{array}{c}\text { Социалы } \\
(\mathrm{C})\end{array}$ & $\begin{array}{c}\text { Гумани- } \\
\text { тарии }(\Gamma)\end{array}$ & $\begin{array}{l}\text { Сайенти- } \\
\text { сты (Са) }\end{array}$ & $\begin{array}{c}\text { Управ- } \\
\text { ленцы (У) }\end{array}$ & $\mathrm{P}<0.05$ \\
\hline \multirow[b]{2}{*}{ Невротизация } & юноши & $39,8 \pm 4,0^{*}$ & $44,2 \pm 6,5^{*}$ & $22,6 \pm 7,9$ & $38,1 \pm 9,0 *$ & $\begin{array}{l}\mathrm{C}-\mathrm{Ca}, \\
\Gamma-\mathrm{Ca}\end{array}$ \\
\hline & девушки & $29,1 \pm 5,1$ & $13,1 \pm 5,4$ & $9,1 \pm 6,0$ & $17,0 \pm 5,0$ & $\begin{array}{c}\mathrm{C}-\Gamma, \\
\mathrm{C}-\mathrm{Ca}, \\
\mathrm{C}-\mathrm{Y}\end{array}$ \\
\hline \multirow[t]{2}{*}{ Психопатизация } & юноши & $13,4 \pm 1,6^{*}$ & $16,2 \pm 2,0^{*}$ & $11,3 \pm 1,2^{*}$ & $10,1 \pm 1,5^{*}$ & $\begin{array}{c}\Gamma-\mathrm{CA}, \\
\Gamma-\mathrm{y}\end{array}$ \\
\hline & девушки & $23,4 \pm 1,9$ & $22,5 \pm 1,9$ & $25,1 \pm 2,5$ & $22,1 \pm 1,8$ & \\
\hline \multirow[b]{2}{*}{ Лживость } & юноши & $4,2 \pm 0,4$ & $4,3 \pm 0,6^{*}$ & $5,0 \pm 0,7^{*}$ & $4,8 \pm 0,5^{*}$ & \\
\hline & девушки & $3,8 \pm 0,4$ & $3,3 \pm 0,2$ & $3,2 \pm 0,5$ & $3,1 \pm 0,3$ & $\begin{array}{l}\text { C-У, } \\
\Gamma-\mathrm{Y} \\
\text { Ca-У }\end{array}$ \\
\hline
\end{tabular}

Примечание: * - достоверные различия по полу;

буквами - различия между социотипами в одной половой группе.

Оиенка стрессоустойчивости студентов разных соииотипов.

Стрессоустойчивость - представляет собой совокупность личностных качеств, позволяющих человеку переносить значительные интеллектуальные, волевые и эмоциональные нагрузки, обусловленные особенностями профессиональной деятельности. 
Вестник Новосибирского государственного педагогического университета Novosibirsk State Pedagogical University Bulletin

Внутренние факторы стрессоустойчивости это предшествующий опыт, индивидуальнопсихологические качества (свойства нервной системы, темперамент), некоторые личностные характеристики.

Стрессоустойчивость представляет собой совокупность личностных качеств, позволяющих человеку переносить значительные интеллектуальные, волевые и эмоциональные перегрузки,
Показатели стрессоустойчивости не имели достоверных различий в зависимости от социотипа. Анализ уровня стрессоустойчивости свидетельствует о том, что как юноши, так и девушки в среднем обладают оптимальным уровнем стрессоустойчивости, который соответствует в меру напряженной жизни активного человека (31-45 баллов).

Рисунок 2

Показатели стрессоустойчивости у юношей и девушек с разнымисоциотипами.

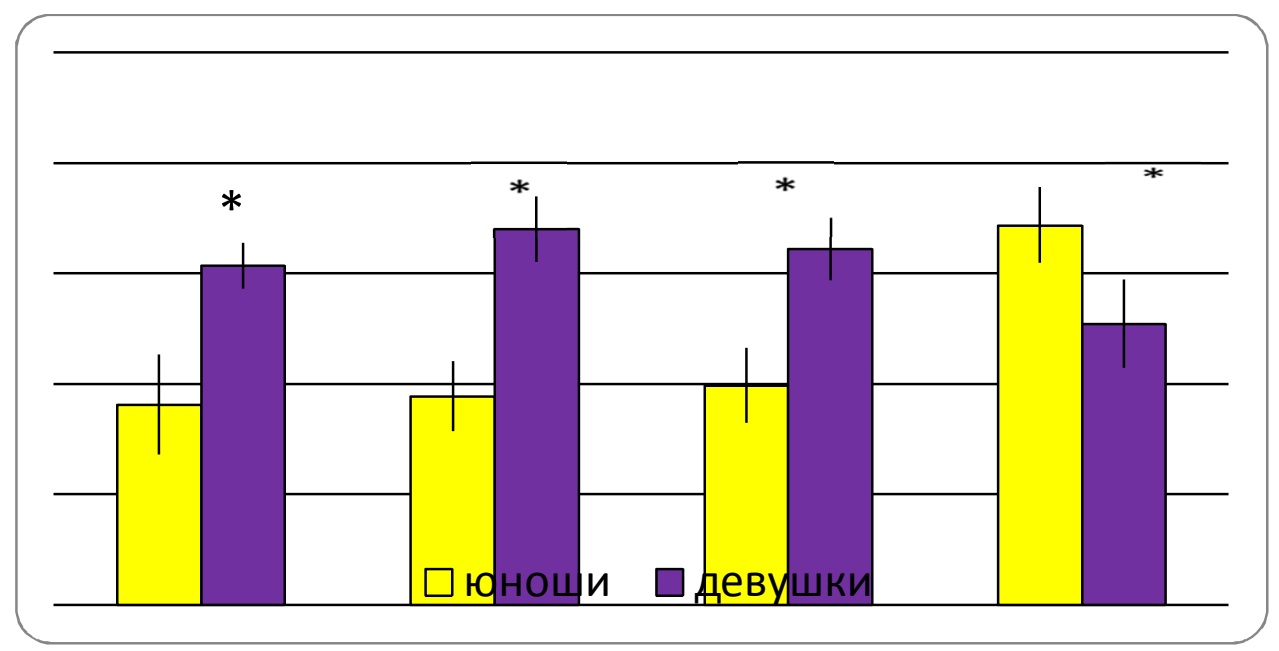

Примечания * - достоверные различия по полу.

Обнаружено, что у девушек стрессоустойчивость не различается в зависимости от социотипов, а у юношей она достоверно ниже у управленцев по сравнению с остальными социотипами (рисунок 2). Юноши оказались более стрессоустойчивыми, чем девушки, это связано с тем, что девушки более тревожны и не умеют преодолевать трудные ситуации, чувствительны к даже незначительным жизненным проблемам.
Оиенка стратегии поведения личности в конфликтном взаимодействии в зависимости от социотипа (К. Томас).

Анализ стратегий поведения в конфликтной ситуации показал, что в группе социалов и управленцев используются все стратегии поведения в конфликтных ситуациях. Гуманитарии предпочитают не использовать стратегию соперничества, у них преобладают компромиссы и избегание конфликтных ситуаций. У сайентистов преобладают страте- 
Вестник Новосибирского государственного педагогического университета Novosibirsk State Pedagogical University Bulletin

гии избегания, компромисса и приспособления.

У юношей-социалов достоверных различий в формах поведения не обнаружено. У юношей-гуманитариев наиболее выраженными оказались компромиссы и приспособление в конфликтной ситуации, у них почти отсутствует поведенческая стратегия соперничества, у сайентистов минимально выражена тенденция к сотрудничеству, у управленцев преобладание компромисса над избеганием.

Таблица 4

Стратегии в конфликтной ситуащии у юношей и девущек с разными соџиотипами

\begin{tabular}{|c|c|c|c|c|c|c|}
\hline & & Социалы & $\begin{array}{c}\text { Гуманита- } \\
\text { рии }\end{array}$ & Сайентисты & Управленцы & $\mathrm{P}<0.05$ \\
\hline \multirow{2}{*}{$\begin{array}{c}\text { Соперниче- } \\
\text { ство }\end{array}$} & Юноши & $6,46 \pm 0,37$ & $4,11 \pm 0,55^{*}$ & $6,25 \pm 0,58^{*}$ & $6,25 \pm 0,53$ & $\mathrm{Co}-\Gamma$ \\
\hline & девушки & $6,13 \pm 0,47$ & $5,63 \pm 0,52$ & $4,92 \pm 0,51$ & $6,65 \pm 0,51$ & Сай-У \\
\hline \multirow{2}{*}{$\begin{array}{c}\text { Сотрудни- } \\
\text { чество }\end{array}$} & юноши & $5,96 \pm 0,28$ & $5,74 \pm 0,34$ & $4,92 \pm 0,40 *$ & $6,13 \pm 0,43$ & $\begin{array}{c}\text { Со-Сай, } \\
\text { Со-У }\end{array}$ \\
\hline & девушки & $6,58 \pm 0,38$ & $6,54 \pm 0,31$ & $6,04 \pm 0,45$ & $5,65 \pm 0,26$ & \\
\hline \multirow{2}{*}{$\begin{array}{l}\text { Компро- } \\
\text { мисс }\end{array}$} & Юноши & $6,50 \pm 0,28$ & $7,00 \pm 0,34^{*}$ & $6,58 \pm 0,49$ & $6,96 \pm 0,35^{*}$ & Сай-У \\
\hline & девушки & $6,58 \pm 0,26$ & $6,25 \pm 0,28$ & $6,21 \pm 0,39$ & $5,74 \pm 0,38$ & \\
\hline \multirow{2}{*}{ Избегание } & юноши & $6,61 \pm 0,34$ & $6,16 \pm 0,37$ & $7,08 \pm 0,34 *$ & $5,79 \pm 0,38$ & \\
\hline & девушки & $6,26 \pm 0,35$ & $5,77 \pm 0,28$ & $6,25 \pm 0,42$ & $5,63 \pm 0,41$ & \\
\hline \multirow{2}{*}{$\begin{array}{c}\text { Приспособ- } \\
\text { ление }\end{array}$} & юноши & $5,64 \pm 0,35^{*}$ & $7,00 \pm 0,31$ & $6,08 \pm 0,44$ & $6,50 \pm 0,44$ & \\
\hline & девушки & $6,95 \pm 0,37$ & $6,40 \pm 0,35$ & $6,50 \pm 0,29$ & $6,42 \pm 0,49$ & \\
\hline
\end{tabular}

Примечание: * - достоверные различия по полу;

буквами - различия между социотипами в одной половой группе.

В группе девушек у социалов и гуманитариев отсутствуют достоверные различия типов поведения в конфликтной ситуации, у сайентистов достоверно ниже соперничество по сравнению с другими стратегиями поведения, а у управленцев доминирует - соперничество.

Таким образом, на наш взгляд, выявленные характеристики разных социотипов студентов Тувинского государственного университета могут оказывать существенное влияние на процесс адаптации студентов к условиям вуза, их стиль учебы и поведение в целом. Знание подобных особенностей может найти свое применение при реализации в вузе индивидуально-ориентированного подхода к обучению студентов.

\section{СПИСОК ЛИТЕРАТУРЫ}

1. Айзман Р. И., Айзман Н. И., Лебедев А. В. Методика оценки социально-психологической адаптации и личностного потенциала студентов: метод. пособ. - Новосибирск. 2013 - 40 с.

2. Айзман Р. И., Айзман Н. И., Рубанович В. Б., Лебедев А. В. Программа комплексной оценки здоровья и развития студентов высших и средних учебных заведений. / ФГУП 
Вестник Новосибирского государственного педагогического университета Novosibirsk State Pedagogical University Bulletin

1(17) $2014 \quad$ www.vestnik.nspu.ru ISSN 2226-3365

НТЦ «ИНФОРМРЕГИСТР» регистрационное свидетельство № 13930 от «18» августа 2008 г., Москва.

3. Аугустинавичюте А. Соционика: Введение. - СПб.: Terra Fantastica, 1998. - С. 25-32.

4. Будук-оол Л. К. Адаптация студентов к обучению в вузе: этнические аспекты. Монография. - Кызыл : Изд-во ТывГУ, 2009. - 220 с.

5. Будук-оол Л. К., Айзман Р. И. Морфофункциональные показатели у студентов Тывинского государственного университета // Гигиена и санитария. - 2009. - № 3. - С. 82-83.

6. Будук-оол Л. К., Красильникова В. А., Айзман Р. И. Динамика процессов адаптации к обучению студентов, проживающих в дискомфортном климато-географическом регионе // Физиология человека. - 2009. - Т. 35. - № 4. - С. 103-110.

7. Букалов А. В., Карпенко О. Б., Чикирисова Г. В. О распределении соционических типов в различных производственных коллективах // Соционика. - М., 2000. - № 1. С. $94-102$.

8. Васильев В. Н., Рамазанова А. П., Богомаз С. А. Познай других - найди себя. - Томск, 1996. - $185 \mathrm{c}$.

9. Пиликян К. Г. Профессиональная ориентация: консультирование с применением соционических подходов // Муниципальное образование: инновации и эксперимент. 2009. - № 1. - С. 32-40.

10. Лебедев А. В. Психофизиологические и морфофункциональные особенности девушек разных социотипов. автореф. дис. ...канд. биол. наук. Кемерово. $-2011 .-25$ с.

11. Лебедев А. В., Суботялов М. А., Айзман Р. И. Социотипический портрет студенток вуза с учетом их психофизиологических особенностей // Вестник КемГУ. - № 3 (47). 2011. C. $154-159$.

12. Ондар А. О., Айзман Р. И., Будук-оол Л. К., Шыырапай Скрининговая оценка уровня здоровья студентов-первокурсников Тувинского государственного университета Вестник Костромского государственного университета им. Н. А. Некрасова, 2013. - Т. 19. - № 1. C. $101-105$.

13. Ондар А. О., Ондар С. О., Айзман Р. И. Сравнительная характеристика уровней физического здоровья и физической подготовленности студентов-первокурсников ТувГУ // Вестник Новосибирского государственного педагогического университета. - 2013. - № 4. - С. $68-79$.

14. Рубанович В.Б., Айзман Р.И. Основы здорового образа жизни: учеб. пособ. - Новосибирск : АРТА, 2011. - $256 \mathrm{c}$.

15. Aizman R. I., Krasilnikova V. A., Buduk-ool L. K. Morphological, functional, and Psychological development of children living permanently in the Tuva Republic. Alaska medicine, 2007, vol. 49 , no. 2 , pp. $133-138$.

16. Buduk-ool L. K., Aizman R. I. The ethnic peculiarities to adaptation of the cardiovascular system of students living in Tuva republic. European Journal of Natural History, 2008, no. 3, pp. $81-85$. 
Вестник Новосибирского государственного педагогического университета Novosibirsk State Pedagogical University Bulletin

1(17) $2014 \quad$ www.vestnik.nspu.ru ISSN 2226-3365

(C) L. K. Buduk-ool, S. K. Saryg. A. M. Khovalyg

UDC $612.821+159.9+378+316.6$

\title{
PSYCHOPHYSIOLOGICAL CHARACTERISTICS OF TUVINIAN STUDENTS WITH DIF- FERENT SOCIAL TYPES
}

\author{
L. K. Buduk-ool, S. K. Saryg. A. M. Khovalyg (Kyzyl, Russia)
}

The paper analyzes the physiological characteristics of students of the Tuvan State University depending on socialtypes. Purpose of the article is to identify physiological characteristics of the personality of the student with different socialtypes. The social and humanitarian direction of training of specialists is dominated at the Tuva state university. It is shown that among young students is dominated socials, followed by managers, among the girls also is dominated the humanities and socials. Among girls it appeared least of all managers, and among young men - scientists. The following physiological characteristics of students are defined: socials and managers were characterized authentically by higher level of a nevrotization, they are used various strategy of behavior in conflict situations, managers differed authentically lower level of a psikhopatization. Humanists and scientists were more highly disturbing. For the humanities is characterized by compromise and avoidance in conflict resolution, Scientist at the prevailing strategy of avoidance, compromise and accommodation. All socialtypes are characterized by the optimal level of stress.

Keywords: students, socialtypes, trait anxiety, behavioral strategies psihopatisation, neuropatisation.

\section{REFERENCES}

1. Aizman R. I., Aizman N. I., Lebedev A. V. Metodika otsenki sotsial'no-psikhologicheskoi adaptatsii $i$ lichnostnogo potentsiala studentov [Methods of assessing the socio- psychological adaptation and personal potential students], Novosibirsk, 2013, 40 p.

2. Aizman R. I., Aizman N. I., Rubanovich V. B., Lebedev A. V. Programma kompleksnoi otsenki zdorov'ya i razvitiya studentov vysshikh $i$ srednikh uchebnykh zavedenii [The program is a comprehensive assessment of the health and development of students of higher and secondary educational institutions]. FSUE STC " INFORMREGISTER " certificate of registration number 13930 from "18" in August 2008, Moscow.

3. Augustinavichiute A. Sotsionika: Vvedenie [Socionics: Introduction]. St. Petersburg, Terra Fantastica, 1998, pp. 25-32.

4. Buduk-ool L. K. Adaptatsiya studentov $k$ obucheniyu v vuze: etnicheskie aspekty [Adaptation of students to learn in high school: the ethnic dimension]. Kyzyl, Publ TyvGU, 2009, 220 p.

5. Buduk-ool L. K., Aizman R. I. Morfofunktsional'nye pokazateli u studentov Tyvinskogo gosudarstvennogo universiteta [Morphological and functional parameters at students of Tuva State University]. Hygiene and sanitary, 2009, no. 3, pp. 82-83.

6. Buduk-ool L. K., Krasil'nikova V. A., Aizman R. I. Dinamika protsessov adaptatsii k obucheniyu studentov, prozhivayushchikh $\mathrm{v}$ diskomfortnom klimato-geograficheskom regione [Dynamics of processes of adaptation to training the students living in discomfortable climate-geographical region]. Human physiology, 2009, vol. 35, no.4, pp. 103-110. 
7. Bukalov A. V, Karpenko O. B, Chykyrysova G. O raspredelenii sotsionicheskikh tipov v razlichnykh proizvodstvennykh kollektivakh [The distribution of personality types in different production teams]. Socionics, Moscow, 2000, no. 1, pp. 94-102.

8. Vasiliev V. N, Ramazanov A. P., Bogomaz S. A. Poznai drugikh - naidi sebya [Know other - find themselves]. Tomsk, 1996, $185 \mathrm{p}$.

9. Pilikyan C. G. Professional'naya orientatsiya: konsul'tirovanie s primeneniem sotsionicheskikh podkhodov [Career guidance: consultation with application sotsionicheskikh approaches]. Municipal education: innovation and experiment, 2009, no. 1, pp. 32-40.

10. Lebedev A. V. Psikhofiziologicheskie i morfofunktsional'nye osobennosti devushek raznykh sotsiotipov. Avtoref. diss. kand. biol. nauk [Physiological and morphological and functional features of different girls sociotypes. Author. Candidate biol. Science diss.]. Kemerovo, 2011, 25 p.

11. Lebedev A. V., Subotyalov M. A., Aizman R. I. Sotsiotipicheskii portret studentok vuza s uchetom ikh psikhofiziologicheskikh osobennostei [Sotsiotipichesky portrait of high school students with their psycho-physiological characteristics]. Herald KemSU, vol. 47, no. 3, 2011, pp. 154-159.

12. Ondar A. O., Aizman R. I., Buduk-ool L. K. Shyyrapai Skriningovaya otsenka urovnya zdorov'ya studentov-pervokursnikov Tuvinskogo gosudarstvennogo universiteta [Screening estimation of a level of health of students-first-year students of the Tuva State University]. Bulletin of Kostroma State University it. N.A.Nekrasov, 2013, vol. 19, no. 1, pp. 101-105.

13. Ondar A. O., Ondar S. O., Aizman R. I. Sravnitel'naya kharakteristika urovnei fizicheskogo zdorov'ya i fizicheskoi podgotovlennosti studentov-pervokursnikov TuvGU [Comparative characteristics of the level of physical health and physical preparedness of students in their freshman year TuvSU]. Novosibirsk State Pedagogical University Bulletin, 2013, no. 4, pp. 68-79.

14. Rubanovich V. B., Aizman R. I. Osnovy zdorovogo obraza zhizni: uchebnoe posobie [Bases of a healthy way of life]. Novosibirsk, 2011, $256 \mathrm{p}$.

15. Aizman R. I., Krasilnikova V. A., Buduk-ool L. K. Morphological, functional, and Psychological development of children living permanently in the Tuva Republic. Alaska medicine, 2007, vol. 49, no. 2, pp. $133-138$.

16. Buduk-ool L. K., Aizman R. I. The ethnic peculiarities to adaptation of the cardiovascular system of students living in Tuva republic. European Journal of Natural History, 2008, no. 3, pp. 81-85.

Buduk-ool Larissa Kara-Salovna, the doctor of biological Sciences, associate professor, department of anatomy, physiology and life safety, Tuvan State University.

E-mail: buduk-ool@mail.ru

Saryg Sailyk Kyzyl-oolovna, the candidate of biological Sciences, department of anatomy, physiology and life safety, Tuvan State University.

Khovalyg Ayana Mogushovna, the post-graduate student of the department of anatomy, physiology and life safety, Tuvan State University. 
Вестник Новосибирского государственного педагогического университета Novosibirsk State Pedagogical University Bulletin

1(17) $2014 \quad$ www.vestnik.nspu.ru ISSN 2226-3365

(C) К. М. Жомин, В. Б. Рубанович

УДК $612+796$

\title{
МОРФОФУНКЦИОНАЛЬНЫЕ ОСОБЕННОСТИ ДЕВУШЕК В ЗАВИСИМОСТИ ОТ УРОВНЯ ДВИГАТЕЛЬНОЙ АКТИВНОСТИ В ПРОЦЕССЕ ОБУЧЕНИЯ В ВУЗЕ*
}

\author{
К. М. Жомин, В. Б. Рубанович (Новосибирск, Россия)
}

\begin{abstract}
Для оценки влияния различных видов и режсимов физкультурно-оздоровительной и спортивной деятельности на морфофункииональное развитие студенток изучали показатели физического развития, кардиореспираторной системы и физической работоспособности. Изучено влияние разного уровня двигательной активности в условиях вуза на интегральный показатель здоровья студенток 1-4 курсов. Выявлено, что занятия легкой атлетикой, баскетболом и в меньшей степени волейболом влияют на оптимизацию компонентов телосложения, развитие мылечной силы и повышение резервных возможностей кардиореспираторной системы. Установлено, что самостоятельное выполнение физических упражнений аэробной направленности по 1 часу в неделю дополнительно к занятиям по физическому воспитанию достоверно улучшает ряд показателей кардиореспираторной системы и физической работоспособности. Физкультурно-оздоровительная деятельность в группе ритмической гимнастики по 4 часа в неделю и по программе основной медиџинской группы не несет положительного оздоровительного эффекта.
\end{abstract}

Ключевые слова: студентки, оздоровительная физкультурная деятельность, занятия спортом, физическое развитие, функииональное состояние, интегральный уровень здоровья.

\section{Актуальность}

Проблема физического здоровья студентов привлекает внимание многих специалистов $[1$, с. $3 ; 12$, с. $12 ; 14$, с. $79 ; 21]$. Особую значимость эта проблемы приобретает в связи с устойчивой тенденцией к ухудшению состояния здоровья студенческой молодежи $[2 ; 8 ; 10 ; 18]$.
Важная роль в деле развития и сохранения здоровья принадлежит физической культуре. В то же время занятия по традиционной программе физического воспитания в ВУЗе, не ведут к достоверному изменению показателей физического развития и кардиореспираторной системы [16, с. 244; 17, с. 12].

* Статья подготовлена по результатам работы Всероссийской научной школы с Международным участием «Опыт использования мониторинга здоровья и физической подготовленности учащейся молодежи» (12-14 ноября 2013 г.).

Жомин Константин Михайлович - доцент, кафедра спортивных игр и единоборств, Новосибирский государственный педагогический университет.

E-mail: kos-jom83@mail.ru

Рубанович Виктор Борисович - доктор медицинских наук, профессор, кафедра физического воспитания, Новосибирский государственный педагогический университет.

E-mail: rubanovich08@mail.ru 
По мнению специалистов одним из путей выхода из сложившейся ситуации является внедрение новых образовательных технологий в процесс преподавания физического воспитания [11, с. $173 ; 22$, с. 89$]$ и оценка их эффективности [10; 13]. Однако в большинстве работ использован метод поперечных наблюдений, что может быть поводом к недостаточной объективности выводов. Это побудило нас провести комплексное многолетнее наблюдение за практически здоровыми студентками в условиях разных режимов и видов физкультурно-оздоровительной и спортивной деятельности. Целью исследования было выяснение особенностей динамики показателей физического развития, функции внешнего дыхания, системы кровообращения в процессе обучения в ВУЗе.

\section{Организация и методы исследования}

Проведено лонгитудинальное наблюдение за шестью группами студенток 1-4 курсов Новосибирского государственного педагогического университета (НГПУ). Первая группа состояла из девушек, занимающихся физической культурой по программе ВУЗа в основной медицинской группе (ОМГ - 19 чел.) 2 раза в неделю по 2 часа. Студентки второй группы дополнительно к учебным занятиям физкультурой по программе ВУЗа занимались самостоятельно (С3 - 14 чел.) 1 раз в неделю по 1 часу упражнениями циклического характера с преимущественным воздействием на аэробные возможности (бег, плавание, катание на велосипеде, ходьба на лыжах). Студентки третьей группы занимались оздоровительной ритмической гимнастикой (РГ - 26 чел.) 2 раза в неделю по 2 часа. В четвертую, пятую и шестую группы были включены девушки, занимающиеся в спортивном клубе НГПУ волейболом (В/Б 19 чел.), баскетболом (Б/Б - 19 чел.) и легкой атлетикой (ЛА - 27 чел.) по 2 часа 3-4 раза в неделю в зависимости от этапа подготовки (бег на 800-3000 м).

Все девушки исследовались только в период фолликулиновой фазы менструального цикла.

Программа обследования включала антропометрию с определением длины и массы тела, силы мышц сгибателей кистей рук и разгибателей спины (кистевая и становая динамометрия). Рассчитывали масса-ростовой индекс Кетле [19]. Содержание резервного жира определяли методом калиперметрии, по схеме Б.Х. Хит - Дж.Е.Л. Картер определяли выраженность в баллах трех первичных компонентов тела - эктоморфии, мезоморфии и эндоморфии [23].

Систему внешнего дыхания оценивали по показателям жизненной емкости легких (ЖЕЛ), максимальной скорости потока воздуха при форсированном вдохе и выдохе (МСПВ вд. и МСПВ выд.) [19]. Рассчитывали жизненный индекс. Оценивали продолжительность максимальной произвольной задержки дыхания на субмаксимальном вдохе (проба Штанге) и на максимальном выдохе (проба Генче). Рассчитывали циркуляторнореспираторный коэффициент Скибинского [19].

Состояние системы кровообращения оценивали по частоте сердечных сокращений (ЧСС) в условиях относительного покоя, при выполнении стандартных степ-эргометрических нагрузок. Рассчитывали систолический объем крови (СОК) и минутный объем кровообращения (МОК) [15].

Особенности вегетативной регуляции деятельности сердца, степень напряжения регуляторных механизмов и состояние вегетативного гомеостаза изучали методом вариационной пульсометрии с определением моды (Мо), амплитуды моды (АМо), вариационного размаха ( $\Delta \mathrm{R}-\mathrm{R})$, индекса напряжения [9]. 
Определяли показатели физической работоспособности и аэробной производительности (PWC170 и МПК) [15]. По показателю эффективности кровообращения оценивали качество адаптации сердечно-сосудистой системы к физической нагрузке. Экономичность деятельности системы кровообращения при выполнении стандартной степэргометрической нагрузки оценивали по хронотропной реакции сердца и двойному произведению (ДП) [24].

Интегральная оценка уровня физического здоровья (УФЗ) выполнена с помощью компьютерной программы «Комплексная оценка физического, психического здоровья и физической подготовленности студентов» [37]. Для этого показатели физического развития, дыхательной, сердечно-сосудистой системы в условиях относительного покоя и стандартной стэп-эргометрической нагрузки вводили в компьютер, где рассчитывались величины массо-ростового, кистевого и жизненного индексов, двойного произведения, показатели эффективности кровообращения и физической работоспособности. Затем эти показатели автоматически сопоставлялись с нормативными данными, переводились в баллы и по их сумме определялся интегральный УФЗ: низкий, ниже среднего, средний, выше среднего, высокий уровени.

Статистическая обработка полученных результатов исследования выполнена на персональном компьютере с использованием пакета программы Statistika - 6.0. Статистический анализ проводили на основе расчета средних арифметических (М) и их ошибок $( \pm \mathrm{m})$. Различия показателей между выборками оценивали по t-критерию Стьюдента, по результатам однофакторного дисперсионного анализа (ANOVA) для непараметрических и независимых выборок и критерию Вилкоксона-Манна-Уитни для независимых выборок.

\section{Результаты исследования}

Согласно данным исследования у студенток ОМГ к четвертому курсу по сравнению с первым обнаружено увеличение массы тела и плотности телосложения, что сопровождалось существенным повышением процентного содержания резервного жира и снижением показателей мышечной силы (табл.). В группах С3 и РГ существенных изменений изученных показателей физического развития за исследуемый период выявлено не было. В то же время у девушек, занимающихся в спортивных секциях, наблюдалось снижение процентного содержания резервного жира, тенденция к повышению выраженности мезоморфного компонента у баскетболисток и легкоатлеток, и увеличение показателей динамометрии, причем в большинстве случаев значимое $(\mathrm{p}<0,05)$.

По данным исследования функции внешнего дыхания у студенток ОМГ (табл.) в динамике наблюдений отмечалось существенное ухудшение большинства показателей (ЖЕЛ, ЖИ, проба Генче, ЦРКС). Обнаружено усиление хронотропной и хроноинотропной функции сердца в условиях относительного покоя. Все это свидетельствовало о снижении адаптационных возможностях организма студенток ОМГ. Ухудшение функционального состояния подтверждалось существенным увеличением количества девушек, характеризующихся состоянием функционального напряжения и перенапряжения регуляторных механизмов (рис. 1).

Анализ показателей системы кровообращения в условиях мышечной нагрузки выявил, что занимающиеся в ОМГ к 4-му курсу по сравнению с первым стали характеризоваться существенным усилением хронотропной адаптивной реакции сердца к стандартной нагрузке и увеличением МОК (табл.1), значительным уменьшением PWC170/кг (на 
$20,3 \%$ ) и аэробной производительности (на $20,4 \%)$.

У девушек, занимающихся в группе РГ, показатели функции внешнего дыхания и системы кровообращения в процессе обучения практически не изменялись. В то же время у студенток группы С3 к 4-му курсу отмечалось некоторое улучшение изученных показателей кардиореспираторного аппарата, причем увеличение значений ЖИ, ЦРКС и
PWC170/кг оказалось существенным $(\mathrm{p}<0,05)$. В динамике исследования обнаружено уменьшение количества девушек этой группы с состоянием функционального напряжения и перенапряжения регуляторных механизмов ритма сердца (рис. 1). Все это может свидетельствовать о некотором положительном влиянии дополнительных нагрузок аэробного характера на функцию дыхания и систему кровообращения студенток.

Таблица 1

Морфофункииональные показатели студенток с различной двигательной активностью $(M \pm m)$

\begin{tabular}{|c|c|c|c|c|c|c|c|}
\hline \multirow{2}{*}{$\begin{array}{c}\text { Показате- } \\
\text { ли }\end{array}$} & \multirow{2}{*}{$\begin{array}{c}\text { Период } \\
\text { исследования }\end{array}$} & \multicolumn{6}{|c|}{ Группы по двигательной активности } \\
\hline & & OMГ $(\mathrm{n}=19)$ & C3 $(n=14)$ & $\mathrm{P} \Gamma(\mathrm{n}=26)$ & $\mathrm{B} / \mathrm{B}(\mathrm{n}=19)$ & Б/Б $(n=19)$ & ЛА $(\mathrm{n}=27)$ \\
\hline \multirow{2}{*}{$\begin{array}{c}\text { Масса } \\
\text { тела, кг }\end{array}$} & 1 курс & $52,9 \pm 0,9$ & $56,3 \pm 1,7$ & $56,4 \pm 1,8$ & $55,6 \pm 1,3$ & $62,9 \pm 3,6$ & $53,7 \pm 1,1$ \\
\hline & 4 курс & $57,1 \pm 1,8^{+}$ & $54,3 \pm 1,1$ & $55,8 \pm 1,3$ & $55,6 \pm 1,3$ & $61,8 \pm 0,6$ & $55,8 \pm 0,7$ \\
\hline \multirow{2}{*}{$\begin{array}{l}\text { Индекс } \\
\text { Кетле, } \\
\text { кг/м² }\end{array}$} & 1 курс & $19,9 \pm 0,4$ & $20,4 \pm 0,6$ & $20,6 \pm 0,6$ & $19,9 \pm 0,4$ & $21,6 \pm 1,1$ & $19,6 \pm 0,3$ \\
\hline & 4 курс & $21,6 \pm 0,7^{+}$ & $19,7 \pm 0,5$ & $20,5 \pm 0,4$ & $20,0 \pm 0,4$ & $21,2 \pm 0,5$ & $20,3 \pm 0,2$ \\
\hline \multirow{2}{*}{$\begin{array}{c}\text { Содержа- } \\
\text { ние резерв } \\
\text { жира, \% }\end{array}$} & 1 курс & $24,5 \pm 0,3$ & $24,9 \pm 0,6$ & $25,1 \pm 0,6$ & $23,1 \pm 0,6$ & $25,8 \pm 1,0$ & $22,7 \pm 0,3$ \\
\hline & 4 курс & $27,3 \pm 0,5^{+}$ & $23,8 \pm 0,5$ & $24,2 \pm 0,4$ & $22,2 \pm 0,6$ & $22,8 \pm 0,4^{+}$ & $21,0 \pm 0,3^{+}$ \\
\hline \multirow{2}{*}{$\begin{array}{c}\text { Становая } \\
\text { сила, кг }\end{array}$} & 1 курс & $83,0 \pm 3,3$ & $75,7 \pm 3,0$ & $79,9 \pm 2,7$ & $92,0 \pm 3,0$ & $83,5 \pm 2,7$ & $77,3 \pm 2,6$ \\
\hline & 4 курс & $64,8 \pm 2,7^{+}$ & $79,3 \pm 3,6$ & $80,3 \pm 2,4$ & $102,4 \pm 2,5^{+}$ & $96,0 \pm 3,3^{+}$ & $93,9 \pm 1,2^{+}$ \\
\hline \multirow{2}{*}{ ЖЕЛ, мЛ } & 1 курс & $2961 \pm 78$ & $3093 \pm 78$ & $3195 \pm 85$ & $3304 \pm 99$ & $3513 \pm 80$ & $3441 \pm 81$ \\
\hline & 4 курс & $2590 \pm 71^{+}$ & $3329 \pm 102$ & $3204 \pm 52$ & $3440 \pm 78$ & $3725 \pm 108$ & $3733 \pm 53^{+}$ \\
\hline \multirow{2}{*}{ ЖИ, мл/кг } & 1 курс & $56,1 \pm 1,7$ & $55,4 \pm 1,7$ & $57,3 \pm 1,8$ & $59,7 \pm 1,5$ & $57,3 \pm 1,9$ & $64,3 \pm 1,3$ \\
\hline & 4 курс & $45,7 \pm 1,3^{+}$ & $61,5 \pm 2,1^{+}$ & $58,0 \pm 1,5$ & $62,2 \pm 1,5$ & $60,5 \pm 1,4$ & $67,4 \pm 0,9$ \\
\hline \multirow{2}{*}{$\begin{array}{l}\text { ЦРКС, } \\
\text { усл.ед. }\end{array}$} & 1 курс & $20,4 \pm 1,1$ & $20,8 \pm 1,5$ & $20,6 \pm 1,3$ & $22,7 \pm 1,5$ & $24,0 \pm 1,5$ & $27,6 \pm 2,1$ \\
\hline & 4 курс & $14,5 \pm 0,9^{+}$ & $24,5 \pm 1,0^{+}$ & $21,2 \pm 0,9$ & $26,8 \pm 1,3$ & $37,1 \pm 2,7^{+}$ & $45,9 \pm 3,4^{+}$ \\
\hline \multirow{2}{*}{$\begin{array}{l}\text { ЧСС (по- } \\
\text { кой), уд/ } \\
\text { мин }\end{array}$} & 1 курс & $82,8 \pm 2,6$ & $87,3 \pm 2,7$ & $93,9 \pm 3,3$ & $88,3 \pm 3,4$ & $81,8 \pm 2,6$ & $78,1 \pm 3,0$ \\
\hline & 4 курс & $95,3 \pm 3,7^{+}$ & $86,1 \pm 2,8$ & $91,3 \pm 2,5$ & $83,2 \pm 1,4$ & $69,6 \pm 2,3^{+}$ & $64,1 \pm 1,3^{+}$ \\
\hline \multirow{2}{*}{$\begin{array}{c}\text { ЧСС } \\
\text { (нагруз- } \\
\text { ка), } \\
\text { уд/мин }\end{array}$} & 1 курс & $158,8 \pm 2,0$ & $168,1 \pm 3,5$ & $173,6 \pm 3,7$ & $169,1 \pm 3,9$ & $160,3 \pm 3,2$ & $144,0 \pm 1,8$ \\
\hline & 4 курс & $180,3 \pm 2,2^{+}$ & $162,7 \pm 1,9$ & $171,4 \pm 3,0$ & $156,9 \pm 2,5^{+}$ & $140,7 \pm 3,0^{+}$ & $130,6 \pm 1,2^{+}$ \\
\hline \multirow{2}{*}{$\begin{array}{c}\text { МОК } \\
\text { (нагруз- } \\
\text { ка), л/мин }\end{array}$} & 1 курс & $14,99 \pm 0,54$ & $16,55 \pm 0,46$ & $16,64 \pm 0,35$ & $15,68 \pm 0,72$ & $15,11 \pm 0,72$ & $14,07 \pm 0,43$ \\
\hline & 4 курс & $18,39 \pm 0,49^{+}$ & $15,99 \pm 0,55$ & $16,60 \pm 0,28$ & $14,16 \pm 0,62$ & $14,02 \pm 0,31$ & $\underset{+}{11,52 \pm 0,24}$ \\
\hline \multirow{2}{*}{$\begin{array}{c}\mathrm{PWC170/ \kappa} \\
\text { г, } \\
\text { кГм/мин/к } \\
\text { г }\end{array}$} & 1 курс & $11,3 \pm 0,2$ & $10,0 \pm 0,3$ & $9,7 \pm 0,6$ & $10,1 \pm 0,4$ & $11,0 \pm 0,4$ & $13,3 \pm 0,3$ \\
\hline & 4 курс & $9,0 \pm 0,2^{+}$ & $10,8 \pm 0,2^{+}$ & $10,0 \pm 0,4$ & $11,3 \pm 0,3^{+}$ & $13,7 \pm 0,3^{+}$ & $16,5 \pm 0,3^{+}$ \\
\hline
\end{tabular}




\section{1(17) $2014 \quad$ www.vestnik.nspu.ru ISSN 2226-3365}

\begin{tabular}{|c|c|c|c|c|c|c|c|}
\hline \multirow{2}{*}{$\begin{array}{c}\text { МПК/кг, } \\
\text { мЛ/мин/кг }\end{array}$} & 1 курс & $37,2 \pm 0,9$ & $34,6 \pm 1,1$ & $35,0 \pm 1,8$ & $34,1 \pm 2,1$ & $34,9 \pm 1,2$ & $42,3 \pm 0,8$ \\
\cline { 2 - 8 } & 4 курс & $29,6 \pm 0,6^{+}$ & $37,2 \pm 1,1$ & $35,0 \pm 0,9$ & $37,4 \pm 0,8$ & $42,2 \pm 0,7^{+}$ & $49,2 \pm 1,1^{+}$ \\
\hline
\end{tabular}

Примечание:

${ }^{+}$- статистически значимые различия средних величин между студентками 1 и 4 курсов при p<0,05

По результатам исследования функции внешнего дыхания и ССС в условиях относительного покоя у баскетболисток и легкоатлеток за период наблюдений обнаружено улучшение всех изученных показателей, причем по большинству из них существенное $(\mathrm{p}<0,05)$, тогда как у волейболисток выявлены лишь тенденции к улучшению (табл. 1).

По данным вариационной пульсометрии в условиях относительного покоя у занимающихся легкой атлетикой к 4-му курсу было выявлено значимое снижение индекса напряжения, что свидетельствует о более экономичном функционировании механизмов регуляции сердечной деятельности. В динамике исследования отмечалось уменьшение количества лиц с функциональным напряжением среди волейболисток (на 10,5 \%), а в группах баскетболисток и легкоатлеток случаев напряжения и перенапряжения регуляторных механизмов ритма сердца на 4-ом курсе не было (рис. 1).

Рисунок 1

Случаи функиионального напряжения и перенапряжения регуляторных механизмов ритма сердиа студенток с различной двигательной активностью в процессе обучения в вузе (в \%).
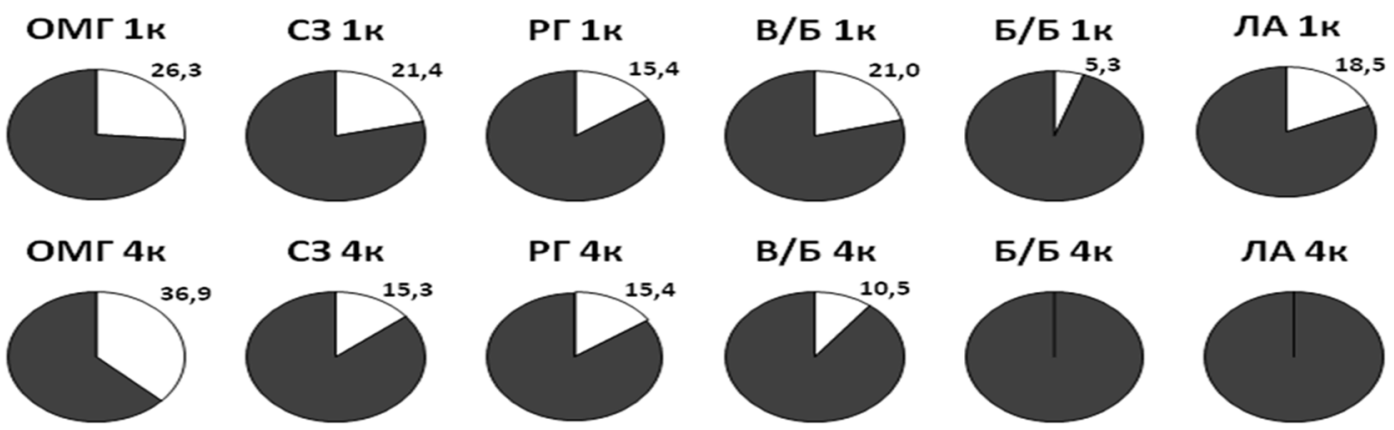

$\square$ - случаи функционального напряжения

Исследование системы кровообращения в условиях выполнения стандартной степэргометрической нагрузки (табл.) выявило более экономную хронотропную реакцию сердца у спортсменок 4 курса всех обследованных групп по сравнению с исходными данными $(\mathrm{p}<0,05)$. Об экономизации хроноинотропной реакции сердца при выполнении стандартной нагрузки у спортсменок в динамике наблюдений свидетельствовало уменьшение величин минутного объема крови от 1 курса к 4-му на 1,09-2,55 л/мин, причем у 
Вестник Новосибирского государственного педагогического университета Novosibirsk State Pedagogical University Bulletin

легкоатлеток уменьшение МОК было существенным $(\mathrm{p}<0,05)$. В динамике наблюдений у спортсменок обнаружено увеличение показателей физической работоспособности и аэробной производительности. При этом наименьшими величинами $\mathrm{PWC170/кг} \mathrm{и}$ МПК/кг на всех этапах исследования характеризовались волейболистки, а самыми высокими - легкоатлетки.
Комплексное исследование морфофункционального развития студенток позволило оценить уровень физического здоровья, выявить значительные различия между группами с разной двигательной активностью в процессе обучения в ВУЗе. У большинства студенток ОМГ к 4-му курсу наблюдалось снижение уровня физического здоровья (рис. 2), в связи, с чем в среднем по группе УФЗ у них стал на 5,9 балла ниже $(\mathrm{p}>0,05)$.

Рисунок 2

Распределение студенток по уровню физического здоровья (в \%)

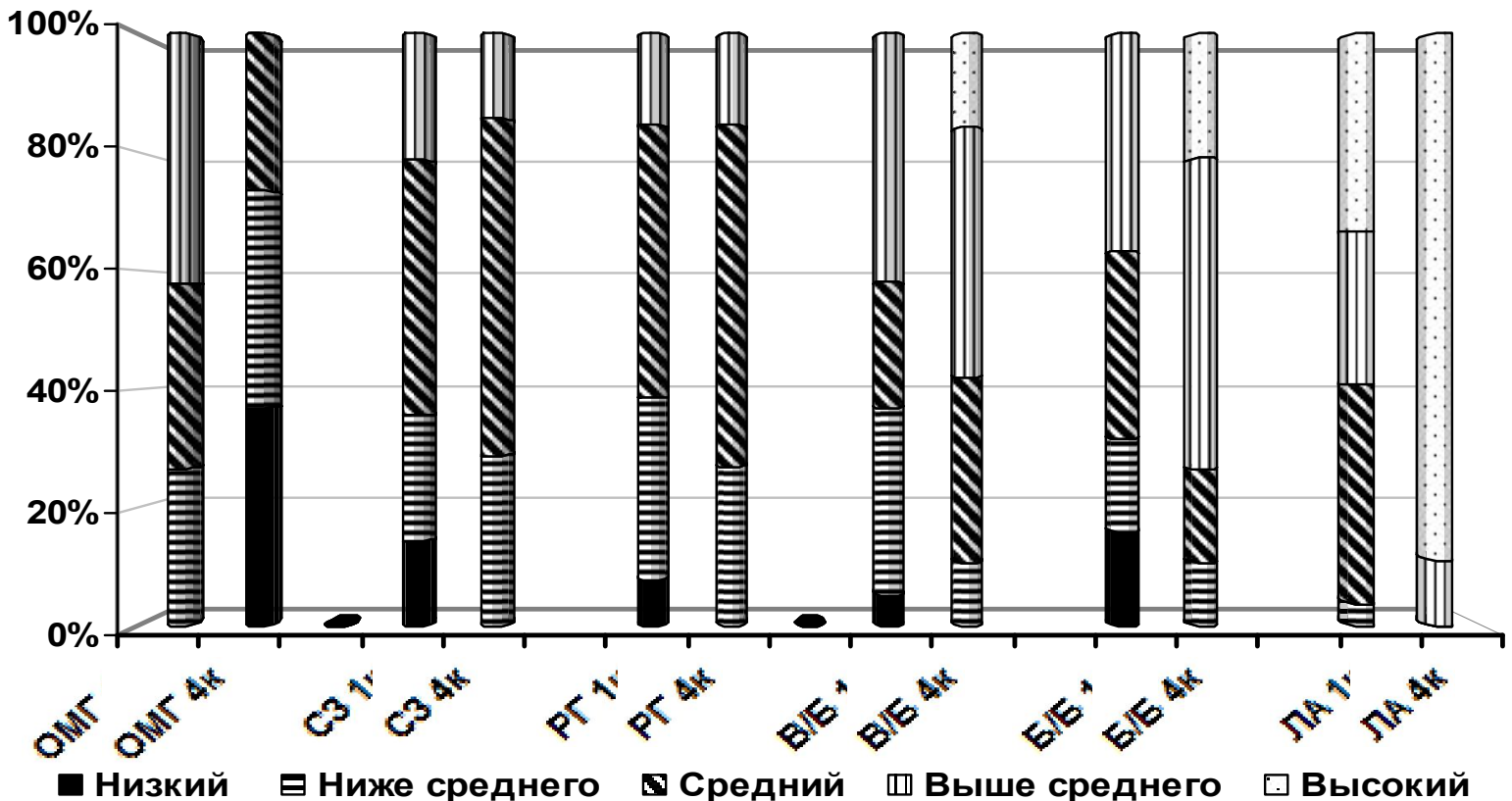

В группах С3 и РГ в динамике наблюдений прослеживалось увеличение количественной оценки физического здоровья на 0,9-1,4 балла $(\mathrm{p}>0,05)$ и некоторое улучшение состава групп по УФЗ (рис. 2).

В спортивных группах к 4-му курсу обнаружен существенный прирост интегральной оценки физического здоровья (на 19,5-
26,4 \%). Как видно из представленных данных (рис. 2) к 4 курсу у большинства волейболисток и баскетболисток УФЗ стал выше среднего и высоким (57,9 и 73,7 \%), а у легкоатлеток - высоким (88,9 \%). Вместе с тем, установлено, что увеличение интегрального показателя физического здоровья у девушек, занимающихся Б/Б и ЛА, в основном было 
Вестник Новосибирского государственного педагогического университета Novosibirsk State Pedagogical University Bulletin

1(17) $2014 \quad$ www.vestnik.nspu.ru ISSN 2226-3365

связано с улучшением показателей ССС и физической работоспособности, а у волейболисток за счет мышечной силы.

Таким образом, динамика морфофункциональных характеристик студенток в про- цессе обучения в ВУЗе зависит от вида и режима физкультурно-спортивной деятельности.

\section{СПИСОК ЛИТЕРАТУРЫ}

1. Агаджанян Н.А., Радыш И.В. Качество и образ жизни студенческой молодежи // Экология человека. - 2009. - № 5. - С. 3-8.

2. Айзман Р.И. Здоровье педагогов и обучающихся - ключевая задача современной школы // Вестник Новосибирского государственного педагогического университета. - 2012. №3(7). - С. 24-35.

3. Айзман Р.И., Айзман Н.И., Лебедев А.В. Методика оценки социально-психологической адаптации и личностного потенциала студентов: метод. пособ. - Новосибирск. 2013 - 40 с.

4. Айзман Р.И., Айзман Н.И., Лебедев А.В., Рубанович В.Б. Компьютерная программа скрининг контроля состояния здоровья участников образовательного процесса // Сибирский учитель. - 2011. - № 2(75). - С. 36-39.

5. Айзман Р.И., Айзман Н.И., Лебедев А.В., Рубанович В.Б. Методика комплексной оценки физического и психического здоровья, физической подготовленности студентов высших и средних профессиональных учебных заведений. - Новосибирск, 2010. - 100 с.

6. Айзман Р.И., Айзман Н.И., Лебедев А.В., Рубанович В.Б. Методика комплексной оценки физического и психического здоровья, физической подготовленности студентов высших и средних профессиональных учебных заведений: метод. пособ. - Новосибирск : Изд. «РИФ Новосибирск». 2009. - 100 с.

7. Айзман Р.И., Айзман Н.И., Рубанович В.Б., Лебедев А.В. Принципы и алгоритмы мониторинга здоровья учащихся и студентов. Сибирское медицинское обозрение. 2009. № 3(57). - С. 101-103.

8. Айзман Р.И., Рубанович В.Б., Суботялов М.А. Основы медицинских знаний и здорового образа жизни: учеб. пособ. - Новосибирск, 2010. - 286 с.

9. Баевский Р.М., Берсенева А.П. Оценка адаптационных возможностей организма и риск развития заболеваний. - М.: Медицина, 1997. - $236 \mathrm{c.}$

10. Боева А.В., Лещенко Я.А. Характеристика физического развития и функциональных возможностей организма студентов // Сибирский медицинский журнал. - 2009. - № 5. C. $97-100$

11. Гусева Н.Л., Шилько В.Г. Физическое воспитание студентов с использованием учебных и внеучебных технологий физкультурно-спортивной деятельности в вузе // Вестник Томского государственного университета. - 2011. - № 345. - С. 173-176.

12. Ендропов О.В. Здоровьесбережение и проблемы оптимизации двигательной активности учащейся молодежи // Сибирский учитель. - 2011. - № 5. - С. 12-14.

13. Забелина Л.Г. Мониторинг здоровья студентов // Мониторинг здоровья и физической подготовленности молодежи: матер. ІІ-й Республ. Науч.-практ. конфер. - Новосибирск, -2010. - C. $68-71$. 
Вестник Новосибирского государственного педагогического университета Novosibirsk State Pedagogical University Bulletin

14. Капилевич Л.В., Шилько В.Г., Гусева Н.Г. Характеристика физического воспитания студентов в вузах сибирского федерального округа // Мониторинг физического здоровья и физической подготовленности молодежи: материалы II-й Респуб. науч.-практ. Конф. - Новосибирск, 2010. - С. 79-81.

15. Карпман В.Л., Белоцерковский 3.Б., Гудков И.А. Исследование физической работоспособности у спортсменов: учебно-методическое пособие. - М.: Физкультура и спорт, 1988. $208 \mathrm{c}$.

16. Кончиц Н.С. Физиологические основы физического воспитания студентов в связи с индивидуальными особенностями организма: Дис. ... докт. мед. наук. - Новосибирск, 1990. - $346 \mathrm{c}$.

17. Кужугет А.А. Особенности физического развития, функции кардиореспираторной системы и соматического здоровья студентов в зависимости от организованной двигательной активности: Автореф. дис. канд. биол. наук. - Челябинск, 2012. - 24 с.

18. Мнухина О.Н. Профессиональная направленность физического воспитания студентов в педагогическом вузе : дис. ... канд. пед. наук. - М., 2003. - 135 с.

19. Рубанович В.Б. Врачебно-педагогический контроль при занятиях физической культурой: учебное пособие - 2-е изд., доп и переработ. - Новосибирск: Изд-во НГПУ, 2003. - 262 с.

20. Рубанович В.Б., Айзман Р.И. Основы здорового образа жизни: учеб. пособ. Новосибирск: АРТА, 2011. - 256 с.

21. Тихонова И.Л., Латуха О.А. Инновации медицинского вуза в обучении студентов // Медицина и образование в Сибири. - 2009. - № 1. - С. 2

22. Томаров С.А., Мокеев Г.И. Экспериментальная проверка эффективности различных вариантов организации и содержания физического воспитания студентов // Ученые записки университета им. П.Ф. Лесгафта. - 2006. - № 22. - С. 89-95.

23. Хит Б.Х, Картер Дж. Современные методы соматотипирования // Вопросы антропологии. - 1969. Вып. 33. - С. 19.

24. Чанчаева Е.А., Айзман Р.И., Герасёв А.Д. Современное представление об антиоксидантной системе организма человека // Экология человека, 2013. - № 7. - С. 50 58.

25. Чурин В.Д. О хроноинотропном резерве миокарда // Физиология человека. - 1978. - Т. 4.№ 3. - С.394-402. 
Вестник Новосибирского государственного педагогического университета Novosibirsk State Pedagogical University Bulletin

1(17) $2014 \quad$ www.vestnik.nspu.ru ISSN 2226-3365

(C) K. M. Zhomin, V. B. Rubanovich

UDC $612+796$

\title{
MORPHOFUNCTIONAL FEATURES OF GIRLS DEPENDING ON THE LEVEL OF PHYSICAL ACTIVITY DURING UNIVERSITY EDUCATION
}

\author{
K. M. Zhomin, V. B. Rubanovich (Novosibirsk, Russia)
}

For an estimation of influence of various kinds and modes of physical improving and sports activity on morphological and functional development of students some parameters of physical development, blood circulation and respiratory systems and physical working capacity are studied. We studied the influence on the integral indicator of the health in female student of 1-4 grades in the high education institutes with different levels of sport activity. It is revealed that athletics, basketball and volleyball affect the optimization of the components of the physique, the development of muscle strength and increasing the reserve capacity of the cardiorespiratory system. It is established that independent performance of physical exercises of an aerobic orientation 1 hour per week in addition to classes in physical training authentically improves a number of indicators of cardiorespiratory system and physical working capacity. Physical improving activity in group of rhythmic gymnastics for 4 hours per week and under the program of the basic medical group does not bear positive improving effect.

Keywords: students, improving physical culture, sports activity, physical development, functional condition, the integral level of health.

\section{REFERENCES}

1. Agadzhanyan N. A. Radysh I. V. Kachestvo i obraz zhizni studencheskoi molodezhi [Quality and way of life of student's youth]. Ecology of the Person, 2009, no. 5, pp. 3-8.

2. Aizman R. I. Zdorov'e pedagogov i obuchayushchikhsya - klyuchevaya zadacha sovremennoi shkoly [Health educators and students - a key task of the modern school]. Bulletin of the Novosibirsk State Pedagogical University, 2012, no. 3, pp. 24-35.

3. Aizman R. I., Aizman N. I., Lebedev A. V. Metodika otsenki sotsial'no-psikhologicheskoi adaptatsii i lichnostnogo potentsiala studentov [Methods of assessing the socio-psychological adaptation and personal potential students], Novosibirsk, 2013, $40 \mathrm{p}$.

4. Aizman R.I., Aizman N.I., Lebedev A.V., Rubanovich V. B. Komp'yuternaya programma skrining kontrolya sostoyaniya zdorov'ya uchastnikov obrazovatel'nogo protsessa [The computer program of the screening control of a state of health of participants of educational process]. Siberian teacher, 2011, vol. 75, no. 2, pp. 36-39.

5. Ayzman R. I. Ayzman N. I. Lebedev A. V. Rubanovich V. B. Metodika kompleksnoi otsenki fizicheskogo i psikhicheskogo zdorov'ya, fizicheskoi podgotovlennosti studentov vysshikh i srednikh professional'nykh uchebnykh zavedenii [Integrated assessment method of physical and mental health, physical fitness of students of higher and secondary vocational schools]. Novosibirsk, 2010, $100 \mathrm{p}$.

6. Aizman R.I., Aizman N.I., Lebedev A.V., Rubanovich V.B. Metodika kompleksnoi otsenki fizicheskogo i psikhicheskogo zdorov'ya, fizicheskoi podgotovlennosti studentov vysshikh i srednikh professional'nykh uchebnykh zavedenii [Methodology comprehensive assessment of 
physical and mental health, physical fitness of students of higher and secondary vocational schools]. Novosibirsk, 2009, 100 p.

7. Aizman R.I., Aizman N.I., Rubanovich V.B., Lebedev A.V. Printsipy i algoritmy monitoringa zdorov'ya uchashchikhsya i studentov [Principle and algorithms of monitoring of health of pupils and students]. The Siberian medical review, 2009, no. 3, pp. 101-103.

8. Aizman R.I., Rubanovich V.B., Subotyalov M. A. Osnovy meditsinskikh znanii i zdorovogo obra$z a$ zhizni [Bases of medical knowledge and healthy way of life]. Novosibirsk, 2010, $286 \mathrm{p}$.

9. Bayevsky P. M., Berseneva A. P. Baevskii R. M., Berseneva A. P. Otsenka adaptatsionnykh vozmozhnostei organizma i risk razvitiya zabolevanii [Assessment of adaptation opportunities of an organism and risk of development of diseases]. Moskow, Medicine, 1997, $236 \mathrm{p}$.

10. Boev A. V., Leshchenko Ya. A. Kharakteristika fizicheskogo razvitiya i funktsional'nykh vozmozhnostei organizma studentov [Characteristic of physical development and functionality of an organism of students]. Siberian Medical Magazine, 2009, no. 5, pp. 97-100.

11. Gusev N. L., Shilko V. G. Fizicheskoe vospitanie studentov s ispol'zovaniem uchebnykh i vneuchebnykh tekhnologii fizkul'turno-sportivnoi deyatel'nosti v vuze [Physical training of students with use of educational and nonlearning technologies of sports and sports activity in higher education institution]. The Messenger of Tomsk State University, 2011, no. 345, pp. 173-176.

12. Endropov O. V. Zdorov'esberezhenie i problemy optimizatsii dvigatel'noi aktivnosti uchashcheisya molodezhi [Health-saving and problems of optimization of physical activity of studying youth]. Siberian Teacher, 2011, no. 5, pp. 12-14.

13. Zabelin L. G. Monitoring zdorov'ya studentov [Monitoring of health of students]. Monitoring of Health and Physical Readiness of Youth: Mater. II-nd Respubl. Nauch-prakt. Konfer. Novosibirsk, 2010, pp. 68-71.

14. Kapilevich L. V., Shilko V. G., Gusev N. G. Kharakteristika fizicheskogo vospitaniya studentov v vuzakh sibirskogo federal'nogo okruga [The characteristic of physical training of students in higher education institutions of Siberian federal district]. Monitoring of Health and Physical Readiness of Youth: Mater. II-nd Respubl. Nauch-prakt. Konfer. Novosibirsk, 2010, pp. 79-81.

15. Karpman V. L., Belotserkovsky Z. B., Gudkov I. A. Issledovanie fizicheskoi rabotosposobnosti u sportsmenov: uchebno-metodicheskoe posobie [Investigation of physical working capacity in sportsmen: textbook]. Moskow, Physical Culture and Sport, 1988, 208 p.

16. Konchits N. S. Fiziologicheskie osnovy fizicheskogo vospitaniya studentov $v$ svyazi $s$ individual'nymi osobennostyami organizma. Diss. dokt. med. nauk. [Physiological bases of physical training of students in connection with specific features of an organism. Doc. medical sciences diss.]. Novosibirsk, 1990, $346 \mathrm{p}$.

17. Kuzhuget A. A. Osobennosti fizicheskogo razvitiya, funktsii kardiorespiratornoi sistemy i somaticheskogo zdorov'ya studentov v zavisimosti ot organizovannoi dvigatel'noi aktivnosti. Avtoref. diss. kand. biol. nauk. [Features of physical development, function of cardiorespiratory system and somatic health of students depending on the organized physical activity. Avtoref. yew. Cand. Biol. Sci.]. Chelyabinsk, 2012. 24 p.

18. Mnukhina O. N. Professional'naya napravlennost' fizicheskogo vospitaniya studentov v pedagogicheskom vuze. Diss. kand. ped. nauk. [Professional orientation of physical training of students in pedagogical higher education institution. Cand. pedag. Sciences diss.]. Moskow, 2003, 135 p.

19. Rubanovich V. B. Vrachebno-pedagogicheskii kontrol' pri zanyatiyakh fizicheskoi kul'turoi: uchebnoe posobie [Medical and pedagogical control at occupations by physical culture: the manual]. Novosibirsk, Publ. NGPU, 2003, 262 p. 
20. Rubanovich V.B., Aizman R.I. Osnovy zdorovogo obraza zhizni [Bases of a healthy way of life]. Novosibirsk, 2011, $256 \mathrm{p}$.

21. Tikhonova I. L., Latukha O. A. Innovatsii meditsinskogo vuza v obuchenii studentov [Innovations of medical high school in training students]. Medicine and education in Siberia, 2009, no. 1, p. 2.

22. Tomarov S. A., Mokeev G. I. Eksperimental'naya proverka effektivnosti razlichnykh variantov organizatsii i soderzhaniya fizicheskogo vospitaniya studentov [Experimental check of efficiency of various options of the organization and the content of physical training of students]. Scientific notes of university of P.F. Lesgafta, 2006, no. 22, pp. 89-95.

23. Hit B. H., Karter Dg. Sovremennye metody somatotipirovaniya [Modern methods of somatotyping]. Questions of anthropology. 1969, vol. 33. p. 19.

24. Chanchaeva E. A., Aizman R. I., Gerasev A. D. Sovremennoe predstavlenie ob antioksidantnoi sisteme organizma cheloveka [Modern representation about antyoxygen to system of an organism of the person]. Ecology of the person, 2013, no. 7, pp. 50-58.

25. Churin V. D. O khronoinotropnom rezerve miokarda [On chronoinotrophic myocard reserve]. Human Physiology, 1978, vol. 4, no. 3, pp. 394-402.

Zhomin Konstantin Michajlovich, the associate professor of department of sports games and martial arts, Novosibirsk State Pedagogical University.

E-mail: kos-jom83@mail.ru

Rubanovich Victor Borisovich, the doctor of medical sciences, professor of department of anatomy, physiology and safety of life, Novosibirsk State Pedagogical University.

E-mail: rubanovich08@mail.ru 
Вестник Новосибирского государственного педагогического университета Novosibirsk State Pedagogical University Bulletin

1(17) $2014 \quad$ www.vestnik.nspu.ru ISSN 2226-3365

(C) М. А. Попова, А. А. Говорухина, А. Ю. Дронь

УДК 614+57.023

\title{
МОНИТОРИНГ ФУНКЦИОНАЛЬНОГО СОСТОЯНИЯ ПЕДАГОГОВ, ПРОЖИВАЮЩИХ НА СЕВЕРЕ*
}

\author{
М. А. Попова, А. А. Говорухина, А. Ю. Дронь (Сургут, Россия)
}

В результате исследования функиионального состояния и регуляторно-адаптивных возможностей организма педагогов установлено, что функииональное состояние и адаптаиионные возможности организма находятся в зависимости от продолжительности проживания на Севере и возраста обследованных лиц.

На основании компартментно-кластерного анализа выделены критические периоды адаптации для сердечно-сосудистой системы и вегетативной регуляиии с учетом возраста обследованных педагогов. Установлено, что чем больше возраст переезжающих на Север преподавателей, тем раньще возникают у них нарушения функиионирования сердечнососудистой системы. Преобладание центрального контура регуляции в управлении сердечным ритмом отмечено в периоды от 6 до 10 и от 21 до 25 лет проживания на Севере в обеих возрастных группах.

Ключевые слова: функциональное состояние, адаптаџия, педагоги и учащиеся.

Развитие нефтегазодобывающей промышленности в нашей стране связано с переселением большого количества лиц разного возраста в северные регионы. При этом мигранты представляют собой неоднородную группу, генетически не связанную с условиями высоких широт и, следовательно, не обладающую сформированными наслед-

* Статья подготовлена по результатам работы Всероссийской научной школы с Международным участием «Опыт использования мониторинга здоровья и физической подготовленности учащейся молодежи» (12-14 ноября 2013 г.).

Попова Марина Андреевна - доктор медицинских наук, профессор, заведующий кафедрой госпитальной терапии, Сургутский государственный университет.

E-mail: m_a_popova@mail.ru

Говорухина Алена Анатольевна - кандидат биологических наук, доцент кафедры медикобиологических дисциплин и безопасности жизнедеятельности, старший научный сотрудник научно-исследовательской лаборатории «Здоровый образ жизни и охрана здоровья», Сургутский государственный педагогический университет.

E-mail: govalena@mail.ru

Дронь Антон Юрьевич - кандидат биологических наук, старший научный сотрудник научноисследовательской лаборатории «Здоровый образ жизни и охрана здоровья», Сургутский государственный педагогический университет.

E-mail: leeg86rus@mail.ru 
Вестник Новосибирского государственного педагогического университета Novosibirsk State Pedagogical University Bulletin

1(17) $2014 \quad$ www.vestnik.nspu.ru ISSN 2226-3365

ственно-закрепленными адаптационными реакциями. При этом многими исследователями установлено, что профессиональные факторы в условиях Севера накладываются на действие биологически-дискомфортной среды. Анализ причин, приводящих к нарушению адаптации представителей различных профессиональных и социальных групп становится одним из наиболее активно развивающихся научных направлений $[1$, с. 27 ; 2, с. 56; 3-4; 6, с. 8; 9-12]. Системные физиологические механизмы, выполняющие основную функции по поддержанию жизнедеятельности организма при действии экстремальных факторов весьма разнообразны [7, с. 148], при этом на адаптационные возможности и функциональное состояние влияют: возраст, пол, вид профессиональной деятельности, продолжительность проживания в условиях высоких широт. Изучение механизмов адаптации, резервных возможностей организма человека при действии экстремальных факторов в районах Севера в процессе трудовой деятельности преподавателей является одной из важнейших биологических проблем, поскольку протекает на фоне природноэкологического и социального прессинга.

В связи с этим целью настоящего исследования был мониторинг функционального состояния педагогов, проживающих на $\mathrm{Ce}-$ вере.

\section{Методы исследования}

В исследовании приняли участие 287 педагогов-женщин некоренной национальности, среди них: педагоги средних общеобразовательных учреждений (n=97), педагоги высших учебных заведений (n=124), педагоги средних специальных учебных заведений $(\mathrm{n}=32)$, педагоги центра дополнительного образования $(\mathrm{n}=32)$ г. Сургута. Все обследованные педагоги были разделены на группы первого (21-35 лет) и второго зрелого (36-55 лет) возраста в соответствии с возрастной физиологической классификацией, внутри которых были выделены подгруппы с разной продолжительностью проживания на Севере.

Офисное измерение артериального давления выполняли с учетом Национальных рекомендаций по диагностике и лечению артериальной гипертензии (АГ) [8, с. 2]. Для оценки вегетативной регуляции сердечного ритма использовали запись и анализ кардиоритмограммы на аппаратно-программном комплексе «Поли-Спектр-8» (Нейрософт, Россия). Анализ ВРС осуществляли в соответствии с рекомендациями стандарта Европейского кардиологического общества и $\mathrm{Ce}$ вероамериканского общества электростимуляции и электрофизиологии.

Статистический анализ полученных результатов выполняли при помощи пакета программ «Биостатистика 4.03», «Statistica 8.0», расчет параметров квазиаттракторов вектора состояния организма человека проводили с помощью программы «Identity» [5].

\footnotetext{
Результаты исследования и их обсуждение

Установлено, что у всех обследованных педагогов частота встречаемости нарушений артериального давления была максимальной в группах, чья продолжительность проживания на Севере составляла менее 5 и более 20 лет (таблица 1).
} 
Вестник Новосибирского государственного педагогического университета Novosibirsk State Pedagogical University Bulletin
1(17) 2014
www.vestnik.nspu.ru
ISSN 2226-3365

Таблица 1

Частота встречаемости нарушений артериального давления у педагогов разного возраста, \%

\begin{tabular}{|c|c|c|c|c|c|c|c|}
\hline \multirow{2}{*}{$\begin{array}{c}\text { Уровень } \\
\text { артериального } \\
\text { давления }\end{array}$} & \multicolumn{7}{|c|}{ Проживание на Севере, лет } \\
\hline & $0-5$ & $6-10$ & $11-15$ & $16-20$ & $21-25$ & $26-30$ & $31-35$ \\
\hline \multicolumn{8}{|c|}{ 1-й зрелый возраст, 21-35 лет } \\
\hline Оптим. АД & 10,5 & 18 & 22,5 & 16,4 & 10 & 18 & 22 \\
\hline Нормальное АД & 21,7 & 50 & 32,5 & 34,6 & 15 & 38 & 24 \\
\hline ВНАД & 30 & 12 & 21 & 16 & 30 & 36 & 18 \\
\hline АГ І степени & 30 & 18 & 14 & 3 & 12,5 & 26 & 14,6 \\
\hline АГ II степени & - & 2 & - & 10 & 12,5 & - & 21,4 \\
\hline \multicolumn{8}{|c|}{ 2-й зрелый возраст, $36-55$ лет } \\
\hline Оптим. АД & 8 & 12 & 14 & 24 & 16 & 18 & 20 \\
\hline Нормальное АД & 12 & 15,6 & 18,8 & 20 & 26 & 12 & 22,4 \\
\hline ВНАД & 46 & 24,6 & 22,2 & 14 & 28 & 30 & 24,6 \\
\hline АГ І степени & 30 & 10,2 & 20 & 32 & 40 & 30 & 25 \\
\hline АГ II степени & - & 4,8 & 15 & 10 & - & - & 4,8 \\
\hline АГ III степени & - & - & - & - & - & - & 3,2 \\
\hline
\end{tabular}

Примечание:

ВНАД - высокое нормальное артериальное давление, АГ - артериальная гипертензия.

Полученные нами результаты свидетельствуют о широкой распространенности нарушений артериального давления среди педагогов, что указывает на недостаточную степень адаптированности их сердечнососудистой системы к условиям Севера. Си- стемный анализ гемодинамических параметров показал, что педагоги в возрасте от 21 до 35 лет отличались максимальными объемами квазиаттрактора в группах с продолжительностью проживания на Севере менее 5 и более 20 лет (таблица 2).

Таблица 2

Результаты обработки в 12-мерном фазовом пространстве параметров аттрактора по показателям гемодинамики для педагогов с различной продолжительностью проживания на Севере

\begin{tabular}{|c|c|c|c|c|c|c|}
\hline \multirow{2}{*}{\begin{tabular}{c} 
Прожи- \\
вание на \\
Севере, \\
\cline { 2 - 7 }
\end{tabular}} & \multicolumn{5}{|c|}{ Везрастная группа } \\
\cline { 2 - 7 } & $\mathrm{n}$ & $\begin{array}{c}\text { General } \\
\text { asymmetry } \\
\text { value, } \mathrm{rX}\end{array}$ & $\begin{array}{c}\text { General V } \\
\text { value, vX }\end{array}$ & $\mathrm{n}$ & $\begin{array}{c}\text { General } \\
\text { asymmetry } \\
\text { value, rX }\end{array}$ & $\begin{array}{c}\text { General V } \\
\text { value, vX }\end{array}$ \\
\hline $0-5$ & 20 & 822,299 & $1,7 * 10^{24}$ & 21 & 32,935 & $2,6^{*} 10^{16}$ \\
\hline $6-10$ & 10 & 658,230 & $9,5^{*} 10^{19}$ & 20 & 546,268 & $4,6^{*} 10^{25}$ \\
\hline
\end{tabular}


Вестник Новосибирского государственного педагогического университета Novosibirsk State Pedagogical University Bulletin

\begin{tabular}{|c|c|c|c|c|c|c|}
\hline $11-15$ & 11 & 109,544 & $4,8^{*} 10^{16}$ & 23 & 417,123 & $1,8 * 10^{27}$ \\
\hline $16-20$ & 13 & 15,589 & $4,9^{*} 10^{14}$ & 15 & 449,774 & $1,1 * 10^{27}$ \\
\hline $21-25$ & 15 & 138,438 & $2,1 * 10^{24}$ & 29 & 358,017 & $1,4 * 10^{26}$ \\
\hline $26-30$ & 10 & 344,241 & $1,3^{*} 10^{24}$ & 22 & 507,045 & $3,8 * 10^{24}$ \\
\hline $31-35$ & 10 & 231,018 & $3,5^{*} 10^{23}$ & 21 & 622,773 & $1,9 * 10^{23}$ \\
\hline
\end{tabular}

Примечание:

rX - показатель асимметрии (General asymmetry value); vX - объем квазиаттрактора (General V value).

У педагогов второго зрелого возраста при длительности проживания на Севере от 6 до 10 лет происходило резкое увеличение объема квазиаттрактора по сравнению с предыдущим периодом адаптации. Важно отметить, что педагогов 36-55 лет работа сердечно-сосудистой системы характеризовалась большей хаотичностью во все адаптационные периоды от 0 до 25 лет проживания на Севере, и лишь в более поздние периоды адаптации уменьшался объем квазиаттрактора, что свидетельствовало об уменьшении хаотичности системы.

Таким образом, установлено, что гемодинамические параметры обследованных педагогов находились в зависимости от возраста и продолжительности проживания на Севере. Чем больше возраст переезжающих на Север преподавателей, тем раньше возникают у них нарушения функционирования сердечно-сосудистой системы. Отмеченные группы преподавателей попадают в группу риска по развитию гемодинамических дисфункций, их функциональное состояние характеризуется наименьшей стабильностью и требует мониторинга и коррекции.

Комплексный анализ параметров вегетативной регуляции ритма сердца показал, что они находились в зависимости от возраста и длительности проживания в условиях высоких широт. Так, величина индекса централизации (ИЦ), физиологический смысл которого состоит в том, что он отражает соотношение между центральным и автономным контурами управления сердечным ритмом, был максимальным у педагогов обеих возрастных групп в группах лиц, проживающих на Севере от 6 до 10 лет (табл. 3).

Таблица 3

Индексы иеентрализаччии и активации подкорковых цุентров педагогов с разной продолжительностью проживания на Севере, $M \pm m$

\begin{tabular}{|c|c|c|c|c|}
\hline \multirow{2}{*}{$\begin{array}{c}\text { Проживание на } \\
\text { Севере, лет }\end{array}$} & \multicolumn{4}{|c|}{ Возрастная группа } \\
\cline { 2 - 5 } & ИЦ, у.е. & ИАПЦ, у.е. & ИЦ, у.е. & ИАПЦ, у.е. \\
\cline { 2 - 5 } & $4,1 \pm 0,07$ & $0,5 \pm 0,01$ & $4,2 \pm 1,1$ & $0,6 \pm 0,22$ \\
\hline $0-5$ & $5,2 \pm 0,03$ & $0,8 \pm 0,01$ & $6,9 \pm 0,1$ & $0,7 \pm 0,03$ \\
\hline $6-10$ & $2,7 \pm 0,05$ & $0,8 \pm 0,02$ & $3,1 \pm 0,1$ & $0,6 \pm 0,06$ \\
\hline \multirow{2}{*}{$11-15$} & $P 2-3=0,045$ & & $P 2-3=0,005$ & \\
\hline \multirow{2}{*}{$16-20$} & $1,7 \pm 0,04$ & $1,6 \pm 0,05$ & $3,5 \pm 0,52^{*}$ & $0,6 \pm 0,04^{* *}$ \\
& $P 2-4=0,002$ & & $P 2-4=0,018$ & \\
\hline
\end{tabular}


Вестник Новосибирского государственного педагогического университета Novosibirsk State Pedagogical University Bulletin

\begin{tabular}{|c|c|c|c|c|}
\hline $21-25$ & $\begin{array}{c}4,5 \pm 0,06 \\
P 4-5=0,026\end{array}$ & $1,5 \pm 0,03$ & $6,5 \pm 0,06^{*}$ & $0,6 \pm 0,01^{* *}$ \\
\hline $26-30$ & $3,6 \pm 0,02$ & $1,2 \pm 0,03$ & $5,5 \pm 1,0$ & $0,8 \pm 0,01$ \\
\hline \multirow{2}{*}{$31-35$} & $1,4 \pm 0,02$ & $0,9 \pm 0,02$ & $2,7 \pm 0,08$ & $0,6 \pm 0,03$ \\
& $P 1-7=0,002$ & & & \\
& $P 2-7=0,014$ & & & \\
\hline
\end{tabular}

Примечание:

$\mathrm{p}$ - достоверность различий по t-критерию Стьюдента между группами одного возраста с разной продолжительностью проживания на Севере; различия между группами разного возраста с одинаковой продолжительностью проживания на Севере достоверны: *-p $\leq 0,05 ; *^{*}$ - $\mathrm{p} \leq 0,01$.

Индекс активации подкорковых центров (ИАПЦ) позволяет оценить состояние сердечно-сосудистого подкоркового нервного центра с точки зрения соотношений специфичного барорефлекторного (сосудистого) компонента регуляции и неспецифических симпатических влияний (стрессорный компонент), установлено, что величина ИАПЦ в группе преподавателей в возрасте 21-35 лет, была статистически выше при проживании в условиях Севера от 16 до 25 лет, чем в других группах, различающихся по продолжительности проживания на Севере. У педагогов, относящихся ко второму зрелому возрасту (36-55 лет), статистически значимых отличий между педагогами с разной продолжительностью проживания на Севере по ИАПЦ выявлено не было.

Анализ результатов вариабельности ритма сердца методом компартментнокластерного анализа представлен в таблице 4.

Таблица 4

Результаты обработки в 17-мерном фазовом пространстве параметров аттрактора по показателям временного и спектрального анализа вариабельности ритма сердия для педагогов с различной продолжительностью проживания на Севере

\begin{tabular}{|c|c|c|c|c|c|c|}
\hline $\begin{array}{c}\text { Прожива- } \\
\text { ние на Се- } \\
\text { вере, лет }\end{array}$ & $\mathrm{n}$ & $\begin{array}{c}\text { General } \\
\text { asymmetry } \\
\text { value, rX }\end{array}$ & $\begin{array}{c}\text { General V } \\
\text { value, vX }\end{array}$ & $\mathrm{n}$ & $\begin{array}{c}\text { General } \\
\text { asymmetry } \\
\text { value, } \mathrm{rX}\end{array}$ & $\begin{array}{c}\text { General V } \\
\text { value, vX }\end{array}$ \\
\hline $0-5$ & 20 & 599,809 & $5,1^{*} 10^{33}$ & 21 & 67,189 & $1,5^{*} 10^{27}$ \\
\hline $6-10$ & 10 & 380,266 & $3,4^{*} 10^{24}$ & 20 & 2915,360 & $2,6^{*} 10^{42}$ \\
\hline $11-15$ & 11 & 36,636 & $7,3^{*} 10^{23}$ & 23 & 1114,026 & $1,6^{*} 10^{35}$ \\
\hline $16-20$ & 13 & 389,501 & $2,7^{*} 10^{29}$ & 15 & 935,742 & $1,9^{*} 10^{35}$ \\
\hline $21-25$ & 15 & 1621,980 & $4,4^{*} 10^{39}$ & 29 & 1264,396 & $2,0^{*} 10^{35}$ \\
\hline $26-30$ & 10 & 1476,275 & $5,0^{*} 10^{37}$ & 22 & 4007,396 & $3,5^{*} 10^{38}$ \\
\hline $31-35$ & 10 & 659,912 & $9,2^{*} 10^{30}$ & 21 & 319,501 & $1,2^{*} 10^{33}$ \\
\hline
\end{tabular}

Примечание:

$\mathrm{rX}$ - показатель асимметрии (General asymmetry value); vX - объем квазиаттрактора (General V value). 
Вестник Новосибирского государственного педагогического университета Novosibirsk State Pedagogical University Bulletin

1(17) $2014 \quad$ www.vestnik.nspu.ru ISSN 2226-3365

Установлено, что напряжение регуляторных систем у педагогов 1-го зрелого возраста возникало на начальном этапе адаптации к условиям Севера (до 5 лет) и снижалось при проживании на Севере от 6 до 15 лет, что свидетельствует о развитии адаптационных реакций. Однако процесс адаптации нельзя считать завершенным, поскольку отмечено увеличение нестабильности системы вегетативной регуляции у этой группы преподавателей в период проживания на Севере от 21 до 25 лет и больше.

У педагогов 2-го зрелого возраста напряжение регуляторных систем возникало позднее, чем у их более молодых коллег (в период проживания на Севере от 6 до 10 лет), снижаясь на более поздних этапах адаптации. Повышение нестабильности регуляторных механизмов от- мечено в этой группе педагогов при длительности проживания на Севере от 26 до 30 лет. Важно отметить, что объемы квазиатрактора педагогов 36-55 лет были выше во время большинства адаптационных периодов по сравнению с таковыми преподавателей в возрасте 21-35 лет.

Таким образом, можно говорить о том, что на успешность развития адаптации к сложным климато-экологическим условиям Севера влияют не только продолжительность проживания в условиях высоких широт, но и возраст, во время которого была осуществлена миграция. Широкая распространенность выявленных гемодинамических и регуляторных нарушений указывает на необходимость системного мониторинга состояния здоровья этой профессиональной группы.

\section{СПИСОК ЛИТЕРАТУРЫ}

1. Антропова О.Н., Осипова И.В., Симонова Г.И. Профессиональный стресс и развитие стресс-индуцированной гипертонии // Кардиология, 2009. - № 6 - С. 27-30.

2. Бобко Н.А. Влияние стресса на работу сердечно-сосудистой системы операторов преимущественно умственного труда в разное время суток и рабочей недели // Физиология человека, 2007. - Т. 33, № 3.- С. 55-62.

3. Будук-оол Л.К., Айзман Р.И. Морфофункциональные показатели у студентов Тывинского государственного университета // Гигиена и санитария. - 2009. - № 3. - С. 82-83.

4. Будук-оол Л.К., Красильникова В.А., Айзман Р.И. Динамика процессов адаптации к обучению студентов, проживающих в дискомфортном климато-географическом регионе Физиология человека. - 2009. - Т. 35, № 4. - С. 103-110.

5. Еськов В.М. Идентификация параметров порядка (наиболее значимых диагностических признаков) вектора состояния биосистем в т-мерном фазовом пространстве / Свидетельство об официальной регистрации программы для ЭВМ №2007614714, РОСПАТЕНТ. Москва, 2007.

6. Концевая А.В., Калинина А.М., Григорян Ц.А. Поведенческие факторы риска и их коррекция в организованных коллективах. Аналитический обзор / Профилактическая медицина, 2009. - №4. - С.8-15.

7. ривощеков С.Г., Леутин В.П., Диверт В.Э., Диверт Г.М., Платонов Я.Г., Ковтун Л.Т., Комлягина Т.Г., Мозолевская Н.В. Системные механизмы адаптации и компенсации // Бюллетень СО РАМН, 2004, № 2(112). - С.148-153.

8. Национальные рекомендации по кардиоваскулярной профилактике, принятые комитетом экспертов Всероссийского научного общества кардиологов. - Москва, 2011. - 4 с. 
Вестник Новосибирского государственного педагогического университета Novosibirsk State Pedagogical University Bulletin

9. Чанчаева Е.А. Айзман Р.И. Особенности морфофункциональной, психофизиологической и биохимической адаптации человека к условиям Горного Алтая // Экология человека. 2011. - № 9. - С. 24-30.

10. Чанчаева Е.А., Айзман Р.И., Герасёв А.Д. Современное представление об антиоксидантной системе организма человека // Экология человека. - 2013. - № 7. - С. 50-58.

11. Aizman R.I., Chanchaeva E.A., Kogteva O.S. Antioxidant Activity of Blood Plasma in Altai Aborigines. Human Physiology, 2012, vol. 38, no. 2, pp. 206-211.

12. Buduk-ool L.K., Aizman R.I. The ethnic peculiarities to adaptation of the cardiovascular system of students living in Tuva republic. European Journal of Natural History, 2008, no. 3, pp. 81-85. 
Вестник Новосибирского государственного педагогического университета Novosibirsk State Pedagogical University Bulletin

1(17) $2014 \quad$ www.vestnik.nspu.ru ISSN 2226-3365

(C) M. A. Popova, A. A. Govoruchina, A. Y. Dron

UDC 614+57.023

MONITORING OF THE FUNCTIONAL CONDITION OF THE TEACHERS LIVING IN THE NORTH

\author{
M. A. Popova, A. A. Govoruchina, A. Y. Dron (Surgut, Russia)
}

As a result of research of functional conditions and regulatory-adaptive opportunities of teachers' organisms the fact that the functional conditions and adaptive opportunities of an organism depend on accommodation duration in the North and surveyed people's age has been established.

The critical adaptation periods for cardiovascular system and vegetative regulation have been investigated on the basis of the compartment-cluster analysis taking into account the surveyed teachers' age. It has been also established that the more the age of teachers moving to the north is, the earlier cardiovascular system functioning violations occur. The central contour regulation prevalence in a heart rhythm management is noted during the periods from 6 to 10 and from 21 to 25 years of accommodation in the north in both age groups.

Keywords: functional condition, adaptation, teachers and pupils.

\title{
REFERENCES
}

1. Antropov O. N, Osipova I. V., Simon G. I. Professional'nyi stress i razvitie stress-indutsirovannoi gipertonii [Occupational stress and the development of stress-induced hypertension]. Cardiology, 2009, no. 6. pp. 27-30.

2. Bobko N. A. Vliyanie stressa na rabotu serdechno-sosudistoi sistemy operatorov preimushchestvenno umstvennogo truda $v$ raznoe vremya sutok i rabochei nedeli [The effects of stress on the cardiovascular system operators primarily intellectual work at different times of the day and working non-Delhi]. Human Physiology, 2007, vol. 33, no. 3. pp. 55-62.

3. Buduk-ool L. K., Aizman R. I. Morfofunktsional'nye pokazateli u studentov Tyvinskogo gosudarstvennogo universiteta [Morphological and functional parameters at students of Tuva State University]. Hygiene and sanitary, 2009, no. 3, pp. 82-83.

4. Buduk-ool L. K., Krasil'nikova V. A., Aizman R. I. Dinamika protsessov adaptatsii k obucheniyu studentov, prozhivayushchikh $\mathrm{v}$ diskomfortnom klimato-geograficheskom regione [Dynamics of processes of adaptation to training the students living in discomfortable climate-geographical region]. Human physiology, 2009, vol. 35, no.4, pp. 103-110.

5. Eskov V. M. Identifikatsiya parametrov poryadka (naibolee znachimykh diagnosticheskikh priznakov) vektora sostoyaniya biosistem v m-mernom fazovom prostranstve [Identification of the order parameter (the most important diagnostic features) of the state vector of biosystems in the $\mathrm{m}$ dimensional phase space]. Patent RF, no. 2007614714, Moscow, 2007.

6. Koncevay A. V., Kalinina A. M., Grigoryan C. A. Povedencheskie faktory riska i ikh korrektsiya v organizovannykh kollektivakh. Analiticheskii obzor [Behavioral risk factors and their correction in organized groups. Analytical review]. Preventive Medicine, 2009, no. 4, pp. 8-15. 
7. Krivoshchekov S. G., Leutin V. P., Divert V. E., Divert G. M., Platonov Y. G., Kovtun L. T., Komlyagina T. G., Mozolevskaya N. V. Sistemnye mekhanizmy adaptatsii i kompensatsii [System mechanisms of adaptation and compensation]. Bulletin SB RAMS, 2004, 112, no. 2, pp. 148-153.

8. Natsional'nye rekomendatsii po kardiovaskulyarnoi profilaktike, prinyatye komitetom ekspertov Vserossiiskogo nauchnogo obshchestva kardiologov [National guidelines for cardiovascular prevention, adoption by committee of experts of the Russian Scientific Society of Cardiology]. Moscow, 2011, 4 p. 1.

9. Chanchaeva E. A. Aizman R. I. Osobennosti morfofunktsional'noi, psikhofiziologicheskoi i biokhimicheskoi adaptatsii cheloveka k usloviyam Gornogo Altaya [Feature of morphological and functional, psychological, physiological and biochemical adaptation of the person to conditions of Gornyi Altai]. Ecology of the person, 2011, no. 9, pp. 24-30.

10. Chanchaeva E. A., Aizman R. I., Gerasev A. D. Sovremennoe predstavlenie ob antioksidantnoi sisteme organizma cheloveka [Modern representation about antyoxygen to system of an organism of the person]. Ecology of the person, 2013, no. 7, pp. 50-58.

11. Aizman R. I., Chanchaeva E. A., Kogteva O. S. Antioxidant Activity of Blood Plasma in Altai Aborigines. Human Physiology, 2012, vol. 38, no. 2, pp. 206-211.

12. Buduk-ool L. K., Aizman R. I. The ethnic peculiarities to adaptation of the cardiovascular system of students living in Tuva republic. European Journal of Natural History, 2008, no. 3, pp. 81-85.

Popova Marina Andreevna, the doctor of medical biological sciences, the professor, Surgut State University.

E-mail: m_a_popova@mail.ru

Govoruchina Alena Anatolevna, the candidate biological sciences, the associate professor, Surgut State Pedagogical University.

E-mail: govalena@mail.ru

Dron' Anton Yurevich, the candidate biological sciences, the associate professor, Surgut State Pedagogical University.

E-mail: leeg86rus@mail.ru 
Вестник Новосибирского государственного педагогического университета Novosibirsk State Pedagogical University Bulletin

1(17) $2014 \quad$ www.vestnik.nspu.ru ISSN 2226-3365

(C) Ханна Либерска, Марзана Фарниска

УДК $612.66+371.7$

\title{
ПСИХИЧЕСКОЕ ЗДОРОВЬЕ ЖЕНЩИН, ВОВЛЕЧЕННЫХ В ПРОЦЕСС НЕПРЕРЫВНОГО ОБРАЗОВАНИЯ
}

\author{
Ханна Либерска (Быдгощ, Польша), Марзана Фарниска (Зелена Гора, Польша) \\ В статье авторами рассматривается важность непрерывного образования в жизни
} взрослых, в частности, женщин. В эру интенсивного развития циивилизации и технологии, образование взрослых - не просто шанс реализации профессионального уровня, но также и шанс оправдания надежд относительно социально-экономического статуса семейной жизни, различных видов деятельности в свободное от работы время, в том числе и политической деятельности. Во время экономического кризиса ценность образования увеличивается из-за получения возможности приспособиться $\kappa$ фактическим условиям на рынке вакансий. Образовательная деятельность взросльх может быть и фактором улучшения состояния психического благополучия. Повышение уровня знаний способствует улучшению психологического здоровья и открывает возможности к сочиальному и профессиональному продвижению.

Авторы отмечают, что на протяжении многих веков сфера образования $и$ профессиональная карьера были прерогативой мужчин, а женщины должны были заботиться о доме и детях. Доступ к образованию и профессиональному развитию, что был накоплен женшинами в течение последних нескольких десятилетий оказался большим прорывом в социальной эволючии. Вопрос в том, внес ли этот доступ к образованию и профессиональной жизни свой вклад в благополучие женщин. Возможно, доступ к новым сферам развития (образованию и профессиональной деятельности) снизил чувство благополучия, ограничивая участие женщин в деятельности, связанной с заботой о семье.

Авторы выдвигают рабочие гипотезы, связанные с общим благосостоянием, психическим, сочиальным и эмочиональным благополучием женщин, занимающихся самообразованием и тех женщин, которые этим не занимаются.

Чтобы проверить вышеупомянутые гипотезы, было проведено сравнительное исследование двух групп женщин по 30 чел. в каждой в возрасте от 21 до 35 лет. Одна группа включала женщин, которые продолжали постоянное обучение и другая группа женщин, которые не продолжали обучение. Все женщины работали, и у всех были семьи (муж, ребенок

Ханна Либерска - доктор психологических наук, профессор, директор отдела социальной психологии и исследований молодежи факультета педагогики и психологии, университет г. Быдгощ им. Казимира Великого.

E-mail: hanna.liberska@op.pl

Марзана Фарниска - кандидат наук, кафедра педагогики, социологии и наук о здоровье, университет г. Зелена Гора.

E-mail: marzanna@farnicka.pl 
Вестник Новосибирского государственного педагогического университета Novosibirsk State Pedagogical University Bulletin

1(17) 2014

www.vestnik.nspu.ru

ISSN 2226-3365

или дети). Они жили в городах или пригородах с населением приблизительно 60000 жителей. $B$ качестве инструментов исследования авторы использовали анкетный опрос для оченки психического благополучия (L.Wojciechowska, 2008). Авторы приходят к выводам, что женщиины, продолжающие обучение на протяжении жизни, испытывают лучшее психическое, сочиальное, эмоциональное и физическое состояние по сравнению с теми, кто не обучается.

Ключевые слова: непрерывное образование, благополучие, психическое, сочииальное, эмоциональное и физическое состояние, профессиональное развитие, самообразование.

\section{Introduction}

Education is an important element in human development and usually translates into success in life. It is essential not only for gaining knowledge and abilities that could be helpful in coping with developmental stress related to realisation of tasks in subsequent stages of life, but also contributes to the social status and wellbeing in general. In adulthood, particularly important is professional development and social position. From the point of view of the sphere of the nearest development, education is necessary for realisation of developmental potential of human being (Wygotski, 1972), therefore, education can be treated as a factor activating human resources. The level of education is also highly relevant for economic and cultural development of a country or region. The awareness of engagement into this development can be a factor optimising the wellbeing of individual.

\section{Education in human development}

Education supports a few areas of development, i.e. (1) gaining of knowledge, (2) orientation in the world of values, (3) development of interpersonal abilities [or interpersonal contact abilities], (4) development of the ability of functioning in social world, (5) development of the ability of self-knowledge and (6) development of the ability of directing self- development (Łuczyński, 2011, Liberska, Farnicka, 2013). In the era of intensive development of civilisation and technology, education of adults is not just a chance of realisation of professional carrier, but also brings a chance of meeting the expectations as to the socio-economic status, family life, forms of leisure activity, political activity and others. In the time of economical crisis, the worth of education increase because of the possibility of getting the ability to adapt to the actual conditions on the job market. When the problems with employment continue, education can have a protective role making grounds for positive thinking about oneself as a person capable of development and taking care of ones image in spite of objective difficulties. Therefore, educational activity of adults can be a factor favouring maintenance or improving the state of psychological wellbeing. Elevation of the level competences contributes to improvement of one's image and opens a possibility of social and professional promotion. The belief that a person brings personal contribution to development of an institution at which he/she is employed or success of an organisation to which he/she belongs is a personal profit of the one who takes care about the level of his/ her education in adult life. It can also contribute to a higher level of wellbeing. In general, taking up education by an adult is a manifestation of his/her activity as a subject creating his/her personality and life path (Tyszkowa, 2000). However, as yet the 
psychological knowledge on the significance of education of adults for the state of psychological wellbeing is relatively limited.

\section{The sense of wellbeing and psycho-social functioning}

The sense of wellbeing has a direct influence on the general state of health, interpersonal relations, engagement in professional work and satisfaction from work. In fact we can talk about a spiral of cyclic relations: (1) engagement in education - (2) increased level of professional, social competence - (3) increased engagement in work - (4) higher social status (social and economic gratifications) - (5) increased sense of wellbeing - (6) increased appreciation of education leading to decision about its continuation.
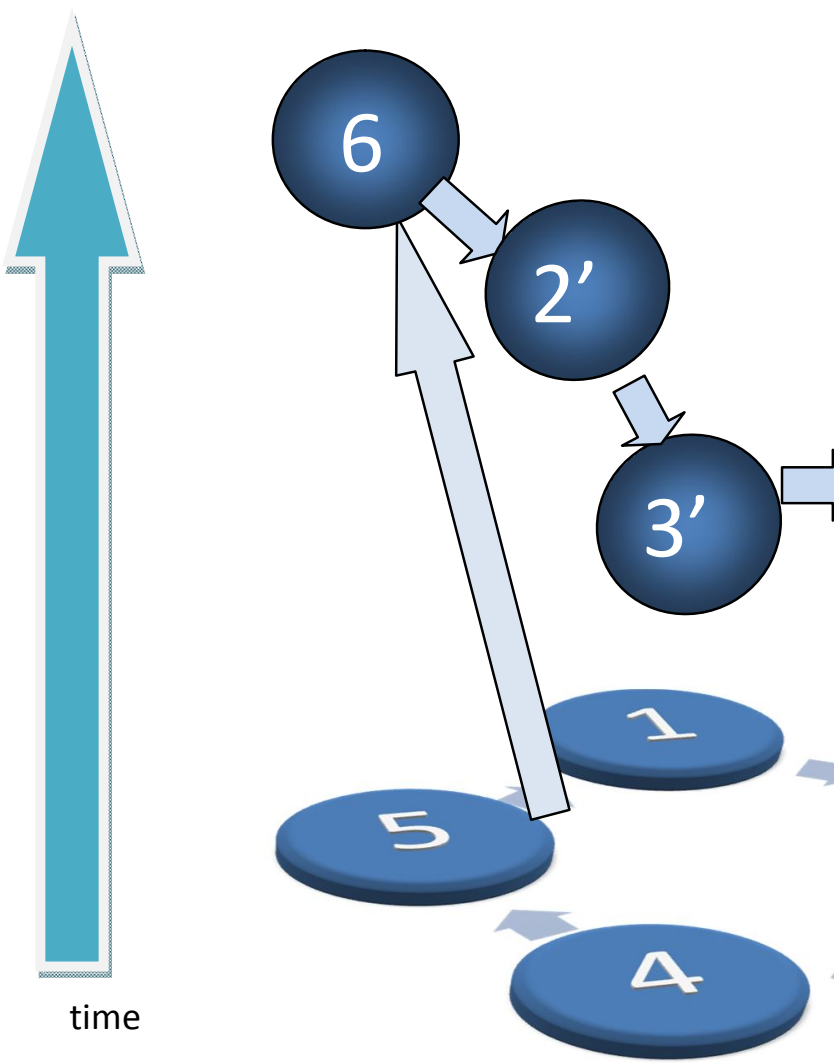

Persons of high sense of wellbeing are higher appreciated in professional life by superiors and subordinates, are more successful in work, are in better health and rarer take doctors' leave, also rarer suffer from syndrome of professional burnout. Such persons are more satisfied with professional life and social position.

In psychological literature the notion of wellbeing is related to many aspects of human health, including physical, emotional and
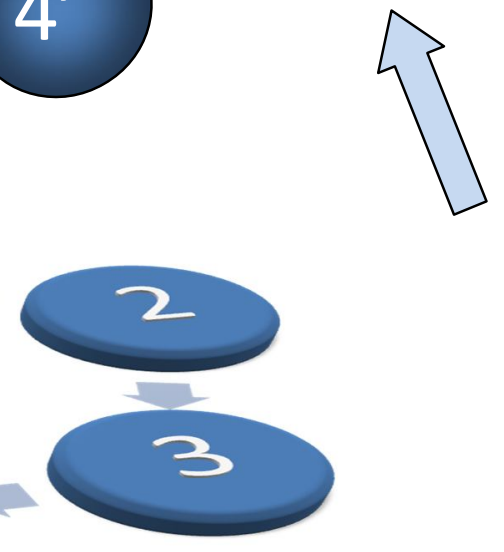

psychological health. According to the definition of WHO, wellbeing is complete physical, psychological and social wellness manifested as the lack of symptoms of diseases. According to some authors wellbeing is happiness, while others describe it as high quality of life (Sęk, 2007). Most of psychologists agree that it is a multi-aspect notion. In this text we assume that the sense of wellbeing develops by cognitive and emotional evaluation of one's life. High sense of wellbeing is related to the domination of positive 
emotions, good atmosphere and general satisfaction with life (Diener, Lucas, Oshi, 2002).

According to the socio-ecological model, a human being is a complete system subjected to many interactions that stimulate him/ her to allround development of his/ her potential. The most important are believed to be social interactions, including those imposed by the educational environment and work environment.

According to the conception of developmental tasks proposed by Havighurst (1972), the tasks related to education are usually realised in the period of adolescence (12- 21 years of age) and early adulthood (21 - 35 years of age) (Liberska, 2011). Many people end their education in the period of adolescence and in early adulthood they already realise the task of "starting work". The current state of civilization imposes extension of time allotted to realization of the task of preparation for working life (in other words education) over not only early adulthood but also in further stages of human development. Continuous education has become a necessary condition for successful coping with changes related to professional life, e.g. on the job market or changes induced by technological progress. It is not easy. Education requires much energy, time, reduction of social contacts - often at the expense of other life tasks e.g. those related to family life. On the other hand, it brings considerable profits, such as a chance of acquiring higher social and economical status, improved image of oneself, acquiring and maintenance of professional competence and higher social prestige. As a consequence, the strength of the influence of a person on his/her environment increases. All these factors contribute to enhance the sense of wellbeing.

\section{The problem of study}

The above-mentioned profits following from the engagement in lifelong education have been concluded from literature on the subject. For many centuries the sphere of education and professional career were the domain of men, while women were supposed to take care of home and children. The access to education and professional development that has been gained by women over the last few decades was a great breakthrough in social evolution. The question is if this access to education and professional life has contributed to the wellbeing of women. Perhaps the access to new spheres of development (long time education and professional activity) has reduced the sense of wellbeing by limiting the women engagement in the activities related to taking care of the family.

\section{Working hypotheses}

The following working hypotheses were put forward.

$\mathrm{H}-1$ : There are significant differences in the sense of general, psychological, social, and emotional wellbeing between the women who are and those who are not engaged in selfeducation.

It is expected that the women engaged in education have a higher sense of general, psychological, social, and emotional wellbeing than those who are not.

$\mathrm{H}-2$ : There are significant differences in the degree of satisfaction from being useful to other people, to the country/ region between the women who are and those who are not engaged in self-education.

It is expected that the women engaged in self-education have a higher level of satisfaction from being useful to other people, to the country/ region than those who are not. 
H-3: There is a significant correlation between the general sense of wellbeing and the general level of satisfaction from being useful.

It is expected that there is a significant correlation between the general sense of wellbeing and the level of satisfaction from being useful.

\section{Study group}

To verify the above hypotheses a comparative study was performed on two groups of women in early adulthood, from 21 to 35 years of age. Group one comprised the women who continued life-long education and group two comprised the women who did not continue education. The condition for classification to group one was current engagement in selfeducation: studies, postgraduate studies, seminars, workshops, learning at high school, etc. All women were working and all had families (husband, child or children). Each group comprised 30 women, so the total number of respondents was 60 women. They were living in a city of about 60000 inhabitants or near this city.

\section{Study tools}

We used the questionnaire for evaluation of subjective wellbeing DAE written by L.Wojciechowska (2008) and a questionnaire to collect data on the family situation and material conditions of the respondents and their satisfaction from being useful for other people, for the country or region.

\section{Results}

Statistical analysis was performed on the basis of U - Mann Whitney test and analysis of correlations. Results are presented in Table 1.

Table 1

Results of U-Mann Whitney test

\begin{tabular}{|c|c|c|c|c|c|}
\hline \multirow[t]{2}{*}{ Type of wellbeing } & $\begin{array}{l}\text { Women } \\
\text { engaged in life- } \\
\text { long education }\end{array}$ & $\begin{array}{l}\text { Women not } \\
\text { engaged in } \\
\text { life-long } \\
\text { education }\end{array}$ & $\mathbf{U}$ & $\mathbf{Z}$ & $\mathbf{p}$ \\
\hline & Total of ranks & Total of ranks & & & \\
\hline General wellbeing & 1244,00 & 467,00 & 61,00 & 5,58 & 0,0002 \\
\hline $\begin{array}{l}\text { Psychological } \\
\text { wellbeing }\end{array}$ & 1132,30 & 578,70 & 173,00 & 3,83 & 0,0001 \\
\hline Social wellbeing & 1037,00 & 671,00 & 266,00 & 2,36 & 0,02 \\
\hline Emotional wellbeing & 1304,00 & 406,00 & 0,00 & 6,53 & 0,0006 \\
\hline $\begin{array}{l}\text { Level of satisfaction } \\
\text { from being useful to } \\
\text { others, to the } \\
\text { country/ region }\end{array}$ & 1295,00 & 416,50 & 10,50 & 6,35 & 0,0001 \\
\hline
\end{tabular}




\section{Verification of H-1}

The results reveal that the level of the sense of general, psychological, social, and emotional wellbeing is higher in the women engaged in education than in those not engaged in education. The differences are statistically significant (Table 1).

\section{Verification of $\mathrm{H}-2$}

Results of the statistical analysis indicate significant differences in the level of satisfaction from being useful to other people, to the country or region between the women engaged and not engaged in life-long education.

\section{Verification of $\mathrm{H}-3$}

Analysis of correlation has shown a significant relation between the sense of general wellbeing and the level of satisfaction from being useful (Table 2).

Table 2

Results of linear r-Pearson's correlation

\begin{tabular}{|l|l|l|l|l|l|}
\hline Average & $\begin{array}{l}\text { Standard } \\
\text { deviation }\end{array}$ & $\mathrm{r}(\mathrm{X}, \mathrm{Y})$ & $\mathrm{r}^{2}$ & $\mathrm{t}$ & $\mathrm{P}$ \\
\hline 257.40 & 28.22 & & & & \\
\hline 6.90 & 2.55 & 0.80 & 0.64 & 10.15 & 0.0003 \\
\hline
\end{tabular}

The analysis shows that with increasing level of the sense of general wellbeing, the level of satisfaction from being useful to other people, the country / region is increased.

\section{Summary}

In general, the women who continue their education have a higher level of wellbeing than those who decided to end their education at a certain level. The group of women engaged in continuing education also have greater satisfaction from being useful. Results collected from two groups of women have also proved a positive correlation between the sense of wellbeing and the level of satisfaction from being useful.

As follows from the data collected, continuation of education and combining it with professional and family duties make conditions leading to higher level of wellbeing than concentration on the family and work. Although taking up learning by adult women who are already wives and mothers requires greater efforts, it brings a stronger sense of wellbeing and increased sense of being useful. In terms of the concept relating health and wellbeing, the decision of engagement in learning gives a better health condition. According to the results, a change in the woman's life caused by the decision of continuing education leads to enrichment of life tasks in the period of early adulthood, gives a chance of better psychological, emotional and social conditions than those of women concentrated on being mothers, wives and workers. However the engagement in education can be a source of many difficult dilemmas (Liberska, Farnicka, 2013). Also other consequences more distant in time should be considered. Continued education can protect women against the appearance of developmental crises that could take place in the 
period of middle and late adulthood, or at least reduce their gravity. One of such crises is that of an empty nest caused by the fact that children have left home (Olejnik, 2011). Another crisis is related to the loss of procreation abilities and often with decrease in physical attractiveness (at least in self-evaluation of women). These crises can be lighter as the sense of wellbeing and usefulness is not dependent only on the physical attractiveness and realisation of family roles. However, formulation of a reliable conclusion about the protective function of engagement in education needs further study on a larger number of women, including those living in large agglomerations and in the country.

\section{REFERENCES}

Diener E., Lucas R.E., Oishi S. (2004). Dobrostan psychiczny. Nauka o szczęściu i zadowoleniu z życia. W: J.Czapiński (red.), Psychologia pozytywna (s.35-50). Warszawa: PWN.

Erikson E. H. (1982). The life cycle completed. New York - London: W.W.Norton.

Havighurst R.J. (1972). Developmental task and education. New York: David McKay.

Liberska H. (2011). Teorie rozwoju psychicznego. W: J.Trempała (red.). Psychologia rozwoju czlowieka (71-126). Warszawa: PWN.

Liberska H., Farnicka M. (2013). The educational activity and personal development of woman: an exploration of success and threat areas. In: N.A.Lobanov, V.N.Skvortsov (Ed.), Lifelong learning, vol 11, p.I (102 - 105). Saint-Petersburg: Pushkin State University.

Łuczyński J. (2011). Zarządzanie edukacją wspierającą rozwój indywidualny uczniów. W: J.Trempała (red.). Psychologia rozwoju człowieka (379-392). Warszawa: PWN.

Olejnik (2011). Średnia dorosłość. W: J.Trempała (red.). Psychologia rozwoju człowieka (312-325). Warszawa: PWN.

Sęk H. (2003). Wstęp do psychologii klinicznej. Warszawa: Scholar. Wygotski L.S. (1971). Wybrane prace psychologiczne. Warszawa: PWN. 
Вестник Новосибирского государственного педагогического университета Novosibirsk State Pedagogical University Bulletin

(C) Hanna Liberska, Marzanna Farnicka

UDC $612.66+371.7$

\title{
THE SENSE OF WELL-BEING OF WOMEN INVOLVED IN LIFELONG EDUCATION
}

\author{
Hanna Liberska (Bydgoszcz, Poland), Marzanna Farnicka (Zielona Gora, Poland)
}

In the article authors consider importance of continuous education in a life adult, in particular, women. In the era of intense development of civilisation and technology, education of adults is not just a chance of realisation of professional carrier, but also brings a chance of meeting the expectations as to the socio-economic status, family life, forms of leisure activity. political activity and others. In the time of economical crisis, the worth of education increase because of the possibility of getting the ability to adapt to the actual conditions on the job market. educational activity of adults can be a factor favouring maintenance or improving the state of psychological wellbeing. Increasing knowledge improves and offers opportunities for social and professional advancement.

Further, the authors note that for many centuries the sphere of education and professional career were the domain of men, while women were supposed to take care of home and children. The access to education and professional development that has been saved up by women over the last few decades was a great breakthrough in social evolution. The question is if this access to education and professional life has contributed to the wellbeing of women. Perhaps the access to new spheres of development (long time education and professional activity) has reduced the sense of wellbeing by limiting the women engagement in the activities related to taking care of the family.

Authors put forward the working hypotheses connected with the general well-being, mental, social and emotional well-being of the women who are engaged in self-education and those women which are not engaged in it.

To check up aforementioned hypotheses, the comparative research of two groups of women, on 30 people in each group, has been carried out everyone at the age from 21 till 35 years. One group included women who were continued life-long education and other group of women which did not continue education. All women worked, and all had families (the husband, the child or children). They lived in cities or suburbs with the population approximately 60000 inhabitants. As tools of research authors used questionnaire for an estimation of mental well-being (L. Wojciechowska, 2008). Authors come to conclusions, that the women continuing life-long education, had the best mental, social, emotional and physical condition in comparison with those who were not educated.

Keywords: lifelong education, well-being, mental, social, emotional and physical condition, professional development, self-education.

\section{REFERENCES}

Diener E., Lucas R.E., Oishi S. (2004). Dobrostan psychiczny. Nauka o szczęściu i zadowoleniu z życia. W: J.Czapiński (red.), Psychologia pozytywna (s.35-50). Warszawa: PWN.

Erikson E. H. (1982). The life cycle completed. New York - London: W.W.Norton.

Havighurst R.J. (1972). Developmental task and education. New York: David McKay.

Liberska H. (2011). Teorie rozwoju psychicznego. W: J.Trempała (red.). Psychologia rozwoju czlowieka (71-126). Warszawa: PWN. 
Liberska H., Farnicka M. (2013). The educational activity and personal development of woman: an exploration of success and threat areas. In: N.A.Lobanov, V.N.Skvortsov (Ed.), Lifelong learning, vol 11, p.I (102 - 105). Saint-Petersburg: Pushkin State University.

Łuczyński J. (2011). Zarządzanie edukacją wspierającą rozwój indywidualny uczniów. W: J.Trempała (red.). Psychologia rozwoju człowieka (379-392). Warszawa: PWN.

Olejnik (2011). Średnia dorosłość. W: J.Trempała (red.). Psychologia rozwoju człowieka (312-325). Warszawa: PWN.

Sęk H. (2003). Wstęp do psychologii klinicznej. Warszawa: Scholar. Wygotski L.S. (1971). Wybrane prace psychologiczne. Warszawa: PWN.

Hanna Liberska, the Doctor of Psychology Sciences, Professor, Director of the Department of Social Psychology and Youth Research [Zakład Psychologii Społecznej i Badań nad Młodzieżą], the Faculty of Pedagogy and Psychology, Kazimierz Wielki University in Bydgoszcz.

E-mail: hanna.liberska@op.pl

Marzanna Farnicka, PhD, Department of Pedagogy, Sociology and Health Sciences, University of Zielona Gora.

E-mail: marzanna@farnicka.pl 


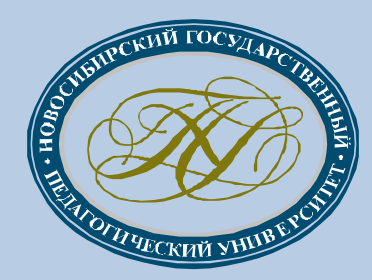

www.vestnik.nspu.ru

\title{
БИОЛОГИЧЕСКИЕ, ХИМИЧЕСКИЕ, \\ МЕДИЦИНСКИЕ НАУКИ
}

\author{
Влияние различных факторов
}

на здоровье человека 
Вестник Новосибирского государственного педагогического университета Novosibirsk State Pedagogical University Bulletin

\title{
ОЦЕНКА ФУНКЦИОНАЛЬНОГО СОСТОЯНИЯ И ФИЗИЧЕСКОЙ ПОДГОТОВЛЕННОСТИ СПОРТСМЕНОВ ПО ПОКАЗАТЕЛЯМ ВАРИАБЕЛЬНОСТИ СЕРДЕЧНОГО РИТМА*
}

\author{
О. Н. Кудря (Омск, Россия)
}

\begin{abstract}
В ходе исследования были использованы различные методы оценки функционального состояния и физической подготовленности спортсменов (физиологические, биохимические, метод тестирования в лабораторных условиях). Выявлено, что для контроля функционального состояния спортсменов целесообразно использовать метод анализа вариабельности сердечного ритма, как наиболее информативный, доступный и объективный. Установлено, что рост физической работоспособности и эффективности соревновательной деятельности спортсменов игровых видов спорта связаны с усилением автономного контура регуляиии, увеличением общей мощности спектра, умеренной активацией симпатического отдела ВНС при проведении активной ортостатической пробы. Отсутствие роста работоспособности и уменьшение результативности соревновательной деятельности сопряжены со снижением активности симпатического отдела ВНС при проведении функииональных проб, при этом происходит снижение мощности всех составляющих спектра в состоянии покоя.
\end{abstract}

Ключевые слова: спортсмены, функииональное состояние, методы оценки, вариабельность сердечного ритма, физическая работоспособность, биоэнергетика.

Рациональная организация учебнотренировочного процесса является ведущей в системе эффективного управления подготовкой спортсменов высшей квалификации, многие из которых являются учащимися высших учебных заведений и испытывают влияние как тренировочных, так и учебных нагрузок. Для правильного построения и коррекции тренировочного процесса необходимо иметь достаточно полную информацию о динамике происходящих в процессе тренировке изменений функционального состояния и физической подготовленности спортсменов.

Физическая активность оказывает влияние на все системы организма, но несоответствие нагрузок возможностям организма спортсмена может привести к срыву процессов адаптации, развитию донозологических состояний и патологических процессов.

* Статья подготовлена по результатам работы Всероссийской научной школы с Международным участием «Опыт использования мониторинга здоровья и физической подготовленности учащейся молодежи» (12-14 ноября 2013 г.)

Кудря Ольга Николаевна - кандидат биологических наук, доцент кафедры медикобиологических основ физической культуры и спорта, Сибирский государственный университет физической культуры и спорта.

E-mail: olga27ku@mail.ru 
Вестник Новосибирского государственного педагогического университета Novosibirsk State Pedagogical University Bulletin

1(17) $2014 \quad$ www.vestnik.nspu.ru $\quad$ ISSN 2226-3365

В этой связи вопросы комплексного контроля функционального состояния спортсменов на разных этапах подготовки и прогнозирование спортивной результативности становятся все более значимыми и актуальными. Поиск простых и информативных методов контроля функционального состояния людей, систематически занимающихся спортом, остается одним из приоритетных направлений научных исследований.

Цель настоящего исследования оценка функционального состояния и физической подготовленности спортсменов на разных этапах годичного цикла.

Объект и методы исследования.

В исследовании принимали участие спортсмены мужского пола, занимающиеся гандболом, (n=22), средний возраст 20,3 $\pm 1,7$ лет, стаж занятий 8-14 лет, спортивная квалификация: 1 разряда - мастер спорта.

Обследование спортсменов проводили 6 раз в течение годичного цикла: 1 обследование - начало подготовительного периода, 2 обследование - конец подготовительного периода. 3 обследование - начало соревновательного периода, 4 обследование - соревновательный период (окончание 1 круга игр), 5 обследование - соревновательный период (начало 2 круга игр), 6 обследование - конец соревновательного периода.

Для оценки уровня физической работоспособности проводили тестирование в лабораторных условиях с использованием велоэргометрических проб [2]. Запись кардиоритмограммы в покое и при выполнении активной ортостатической пробы (АОП) выполняли с использованием 12-канального электрокардиографа «Полиспектр-8» фирмы «Нейрософт» (г. Иваново). Для оценки состояния механизмов нейрогуморальной регуляции сердца, активности сегментарных и надсег- ментарных отделов вегетативной нервной системы использовали математический и спектральный методы анализа вариабельности сердечного ритма (ВСР) [12].

При анализе ВСР использовали короткие (5-минутные) записи в соответствии с Международным стандартом (1996) [14].

Для определения биоэнергетических параметров и для изучения метаболических процессов при мышечной работе и в процессе срочного восстановления определяли концентрацию лактата в капиллярной крови в покое, на 3-й и 10-й минутах срочного восстановления. Для определения концентрации лактата использовали биохимический анализатор «Super Easy» (Германия), рассчитывали эффективность анаэробного гликолиза. Для оценки аэробной производительности и окислительной способности организма использовали величину МПК (максимальное потребление кислорода) - как наиболее информативный показатель производительности кардиореспираторной системы.

В ходе исследования проводили оценку эффективности соревновательной деятельности в играх чемпионата России среди мужских гандбольных команд высшей лиги. При анализе эффективности соревновательной деятельности учитывали общее количество игровых действий, выполненных игроком, действия в позиционном и быстром нападении, учитывали результативность бросков с разных позиций, потери мяча. Для каждого игрока рассчитывали коэффициент брака, который представляет отношение суммы отрицательных технико-тактических действий к общей сумме всех технико-тактических действий, выраженное в процентах.

Статистическая обработка результатов исследования проводилась с использованием 
Вестник Новосибирского государственного педагогического университета Novosibirsk State Pedagogical University Bulletin

пакета статистических программ Statistica 6.0 for Windows.

\section{Результаты исследования.}

Функциональное состояние спортсмена и его физическая подготовленность определяется морфологической и функциональной адаптацией систем организма для выполнения основного соревновательного упражнения. В практике спорта существует большое количество методов, используемых для оценки функционального состояния и физической подготовленности спортсменов [2; 4; 9-10].

Общепризнанно, что одним из объективных критериев здоровья и функциональной подготовленности организма спортсмена к предстоящим стартам служат показатели физической работоспособности [2-3; 11].
По результатам исследования было выявлено, что у представителей игровых видов спорта показатели физической работоспособности в смешанном режиме (тест $\mathrm{PWC}_{170}$ ) достоверно увеличились к началу соревновательного периода, но в течение соревновательного периода оставались на достигнутом уровне (табл.1). Абсолютные показатели физической работоспособности в анаэробном режиме достоверно выросли к началу соревновательного периода, что связано с изменением массы тела спортсменов в подготовительном периоде. Однако в пересчете на 1 кг массы тела (Wсуб/кг) показатели не имели достоверных различий в течение всего годичного цикла (табл.1).

Таблица 1

Показатели физической работоспособности гандболистов

на разных этапах годичного ичикла $(M \pm m)$

\begin{tabular}{|c|l|l|l|l|}
\hline $\begin{array}{c}\text { № } \\
\text { обследования }\end{array}$ & $\begin{array}{l}\mathrm{PWC}_{170}, \\
\text { кгм/мин }\end{array}$ & $\begin{array}{l}\mathrm{PWC}_{170} / \text { кг, } \\
\text { кгм/мин/кг }\end{array}$ & $\begin{array}{l}\text { Wсуб, } \\
\text { кгм/мин }\end{array}$ & $\begin{array}{l}\text { Wсуб/кг, } \\
\text { кгм/мин/кг }\end{array}$ \\
\hline 1 & $1395,20 \pm 77,61$ & $18,10 \pm 0,77$ & $1853,33 \pm 106,25$ & $24,16 \pm 1,11$ \\
\hline 2 & $1531,20 \pm 122,15$ & $20,06 \pm 1,13$ & $1902,00 \pm 114,21$ & $25,04 \pm 1,07$ \\
\hline 3 & $1774,08 \pm 62,55$ & $21,00 \pm 0,67$ & $2136,00 \pm 60,13$ & $25,29 \pm 0,63$ \\
\hline 4 & $1643,21 \pm 56,34$ & $19,30 \pm 0,68$ & $2078,57 \pm 58,32$ & $24,24 \pm 0,57$ \\
\hline 5 & $1694,61 \pm 47,61$ & $19,81 \pm 0,50$ & $2113,85 \pm 37,92$ & $24,90 \pm 0,48$ \\
\hline 6 & $1648,69 \pm 85,54$ & $20,35 \pm 0,70$ & $1980,00 \pm 99,60$ & $24,38 \pm 0,52$ \\
\hline Различия & $1 / 3,1 / 4,1 / 5,1 / 6$ & $1 / 3,1 / 6$ & $1 / 3,1 / 5$ & \\
\hline
\end{tabular}

Примечание:

$1 / 3,1 / 4,1 / 5,1 / 6$ - различия между показателями статистически значимы при $\mathrm{p}<0,05$.

Спортивный результат в определенной степени лимитируется уровнем развития механизмов энергообеспечения организма. Поэтому в практике спорта уровень тренированности и функциональное состояние можно оценить по биоэнергетическим параметрам.

Для оценки аэробной производительности и окислительной способности организма использовали величину МПК (максимальное потребление кислорода) - как наиболее информативный показатель производительности кардиореспираторной системы.

Как показали результаты исследования, у гандболистов к началу соревновательного периода достоверно увеличились окислительные возможности организма (по показателям МПК), в течение соревновательного периода эти показатели не изменялись (табл. 2). 
Вестник Новосибирского государственного педагогического университета Novosibirsk State Pedagogical University Bulletin

1(17) $2014 \quad$ www.vestnik.nspu.ru ISSN 2226-3365

Таблица 2

Основные биоэнергетические показатели гандболистов в годичном цикле подготовки (M士m)

\begin{tabular}{|c|l|l|l|l|l|}
\hline $\begin{array}{c}\text { № } \\
\text { обследования }\end{array}$ & $\begin{array}{l}\text { МПК, } \\
\text { мл/мин }\end{array}$ & $\begin{array}{l}\text { МПК/кг, } \\
\text { мл/мин/кг }\end{array}$ & $\begin{array}{l}\text { Гликолитиче- } \\
\text { ская емкость }\end{array}$ & $\begin{array}{l}\text { Эффективность } \\
\text { гликолиза }\end{array}$ & $\begin{array}{l}\text { Лактат } \\
\max \end{array}$ \\
\hline 1 & $4139,42 \pm 170,75$ & $53,83 \pm 1,68$ & $19,84 \pm 1,35$ & $2,52 \pm 0,18$ & $11,6 \pm 0,54$ \\
\hline 2 & $4438,65 \pm 268,73$ & $58,39 \pm 2,31$ & $20,82 \pm 1,11$ & $2,74 \pm 0,12$ & $10,6 \pm 0,50$ \\
\hline 3 & $4972,97 \pm 137,61$ & $58,97 \pm 1,59$ & $20,67 \pm 1,43$ & $2,65 \pm 0,15$ & $10,86 \pm 0,44$ \\
\hline 4 & $4685,00 \pm 123,95$ & $55,05 \pm 1,73$ & $20,59 \pm 1,40$ & $2,38 \pm 0,14$ & $11,7 \pm 0,72$ \\
\hline 5 & $4798,15 \pm 104,75$ & $56,18 \pm 1,28$ & $20,25 \pm 1,49$ & $2,58 \pm 0,18$ & $11,81 \pm 0,58$ \\
\hline 6 & $4697,12 \pm 188,18$ & $58,16 \pm 1,51$ & $19,67 \pm 1,30$ & $2,70 \pm 0,16$ & $10,44 \pm 0,48$ \\
\hline Различия & $1 / 3,1 / 4,1 / 5,1 / 6$ & $1 / 3$ & & & \\
\hline
\end{tabular}

Примечание:

$1 / 3,1 / 4,1 / 5,1 / 6$ - различия между обследованиями статистически значимы при р $<0,05$

Для оценки анаэробных механизмов энергообеспечения использовали значения концентрации лактата в крови при выполнении спортсменаит стандартной физической нагрузки на велоэргометре.

Биоэнергетические показатели, обеспечивающие выполнение нагрузок в анаэробном режиме (гликолитическая емкость, эффективность анаэробного гликолиза, максимальная концентрация лактата) не имели достоверных различий в течение всего годичного цикла (табл. 2). Полученные данные объясняют отсутствие прироста физической работоспособности в субмаксимальной зоне мощности при выполнении спортсменами дозированных нагрузок. Как известно, сердечно-сосудистая система является ведущей в достижении определенного уровня работоспособности. Направленность тренировочного процесса, объем, и интенсивность выполняемых нагрузок влияют на деятельность кардиореспираторной системы, что проявляется как в функциональных, так и морфологических изменениях [2; 5-9]. Можно предположить, что на разных этапах годичного цикла показатели сердечно-сосудистой системы будут закономерно изменяться.

При анализе гемодинамических показателей в состоянии относительного покоя отмечено достоверное снижение ЧСС, ДАД, ДП к началу соревновательного периода. По показателям САД, СО, МОК подобной закономерности не выявлено (табл.3).

Таблица 3

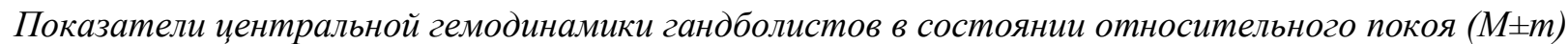

\begin{tabular}{|c|l|l|l|l|l|c|}
\hline $\begin{array}{c}\text { № } \\
\text { Обследования }\end{array}$ & \multicolumn{1}{|c|}{$\begin{array}{c}\text { ЧСС, } \\
\text { уд/мин }\end{array}$} & $\begin{array}{c}\text { САД, } \\
\text { мм рт.ст. }\end{array}$ & $\begin{array}{c}\text { ДАД, } \\
\text { мм рт.ст. }\end{array}$ & $\begin{array}{c}\text { ДП, } \\
\text { усл.ед. }\end{array}$ & $\begin{array}{c}\text { СО, } \\
\text { мл }\end{array}$ & $\begin{array}{c}\text { МОК, } \\
\text { л/мин }\end{array}$ \\
\hline 1 & $65,00 \pm 2,09$ & $123,5 \pm 3,25$ & $82,00 \pm 2,49$ & $80,4 \pm 3,59$ & $59,95 \pm 2,49$ & $3,91 \pm 0,23$ \\
\hline 2 & $62,5 \pm 3,75$ & $120,5 \pm 2,73$ & $78,5 \pm 1,98$ & $75,63 \pm 5,47$ & $63,62 \pm 1,67$ & $3,98 \pm 0,28$ \\
\hline 3 & $55,1 \pm 1,96$ & $118,0 \pm 2,13$ & $75,00 \pm 1,67$ & $65,15 \pm 2,90$ & $64,72 \pm 1,85$ & $3,55 \pm 0,10$ \\
\hline 4 & $54,88 \pm 2,50$ & $122,5 \pm 2,99$ & $76,25 \pm 2,63$ & $67,44 \pm 3,99$ & $65,63 \pm 2,91$ & $3,62 \pm 0,28$ \\
\hline 5 & $54,54 \pm 1,65$ & $116,54 \pm 2,07$ & $77,31 \pm 1,66$ & $63,52 \pm 2,20$ & $61,26 \pm 0,98$ & $3,34 \pm 0,11$ \\
\hline 6 & $58,9 \pm 2,05$ & $116,0 \pm 3,32$ & $73,00 \pm 1,53$ & $68,31 \pm 2,86$ & $67,78 \pm 1,69$ & $4,00 \pm 0,19$ \\
\hline Различия & $1 / 3,1 / 4,1 / 5,1 / 6$ & & $1 / 3,2 / 6,1 / 6$ & $1 / 3,1 / 4,1 / 5,1 / 6$ & $1 / 6,5 / 6$ & $1 / 5,3 / 6,5 / 6$ \\
\hline
\end{tabular}

Примечание:

$1 / 3,1 / 4,1 / 5,1 / 6$ - различия между показателями статистически значимы при р $<0,05$ 
Вестник Новосибирского государственного педагогического университета Novosibirsk State Pedagogical University Bulletin

Полученные результаты могут быть связаны с изменениями в работе системы регуляции. Функциональная система регуляции кровообращения представляет собой многоконтурную, иерархически организованную систему, в которой доминирующая роль отдельных звеньев определяется текущими потребностями организма. Наиболее простая двухконтурная модель регуляции сердечного ритма, предложенная Р.М. Баевским (1984) [1] основывается на кибернетическом подходе, при котором система регуляции синусового узла может быть представлена в виде двух взаимосвязанных уровней (контуров): центрального и автономного. Согласно двухконтурной модели управления ритмом сердца, у гандболистов к началу соревновательного периода достоверно снижается влияние центрального контура (по показателям АМо и ИН) и увеличивается влияние автономного контура управления ритмом сердца. Такое соотношение сохраняется в течение первого круга соревнований. Во втором круге, напротив, отмечено увеличение централизации сердечного ритма и снижение активности автономного контура. Активность гуморального канала в управлении ритмом сердца усиливается к началу первых стартов и удерживается на достигнутом уровне в ходе всего соревновательного периода (табл. 4).

При использовании двухконтурной модели управления ритмом сердца ограничивается число изучаемых регуляторных механизмов (контуров управления), сужается диапазон изучаемых управляющих воздействий, поэтому целесообразно использовать и другие методы изучения вариабельности ритмом сердца, в частности использование спектрального анализа ВСР позволяет выделить участие и вклад сегментарных и надсегментарных отделов вегетативной нервной системы на сердечный ритм.

Таблица 4

Показатели математического анализа сердечного ритма

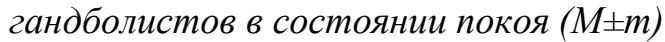

\begin{tabular}{|l|c|c|c|c|c|c|}
\hline Показатели & \multicolumn{6}{|c|}{ № обследования } \\
\cline { 2 - 7 } & 1 & 2 & 3 & 4 & 5 & 6 \\
\hline Мо, с & $0,91 \pm 0,03$ & $0,99 \pm 0,05$ & $\begin{array}{c}1,09 \pm 0,06 \\
1 / 3\end{array}$ & $\begin{array}{c}1,14 \pm 0,06 \\
1 / 4\end{array}$ & $\begin{array}{c}1,10 \pm 0,04 \\
1 / 5\end{array}$ & $\begin{array}{c}1,04 \pm 0,04 \\
1 / 6\end{array}$ \\
\hline АМо, \% & $36,34 \pm 2,17$ & $30,93 \pm 3,49$ & $\begin{array}{c}29,12 \pm 2,16 \\
1 / 3\end{array}$ & $27,11 \pm 4,00$ & $34,39 \pm 3,29$ & $32,49 \pm 2,60$ \\
\hline ВР, с & $0,34 \pm 0,03$ & $0,40 \pm 0,04$ & $\begin{array}{c}0,43 \pm 0,05 \\
1 / 3\end{array}$ & $0,51 \pm 0,07$ & $0,39 \pm 0,03$ & $0,35 \pm 0,03$ \\
\hline $\begin{array}{l}\text { ИН, } \\
\text { усл.ед. }\end{array}$ & $64,01 \pm 6,98$ & $52,15 \pm 7,11$ & $\begin{array}{c}35,94 \pm 5,26 \\
1 / 3\end{array}$ & $\begin{array}{c}33,01 \pm 8,98 \\
1 / 4\end{array}$ & $45,55 \pm 6,78$ & $52,09 \pm 9,60$ \\
\hline
\end{tabular}

Примечание:

$1 / 3,1 / 4,1 / 5,1 / 6$ - различия между показателями статистически значимы при $p<0,05$.

Как показали результаты исследования, в течение подготовительного периода и первой половине соревновательного происходит достоверное увеличение общей мощности спектра, что свидетельствует о росте трени- рованности спортсменов. Рост общей мощности спектра происходит за счет увеличения всех составляющих спектра, хотя основной вклад принадлежит HF-компоненту (табл. 5). 
Вестник Новосибирского государственного педагогического университета Novosibirsk State Pedagogical University Bulletin

Фоновые показатели спектрального анализа ВСР у гандболистов

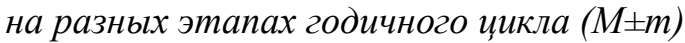

\begin{tabular}{|c|c|c|c|c|c|}
\hline \multirow{2}{*}{$\begin{array}{c}\text { № } \\
\text { обследования }\end{array}$} & $\mathrm{TP},\left(\mathrm{Mc}^{2}\right)$ & $\mathrm{VLF},\left(\mathrm{Mc}^{2}\right)$ & $\mathrm{LF},\left(\mathrm{Mc}^{2}\right)$ & $\mathrm{HF},\left(\mathrm{Mc}^{2}\right)$ & $\mathrm{LF} / \mathrm{HF},($ усл.ед.) \\
\cline { 2 - 6 } & $2781,3 \pm 236,3$ & $991,9 \pm 111,2$ & $1099,1 \pm 158,7$ & $690,6 \pm 159,1$ & $2,6 \pm 0,9$ \\
\hline 1 & $4663,6 \pm 702,1$ & $1592,1 \pm 299,1$ & $1445,2 \pm 221,3$ & $1626,6 \pm 348,7$ & $1,1 \pm 0,22$ \\
\hline 2 & $5275,4 \pm 765,3$ & $1710,4 \pm 380,6$ & $1579,6 \pm 439,2$ & $1985,7 \pm 632,6$ & $1,2 \pm 0,4$ \\
\hline 3 & $8014,8 \pm 788,3$ & $2454,1 \pm 460,5$ & $2271,6 \pm 787,2$ & $3289,1 \pm 786,4$ & $1,1 \pm 0,2$ \\
\hline 4 & $4431,2 \pm 880,5$ & $1565,5 \pm 395,6$ & $1307,4 \pm 245,6$ & $1558,2 \pm 379,1$ & $1,1 \pm 0,1$ \\
\hline 5 & $3926,0 \pm 633,4$ & $1604,4 \pm 361,9$ & $904,7 \pm 119,1$ & $1417,4 \pm 323,8$ & $0,99 \pm 0,2$ \\
\hline 6 & $1 / 2,1 / 3,1 / 4,1 / 5$ & $1 / 2,1 / 3,1 / 4,1 / 6$ & & $1 / 2,1 / 3,1 / 4,1 / 5$ & \\
\hline
\end{tabular}

Примечание:

$1 / 3,1 / 4,1 / 5,1 / 6$ - различия между показателями статистически значимы при $\mathbf{p}<0,05$

Во втором круге соревнований $(5,6$ обследования) отмечено достоверное снижение показателей спектрального анализа вариабельности ритма сердца (табл. 5), наблюдается снижение всех составляющих спектра.

Исследования ритма сердца только в состоянии покоя не позволяют с достаточной полнотой и точностью оценить состояние регуляторных систем организма спортсмена. Для получения объективных данных необхо- димо использовать результаты исследования ритма сердца при функциональных пробах) [12-13].

При проведении активной ортостатической пробы нами выявлено снижение общей мощности спектра (рис.1А) и высокочастотной составляющей спектра (рис.1Б), что свидетельствует о сохранении функциональной активности парасимпатического отдела ВНС на всех этапах обследования.

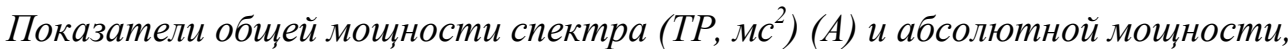

Рисунок 1

НF-волн $\left(\right.$ мс $\left.^{2}\right)(Б)$ в покое и при проведении АОП в течение годичного ичикла
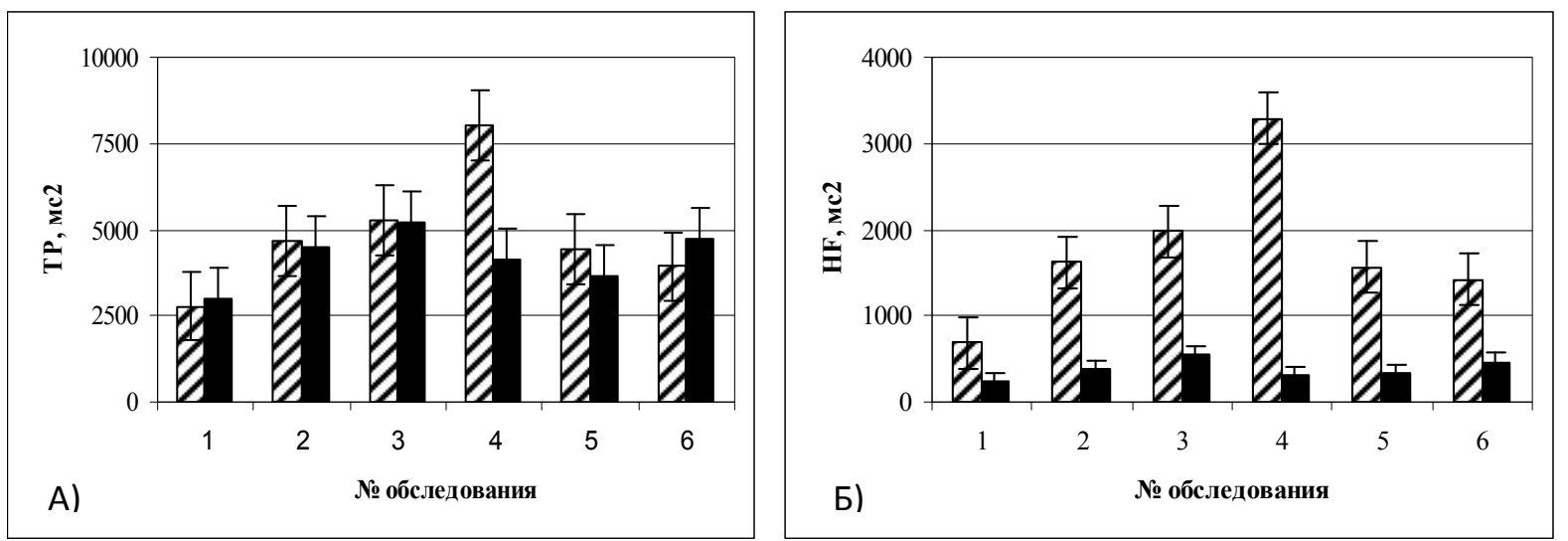
Вестник Новосибирского государственного педагогического университета Novosibirsk State Pedagogical University Bulletin

Активность симпатического регуляторного звена (LF-компонента) при проведении активной ортостатической пробы увеличивается в подготовительном и начале соревновательного периода. К концу 1-ого круга (4 обследование) и в течение 2-ого круга соревнований $(5,6$ обследование) отмечено снижение активности симпатического отдела ВНС при реализации срочной адаптации сердечно- сосудистой системы к изменяющимся внешним условиям (рис. 2А).

Снижение роли высших надсегментарных отделов BHC (VLF-компонента) в процесс срочной адаптации аппарата кровообращения при проведении АОП отмечено только в конце 1-ого круга соревнований (4 обследование), на остальных этапах годичного цикла происходит вовлечение центральных структур в адаптационный процесс (рис. 2Б).

Рисунок 2

Показатели абсолютной мощности LF-волн (A) u VLF-волн (Б) у гандболистов в состоянии покоя и при проведении АОП в течение годичного цикла

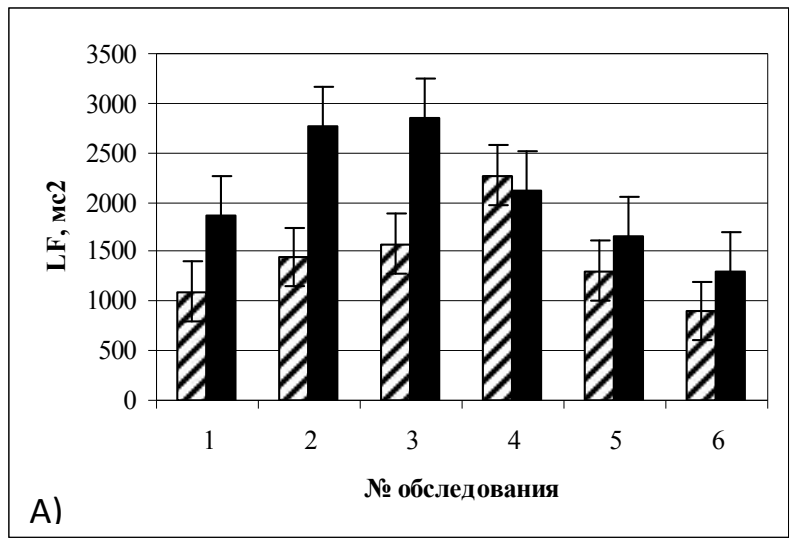

Примечание: $\mathbb{Z Z}$ - покой, $-\mathrm{AO \Pi}$
При выполнении спортсменами дозированных нагрузок было отмечено достоверное снижение инотропной функции сердца (по показателям СО и ИИР) в конце 1-ого и во 2ом круге соревнований $(4,5,6$ обследование) (рис. 3А, Б), что, на наш взгляд, связано со снижением функциональной активности симпатического отдела ВНС.

Таким образом, в ходе проведенного исследования выявили усиление автономного контура регуляции к началу соревновательного сезона, но во второй половине соревновательного периода отмечено увеличение

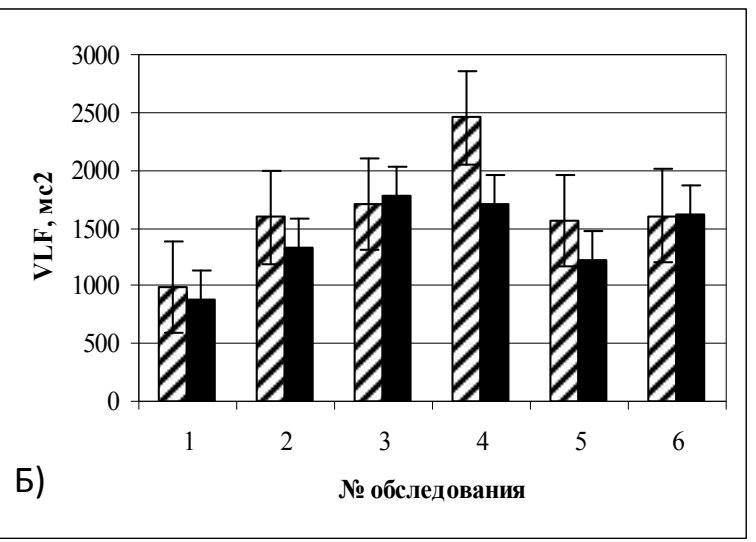

централизации управления ритмом сердца и снижение функциональной активности симпатического отдела ВНС, при этом отсутствует рост работоспособности спортсменов.

При анализе эффективности соревновательной деятельности в течение годичного цикла выявили, что при незначительном увеличении общего количества игровых действий во 2-ом круге соревнований $(5,6,7$ тур), уменьшается количество заброшенных мячей, как в позиционном, так и в стремительном нападении, увеличивается количество незаброшенных мячей (рис.4 А, Б). 
Вестник Новосибирского государственного педагогического университета Novosibirsk State Pedagogical University Bulletin

1(17) $2014 \quad$ www.vestnik.nspu.ru ISSN 2226-3365

Рисунок 3

Показатели систолического объема крови (СО, мл) (А) и индекса инотропного резерва (ИИР, усл.ед.) (Б) при выполнении дозированных нагрузок гандболистами в течение годичного циикла
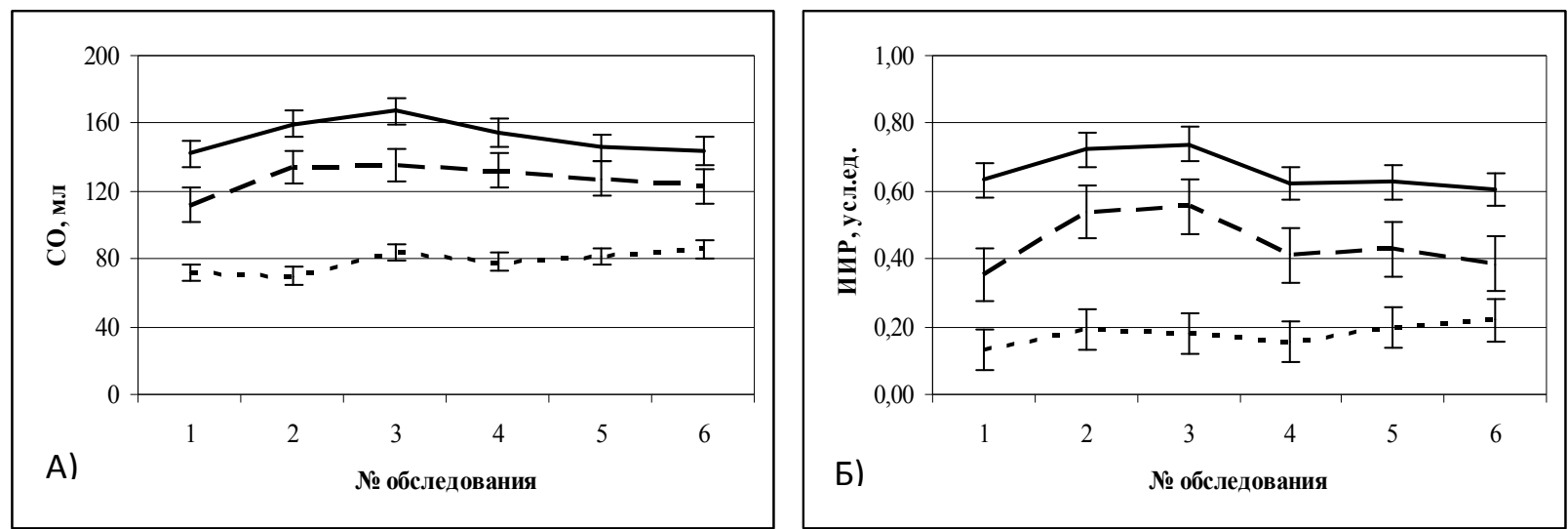

Примечание: ............-1 нагрузка, - - - - - 2 нагрузка,

Рисунок 4

Эффективность игровых действий гандболистов в соревновательном периоде
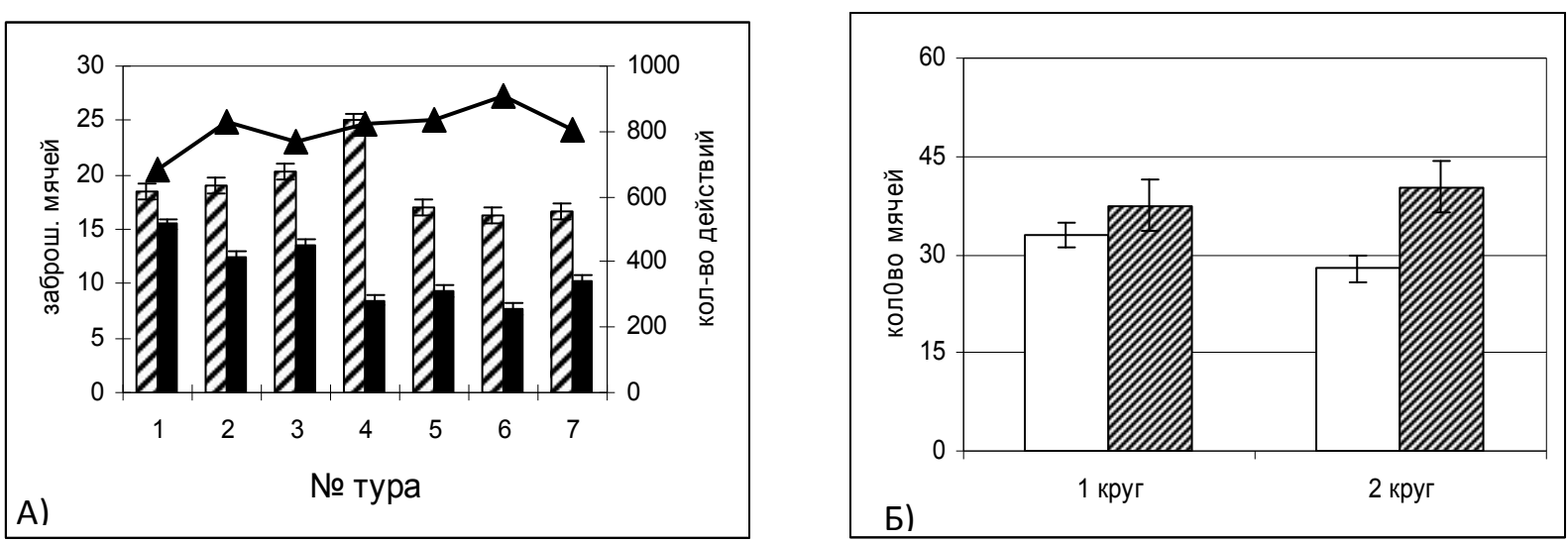

Примечание:

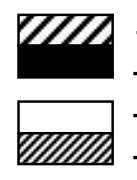

- кол-во мячей, заброшенных в позиционном нападении

- кол-во мячей, заброшенных в стремительном нападении

- среднее кол-во мячей, заброшенных за игру

- среднее кол-во незаброшенных мячей за игру

— - общее кол-во действий команды за игру

Отсутствие роста работоспособности спортсменов, снижение эффективности работы сердца в соревновательный период и снижение эффективности технико-тактических действий во 2-ом круге соревнований проис- ходит одновременно с изменением состояния регуляторных механизмов.

Выявленные изменения в работе регуляторных механизмов (централизация сердечного ритма в покое, снижение функциональной активности симпатического отдела 

Novosibirsk State Pedagogical University Bulletin

ВНС при проведении функциональных проб), вероятно, связаны с изменениями в работе центральной нервной системы. Снижение функционального состояния ЦНС обусловлено повышением возбудимости коры больших полушарий, нарушением слаженной, уравновешенной системы корковых процессов возбуждения и торможения. Это ведет к изменению в работе двигательного анализатора: снижается способность к тонкой мышечной координации, к точной дифференцировке усилий и ориентации тела в пространстве. В результате чего снижается эффективность технико-тактических действий во второй половине соревновательного периода.
Таким образом, общепринятые методы оценки функционального состояния и физической подготовленности (определение физической работоспособности, биоэнергетических показателей, оценка гемодинамических параметров в состоянии покоя) не отражают в полной мере происходящие в организме спортсмена изменения в ходе годичного цикла тренировки. Наиболее объективным, информативным и чувствительным методом оценки функционального состояния и физической подготовленности можно считать анализ вариабельности сердечного ритма в покое и при проведении функциональных проб.

\section{СПИСОК ЛИТЕРАТУРЫ}

1. Баевский Р. М. Математический анализ изменений сердечного ритма при стрессе. - М.: Наука, 1984. - 221 с.

2. Белоцерковский 3. Б. Эргометрические и кардиологические критерии физической работоспособности у спортсменов. - М.: Советский спорт, 2005. - 312 с.

3. Блохин А. В. Специальная подготовленность гандболистов высокой квалификации в длительном соревновательном периоде: автореф. дис. ...канд. пед. наук. - Москва, 2003. - 24 с.

4. Волков Н. И. Биоэнергетика спорта: монография. - М.: Советский спорт, 2011. - 160 с.

5. Гиренко Л. А., Головин М. С., Колмогоров А. Б., Айзман Р. И. Влияние занятий лыжным спортом на морфофункциональные и психофизиологические показатели здоровья юношей // Вестник Новосибирского государственного педагогического университета. 2012. - № 1(5). - С. 33-41.

6. Гиренко Л. А., Головин М. С., Айзман Р. И. Морфофункциональное развитие юношей разного типа телосложения с учетом спортивной специализации // Вестник Новосибирского государственного педагогического университета. - 2012. - № 5(9). - С. 67-83.

7. Гиренко Л. А., Головин М. С., Колмогоров А. Б., Айзман Р. И. Функциональные резервы юношей, занимающихся лыжным спортом // Вестник Новосибирского государственного педагогического университета. - 2012. - № 6(10). - С. 45-50.

8. Жомин К. М., Рубанович В. Б., Айзман Р. И. Морфофункциональная характеристика и физическая подготовленность студенток в зависимости от физкультурно-спортивной деятельности // Физическая культура: воспитание, образование, тренировка. - 2011. - № 1 С. $63-67$.

9. Иорданская Ф. А. Мониторинг функциональной подготовленности юных спортсменов резерва спорта высших достижений (этапы углубленной подготовки и спортивного совершенствования): монография. - М.: Советский спорт, 2011. - 142 с. 
Вестник Новосибирского государственного педагогического университета Novosibirsk State Pedagogical University Bulletin

10. Казин Э. М. Комплексный подход к оценке функциональных состояний человека. Исследование показателей функционального состояния различных возрастных групп // Физиология человека. - 2001. - Т. 27, № 2. - С. 112-121.

11. Карпман В. Л. Тестирование в спортивной медицине. - М.: Физкультура и спорт, 1988. $208 \mathrm{c}$.

12. Михайлов В. М. Вариабельность ритма сердца: опыт практического применения метода. Изд. второе, перераб. и доп. - Иваново: Иван. гос. мед. академия, 2002. - 290 с.

13. Хаспекова Н. Б. Диагностическая информативность мониторирования вариабельности ритма сердца // Вестник аритмологии. - 2003. - № 3. - С. 15-23.

14. Task Force of the European Society of Cardiology and the North American Society of Pacing and Electrophysiology. Heart Rate Variability/ Standards of Measurements, Physiological Interpretation, and Clinical Use. Circulation, 1996, vol. 93, pp. 1043-1065. 
Вестник Новосибирского государственного педагогического университета Novosibirsk State Pedagogical University Bulletin

(C) O. N. Kudrya

\title{
UDC 612.176-073+796
}

\section{EVALUATION OF FUNCTIONAL STATE AND PHYSICAL PREPAREDNESS OF ATH- LETES ON INDICATORS OF THE HEART RATE VARIABILITY}

\author{
O. N. Kudrya (Omsk, Russia)
}

The author considers a variety of methods for assessing functional status and physical fitness of athletes (physiological, biochemical, method of testing in the laboratory). It is shown that for the control of the functional state of the athletes it is advisable to use the method of analysis of heart rate variability as the most informative, accessible and objective. It is established that the increase of physical performance and efficiency of competitive activities of athletes playing sports are associated with increased regulation of independent contour, increasing the total capacity of the spectrum, a moderate activation of the sympathetic division of the ANS during active orthostatic test. The lack of growth performance and reducing the impact of competitive activity paired with a decrease in activity of the sympathetic division of the ANS during the functional tests, with a reduction in the power of all spectral components at rest.

Keywords: athletes, functional status, evaluation methods, heart rate variability, physical performance, bioenergetics.

\section{REFERENCES}

1. Baevskii R.M. Matematicheskii analiz izmenenii serdechnogo ritma pri stresse [Mathematical analysis of changes in heart rate during]. Moscow, Nauka, 1984, $221 \mathrm{p}$.

2. Belotserkovskii Z.B. Ergometricheskie $i$ kardiologicheskie kriterii fizicheskoi rabotosposobnosti u sportsmenov [Ergometric and cardiac criteria for physical performance of athletes]. Moscow, Soviet Sport, 2005, $312 \mathrm{p}$.

3. Blokhin A.V. Spetsial'naya podgotovlennost' gandbolistov vysokoi kvalifikatsii v dlitel'nom sorevnovatel'nom periode. Avtoref. kand. ped. nauk diss. [Special training handball qualifications for long-term competitive period. Authoref. candidate. ped. science diss.]. Moscow, 2003, $24 \mathrm{p}$.

4. Volkov N.I. Bioenergetika sporta [Bioenergy sports]. Moscow, Soviet Sport, 2011, 160 p.

5. Girenko L.A., Golovin M.S., Kolmogorov A.B., Ajzman R.I. Vliyanie zanyatii lyzhnym sportom na morfofunktsional'nye i psikhofiziologicheskie pokazateli zdorov'ya yunoshei [Effect of ski sport occupation on morphofunctional and psychophysiological indices of the health of youths]. Novosibirsk State Pedagogical University Bulletin. 2012, no. 1, pp. 33-41.

6. Girenko L.A., Golovin M.S., Ajzman R.I. Morfofunktsional'noe razvitie yunoshei raznogo tipa teloslozheniya s uchetom sportivnoi spetsializatsii [Morpho-functional development of youth of different physique types with the account of sports speciality]. Novosibirsk State Pedagogical University Bulletin. 2012, no. 5, pp. 67-83.

7. Girenko L. A., Golovin M. S., Kolmogorov A. B., AjzmanR. I. Funktsional'nye rezervy yunoshei, zanimayushchikhsya lyzhnym sportom [Functional reserves of the young men engaged skiing]. Novosibirsk State Pedagogical University Bulletin. 2012, no. 6, pp. 45-50. 
8. Zhomin K.M., Rubanovich V.B., Aizman R.I. Morfofunktsional'naya kharakteristika i fizicheskaya podgotovlennost' studentok v zavisimosti ot fizkul'turno-sportivnoi deyatel'nosti [Morphological and functional characteristic and physical readiness student depending on physical culture sports activity]. Physical training: education, formation, training. 2011, no. 1, pp. 63-67.

9. Jordanckay F.A. [Monitoring the functional training of young athletes - a reserve of high performance sport (steps in-depth training and sports perfection)]. Moscow, Soviet Sport, 2011, 142 p.

10. Kazin E.M. Kompleksnyi podkhod k otsenke funktsional'nykh sostoyanii cheloveka. Issledovanie pokazatelei funktsional'nogo sostoyaniya razlichnykh vozrastnykh grupp [An integrated approach to the assessment of the functional state of man. The study of the functional status of the various age groups]. Human Physiology, 2001, vol. 27, no. 2, pp. 112-121.

11. Karpman V.L. Testirovanie v sportivnoi meditsine [Testing in sports medicine]. Moscow, Physical Culture and Sports, 1988, 208 p.

12. Mikhailov V.M. Variabel'nost' ritma serdtsa: opyt prakticheskogo primeneniya metoda [Heart rate variability: the experience of the practical application of the method]. Ivanovo, Ivan. gos. med. academy, 2002, $290 \mathrm{p}$.

13. Haspekova N.B. Diagnosticheskaya informativnost' monitorirovaniya variabel'nosti ritma serdtsa [Diagnostic information monitoring heart rate variability]. Herald arrhythmology, 2003, no. 3, pp. 15-23.

14. Task Force of the European Society of Cardiology and the North American Society of Pacing and Electrophysiology. Heart Rate Variability. Standards of Measurements, Physiological Interpretation, and Clinical Use. Circulation. 1996, vol. 93, pp. 1043-1065.

Kudrya Olga Nikolaevna, the associate professor of department of biomedical foundations of physical culture and sports, Siberian State University of Physical Culture and Sports.

E-mail: olga27ku@mail.ru 
Вестник Новосибирского государственного педагогического университета Novosibirsk State Pedagogical University Bulletin

1(17) $2014 \quad$ www.vestnik.nspu.ru ISSN 2226-3365

(C) М. М. Мельникова

УДК $613.2+378$

\title{
НЕСБАЛАНСИРОВАННОЕ ПИТАНИЕ КАК ФАКТОР РИСКА РАЗВИТИЯ АЛИМЕНТАРНО-ЗАВИСИМЫХ ЗАБОЛЕВАНИЙ*
}

\author{
М. М. Мельникова (Новосибирск, Россия)
}

\begin{abstract}
Статья посвящена факторам риска, влияющим на развитие алиментарно-зависимых заболеваний у студентов. Питание, или алиментарный фактор, в значительной степени определяет важнейшие функиии организма. Алиментарный фактор (питание) и здоровье человека тесно взаимосвязаны. Стратегия профилактики алиментарно-зависимых заболеваний имеет практическое выражение. Поступление в вуз требует сочиализации в новом коллективе, высокого уровня здоровья, соблюдения здорового образа жизни. Автором проведено анкетирование студенток с использованием анкет-опросников, проведена оченка питания студенток методом пищевого дневника - оценка ежедневного фактического питания человека. Основным выводом статьи является утверждение, что совокупность факторов - несбалансированность питания, наследственная отягощенность по ИБС, ожирению, сахарному диабету 2-го типа могут привезти к возникновению заболеваний.
\end{abstract}

Ключевые слова: алиментарно-зависимые заболевания, рациональное питание, студенты, сбалансированное питание, пищевой ращион.

Алиментарно-зависимые заболевания заболевания, вызванные нарушением питания. В России уровень заболеваний, связанных с питанием в 2 раза выше, чем в Европе [8]. Алиментарный фактор (питание) и здоровье человека тесно взаимосвязаны. Большинство алиментарно-зависимых заболеваний относятся к управляемым патологиям. Их возникновение определено очевидными причинами, и стратегия их профилактики имеет практическое выражение [4]. Однако существующие сложности широкого внедрения принципов профилактического питания не позволяют быстро и эффективно решить эту проблему [3]. Для этого требуется не только общегосударственный подход и поддержка, но и наличие знаний и практических навыков здорового питания и образа жизни у каждого человека [7].

* Статья подготовлена по результатам работы Всероссийской научной школы с Международным участием «Опыт использования мониторинга здоровья и физической подготовленности учащейся молодежи» (12-14 ноября 2013 г.)

Мельникова Маргарита Михайловна - кандидат медицинских наук, доцент кафедры анатомии, физиологии и безопасности жизнедеятельности, Новосибирский государственный педагогический университет.

E-mail: melnicovamm@yandex.ru 
Вестник Новосибирского государственного педагогического университета Novosibirsk State Pedagogical University Bulletin

1(17) $2014 \quad$ www.vestnik.nspu.ru $\quad$ ISSN 2226-3365

Эксперты Всемирной организации здравоохранения (ВО3) для того, чтобы обратить внимание международных организаций, государственных деятелей на решающее влияние питания на уровень здоровья, специально проводят декадники, годы, и даже специальные десятилетия, посвященные вопросам питания. Эти мероприятия ВОЗ проходят под девизом «Здоровая пища - хорошее здоровье». Питание, или алиментарный фактор, в значительной степени определяет важнейшие функции организма. Особенно важен характер питания в современных условиях. Это обусловлено рядом факторов, а именно: высокими нервно-психическими нагрузками, стрессами, гиподинамией, загрязнением окружающей среды. Питание необходимо для построения и непрерывного обновления клеток и тканей, поступления энергии для восполнения энергетических затрат организма, биологически активных веществ, из которых образуются в организме ферменты и гормоны - регуляторы и катализаторы биохимических процессов, и, наконец, питание в значительной мере определяет сопротивляемость организма различным инфекциям и выработку общего иммунитета. С одной стороны, питание является способом ослабления влияния негативных факторов окружающей среды на здоровье, с другой, - в условиях интенсивного загрязнения окружающей среды продукты питания сами становятся объектом воздействия загрязнителей. Поэтому, для сохранения здоровья необходимо рациональное питание [1; 5]. Недостаточность питательных веществ приводит к физическому состоянию, которое вызвано неправильно подобранной диетой или физической неспособностью усваивать и метаболизировать питательные вещества, что негативно отражается не только на качестве жизни и учебе, но может при- вести к болезни и смерти [2; 5]. Питание за последние 30-40 лет, т.е. в течение жизни одного поколения, существенно изменилось. В связи с механизацией и автоматизацией условий труда и быта резко снизились энергозатраты человека. Однако употребление меньшего количества пищи приводит к явному дефициту незаменимых микронутриентов (витаминов, минеральных веществ и полиненасыщенных жирных кислот - ПНЖК). Иначе говоря, обмен веществ и энергии, структура и функция всех клеток, тканей, органов и всего организма в целом находятся в прямой зависимости от характера питания.

Поступив после окончания школы в высшее учебное заведение, бывший школьник попадает в новую, непривычную для него среду. Большие нагрузки во время обучения, социализация в новом коллективе - все это требует высокого уровня здоровья, соблюдения здорового образа жизни. Одной из важнейших составляющих здорового образа жизни является рациональное питание [6]. К сожалению, статистика последних лет показывает резкое увеличение среди молодых людей лиц, страдающих ожирением, заболеваниями сердечно-сосудистой системы, сахарным диабетом и т.д. Очевидно, изучение распространенности, структуры и факторов риска развития алиментарно-зависимых заболеваний у студентов НГПУ является актуальной задачей. Растущая распространенность алиментарно-зависимых заболеваний, в значительной мере формирующих основу заболеваний в последующих возрастных группах, указывает на необходимость принятия безотлагательных мер по рационализации питания студентов, как необходимое условие их оздоровления.

Целью работы явилось: на основе антропометрических данных и анализа потреб- 
Вестник Новосибирского государственного педагогического университета Novosibirsk State Pedagogical University Bulletin

ляемых пищевых продуктов оценить нутриционный макро- и микро-нутриентый состав питания студентов. Было проведено анкетирование студенток четвертого курса Новосибирского государственного педагогического университета (28 девушек в возрасте 21-22-х лет), с использованием двух анкет-опросников: первая - для оценки режима и качества питания, вторая - для оценки пищевого статуса и наличия клинических признаков витаминной недостаточности. Оценка питания студентов проводилась методом пищевого дневника - оценка ежедневного фактического питания человека. При этом в течение семи дней составлялись ежедневные письменные отчеты о питании. В дневник записывались все продукты и блюда, съеденные за день, указывались время приема пищи, понятные объемные порции продуктов (стакан, ложка, штука и т.п.). Клинические признаки витаминной недостаточности оценивались методом анкетирования [6, с. 78-81]. В анкете были представлены вопросы, направленные на проявления внешних признаков витаминной недостаточности - состояние кожи, видимых слизистых оболочек, слизистой оболочки губ в области углов рта. Индекс массы тела (ИМТ), или индекс Кетле рассчитывался по формуле (ИМТ=масса тела (кг) : рост(м2).

Анкетирование показало, что у 78,5 \% студенток прием пищи, в основном, происходит два раза в день, а у 22,5 \% - 3 раза, у всех девушек режим питания не соблюдается. Анализ пищевого рациона показал, что у $55 \%$ опрошенных пища имеет нормальный калораж (2300-2700 ккал), а у 45 \% студенток наблюдается преобладание низко калорийной пищи (934-1400 ккал) в рационе.

Клинические признаки витаминной недостаточности, такие как отечность, разрых- ленность и кровоточивость десен, ангулярный стоматит фолликулярный гиперкератоз, сухость кожи были выявлены у 85,7 \% обследуемых. Из всей группы 28,5 \% принимают витаминно-минеральный комплекс для предупреждения витаминной недостаточности. Анализ полученных результатов показал, что питание студентов не соответствует возрастно-половым нормативным требованиям. Проведя анализ индекса массы тела, было выявлено, что у 4,2 \% обследуемых имеется 1 степень ожирения, у 11,1 \% обнаружен недостаток массы тела, а 78,7 \% имеют нормальный ИМТ.

Питание является определяющим фактором, обеспечивающим поддержание желательной массы тела. Вместе с тем избыточная масса тела и ожирение служит предрасполагающим фактором развития и тяжелого течения атеросклероза, сахарного диабета II типа (инсулиннезависимого), гипертонической и желчнокаменной болезней, онкологической патологии. При изучении риска развития алиментарно-зависимых заболеваний и анализе генеалогического древа было выявлено, что имеется высокая предрасположенность к развитию сахарного диабета второго типа, ИБС (ишемическая болезнь сердца), ожирения. Так у $95 \%$ опрошенных близкие родственники страдают сахарном диабетом 2 типа, у 91,6 \% ожирением, а у 83,3 \% близкие родственники больны ИБС.

Учитывая совокупность факторов (несбалансированность питания, наследственную отягощенность по ИБС, ожирению, сахарному диабету 2-го типа) в обследуемой студентов группе высок риск развития алиментарно-зависимых заболеваний. 
Вестник Новосибирского государственного педагогического университета Novosibirsk State Pedagogical University Bulletin

1(17) $2014 \quad$ www.vestnik.nspu.ru $\quad$ ISSN 2226-3365

\section{СПИСОК ЛИТЕРАТУРЫ}

1. Айзман Р.И., Рубанович В.Б., Суботялов М.А. Основы медицинских знаний и здорового образа жизни: учебное пособие. - Новосибирск, 2010. - 286 с.

2. Бессесен Д., Кушнер Р. Избыточный вес и ожирение. - М.: Издательство «Бином», 2004. $240 \mathrm{c}$.

3. Борцова О.А. Медико-социальные аспекты обучения школьников правильному образу жизни // Философия образования. - 2006. - № 1. - С. 211-214.

4. Епоян Т.Г., Плахутина Ю.Б. Фактологический обоснованный подход к профилактическому образованию // Вестник Новосибирского государственного педагогического университета. -2012. - № 5.- С. 5-13.

5. Мельникова М.М., Косованова Л.В. Основы рационального питания: учебнометодическое пособие. - Новосибирск: НГПУ, 2000. - 86 с.

6. Намазова Л.С, Гришина Т.P. и др. Витамины и минералы в современной клинической медицине. Возможности лечебных и профилактических технологий: учеб. пособ. - М., 2005. - Ч. 1-5.

7. Рубанович В.Б., Айзман Р.И. Основы здорового образа жизни: учеб. пособ. - Новосибирск: АРТА, 2011. - $256 \mathrm{c}$.

8. Цыганкова О. В., Клочкова Е. В. Рациональное питание при хронических неинфекционных заболеваниях: учебно-метод. пособ. - М.: ЗАО «Кант», 2011. - 59c. 
Вестник Новосибирского государственного педагогического университета Novosibirsk State Pedagogical University Bulletin

\section{UDC 613.2+378}

\section{UNBALANCED NUTRITION AS RISK FACTOR OF ALIMENTARY-DEPENDENT DISEASES}

\section{M. Mel'niкоva (Novosibirsk, Russia)}

The article is devoted to risk factors affecting the development of nutrition-related diseases among students. Food, or nutritional factors, largely determines the most important functions of the body. Nutritional factors (nutrition) and health are closely linked. Strategy for the prevention of nutrition-related diseases has practical expression. To enter the high school requires socialization to a new team, a high level of health, human healthy lifestyle. Author conducted a survey of students using questionnaires, assessment of students by completing a food diary - a daily assessment of the actual human nutrition. The main conclusion of the article is the claim that a combination of factors - supply imbalance, hereditary abnormalities on coronary heart disease, obesity, diabetes type 2 - can lead to diseases.

Keywords: alimentary-dependent diseases, rational nutrition, students, balanced nutrition food ration.

\section{REFERENCES}

1. Aizman R.I., Rubanovich V.B., Subotyalov M. A. Osnovy meditsinskikh znanii i zdorovogo obraza zhizni: uchebnoe posobie [Bases of medical knowledge and healthy way of life]. Novosibirsk, 2010, $286 \mathrm{p}$.

2. Bessesen A.D. Kushner R. Izbytochnyi ves $i$ ozhirenie [Overweight and obesity]. Moscow, Publishing House "Binom", 2004, 240 p.

3. Bortsova O.A. Mediko-sotsial'nye aspekty obucheniya shkol'nikov pravil'nomu obrazu zhizni [Medicine and social aspects of training of pupils to a correct way of life]. Philosophy of education, 2006, no. 1, pp. 211-214.

4. Epoyan T.G., Plakhutina Yu.B. Faktologicheskii obosnovannyi podkhod k profilakticheskomu obrazovaniyu [The factological proved approach to preventive education and use of informationcommunication technologies in informal education]. Novosibirsk State Pedagogical University Bulletin, 2012, no. 5, pp. 5-13.

5. Melnikova M.M, Kosovanova L.V. Osnovy ratsional'nogo pitaniya [Fundamentals of rational nutrition]. Novosibirsk, 2000, 86 p.

6. Namazova L.S, Grishina T.R and oth. Vitaminy i mineraly v sovremennoi klinicheskoi meditsine. Vozmozhnosti lechebnykh i profilakticheskikh tekhnologii: uchebn. posobie [Vitamins and minerals in modern clinical medicine. The possibilities of therapeutic and preventive technologies]. Training manual, Moscow, 2005, vol. 1-5.

7. Rubanovich V.B., Aizman R.I. Osnovy zdorovogo obraza zhizni [Bases of a healthy way of life]. Novosibirsk, 2011, 256 p. 
Вестник Новосибирского государственного педагогического университета Novosibirsk State Pedagogical University Bulletin

8. Tsygankova O.V, Klochkova E.V. Ratsional'noe pitanie pri khronicheskikh neinfektsionnykh zabolevaniyakh [Balanced diet for chronic noninfectious diseases]. Moscow, ZAO "Kant", 2011, $59 \mathrm{p}$.

Mel'niкova Margarita Michailovna, the candidate of medical science, the associate professor of the department of anatomy, physiology and life safety, Novosibirsk State Pedagogical University.

E-mail:melnicovamm@yandex.ru 
Вестник Новосибирского государственного педагогического университета Novosibirsk State Pedagogical University Bulletin

1(17) $2014 \quad$ www.vestnik.nspu.ru ISSN 2226-3365

(C) Н. Г. Иглина, С. В. Мазур

УДК 618.3-008.6

\title{
ФАКТОРЫ РИСКА В РАЗВИТИИ ГЕСТОЗА У ПАЦИЕНТОК ДНЕВНОГО СТАЦИОНАРА МАУЗ «ГОРОДСКАЯ ПОЛИКЛИНИКА №1» Г. НОВОСИБИРСКА*
}

\author{
Н. Г. Иглина, С. В. Мазур (Новосибирск, Россия)
}

В статье рассматриваются факторы риска, способствующие развитию гестоза у беременных женщин. Сравниваются группы женщин разного возраста: 1 группа до 20 лет (22 человека), 2 группа - от 21 до 30 лет (50 чел.), третья группа - от 31 и старше (50 чел). Указывается, что в настоящее время ведущая роль в патогенезе гестоза отводится острому повреждению периферической сосудистой системы. Важное место в этом проиессе занимает функциональное состояние эндотелия сосудов, который является одним из главных факторов регуляции сосудистого тонуса. Основными факторами развитя гестоза являются: возраст женщины, репродуктивная функиия, наличие ожирения, инфекиий, экстрагенитальной патологии, наличие вредных привычек, сочиальные и экологические факторы. Подчеркивается, что выявление факторов риска, проведение профилактических мероприятий по предупреждению гестоза имеет важное медико-сочиальное значение. Представлены профилактические рекомендации для беременных женщин с гестозами.

Ключевые слова: гестоз, беременные женщины, факторы риска.

Проблема гестоза - одна из наиболее актуальных в современном акушерстве, так как в структуре акушерской заболеваемости данная патология занимает ведущее место. Гестоз - это осложнение беременности, обусловленное несоответствием возможностей адаптационных систем организма матери адекватно обеспечить потребности развивающегося плода, характеризуется глубоким расстройством функций жизненно важных органов и систем [1]. Это сложный нейрогуморальный патологический процесс, проявляющийся различными расстройствами функций центральной и вегетативной нервной, сердечнососудистой и эндокринной систем, а также нарушением ряда обменных процессов, иммунного ответа и других функций организма беременной [2].

* Статья подготовлена по результатам работы Всероссийской научной школы с Международным участием «Опыт использования мониторинга здоровья и физической подготовленности учащейся молодежи» (12-14 ноября 2013 г.).

Иглина Нина Григорьевна - кандидат биологических наук, профессор кафедры анатомии, физиологии и безопасности жизнедеятельности, Новосибирский государственный педагогический университет.

E-mail: iglina60@mail.ru

Мазур Снежанна Васильевна - студентка 5 курса, специальности «Безопасность жизнедеятельности», Новосибирский государственный педагогический университет. 
Вестник Новосибирского государственного педагогического университета Novosibirsk State Pedagogical University Bulletin

1(17) $2014 \quad$ www.vestnik.nspu.ru $\quad$ ISSN 2226-3365

Изучение данной темы сохраняет свою актуальность по следующим причинам:

1. Среди причин материнской смертности по РФ гестоз стабильно занимает третье место и составляет $15-25 \%$.

2. Частота преждевременных родов при гестозе составляет 20-30\%.

3. Перинатальная заболеваемость $56 \%$, а перинатальная смертность в 3-4 раза превышает популяционную, достигая $12 \%$.

4. Актуальность проблемы обусловлена также и тяжелыми последствиями этого заболевания. У женщин, перенесших гестоз, формируется хроническая патология почек и гипертоническая болезнь [4].

Существует несколько теорий возникновения гестозов: иммуногенетическая, гормональная, почечной интоксикации и повреждения эндотелия, гемодинамическая, плацентарная (морфологические изменения в плаценте и нарушение продукции гормонов), психогенная, неврологическая, наследственная и другие. Большинство исследователей склоняются к мнению о полиэтиологичности возникновения гестозов [3].

В настоящее время ведущая роль в патогенезе гестоза отводится острому повреждению периферической сосудистой системы. Возникающая гипоперфузия тканей вследствие вазоконстрикции, гиповолемии, нарушений реологических свойств крови и гиперкоагуляции неизбежно приводит к ишемическим повреждениям в тканях различных органов с формированием полиорганной недостаточности [3, 6]. Важное место в этом процессе занимает функциональное состояние эндотелия сосудов, который является одним из главных факторов регуляции сосудистого тонуса, иммунных реакций организма, состояния микроциркуляции и всех ее составляющих. кроме того, эндотелий, являясь уникальной тканью, присутствует в основных органахмишенях (печени, почках, цнс, матке, плаценте), изменения в которых при гестозе предопределяют исход для матери и плода $[3,6]$.

Из литературных источников известно, что основными факторами, влияющими на развитие гестоза являются: возраст женщины (юные и старше 30 лет), репродуктивная функция, наличие ожирения, инфекций, экстрагенитальной патологии, наличие вредных привычек, социальные и экологические факторы. Выявление факторов риска, проведение профилактических мероприятий по предупреждению гестоза имеет важное медикосоциальное значение. Дети от таких матерей, как правило, имеют нарушения физического и психоэмоционального развития, при этом значительно возрастает заболеваемость в младенческом и раннем детском возрасте.

В связи с этим была поставлена цель исследования: определить факторы риска развития гестоза II половины беременности, встречаемые у пациенток дневного стационара Женской консультации Центрального района г. Новосибирска.

Данная работа была проведена на базе дневного стационара Муниципального автономного учреждение здравоохранения «Городская поликлиника № 1».

Были проанализированы следующие документы: отчеты, статистические данные, истории беременных, обменные карты, результаты анализов, листы назначений, процедурные журналы.

Беременные женщины были разделены на 3 возрастных группы: до 20 лет (22 человека), от 21 до 30 лет (50 чел.), от 31 и старше (50 чел).

Для анализа брали следующие показатели: репродуктивная функция, артериальное давление при поступлении в стационар, нали- 
чие ожирения, патологическая прибавка веса при поступлении, наличие инфекций, передаваемых половым путём в анамнезе, уровень образования, наличие вредных привычек (курение), экстрагенитальной патологии, анемии беременных.

В дневном стационаре беременные женщины проходят лечение по поводу различных осложнений. Так, сравнивая показатели за 2011-2012 гг., следует отметить, что наиболее часто лечение получали пациентки с угрозой выкидыша более 12 недель беременности, с угрозой выкидыша до 12 недель, с отёками, плацентарными нарушениями, с рво- той беременных . Анализируя эти показатели, можно увидеть, что более чем в 2 раза выросло количество плацентарных нарушений в 2012 г. по сравнению с 2011 г. Чаще всего представленная структура по нозологии приводит к гестозу.

Анализируя показатели трех обследуемых групп, мы определили, что в каждой группе встречаются данные осложнения, но встречаемость данной патологии выше во второй и третьей группах. Это связано с тем, что большинство родов приходится на женщин этих групп. Данные представлены на рисунке 1.

\section{Рисунок 1}

Наличие гестоза у женщин в обследованных группах.

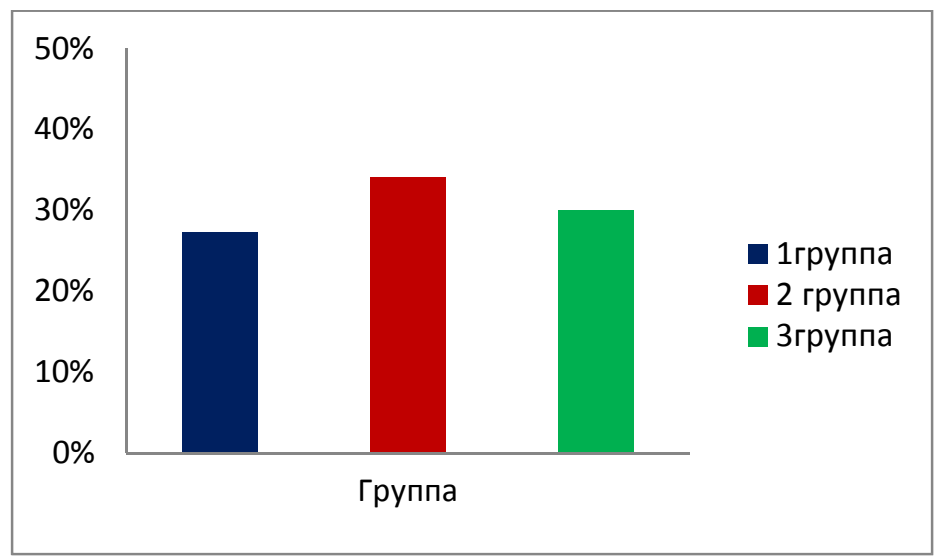

Уровень образования, общей культуры женщины, её знания в области гигиены и сохранения репродуктивного здоровья, несомненно, оказывают влияние на течение беременности. Анализируя уровень образования в данных группах установили, что высшее образование имеют большинство женщин второй и третьей групп, тогда как в первой группе равное количество женщин со средним и высшим образованием.

Огромное влияние на репродуктивное здоровье женщины в целом, а так же на возникновение и развитие гестоза в частности, оказывает количество беременностей. С каждой последующей беременностью риск возрастает. На долю первой беременности в 1 гр. женщин приходится 68 \%, во 2 гр. $42 \%$, в 3 гр. только $12 \%$, тогда как на долю 3 беременности в 3 гр. приходится $34 \%$ случаев по сравнению с 12 и $14 \%$ в 1 и 2 гр. соответственно.

Наличие инфекций, передаваемых половым путем, играет огромную роль при вынашивании беременности, оказывает влияние на ее течение и развитие гестоза. Особенностями инфекций, передаваемых 
Вестник Новосибирского государственного педагогического университета Novosibirsk State Pedagogical University Bulletin

половым путем (ИППП), на современном этапе является то, что часто диагностируются mixt-инфекции, течение которых латентно, малосимптомно, часто хроническое, что создает дополнительные трудности при выявлении и лечении ИППП отрицательно влияет на состояние плода и здоровье ребенка после рождения.

Из рисунка 2 мы видим, что первое место во всех 3 группах занимает трихомониаз. Кроме того часто встречаются хламидиоз, уреаплазмоз.

Рисунок 2

Анамнестические данные по инфекияям, передаваемым половым путем

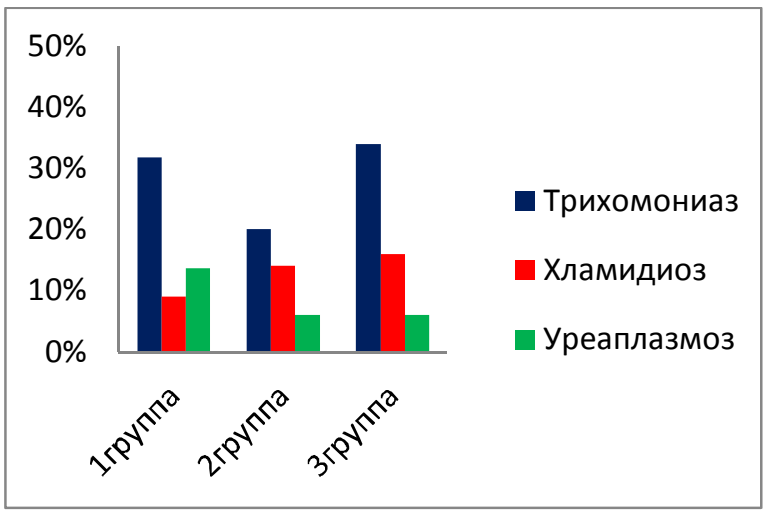

Наличие экстрагенитальной патологии у беременной женщины является одним из важнейших факторов риска возникновения и развития сочетанного гестоза II половины беременности, различных осложнений. В настоящее время часто у одной и той же женщины мы можем наблюдать сочетание эктрагенитальных патологий, что существенно осложняет течение беременности, повышает риск развития гестоза, способствует его утяжелению. У большинства обследуемых женщин разных групп в анамнезе был выявлен хронический танзилит.

Наличие ожирения у беременной женщины так же является одним из факторов риска развития гестоза. Из рисунка 3 видно, что ожирение было выявлено у $10 \%$ беременных женщин 2-ой группы - и $8 \%$ - 3-й группы.

Наличие ожирения у обследованных женщуин

Рисунок 3

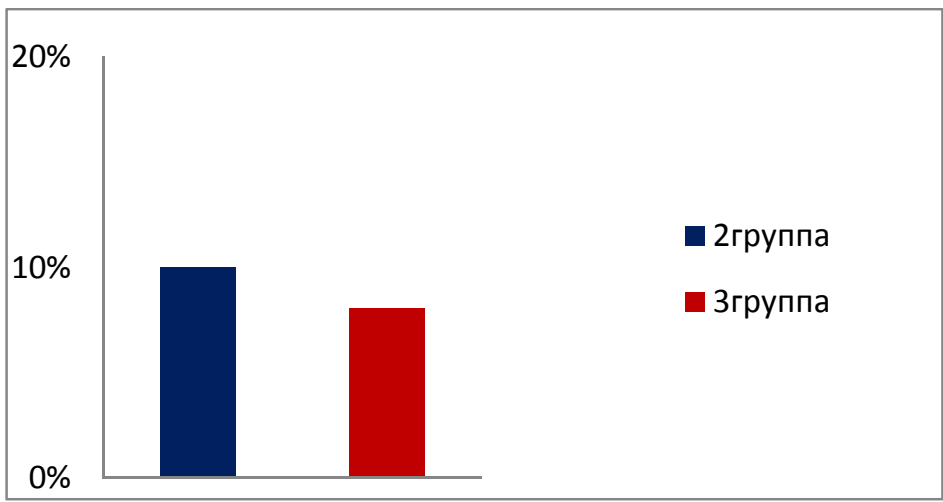


Вестник Новосибирского государственного педагогического университета Novosibirsk State Pedagogical University Bulletin

Патологическая прибавка веса является признаком гестоза, так же может указывать на наличие скрытых отеков. Количество бе- ременных с патологической прибавкой в третьей группе больше, соответственно риск развития гестоза - выше (Рис.4).

\section{Патологическая прибавка веса у обследуемых женщин}

Рисунок 4

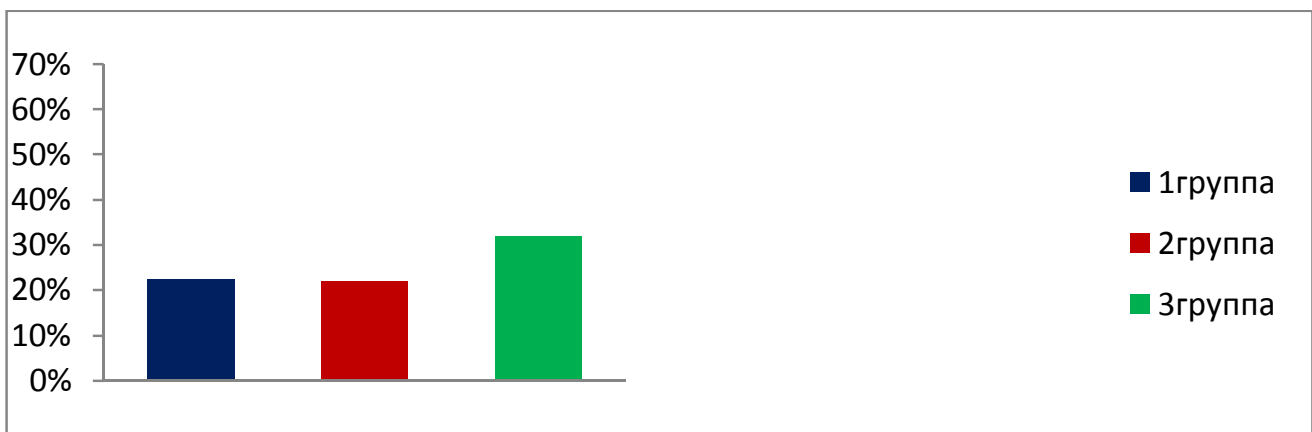

Вредные привычки оказывают пагубное влияние на организм беременной женщины и развивающегося плода, способствуя развитию гестоза. Было установлено, что $13 \%$ женщин первой группы курят, во II группе таких женщин - 10 \% , в III группе - 6 \%.
Анемия беременных способствует развитию гестоза и, наоборот, гестоз может послужить причиной анемии беременных. Из представленных данных рисунка 5, можно увидеть, что анемия беременных встречается во всех группа, но в третьей группе процент встречаемости выше.

Наличие анемии у обследуемых беременных женщин

Рисунок 5

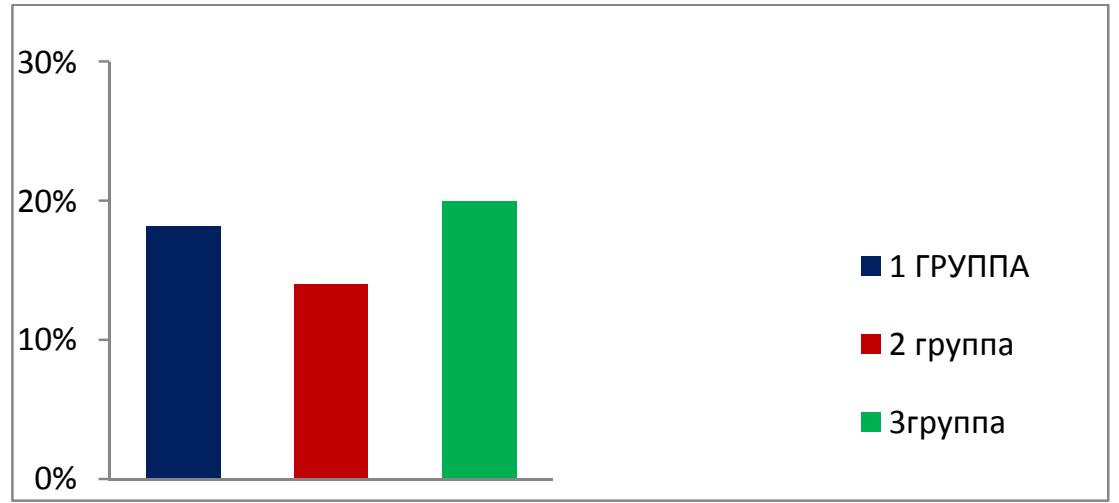

Нами были составлены рекомендации для беременных женщин с гестозом:

- Профилактика и лечение экстрагенитальной патологии, инфекций.
- Планирование последующей беременности.

- Ранняя первая явка в женскую консультацию. 
Вестник Новосибирского государственного педагогического университета Novosibirsk State Pedagogical University Bulletin

- Мониторинг беременности.

- Соблюдение режима труда и отдыха.

- Рациональное питание.

- Гимнастика для беременных (при отсутствии противопоказаний) [5]. Фитотерапия для профилактики и лечения гестозов очень актуальна, особенно при отеках, так как многие лекарственные растения обладают мочегонным эффектом. При гестозе назначают почечный чай, клюквенный или брусничный морс, отвар шиповника. Седативные настойки из пустырника можно применять, начиная с первых недель беременности для профилактики гестозов [5].

\section{Выводы}

1. Большинство пациенток дневного стационара МАУЗ «Городская поли- клиника №1» женской консультации Центрального района г. Новосибирска имели осложнения беременности - гестозы.

2. У пациенток дневного стационара МАУЗ «Городская поликлиника № 1» женской консультации Центрального района г. Новосибирска основными факторами в развитии гестоза II половины беременности являются: возраст беременных женщин, наличие ожирения, соматической патологии, инфекций, передаваемых половым путем, вредных привычек, анемии.

4. Разработаны рекомендации для женщин с осложнениями беременности.

\section{СПИСОК ЛИТЕРАТУРЫ}

1. Айламазян Э.К., Мозговая Е.В. Гестоз. Теория и практика. - М. : МЕДпресс-информ, 2008. $-272 \mathrm{c}$.

2. Башмакова Н.В., Крысова Л.А., Ерофеев Е.Н. Современные подходы к профилактике гестоза // Акушерство и гинекология, 2006. - № 5. - С. 45-47.

3. Блощинская И.А., Петричко Т.А., Давидович И.М. Вазорегулирующая функция сосудистого эндотелия при физиологической беременности и гестозе // Журн. акушер. и женских болезней, 2003. - Т. LII, вып. 1.- С. 26-32

4. Демарчук Е.Л., Щедрина А.Г. Лечебная физкультура в акушерстве: учеб.-метод. пособ. // Новосибирская Государственная Медицинская Академия. - Новосибирск, 2003. - 33 с.

5. Мозговая Е.В., Аржанова О.Н. Медикаментозная терапия и профилактика гестоза: методические рекомендации. - СПб., Изд-во Н-Л, 2008. - 40 с.

6. Blennow M., Savman K., Lives P. et al. Brain-specific proteins in the cerebrospinal fluid of severely asphyxiated newborn infants. Acta Paediatr, 2001, vol. 90, pp. 1171-1175. 
Вестник Новосибирского государственного педагогического университета Novosibirsk State Pedagogical University Bulletin

\title{
UDC 618.3-008.6
}

\section{RISK FACTORS OF GESTATIONAL TOXICOSIS DEVELOPING OF PATIENTS OF CITY HOSPITAL NUMBER 1OF NOVOSIBIRSK}

\author{
N. G. Iglina, S. V. Masur (Novosibirsk, Russia)
}

The paper presents risk factors, which enhance development of gestational toxicosis in pregnant women. There is comparison among different groups: up to 20 years old (22 people), from 21 to 30 years (50 people) and older than 31 (50 people). Stresses that currently play the leading role in the pathogenesis of preeclampsia are leading to acute damage of the peripheral vascular system. The important role in this process takes vascular endothelial disfunction, which is one of the main factors in regulation of vascular tone. The main factors of development of preeclampsia are: woman's age, reproductive function, presence of obesity, infections, extragenital pathology, bad habits, social and environmental factors. It is shown that identification of risk factors and realization preventive measures for reducing gestational toxicosis have important medical and social importance. Prophylactic recommendations are presented for pregnant women.

Key words: gestational toxicosis, pregnant women, risk factors.

\section{REFERENCES}

1. Ailamazyan E. K. Gestoz. Teoriya i praktika [Gestational toxicosis. Theory and practice]. Moscow, MEDpress-Inform, 2008, 272 p.

2. Bashmakova N. V., Krysov L. A., Erofeev E. N. Sovremennye podkhody k profilaktike gestoza [Current approaches to the prevention of gestational toxicosis]. Obstetrics and Gynecology, 2006, no. 5 , pp. $45-47$.

3. Bloschinskay I. A., Petrichko T. A., Davidovich I. M. Vazoreguliruyushchaya funktsiya sosudistogo endoteliya pri fiziologicheskoi beremennosti i gestoze [Vasoregulating function of the vascular endothelium in physiological pregnancy and gestational toxicosis]. Journal of Obstetrics and women's diseases, 2003, vol. LII, no. 1. pp. 26-32.

4. Demarchuk E. L., Shchedrin A. G. Lechebnaya fizkul'tura v akusherstve: ucheb.-metod. posob. [Remedial gymnastic in obstetrics. Study guide]. Novosibirsk State Medical Academy, EL Demarchuk, Novosibirsk, 2003, $33 \mathrm{p}$.

5. Mozgovaya E. V., Arzhanova O. N. Medikamentoznaya terapiya i profilaktika gestoza: metodicheskie rekomendatsii [Drug therapy and prevention of gestational toxicosis: guidelines]. St. Petersburg, Publishing House of the H-L, 2008, 40 p. 
Вестник Новосибирского государственного педагогического университета Novosibirsk State Pedagogical University Bulletin

6. Blennow M., Savman K., Lives P. et al. Brain-specific proteins in the cerebrospinal fluid of severely asphyxiated newborn infants. Acta Paediatr, 2001, vol. 90. pp. 1171-1175.

Iglina Nina Grigor'evna, the candidate of biological science, the associated professor of the department of anatomy, physiology and life safety, Novosibirsk State Pedagogical University.

E-mail: iglina60@mail.ru

Mazur Snezanna Vasil'evna, the student, Life Safety specialty, Novosibirsk State Pedagogical University. 
Вестник Новосибирского государственного педагогического университета Novosibirsk State Pedagogical University Bulletin

1(17) $2014 \quad$ www.vestnik.nspu.ru ISSN 2226-3365

(C) 3. Р. Хайбуллина, Ч. К. Собиржанова

УДК 616.153.915 + 616.831 + 005.07

\title{
НЕКОТОРЫЕ АСПЕКТЫ ДЕЙСТВИЯ СВЕРХМАЛЫХ ДОЗ АНТИОКСИДАНТОВ ПРИ ЭКСПЕРИМЕНТАЛЬНОЙ ГИПОКСИИ ПЛОДА
}

\author{
3. Р. Хайбуллина, Ч. К. Собиржанова (Ташкент, Узбекистан)
}

Статья посвящена анализу изменений фосфолипидного состава и активности ферментов антиоксидантной системь в мозговой ткани на фоне введения сверхмальх доз антиоксидантов животным, перенесшим внутриутробную гипоксию. Актуальность проводимого экспериментального исследования обусловлена тем, что гипоксия плода, вызывая задержку внутриутробного развития и иеребральную ииемию у новорожденного, вносит вклад в рост инвалидности детей. Концепция нейропротекции антиоксидантами активно применяется при лечении ишемического инсульта у взросльх, однако не используется у новорожденных, вероятно, в виду отсутствия фундаментальных разработок, доказываюших ее эффективность. Тем более не исследовано действие сверхмальх доз (СМД), хотя в настоящее время уже не вызывает сомнений реальное существование способности веществ различной природы, примененньх в дозах $10^{-10}-10_{-}^{17} \mathrm{M}$, оказывать эффект на различные биообъекты на молекулярном уровне. Обнаружено, что у животных, перенесиих внутриутробную гипоксию, на 1-5 сутки жизни в мозговой ткани происходит накопление малонового диальдегида (МДА), угнетается активность супероксиддисмутазы (СОД), снижается абсолютное количество легкоокисляемых и функиионально важных ФЛ: фосфатидилсерина (ФС) и фосфатидилинозитола (ФИ). При введении СМД водорастворимого антиоксиданта фенозана снижение МДА до контрольного уровня наблюдается к 10 суткам, при введении жирорастворимого альфа-токоферола - на 12 сутки, без введения - на 21 сутки. Активность СОД при введении СМД фенозана восстанавливается значительно быстрее, становясь сравнимой с контролем с 5 суток жизни, активность каталазы - с 8 суток жизни, тогда как при введении альфа-токоферола активность СОД и каталазы становилась сравнимой с контролем лишь на 21 сутки жизни. На 7-14 сутки постгипоксического периода в мозговой ткани отмечено уменьшение структурных ФЛ - фосфатидилхолина (ФХ), фосфатидилинозитола (ФЭА). Изменения содержания сфингомиелина (СФМ) проявились в ранние сроки его увеличением, что указывает на повышение ригидности мембран и их насыщенности, а в поздние сроки - уменьшением, что указывает на нарушения миелинизации. После 10 суток жизни отмечалось максимально выраженное снижение содержания кардиолипина (КЛ), что создает предпосылки для нарушения развития митохондрий и энергообмена в мозговой ткани. Полученные результаты доказывают, что водорастворимый антиоксидант фенозан в сверхмальх дозах обладает высокой эффективностью в мозговой ткани,

Хайбуллина Зарина Руслановна - доктор медицинских наук, доцент кафедры Биологической химии Ташкентского Педиатрического медицинского института.

E-mail: zr-khaybullina@rambler.ru

Собиржанова Чарос Кахрамон кизи - студентка 5 курса педиатрического факультета Ташкентского педиатрического медицинского института. 
Вестник Новосибирского государственного педагогического университета

Novosibirsk State Pedagogical University Bulletin

1(17) $2014 \quad$ www.vestnik.nspu.ru ISSN 2226-3365

т.к. приводит к ранней нормализации фосфолипидного состава и активности ферментов антиоксидантной системы в мозге, создавая благоприятные условия для развития мозговых функций и нейропластичности в постгипоксическом периоде.

Ключевые слова: гипоксия плода, антиоксиданты, сверхмалые дозы, фосфолипиды мозга, каталаза, супероксиддисмутаза.

\section{Актуальность проблемы.}

Около 10 \% новорожденных, перенесших перинатальную гипоксию, составляют группу риска по смертности в остром периоде, а среди выживших 30 \% имеют риск развития нарушений нервно-психических функций, эпилепсии, шизофрении, аутизма [1]. Примерно 0,2-04 \% всех живорожденных страдают перинатальной ишемией-гипоксией [2], которая обусловливает развитие неврологического дефицита и школьной неуспеваемости у детей. Указанное диктует необходимость поиска оптимальной нейропротекции, основанной на молекулярных механизмах повреждения при гипоксии плода. Концепция нейропротекции антиоксидантами активно применяется при лечении ишемического инсульта у взрослых [3-5], однако не используется у новорожденных, вероятно, в виду отсутствия фундаментальных разработок, доказывающих ее эффективность. Тем более не исследовано действие сверхмалых доз (СМД), хотя в настоящее время уже не вызывает сомнений реальное существование способности веществ различной природы, примененных в дозах $10^{-10}-10^{-17} \mathrm{M}$, оказывать эффект на различные биообъекты на молекулярном уровне [6]. Выявлены некоторые общие характерные закономерности низкоинтенсивных воздействий как химических, так и физических факторов - нелинейная, немонотонная, полимодальная зависимость эффекта от дозы, зависимость эффекта от начальных характеристик биообъекта, изменение чувствительности биообъектов к последующим воздействиям [7]. Особенностями воздействия сверхмалых доз биологически активных веществ (БАВ) являются сложная полимодальная зависимость доза - эффект, когда вещество проявляет активность при концентрации $10^{-3} \mathrm{M}$ и $10^{-14} \mathrm{M}$, а в промежутке между этими концентрациями образуется «мертвая зона» с отсутствием эффекта; преимущественное действие на уровне биологических мембран, воздействие на различные сигнальные системы клеточной регуляции [6-7]. Молекулярные механизмы действия сверхмалых - «нанодоз» антиоксидантов на структурнофункциональные параметры биологических мембран при внутриутробной гипоксии плода не исследованы, хотя именно повреждение мембран под действием активных форм кислорода (АФК) лежит в основе патогенеза гипоксии плода и гибели нейроцитов [8].

Целью работы явилось исследование становления антиоксидантной системы (AОC) и уровня генерации АФК, динамики фосфолипидного (ФЛ) спектра в тотальных гомогенатах мозга в различные сроки постнатального периода после внутриутробной гипоксии плода, а также сравнительная оценка динамики этих параметров на фоне введения антиоксидантов различных классов в СМД.

\section{Материалы и методы.}

Моделирование хронической внутриутробной гипоксии: беременным крысамсамкам со второй недели гестации в хроническом эксперименте проводилась путем общей гипобарической гипоксии. Животных ежедневно в течение 10 дней погружали в специ- 
Вестник Новосибирского государственного педагогического университета Novosibirsk State Pedagogical University Bulletin

1(17) $2014 \quad$ www.vestnik.nspu.ru $\quad$ ISSN 2226-3365

альную камеру, снабженную манометром, предохранительным клапаном, смотровым окошком, щелочным поглотителем для устранения избытка углекислого газа, где создавалось давление 41,1 к Па (308 мм. рт. ст.), что соответствует подъему на высоту 7000 м над уровнем моря. Скорость компрессии и декомпрессии - 0,5 кПа/мин (в течение 80 мин). Экспозиция в условиях разрежения воздуха - 1 час под контролем содержания $\mathrm{O}_{2}$ и $\mathrm{CO}_{2}$ в воздухе. Выбранная модель является адекватной, т.к. в результате высотной гипобарической гипоксии происходит нарушение плацентарного кровотока у самок, что является основной причиной фето-плацентарной недостаточности у беременных женщин [9]. Именно плацентарная недостаточность и внутриутробная гипоксия обусловливают нарушения нервно-психического развития и поведения, имея неблагоприятные отдаленные последствия, механизмы развития которых полностью не известны [10-11].

В группах для каждой серии экспериментов использовано по 7-16 животных. Распределение опытных крысят на группы производилось следующим образом. Контрольная группа - интактные крысята в возрасте 021 дня. Опытная группа - крысята, перенесшие хроническую внутриутробную гипоксию плода, аналогичного возраста. Группа наблюдения - крысята, перенесшие хроническую внутриутробную гипоксию плода, получавшие фенозан (препарат синтезирован в Институте химической физики АН СССР, относится к экранированным пространственно затрудненным фенолам) в СМД $\left(10^{-16} \mathrm{M}\right.$ в 0,1 мл). Группа сравнения - крысята, перенесшие хроническую внутриутробную гипоксию плода, получавшие альфа-токоферол в СМД $\left(10^{-15} \mathrm{M} \mathrm{в} 0,1\right.$ мл).
СМД фенозана получали путем последовательного дробного разведения рабочей смеси, состоявшей из 27,8 мг калиевой соли фенозана, доведенной до 1,0 л $0,036 \mathrm{M}$ раствора гидроксида калия (раствор фенозана $\left.10^{-12} \mathrm{M} / л\right)$. Животным группы наблюдения ежедневно в течение 5 первых дней жизни вводили по 0,1мл этого раствора, содержащего $10^{-16} \mathrm{M}$ фенозана. Для введения внутрь пищевода использовали длинную иглу с наконечником.

Аналогичным способом животным группы сравнения в течение первых 5 дней жизни вводили жирорастворимый антиоксидант альфа-токоферол. Масляный 5 \% раствор альфа-токоферола разводили дробно последовательно в растительном масле до концентрации $10^{-15} \mathrm{M}$ в 0,1 мл.

После родов произведено обследование новорожденных крысят: при рождении, на 1 , $3,5,8,10,12,21$ дни жизни. Забой животных проводили путем декапитации под эфирным наркозом с соблюдением этических требований Международной конвенции о гуманном обращении с животными. Из мозга крысят готовили гомогенаты. Среда выделения состояла из $0,125 \mathrm{M} \mathrm{KCl}$. Экстракцию общих липидов проводили по методу Фолча с рекомендациями (Кейтс М., 1975), с использованием хлороформ-метаноловой смеси в соотношении 2:1. Фракционирование фосфолипидов (ФЛ) проводили методом тонкослойной хроматографии на силикагеле. О количестве общих ФЛ и их отдельных фракций судили по содержанию фосфора в них по методу Васьковского. Количество малонового диальдегида (МДА) определяли тестом с тиобарбитуровой кислотой по методу Стальной И. Д. и соавт. (1977), активность супероксиддисмутазы (СОД) определяли по скорости аутоокисления адреналина по Mirsa P.H., Fridovich I. в 
Вестник Новосибирского государственного педагогического университета Novosibirsk State Pedagogical University Bulletin

1(17) $2014 \quad$ www.vestnik.nspu.ru $\quad$ ISSN 2226-3365

модификации О. С. Брусова с соавт. (1976), каталазы - перманганатометрически по С. М. Зубковой и соавт. (1976).

\section{Результаты.}

В период с момента рождения до 21 дня жизни крыс, что аналогично периоду от рождения до первых 4-5 лет жизни у человека, происходят существенные перестройки как в составе мембранных ФЛ, так и уровня МДА, активности ферментов антиоксидантной защиты, что можно рассматривать как следствие созревания мозговых структур и синхронизации активности АОС с уровнем генерации АФК. Продукция АФК в мозге усиливается на 8-10 сутки жизни в 1,2-1,4 раза, а активность СОД и каталазы в эти сроки достоверно увеличивается в 1,8-2,1 и 1,3-1,4 раза относительно аналогичных показателей при рождении соответственно (таблица 1).

Таблица 1

Динамика уровня МДА (нмоль/мг белка х мин) в мозговой ткани при коррекции антиоксидантами различных классов в СМД

\begin{tabular}{|l|l|l|l|l|l|l|l|l|}
\hline Сутки жизни & 1 час & 24 часа & 3 сут & 5 сут & 8 сут & 10 сут & 12 сут & 21 сут \\
\hline Контрольная гр., P1 & $3,86 \pm 0,09$ & $4,10 \pm 0,11$ & $4,21 \pm 0,12$ & $4,15 \pm 0,12$ & $4,53 \pm 0,11$ & $5,42 \pm 0,10$ & $5,43 \pm 0,08$ & $5,50 \pm 0,09$ \\
\hline Опытная группа, P2 & $5,33 \pm 0,09$ & $8,34 \pm 0,09$ & $7,67 \pm 0,07$ & $7,83 \pm 0,08$ & $6,12 \pm 0,06$ & $5,80 \pm 0,12$ & $5,70 \pm 0,07$ & $5,57 \pm 0,07$ \\
\hline $\begin{array}{l}\text { Гр.наблюдения } \\
\text { (фенозан), Р3 }\end{array}$ & - & $8,00 \pm 0,12$ & $6,17 \pm 0,0$ & $6,19 \pm 0,07$ & $5,73 \pm 0,08$ & $5,51 \pm 0,06$ & $5,49 \pm 0,05$ & $5,54 \pm 0,05$ \\
\hline $\begin{array}{l}\text { Гр. сравнения (то- } \\
\text { коферол), Р4 }\end{array}$ & - & $8,12 \pm 0,11$ & $6,87 \pm 0,11$ & $6,80 \pm 0,14$ & $5,90 \pm 0,11$ & $5,86 \pm 0,15$ & $5,53 \pm 0,11$ & $5,56 \pm 0,09$ \\
\hline P1:2 & $<0,001$ & $<0,001$ & $<0,001$ & $<0,001$ & $<0,001$ & $<0,05$ & $<0,05$ & $>0,05$ \\
\hline P 1:3 & - & $<0,001$ & $<0,001$ & $<0,001$ & $<0,001$ & $>0,05$ & $>0,05$ & $>0,05$ \\
\hline P 1:4 & - & $<0,05$ & $<0,05$ & $<0,05$ & $<0,05$ & $<0,05$ & $>0,05$ & $>0,05$ \\
\hline P 2:3 & - & $<0,05$ & $<0,05$ & $<0,05$ & $<0,05$ & $<0,05$ & $<0,05$ & $>0,05$ \\
\hline P 2:4 & - & $>0,05$ & $<0,05$ & $<0,05$ & $>0,05$ & $>0,05$ & $>0,05$ & $>0,05$ \\
\hline P 3:4 & - & $>0,05$ & $<0,05$ & $<0,05$ & $>0,05$ & $<0,05$ & $>0,05$ & $>0,05$ \\
\hline
\end{tabular}

Эти данные свидетельствуют об определенном уровне АФК, необходимом для развития синаптогенеза и гиппокампальной активности, лежащих в основе формирования когнитивных функций и памяти. АФК являются участниками рецепторных функций центральной нервной системы (ЦНС) - Nметил-D-аспартат (NMDA), глутаматных и других рецепторных систем, широко распространенных в постсинаптических дендритах ЦНС, кортикальных астроцитах, базальных ганглиях, гиппокампе [12]. При введении СМД водорастворимого антиоксиданта фено- зана снижение МДА до контрольного уровня наблюдается раньше - к 10 суткам, при введении жирорастворимого альфа-токоферола на 12 сутки, без введения - на 21 сутки.

Активность СОД при введении СМД фенозана восстанавливается значительно быстрее, становясь сравнимой с контролем, начиная с 5 суток жизни, активность каталазы - с 8 суток жизни, тогда как при введении альфа-токоферола в СМД активность СОД и каталазы становилась сравнимой с контролем лишь на 21 сутки жизни (таблица 2). 
Вестник Новосибирского государственного педагогического университета Novosibirsk State Pedagogical University Bulletin

1(17) $2014 \quad$ www.vestnik.nspu.ru ISSN 2226-3365

Таблица 1

Активность СОД (Е/мг белка) в мозговой ткани при введении СМД антиоксидантов

\begin{tabular}{|l|l|l|l|l|l|l|c|c|}
\hline \multicolumn{1}{|c|}{ Сутки жизни } & \multicolumn{1}{|c|}{1 час } & \multicolumn{1}{c|}{24 часа } & \multicolumn{1}{c|}{3 сут } & \multicolumn{1}{c|}{5 сут } & \multicolumn{1}{c|}{8 сут } & 10 сут & 12 сут & 21 сут \\
\hline $\begin{array}{l}\text { Контрольная гр., } \\
\text { Р1 }\end{array}$ & $0,53 \pm 0,04$ & $0,58 \pm 0,05$ & $0,57 \pm 0,07$ & $0,72 \pm 0,05$ & $0,95 \pm 0,03$ & $1,11 \pm 0,06$ & $1,31 \pm 0,11$ & $1,36 \pm 0,09$ \\
\hline $\begin{array}{l}\text { Опытная группа, } \\
\text { Р2 }\end{array}$ & $0,96 \pm 0,07$ & $0,31 \pm 0,02$ & $0,36 \pm 0,02$ & $0,47 \pm 0,03$ & $0,72 \pm 0,06$ & $1,06 \pm 0,07$ & $1,37 \pm 0,07$ & $1,32 \pm 0,07$ \\
\hline $\begin{array}{l}\text { Гр. наблюдения } \\
\text { (фенозан), Р3 }\end{array}$ & - & $0,34 \pm 0,02$ & $0,36 \pm 0,03$ & $0,64 \pm 0,03$ & $0,89 \pm 0,02$ & $1,12 \pm 0,08$ & $1,11 \pm 0,03$ & $1,18 \pm 0,05$ \\
\hline $\begin{array}{l}\text { Гр. сравнения } \\
\text { (токоферол), Р4 }\end{array}$ & - & $0,32 \pm 0,02$ & $0,39 \pm 0,01$ & $0,51 \pm 0,05$ & $0,65 \pm 0,06$ & $0,86 \pm 0,05$ & $0,99 \pm 0,04$ & $1,33 \pm 0,06$ \\
\hline Р1:2 & $<0,001$ & $<0,001$ & $<0,05$ & $<0,001$ & $<0,01$ & $>0,05$ & $>0,05$ & $>0,05$ \\
\hline Р 1:3 & - & $<0,001$ & $<0,05$ & $>0,05$ & $>0,05$ & $>0,05$ & $>0,05$ & $>0,05$ \\
\hline P 1:4 & - & $<0,05$ & $<0,05$ & $<0,05$ & $<0,05$ & $<0,05$ & $<0,05$ & $>0,05$ \\
\hline Р 2:3 & - & $>0,05$ & $>0,05$ & $<0,05$ & $<0,05$ & $>0,05$ & $<0,05$ & $>0,05$ \\
\hline Р 2:4 & - & $>0,05$ & $>0,05$ & $>0,05$ & $>0,05$ & $<0,05$ & $<0,05$ & $>0,05$ \\
\hline Р 3:4 & - & $>0,05$ & $>0,05$ & $<0,05$ & $<0,05$ & $<0,05$ & $<0,05$ & $>0,05$ \\
\hline
\end{tabular}

У животных, перенесших гипоксию, в мозговой ткани было обнаружено накопление МДА, выраженное угнетение СОД на 1-5 сутки жизни, которые сопровождались снижением в первую очередь легкоокисляемых и функционально важных фосфатидилсерина (ФС) и фосфатидилинозитола (ФИ) - на 5 сутки. Снижение количества ФС указывает на его окисление и экстернализацию, приводящие к апоптозу. Стабильно низкое количественное содержание ФС является предпосылкой для гибели нейронов путем апоптоза на протяжении первых 5 суток постнатального периода, а после 8 суток жизни - может рассматриваться как фактор хронизации поражения мозговой ткани за счет активации под действием ФС иммунной реакции [13], что ведет к задержке развития мозга.

На второй неделе жизни постгипоксические изменения в мозге проявились уменьшением структурных ФЛ - фосфатидилхолина (ФХ), фосфатидилинозитола (ФЭА): содержание ФХ достоверно изменялось после 8 суток как по молярной доле, так и количественно. Изменения содержания сфингомиелина (СФМ) проявились в ранние сроки его увеличением, что указывает на повышение регидности мембран и их насыщенности, а в поздние сроки - уменьшением, что указывает на нарушения миелинизации. После 10 суток жизни отмечалось максимально выраженное снижение содержания кардиолипина (КЛ), что создает предпосылки для нарушения развития митохондрий и энергообмена в мозговой ткани. Возможно, это привело к торможению биосинтеза фосфолипидов и их взаимопревращений на 12 сутки жизни, о чем свидетельствует увеличение молярной доли фосфатидной кислоты (ФК), ФЭА, СФМ.

Под действием СМД фенозана в мозговой ткани изменение в сторону нормализации молярной доли индивидуальных ФЛ начинается с 3 суток жизни, когда имеются достоверные отличия показателей СФМ, ФХ, ФЭА, КЛ между опытной группой, и группой, получавшей фенозан в СМД. Не смотря на это, 
Вестник Новосибирского государственного педагогического университета Novosibirsk State Pedagogical University Bulletin

статистически сравнима с контролем в этот срок только молярная доля ФИ. На 5 сутки жизни, являющиеся критическими для развития постгипоксических изменений в мозге, молярные доли ФС и ФИ увеличиваются, однако не достигают контрольных величин, при этом достоверно отличаясь от показателей в опытной группе. Эта разница также достоверна для молярной доли ЛФХ, ФЭА, ФК.

Фенозан и альфа-токоферол в СМД приводят к нормализации количественного содержания суммарных и индивидуальных ФЛ к 12 суткам жизни, что создает морфологическую основу для нормального развития мозга и формирования нейропластичности. При введении СМД фенозана содержание молярной доли ЛФХ, ФХ, ФЭА, КЛ, ФК на 12 сутки жизни достоверно не отличается от контрольного. Молярная доля СФМ при этом значительно ниже, чем в контрольной (в 1,6 раза) и опытной группе (1,2 раза). Вероятно, это обусловлено замедлением превращений ФХ в СФМ, либо перераспределением ЦДФхолина в пользу синтеза $\Phi \mathrm{X}$, молярная доля которого превышает контрольные показатели на $11 \%$, хотя это различие статистически недостоверно (табл. 3).

Таблица 3

Содержание ФЛ фракиий в мозговой ткани при введении СМД антиоксидантов на 12 сутки постнатального периода (\%), сумма - $100 \%$

\begin{tabular}{|c|c|c|c|c|c|c|c|c|}
\hline Группа животных & ЛФХ & СФМ & ФХ & ФС & ФИ & ФЭА & КЛ & ФК \\
\hline $\begin{array}{c}\text { Контрольная группа } \\
\text { (n=8), Р1 }\end{array}$ & $\begin{array}{c}0,92 \pm \\
0,12\end{array}$ & $\begin{array}{c}4,32 \pm \\
0,32\end{array}$ & $\begin{array}{c}42,22 \pm 3 \\
, 51\end{array}$ & $\begin{array}{c}12,27 \pm 0 \\
, 45\end{array}$ & $\begin{array}{c}4,86 \pm \\
0,37\end{array}$ & $\begin{array}{c}28,72 \pm 5 \\
, 24\end{array}$ & $\begin{array}{c}4,12 \pm \\
0,32\end{array}$ & $\begin{array}{c}2,57 \pm \\
0,19\end{array}$ \\
\hline $\begin{array}{c}\text { Опытная группа } \\
\text { (n=8), Р2 }\end{array}$ & $\begin{array}{c}1,34 \pm \\
0,02\end{array}$ & $\begin{array}{c}3,33 \pm \\
0,15\end{array}$ & $\begin{array}{c}37,99 \pm 0 \\
, 31\end{array}$ & $\begin{array}{c}9,00 \pm \\
0,15\end{array}$ & $\begin{array}{c}4,49 \pm \\
0,06\end{array}$ & $\begin{array}{c}35,87 \pm 0 \\
, 34\end{array}$ & $\begin{array}{c}3,91 \pm \\
0,07\end{array}$ & $\begin{array}{c}4,07 \pm \\
0,17\end{array}$ \\
\hline $\begin{array}{c}\text { Группа наблюдения } \\
\text { (фенозан) } \\
\text { (n=8), Р3 }\end{array}$ & $\begin{array}{c}1,03 \pm \\
0,02\end{array}$ & $\begin{array}{c}2,73 \pm \\
0,22\end{array}$ & $\begin{array}{c}47,03 \pm 0 \\
, 63\end{array}$ & $\begin{array}{c}13,87 \pm 0 \\
, 40\end{array}$ & $\begin{array}{c}3,39 \pm \\
0,10\end{array}$ & $\begin{array}{c}26,37 \pm 0 \\
, 53\end{array}$ & $\begin{array}{c}3,50 \pm \\
0,24\end{array}$ & $\begin{array}{c}2,08 \pm \\
0,28\end{array}$ \\
\hline $\begin{array}{c}\text { Группа сравнения } \\
\text { (альфа-токоферол) } \\
\text { (n=8), Р4 }\end{array}$ & $\begin{array}{c}1,11 \pm \\
0,01\end{array}$ & $\begin{array}{c}3,36 \pm \\
\text { (2,03 }\end{array}$ & $\begin{array}{c}36,24 \pm 0 \\
, 49\end{array}$ & $\begin{array}{c}9,27 \pm \\
0,08\end{array}$ & $\begin{array}{c}5,60 \pm \\
0,05\end{array}$ & $\begin{array}{c}37,41 \pm 0 \\
, 29\end{array}$ & $\begin{array}{c}3,55 \pm \\
0,03\end{array}$ & $\begin{array}{c}3,46 \pm \\
0,03\end{array}$ \\
\hline Р1:2 & $<0,01$ & $<0,05$ & $>0,05$ & $<0,001$ & $>0,05$ & $>0,05$ & $>0,05$ & $<0,001$ \\
\hline P 1:3 & $>0,05$ & $<0,01$ & $>0,05$ & $<0,05$ & $<0,01$ & $>0,05$ & $>0,05$ & $>0,05$ \\
\hline P1:4 & $>0,05$ & $<0,01$ & $>0,05$ & $<0,001$ & $>0,05$ & $>0,05$ & $>0,05$ & $<0,01$ \\
\hline P 2:3 & $<0,001$ & $<0,05$ & $<0,001$ & $<0,001$ & $<0,001$ & $<0,001$ & $>0,05$ & $<0,001$ \\
\hline P 2:4 & $<0,001$ & $>0,05$ & $<0,05$ & $>0,05$ & $<0,001$ & $<0,01$ & $<0,01$ & $<0,01$ \\
\hline P 3:4 & $<0,01$ & $<0,05$ & $<0,001$ & $<0,001$ & $<0,001$ & $<0,001$ & $>0,05$ & $<0,01$ \\
\hline
\end{tabular}

Таким образом, использование СМД фенозана в мозговой ткани способствовало восстановлению активности СОД - на 5 суток, каталазы - на 8 суток, МДА - на 10 суток и ФЛ состава на 12 сутки жизни. При введении СМД альфа-токоферола отмечаются разнонаправленные сдвиги содержания единич- ных фракций ФЛ в течение 1-10 суток; на 12 сутки постнатального периода происходит достоверное увеличение до уровня контроля молярной доли ЛФХ, ФХ, ФИ, ФЭА, КЛ, ФК и содержания МДА, тогда как активность СОД и каталазы нормализуются к 21 суткам жизни. Это указывает на специфическое вза- 
Вестник Новосибирского государственного педагогического университета Novosibirsk State Pedagogical University Bulletin

1(17) $2014 \quad$ www.vestnik.nspu.ru $\quad$ ISSN 2226-3365

имодействие альфа-токоферола в СМД с фосфолипидами мозговой ткани. При использовании СМД водорастворимого антиоксиданта фенозана в мозговой ткани в постгипоксическом периоде происходит достоверное восстановление активности СОД - на 5 сутки, снижение до уровня контроля МДА - на 10 сутки, чем обусловлены положительные сдвиги содержания отдельных ФЛ фракций: ЛФХ, ФХ, ФЭА, КЛ, ФК на 12 сутки постгипоксического периода.

Полученные результаты свидетельствуют о преимущественном влиянии СМД фенозана на ферментативное звено защиты от АФК в мозговой ткани, способствующей снижению окисления ФЛ в течение постнатального периода и созданию благоприятных условий для развития мозга. Примечательно, что в процессе коррекции нарушений ФЛ состава антиоксидантами в СМД происходит нормализация молярной доли и оптимизация до нормы соотношения фосфолипидных фракций, тогда как их абсолютное содержание (ммоль Р/кг ткани) не восстанавливается. Это указывает на стимуляцию компенсаторных свойств мозга и восстановление клеточного гомеостаза за счет ремоделирования мембран на фоне снижения интенсивности биосинтеза ФЛ.

Полученные данные о различной эффективности фенозана и альфа-токо-ферола в мозговой ткани согласуются с ранее выявленными фундаментальными представлениями о механизмах действия антиок-сидантов в зависимости от дозы [14]. Существуют данные, что эффекты фенозана в СМД обусловлены его прямым влиянием на ферменты, суперактивацией протеинкиназы $\mathrm{C}$, а также реакцией с пероксирадикалами, активными формами кислорода, рецепторными взаимодействиями, параметрическим резонансом, структурной памятью воды [6]. Возможно, обнаруженное нами увеличение активности СОД и каталазы под дейсвием СМД антиоксидантов указывает на их модулирующие свойства в отношении этих ферментов. Понижение концентрации конечного продукта липопероксидации МДА под действием СМД фенозана, возможно, обусловлено снижением его образования за счет обрыва цепи в результате реакции самонейтрализации (рекомбинации) свободных радикалов, что в свою очередь может быть обусловлено свойствами особых структур воды, упорядоченной фенозаном. Мы полагаем, что нормализация редокс-статуса в мозговой ткани под действием СМД фенозана приводит к снижению переокисления ФЛ и оптимизации их биосинтеза, что проявляется нормализацией содержания отдельных ФЛ фракций.

\section{Выводы}

1. В постгипоксическом периоде в мозговой ткани отмечается высокое содержание МДА и низкая активность СОД, которые обусловили снижение функционально значимых, а затем и структурных ФЛ, торможение биосинтеза ФЛ мозговой ткани, следствием чего стало понижение суммарных ФЛ и дисбаланс ФЛ фракций.

2. Водорастворимый антиоксидант фенозан в СМД обладает высокой эффективностью в мозговой ткани, т.к. приводит к ранней нормализации фосфолипидного состава и активности ферментов антиоксидантной системы в мозге, создавая благоприятные условия для развития мозговых функций в постгипоксическом периоде. 
Вестник Новосибирского государственного педагогического университета Novosibirsk State Pedagogical University Bulletin

1(17) $2014 \quad$ www.vestnik.nspu.ru ISSN 2226-3365

\section{СПИСОК ЛИТЕРАТУРЫ}

1. Mwaniki M.K., Atieno M., Lawn J.E., Newton C.R. Long-term neurodevelopmental outcomes after intrauterine and neonatal insults: a systematic review. Lancet, 2012, no. 379(9814), pp. 445-452.

2. Gill M.B., Bockhorst K., Narayana P., Perez-Polo J.R. Bax shuttling after neonatal hypoxiaischemia: hyperoxia effects. J Neurosci Res, 2008, no. 86(16), pp. 3584-3604.

3. Володин Н.Н., Медведев М.И., Горбунов А.В. Клинические синдромы нарушения нейрональной пролиферации - семиотика и современная диагностика // Вопросы практической педиатрии. - 2009. - № 4(3). - С. 12-19.

4. Суслина 3.А., Максимова М.Ю. Концепция нейропротекции: новые возможности ургентной терапии ишемического инсульта // Нервные болезни. - 2004. - № 3. - С. 4-7.

5. Hannah C. Glass, David Glidden, Rita J. Jeremy, A. James Barkovich, Donna M. Ferriero, Steven P. M. Clinical Neonatal Seizures are Independently Associated with Outcome in Infants at Risk for Hypoxic-Ischemic Brain Injury. The Journal of Pediatrics, 2009, vol. 155, no. 3, pp. 318-323.

6. Burlakova E.B., Konradov A.A., Mal'tseva E.L. The Effect of Ultra Low Doses of Biologically Active Substances and Low Rate Physical Factors. LIFE and MIND - In Search of the Physical Basis, Ed. S. Savva. MISAHA, Trafford Publishing, ISBN 1-4251-1090-8, 2007, pp. 79-113.

7. Бурлакова Е.Б. Биоантиоксиданты. Наномир слабых воздействий - «карликов», его законы, общность и различия с миром «гигантов» // Биоантиоксидант: Тез. докл. YIII Междунар. конференции 4-6 окт. 2010, Москва, 2010, С. 69-71.

8. Northington F.J., Zelaya M.E., O'Riordan D.P., Blomgren K., Flock D.L., Hagberg H., Ferriero D.M., Martin L.J. Failure to complete apoptosis following neonatal hypoxia-ischemia manifests as "continuum" phenotype of cell death and occurs with multiple manifestations of mitochondrial dysfunction in rodent forebrain. Neuroscience, 2007, vol. 149, no. 4, pp. 822-833.

9. Moore L.G., Charles S.M., Julian C.G. Humans at high altitude: hypoxia and fetal growth. Respir Physiol Neurobiol, 2011, no. 178(1), pp. 181-190.

10. Anastario M., Salafia C.M., Fitzmaurice G., Goldstein J.M. Impact of fetal versus perinatal hypoxia on sex differences in childhood outcomes: developmental timing matters. Soc Psychiatry Psychiatr Epidemiol, 2012, no. 47(3), pp. 455-464.

11. Morton J.S., Rueda-Clausen C.F., Davidge S.T. Flow-mediated vasodilation is impaired in adult rat offspring exposed to prenatal hypoxia. J Appl Physiol, 2011, no. 110(4), pp. 1073-1082.

12. Chang J.Y., Lee K.S., Hahn W.H., Chung S.H., Choi Y.S., Shim K.S., Bae C.W. Decreasing trends of neonatal and infant mortality rates in Korea: compared with Japan, USA, and OECD nations. J Korean Med Sci, 2011, no. 26(9), pp. 1115-1123.

13. Chaurio R.A., Janko C., Muñoz L.E., Frey B., Herrmann M., Gaipl U.S. Phospholipids: key players in apoptosis and immune regulation. Molecules, 2009, vol. 14, no. 12, pp. 4892-4914.

14. Хайбуллина 3.Р., Ибрагимов У.К. Биохимическое обоснование применения сверхмалых доз биологически активных веществ (обзор) // Инфекция, иммунитет, фармакология. 2013. - № 4. - С. 64-68. 
Вестник Новосибирского государственного педагогического университета Novosibirsk State Pedagogical University Bulletin

1(17) $2014 \quad$ www.vestnik.nspu.ru ISSN 2226-3365

(C) Z. R. Khaybullina, Ch. K. Sobirjanova

UDC 616.153.915 + 616.831 + 005.07

\title{
ULTRA LOW CONCENTRATIONS OF ANTIOXIDANTS AT EXPERIMENTAL HYPOXIA OF FETUS - SOME ASPECTS OF ACTION MECHANISM
}

\author{
Z. R. Khaybullina, Ch. K. Sobirjanova (Tashkent, Uzbekistan)
}

The article is devoted to the analyzes the changes in phospholipids composition and activity of antioxidant enzymes in brain tissue in animals undergoing intrauterine hypoxia and treatment by ultra-low doses of antioxidants in postnatal period. Urgency of problem. Fetal hypoxia causes fetal growth retardation and cerebral ischemia in newborn. The concept of neuroprotection by antioxidants is actively used in the treatment of ischemic stroke in adults, but it is not used in infants, probably due to lack of fundamental research to prove its effectiveness. Especially there are not studied the action of ultra-low doses (ULD), despite of there was established the ability of many substances to have an effects in ultra low doses of $10^{-10}-10^{-17} \mathrm{M}$ on various biological objects at the molecular level. Results. It was studied the changes of phospholipids (PL) composition and antioxidant system activity in brain tissues during the postnatal period in normal conditions and after intrauterine hypoxia. Accumulation of malondialdehyde (MDA), low activity of superoxide dismutase (SOD), decreasing the absolute amount of easily oxidized and functionally important PL (phosphatidylserine (PS) and phosphatidylinositol (PI)) in brain tissues were founded after intrauterine hypoxia at 1-5 days of life. After treatment with the water-soluble antioxidant phenazan in ULD caused decreasing of MDA concentration, that is observed at 10 day. After treatment with the fat-soluble antioxidant alpha-tocopherol decreasing of MDA level was observed at 12 day, without treatment - at 21 day. SOD and catalase activities after treatment with phenazan at ULD recovered significantly faster, then after alphatocopherol treatment and becomes comparable to the control, starting from 5 and 8 days of life, whereas after alpha-tocopherol introduction the SOD and catalase activity is comparable to the control only on 21 day of life. Decreasing of structural FL - phosphatidylcholine (PC), phosphatidylinositol (PEA) at 7-14 day of postnatal period after intrauterine hypoxia in brain tissues. Changes in the content of sphingomyelin (SPM) at postnatal period indicates its increasing in the first week after birth, and decreasing in the later, that's causing an increase in rigidness of membranes and their saturation, which changes to myelination disorders in the later stages of postnatal period. Cardiolipin (CL) amount was decreased at 10 day of post hypoxic period, that creates of energy metabolism disorders in mitochondria of the brain tissues. The results demonstrate that the water-soluble antioxidant phenazan in ultralow doses is highly effective in brain tissue, as leads to early normalization of phospholipids composition and activity of antioxidant enzymes in the brain, creating favorable conditions for the development of brain function and neuroplasticity in the post hypoxic period.

Keywords: fetal hypoxia, antioxidants, ultra-low doses, brain phospholipids, catalase, superoxide dismutase. 


\section{REFERENCES}

1. Mwaniki M.K., Atieno M., Lawn J.E., Newton C.R. Long-term neurodevelopmental outcomes after intrauterine and neonatal insults: a systematic review. Lancet, 2012, no. 379(9814), pp. 445452.

2. Gill M.B., Bockhorst K., Narayana P., Perez-Polo J.R. Bax shuttling after neonatal hypoxiaischemia: hyperoxia effects. J Neurosci Res, 2008, no. 86(16), pp. 3584-3604.

3. Volodin N.N., Medvedev M.I., Gorbunov A.V. Klinicheskie sindromy narusheniya neironal'noi proliferatsii - semiotika i sovremennaya diagnostika [Clinical syndromes of neuronal proliferation disturbances, it's semiotics and modern diagnostics]. Questions practical pediatric, 2009, no. 4(3), pp. 12-19.

4. Suslina Z.A., Maksimova M.Yu. Kontseptsiya neiroprotektsii: novye vozmozhnosti urgentnoi terapii ishemicheskogo insul'ta [The new opportunities of ischemic stroke therapies by neuroprotection conception]. Nervous illnesses, 2004, no. 3, pp. 4-7.

5. Hannah C. Glass, David Glidden, Rita J. Jeremy, A. James Barkovich, Donna M. Ferriero, Steven P. M. Clinical Neonatal Seizures are Independently Associated with Outcome in Infants at Risk for Hypoxic-Ischemic Brain Injury. The Journal of Pediatrics, 2009, vol. 155, no. 3, pp. 318-323.

6. Burlakova E.B., Konradov A.A., Mal'tseva E.L. The Effect of Ultra Low Doses of Biologically Active Substances and Low Rate Physical Factors. LIFE and MIND - In Search of the Physical Basis, Ed. S. Savva. MISAHA, Trafford Publishing, ISBN 1-4251-1090-8, 2007, pp. 79-113.

7. Burlakova E.B. Bioantioksidanty. Nanomir slabykh vozdeistvii - «karlikov», ego zakony, obshchnost' i razlichiya s mirom "gigantov» [Bioantioxidants. Nanoworld of low influences "Dwarfs", its laws, a generality and distinctions with the world of "giants"]. The YIII International conference "Bioantioxidants" Theses of reports, 2010, pp. 69-71.

8. Northington F.J., Zelaya M.E., O'Riordan D.P., Blomgren K., Flock D.L., Hagberg H., Ferriero D.M., Martin L.J. Failure to complete apoptosis following neonatal hypoxia-ischemia manifests as "continuum" phenotype of cell death and occurs with multiple manifestations of mitochondrial dysfunction in rodent forebrain. Neuroscience, 2007, vol. 149, no. 4, pp. 822-833.

9. Moore L.G., Charles S.M., Julian C.G. Humans at high altitude: hypoxia and fetal growth. Respir Physiol Neurobiol, 2011, no. 178(1), pp. 181-190.

10. Anastario M., Salafia C.M., Fitzmaurice G., Goldstein J.M. Impact of fetal versus perinatal hypoxia on sex differences in childhood outcomes: developmental timing matters. Soc Psychiatry Psychiatr Epidemiol, 2012, no. 47(3), pp. 455-464.

11. Morton J.S., Rueda-Clausen C.F., Davidge S.T. Flow-mediated vasodilation is impaired in adult rat offspring exposed to prenatal hypoxia. J Appl. Physiol., 2011, no. 110(4), pp. 1073-1082.

12. Chang J.Y., Lee K.S., Hahn W.H., Chung S.H., Choi Y.S., Shim K.S., Bae C.W. Decreasing trends of neonatal and infant mortality rates in Korea: compared with Japan, USA, and OECD nations. J Korean Med. Sci., 2011, no. 26(9), pp. 1115-1123.

13. Chaurio R.A., Janko C., Muñoz L.E., Frey B., Herrmann M., Gaipl U.S. Phospholipids: key players in apoptosis and immune regulation. Molecules, 2009, vol. 14, no. 12, pp. 4892-4914. 
Вестник Новосибирского государственного педагогического университета Novosibirsk State Pedagogical University Bulletin

14. Khaybullina Z.R., Ibragimov U.K. Biokhimicheskoe obosnovanie primeneniya sverkhmalykh doz biologicheski aktivnykh veshchestv (obzor) [Biochemical substantiation of using biologically active substances in ultra low doses (review)]. Infection, immunity and pharmacology, 2013, no. 4, pp.64-68.

Khaybullina Zarina Ruslanovna, the doctor of medicine, the head of biochemistry and microbiology department, Republican Specialized Center of Surgery at academician V. Vakhidov.

E-mail: zr-khaybullina@rambler.ru

Sobirzganova Charos Kahramon kizi, the student of pediatric department, Tashkent Medicine Pediatric Institute.

E-mail: zr-khaybullina@rambler.ru 
Вестник Новосибирского государственного педагогического университета Novosibirsk State Pedagogical University Bulletin

1(17) $2014 \quad$ www.vestnik.nspu.ru $\quad$ ISSN 2226-3365

(C) Н. И. Мамадалиева, Т. С. Саатов, 3. Р. Хайбуллина, О. И. Умеров

УДК 616.152.21 + 616.12-08

\title{
ВЛИЯНИЕ ФАРМАКОКОРРЕКЦИИ НА АКТИВНОСТЬ ФЕРМЕНТОВ ЗАЩИТЫ ОТ АКТИВНЫХ ФОРМ КИСЛОРОДА В СЕРДЦЕ ПРИ АДАПТАЦИИ К ГИПОКСИИ РАЗЛИЧНОЙ ИНТЕНСИВНОСТИ И ДЛИТЕЛЬНОСТИ
}

\author{
Н. И. Мамадалиева, Т. С. Саатов, 3. Р. Хайбуллина, О. И. Умеров (Ташкент, Узбекистан)
}

В статье рассматриваются некоторые аспекты действия жиро- и водорастворимых антиоксидантов на активность ферментов защиты от активных форм кислорода в сердечной ткани при хронической периодической гипоксии. Экспериментальное исследование проведено на крысах-самиах. Модель гипобарической гипоксии воспроизводили путем погружения животных в камеру, где создавалось давление ниже атмосферного, соответственно подъему на высоту 4000 м, 5000 м, 6000 м, 7000 м над уровнем моря. Длительность воздействия гипоксией составляла 10, 20, 30 сеансов. Фармакокоррекиию проводили препаратом альфалипоевой кислоты (а-ЛК) и липосомальным препаратом, содержащим фосфолипиды и альфатокоферол (ЛП). ЛП получали путем озвучивания на ультразвуковом диспергаторе УЗДН-1М при частоте $22 \kappa Г$. Установлено, что чувствительность СОД и каталазы сердечной ткани к фармакоррекции антиоксидантами зависит от исходного состояния их ферментативной активности, что определяется интенсивностью и длительностью гипоксии. Активность каталазы сердечной ткани достоверно увеличивается при гипоксии низкой и средней интенсивности (4000 м и 5000 м), и достоверно понижается относительно контроля во все сроки наблюдения при гипоксии сильной и умеренно сильной интенсивности (6000 и 7000 м). а-ЛК и ЛП не оказывают действия на нормальную и повышенную активность СОД, но приводят к активации фермента при его угнетении. При гипоксии низкой и средней интенсивности под действием а-ЛК повышенная активность каталазы нормализуется, а ЛП не оказывает эффекта. Чувствительность СОД и каталазы к действию препаратов а-ЛК и ЛП проявляется при гипоксии

Мамадалиева Нодира Исааковна - соискатель, лаборатория биохимии липидов Института биоорганической химии Академии наук Республики Узбекистан.

E-mail: n-mamadliyeva2013@mail.ru

Саатов Тальат Саатович - академик Академии Наук Республики Узбекистан, доктор биологических наук, профессор, руководитель лаборатории биохимии липидов Института биоорганической химии Академии наук Республики Узбекистан.

E-mail: t.saatov@yandex.ru

Хайбуллина Зарина Руслановна - доктор медицинских наук, руководитель отделения биохимии с группой микробиологии, Республиканский специализированный центр хирургии им. ак. В. Вахидова.

E-mail: zr-khaybullina@rambler.ru

Умеров Ойбек Ильясович - младший научный сотрудник, лаборатория биохимии липидов Института биоорганической химии Академии наук Республики Узбекистан.

E-mail: oybek.umerov@.yandex.ru 
Вестник Новосибирского государственного педагогического университета Novosibirsk State Pedagogical University Bulletin

1(17) $2014 \quad$ www.vestnik.nspu.ru ISSN 2226-3365

умеренно сильной интенсивности, с преимущественным эффектом жирорастворимого антиоксиданта в комплексе с фосфолипидными липосомами.

Ключевые слова: активность каталазы сердечной ткани, липосомы, альфа-липоевая кислота, гипобарическая гипоксия, супероксиддисмутаза, каталаза.

\section{Актуальность проблемы.}

Показатели заболеваемости сердечнососудистой патологией высоки почти во всех странах мира, несмотря на внедрение новейших антиангинальных медикаментозных средств, усовершенствование хирургических методов лечения, проведение большого комплекса профилактических мероприятий [1]. Это диктует необходимость поиска эффективной кардиопротекции.

Хроническая гипоксия, наблюдаемая при заболеваниях сердечнососудистой системы, обусловливает развитие окислительного стресса, эндогенной интоксикации. При гипоксии/реоксигенации в кардиомиоцитах увеличивается продукция активных форм кислорода (АФК), индуцируется апоптоз, нарушается трансмембранный потенциал в митохондриях, происходит повреждение антиапоптозных белков семейства bcl-2, высвобождение цитохрома $c$, активация каспазы-3 и каспазы-9, снижается активность магнийзависимой супероксиддисмутазы [2]. В тоже время, как показывают результаты некоторых экспериментальных исследований, гипоксия повышает устойчивость миокарда к острой асфиксии [2; 3]. При этом неизвестно, когда адаптативное влияние гипоксии сменяется патологическим, тем более не исследованы эти эффекты на фоне фармакокоррекции.

Одним из важных факторов адаптации клеток к гипоксии является изменение активности ферментов антиоксидантной защиты. Полагают, что именно с активацией СОД, каталазы и глутатионпероксидазы связана адап- тация сердечной ткани к гипоксии [4; 5] и устойчивость к острой асфиксии, т.к. прекондиционирование хронической гипоксией способствует снижению площади инфаркта и развитию толерантности к ишемии [3].

Лекарственные препараты, различные по механизму действия, вызывают однонаправленные сдвиги в активности ферментов антиоксидантной системы (АОС), что позволяет предположить отсутствие специфичности их эффектов и опосредованность этих эффектов действием АФК $[6 ; 7]$. В связи с этим, исследование состояния ферментов AOC в сердечной ткани и модуляция их активности под действием фармакокоррекции представляет интерес в плане выявления закономерностей адаптации ферментативного звена АОС к гипоксии различной интенсивности и длительности, а также определения чувствительности ферментов АОС к введению водо- и жирорастворимых антиоксидантов.

Цель: изучить активность ферментов защиты от АФК в сердечной ткани в условиях гипоксии различной продолжительности и интенсивности и ее фармакокоррекции антиоксидантами различных классов.

\section{Материалы и методы.}

Хроническая гипоксия создавалась путем адаптации белых беспородных крыссамцов $(\mathrm{n}=432)$, весом 180-220 грамм к хронической гипобарической гипоксии после определения индивидуальной чувствительности по Л.Д. Лукьяновой, 2003 [8], использовали низкоустойчивых крыс. Содержание 
животных и проведение экспериментов проводили в соответствии с международными правилами «Guide for the Care and Use of Laboratory Animals». Животных ежедневно погружали в специальную камеру, снабженную манометром, предохранительным клапаном, смотровым окошком, щелочным поглотителем для устранения избытка углекислого газа, где создавалось давление ниже атмосферного, соответственно подъему на высоту 4000 м, 5000 м, 6000 м, 7000 м над уровнем моря: 61,660 кПа (462,5 мм.рт.ст; 4000 м); 54,048 кПа (405,4 мм.рт.ст; 5000м); 47,218 кПа (354,2 мм.рт.ст.; 6000 м); 41,105 кПа (308,3 мм рт.ст; 7000 м). В качестве препаратов для фармакокоррекции были избраны Берлитион, содержащий альфалипоевую кислоту и липосомальный препарат, содержащий фосфолипиды и альфатокоферол. Препарат альфа-липоевой кислоты (а-ЛК) вводили в дозе 600мг/кг массы тела в течение 10-ти, 20-ти и 30-ти дней. Липосомальный препарат (ЛП) имел следующий состав: фосфолипиды из сердца крупнорогатого скота - 2,5 г; холестерин из сердца крупнорогатого скота - 0,35 г; альфатокоферол - 0,05 г. Липосомальный препарат из различных классов фосфолипидов получали путем озвучивания фосфолипидов с холестерином на ультразвуковом диспергаторе УЗДН-1М при частоте 22 кГц дважды в течение 5 минут с 30 секундным перерывом.

Было проведено 3 серии экспериментов: 1) гипоксия без коррекции; 2) гипоксия + а-ЛК; 3) гипоксия + ЛП. В каждой серии были выделены группы животных в зависимости от интенсивности гипоксии: 1 опытная $(4000$ м), 2 опытная $(5000$ м), 3 опытная $(6000$ м), 4 опытная (7000 м). Внутри каждой опытной группы были выделены по 3 подгруппы в зависимости от длительности эксперимента: подгруппы а) - подвергались ги- поксии 10-ти кратно, животные подгрупп б) - 20-ти кратно, подгрупп в) - 30-ти кратно. В каждой подгруппе было по 10-12 животных. Контрольную группу составило 36 крыс, 9 из которых были интактными, по 9 крыс получали физиологический раствор в течение 10, 20 и 30-ти дней соответственно.

Основанием для выбора модели послужило то, что биологическая модель гипоксической формы гипоксии относится к категории хорошо управляемых состояний [9], позволяет получить динамическую характеристику нарастающего процесса. В таких условиях можно выявить регуляторную направленность в изменении метаболической адаптации в общем комплексе гипоксических сдвигов, выявить интеграцию между кислородным режимом системы и ее метаболическим ответом.

Гомогенизацию сердечной ткани проводили в жидком азоте, непосредственно после забоя. Среда выделения для определения активности СОД, каталазы, общего белка состояла из $0,125 \mathrm{M} \mathrm{KCl}$.

Активность СОД в тотальном гомогенате сердца исследовали по методу Mistra P.H., Fridovich I. в модификации Брусова О.С. с соавт. $[10,11]$. Активность каталазы исследовали по Королюк М.А. и соавт. (1988) [12] с помощью молибдата аммония, активность каталазы выражали в ммоль $\mathrm{H}_{2} \mathrm{O}_{2} /$ г белка.

\section{Полученные результаты}

Моделирование гипоксии на высоте 4000 и 5000м мы условно считали гипоксией низкой и средней интенсивности; моделирование гипоксии на высоте 6000 и 7000 - гипоксией умеренно сильной и сильной интенсивности. Такое условное разделение было принято нами в соответствии с литературными данными, и, исходя из того, что погружение животных на высоту 8000м и более со- 


1(17) $2014 \quad$ www.vestnik.nspu.ru ISSN 2226-3365

провождалось развитием несовместимых с жизнью изменений - отеком легких, гибелью [9]. Оценивая динамику активности СОД и каталазы, а также эффективность фармакокоррекции а-ЛК и ЛП на активность ферментов АОС, обнаружены некоторые закономерности.

У животных 1 и 2 опытных групп в гомогенате сердечной ткани активность СОД имела тенденцию к увеличению на $22 \%$ и $28 \%$ относительно контроля соответственно после кратковременной периодической гипоксии (10 сеансов), и снижалась в динамике после долговременной адаптации к гипоксии (30 сеансов), становясь сравнимой с контролем во 2в подгруппе, и достоверно снижаясь относительно контроля в 1в подгруппе (табл.1).

Как показали наши результаты, а-ЛК и ЛП оказывали выраженный активирующий эффект при достоверном снижении СОД, что имело место на 30 сутки адаптации к гипоксии низкой интенсивности. При этом оба препарата не влияли на активность СОД, если она находилась на уровне контроля. При увеличении активности СОД, что наблюдалось при краткосрочной адаптации к гипоксии на 10 сутки эксперимента при гипоксии низкой интенсивности, а-ЛК и ЛП способствовали нормализации активности фермента до уровня контроля, а при гипоксии средней интенсивности - не проявляли значимого эффекта. Таким образом, становится очевидным, что аЛК и ЛП не оказывают действия на нормальную и повышенную активность СОД, но приводят к активации фермента при его угнетении.

При гипоксии низкой и средней интенсивности введение как а-ЛК, так и ЛП способствовало модуляции активности СОД, предотвращая ее увеличение на 10 сутки эксперимента, и достоверно увеличивая ее на 30 сутки эксперимента как относительно опыта, так и контроля.

У животных 3 и 4 опытных групп при хронической периодической гипоксии умеренно высокой и высокой интенсивности обнаружено угнетение активности СОД, пропорциональное тяжести гипоксии и длительности адаптации к ней. Так активность СОД была снижена на $11 \%$ и $29 \%$ относительно контроля после 20 и 30 сеансов гипоксии на высоте 6000 м соответственно. При гипоксии сильной интенсивности (7000 м) активность СОД снижалась в 2 и 2,4 раза по сравнению с контролем после 20 и 30 сеансов соответственно.

При введении а-ЛК животным, подвергнутым гипоксии умеренно сильной интенсивности (6000 м), активность СОД увеличивалась во всех подгруппах, однако различия были недостоверны как относительно опыта, так и групп, получавших липосомальный препарат. Тем не менее, влияние липосомального препарата при гипоксии умеренно сильной интенсивности на активность СОД было более выражено, проявляясь полной нормализацией активности фермента в подгруппах, подвергнутых 10 и 20 сеансам периодической гипоксии. Как видно из таблицы 1 , при гипоксии сильной интенсивности (7000 м) на фоне введения фармакокоррекции имелась лишь тенденция к увеличению активности СОД во все сроки наблюдения. Не смотря на это, преимущество ЛП перед а-ЛК в отношении нормализации активности СОД у животных этой группы доказывается достоверностью отличий между подгруппами получавшими ЛП и а-ЛК. 
Вестник Новосибирского государственного педагогического университета Novosibirsk State Pedagogical University Bulletin

1(17) 2014

www.vestnik.nspu.ru

ISSN 2226-3365

Таблица 1

Влияние а-ЛК и ЛП на активность СОД (Е/мг белка) в сердечной ткани при гипоксии различной интенсивности

\begin{tabular}{|c|c|c|c|c|c|c|c|c|c|c|c|c|}
\hline $\begin{array}{c}\text { Интенсивность } \\
\text { гипоксии }\end{array}$ & \multicolumn{3}{|c|}{$4000 \mathrm{~m}$} & \multicolumn{3}{|c|}{$5000 \mathrm{M}$} & \multicolumn{3}{|c|}{$6000 \mathrm{M}$} & \multicolumn{3}{|c|}{$7000 \mathrm{~m}$} \\
\hline $\begin{array}{l}\text { количество се- } \\
\text { ансов гипоксии }\end{array}$ & 10 & 20 & 30 & 10 & 20 & 30 & 10 & 20 & 30 & 10 & 20 & 30 \\
\hline Контроль, Р1 & \multicolumn{12}{|c|}{$\frac{1}{3,02 \pm 0,03}$} \\
\hline Опыт, Р2 & $\begin{array}{c}3,68 \pm \\
0,2\end{array}$ & $\begin{array}{c}2,92 \pm \\
0,07\end{array}$ & $\begin{array}{c}2,84 \pm \\
0,05\end{array}$ & $\begin{array}{c}3,88 \pm \\
0,21\end{array}$ & $\begin{array}{c}3,04 \pm \\
0,05\end{array}$ & $\begin{array}{c}3,14 \pm \\
0,14\end{array}$ & $\begin{array}{c}3,85 \pm \\
0,17\end{array}$ & $\begin{array}{c}2,71 \pm \\
0,01\end{array}$ & $\begin{array}{c}2,33 \pm \\
0,1\end{array}$ & $\begin{array}{c}2,05 \pm \\
0,08\end{array}$ & $\begin{array}{c}1,51 \pm \\
0,04\end{array}$ & $\begin{array}{c}1,27 \pm \\
0,07\end{array}$ \\
\hline $\begin{array}{c}\text { Гипоксия + a- } \\
\text { ЛК, Р3 }\end{array}$ & $\begin{array}{c}3,02 \pm \\
0,07\end{array}$ & $\begin{array}{c}3,15 \pm \\
0,08\end{array}$ & $\begin{array}{c}3,26 \pm \\
0,07\end{array}$ & $\begin{array}{c}3,83 \pm \\
0,08\end{array}$ & $\begin{array}{c}3,09 \pm \\
0,08\end{array}$ & $\begin{array}{c}3,02 \pm \\
0,05\end{array}$ & $\begin{array}{c}4,04 \pm \\
0,04\end{array}$ & $\begin{array}{c}2,87 \pm \\
0,1\end{array}$ & $\begin{array}{c}2,61 \pm \\
0,09\end{array}$ & $\begin{array}{c}2,45 \pm \\
0,11\end{array}$ & $\begin{array}{c}2,02 \pm \\
0,04\end{array}$ & $\begin{array}{c}2,47 \pm \\
0,05\end{array}$ \\
\hline $\begin{array}{c}\text { Гипоксия + } \\
\text { ЛП, Р4 }\end{array}$ & $\begin{array}{c}3,05 \pm \\
0,09\end{array}$ & $\begin{array}{c}3,07 \pm \\
0,05\end{array}$ & $\begin{array}{c}3,39 \pm \\
0,12\end{array}$ & $\begin{array}{c}3,79 \pm \\
0,11\end{array}$ & $\begin{array}{c}2,96 \pm \\
0,06\end{array}$ & $\begin{array}{c}2,99 \pm \\
0,05\end{array}$ & $\begin{array}{c}3,63 \pm \\
0,16\end{array}$ & $\begin{array}{c}2,94 \pm \\
0,07\end{array}$ & $\begin{array}{c}2,81 \pm \\
0,11\end{array}$ & $\begin{array}{c}2,87 \pm \\
0,01\end{array}$ & $\begin{array}{c}2,35 \pm \\
0,03\end{array}$ & $\begin{array}{c}2,79 \pm \\
0,06\end{array}$ \\
\hline P 1:2 & $<0,01$ & $>0,05$ & $<0,01$ & $<0,01$ & $>0,05$ & $>0,05$ & $<0,01$ & $<0,00$ & $<0,001$ & $<0,001$ & $<0,001$ & $<0,001$ \\
\hline P 1:3 & $>0,05$ & $>0,05$ & $<0,01$ & $<0,00$ & $>0,05$ & $>0,05$ & $<0,001$ & $>0,05$ & $<0,05$ & $<0,001$ & $<0,001$ & $<0,001$ \\
\hline P 1:4 & $>0,05$ & $>0,05$ & $<0,01$ & $<0,00$ & $>0,05$ & $>0,05$ & $<0,01$ & $>0,05$ & $>0,05$ & $<0,001$ & $<0,001$ & $<0,001$ \\
\hline P 2:3 & $<0,01$ & $<0,05$ & $<0,001$ & $>0,05$ & $>0,05$ & $>0,05$ & $>0,05$ & $>0,05$ & $>0,05$ & $<0,05$ & $<0,001$ & $<0,001$ \\
\hline P 2:4 & $>0,05$ & $>0,05$ & $<0,01$ & $>0,05$ & $>0,05$ & $>0,05$ & $>0,05$ & $>0,05$ & $<0,05$ & $<0,001$ & $<0,001$ & $<<0,001$ \\
\hline P 3:4 & $>0,05$ & $>0,05$ & $>0,05$ & $>0,05$ & $>0,05$ & $>0,05$ & $<0,05$ & $<0,05$ & $<0,05$ & $<0,05$ & $<0,001$ & $<0,05$ \\
\hline
\end{tabular}

Изменения активности каталазы при хронической периодической гипоксии зависели преимущественно от интенсивности гипоксии (табл. 2). Как видно из таблицы 2, при гипоксии низкой и средней интенсивности отмечалось компенсаторное увеличение активности фермента (1 и 2 опытная группы), а при гипоксии умеренно сильной и сильной интенсивности (3 и 4 опытные группы) отмечалось выраженное угнетение активности фермента, причем, пропорционально количеству сеансов гипоксии. Так, активность каталазы составила лишь 89, 77 и 66 \% от нормальной у животных 3 группы при воздействии 10, 20 и 30 сеансов гипоксии соответственно. У животных 4 группы каталазная активность в эти сроки составляла 82, 62 и $54 \%$ от контрольной соответственно.

Влияние а-ЛК на активность каталазы в сердечной ткани при гипоксии низкой интенсивности $(4000$ м) проявилось в еще большем увеличении активности фермента во все сроки наблюдения. Так, каталазная активность составила 105, 110 и $111 \%$ от контрольной после 10, 20 и 30 сеансов гипоксии соответственно. Схожие данные получены при использовании ЛП в этой группе животных. Причем, после 30 сеанса гипоксии как а-ЛК, так и ЛП препарат способствовали достоверному увеличению амплитуды роста активности каталазы, поддерживая ее тенденцию к увеличению, имеющуюся в опытной группе (Р2: $3<0,05$ и Р2: 4<0,05). Достоверных отличий эффектов а-ЛК и ЛП не обнаружено.

При гипоксии средней интенсивности (5000м) достоверное относительно контроля увеличение активности каталазы отмечается при введении ЛП после 20 и 30 сеансов гипоксии, а а-ЛК предотвращает активацию каталазы на 30 сутки эксперимента. Отметим, что при гипоксии средней интенсивности в опытной группе имеется тенденция к увеличению активности каталазы с увеличением 
Вестник Новосибирского государственного педагогического университета Novosibirsk State Pedagogical University Bulletin

1(17) $2014 \quad$ www.vestnik.nspu.ru

ISSN 2226-3365

количества сеансов гипоксии, тогда как при введении а-ЛК во все сроки наблюдения активность каталазы достоверно не отличается от контроля. При введении ЛП сохраняется тенденция, характерная для опытной группы. Данные результаты показывают стабилизирующий эффект а-ЛК при отсутствии нормализующей активности у ЛП на увеличенную активность фермента антипероксидной защиты в сердечной ткани.

Таким образом, в отличие от СОД, активность каталазы сердечной ткани была до- стоверно выше контроля при гипоксии низкой и средней интенсивности и ниже контроля во все сроки наблюдения при действии гипоксии сильной и умеренно сильной интенсивности. Чувствительность каталазы к действию препаратов а-ЛК и ЛП проявлялась при гипоксии умеренно сильной интенсивности, когда ее активность восстанавливалась до уровня контроля после 10 и 20 сеансов гипоксии.

Таблица 2

Влияние а-ЛК и ЛП на активность каталазы (ммоль $\mathrm{H}_{2} \mathrm{O}_{2}$ / 2 белка) в сердечной ткани при гипоксии различной интенсивности

\begin{tabular}{|c|c|c|c|c|c|c|c|c|c|c|c|c|}
\hline Интенсивность & \multicolumn{3}{|c|}{$4000 \mathrm{M}$} & \multicolumn{3}{|c|}{$5000 \mathrm{M}$} & \multicolumn{3}{|c|}{$6000 \mathrm{M}$} & \multicolumn{3}{|c|}{$7000 \mathrm{M}$} \\
\hline $\begin{array}{l}\text { Кол-во сеан- } \\
\text { сов гипоксии }\end{array}$ & 10 & 20 & 30 & 10 & 20 & 30 & 10 & 20 & 30 & 10 & 20 & 30 \\
\hline Контроль, Р1 & \multicolumn{12}{|c|}{$1,24 \pm 0,01$} \\
\hline Опыт, Р2 & $\begin{array}{c}1,26 \pm \\
0,02\end{array}$ & $\begin{array}{c}1,30 \pm \\
0,03\end{array}$ & $\begin{array}{c}1,29 \pm \\
0,03\end{array}$ & $\begin{array}{c}1,23 \pm \\
0,01\end{array}$ & $\begin{array}{c}1,28 \pm \\
0,03\end{array}$ & $\begin{array}{c}1,35 \pm \\
0,02\end{array}$ & $\begin{array}{c}1,11 \pm \\
0,01\end{array}$ & $\begin{array}{c}0,95 \pm \\
0,03\end{array}$ & $\begin{array}{c}0,82 \pm \\
0,04\end{array}$ & $\begin{array}{c}1,02 \pm \\
0,01\end{array}$ & $\begin{array}{c}0,77 \pm \\
0,03\end{array}$ & $\begin{array}{c}0,67 \pm \\
0,03\end{array}$ \\
\hline $\begin{array}{c}\text { Гипоксия + a- } \\
\text { ЛК, P3 }\end{array}$ & $\begin{array}{c}1,30 \pm \\
0,02\end{array}$ & $\begin{array}{c}1,37 \pm \\
0,02\end{array}$ & $\begin{array}{c}1,38 \pm \\
0,02\end{array}$ & $\begin{array}{c}1,22 \pm \\
0,01\end{array}$ & $\begin{array}{c}1,30 \pm \\
0,03\end{array}$ & $\begin{array}{c}1,26 \pm \\
0,02\end{array}$ & $\begin{array}{c}1,08 \pm \\
0,01\end{array}$ & $\begin{array}{c}0,91 \pm \\
0,03\end{array}$ & $\begin{array}{c}1,03 \pm \\
0,02\end{array}$ & $\begin{array}{c}1,07 \pm \\
0,01\end{array}$ & $\begin{array}{c}0,83 \pm \\
0,04\end{array}$ & $\begin{array}{c}0,88 \pm \\
0,02\end{array}$ \\
\hline $\begin{array}{c}\text { Гипоксия + } \\
\text { ЛП, Р4 }\end{array}$ & $\begin{array}{c}1,29 \pm \\
0,02\end{array}$ & $\begin{array}{c}1,41 \pm \\
0,02\end{array}$ & $\begin{array}{c}1,39 \pm \\
0,02\end{array}$ & $\begin{array}{c}1,26 \pm \\
0,02\end{array}$ & $\begin{array}{c}1,32 \pm \\
0,02\end{array}$ & $\begin{array}{c}1,34 \pm \\
0,02\end{array}$ & $\begin{array}{c}1,25 \pm \\
0,02\end{array}$ & $\begin{array}{c}1,22 \pm \\
0,02\end{array}$ & $\begin{array}{c}1,19 \pm \\
0,02\end{array}$ & \begin{tabular}{c|}
$1,22 \pm$ \\
0,02
\end{tabular} & $\begin{array}{c}0,92 \pm \\
0,04\end{array}$ & $\begin{array}{c}0,95 \pm \\
0,02\end{array}$ \\
\hline $\mathrm{P} 1: 2$ & $>0,05$ & $>0,05$ & $>0,05$ & $>0,05$ & $>0,05$ & $<0,001$ & $<0,001$ & $<0,001$ & $<0,001$ & $<0,001$ & $<0,001$ & $<0,001$ \\
\hline P 1:3 & $<0,05$ & $<0,001$ & $<0,001$ & $>0,05$ & $>0,05$ & $>0,05$ & $<0,001$ & $<0,001$ & $<0,001$ & $<0,001$ & $<0,001$ & $<0,001$ \\
\hline P 1:4 & $<0,05$ & $<0,001$ & $<0,001$ & $>0,05$ & $<0,01$ & $<0,001$ & $>0,05$ & $>0,05$ & $<0,05$ & $>0,05$ & $<0,001$ & $<0,001$ \\
\hline P 2:3 & $>0,05$ & $>0,05$ & $<0,05$ & $>0,05$ & $>0,05$ & $<0,01$ & $>0,05$ & $>0,05$ & $<0,001$ & $<0,01$ & $>0,05$ & $<0,001$ \\
\hline P 2:4 & $>0,05$ & $>0,05$ & $<0,05$ & $>0,05$ & $>0,05$ & $>0,05$ & $<0,001$ & $<0,001$ & $<0,001$ & $<0,001$ & $<0,05$ & $<0,001$ \\
\hline P $3: 4$ & $>0,05$ & $>0,05$ & $>0,05$ & $>0,05$ & $>0,05$ & $<0,05$ & $<0,001$ & $<0,001$ & $<0,001$ & $<0,001$ & $<0,05$ & $<0,05$ \\
\hline
\end{tabular}

Как показали результаты исследования, чувствительность СОД и каталазы к фармакоррекции антиоксидантами зависит от исходного состояния ферментативной активности, что определяется интенсивностью и длительностью гипоксии, т.е. уровнем генерации АФК [13-14].

Адаптация клетки к гипоксии происходит путем активации через неспецифическую редокс-сигнализацию под действием АФК гипоксия-индуцибельных генов, когда в отсутствие специфических рецепторов развивается клеточный ответ на действие гипоксии. Важнейшим следствием инициации редокссигнализации является активация факторов транскрипции: NF-kB, AP-1, HIF-1-альфа, HIF-Зальфа, индуцирующих защитные белки и способствующих адаптации и выживаемости организма. Так, к настоящему времени известно более 60 генов, активируемых 


1(17) $2014 \quad$ www.vestnik.nspu.ru ISSN 2226-3365

HIF-1-альфа. Основными белками ответа на АФК-сигнал при стрессе, гипоксии, ишемии являются ферменты антиоксидантной защиты, белки теплового шока (семейства HSP), $\mathrm{Fe}-$ регулируюшие белки, ферменты репарации, пероксиредоксины [6].

Вероятно, обнаруженный нами эффект гипоксии на активность СОД и каталазы является опосредованным АФК и их сигнальными функциями - неспецефической редокссигнализацией. Данное предположение основано на концепции участия АФК в создании неспецифической компоненты повышения устойчивости организма при периодически действующем факторе внешней среды [6]. Было показано, что медиаторы, действие которых опосредовано специфическими рецепторами, - гормональными, цитокиновыми, активируют неспецифическую редокс-сигнализацию и участвуют в перекрестной активации и взаимодействии рецепторов, что является основой перекрестных эффектов адаптации, при которых тренировка к одному повреждающему фактору повышает резистентность организма к действию другого фактора. В результате редокс-сигнализация приводит к насыщению клетки молекулами, повышающими ее защиту от повреждающих воздействий, причем эндогенная, т.е. сформировавшаяся в самой клетке защита эффективней внешней, с помощью экзогенных добавок.

Вероятно, поэтому а-ЛК и ЛП не оказывали влияния на нормальную и повышенную активность СОД, когда эндогенные компенсаторные механизмы еще были полностью задействованы. Причина большей эффективности эндогенной защиты относительно экзогенной лежит в кратности действия редокссигнализации. Повторная индукция защитных систем осуществляется новым АФКсигналом, поэтому с помощью поступления периодических АФК-сигналов и следующей за ними индукции протекторных систем реализуется основной принцип периодической адаптации при хронической гипобарической гипоксии. Необходимо учитывать, что АФКиндукция факторов транскрипции и протекторных белков, в том числе ферментовантиоксидантов, сменяется их ингибированием высоким уровнем тех же антиоксидантов, и синтез защитных белков прекращается. При усилении мощности действия повреждающего фактора - гипоксии, а также увеличении ее длительности происходит истощение эндогенных механизмов компенсации антирадикальной и антипероксидной защиты. В этих условиях наиболее четко реализуется положительное действие антиоксидантов, их способность частично восстанавливать активность СОД и каталазы, причем эффект жирорастворимого липосомального препарата более выражен.

\section{Выводы.}

1. Чувствительность СОД и каталазы к фармакоррекции антиоксидантами зависит от исходного состояния ферментативной активности, что определяется интенсивностью и длительностью гипоксии.

2. а-ЛК и ЛП не оказывают действия на нормальную и повышенную активность СОД, но приводят к активации фермента при его угнетении при хронической периодической гипоксии.

3. Активность каталазы сердечной ткани достоверно увеличивается при гипоксии низкой и средней интенсивности, и достоверно понижается во все сроки наблюдения при действии гипоксии сильной и умеренно сильной интенсивности.

4. При гипоксии низкой и средней интенсивности под действием а-ЛК повышенная активность каталазы нормализуется, липосомальный препарат не оказывает эффекта. 
Вестник Новосибирского государственного педагогического университета Novosibirsk State Pedagogical University Bulletin

1(17) $2014 \quad$ www.vestnik.nspu.ru ISSN 2226-3365

5. Чувствительность СОД и каталазы к действию препаратов а-ЛК и ЛП проявляется при гипоксии умеренно сильной интенсивно- сти, с преимущественным эффектом жирорастворимого антиоксиданта в комплексе с фосфолипидными липосомами.

\section{СПИСОК ЛИТЕРАТУРЫ}

1. Шаноян А.С. Отдаленные результаты стентирования коронарных артерий у больных со стабильной стенокардией: автореф. дис. ... канд. мед. наук. - Москва, 2006. - 22с.

2. Li W.J., Nie S.P., Chen Y., Xie M.Y., He M., Yu Q., Yan Y. Ganoderma atrum polysaccharide protects cardiomyocytes against anoxia/reoxygenation-induced oxidative stress by mitochondrial pathway. J Cell Biochem., 2010, no. 110(1), pp. 191-200.

3. Kolár F., Jezková J, Balková $\mathbf{P}$, Breh J, Neckár J, Novák F, Nováková O, Tomásová H, Srbová M, Ost'ádal B, Wilhelm J, Herget J. Role of oxidative stress in PKC-delta upregulation and cardioprotection induced by chronic intermittent hypoxia. Am J Physiol Heart Circ Physiol, 2007, no. 292(1), pp. H224-30.

4. Nouette-Gaulain K., Biais M, Savineau JP, Marthan R, Mazat JP, Letellier T, Sztark F. Chronic hypoxia-induced alterations in mitochondrial energy metabolism are not reversible in rat heart ventricles, 2011, no. 89(1), pp. 58-66.

5. Ornoy A., Rand S. B., Bischitz N. Hyperglycemia and hypoxia are interrelated in their teratogenic mechanism: studies on cultured rat embryos. Birth Defects Res B Dev Reprod Toxicol., 2010, no. 89(2), pp. 106-115.

6. Анчишкина Н. А. Роль свободнорадикального окисления и индукции белков семейства HSP в защитном эффекте адаптации к гипоксии и гипероксии при физических нагрузках: автореф. дис. ... канд. биол. наук. - Москва, 2009. - 20 с.

7. Policastro L., Molinari B., Larcher F., Blanco Paticia, Podhajcer O., Costa C., Rojas P., Duran H. Imbalance of antioxidant enzymes in tumor cells and inhibition of proliferation and malignant features by scavenging hydrogen peroxide. Mol. Carcinogenes, 2004, no. 2, pp. 103-113.

8. Лукьянова Л. Д. Биоэнергетическая гипоксия молекулярный механизм тканевой гипоксии и адаптации организма // Физиол. укр. журн. - 2003, - Т. 49, № 3. - С. 17-35.

9. Накусов Т. Т. Влияние кверцетина и дигидрокверцетина на свободнорадикальные процессы в разных органах и тканях крыс при гипоксической гипоксии: автореф. дис. ... канд. биол. наук. - Р/ на Дону, 2010. - 21 с.

10. Брусов О. С., Герасимов А. И., Панченко Л. Ф. Влияние природных ингибиторов радикальных реакций на автоокисление адреналина // Бюлл. эксперим. биол. и мед. - 1976. № 87(1). - C. 33-35.

11. Mirsa P. H., Fridovich I. The role of superoxide anion in the antioxidation of epinephrine and a simple assay for superoxide dismutase. J. Biol. Chem, 1972, vol. 247, no. 10. pp. 3170-3175.

12. Королюк М. А., Иванова Л. И., Майорова И. Г., Токарев В. Е. Метод определения активности каталазы // Лабораторное дело. -1988. - № 1. - С.16-19.

13. Хайбуллина 3. Р. Интенсивность окислительного стресса и количественные изменения в составе крови при экспериментальной общей гипобарической гипоксии // Медицинский журнал Узбекистана. - 2009. - № 6. - С. 89-93.

14. Мамадалиева Н. И., Саатов Т. С., Хайбуллина 3. Р., Умеров О. И. Динамика фосфолипидного состава сердечных тканей как основа для формирования толерантности к гипоксии // Вестник Ташкентской Медицинской Академии. - 2013. - № 1. - С. 25-31. 
Вестник Новосибирского государственного педагогического университета Novosibirsk State Pedagogical University Bulletin

1(17) $2014 \quad$ www.vestnik.nspu.ru ISSN 2226-3365

(C) N. I. Mamadalyeva, T. S. Saatov, Z. R. Khaybullina, O. I. Umerov

UDC 616.152.21 + 616.12-08

\title{
ACTIVITY OF THE REACTIVE OXYGEN SPECIES SCAVENGER ENZYMES IN THE HEART TISSUES AFTER PHARMACOLOGICAL CORRECTION OF HYPOXIA OF VARIOUS INTENSITY AND DURATION
}

\author{
N. I. Mamadalyeva, T. S. Saatov, Z. R. Khaybullina, O. I. Umerov (Tashkent, Uzbekistan)
}

The article is devoted to the problems of water and fat-soluble antioxidants action on the reactive oxygen species scavenger enzymes activity in the heart tissues at chronic periodic hypoxia. Experimental study was performed on male rats. Hypobaric hypoxia model reproduced by immersing the animals in the chamber where was created sub-atmospheric pressure, respectively, rise to a altitude of $4000 \mathrm{~m}, 5000 \mathrm{~m}, 6000 \mathrm{~m}, 7000 \mathrm{~m}$ above sea level. The duration of exposure to hypoxia was 10, 20, 30 sessions. Animals were treated with alpha-lipoic acid (a-LA) and liposomal substance, containing composition of phospholipids and alpha -tocopherol (LP). LP was obtained by scoring on ultrasonic disperser «UZDN-1M» at a frequency of $22 \mathrm{kHz}$. It has been established that the sensitivity of SOD and catalase in heart tissues to antioxidants depends on its initial enzymatic activity, as determined by the intensity and duration of hypoxia. Catalase activity in heart tissues was significantly increased at low and average intensity $(4000 \mathrm{~m}$ and $5000 \mathrm{~m}$ ) of hypoxia, but significantly reduced relative to the control during strong and moderately strong intensity ( 6000 and $7000 \mathrm{~m})$ of hypoxia in all periods of observation. a-LA and LP have no effect on normal and increased SOD activity, but lead to the activation of the enzyme at its oppression. a-LA increased catalase activity returned to normal, whereas the $L P$ has no effect at low and average intensity of hypoxia. Sensitivity of SOD and catalase to the a-LA and LP is manifested during moderately strong intensity of hypoxia, with the predominant effect of the fat-soluble antioxidant in combination with phospholipids liposome.

Keywords: heart tissues, liposomes, an alpha-lipoic acid, hypobaric hypoxia, superoxiddismutase, catalase.

\section{REFERENCES}

1. Shanoyn A.S. Otdalennye rezul'taty stentirovaniya koronarnykh arterii u bol'nykh so stabil'noi stenokardiei: avtoref. kand. med. nauk diss. [The late results of stent implantation to the coronary arteries at patients with a stable stenocardia. Avtoref. Ph. d. diss.]. Moscow, 2006. -22 p.

2. Li W.J., Nie S.P., Chen Y., Xie M.Y., He M., Yu Q., Yan Y. Ganoderma atrum polysaccharide protects cardiomyocytes against anoxia/reoxygenation-induced oxidative stress by mitochondrial pathway. J Cell Biochem., 2010, no. 110(1), pp. 191-200.

3. Kolár F., Jezková J, Balková P, Breh J, Neckár J, Novák F, Nováková O, Tomásová H, Srbová M, Ost'ádal B, Wilhelm J, Herget J. Role of oxidative stress in PKC-delta upregulation and cardioprotection induced by chronic intermittent hypoxia. Am J Physiol Heart Circ Physiol, 2007, no. 292(1), pp. H224-30.

4. Nouette-Gaulain K., Biais M, Savineau JP, Marthan R, Mazat JP, Letellier T, Sztark F. Chronic hypoxia-induced alterations in mitochondrial energy metabolism are not reversible in rat heart ventricles, 2011, no. 89(1), pp. 58-66. 
5. Ornoy A., Rand S. B., Bischitz N. Hyperglycemia and hypoxia are interrelated in their teratogenic mechanism: studies on cultured rat embryos. Birth Defects Res B Dev Reprod Toxicol., 2010, no. 89(2), pp. 106-115.

6. Anchichkina N. A. Rol' svobodnoradikal'nogo okisleniya i induktsii belkov semeistva HSP v zashchitnom effekte adaptatsii k gipoksii i giperoksii pri fizicheskikh nagruzkakh. Avtoref. diss. kand. biol. nauk. [The role of free radical oxidation and heat shock proteins induction after adaptation to hypoxia and hyperoxya at physical training. Avtoref. Ph. d. diss.]. Moscow, 2009, 20 p.

7. Policastro L., Molinari B., Larcher F., Blanco Paticia, Podhajcer O., Costa C., Rojas P., Duran H. Imbalance of antioxidant enzymes in tumor cells and inhibition of proliferation and malignant features by scavenging hydrogen peroxide. Mol. Carcinogenes, 2004, no. 2, pp. 103-113.

8. Luckyanova L. D. Bioenergeticheskaya gipoksiya molekulyarnyi mekhanizm tkanevoi gipoksii i adaptatsii organizma [Bioenergetical hypoxia as molecular mechanism of tissue adaptation of organism]. Ukrainian journal of physiology, 2003, no 49(3), pp.17-35.

9. Nakusov T. T. Vliyanie kvertsetina i digidrokvertsetina na svobodnoradikal'nye protsessy v raznykh organakh i tkanyakh krys pri gipoksicheskoi gipoksii. Avtoref. diss. kand. biol. nauk. [Kvercetin and dihydrokvercetin effects on free radical oxidation in different organs and tissues of rats at hypoxic hypoxia. Avtoref. Ph. d. diss.]. Rostov na Donu, 2010, 21 p.

10. Brusov O. S., Gerasimov A. I., Panchenko L. F. Vliyanie prirodnykh ingibitorov radikal'nykh reaktsii na avtookislenie adrenalina [The influence of native ingibitors of free radical reactions on epinephrine oxidation]. Bulleten of experimental biology and medicine, 1976, no. 87(1), pp. 33-35.

11. Mirsa P.H., Fridovich I. The role of superoxide anion in the antioxidation of epinephrine and a simple assay for superoxide dismutase. J. Biol. Chem, 1972, vol. 247, no. 10. pp. 3170-3175.

12. Koroluck M. A., Ivanova L. I., Mayorova I. G., Tokarev V. E. Metod opredeleniya aktivnosti katalazy [Method of catalase identification]. Laboratory work, 1988, no. 1, pp. 16-19.

13. Khaybullina Z.R. Intensivnost' okislitel'nogo stressa i kolichestvennye izmeneniya $\mathrm{v}$ sostave krovi pri eksperimental'noi obshchei gipobaricheskoi gipoksii [Intensity of oxidative stress and quantitative changes in the blood composition at common hypobaric hypoxia]. Medical journal of Uzbekistan, 2009, no. 6, pp. 89-93.

14. Mamadalyeva N. I., Saatov T. S., Khaybullina Z. R., Umerov O. I. Dinamika fosfolipidnogo sostava serdechnykh tkanei kak osnova dlya formirovaniya tolerantnosti k gipoksii [Dinamics of phospholipids composition of heart tissues as the basis of tolerance formation to the hypoxia]. The bulletin of Tashkent Medical Academy, 2013, no. 1, pp. 25-31.

Mamadalyeva Nodira Isakovna - the scientific researcher of the laboratory of lipids metabolism, Institute of bioorganic chemistry, Academy of Sciences of Republic Uzbekistan.

E-mail: n-mamadliyeva2013@mail.ru

Saatov Talat Saatovich - the academician of Academy of Sciences of Republic Uzbekistan, the doctor of biology, the professor, the head of the laboratory of lipids metabolism, Institute of Bioorganic Chemistry of Academy of Sciences of Republic Uzbekistan.

E-mail: t.saatov@yandex.ru

Khaybullina Zarina Ruslanovna - the doctor of medicine, the head of biochemistry and microbiology department, Republican Specialized Centre of Surgery named after academician V. Vakhidov.

E-mail: zr-khaybullina@rambler.ru

Umerov Oybek Ilyasovich - the scientific researcher of the laboratory of lipids metabolism, Institute of Bioorganic Chemistry of Academy of Sciences of Republic Uzbekistan.

E-mail: oybek.umerov@.yandex.ru 


\section{К СВЕДЕНИЮ АВТОРОВ ЖУРНАЛА}

Научный журнал «Вестник Новосибирского государственного педагогического университета» - электронное периодическое издание, учрежденное ФГБОУ ВПО «Новосибирский государственный педагогический университет», в котором публикуются ранее не опубликованные статьи, содержащие основные результаты исследований в ведущих областях научного знания.

Материалы статей, подготовленные автором в соответствии с правилами оформления регистрируются, лицензируются, проходят научную экспертизу, литературное редактирование и корректуру.

Решение о публикации принимается редакционной коллегией и редакционным советом электронного журнала.

Регистрация статьи осуществляется в on-line режиме на основе заполнения электронных форм. По электронной почте статьи не регистрируются.

Редакционная коллегия электронного журнала оставляет за собой право отбора присылаемых материалов. Все статьи, не соответствующие тематике электронного журнала, правилам оформления, не прошедшие научную экспертизу, отклоняются. Корректура статей авторам не высылается.

Тексты статей необходимо оформлять в соответствии с профессиональными требованиями к научной статье, объемом в пределах одного печатного листа (40000 знаков).

Публикуемые сведения к статье на русском и английском языках:

$>$ заглавие - содержит название статьи, инициалы и фамилию автора/ авторов, город, страна, а также УДК;

$>$ адресные сведения об авторе - указывается основное место работы, занимаемая должность, ученая степень, адрес электронной почты для связи;

$>$ аннотация статьи (от 1000 знаков) - отражает ее основное содержание, обобщающие результаты и ключевые слова;

$>$ пристатейный список литературы - оформляется в соответствии с требованиями ГОСТ Р 7.0.5-2008; формируется в соответствии с порядком упоминания в тексте статьи; регистрируется ссылкой (ссылки в тексте оформляются в квадратных скобках, содержат порядковый номер в списке литературы и страницы цитируемой работы).

Одновременно с направлением в редакцию журнала текста статьи, подготовленного для публикации, автору необходимо выслать сопроводительные документы к статье, оформленные в соответствии с требованиями.

Сопроводительные документы к статье:

$>$ оригинал развернутой рецензии направляющей организации / научного руководителя / специалиста по теме публикации (с подписью и печатью);

$>$ авторский лицензионный договор.

Подробно с правилами публикации можно ознакомиться на сайте журнала:

http://vestnik.nspu.ru/avtoram 


\section{FOR AUTHORS. THE INFORMATION ABOUT THE ORDER OF PUBLICATION OF ARTICLE}

The scientific journal «Novosibirsk State Pedagogical University Bulletin» is electronic periodical founded by Novosibirsk State Pedagogical University. Journal articles containing the basic results of researches in leading areas of knowledge were not published earlier.

The materials of articles, carefully prepared by the author, are registered, are licensed, materials are scientific expertise, literary editing and proof-reading.

The decision about the publication is accepted by an editorial board and editorial advice of electronic journal.

Also it is displayed in personal "cabinet" of the author.

Registration of article is carried out in on-line a mode on the basis of filling electronic forms e-mail articles are not registered.

The Editorial Board of the electronic journal reserves the right to itself selection of sent materials. All articles are not relevant to the content of electronic magazine, to rules of the registrations rules that have not undergone scientific expertise, are rejected. The proof-reading of articles is not sent to authors. Manuscripts are not returned.

Texts of articles are necessary for making out according to professional requirements to the scientific article, volume within the limits of one printed page (40000 signs).

Published data to article in Russian and English languages:

$>$ the title - contains article name, the initials and a surname of authors / authors, the city, the country, and also UDC;

$>$ address data on the author - the basic place of work, a post, a scientific degree, an e-mail address for communication is underlined;

$>$ the abstract (100-250 words) - reflects its basic maintenance, generalizing results and keywords;

$>$ the references - is made out according to requirements of GOST P 7.0.5-2008; it is formed according to order of a mention in the text of paper; it is registered by the reference (references in the text are made out in square brackets, contain a serial number in the References and page of quoted work)

Simultaneously with a direction in edition of electronic journal of the text of articles prepared for the publication, it is necessary for author to send accompanying documents to articles, issued according to requirements.

Accompanying documents to article:

$>$ the original of the developed review of the directing organization / the research supervisor / expert in a publication subject (with the signature and the press);

$>$ author's license contract.

In detail the rules of the publication on the site of journal:

http://vestnik.nspu.ru/avtoram 